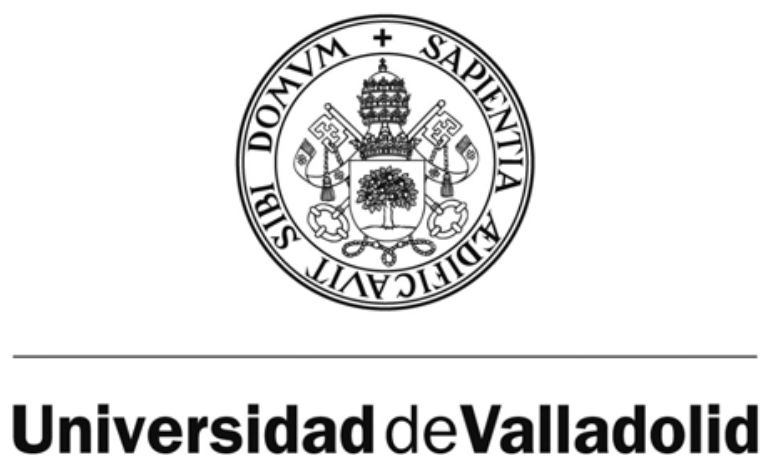

FACULTAD DE DERECHO

DEPARTAMENTO DE DERECHO CIVIL

TESIS DOCTORAL:

\title{
LA RESPONSABILIDAD POR LOS HECHOS DAÑOSOS DE LOS MENORES (ESPECIAL CONSIDERACIÓN DE LOS CENTROS DE ENSEÑANZA NO UNIVERSITARIOS)
}

Presentada por Jesús PLAZA SANZ para optar al grado de Doctor por la Universidad de Valladolid

Dirigida por:

Prof. Dr. D. Andrés Augusto Domínguez LueLmo 


\section{PARTE PRIMERA: LA RESPONSABILIDAD}

\section{CIVIL EXTRACONTRACTUAL DE LOS}

\section{MENORES EN GENERAL}

\section{CAPITULO PRIMERO: INTRODUCCIÓN}

1. ARTÍCULOS 1902 Y 1903 DEL CÓDIGO CIVIL 16

2. DERECHO ROMANO 17

2.1. LEY DE LAS DOCE TABLAS 18

2.2. ESCLAVITUD Y EDUCACIÓN EN ROMA 19

$\begin{array}{ll}\text { 2.3. LA FAMILIA ROMANA } & 21\end{array}$

2.4. EL PATER FAMILIAS 22

2.5. LA EDAD DE LOS MENORES 24

2.6. LA ACCIÓN NOXAL 26

2.7. EL CASO DE APRENDIZ DE ZAPATERO 26

3. GLOSADORES Y COMENTARISTAS 28

4. DECRETO DE GRACIANO 29

5. EL FUERO JUZGO 30

6. EL FUERO REAL Y LAS SIETE PARTIDAS DEL ALFOSO X EL SABIO 30

7. LA CODIFICACIÓN FRANCESA 31

7.1. INFLUENCIA DEL CODE CIVIL FRANCÉS EN EL MUNDO 34

8. EL DERECHO INGLÉS

9. CODIFICACIÓN ALEMANA 39

9.1. INFLUENCIA DEL CÓDIGO CIVIL ALEMÁN EN EL MUNDO 42

10. CODIFICACIÓN ESPAÑOLA

10.1. CODIFICACIÓN PENAL 44

10.1.1. CÓDIGO PENAL DE $1822 \quad 44$

10.1.2. CÓDIGO PENAL DE $1848 \quad 44$

10.1.3. CÓDIGO PENAL DE $1850 \quad 45$

10.1.4. CÓDIGO PENAL DE $1870 \quad 45$

10.1.5. CÓDIGO PENAL DE $1928 \quad 45$

10.1.6. CÓDIGO PENAL DE $1932 \quad 46$

10.1.7. CÓDIGO PENAL DE $1944 \quad 47$

10.2. CODIFICACIÓN CIVIL $\quad 47$

11. CONSTITUCIONALIZACIÓN DEL DERECHO A LA EDUCACIÓN

12. PRINCIPIOS DEL DERECHO EUROPEO DE LA RESPONSABILIDAD CIVIL 50 
CAPITULO SEGUNDO: LA RESPONSABILIDAD DEL MENOR QUE CAUSA EL DAÑO

1. LA RESPONSABILIDAD CIVIL EN EL ORDENAMIENTO JURIDICO ESPAÑOL 54

2. LA IMPUTABILIDAD PENAL

3. TEORÍA DEL DESARROLLO HUMANO 56

3.1. INFANCIA 56

3.2. NIÑEZ

3.3. ADOLESCENCIA 58

4. LA EDAD PENAL EN LA LORRPM

4.1. MENORES DE CATORCE A DIECIOCHO AÑOS 59

4.2. MENORES DE CARTORCE AÑOS 61

5. CAUSAS DE EXENCIÓN DE LA RESPONSABILIDAD CRIMINAL 62

6. EL ACTO DAÑOSO DEL MENOR CONTEMPLADO EN EL CÓdIGO PENAL COMO DELITO O FALTA

7. LA EDAD EN EL CÓDIGO CIVIL $\quad 67$

8. LA ANTIJURICIDAD EN LA RESP. CIVIL EXTRACONTRACTUAL 69

9. LA IMPUTABILIDAD CIVIL

9.1. LA IMPUTABILIDAD CIVIL EN EL CODE CIVILE

9.2. LA IMPUTABILIDAD CIVIL EN EL CODICE CIVILE ITALIANO 73

10. LA RESPONSABILIDAD CIVIL DEL MENOR CIVILMENTE IMPUTABLE 75

10.1. EL ARTÍCULO 1902 EN RELACIÓN CON EL 1104 PARA DETERMINAR LA NEGLIGENCIA DEL $\begin{array}{ll}\text { MENOR } & 75\end{array}$

10.2. TIPOS DE RESPONSABILIDAD DEL MENOR CIVILMENTE IMPUTABLE 76

10.3. LEGISLACIÓN NACIONAL E INTERNACIONAL EN RELACIÓN CON LA RESPONSABILIDAD DE

$\begin{array}{ll}\text { LOS MENORES } & 78\end{array}$

11. LA RESPONSABILIDAD CIVIL DEL MENOR CIVILMENTE INIMPUTABLE 81 11.1. ARGUMENTOS PARA EXIGIR RESPONSABILIDAD A UN MENOR INIMPUTABLE 84

CAPITULO TERCERO: LA RESPONSABILIDAD DE LOS PADRES TUTORES, ACOGEDORES Y GUARDADORES LEGALES Y DE HECHO.

1. GENERALIDADES 
2. PRINCIPIOS DEL DERECHO EUROPEO DE LA RESPONSABILIDAD CIVIL (EUROPEAN GROUP ON TORT LAW) 93

3. RESPONSABILIDAD DE LOS PADRES EN EL CODIGO PENAL 99

4. RESPONSABILIDAD DE LOS PADRES EN EL CODIGO CIVIL 101

4.1. OBJETIVACIÓN POR LA JURISPRUDENCIA 102

4.2. RESPONSABILIDAD POR HECHO AJENO 103

4.3. RESPONSABILIDAD DE LOS PADRES EN LA LORRPM 106

5. DOLO O NEGLIGENCIA GRAVE DEL ARTÍCULO 61.3 LORPM 113

5.1. CONCEPTO DE DOLO O CULPA GRAVE 115

5.2. CONCEPTO DE NEGLIGENCIA

5.3. CONCEPTO DE LA DILIGENCIA DE UN BUEN PADRE DE FAMILIA 119

5.4. LA CULPA EN LOS PETL 121

6. LA RELACIÓN DE CAUSALIDAD 126

6.1. TEORÍAS SOBRE LA CAUSALIDAD 128

6.1.1. TEORÍA DE LA EQUIVALENCIA DE LAS CONDICIONES 128

6.1.2. TEORÍA DE LA CAUSALIDAD PRÓXIMA 129

6.1.3. TEORÍA DE LA CAUSALIDAD ADECUADA 130

6.1.4. TEORÍA DE LA CAUSA EFICIENTE 131

6.1.5. CRITERIOS DE IMPUTACIÓN OBJETIVA 133

6.2. INTERDEPENDENCIAS DE CIRCUNSTACIAS EXTRAÑAS EN EL NEXO CAUSAL 136

6.2.1. EL CASO FORTUITO Y LA FUERZA MAYOR 136

6.2.2. EL HECHO DE UN TERCERO 139

6.2.3. LA CONDUCTA DEL PERJUDICADO 140

6.2.4. LOS PETL EN LA RELACIÓN DE CAUSALIDAD 142

7. LA MODERACIÓN 143

7.1. EL ARTÍCULO 114 DEL CÓDIGO PENAL 143

7.2. EL ARTÍ́CULO 1103 DEL CODIGO CIVIL 144

7.3. DISCRECIONALIDAD DE LA MODERACIÓN 145

7.4. SUJETOS A LOS QUE SE APLICA LA MODERACIÓN 146

7.5. CUANTÍA DE LA MODERACIÓN

7.6. FUNDAMENTO Y OBJETO DE LA MODERACIÓN 148

8. LA RESPONSABILIDAD DE LOS PADRES 149

8.1. FUNDAMENTO 149

8.2. LA RESPONSABILIDAD DE LOS PADRES EN EL DERECHO COMPARADO 153

8.2.1. DERECHO FRANCÉS 153

8.2.2. DERECHO ALEMÁN 156

8.2.3. DERECHO ITALIANO 159

8.3. EL ARTÍCULO 1903.2 DEL CÓDIGO CIVIL 163

8.4. CONDICIONES QUE SE HAN DE CUMPLIR PARA PODER EXIGIR RESPONSABILIDAD A LOS

PADRES 171

8.4.1. CAUSACIÓN DIRECTA DE UN DAÑO POR EL HIJO 172

8.4.2. RELACIÓN DE CAUSALIDAD 172 
8.4.3. EL HIJO BAJO LA GUARDA DE SUS PADRES

8.4.4. EL HIJO HA DE SER MENOR DE EDAD

8.5. RÉGIMEN DE SOLIDARIDAD DEL ARTÍCULO 61.3 LORRPM 179

8.5.1. EFECTOS DE LA SOLIDARIDAD 181

8.5.2. LA RESPONSABILIDAD DE LOS OBLIGADOS SOLIDARIOS 182

8.6. ESTUDIO DE LA EXPERESIÓN “POR ESTE ORDEN” DEL ARTÍCULO 61.2 DE LA LORRPM 184

8.6.1. TESIS DEL ORDEN EXCLUYENTE 185

8.6.2. TESIS DEL ORDEN ACUMULATIVO 186

8.6.3. TESIS DE LA GESTIÓN EFECTIVA DEL PROCESO EDUCATIVO 186

8.6.4. LA EXPRESIÓN POR ESTE ORDEN EN LA JURISPRUDENCIA 187

8.7. OBLIGACIÓN DE INDEMNIZAR DE LOS PADRES SEGÚN LAS SITUACIONES FAMILIARES 190

8.7.1. SITUACIONES CONVENCIONALES 190

8.7.2. REGIMEN DE GANANCIALES 191

8.7.3. REGIMEN DE SEPARACIÓN DE BIENES 193

8.7.4. REGIMEN DE PARTICIPACIÓN 194

8.7.5. LAS CAPITULACIONES MATRIMONIALES 195

8.7.6. SITUACIONES FAMILIARES NO CONVENCIONALES 196

8.7.6.1. SEPARACIÓN DE HECHO 198

8.7.6.2. SEPARACIÓN JUDICIAL, DIVORCIO, NULIDAD DE MATRIMONIO 200

8.7.6.3. PADRES NO CASADOS ENTRE SÍ 204

8.7.6.4. LA JURISPRUDENCIA ANTE LAS DISTINTAS SITUACIONES FAMILARES 205

8.7.7. LAS SITUACIONES FAMILIARES NO CONVENCIONALES EN EL DERECHO COMPARADO 212

8.7.7.1. DERECHO FRANCÉS 212

$\begin{array}{ll}\text { 8.7.7.2. DERECHO ALEMAN } & 215\end{array}$

$\begin{array}{ll}\text { 8.7.7.3. DERECHO ITALIANO } & 223\end{array}$

8.7.7.4. DERECHO PORTUGUÉS 235

8.7.7.5. ESTATUTO DEL CONYUGE DEL PROGENITOR EN LA LEGISLACIÓN EUROPEA 240

8.7.7.5.1. SITUACIÓN EN FRANCIA 241

8.7.7.5.2. SITUACIÓN EN REINO UNIDO

8.7.7.5.3. ALEMANIA, DINAMARCA Y PAISES BAJOS 244

8.7.7.5.4. SITUACIÓN EN SUIZA 245

8.7.7.5.5. SITUACIÓN EN BÉLGICA

8.7.7.5.6. SITUACIÓN EN ITALIA $\quad 247$

8.7.7.5.7. SITUACIÓN EN ESPAÑA

8.7.8. LA PATRIA POTESTAD PRORROGADA Y REHABILITADA 248

8.7.8.1. PATRIA POTESTAD PRORROGADA 251

8.7.8.2. PATRIA POTESTAD REHABILITADA 255

9. RESPONSABILIDAD DE LOS TUTORES 259

9.1. LOS TUTORES EN EL CÓDIGO CIVIL 259

9.2. LOS TUTORES EN LA LORRPM

9.3. LOS ABUELOS COMO TUTORES 265

9.3.1. DERECHO DE VISITAS ABUELOS-NIETOS 269

9.3.2. LOS ABUELOS EN LA CUSTODIA ORDINARIA DE LOS NIETOS 271

9.3.3. LOS ABUELOS COMO TUTORES SOBRE LOS NIETOS 273

9.3.4. LAS FUNCIONES TUTELARES DE LOS ABUELOS EN LA JURISPRUDENCIA 274

10. RESPONSABILIDAD DE LOS ACOGEDORES 279

10.1 DEFINICIÓN Y CARACTERÍSTICAS 279

10.2 ACOGIMIENTO FAMILIAR 280 
10.3 ACOGIMIENTO RESIDENCIAL 282

10.4 EL ACOGIMIENTO EN LA JURISPRUDENCIA 283

10.5 EL ACOGIMIENTO EN EL DERECHO PORTUGUÉS 286

10.5.1 GENERALIDADES 286

10.5.2 LOS AHIJADOS CIVILES 288

10.5.3 PADRINOS Y MADRINAS CIVILES 289

10.5.4 LAS RELACIONES DEL APADRINAMIENTO CIVIL 290

10.5.5 LOS PADRES 291

11. GUARDADORES LEGALES Y DE HECHO 293

11.1 GUARDADORES LEGALES 293

11.2 GUARDADORES DE HECHO 295

12. LAS COMUNIDADES AUTÓNOMAS ANTE LA RESPONSABILIDAD PENAL DE LOS MENORES $\quad 298$

12.1 LEGISLACIÓN ESPAÑOLA SOBRE COMUNIDADES AUTÓNOMAS EN RELACIÓN CON LA RESPONSABILIDAD DE LOS MENORES 298

12.2 LA PROBLEMÁTICA DE LAS COMUNIDADES AUTÓNOMAS EN RELACIÓN CON LOS MENORES

INMIGRANTES NO ACOMPAÑADOS 301

12.2.1 LA UNIÓN EUROPEA 302

12.2.2 LA PRÁCTICA ESPAÑOLA CON LOS MENORES NO ACOMPAÑADOS 304

12.3 LA LORRPM EN RELACIÓN CON LA RESPONSABILIDAD CIVIL DE LOS MENORES EN LAS COMUNIDADES AUTÓNOMAS. 307

12.4 LA RESPONSABILIDAD DE LAS COMUNIDADES AUTÓNOMAS EN LA JURISPRUDENCIA 309 12.4.1 RESOLUCIONES QUE ADMITEN LA CONDENA DE LAS ENTIDADES PÚBLICAS Y DE LOS PADRES 309 12.4.2 RESOLUCIONES QUE CONDENAN EXCLUSIVAMENTE A LAS ENTIDADES PÚBLICAS 310 12.4.3 RESOLUCIONES QUE CONDENAN A LA CC.AA. POR HECHOS COMETIDOS POR MENORES SOMETIDOS A MEDIDAS DE PROTECCIÓN O REFORMA 


\section{PARTE SEGUNDA: LA RESPONSABILIDAD}

\section{SOBRE LOS MENORES EN LOS CENTROS}

\section{DE ENSEÑANZA NO UNIVERSITARIOS.}

\section{CAPÍTULO PRIMERO: LA RESPONSABILIDAD DE LOS PROFESORES}

1. LA EDUCACIÓN EN ESPAÑA A PARTIR DE 1850.

1.1 LA EDUCACIÓN EN LAS CONSTITUCIONES; LA CONSTITUCIÓN REPUBLICANA DE 1931318

2. LA RESPONSABILIDAD DEL PROFESOR EN EL DERECHO COMPARADO. 321

2.1 FRANCIA 321

2.1.1 LA LEY DE 20 DE JULIO DE 1899

2.1.2 LA LEY DE 5 DE ABRIL DE 1937

2.2 ALEMANIA 329

2.2.1 PROFESORES DE ENSEÑANZA PÚBLICA 329

2.2.2 PROFESORES DE ENSEÑANZA PRIVADA 330

2.3 ITALIA 332

2.3.1 PROFESORES DE ENSEÑANZA PRIVADA 332

2.3.2 PROFESORES DE ENSEÑANZA PÚBLICA 334

3. RESPONSABILIDAD DE LOS PROFESORES EN EL CÓDIGO CIVIL ESPAÑOL. 337

3.1 LOS PROFESORES DE LA ENSEÑANZA PRIVADA 337

3.1.1 PERSONAL DOCENTE 339

3.1.2 DOLO O CULPA GRAVE DEL PROFESOR 340

3.1.3 LA ACCIÓN DE REGRESO DEL ARTÍCULO 1904 II C.C 342

3.1.4 LA RESPONSABILIDAD DE LOS PROFESORES DE ENSEÑANZA PRIVADA EN LA JURISPRUDENCIA 345

3.2 LA RESPONSABILIDAD DE LOS PROFESORES EN LA ENSEÑANZA PÚBLICA 353

3.2.1 PROCEDIMIENTO PARA LA ACCIÓN 357

3.2.2 RESPONSABILIDAD DE LOS PROFESORES DE LA ENSEÑANZA PÚBLICA EN LA JURISPRUDENCIA 358

\section{CAPÍTULO SEGUNDO: LA RESPONSABILIDAD DE LOS CENTROS DOCENTES}

1. LOS CENTROS DE ENSEÑNANZA EN GENERAL 364

1.1 LOS CENTROS DE ENSEÑANZA PRIVADOS 364

1.1.1 TITULARIDAD DEL CENTRO DOCENTE 364 
1.1.2 RESPONSABILIDAD DEL TITULAR DEL CENTRO DOCENTE POR EL ARTÍCULO 1903 IV 366

1.1.2.1 PRESUPUESTOS DE APLICACIÓN DEL ARTÍCULO 1903 IV CC 368

1.1.2.2 EL ARTÍCULO 1903 IV EN EL DERECHO COMPARADO 369

1.1.2.3 EL ARTÍCULO 1903 IV EN EL DERECHO EUROPEO DE LA RESPONSABILIDAD CIVIL 373

1.1.2.4 EL ARTÍCULO 1903 IV EN LA JURISPRUDENCIA 376

1.1.3 RESPONSABILIDAD DEL TITULAR DEL CENTRO DOCENTE POR EL ARTÍCULO 1903 V CC 384

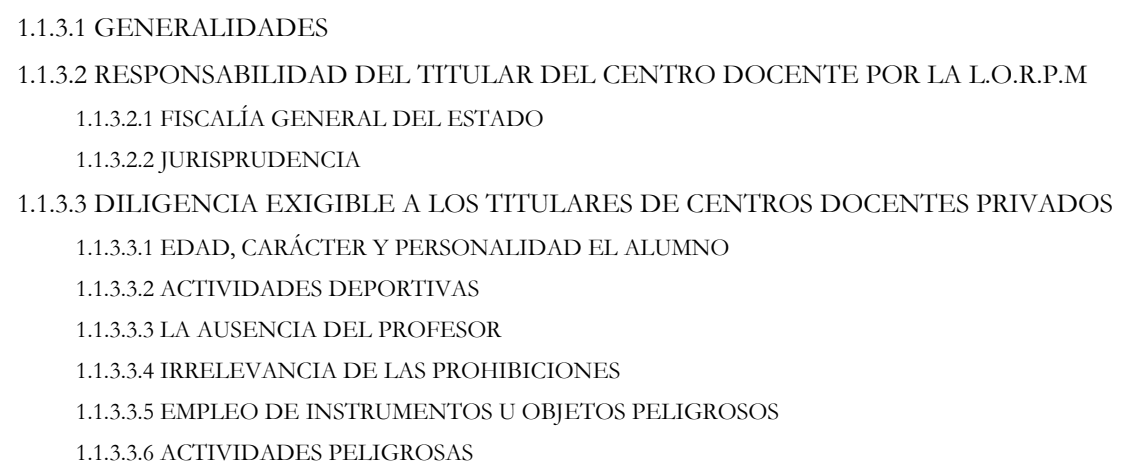

\section{LOS CENTROS DOCENTES PÚBLICOS}

2.1 GENERALIDADES

2.2 EL RECONOCIMIENTO DE LA RESPONSABILIDAD DE LA ADMINISTRACIÓN EN EL DERECHO COMPARADO

2.3 EL RECONOCIMIENTO DE LA RESPONSABILIDAD DE LA ADMINISTRACIÓN EN EL DERECHO ESPAÑOL

2.4 RESPONSABILIDAD OBJETIVA Y DIRECTA DE LA ADMINISTRACIÓN PÚBLICA

2.5 JURISDICCIÓN COMPETENTE SOBRE LA RESPONSABILIDAD CIVIL EN LOS CENTROS PUBLICOS DE EDUCACIÓN

\section{GENERALIDADES}

1.1 VIOLENCIA DE LOS ALUMNOS SOBRE LOS PROFESORES 436

1.2 VIOLENCIA DE LOS PROFESORES CONTRA LOS ALUMNOS 438

1.3 VIOLENCIA DE LOS PADRES DE LOS ALUMNOS SOBRE LOS PROFESORES 440

2. VIOLENCIA O MALTRATO ENTRE IGUALES, BULLYING 441

2.1 INTRODUCCIÓN 441

2.2 DEFINICIÓN Y CARACTERÍSTICAS

2.3 MECANISMOS LEGALES DE PROTECCIÓN 446

2.4 EL ACOSO ESCOLAR EN LOS PAISES DE NUESTRO ENTORNO 450 
2.7 EL ACOSO ESCOLAR EN EL CÓDIGO PENAL

\section{PARTE TERCERA:}

CONCLUSIONES 


\section{PARTE PRIMERA: LA RESPONSABILIDAD CIVIL EXTRACONTRACTUAL DE LOS MENORES EN GENERAL}

\section{CAPÍTULO PRIMERO: INTRODUCCIÓN}

\section{ARTÍCULO 1902 Y 1903 DEL CÓDIGO CIVIL}

El presente trabajo trata de la responsabilidad civil extracontractual de los menores con especial referencia a los centros de enseñanza no universitarios.

Esta responsabilidad extracontractual se halla contemplada en el art. 1902 que dice: "El que por acción u omisión causa daño a otro, interviniendo culpa o negligencia está obligado a reparar el daño causado”. Este artículo es el genérico de este tipo de responsabilidad, por lo que habremos de referirnos a él en numerosas ocasiones.

El art. 1903 es complementario del art. 1902, tiene con él una relación de especialidad y dice lo siguiente:

"La obligación que impone el artículo anterior es exigible, no sólo por los actos u omisiones propios, sino por los de aquellas personas de que se debe responder.

Los padres son responsables de los daños causados por los hijos que se encuentren bajo su guarda.

Los tutores lo son de los perjuicios causados por los menores o incapacitados que estén bajo su autoridad y habiten en su compañía.

Lo son igualmente los dueños o directores de un establecimiento o empresa respecto de los perjuicios causados por sus dependientes, en el servicio de los ramos en que los tuvieran empleados, o con ocasión de sus funciones.

Las personas o entidades que son titulares de un centro de enseñanza no superior responderán por los daños y perjuicios que causen sus alumnos menores de edad durante los periodos de tiempo en que los mismos se hallen bajo el 
control o vigilancia del profesorado del centro, desarrollando actividades escolares o extraescolares y complementarias.

La responsabilidad de que trata este artículo cesará cuando las personas en él mencionadas prueben que emplearon toda la diligencia de un buen padre de familia para prevenir el daño."

La relación de especialidad se da en la expresión "no sólo por los actos u omisiones propios sino por los de aquellas personas de quienes se debe responder". Para los actos u omisiones propios, los contempla el art. 1902, mientras que en el art. 1903, se hace referencia a determinadas personas tanto físicas como jurídicas y las va enumerando, padres, tutores, dueños o director de un establecimiento o empresa, centros de enseñanza no superior. Se trata de responder no por los hechos propios, sino por los de otros. En su apartado final contempla la exención de responsabilidad para las personas que han obrado con diligencia pues al no obrar con negligencia no son culpables y por ello quedan exentas de responsabilidad.

En el art. 1904 se da igualmente una relación de especialidad con el art.1902 tratando de la acción de regreso sobre los dependientes, así como de la responsabilidad de los profesores y dice:

"El que paga el daño causado por sus dependientes puede repetir de éstos lo que hubiera satisfecho.

Cuando se trate de centros docentes de enseñanza no superior, sus titulares podrán exigir de los profesores las cantidades satisfechas, si hubieren incurrido en dolo o culpa grave en el ejercicio de sus funciones que fuesen causa del daño"

Estos tres artículos serán analizados a lo largo del trabajo, empezando con el Derecho Romano hasta nuestros días, comparándolos con los códigos civiles de los países de nuestro entorno, así como con la doctrina y la jurisprudencia.

\section{DERECHO ROMANO}

El Derecho Romano constituye la base de nuestro derecho civil. Se 
impuso en España al ser ocupada por los romanos y convertirse en una provincia más de su Imperio. El gobernador de cada provincia tenía la máxima jurisdicción y aplicaba el derecho principalmente romano, pero teniendo en cuenta las normas consuetudinarias del territorio de su demarcación provincial.

En un principio Roma se encontraba constituida en forma de monarquía con su rey en la cúspide detentando el máximo poder, unido estrechamente al Pontífices Máximus, el cual dirigía a la clase sacerdotal como sucede en los pueblos antiguos.

El Colegio Pontifical presidido por el Pontífices Máximus era el encargado de desarrollar e interpretar la ley de acuerdo con la costumbre y la tradición. Los Pontífices custodiaban los formularios procesales y negociables, cuyos ritos y fórmulas eran secretos, dependiendo de su conocimiento el éxito de las partes litigantes. Al estar muy unida la clase sacerdotal al poder político, disponer en secreto de los ritos y formulas para la resolución de los litigios, la dotaba de gran poder, así como de un aura de respeto y prestigio ante los demás.

Esto desaparece al establecerse la Ley de las Doce Tablas y publicar Cneo Flavio las fórmulas procesales, hasta entonces mantenidas en secreto ${ }^{1}$.

\subsection{LEY DE LAS DOCE TABLAS.}

La Ley de las XII Tablas (Lex Duodecim Tabularium) es el código más antiguo de Derecho Romano y el primer cuerpo normativo de que se tiene noticia en Occidente. Fue promulgado en el siglo V a.C.

Con esta ley el Derecho Romano emprende su secularización, al salir de la mano de los Pontífices, estos pierden el monopolio de la jurisprudencia, haciéndose un derecho público, conocido por todos los ciudadanos.

No ha llegado a nosotros el texto de la ley, así lo que sabemos de ella es a través de los textos de los historiadores y juristas de la antigüedad. Se ha reconstruido de forma aproximada y su contenido se refiere a materias de derecho privado, procesal y penal. Es una ley arcaica, por tanto, sus preceptos

\footnotetext{
${ }^{1}$ RASCÓN GARCÍA, César: Manual de Derecho Romano, Tecnos 1992, Madrid, págs.. 54 y ss.
} 
son breves, claros, concisos y de gran dureza.

En ella se contempla la Ley de Talión, cuyo texto clásico era "ojo por ojo y diente por diente", que aunque pueda parecer dura, en su tiempo representó un progreso, pues entonces se daba la venganza privada y si alguien se peleaba con otro y le originaba una lesión no muy importante, se peleaban unas familias con otras, lo que daba lugar a grandes enfrentamientos con la producción de muertes. De esta forma, se conseguía un elemento de intimidación o de disuasión con lo que se evitaba la comisión de abusos, mejorando la convivencia social ${ }^{2}$.

La ley del Talión era en algunos casos de muy difícil aplicación como cuando un tuerto le sacaba un ojo al que tenía dos, si se aplicaba esta ley el ofensor se quedaría ciego, y así en otros casos similares. Para evitar esta dureza se fue sustituyendo por la compensación pecuniaria, en la que se indemnizaba a la víctima en lugar de aplicar daños físicos.

De la noxalidad trata en la tabla VIII o de los delitos, se halla contemplado el caso del siervo que comete un hurto, por el que el dóminus o propietario del siervo se exime de responsabilidad dándolo en noxa al perjudicado.

Tuvo una vigencia de mil años aproximadamente desde el siglo $\mathrm{V}$ a.C. hasta el Corpus Iuris Civilis del Emperador Justiniano. A partir del siglo I d.C. fue aplicada cada vez menos ${ }^{3}$.

\subsection{ESCLAVITUD Y EDUCACIÓN EN ROMA.}

La educación en Roma se encontraba encomendada a los esclavos y libertos extranjeros deportados ${ }^{4}$. El origen de la esclavitud en los tiempos antiguos se

\footnotetext{
${ }^{2}$ La Ley de Talión se contempló en el Código de Hammurabi. "El significado histórico de Hammurabi ha sido realmente extraordinario, no sólo por sus grandes dotes de estadista que reveló poseer, sino especialmente por su labor en el campo del derecho cuya influencia pervivió hasta la época romana, el reflejarse muchos de sus postulados legales de un modo clarísimo en la Ley de las XII Tablas. O lo que es lo mismo, durante casi catorce siglos la humanidad hubo de ser regida jurídicamente, de un modo más o menos directo por lo que había codificado el rey babilónico". Código de Hammurabi, Federico Lara Peinado, Editora Nacional, Madrid 1982, págs. 39 y ss.

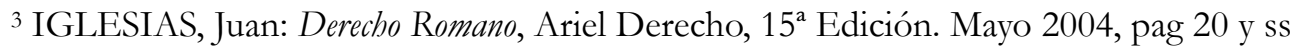

${ }^{4}$ MORENO, Juan Manuel, POBLADOR, Alfredo y DEL RÍO, Dionisio: Biblioteca de Innovación Educativa, $4^{\mathrm{a}}$
} 
encontraba en la guerra. Cuando un ejército derrotaba a otro, generalmente se mataba a los vencidos. Con el paso del tiempo se dieron cuenta de que podían utilizarlos para los trabajos domésticos, industriales, mineros, etc., por ello, la esclavitud en este sentido representa un progreso, por ser preferible ser un esclavo a que le maten a uno. Esto unido a la aversión, contrariedad o rechazo que el hombre tiene hacia los trabajos físicos, hizo que aumentará de forma extraordinaria la esclavitud por todas partes.

Los oficios que ejercían los esclavos eran muy heterogéneos. Se dividían los esclavos en públicos y privados. Los esclavos públicos estaban asignados al Estado y a las ciudades o municipios, se encargaban de las obras públicas y como auxiliares en los distintos ramos de la administración. En cuanto a los esclavos privados, se empleaban en el ámbito doméstico, en las fincas rústicas, el comercio, etc. Dentro de los privados los que interesan son los dedicados al servicio doméstico, pues dentro de ellos los había dedicados a las artes, literatura, bibliotecarios, pedagogos, preceptores, gramáticos y filósofos.

El sistema organizativo de la educación en Roma, se puede dividir en cuatro fases o etapas: la época de los tiempos primitivos, la fase republicana, la etapa imperial y la época decadente.

En la época primitiva la educación de los niños, se desarrollaba dentro de la familia y la ejercía el paterfamilias, que con el paso del tiempo dio lugar a las primeras escuelas elementales, las cuales eran dirigidas por el "ludi magister o litterator". El periodo de edad de los alumnos comprendida entre los siete y doce años, en los que se enseñaban cosas muy elementales como lectura, escritura, cálculos básicos, máximas con fondo moral y algunas nociones de literatura. La disciplina ejercida por el maestro era bastante severa, llegándose a emplear la palmeta en las faltas leves y la vara y el látigo en las graves. Los maestros tenían muy poco prestigio social y su retribución era muy escasa, por lo que tenían que recurrir a otros oficios. Para poder ganar un sueldo equivalente a un artesano cualificado, era preciso reunir unos treinta alumnos, lo que no era frecuente al 
desarrollarse esta enseñanza en el ámbito familiar.

Con la etapa republicana continua la educación en el ámbito familiar y la del ludi magister o litterator, aunque con el paso del tiempo resultó insuficiente. Se da a partir de este periodo un interés por la gramática y la retórica, organizándose las primeras escuelas del gramaticum y del rethor. Roma sigue careciendo de una política escolar, quedando la educación en manos de la iniciativa y la actividad privada.

En la etapa imperial se establecen los distintos grados de enseñanza primaria, secundaria y terciaria con cada uno de los profesores correspondientes, ludi magister, gramaticus y rethor. A la escuela del gramático acuden los niños de doce a quince años. El gramático como a finales de la república se había puesto de manifiesto, gozaba en la etapa imperial de una condición superior, tiene más prestigio que un maestro de escuela y tal es así, que su sueldo es cuatro veces superior al que percibía un preceptor. La escuela de gramática ocupa un escalón inferior a la de retórica y es un paso previo de preparación para la oratoria. Ingresaban en la escuela de retórica los alumnos a partir de los quince años.

Durante la época decadente las escuelas perdieron parte de su influencia; hasta ir desapareciendo progresivamente, sobre todo, con la invasión de los pueblos del norte, llegando hasta su casi total extinción. De todo ello se puede afirmar que la educación en Roma se mantuvo en el ámbito familiar y municipal con el Estado permaneciendo al margen, dejando a la iniciativa privada su impulso y organización, con una baja consideración de los maestros, como pone de manifiesto el hecho de que fueran esclavos y no ciudadanos romanos ${ }^{5}$.

\subsection{LA FAMILIA ROMANA.}

Se llama familiar en Derecho Romano al conjunto de personas que por naturaleza o por derecho, se encuentran sujetas a la potestad de uno solo, por ejemplo el padre de familia (D-50-16,199.2). Pero lo que caracteriza a la familia

${ }_{5}^{5}$ MORENO MARTÍNEZ, Juan Antonio: Responsabilidad del centro docente y profesorado por daños causados a sus alumnos, Mc Graw Hill, Madrid 1996, págs.. 1-5. 
romana es la sumisión o el estar todos sus miembros sometidos a la autoridad de uno, que es el paterfamilias.

Hay que distinguir en la familia romana los cognados y agnados. Son cognados por razones de parentesco natural o vínculos de sangre, por eso dice Modestino "Más se considera que se llaman cognados porque son nacidos juntamente o en común, o nacidos o engendrados de uno mismo" (D38,10.4.1). Agnados son las personas ligadas por parentesco civil y se hallan sometidas a un paterfamilias. Este parentesco civil en los tiempos más antiguos de Roma fue más importante que el de sangre (cognaticio) y afectaba a todos los sometidos a la potestad del paterfamilias, tales como hijos, nietos, mujer y adoptados. (Gayo 1, 58 y 1-163) (D.-38,8,4).

La familia romana es agnaticia y se confunde con la gens, en la que por razones de defensa y orden, se forman familias muy numerosas. Al pasar de la economía agraria a otra en que interviene más el comercio, la familia agnasticia no resulta operativa, por lo que se pasa a la familia cognaticia, que es más operativa para el comercio y la expansión imperial, menos numerosa, más sencilla; con mayor libertad de la mujer, de los hijos y los esclavos, prevaleciendo hasta la época de Justiniano.

La familia así formada se compone del fundo o finca familiar, los esclavos, los animales de tiro y carga y los aperos de labranza. Adquiere gran importancia la pecunia en este tipo de familia por ser necesaria como bien de cambio en el nuevo comercio y sustituye a la res mancipi (que se toma con la mano) de la economía agraria. "La familia se considera además, como la base y fundamento de la organización política. Cicerón considera la familia, como principium urbis et quasi seminarium republicae".

\subsection{EL PÁTER FAMILIAS.}

Paterfamilias es el que tiene el mando soberano y en un principio es absoluto sobre todos los miembros de la familia, tales como la mujer y los hijos tanto

${ }^{6}$ GARCÍA GARRIDO, Manuel Jesús: Derecho Privado Romano, Dikynson 1989, Pág. 691. 
naturales o adoptados como esclavos.

El Padre tiene unos poderes sobre los que están bajo su mando, es decir, sobre los hijos la patria potestad; sobre la mujer, la manus, y sobre los esclavos, la dominica potestas. La patria potestas comprendía a los hijos y también a sus esposas, pues podía estar casado el hijo y ser menor de veinticinco años (que era la mayoría de edad), con lo que su esposa y los hijos que pudieran tener, se hallaban igualmente sometidos a la patria potestad del paterfamilias.

Este poder del padre sobre los hijos comprende varios derechos:

Derecho de vida y muerte sobre los hijos (ius vitae et necis), este derecho estuvo siempre mal visto desde sus inicios por su manifiesta inhumanidad. Se hallo siempre sujeto a muchas limitaciones y sobre todo, a medida que se fue implantando el cristianismo los emperadores lo castigaban con la pena capital y considerado como parricidio.

Un derecho de vender (ius vendendi) como esclavo al hijo en territorio extranjero, el cual fue mal visto desde el principio y con limitaciones al igual que en el caso anterior. Fue tolerado por los emperadores sólo para el caso de que la familia llegase a un grado de extrema necesidad y con la posibilidad de poder recuperarlo.

Por el ius noxae dandi, el padre puede entregar su hijo al perjudicado, por un acto cometido por ese hijo, con el fin de exonerarse, liberarse o descargarse de la responsabilidad. Fue abolido por Justiniano.

Sobre la mujer tiene el paterfamilias el poder el llamado manus y la ceremonia por la que la mujer entró en la nueva familia, se denomina conventio in manus, en la que pierde el vínculo que tenía con su familia original. Puede decirse que la mujer ocupa en la familia una posición digna pero carece de derechos y su función principal es procrear.

Se extingue la patria potestad por la muerte del paterfamilias, ya que al morir el padre, los hijos pasan a ser padres y a formar sus propias familias (D-50, 16, 195, 2).

Se extingue igualmente cuando se entrega al hijo en adopción, así como 
cuando se le concede la emancipación para que sea libre.

\subsection{LA EDAD DE LOS MENORES.}

La edad constituye uno de los aspectos más significativos para establecer con claridad y precisión la responsabilidad de los menores. En Derecho Romano, se establecía la diferencia entre púberes e impúberes, y dentro de ellos otras diferencias que se exponen a continuación.

Impúber es el que no tienen la actitud fisiológica o capacidad para procrear y por tanto para contraer matrimonio. En la época clásica (130 a.C. a 230 d. C.), se consideraba que habían alcanzado la pubertad los varones a la edad de catorce años y las hembras a los doce. Sobre esta cuestión se dieron diferencias entre sabinianos y proculeyanos. Los proculeyanos establecían la edad de la pubertad a los catorce años en los varones y doce en las hembras con el fin de establecer una uniformidad legal. Los sabinianos establecían que esta edad debía darse, caso por caso, averiguándose mediante una "inspectio corporis", es decir, llevando a cabo una "inspección ocular" sobre el pubis del individuo en cuestión, para apreciar si tenía o no el vello púbico ${ }^{7}$.

Dentro de los impúberes existen tres clases: infanti, infanti proximi y pubertati proximi.

- Infanti, es el impúber que no sabe hablar con razón y juicio (qui fari non potest). Se dieron importantes polémicas sobre el periodo de edad que abarcaba la infancia, estableciendo unos que llegaba hasta los cinco años, otros hasta los siete y algunos hasta los doce. Finalmente Justiniano estableció que llegaba hasta los siete años ${ }^{8}$

El infanti, no puede ser imputado por ningún delito, no es responsable, pues carece de voluntad e inteligencia para causar males a otras personas. No tiene capacidad para interpretar el lenguaje que emplea, de forma razonada y

\footnotetext{
7 Ibidem: op. cit., pág. 728.

8 ARIAS RAMOS, J. y ARIAS BONET, Revista de Derecho Romano, Editora de Derecho Reunidos, Madrid 1988, pág. 87. Ver igualmente GARCÍA GARRIDO Manuel Jesús: Diccionario de Jurisprudencia Romana, pág. 170.
} 
sistemática. Es asimilado al loco (furiosi), así dice Cayo (I- 3, 109), "El infanti y el que está próximo a la infancia no se diferencian mucho del loco, porque los pupilos de esa edad, no tienen ninguna inteligencia”. Se encontraba sometido a tutela por no ser responsable de sus actos, ni de llevar a cabo actos jurídicos y sus declaraciones no se podían tener en cuenta: de todo ello era responsable el tutor.

- Después del infante estaba el infanti próximi, en torno a los nueve o diez años que quedaba equiparado al infanti y no era responsable de sus actos. No podía obligarse ni enajenar, es decir, aquellos actos o negocios que pudieran originarle algún perjuicio. Necesitaba la asistencia de un tutor. Sí podía en cambio, realizar actos que le eran favorables como aceptar un regalo, recibir una cosa, una herencia.

- La última clase o periodo de edad, eran los pubertati próximi que ya eran responsables de algunos hechos delictivos, pues sabían que delinquían y debían responder de esos hechos delictivos. Sus opiniones eran tenidas en cuenta y necesitaban la asistencia de un tutor como en los casos anteriores. Podían llevar a cabo negocios jurídicos, pero siempre reforzados con la autoridad el tutor.

A la pubertad se llegaba a la edad de catorce años en los hombres y doce en las mujeres como se vio anteriormente, con lo que se alcanzaba la plena capacidad para contraer matrimonio, realizar testamento y otros muchos negocios jurídicos. Ello dio lugar a que se cometieran fraudes debido a su inexperiencia, para evitarlo se estableció un curador o curator, cuya misión consistía en intervenir cuando éstos púberes participarán en un negocio complejo como puede ser la enajenación de un patrimonio. El nombramiento de curador o curator se hizo obligatorio para todos los púberes entre catorce y veinticinco años (minori viginti quinque annis). La mayoría de edad se obtenía en Derecho Romano a los veinticinco años, con lo que llegados los púberes a esta edad eran totalmente autónomos para realizar todo tipo de actos y negocios de toda clase. 


\subsection{LA ACCIÓN NOXAL.}

La palabra noxa deriva del latín y quiere decir daño. Consiste en la entrega del autor de un delito al perjudicado, por aquel que le tiene en su poder, para que con el trabajo del infractor quede la víctima indemnizada. Al principio el perjudicado podía elegir entre la exigencia de entrega del infractor o una compensación pecuniaria, pero con el paso del tiempo la compensación pecuniaria se estableció con carácter obligatorio. El hecho de que esta institución se halle regulada en la Ley de las XII Tablas, indica que es el referente más antiguo que se conoce, sobre la actual responsabilidad de los padres por los hechos dañosos de sus hijos del art 1.903 del Código Civil. Todo ello, salvando el paso del tiempo transcurrido y de que actualmente no tenga que entregarse al culpable, el planteamiento del problema y la necesidad de reparar el daño causado responde al mismo fin que se daban en la acción noxal.

Para que se diera la acción noxal, era necesario que el paterfamilias o el dóminus según se tratara de hijo o esclavo, no tuvieran conocimiento del delito, pues si lo conocían, respondían ellos de forma directa, como si lo hubieran realizado ellos mismos y respondía por el todo.

Esta institución se consideró excesivamente cruel, por lo que fue evolucionando paulatinamente. $\mathrm{Al}$ entregar el hijo en noxa y sobre todo la hija del padre padece más que los propios hijos, por todo ello el emperador Justiniano prohibió las acciones noxales con los hijos, quedando subsistente sólo contra los esclavos (Iustituta de Justiniano 4, 8, 7).

\subsection{EL CASO DEL APRENDIZ DE ZAPATERO.}

Este caso es el antecedente más remoto que se conoce sobre la responsabilidad de los maestros sobre los alumnos, se encuentra contemplado en el libro nueve, Título II, fragmento cinco, (D-9-2-5) del Digesto, sobre el Edicto XVIII de Ulpiano. Este mencionado Edicto dio lugar a distintas polémicas entre Chadelaud, Damat y Roujaud sobre si fue o no utilizado en la redacción del $\operatorname{art}^{\circ}$ 1-384 del Code de Napoleón, antecedente del art 1.903 de nuestro Código Civil. 
Chadelaud advierte de la inexistencia de la influencia de este Edicto en la codificación francesa.

Damat obtiene la conclusión contraria y afirma la evidencia de su aplicación al redactar el $\operatorname{art}^{\mathrm{O}} 1384$ del Code.

Por su parte Roujaud dice que el Edicto estuvo claramente presente en los redactores del Código de Napoleón y lo prueba, por los artículos 16 y 17 de la redacción inicial del Code en la que se hallan esos supuestos, los cuales al ser suprimidos en el proyecto definitivo, quedaron inmersos en los genéricos términos del $\operatorname{art}^{\mathrm{o}} 1384$.

Igualmente García Goyena, al comentar el art 1.901 del Proyecto de Código Civil de 1851, se refiere expresamente a un texto inmerso en el ámbito del referido Edicto ${ }^{9}$

El caso del aprendiz de zapatero trata de lo siguiente: "Un zapatero golpeó a un aprendiz libre de nacimiento e hijo de familia, que no hacía bien lo que le había enseñado, en forma tal que con la horma sacó un ojo al aprendiz. Se pregunta la acción que procede contra el zapatero".

Las acciones que intervienen son las siguientes: a) actio ex locato, b) actio iniuriarium, c) actio doli, d) actio legis Aquiliae, e) actio legis Aquiliae utilis.

La actio ex locato o acción derivada del arrendamiento de servicios que el padre del niño contrato con el maestro zapatero, la respuesta de Juliano es que el padre del aprendiz tiene esta acción y por ello dice: "El padre del niño tendrá la acción de locación pues si bien se permite a los maestros dar un leve castigo, no se había atenido a tal medida".

De la actio iniuriarium (acción de injuriar) no se puede aplicar porque no se llevó a cabo el hecho con ánimo de injuriar sino de amonestación.

La actio doli o acción de dolo, atribuida al jurista Aquilio Galo consiste en actuar de mala fe, maquinando o engañando a alguien para perjudicarle. Esta acción no proceder por no existir dolo, sino culpa del zapatero.

En cuanto a la actio legis Aquilae o Ley Aquilia se aplicaba sólo los

${ }_{9}^{9}$ MORENO MARTÍNEZ, Juan Antonio: Responsabilidad... op. cit., págs.. 5 y 6. 
esclavos, por lo que al ser el aprendiz hijo de familia y libre no procede su aplicación.

La actio legis Aquilae utilis sí procede por tratarse el aprendiz de una persona libre, por lo que dice Ulpiano: "Yo no dudo que pueda demandarse por la Ley Aquilia. Cuando la víctima es persona libre tiene una acción de la Ley Aquilia utilis (D-9.2,13). Contra tal acción el padre habrá de conseguir lo que deje de adquirir de los trabajos del hijo a causa del ojo mutilado y los gastos que hubiesen hecho para su curación (D-9.2-7)".

En consecuencia: el Padre tiene la actio ex locato por no tratarse de un leve castigo, sino por haberse excedido gravemente y la actio legis Aquiliae utilis para reclamar los gastos de curación, así como lo dejado de percibir por el ojo dañado ${ }^{10}$.

\section{GLOSADORES Y COMENTARISTAS.}

Los tratadistas medievales siguieron los principios del Derecho Romano y entre los mismos se asimilaba al infans (hasta siete años) con el loco, resultando ambos irresponsables por no tener la capacidad necesaria para discernir entre el bien y el mal. La responsabilidad por sus actos la tenían sus padres o guardadores. A partir de la recepción, los Glosadores del siglo XI restablecieron los tres periodos diferenciados en el Derecho Romano, con alguna variación en torno a la delimitación por edades: infans de cero a siete años; proximus infanti entre 7 y 10 años; y proximus pubertati, de 10 a 14 años en los varones y de 10 a 12 años en las mujeres.

Los Postglosadores o comentaristas siguieron los mismos principios: asimilación del infans con el loco, la obligación de sus padres o guardadores de responsabilizarse de sus actos. "Entre los comentaristas Bártolo de Sassoferrato estableció que los padres of familiares debian responder por los daños ocasionados por los parientes locos", de lo que se deduce que también los infans al asimilarse al loco eran igualmente

\footnotetext{
${ }^{10}$ GARCÍA GARRIDO, Manuel Jesús: Responsa... Centro de Estudios Ramón Areces , Madrid 1989, págs.. $107-$ 109.
} 
irresponsables ${ }^{11}$.

\section{DECRETO DE GRACIANO.}

El Decreto de Graciano sigue los mismos presupuestos o principios del Derecho Romano, vistos anteriormente ${ }^{12}$, la irresponsabilidad del menor de siete años, la división por etapas para delimitar la responsabilidad y la asimilación del infans con el loco. "Si bien Graciano en su obra refleja la procedencia del Derecho Romano, sin embargo, no señaló una edad concreta que delimitará la irresponsabilidad. Los canonistas de la época clásica fueron quienes fijaron el límite mínimo a los siete años, y por encima de esta edad, la capacidad delictual era una cuestión de apreciación en cada caso particular; es decir, hasta la pubertad, fijada ahora a los catorce años para ambos sexos, la exoneración de responsabilidad sólo se producía si se probaba la incapacidad de la persona, pues de otro modo, la impubertad sólo constituía una circunstancia atenuante. Del pensamiento de Graciano se extraen cuáles eran los elementos esenciales que constituían la imputabilidad. En este sentido, destacó la importancia de la voluntad y del conocimiento, siempre que la primera fuera libre y el conocimiento suficiente, pues de otro modo, el acto humano no sería posible”13. Antes de los catorce años, a los niños no se les podrá obligar a jurar y por tanto a ser testigos ${ }^{14}$.

${ }^{11}$ LÓPEZ SÁNCHEZ, Cristina: La responsabilidad civil del menor, Dykinson 2001, (Madrid) págs. 49-50.

12 'El paralelismo en la evolución del derecho de la Iglesia y del derecho secular muestra en la Alta Edad Media Europea cuánto tienen de común ambos derechos. Pues el monje camaldulense y accidente de Bolonia, Graciano, quien con su Decreto que creó la base del Corpus Iuris Canonici, fue coetáneo del fundador de la Escuela de los Glosadores, Irnerio. La cuna de la renovación del derecho de la Iglesia y del derecho secular en la Alta Edad Media se encontró así en la misma ciudad”. WESENBERG, Gerhard y WESENER, Gunter. Hitoria del Derecho Priado Moderno en Alemania y en Europa, Editorial Lex Nova, Valladolid, 1998, pag 49.

${ }^{13}$ LÓPEZ SÁNCHEZ, Cristina, op. cit., pág. 50.

14 'Pueri ante annos quattuordecim non cognatur jurare. Puella cuoque, si in puerili aetate sita in domo patris, illo nesciente, juramento se contrinserit et pater ejes, ut audierit, statim contradixerit, vota ejes et juramenta irritaerunt, et facilius emendatibur”. Decreto de Graciano, Patrología Latina, Tomo CLXXX, CausaXXII, Question V, Canon XV, pág. 1156, Parisis, Apud Garnier Fratres, Editores ET, JP, Mique Successores, In Via 


\section{EL FUERO JUZGO.}

El Fuero Juzgo, fue el código de leyes vigente en España en época de la dominación visigoda y durante la reconquista hasta el reinado de Alfonso X el Sabio. Se encuentra estructurado en doce libros. La tutela se halla regulada en el libro cuarto, título tercero, en cuatro leyes. Es de origen germánico, pues no distingue entre tutela y curatela y sólo trata de la tutela. Llama huérfanos a los que no tienen padre ni madre menores de quince años. No distingue entre derecho civil y penal. La noxalidad la trata en el libro VI, Título V, Ley X y se refiere únicamente a los siervos.

En lo relativo a la enseñanza la trata con gran crueldad, al disponer que si algún hombre mata a su discípulo, al mancebo al que le sirve, sino lo hace con mala intención, no debe ser penado, ni difamado por homicidio ${ }^{15}$. La edad para exigir la responsabilidad se establece a partir de los doce años.

\section{EL FUERO REAL $Y$ SIETE PARTIDAS DE ALFONSO $X$ EL SABIO.}

En el Fuero Real se da una gran influencia del Fuero Juzgo de tal forma que algunos preceptos son muy parecidos. Para poder actuar en los juicios, se exige la edad de dieciséis años como mínimo en los que sean contrarios a sus intereses, pero si sus intereses le son favorables no es necesario que tenga esa edad. Igualmente se exige los dieciséis años para ser testigo en una demanda.

La acción noxal se encuentra referida al caso de hurto, en la que el señor puede deshacerse del siervo en manos de la víctima ${ }^{16}$.

Dicta: Avenue Du Maine, 208. 1891.

15 'Si el maestro que castiga su discípulo loramientre, si por ventura muere daquellas feridas; o el padrón mata a aquel que ainda por ocasión, ó el señor mata al mancebo que lo sirve; si el maestro o el padrón, ó el señor no lo fizo por ninguna malquerencia, ni por ningún odio, non debe ser penado ni desfamado por el omezilio: ca assi cuemo dize la sancta escriptura: Mal aventurado es quien no quiere disciplina”. Fuero Juzgo, Libro VI, Título V, Ley VIII.

16 'Si por mandato de su señor el siervo ficiere algún furto, el señor sea tenido por el furto, e non el siervo: et si 
Las Siete Partidas, tienen una gran influencia del Derecho Romano Clásico, a través de los juristas españoles de la época que habían estudiado en la Universidad de Bolonia. Podemos decir que se da una gran influencia de este derecho en detrimento del derecho germánico propio del Fuero Juzgo. Ello podemos verlo en el tratamiento de la tutela en que en el mencionado Fuero sólo admitió la tutela legítima, mientras que Las Partidas tratan de la legítima, la dativa y la testamentaria, así como de la curatela.

Se establece la menor edad del huérfano en los catorce años para el hombre y doce para la mujer. Para ser tutor se exige como mínimo la edad de veinticinco años, que sea varón y no mujer, que no sea mudo ni sordo, ni desmemoriado ni desgastador, ni de malas maneras. La madre no puede tener a los hijos en tutela si se casa después de haber muerto el marido.

Son curadores los que dan por guardadores a los mayores de catorce años y menores de veinticinco y aún los que fuesen mayores de esa edad si fuesen locos o desmemoriados, se trata por tanto de la institución de la curatela.

$\mathrm{Si}$ es menor de catorce años no puede ser acusado de adulterio, ni de lujuria por entender que no puede darse a esa edad ese tipo de falta. Para el homicidio y el hurto se le puede acusar y castigar por ellos si es mayor de diez años y medio, pero no se le puede dar tan gran pena como a los otros mayores, por lo que podemos ver que constituye una circunstancia atenuante. Otra circunstancia atenuante se da a los menores de diecisiete años ${ }^{17}$.

\section{CODIFICACIÓN FRANCESA.}

Existen tres sistemas de legislación, recopilada, consuetudinaria y codificada.

lo ficiere sin su mandato, el señor faga la enmienda por el siervo, e si no quisiere, de el siervo a aquel a quien fizo el furto”. Fuero Real, pág. 142, Libro IV, Ley V, De los furtos e de las cosas encubiertas.

17 "Qué cosas deben catar los jueces ante que manden dar las penas, et por qué razones los pueden crecer o menguar ó toller... Et por ventura el que habiese así errado fuese menor de diez años et medio, non le deben darpena ninguna: et si fuese mayor desta edad et menor de diez et siete años, débenle menguar la pena que darien á los otros mayores por tal yerro...”. Las Siete Partidas. Partida VII, Ley VIII, Título XXXI. 
La recopilada consiste en unir diversas leyes en general heterogéneas y por orden cronológico, como la Novísima Recopilación en España. En Francia antes de la promulgación del Código de 1804 existían recopilaciones por todo su territorio, muy heterogéneas, sin orden sistemático y que trataban de privilegios feudales. Para evitar esto se trató ya desde antes del siglo XVIII de unificarlas y codificarlas.

Una codificación tiene inconvenientes y ventajas. Entre sus inconvenientes está la resistencia que encuentra en las regiones que tiene su propio derecho. Las modificaciones resultan muy difíciles, pues, si se modifica una parte puede afectar a otras, por lo que se tarda mucho en revisarse. Su formación requiere bastante tiempo y gran cuidado en el legislador para evitar errores.

En cuanto a sus ventajas se consigue antes el dominio de la materia de que se trata; se simplifica su estudio y consulta; son de más fácil aplicación las reglas jurídicas y resulta menos extensa que si se recurre a leyes especiales.

Un código debe de satisfacer unas exigencias formales y de contenido. Debe de ser una ley general y duradera, por ello no debe contener normas ocasionales que solamente se dan para una ocasión determinada, pasajera, más propia de las leyes especiales con un periodo de vigencia limitado. El código más bien debe regular sólo aquellas relaciones que se muestran como elementos inmutables, duraderos de la convivencia social y como dice Bentham: "Un código sólo necesita revisarse aproximadamente cada cien años y esto sólo porque podían haberse introducido cambios en el lenguaje"18.

Por lo que se refiere al contenido, "debe ser proyectado para una sociedad de hombres libres e iguales y proteger la libertad, la igualdad y la propiedad. Tiene que adaptarse a las circunstancias culturales y de desarrollo de un pueblo.

En cuanto a su forma debe establecer reglas, no decisiones de casos; debiendo estar estas reglas formuladas clara y sencillamente, para que cada ciudadano pueda entender el código y conocer sus derechos y limitaciones. Un código debe además estar articulado claramente y construido sistemáticamente y

${ }^{18}$ COING, Helmut: Derecho Privado Europeo. Clásicos Contemporáneos. Munchen, 1989. Tomo II, pág. 28 
con ello ser claro. Debe estar redactado de tal modo que en la decisión de los casos particulares no quede libertad de apreciación. Es la ley quien debe dominar, no el magistrado" 19 .

Antes y durante el siglo XVIII se intentó en Francia la ordenación y simplificación de las leyes, con un código de las características anteriormente expuestas, que superara la división del derecho francés en germánico y romano, lo que no se logró hasta 1804.

Desde 1793 hasta 1799 se presentaron cuatro proyectos de código civil, los tres primeros de Cambacérès y el cuarto de Jaqueminot, todos ellos fueron desestimados, pero del tercero y cuarto se tomaron muchas de sus disposiciones para el definitivo.

El Código Civil o Código de Napoleón fue aprobado el día 21 de marzo de 1804, encargado a una comisión presidida por Cambacérès y formada por prestigiosos juristas como Jean Bigot de Préameneu, Portalis, Tronchet y Malleville.

El actual $\operatorname{art}^{\mathrm{o}} 1384$ se corresponde con el $\operatorname{art}^{\mathrm{o}} 19$ (Tit. IV, libro III) del proyecto de Código Civil presentado por Bigot de Préameneu el 24 de noviembre de 1803 , quedando la responsabilidad de los padres intacta hasta el final, estableciendo en su primer inciso "Se es responsable no solamente del daño causado por el hecho propio, sino también del daño causado por el hecho de las personas de los que se debe responder o de las cosas que se tiene bajo la guarda". A continuación en el inciso segundo, "El padre y la madre tras la muerte del marido, son responsables del daño causado por sus hijos menores que habiten con ellos". Finalmente en el quinto y último inciso se indicaba que esta responsabilidad tenía lugar, a menos que el padre y la madre, patrones y comitentes, probasen que no pudieran impedir el hecho que daba lugar a esta responsabilidad ${ }^{20}$.

${ }^{19}$ Ibidem: op. cit., pág. 28

${ }^{20}$ LÓPEZ SÁNCHEZ, Cristina: op. cit., pág. 65. 
Bertrand de Grenille en su informe al Tribunado declaró que el proyecto no se limitaba a hacer responder a una persona de sus propios actos, sino que pretendía garantizar a la víctima una justa indemnización, permitiéndole además accionar contra la persona de quien dependía el que había causado el daño. De igual forma Tarrible en su discurso al Cuerpo Legislativo dijo: "Los padres, patronos comitentes, artesanos y maestros estaban investidos de un autoridad suficiente para mantener a sus subordinados en los límites del deber y respetando los intereses ajenos. Como consecuencia de ello, si esos intereses eran transgredidos, debía entenderse que había existido un claro relajamiento de la disciplina doméstica y este relajamiento constituye una falta: forma una causa de daño indirecto pero suficiente para hacer recaer sobre ellos la carga de la reparación ${ }^{, 21}$.

\subsection{INFLUENCIA DEL CODE CIVIL FRANCÉS EN EL} MUNDO.

El Code Civil representa lo mejor de los valores de la revolución francesa y del antiguo régimen, por su tolerancia, libertad e igualdad, su lenguaje limpio y sencillo, así como por su perfección técnica, lo que ha hecho que se haya difundido por casi todo el mundo, sirviendo como modelo para muchos países, los cuales en muchos casos han copiado literalmente sus artículos. Su influencia ha tenido lugar en Europa, Rusia, Extremo Oriente, Latinoamérica y África Subsahariana, como expondremos a continuación ${ }^{22}$.

Se introdujo el Code Civil en primer lugar, en los países dominados por Napoleón, como Bélgica, que continuo vigente al alcanzar su independencia en 1830; en Holanda de 1809 a 1838; en Polonia, que entonces se llamaba el Gran Ducado de Varsovia.

En las colonias francesas de América como La Luisiana, que fue vendida

\footnotetext{
21 Ibidem: op. cit., págs. 66 y 67.

${ }^{22}$ NÚÑEZ IGLESIAS, Álvaro. Código Civil Francés, Traducido, Marcial Pons, Madrid 2005.
} 
por Francia a los Estados Unidos en 1803, pero el derecho civil francés continuo vigente, promulgándose en 1808 el Lousianais Digest o Digesto de La Louisiana.

Para Quebec, que fue colonia francesa hasta 1759, continuó siendo regida por el derecho francés dentro del Dominio Británico de Canadá, promulgándose en 1866 un código denominado Code Civil du Bas Canadá, luego Códe Civil de la Province de Quebec, en el que se dan influencias del Common Law.

Por lo que se refiere a Suiza, el Códe entró en vigor en 1804 en los cantones de Ginebra y Berna que eran entonces territorio francés, incorporándose posteriormente a suiza, estuvieron vigentes hasta que entró en vigor el Código Civil Suizo de 1912. Otros cantones suizos como Vaud, Tesino, Friburgo, Neuchâtel o Valais redactaron sus códigos civiles en la primera mitad del siglo XIX siguiendo el Códe Napoleón, estando vigentes igual que los de Ginebra y Berna, hasta 1912.

En Alemania, algunos estados de la orilla izquierda del Rhin fueron incorporados a Francia en 1801, entrando en ellos en vigor el Códe en 1804. Poco después se incorporaron como estado sometidos Danzig y Westfalia en 1807; Baden en 1809; Frankfurt, etc., en los que se impuso el Códe hasta la caída de Napoleón. De ellos sólo continuó en vigor en el Gran Ducado de Baden y en Renania hasta 1900 en que se publicó el Código Civil Alemán (BGB).

Italia siguió una evolución semejante a la de Alemania, pues todavía no había llegado la unificación por lo que se hallaba dividida en varios estados que fueron incorporados a Francia a principios de siglo XIX, entre ellos Génova, Modena, Luca, Toscana, Nápoles, etc., los cuales aplicaron el Códe mientras duró el Imperio de napoleónico.

El primer código civil para todo el reino de Italia es el Codice Civile, Codice Pisanelli o Codice Civile Unitario de 1865, que sigue las mismas tendencias que los códigos anteriores a la unificación; la responsabilidad extracontractual se regula en los artículos 1151 y siguientes bajo el título "Delitti e quasi delitti" y su base lo constituye la culpa, para la cual se exigía dolo. En su artículo 1153 se disponía que cada uno debía responder no sólo por el daño que 
ocasionase, sino también por el que causase la persona de la cual debía responder o las cosas que tenía bajo su custodia; este artículo se corresponde con el 1384 del código civil francés, al igual que los de los textos anteriores a la unificación. Continuo vigente hasta $1942^{23}$.

Portugal tuvo su primer código en 1867, en el que se respeta el derecho tradicional, admitiendo gran parte de las tendencias imperantes en la época. Toma parte del Códe francés, pero no emplea su misma estructura y es más científico o académico. Estuvo vigente durante cien años hasta que en 1966 se aprueba el actual que entró en vigor el primero de enero de 1967. En su artículo 488, señalaba que quien en el momento de producirse el hecho dañoso, no tenía capacidad de entender o de querer no respondería por ello, a no ser que se colocara o pusiera culposamente en ese estado. Presume en su apartado segundo como inimputables a los menores de siete años y a los que sufran anomalía psíquica. Aunque los menores de siete años son inimputables, en el artículo 489 dispone que el inimputable podrá ser condenado, por motivos de equidad, a reparar total o parcialmente, desde el momento en que no sea posible obtener la reparación de las personas encargadas de su vigilancia, debiendo esta reparación o indemnización no privar al menor de los medios indispensables para su alimento conforme a su estado. Vemos por tanto en este artículo del Código de 1967 influencias del derecho germánico y en ese sentido se aparta del Códe.

Los países de Iberoamérica que se independizaron a principios del siglo XIX aplicaban el Derecho español de la época que para ellos eran Las Siete Partidas, las Leyes de Indias y la Novísima Recopilación. A partir de la independencia al hallarse sus dirigentes influidos notoriamente por las ideas de la revolución francesa, el Códe civil francés representará para ellos el ideal a seguir. Por todo ello, empezaron a codificar sus leyes civiles siguiendo el modelo francés, siendo el primero Bolivia (1830), República Dominicana (1845), Perú (1852), México (1866), Venezuela (1873), etc. Sin embargo, a finales del siglo XIX y en el siglo XX algunos de estos países cambiaron de sistema y codificaron sus leyes

${ }^{23}$ LÓPEZ SÁNCHEZ, Cristina: op.cit., pág. 81. 
civiles siguiendo el sistema germánico como es el caso de Perú en su Código de 1984.

En el art. 1975 de este Código de Perú, trata de la persona sujeta a incapacidad, la cual queda obligada a la reparación si ha actuado con discernimiento, siendo solidario con ella su representante legal. Si ha actuado sin discernimiento responde su representante legal ( $\operatorname{art}^{\circ}$. 1976). Para el caso de que la víctima no hubiera conseguido obtener una reparación en el supuesto anterior, en el art. 1977 se halla contemplada una indemnización por equidad, que el Juez considerará de acuerdo con la situación económica de las partes. Quiere ello decir, que se exige responsabilidad a cargo del autor directo del daño como en el sistema germánico.

Para los países de Oriente Próximo, Norte de África y África Subsahariana, que fueron colonias de Francia y algunos que no lo fueron, como Egipto, se ha aplicado el Códe, aunque de forma parcial, pues al tratarse de países islámicos, en lo relativo a familia y sucesiones siempre ha sido aplicadas las leyes islámicas tradicionales.

En consecuencia, el Códe por su perfección técnica, claridad, lenguaje sencillo, tolerancia y demás, ha tenido una influencia de ámbito mundial por lo que puede considerarse el primer código global de la historia.

\section{EL DERECHO INGLÉS.}

En la mayor parte de los países se emplean códigos en su legislación, pero en otros como Inglaterra, Estados Unidos (excepto Louisiana), Canadá (excepto Quebec), Australia, Nueva Zelanda, Islandia y algunos otros países del antiguo Imperio Británico, siguen sistema consuetudinario denominado Common Law.

¿Por qué Inglaterra siguió el sistema consuetudinario? Durante la Edad Media hubo estudiantes ingleses en Bolonia que trataron de introducir el Derecho Romano en Inglaterra, pero ello no les fue posible por encontrarse la justicia residenciada en el Rey, el cual disponía de una Curia Regis, formada por juristas 
profesionales, que se oponían a la penetración de ideas jurídicas extrañas ${ }^{24}$.

La centralización de la justicia se llevó a cabo progresivamente desde el reinado de Enrique II (1154-1189), eligiéndose los juristas entre los secretarios reales, se establecen con Enrique III (1216-1272) en Londres, llegando a formar un estamento que a principios de siglo XIV se llama "legal profession" y forman a sus propios juristas. La abogacía formaba parte del mismo y se dividía en dos clases de abogados: los "pleaders" que actuaban ante los tribunales (actuales barristers) y los "attorneys", que trataban directamente con las partes (actuales sollicitors). Este estamento de juristas se hicieron con el tiempo imprescindibles por lo complejo de la casuística, los estatutos reales y la jurisprudencia de equidad del Canciller.

El derecho común inglés, Common Law, se encuentra formado por las reglas escritas o estatutarias y por las no escritas o consuetudinarias. Las disposiciones del parlamento se llaman actas, en inglés “act". El derecho consuetudinario se compone de la tradición, de las decisiones de los Tribunales, las colecciones de jurisprudencia y los tratados de los jurisconsultos. Este derecho aunque no está comprendido en la ley general, es decir en las actas ( $a c t$ ) del Parlamento tiene el mismo valor que ellas. Esta evolución del derecho inglés, ha sido la que le ha hecho permanecer fuera del derecho continental de tradición romana ${ }^{25}$.

La forma de operar del derecho inglés consiste en buscar la solución del caso, no en que se halle contenida en una definición legal, sino en la similitud con un caso anterior ya resuelto; quiere ello decir, que no tiene en cuenta la abstracción de los códigos y lo deja en manos de la jurisprudencia de los tribunales, del case law.

\footnotetext{
24 Trevelyan: "Si la nación debia recibir un derecho común, éste debia surgir de una única fuente, y ésta sólo podía ser la Curia Real’. WESEMBERG, Gerhard y WESENER, Gunter, op.cit. pag. 128.

25 Trevelyan: "El Common Law, el gran patrimonio heredado de los pueblos de lengua inglesa, los ha separado claramente en sus hábitos de pensamiento del mundo de la traición romana y no se transformó en un código limitado del Codex Justinianus, sino en un laberinto de casos jurídicos, de antiguas y nuevas decisiones, en el que únicamente podía moverse jurista de oficio". Ibidem: op.cit., pág. 129.
} 
Respecto a la edad para ser imputable se establece la edad de siete años, antes de la cual no puede ser condenado por la comisión de un delito, tampoco de los siete a los catorce, salvo prueba en contrario. Para determinar si el acusado, al tiempo de cometer un hecho delictivo, podía distinguir entre un acto bueno y otro malo, había que someterlo a un jurado, que controlara su estado mental y pudiera declarar su irresponsabilidad ${ }^{26}$.

En el Criminal Code Act de 1899, actualmente vigente, la mayoría de edad se establece a partir de los dieciocho años. La persona menor de diez años no es criminalmente responsable y la persona menor de catorce años tampoco es criminalmente responsable, a no ser que se pruebe que al tiempo de cometer el hecho tenía capacidad de saber o conocer que el hecho no debía de ser cometido $^{27}$.

Inglaterra y el derecho anglosajón tienden a la codificación debido a su flexibilidad y al gran número de leyes escritas que se publican continuamente. Ello da lugar a que el caso precedente se vea desplazado en favor de dichas normas escritas.

\section{LA CODIFICACIÓN ALEMANA.}

Alemania antes de 1871 se encontraba fragmentada territorialmente por lo que en cada Estado había un derecho propio con sus correspondientes tribunales.

El primer código que trata de la responsabilidad extracontractual siguiendo el

\footnotetext{
${ }^{26}$ LEYES VICTORIANAS, Volúmenes 46 y 47. Editorial Espasa Calpe, Enciclopedia, Tomo 28, $1^{\text {a }}$ parte.

${ }^{27}$ CRIMINAL CODE ACT, 1899.

1) Part 1, introductory, chapter 1, interpretation in this code: - "Adult means a person of or above the age of 18 years".

2)In mature age, chapter 5, criminal responsibility: - "A person under the age of 10 years is not criminally responsible for any act or omission". - "A person under the age of 14 years is not criminally responsible for an act or omission, unless it is proved that at the time of doing the act or making the omission the person had capacity to know that the person ought not to do the act or make the omission".
} 
modelo racionalista-iusnaturalista es el Código Prusiano de 1794 (Allgemeine Landrecbt für die Preußischen Staaten, ALR). Se aparta de la traición romana en que las acciones son ex delicto, mientras que en el sistema racionalista-iusnaturalista las acciones son ex aequitate. Quiere ello decir, que en la tradición romana, el menor carente de discernimiento y voluntad, de muy corta edad, cuando causa un daño son responsables sus padres, tutores o guardadores y si éstos no son culpables o no pudieron evitar el daño, queda equiparado al caso fortuito o la fuerza mayor; mientras que en el sistema racionalista-iusnaturalista, por el principio de equidad, si los padres, tutores o guardadores no resultan ser culpables, el perjudicado tiene derecho a ser resarcido o indemnizado por el propio autor, aunque este no sea imputable, pero sí es responsable. En todo caso el menor o incapaz en ningún caso se le puede privar de lo necesario para su sustento y educación conforme a su sistema de vida ${ }^{28}$.

A partir de 1871 se empezó a codificar el Derecho Civil de Alemania, nombrando en 1874 una comisión para que formulase un plan informativo. En 1881 a propuesta de la comisión anterior se nombró la que se denominaría "Primera Comisión", presidida por el Presidente del Tribunal Supremo Mercantil "Pape", la cual formó un Primer Proyecto en 1887. En 1890 el Ministerio de Justicia nombró una "Segunda Comisión", que publicó en 1895 el Segundo Proyecto presentándolo al Consejo Federal (Bundesrat) y seguidamente junto a un memorándum al Reichstag en 1896, sin que sufriera modificaciones de importancia, solamente en aspectos de derecho matrimonial y asociaciones. Fue aprobado el día 18 de agosto de 1896 y entró en vigor el día 1 de enero de 1900.

Se encuentra estructurado el Código Civil Alemán (Bürgerliches Gesetzbuch, BGB) en cinco libros: I Parte General, II Derecho de Obligaciones, III Derechos Reales, IV Derecho de Familia y V Derecho de Sucesiones.

28 "El legislador prusiano unificó la categoría de los locos y los niños de edades inferiores a los siete años, puntualizando que siempre que alguno de ellos causase un daño, en primer lugar debían responder las personas encargadas de su vigilancia y sólo cuando éstos no lo hicieran, responderá el propio incapaz, sin que en ningún caso se le pudiera privar de lo imprescindible para su mantenimiento y educación de acuerdo con su modo o forma de vida”. LÓPEZ SÁNCHEZ, Cristina: op.cit., pág. 71. 
La mayoría de edad se establece a los dieciocho años en el artículo número dos. La tutela se trata en el libro IV, sección tercera, título I. La asistencia legal en el título II, de la mencionada sección tercera; y la curatela en el título II de la misma sección. La patria potestad se regula en el título V del libro IV.

En cuanto a la responsabilidad civil extracontractual se encuentra regulado en el libro II, titulo 27, denominado "Actos ilícitos".

Por el artículo 828, en el inciso primero, excluye la responsabilidad de los menores de siete años. En el segundo excluye la responsabilidad de los menores de siete a diez años en lo relativo a accidentes de automóvil, ferrocarril o funicular, a no ser que se hubiera producido dolosamente. En el tercero, el mayor de diez años y menor de dieciocho igualmente no es responsable del acto causante del daño, sino poseía el necesario discernimiento.

El artículo 829 trata del deber de resarcimiento por motivos de equidad y dice: "Quien en los casos previstos por los artículos 823 a 826 no es responsable del daño que ha causado con base en los artículos 827 y 828 debe, no obstante, resarcir el daño, en tanto el resarcimiento del daño no puede ser reclamado de un tercero con deber de vigilancia, si la equidad según las circunstancias, especialmente la relación de las partes, exige una indemnización, siempre y cuando éste no se vea privado de los medios requeridos para su razonable sustento ni para cumplir con sus obligaciones legales de alimentos".

Este artículo 829 hace referencia a los artículos 827 y 828 que tratan de la exclusión y reducción de la responsabilidad, así como de la minoría de edad respectivamente. El daño que causa el que tiene falta de conciencia, enfermedad mental o es menor de edad, tiene que ser reparado por los terceros encargados de su vigilancia, pero si esto no fuera posible se emplea el argumento de la equidad, para exigir una indemnización de acuerdo con las circunstancias y la relación de las partes. Esta indemnización se exigirá al tercero con deber de vigilancia, sin que éste se vea igualmente privado de su razonable sustento, ni para cumplir con sus obligaciones legales de alimentos.

El artículo 827 excluye la responsabilidad a que se encuentra en estado de 
falta de consciencia o de enfermedad mental, por impedir la libre determinación de la voluntad. Si por el contrario, esa falta de consciencia se ha producido, de forma transitoria, por la ingesta de alcohol o cualquier otra sustancia similar, en este caso, el que causa el daño, de responder por realizarlo de forma antijurídica, es decir, contraria a derecho y se le exige como si le fuera imputable la negligencia o lo que es lo mismo falta de diligencia. Si el que causa el daño no tiene culpa la responsabilidad se excluye $e^{29}$.

\subsection{INFLUENCIA DEL CÓDIGO CIVIL ALEMÁN (BGB) EN OTROS PAÍSES.}

El Código Civil alemán ha influido en la codificación civil de varios países por considerarse una obra jurídica maestra, técnicamente más moderna que el Code Civile y opuesta a él. Ello lo podemos ver en países que al dotarse de una codificación moderna, han elegido como modelo al BGB alemán.

Fue Austria la primera en recibir la influencia del BGB, a través de la Novela de $1916^{30}$. Otros países del este de Europa han recibido su influencia como Polonia y Rusia en 1964, así como Grecia en su Código de 1946.

En el código civil italiano de 21 de abril de 1942 se ve también la influencia del BGB, pues aunque en el siglo XIX su código de 1865 estaba influenciado por el Códe francés, en el siglo XX cambia de orientación pasándose al derecho germánico. Por lo que se refiere a la responsabilidad extracontractual esa influencia se contempla en el art ${ }^{\circ}$. 2047, apartado segundo, por lo que en el caso de no obtener el perjudicado una indemnización de los encargados de la vigilancia del menor, el Juez, en consideración a las condiciones económicas de las partes, puede condenar al autor del daño a una indemnización equitativa $^{31}$.

\footnotetext{
${ }^{29}$ Estos artículos del BGB se han obtenido de la traducción del BGB de D. Alberto Lamarca Marqués. Marcial Pons, Madrid 2008.

${ }^{30}$ WIEACKER, Franz: Historia del Derecho Privado en la Edad Moderna. Ed. Aguilar. Madrid 1957. Pág. 311.

$31 \mathrm{Art}^{\circ} .2047$, ap. $2^{\circ}$, "Nel caso in cui il danneggiato non abbia potuto ottenere il risarcimento da chi é tenuto alla
} 
El código civil de Brasil de 11 de enero del 2003 en su artículo 3º declara absolutamente inimputables a los menores de dieciséis años, a los que por enfermedad o deficiencia mental, no tuvieren el discernimiento necesario y a los que por trastorno mental transitorio no podían expresar su voluntad. Por su artículo $4^{\circ}$ a los mayores de dieciséis años y menores de dieciocho los considera parcialmente imputables para ciertos actos. Establece el artículo 928 que el incapaz responde de los daños que cause, si las personas responsables de su guarda no tuvieren obligación de hacerlo, en cuyo caso, la indemnización que deberá ser equitativa, no se llevará a cabo si hay que privar de los medios necesarios al incapaz o personas de los que él dependan. Vemos en este artículo que la inimputabilidad se da hasta una edad muy elevada, lo cual contrasta con otros códigos.

En el código civil de México de 1871, en su artículo 1911, establece que el incapaz que causó un daño a otro debe repararlo, excepto si la responsabilidad recae sobre las personas encargadas de su guarda o vigilancia, tales como padres, tutores, profesores, jefe de taller, maestros artesanos, etc. En el caso de que estas personas no sean responsables y resulten exonerados de ella, la obligación de reparar el daño causado corresponde al propio incapaz ${ }^{32}$.

\section{CODIFICACIÓN ESPAÑOLA.}

La codificación España se produce en el primer tercio del siglo XIX con el código penal de 1822 y la civil en el último tercio del mencionado siglo con el Código Civil de 1889. Se da antes la codificación penal por la necesidad de reforma ya sentida a finales del siglo XVIII, al pedirlo la doctrina y por la no existencia de oposición de los intereses territoriales de las regiones a la misma. En cuanto la codificación civil, se tarda más por no haber una doctrina que

\footnotetext{
sorveglianza, il giudice, in considerazione delle condicioni economiche delle parti, puó condenare l'autore del danno a un'equa indenitá". PERLINGIERI, Giovanni: Codice civile italiano annotato con la dottrina e la giurisprudenza, Edizioni Sccientifiche Italiane, Napoli 2010.

32 Código Civil de México, art. 1911: “El incapaz que cause daño debe repararlo, salvo que la responsabilidad recaiga en las personas de él encargados, conforme lo dispuesto en los artículos 1919, 1920, 1921 y 1922 ”.
} 
sentase los principios en que había de basarse, a la adaptación que la jurisprudencia iba realizando de las leyes del Antiguo Régimen a las necesidades del momento, a los conflictos entre el poder central y los territorios forales y a la inestabilidad política ${ }^{33}$.

\subsection{CODIFICACIÓN PENAL.}

\subsubsection{CÓDIGO PENAL DE 1822.}

En España cada código penal se ha basado en la constitución del momento. En el de 1822 se adapta a los principios de la Constitución de Cádiz de 1812, por lo que es un código liberal. En su artículo 23 se declara irresponsables a los menores de siete años. Si es mayor de siete y menor de diecisiete años, se habrá de examinar si obró o no con discernimiento y según se hallen de desarrolladas sus facultades mentales; si obró sin discernimiento se entrega a las personas encargadas de su guarda y si ellas no pudieran hacerlo se le entregará a una "casa de corrección". Si se declara haber obrado con discernimiento ( $\operatorname{art}^{\circ}$. 25), su castigo será de la cuarta parte a la mitad de la pena señalada al delito cometido. Este código no fue aplicado nunca debido a la inestabilidad política.

\subsubsection{CÓDIGO PENAL DE 1848.}

Este código separa claramente la responsabilidad penal y civil en su artículo 15 donde dice que "toda persona responsable criminalmente lo es también civilmente". En el siguiente artículo establece las reglas para aplicar la responsabilidad civil, aunque se halle exento de responsabilidad penal.

Emplea el criterio de la edad junto con el del discernimiento, al igual que el de 1822 y eleva el límite de la exención de responsabilidad hasta los nueve años en el artículo 82; en el apartado siguiente declara exentos a los de edades comprendidas entre nueve y quince años, siempre que no hubiesen obrado con discernimiento y encarga su apreciación al Tribunal, el cual ha de manifestarlo expresamente.

\footnotetext{
33 BONILLA CORREA, Jesús Ángel y CLEMENTE, Mario E.: La responsabilidad Civil ante un ilícito penal. Monografías Tirant lo Blanch nº 624. Valencia 2009. Pág. 46.
} 
Establece una responsabilidad directa del menor y subsidiaria de los padres o guardadores. Sólo responden los padres o guardadores en el caso de que hubiera por su parte culpa o negligencia, por lo que si no existe esta culpa o negligencia se entiende que la víctima queda sin indemnización.

\subsubsection{CÓDIGO PENAL DE 1850.}

Distingue claramente como el de 1848 entre responsabilidad civil y responsabilidad penal, sin que la exención de la penal, exima de la civil. Emplea en general los mismos postulados que el de 1848. En su $\operatorname{art}^{\circ} .9,2^{\circ}$ contempla como atenuante de la responsabilidad criminal la de ser el culpable menor de dieciocho años. El menor independientemente de su edad responde de forma directa de su responsabilidad civil y los padres o guardadores de forma subsidiaria y subjetiva.

\subsubsection{CÓDIGO PENAL DE 1870.}

Sigue el mismo criterio de edades que los códigos de 1848 y 1850. Hasta los nueve años está exento de responsabilidad. De los nueve a los quince años está exento si obra sin discernimiento y su responsabilidad sería subsidiaria; si obra con discernimiento su responsabilidad pasaría a ser directa. A medida que aumenta la edad, aumenta también el discernimiento y por tanto la responsabilidad; debido a ello en su artículo $9,2^{\circ}$, establece como atenuante el ser el responsable mayor de quince años y menor de dieciocho.

\subsubsection{CÓDIGO PENAL DE 1928.}

En este código penal se seguía regulando la responsabilidad civil, cuando ya se hallaba vigente el código civil de 1889. Por el artículo 77 de este código penal se dispone que en los casos de los artículos 55 y 56, son responsables civilmente de los actos que ejercitase el responsable, los que le tengan bajos su potestad o guarda legal, a no probar que no hubo por su parte culpa o negligencia. No habiendo persona que los tenga bajo su potestad o guarda legal, o siendo aquella insolvente, responderán con sus bienes los mismos enfermos 
mentales o menores en la forma y con las limitaciones relativas a la congrua alimenticia establecida por la leyes civiles.

Por el artículo 65.5 se da un atenuante de la responsabilidad para la edad comprendida entre dieciséis y dieciocho años.

En su artículo 56 establece la irresponsabilidad de los menores de dieciséis años, señalando que los menores de esta edad, responsables de una infracción criminal, serán sometidos a la jurisdicción especial del competente Tribunal Tutelar para Niños.

Este código sigue el criterio del discernimiento para la responsabilidad, al igual que el de 1870, variando los límites de edad.

\subsubsection{CÓDIGO PENAL DE 1932.}

Declara en su artículo 8 exento de responsabilidad criminal, en primer lugar, al enajenado y al que se halle en situación de trastorno mental transitorio, a no ser que haya sido buscado de propósito. Para que la embriaguez exima de responsabilidad ha de ser plena y fortuita. Cuando un enajenado cometa un hecho tipificado como delito, el Tribunal decretará su internamiento en un hospital destinado a esos enfermos, del cual no podrá salir sin la autorización del mismo Tribunal.

En segundo lugar, el menor de dieciséis años, cuando cometa un hecho delictivo será entregado a la jurisdicción de los Tribunales Tutelares de Menores.

En tercer lugar, el sordomudo de nacimiento o desde la infancia que carezca en absoluto de instrucción, si comete un hecho delictivo, será ingresado en un establecimiento de educación de anormales.

En su artículo 20 establece que la exención de responsabilidad criminal no comprende la de la responsabilidad civil, que regula la forma de exigirla en su regla primera: "declarando responsables del enajenado, el menor de dieciséis años y el sordomudo, a los que los tengan bajo su potestad o guarda legal, a no hacer constar que no hubo por su parte culpa ni negligencia. Si no hay persona que los tenga bajo su potestad, guarda legal o fuera ésta insolvente, responderán con sus bienes los mismos enajenados, menores o sordomudos, dentro de los límites que 
señala la ley de Enjuiciamiento Civil para el embargo de bienes".

Sigue por tanto los mismos criterios que el código de 1928 y que a su vez seguirá el de 1944.

\subsubsection{CÓDIGO PENAL DE 1944.}

En este código de 1944, la regulación de la responsabilidad civil y las personas responsables no sufrió ninguna variación, manteniéndose igual en el texto refundido de 1973, continuando con el criterio de los dieciséis años que se mantuvo vigente hasta el Código Penal de 1995. En el artículo 19 de este Código establece que, "los menores de dieciocho años no serán responsables criminalmente con arreglo a este Código. Cuando el menor de dicha edad cometa un hecho delictivo podrá ser responsable con arreglo a lo dispuesto en la ley que regule la responsabilidad del menor".

La ley que regula la responsabilidad del menor es la Ley Orgánica de Responsabilidad Penal de los Menores o LORPM. Ley 5/2000 en cuyo artículo primero, contempla como responsables a los menores de edad comprendida entre catorce y dieciocho años.

\subsection{CODIFICACIÓN CIVIL.}

La codificación civil, como se vio anteriormente, fue más tardía que la penal. Hubo varios proyectos de codificación civil en 1821, 1836 y 1851. El que más interesa es el de 1851 por ser el antecedente del Código Civil de 1889 y al que hace referencia la Ley de Bases de 11 de mayo de 1888, publicadas en la Gaceta de Madrid del día 22 de dicho mes y año, en su Base $1^{\text {a }}$.

En el artículo 5 de la mencionada Ley de Bases contempla la subsistencia del derecho foral en su integridad, sin que sufra alteración por la publicación del Código, que regirá de forma supletoria a esas leyes especiales. El título preliminar del Código será obligatorio para todas las provincias del Reino al igual que la Base $3^{\text {a }}$ sobre el matrimonio. 
El proyecto de Código Civil de 1851, cuyo autor es Don Florencio García Goyena, Presidente de la Sección del Código Civil, y se toma por base según se vio en la Base $1^{\mathrm{a}}$. En la Base $7^{\circ}$, trata de la tutela de los menores no emancipados, dementes y los declarados pródigos o en interdicción civil. La mayor edad la fija en los veintitrés años en la Base $8^{a}$.

La responsabilidad civil la trata en la Base 21, en la que dice en su apartado segundo, "Las obligaciones procedentes de delito o falta quedarán sometidas al Código Penal, ora la responsabilidad civil deba exigirse a los reos, ora las personas bajo cuya custodia y autoridad estuviesen constituidos". Resulta sorprendente que se remita al Código Penal la responsabilidad civil cuando podía haberse aprovechado para tratarla en su correspondiente Código Civil que se estaba redactando ${ }^{34}$.

Su artículo 1900 es el antecedente del 1902 actual y dice: "Todo el que ejecuta un hecho en que interviene algún género de culpa o negligencia, aunque no constituya delito o falta, está obligado a la reparación del perjuicio ocasionado a tercero". El artículo 1901 antecedente del 1903 actual, dice: "La obligación expresada en el artículo precedente no se limita a la reparación de los perjuicios ocasionados por un hecho propio, sino que se extiende a la de los causados por el hecho de las personas que uno tiene bajo su dependencia, o por las cosas que uno se sirve o tiene a su cuidado.

En su consecuencia, el padre la madre viuda son responsables de los perjuicios causados por los hijos que están bajo su potestad, y viven en su compañía.

Los tutores lo son de los perjuicios causados por los menores que están bajo su

34 Base 21 "Se mantendrá el concepto de los cuasi contratos, determinando las responsabilidades que pueda surgir de los distintos hechos voluntarios que les dan causa, conforme a los altos principios de justicia en que descansaba la doctrina del antiguo derecho, unánimemente seguido por los modernos códigos, se fijarán los efectos de la culpa y negligencia, que no constituyan delito ni falta, aun respecto de aquellos bajo cuyo cuidado o dependencia estuviesen los culpables o negligentes, siempre que sobrevenga perjuicio a tercera persona.

Las obligaciones procedentes de delito o falta quedarán sometidas a las disposiciones del Código Penal, ora la responsabilidad civil deba exigirse a los reos, ora a las personas bajo cuya custodia y autoridad estuviesen constituidos". 
autoridad y en su compañía".

Vemos en este artículo que el padre tiene preferencia sobre la madre, es decir, que ésta es responsable sólo en el caso de que se encuentre viuda, en caso contrario la responsabilidad recae sobre el padre. Es necesario para que haya responsabilidad que las personas de las que se responde estén bajo su dependencia, su potestad y que vivan en su compañía.

Se da una exoneración o exculpación en el último apartado donde dice: "La responsabilidad de que se trata en todos los casos de este artículo, cesará cuando las personas en ellos mencionados prueben que emplearon toda la diligencia de un buen padre de familia para prevenir el daño".

En el Código Civil de 1889 la redacción del art ${ }^{\circ} .1903$ es similar a la del art ${ }^{\circ} .1901$ del Proyecto de 1851 y dice: "La obligación que impone el artículo anterior es exigible, no sólo por los actos u omisiones propias, sino por las de aquellas personas de quienes debe responder. El padre y por muerte o incapacidad de este la madre, son responsables por los perjuicios por los hijos menores de edad que viven en su compañía".

Por su redacción original vemos que responder en primer lugar el padre y la madre por muerte o incapacidad del marido, no hablando de incapacidad en el Proyecto de 1851, que dice: "el padre y la madre viuda". Emplea la expresión, "por los hijos menores de edad que viven en su compañía", mientras que el Proyecto de 1851 decía: "por los hijos que están bajo su potestad y viven en su compañia".

En el último párrafo trata de la exoneración de las personas responsables en términos similares al Proyecto de 1851, "si hubieran empleado la diligencia de un buen padre de familia para prevenir el daño".

Debido la reforma de $1981^{35}$, se modificó el párrafo segundo de este artículo, quedando redactado así: "Los padres son responsables de los daños causados por los hijos que se encuentran bajo su guarda". Ya se habla de guarda, no de potestad, y se suprime el requisito de que viven en su compañía. Se establece una

\footnotetext{
${ }^{35}$ Ley 11/1981, de 13 de mayo de modificación del Código Civil en materia de filiación, patria potestad y régimen económico del matrimonio, publicada en el BOE, $\mathrm{n}^{\circ}$ 119, de 19 de mayo.
} 
patria potestad dual o conjunta, es decir, conjuntamente por ambos progenitores, o por uno solo, con el consentimiento del otro, en el artículo 156 donde dice: "La patria potestad se ejercerá conjuntamente por ambos progenitores o por uno solo con el conocimiento expreso o tácito del otro. Serán válidos los actos que realice uno de ellos conforme al uso social y a las circunstancias o en situaciones de urgente necesidad".

\section{CONSTITUCIONALIZACIÓN DEL DERECHO A LA EDUCACIÓN.}

Las primeras constituciones que contemplaron el derecho a la educación se dieron en la segunda década del siglo XX. La primera fue la Constitución de México de 1917 y la segunda la Constitución alemana de Weimar de 1919.

A partir de los años 50 el derecho a la educación se ha generalizado en todos los países, por lo que aparece contemplado en todas las constituciones.

Para España la primera que contempla tal derecho es la Constitución de 1931 y después la de 1978, que serán analizadas en el capítulo correspondiente a la responsabilidad del profesorado.

\section{PRINCIPIOS DEL DERECHO EUROPEO DE LA RESPONSABILIDAD CIVIL.}

En las últimas décadas se viene produciendo en Europa diversos intentos de europeización del Derecho Privado, orientados a conseguir algo parecido al ius commune que se daba en Europa antes de llegar a la formación de las codificaciones nacionales.

Para conseguir esta europeización del Derecho Privado se pueden adoptar varias modalidades como las siguientes:

- Realización de estudios de Derecho comparado por parte de los juristas de diversos países, para influir en los parlamentos y conseguir 
modificaciones legislativas.

- Tratar de conseguir una unificación del Derecho Privado mediante la formación de un Código Civil europeo, algo que llegará a conseguirse pero a largo plazo.

- Formación de unas reglas generales o de unos principios para homogeneizar las cuestiones relativas a la responsabilidad civil o law of torts, que es la que nos interesa. ${ }^{36}$

Estos principios han sido redactados por el European Group on Tort Law, (en adelante PETL) o Principios de Derecho Europeo de la responsabilidad civil y son el resultado del trabajo de un amplio grupo internacional de expertos en la materia. Este grupo se llamaba antes Grupo de Tilburg y llevan trabajando desde el año 1992 en el campo de la responsabilidad civil, así como sobre cuestiones de reciente desarrollo y de futura orientación de la misma. Es un grupo principalmente europeo, pues sus miembros proceden en su mayor parte de países de la Unión Europea, Europa del Este, Israel, Sudáfrica, así como destacados especialistas Norteamericanos ya que las variaciones que tiene lugar en los Estados Unidos influyen de modo creciente en el Derecho europeo de la responsabilidad civil y deben ser tenidos en cuenta. ${ }^{37}$ Son un primer paso hacia un verdadero Derecho europeo de la responsabilidad civil, "el objetivo de estos principios es servir de base para mejorar y armonizar el Derecho de la responsabilidad civil en Europa. Es de esperar que pueda servir como una especie de marco de referencia para el ulterior desarrollo de un Derecho de la

\footnotetext{
${ }^{36}$ Lasarte Carlos, Derecho de Obligaciones, Tomo II, 17 Edición, Marcial Pons, 2013, pag. 2, 265 y 266.

${ }^{37} \mathrm{El}$ European Group of Tort Law fue fundado en el año 1992 por Jaap Spier y se halla integrado por juristas de países tanto de la Unión Europea como de otros de fuera de ella; como Widmer de Suiza, Neetheling de Sudáfrica y Gilead de Israel. De Estados Unidos Dobbs y Schwartz, éste último sustituido por Green debido a su fallecimiento en 2002.

Para la realización de sus trabajos y la consecución de sus objetivos este grupo se encuentra apoyado por el European Centre of Tort and Insurance Law, cuya sede se encuentra en Viena dirigida por Koziol, miembro a su vez del grupo.

En el grupo participa como ponente español, el profesor Miquel Martín Casals, catedrático de la Universidad de Girona. (Ibidem pag 265 y 266)
} 
responsabilidad civil verdaderamente armonizado. En este sentido, son parecidos, por ejemplo, a los Principios Lando, y adoptan su estructura y sistema de numeración. No son un restatement o reformulación del Derecho de la responsabilidad civil existente en Europa. A fin de cuentas, y a pesar de las muchas similitudes, hay demasiadas diferencias entre los respectivos ordenamientos jurídicos nacionales. Por ello todavía no existen una bases sólidas para llevar a cabo una reformulación" 38 .

Para España la traducción de estos trabajos es la llevada a cabo por miembros de la Red Española de Derecho Privado Europeo y Comparado (REDPEC), formada en la actualidad por componentes de diversos equipos de investigación de una docena de universidades españolas.

En el Tribunal Supremo español y otros Tribunales españoles han sido objeto de atención y tenidos en cuenta en su resoluciones. Como ejemplos podemos citar los SSTS de 6 de marzo de 2007 (RJ 2007/1828) y 10 de octubre de 2007 (RJ 2007/6813) relativos al artº. 6:102 PETL relativo al estándar de conducta exigible en la supervisión de otros. La sentencia de 17 de julio de 2007 (RJ 2007/4895) se refiere al art ${ }^{\circ}$. 4:102 PETL en el estándar de conducta exigible en los supuestos de culpa, en la que se relaciona con el art ${ }^{\circ}$. 1902, así como con el $\operatorname{art}^{\circ} .1104$ sobre la diligencia de un buen padre de familia.

La norma fundamental del PETL se halla contemplada en el Título I, Capítulo 1, $\operatorname{Art}^{\mathrm{o}}$. 1: 101 y dice lo siguiente ${ }^{39}$ :

1) La persona a quien se pueda imputar jurídicamente el daño sufrido por

\footnotetext{
${ }^{38}$ European Group on Tort Law, Introducción General. Thompson, Aranzadi, Navarra 2008. Págs. 44 y 46.

39 TITLE I. Basic Norm.

Chapiter1. Basic Norm.

Art $^{\circ}$. 1:101 Basic Norm.

1) A person to whom damage to another is legally attributed is liable to compensate that damage.

2) Damage may be attributed in particular to the person.

a) whose conduct constituting faults caused; or

b) whose abnormally dangerous activity has caused it; or

c) whose auxiliary has caused it within the scope of his functions.
}

Ibidem, pág. 25. 
otra está obligada a repararlo.

2) En particular, el daño puede imputarse a la persona.

a) cuya conducta culposa lo haya causado; o

b) cuya actividad anormalmente peligrosa lo haya causado; o

c) Cuyo auxiliar lo haya causado en el ejercicio de sus funciones.

En el punto primero quiere decir que para atribuir un daño a una persona tienen que darse unos presupuestos como que sea un daño que corresponda al daño sufrido por la víctima, que sea jurídicamente protegido, es decir, que no se trate por ejemplo de una actividad ilegal. Cada persona tiene que cargar con el daño que sufra a no ser que lo pueda imputar o desplazar a otra. El daño debe ser compensado, por ello, la persona que sufre un daño por obra de otra, según la responsabilidad civil tiene que ser compensada de ese daño. La compensación consiste en una indemnización que la persona responsable tiene que dar a la víctima para restablecerla en la situación anterior.

Los fundamentos de responsabilidad enumerados en el punto segundo no son jerárquicamente descendentes, ni que tengan más valor o importancia unos que otros, simplemente son iguales y alternativos así como diferentes por basarse en fundamentos distintos, coexistiendo uno al lado del otro.

La persona se entiende como persona física y también la jurídica y la conducta puede ser tanto por acción como por omisión ${ }^{40}$.

${ }^{40}$ Ibidem, págs.. 16, 49, 50 y 51. 


\section{CAPÍTULO SEGUNDO: LA RESPONSABILIDAD DEL MENOR QUE CAUSA EL DAÑO}

\section{LA RESPONSABILIDAD CIVIL EN EL ORDENAMIENTO JURÍDICO ESPAÑOL}

En el ordenamiento jurídico español la responsabilidad civil se ha regulado a partir de la codificación en más de un texto legal. El código civil regula la responsabilidad civil extracontractual en los artículos 1902, 1903 y 1904. Por lo que se refiere al actual código penal en su artículo116, apartado $1^{\circ}$, dice: "Toda persona criminalmente responsable de un delito o falta lo es también civilmente si del hecho se derivaran daños o perjuicios". Se efectúa un reenvío del Código penal a la LORPM, mediante el artículo 19 que dice "Los menores de 18 años no serán responsables criminalmente con arreglo a este Código. Cuando un menor de dicha edad cometa un hecho delictivo podrá ser responsable con arreglo a lo dispuesto en la ley que regule la responsabilidad penal del menor".

Para establecer la responsabilidad civil extracontractual aplicada a los menores de edad hay que estar a lo que dispone el Código civil y la LORPM según la edad del infractor, el tipo de delito o falta y según se reserve o no el perjudicado las acciones civiles.

Se aplica el código civil cuando el menor comete unos hechos que no se hallan tipificados penalmente. De igual forma cuando el menor comete un hecho tipificado penalmente siendo menor de catorce años y aunque tenga más de catorce años y menor de dieciocho, si el perjudicado se ha reservado las acciones civiles.

Sólo se aplica la LORPM ${ }^{41}$, cuando el menor mayor de catorce años y menor de dieciocho, hubiera cometido hechos generadores de

\footnotetext{
${ }^{41}$ Ley 0.5/200 de 12 de enero, reformada por Ley 0.8/2006 de 4 de diciembre.
} 
responsabilidad civil, tipificados penalmente y el perjudicado no se hubiere reservado las acciones civiles.

\section{LA IMPUTABILIDAD PENAL}

Imputabilidad deriva del latín imputare y quiere decir atribuir a alguien un hecho, culpa o delito. Imputabilidad desde el punto de vista del Derecho es la aptitud de una persona para que pueda atribuírsele una culpa. Tiene dos elementos, componentes o capacidades: de entender y de querer. La capacidad de entender se refiere a la inteligencia, el juicio y el discernimiento, distinguir entre el bien y el mal; por el contrario, la capacidad de querer hace referencia a la voluntad, a la capacidad de orientar su conducta en el sentido deseado. Los niños de corta edad son abúlicos es decir, carecen de fuerza de voluntad y no son capaces de orientar su conducta.

Tener capacidad de entender y de querer implica ser libre. Si no se tiene libertad, no se le puede imputar a un sujeto ninguna culpa. El derecho se encuentra basado en la idea de libertad, si esta no existe, si el sujeto se encuentra coaccionado, resulta ser inimputable.

La culpabilidad es la conducta reprochable a quien la realizó y es culpable el que omite la diligencia debida. Actúa culpablemente el que con arreglo al ordenamiento jurídico pudo proceder de otra manera distinta a como lo hizo. Por ello, si el sujeto no es libre, si se encuentra coaccionado, no se le puede exigir actuar de una manera determinada, ser diligente o reprocharle una conducta determinada.

Ser imputable y por tanto, culpable es algo subjetivo, interno del sujeto que comete el acto reprochable.

Para la capacidad de entender hay que ver la personalidad del menor que se considere, su grado de madurez intelectual, para poder valorar su grado de discernimiento o capacidad de culpa. La madurez varía significativamente de unas personas a otras y aumenta con el paso de la 
edad. Interesa saber si el menor es capaz de entender el alcance de sus actos y las posibles consecuencias que se derivan de los mismos.

En cuanto al otro componente de la imputabilidad, la voluntad del menor, la capacidad de querer y de acomodar o adaptar su conducta a su entendimiento, a la comprensión del injusto. Supone autocontrol de su comportamiento. $^{42}$

\section{TEORÍA DEL DESARROLLO HUMANO}

La madurez de una persona depende de factores psicológicos, biológicos, morales cognitivos, sociales, etc, por lo que para su estudio conviene utilizar tratados de psicología y dividirlo por etapas y periodos. Estas etapas son: la infancia, la niñez y la adolescencia.

\subsection{INFANCIA}

En la etapa de la infancia se pueden considerar dos periodos: el sensorio motriz de 0 a 2 años y el pre operacional de 2 a 7 años ${ }^{43}$, según Piaget.

El período sensorio motriz según el psicólogo suizo Jean Piaget, el lactante adquiere la capacidad de organizar actividades en torno a su ambiente mediante habilidades sensoriales y motoras. Según Dadivoff, "los niños empiezan a distinguir entre lo bueno y lo malo, y entre ayudar y causar daños a edades tempranas. Los niños de dos años ya suelen intentar acudir en ayuda de personas en situación de desgracia". ${ }^{44}$

En el periodo pre operacional (de 2 a 7 años). El niño desarrolla un

\footnotetext{
42 Existe un rescripto de Adriano en el Digesto "En los maleficios se atiende ala voluntad, no al resultado" (D 48,8,14). "In maleficiis voluntas spectatur non exitus". Tesis Aristotélico - tomista "Toda culpabilidad es culpabilidad de la voluntad; sin un elemento volitivo, un querer del sujeto, no hay culpabilidad". Jose María Rodríguez Devesa, Derecho Penal Español, Dykinson, Madrid, 1990, pag. 433.

${ }^{43}$ Feldman, Robert S (2009), Desarrollo Psicológico, Universidad de Massachusetts, traducción de María Elena Ortiz Salinas, Pearson Educatión, pag 170 y ss.

${ }^{44}$ Bonilla Correa, op.cit, pag. 126, nota 50.
} 
sistema representacional y utiliza símbolos para poder representar objetos, personas, lugares, eventos, etc. Según Piaget, en este periodo aumenta el pensamiento simbólico en los niños, surge el razonamiento y se incrementa el uso de conceptos; el lenguaje y el pensamiento están fuertemente relacionados.

Se da la función simbólica que es la habilidad que tiene un niño para usar un símbolo mental, una palabra o un objeto que signifique o represente algo que no está físicamente presente.

Suelen centrarse en un punto específico de un estímulo e ignorar los demás, no pueden atender toda la información que reciben, sino que se enfocan en los elementos superficiales, obvios, que están al alcance de la vista. Esos elementos externos dominan su pensamiento y dan lugar a imprecisiones.

Los menores de este periodo llamado preescolar por Piaget, son fundamentalmente egocéntricos, quiere ello decir, que son incapaces para tomar en cuenta la perspectiva de los demás, lo cual no implica que piensen de manera egoísta o desconsiderada. Este egocentrismo adopta dos formas: primero, la falta de conciencia de que los demás ven en las cosas desde una perspectiva física diferente y segundo, la incapacidad para darse cuenta de que los demás tienen pensamientos, sentimientos y puntos de vista que quizá difieran de los suyos.

El lenguaje es característico de este periodo, desarrolla igualmente el juego imaginativo, así como el pensamiento intuitivo con su adquisición de conocimientos acerca del mundo y razonamiento primitivo; pero a pesar de ello el pensamiento aún no es lógico ${ }^{45}$.

\subsection{NIÑEZ}

Para el periodo operacional concreto (de 7 a 11 años), el niño es capaz de desarrollar un pensamiento lógico, por lo tanto, tiene la capacidad

\footnotetext{
${ }^{45}$ Friedman, Robert S, Desarrollo, op.cit, pag 235 y ss.
} 
para resolver problemas de manera lógica, pero aún no puede pensar en términos abstractos. Es la etapa de los escolares en que se da el uso de razón. Los niños se encuentran en la etapa de industriosidad frente a inferioridad, concentrándose en lograr destrezas y responder a una amplia gama de desafíos personales. Usan la comparación social para evaluar su conducta, habilidades, pericia y opiniones. Desarrollan su autoestima, si es alta triunfarán seguramente en la vida; pero si es baja, y esta baja autoestima se cronifica, puede dar lugar a que sea en el futuro un fracasado social, si no logra corregirlo.

En cuanto al sentido del bien y del mal, los niños pasan de una moral pre convencional, motivada por recompensas y castigos para inclinarles a obrar bien; a una moral convencional, en la que su referente sea los valores de la sociedad en que se halla inmerso; para llegar a la moralidad pos convencional en la que imperarán los valores morales universales ${ }^{46}$.

\subsection{ADOLESCENCIA}

La etapa de las operaciones formales (de 11 o 12 años hasta la edad adulta), es la etapa en que la persona puede pensar de una manera abstracta, acerca de diferentes situaciones y es capaz de lidiar con situaciones hipotéticas y pensar en las distintas posibilidades. Su crecimiento cognoscitivo es rápido, con grandes avances en el razonamiento científico y mejoras en la capacidad de memoria. El desarrollo de sus habilidades cognoscitivas promueve una cierta forma de egocentrismo adolescente, por la conciencia de sí mismos como entidades independientes, con lo que les resulta difícil aceptar las críticas y las figuras de autoridad ${ }^{47}$. El adolescente es ya plenamente consciente de lo que hace, sabe muy bien discernir entre el bien y el mal y se le pueden exigir responsabilidades por los hechos que realiza, puede resultar imputable por delitos y faltas, sobre todo a medida

\footnotetext{
46 Ibidem, op cit, pag. 385 y ss

47 Ibidem, op cit, pag. 420 y ss.
} 
que se va acercando a la mayoría de edad, a mayor edad mayor responsabilidad.

\section{LA EDAD EN EL CÓDIGO PENAL VIGENTE}

Como vimos anteriormente en el artículo 19CP, los menores de dieciocho años no son responsables criminalmente, por lo que hay que estar a lo que dispone la ley que regule la responsabilidad penal del menor, y esta es la ley Orgánica 5/2000, de 12 de enero, modificada por LO 8/2006.

El legislador y la doctrina, han estimado que los menores de edad incursos en un proceso penal, les sea aplicado un derecho penal apropiado a su edad y orientado a educar y corregir al menor. No quiere ello decir, que el menor vaya a ser declarado irresponsable, o se le imponga una pena menor; de lo que se trata es de diferenciar o separar el derecho penal de adultos del derecho penal de menores, con otras pautas o criterios, es decir, un derecho penal independiente.

Los tramos de edad en la LORPM son en su parte superior los dieciocho años y en la inferior los catorce como establece el artículo $1^{\circ}$, apdo primero, donde dice, "Esta ley se aplicará para exigir la responsabilidad de las personas mayores de catorce años y menores de dieciocho por la comisión de hechos tipificados como delitos o faltas en el Código Penal o las leyes especiales".

\subsection{MENORES DE CATORCE A DIECIOCHO AÑOS}

De acuerdo con el artículo 5 LORPM, Aptado 1, "Los menores serán responsables con arreglo a esta ley cuando hayan cometido los hechos a los que se refiere el artículo 1 y no concurra ninguna de las causas de exención o extinción de la responsabilidad criminal prevista en el vigente Código Penal".

En esta edad el elemento intelectivo se encuentra suficientemente desarrollado, sin embargo, lo que no se ha desarrollado suficientemente es la voluntad, por lo que no se tiene suficiente carácter, madurez social y fuerza 
de voluntad para oponerse a la comprensión material del injusto ${ }^{48}$.

El artículo 12 C. E. establece que "los españoles son mayores de edad a los dieciocho años", por lo que este es el límite superior de la LORPM, al igual que la mayoría de las disposiciones internacionales ${ }^{49}$.

Cuando el menor se halle cumpliendo la condena en un establecimiento especial de menores y llegue a la mayoría de edad, podrá continuar en el mencionado establecimiento, si la conducta de la persona internada responde a los objetivos propuestos en la sentencia, según el $\operatorname{art}^{\circ}$ 14, apartados 1, 2 y 3 de la LORPM. En caso contrario el Juez de Menores puede ordenar su ingreso en un establecimiento penitenciario general. Todo depende por tanto de la conducta del menor.

La LORPM en su redacción original estableció la continuidad del menor que llegara a la mayoría de edad y no hubiera cumplido la pena, en cuyo caso continuaría, hasta los veintiún años o más en el establecimiento de menores. Esto se ha suprimido por la Ley 8/2006, en la que se ha derogado ese precepto, dando una nueva redacción a la Ley 5/2000, variando de forma sustancial diversos preceptos, en los que ya no se contempla la estancia en centros de menores a las edades comprendidas entre dieciocho y veintiún años.

Supone la Ley 8/2006 un endurecimiento de la medida de internamiento en régimen cerrado, para lo que el Juez dispone de importante discrecionalidad, con lo que puede establecer a partir de los dieciocho años del menor la continuidad en el establecimiento de menores,

48 Jesús Ángel Bonilla Correa, op cit, pag. 113.

49- El $\operatorname{art}^{\mathrm{o}} 1$ de la Convención de Derechos del Niño dispone que "niño es la persona que no ha cumplido los dieciocho años".

-El Pacto Internacional de Derechos Civiles y Políticos de Nueva York, de 19 de Diciembre de 1966 (BOE de 30 de abril de 1966), prohíbe la imposición de pena de muerte "por delitos cometidos por personas de menos de dieciocho años".

- Reglas de las Naciones Unidas para la protección de los menores privados de libertad, $\operatorname{art}^{\mathrm{o}}$ 11, a "se entiende por menor toda persona menor de dieciocho años de edad". 
si se cumplen los objetivos propuestos en la sentencia, pero si no es así, deberá oír al Ministerio Fiscal, al letrado del menor, al equipo técnico y a la entidad pública de protección o reforma y ordenar su ingreso en un centro penitenciario del régimen general penitenciario según el $\operatorname{art}^{\circ} 14.2$ de la LORPM.

La mención que hace al equipo técnico el artículo anterior es a los técnicos que asisten a los jueces, tales como psicólogos, médicos especializados en psiquiatría y otras especialidades que son necesarias para que puedan fundamentar correctamente sus resoluciones.

En cuanto al límite inferior en los catorce años, tiene por objeto diferenciar a un niño de un adolescente y no aplicarles a los niños normas penales, pues antes de los catorce años las cualidades volitivas de estos menores no se encuentran plenamente desarrolladas y por ello, precisan la aplicación de unas normas más benignas.

\subsection{MENORES DE CATORCE AÑOS}

De acuerdo con el $\operatorname{art}^{\circ} 3$ LORPM "Cuando el autor de los hechos mencionados en los artículos anteriores sea menor de catorce años, no se le exigirá responsabilidad con arreglo a la presente Ley, sino que se le aplicará lo dispuesto en las normas sobre protección de menores prescritas en el Código Civil y demás disposiciones vigente. El Ministerio Fiscal deberá remitir a la entidad pública de protección de menores testimonio de los particulares que considere precisos respecto al menor, a fin de promover las medidas de protección adecuadas a las circunstancias de aquél conforme a la Ley Orgánica 1/1996 de 15 de enero”:

El establecer la edad de los catorce años por debajo de la cual se excluye la responsabilidad, se fundamenta, según el apartado cuatro de la Exposición de Motivos de la Ley en la que se dice que "las infracciones cometidas por los menores de esta edad son en generar irrelevantes y que en los casos que puedan producir alarma social, son suficientes para darles una respuesta igualmente adecuada los ámbitos familiar y asistencia civil sin 
necesidad de la intervención del aparato judicial sancionadas del Estado".

La expresión de que "son en general irrelevantes", las infracciones de los niños menores de esta edad, no se ajusta a la realidad de los hechos, pues cada vez son más numerosos y desciende la edad de menores que cometen infracciones muy graves ${ }^{50}$.

En consecuencia, se podría haber establecido en los doce años en vez de en los catorce, toda vez que, a partir de los doce los criterios biológico de la edad y psicológico de la madurez, es decir, discernimiento y voluntad estén suficientemente desarrollados para poder ser responsables. Pero el legislador estableció la franja en los catorce años para diferenciar entre niño y adolescente y a ello tenemos que ajustarnos en la exigencia de responsabilidad. Los menores de catorce años son absolutamente irresponsables criminalmente y cuando cometen una infracción penal, han de ser juzgados por lo que disponga el código civil.

\section{CAUSAS DE EXENCIÓN DE LA RESPONSABILIDAD}

\section{CRIMINAL}

El art 5 de la LORPM en su párrafo 1 dice: "Los menores serán responsables con arreglo a esta ley cuando hayan cometido los hechos a los que se refiere el artículo 1 y no concurra en ellos ninguna de las causas de exención o extinción de la responsabilidad criminal previstas en el vigente Código Penal". En su párrafo 2 dice: "No obstante, lo anterior, a los

\footnotetext{
50 STS no 411/ 1999, de 12 de mayo, (RJ 1999/3053) (pte Gullón Ballesteros), El menor Alberto de trece años de edad, disparó con una escopeta de balines contra una persona a la que se le causó la muerte por un disparo, al mismo tiempo que manifestó expresiones de su deseo de matarlo, tales como "voy a cargármelo", "voy a matarlo". Por ellos no es un suceso imprevisible, se trata de algo deliberado, totalmente imputable como autor material de la muerte del hijo de los recurrentes.

STS de 8 de febrero de 1983 (RJ 1983/867), el menor Julio, de doce años de edad, jugando al "pelotón”, junto a otros menores, disparó grapas con tiradores de gorma, alcanzando al menor Eduardo de diez años, no interviniendo en el juego, en su ojo derecho, quedándole como secuela "afasia” en el citado ojo.
} 
menores en quienes concurran las circunstancias previstas en los números $1^{\circ}, 2^{\circ}$ y $3^{\circ}$ del $\operatorname{art}^{\circ} 20$ del vigente Código Penal les serán aplicables en caso necesario, las medidas terapéuticas a las que se refiere el $\operatorname{art}^{\mathrm{O}} 7.1$, letras d) y e), de la presente ley".

Se hallan contempladas en el $\operatorname{art}^{\mathrm{o}} 20$ del C. P., un total de siete casos de exención de la responsabilidad criminal, unas son causas de justificación y otras eximentes.

Las causas de justificación son: la legítima defensa ( $\operatorname{rrt}^{\mathrm{o}}$ 20.4), el estado de necesidad justificante ( $\operatorname{art}^{\mathrm{O}}$ 20.5) y el ejercicio legítimo de un derecho oficio o cargo ( $\left.\operatorname{art}^{\circ} 20.7\right)$, en estos casos cuando se cumplan los requisitos necesario y se halle justificada la conducta, el menor quedará exento de responsabilidad penal y civil, pudiendo el Ministerio Fiscal solicitar el sobreseimiento de la causa de acuerdo con el $\operatorname{art}^{\circ} 30.4$ de la LORPM.

En cuanto a las circunstancias eximentes se dan cuatro: enajenación mental o trastorno mental transitorio, siempre que este no haya sido buscado a propósito para delinquir ( $\operatorname{art}^{\mathrm{o}} 20.1$ ); intoxicación plena por consumo de bebidas alcohólicas o sustancias tóxicas, estupefacientes, psicotrópicos u otros que produzcan efectos análogos o actuación bajo síndrome de abstinencia, siempre como en el caso anterior que no se hayan buscado de propósito para cometerlas o no se hubiese previsto o debido prever su comisión ( $\operatorname{rrt}^{\mathrm{o}}$ 20. 2); alteraciones en la percepción de la realidad $\left(\operatorname{art}^{\mathrm{o}} 20.3\right)$ y miedo insuperable ( $\left.\operatorname{art}^{\mathrm{o}} 20.6\right)$. Al ser en estos casos el menos inimputable se da una irresponsabilidad penal, pero subsiste la civil, sin aplicarle sanción, y se establecen medidas terapéuticas del $\operatorname{art}^{\circ} 7$, de la LORPM.

Para los menores en quienes concurran las circunstancias previstas en los números $1^{\circ}, 2^{\circ}$ y $3^{\circ}$ del artículo 20 del Código Penal, se establecen las medidas contempladas en el artículo 7.1, letras d) y e) de la LORPM, las cuales consisten en internamiento terapéutico y tratamiento ambulatorio. 
El internamiento terapéutico tiene por objeto tratar anomalías o alteraciones psíquicas, alcoholismo, drogadicción, alteraciones en la percepción y otros de carácter análogo. Es una medida de seguridad basada en la peligrosidad criminal de este tipo de jóvenes y tiene prioridad sobre los demás internamientos. Puede darse en régimen cerrado, semiabierto o abierto según la evolución del menor.

A veces se dan en la práctica, situaciones en que a jóvenes declarados imputables, se les asigna un internamiento terapéutico, por tener problemas psíquicos o dependencias menores, a las que se puede aplicar un tratamiento distinto y menos severo. Se ha observado que en ocasiones en los informes técnicos un menor presenta un trastorno de personalidad, en el que se comprenden alteraciones del comportamiento que no llegan a diagnosticarse como anomalías o alteraciones psíquicas, y que podrían tratarse con un tratamiento ambulatorio de tipo psicológico ${ }^{51}$.

En cuanto a los resultados se refiere con los jóvenes infractores adictos, a juicio de los especialistas que trabajan con ellos, son muy pocos los casos de fracaso y abandono, además de realizarles periódicamente seguimientos para evitar recaídas. Estos especialistas cuando se les pregunta sobre su labor son optimistas y reivindican a la Administración autonómica mayores medios ${ }^{52}$.

Los menores en tratamiento ambulatorio, presentan problemas de adicción, alteraciones psíquicas o en la percepción y no precisan el estar alejados de su entorno familiar y educativo. Es suficiente en estos casos, la asistencia a un centro facultativo, con la frecuencia que se indique, para su tratamiento y seguir las prescripciones médicas que se estimen, con el fin de poder superar sus problemas.

\footnotetext{
${ }^{51}$ García Pérez: 2006, Comentarios a la Ley Penal del Menor, María del Carmen Gómez Rivero, Iustel, Portal Derecho, S. A., $1^{a}$ Edición 2007, páginas 116 y 117.
}

${ }^{52}$ Gómez Rivero, Ma del Carmen, Jornadas Técnicas, Drogodependencia, Sevilla, 2006, op cit, pag 117 


\section{ACTO DAÑOSO DEL MENOR CONTEMPLADO EN EL CÓDIGO PENAL COMO DELITO O FALTA.}

En este caso hay que atenerse a lo que dispone el artículo 61. 1. del título VIII de la LORMP que dice: "La acción para exigir la responsabilidad civil en el procedimiento regulado en esta ley se ejecutará por el Ministerio Fiscal, salvo que el perjudicado renuncie a ella, la ejecute por sí miso en el plazo de un mes desde que se le notifique la apertura de la pieza separada de responsabilidad civil o se la reserve para ejecutarla ante el orden jurisdiccional civil conforme a los preceptos del Código Civil y de la Ley de Enjuiciamiento Civil".

Vemos que el perjudicado puede renunciar a la responsabilidad civil, en cuyo caso se archivaría la pieza separada de responsabilidad civil, pues si el perjudicado renuncia, no hay lugar a indemnización y por ello se extingue esa responsabilidad. Si el perjudicado desea ejecutarla por sí mismo, debería realizarlo en el plazo de un mes, desde que se le notifique la apertura de pieza separada de responsabilidad civil, la cual le será notificada por el secretario judicial. Por cada hecho imputado, se tramita siempre, en estos procesos penales, una pieza separada de responsabilidad civil (art ${ }^{\circ} 61.2$ LORPM).

El perjudicado puede reservarse la acción de responsabilidad civil, ante el orden jurisdiccional civil, de acuerdo con el Código Civil y la Ley de Enjuiciamiento Civil y el menor en este caso responderá de acuerdo con el artículo $1.902 \mathrm{Cc}$.

Si por el contrario, el perjudicado no renuncia a la responsabilidad civil, ni la ejercita por sí mismo y tampoco la ejercita ante el orden jurisdiccional civil, se sigue el procedimiento penal, para exigir la responsabilidad civil de la LORPM en su título VIII. Con esta Ley, la jurisprudencia y la doctrina están de acuerdo en la responsabilidad civil directa del menor, autor de un hecho dañoso, que se halle tipificado como delito o falta en el Código Penal. De esta forma queda claro que los 
menores mayores de catorce años y menores de dieciocho son civilmente imputables y están obligados a resarcir los daños ocasionados, de acuerdo con lo dispuesto en el $\operatorname{art}^{\circ}$ 61. 3 LORPM. Este párrafo dice: "Cuando el responsable de los hechos cometidos sea un menor de dieciocho años, responderán solidariamente con él de los daños y perjuicios causados, sus padres, tutores, acogedores y guardadores legales o de hecho, por este orden. Cuando éstos no hubiesen favorecido la conducta del menor con dolo o negligencia grave, su responsabilidad podrá ser moderada por el Juez según los casos. "De este párrafo se infiere que el menor entre catorce y dieciocho años puede ser responsable el mismo con independencia de sus padres, tutores, acogedores o guardadores legales o de hecho; pero se da la circunstancia de que la mayor parte de los menores son insolventes, por este motivo son responsables solidariamente los que le tienen a cargo, con el fin de que se pueda indemnizar a la víctima.

En cuanto a la expresión "sus padres, tutores, acogedores o guardadores legales o de hecho, por este orden", ha dado lugar a muchas polémicas y se han dado varias sentencias de los Tribunales Superiores de Justicia y de las Audiencias Provinciales precisando a quien corresponde la responsabilidad. Pensemos en un matrimonio separado, o que esté bajo la guarda de un tutor, en estos casos no se puede atender al orden de los responsables, sino a quien lo tenga bajo su guarda en el momento de cometerse el hecho que da lugar a la responsabilidad.

Por lo que se refiere a la expresión "en su responsabilidad podrá ser moderada por el Juez según los casos" quiere decir que si las personas responsables de la guarda del menor no hubieran favorecido la conducta del menor con dolo o negligencia grave, el Juez puede moderarla, pues a veces hay varias personas que se encuentran involucradas en la custodia del menor y unos cumplen y otros no, por ello hay que analizar el caso concreto y ver la actuación de cada uno: pensemos por ejemplo, unos padres separados en que uno se ocupa del menor y el otro se desentiende, en este caso se podrá 
moderar la responsabilidad del que se ocupa del menor, pero no del que se ha desentendido.

\section{LA EDAD EN EL CÓDIGO CIVIL}

Al tratar nuestro Código Civil la responsabilidad civil extracontractual no hace ninguna referencia a la edad, al contrario de otros códigos extranjeros que sí lo hacen. Para la responsabilidad civil extracontractual del menor hay que estar a lo que dispone el $\operatorname{art}^{\mathrm{o}} 1.902$, el cual dice: "El que por acción u omisión causa daño a otro, interviniendo culpa o negligencia, está obligado a reparar el daño causado". Por no hacer referencia a una determinada edad, es el Juez el que tiene que decidir en cada caso, si el menor en el momento de causar el daño, tendrá el discernimiento suficiente para calibrar las consecuencias que se derivaban del mismo y haber obrado en ese sentido.

En la mayor parte de los códigos de otros países se establecen varias edades y criterios para delimitar la responsabilidad. Existe un criterio biológico en el que se considera totalmente irresponsable al menor, ésta sería una edad inferior a los siete años, en la que no queda duda de que el menor es total y absolutamente irresponsable, las dudas surgen entre los siete y los catorce años, por lo que hay que establecer un criterio mixto entre biológico y psicológico para poder apreciar si además de la edad el menor es psicológicamente capaz de entender y de querer las consecuencias del acto que da lugar a la responsabilidad.

A partir de los dieciséis años existe acuerdo unánime, doctrinal y normativo, de imputabilidad por razón de la edad ${ }^{53}$.

En varios códigos civiles las edades son diferentes: así el Código Civil portugués el menor de siete años es inimputable ( $\left.\operatorname{art}^{\mathrm{o}} 488\right)$. El Código civil argentino en su $\operatorname{art}^{\circ} 921$ el menor de diez años es igualmente

\footnotetext{
53 Bonilla Correa, Jesús Ángel, op cit, pag 125.
} 
inimputable. Así como el austriaco la fija en catorce años ${ }^{54}$.

El Código Civil alemán en su $\operatorname{art}^{\circ} 828$ dice: "Quien no ha cumplido los siete años de edad, no es responsable de un daño que causa a otro". Vemos por tanto, que es un criterio biológico puro en que es absolutamente irresponsable. En el apartado 2 del mencionado artículo dice: "Quién ha cumplido los siete años de edad pero no los diez no es responsable del daño causado a otro por un accidente de automóvil, ferrocarril o funicular. Ello no rige si la lesión se ha producido dolorosamente," aquí emplea un criterio mixto al hacer referencia "si la lesión se ha producido dolorosamente", por entender que existe mala intención o maldad o una maquinación, lo cual implica discernimiento y por tanto responsabilidad. El apartado 3 del mismo artículo dice: "Quien todavía no ha cumplido los dieciocho años de edad no es responsable por los daños que causa a otro, en tanto sus responsabilidad no resulta excluida según el apartado 1 o 2 , si en la realización del acto causante del daño no poseía el necesario discernimiento para comprender la responsabilidad, "se emplea igualmente un criterio mixto biológico-psicológico al emplear edad y discernimiento. Vemos que emplea el Código Alemán tres franjas de edad, una hasta los siete años totalmente inimputable; otra de siete a diez años inimputable para accidentes con automóviles, ferrocarril y funicular y otra que comprende de los siete a los dieciocho años inimputable si no tiene el suficiente discernimiento, de lo que se deduce, en sentido contrario, si se da el discernimiento o si resulta ya como imputable.

En consecuencia, en nuestro Código Civil, en su artículo 1.902, no se establece ninguna edad para la responsabilidad extracontractual, por lo que hay que buscar criterios para hallar la imputabilidad y por tanto la culpabilidad para exigir la correspondiente responsabilidad.

54 Ibidem, pag 125 


\section{LA ANTIJURIDICIDAD EN LA RESPONSABILIDAD CIVIL EXTRACONTRACTUAL}

Antijuricidad es la conducta contraria a derecho. Es una confrontación entre el acto realizado y lo que la ley pretendía que se realizase. Supone por tanto, vulnerar los valores que informan el ordenamiento jurídico.

Un ordenamiento jurídico se basa en los valores de la sociedad a la que pertenece, para proteger aquellos intereses estables o bienes jurídicos que el legislador desea que sean respetados.

Nuestro artículo 1902 Cc, no hace referencia al concepto de antijuricidad o al ilícito, mientras que otros códigos extranjeros si lo hacen como el italiano, el suizo, el alemán y el portugués ${ }^{55}$.

Hay autores que niegan que sea necesario la ilicitud o antijuricidad para la existencia de responsabilidad civil, pero es necesario. "Para que surja una responsabilidad civil es preciso un ilícito, una antijuricidad de la conducta, la infracción de la norma de conducta que se ha impuesto a una

\footnotetext{
55 (Art 2043 italiano) dice: "Risarcimiento per fatto illecito. - Qualonque fatto doloso o colposo, che ragiona ad altri un danno ingiusto, obliga colni che ha commesso il fatto a risareire il danno".

"Cualquier hecho doloroso o culposo que ocasiona a otros un daño injusto obliga a quien cometió el hecho a resarcir el daño".
}

Art ${ }^{\circ} 41$ código suizo dice: "Celui qui rause d'une maniere illicite, un dammage à ou trui, soit intentio nellement, soit par negligence, ou imprudence, est, tenn de le répare."

"Aquel que cause, de una forma ilícita un daño a otro, ya sea intencionadamente, o por negligencia o por imprudencia, está obligado a repararla."

Art ${ }^{\circ}$ 483.1 Código Civil Portugués “Aquelle que, con dolo en mera culpa, violar ilicitamente e dereito de otrem on qualquer disposicao legal destinada a proteger intereses alheios fira obrigado a indemnizar o lesado pelos danos resultantes da violacao"

"Aquel que con dolo o mera culpa, viola ilícitamente el derecho de otros o cualquier disposición legal destinada a proteger intereses ajenos, queda obligado a indemnizar al lesionado por los daños resultantes de la violación”. 
persona al realizar un determinado comportamiento"56, se trata de un comportamiento contrario a los valores sociales, que el derecho trata de proteger. Los códigos, las leyes y todo el ordenamiento jurídico, con sus diversas normativas, tratan de asegurar la paz social o convivencia, de respetar los valores que imperan en esa sociedad; si alguien comete una infracción, ha vulnerado el ordenamiento jurídico, ha cometido algo ilícito, antijurídico y por tanto contrario a derecho.

El principio alterum non laedere, quiere decir no dañar al otro, pues para que haya responsabilidad civil es necesario que se produzca un daño, pero con el daño no es suficiente, es preciso que ese daño se dé por medio de una conducta ilícita o antijurídica. Lo que aquí interesa no es el resultado, sino la conducta del sujeto que tiene que ser contraria a derecho, es decir, tiene que ser ilícita para que se aplique el artículo 1.902. Este artículo prohíbe determinadas conductas que considera negligentes, donde no se ha observado una conducta correcta y adecuada al caso; con la diligencia debida, con el cuidado, atención o perseverancia que se debe exigir a una persona prudente con la diligencia debida.

En el Código italiano, la antijuricidad o ilicitud se halla contemplada de forma genérica en el artículo 2.043 al decir "un daño injusto". En el artículo 1382 del Códe no se hace referencia a la ilicitud, pues dice: "Cualquier hecho del hombre que cause daño a otro obliga a aquel por cuya culpa sucedió, a repararlo". Sin embargo el BGB es más explícito y en su artículo 823.1, dice "Quien dolosa o negligentemente lesiona antijurídicamente la vida, el cuerpo, la salud, la libertad, la propiedad o cualquier otro derecho de otra persona, queda obligado frente a ésta al resarcimiento del daño que de ello resulta".

Vemos en este artículo no solamente que hace referencia a la antijuricidad o ilicitud, sino que lo hace con supuestos concretos, sobre la vida, el cuerpo, la salud, la propiedad o cualquier otro derecho, por lo que se

${ }^{56}$ Bonilla Correa, Jesús Ángel, op, cit, pag 153. 
da una cierta tipicidad como si se tratara de derecho penal. De igual forma el $\operatorname{art}^{\circ}$ 826 BGB dice: "Quien de una forma que contraviene las buenas costumbres causa dolorosamente un daño a otro está obligado frente a éste al resarcimiento del daño", haciendo con ello referencia a las buenas costumbres, trata de censurar o castigar las conductas responsables, mantener el orden que debe imperar en el cuerpo social.

\section{LA IMPUTABILIDAD CIVIL}

La imputabilidad es la posibilidad de atribuir un hecho dañoso a su autor y supone tener capacidad de entender y de querer ${ }^{57}$. Tener capacidad de entender consiste en tener madurez de juicio, saber distinguir o discernir entre el bien y el mal y aumenta con el paso del tiempo, de tal forma que cuanto más mayor es el menor, a medida que tiene más edad se da un discernimiento mayor. Capacidad de querer se refiere a la voluntad, aumentando con la edad del menor y quiere decir que por medio de esa voluntad puede orientar su conducta a la comisión del hecho que da lugar a la responsabilidad. Imputabilidad es tener aptitud para la culpa.

La culpa es un presupuesto de la responsabilidad y tiene dos sentidos; objetivo y subjetivo. Su sentido objetivo consiste en la violación de normas de conducta que lesionan intereses de los demás, pues, el individuo se encuentra inmerso en una sociedad en la que tiene que hacer uso de su libertad, pero al mismo tiempo respetar y no invadir las libertades de los demás. En su sentido subjetivo se refiere al aspecto psicológico de quien realiza un hecho reprochable, es algo, intrínseco del que comete un acto dañoso del cual se deriva una responsabilidad. En este sentido es preciso que haya conciencia y libre voluntad, pues si no existe libertad no se puede imputar a nadie ninguna culpa.

Para ser imputable es necesario que el hecho que se comete

\footnotetext{
57 Atienza Navarro, $M^{a}$ Luisa (2000), La responsabilidad civil por los hechos dañosos de los menores de edad,
} Editorial Comares, Granada, pag 511. 
constituya un acto negligente, imprudente, que vulnere las normas ${ }^{58}$, en el que no se haya observado la diligencia y la prudencia debidas.

\subsection{LA IMPUTABILIDAD CIVIL EN EL CODE CIVILE}

Nuestro artículo $1.902 \mathrm{Cc}$, es un sistema de responsabilidad subjetiva en el que se tiene en cuenta la capacidad natural de entender y de querer del menor, es decir, si tiene capacidad de discernir y voluntad para autodeterminar su conducta; al igual que el $\operatorname{art}^{\mathrm{o}} 1.382$ del Code civile.

Ahora de lo que se trata es de hacer responder al menor, sin tener en cuenta su capacidad de discernimiento y voluntad, para ello, la doctrina francesa ha adoptado el concepto objetivo o abstracto, en el que no se valora el estado anímico, ni la conciencia del menor al cometer el acto dañoso, por no importar demasiado para el resarcimiento. Este concepto objetivo o abstracto supone valorar el comportamiento del menor causante del daño comparándolo con otra persona en las mismas circunstancias externas y sin tener en cuenta las internas, tales como discernimiento, voluntad, edad, etc, es decir, no tener en cuenta ninguna valoración subjetiva del sujeto causante del daño.

Uno de los precursores de esta teoría fue Mazeaud, que la denomina "falta objetiva" 59 , mediante la cual se puede exigir a los menores carentes de

\footnotetext{
${ }^{58}$ P. TRIMARCHI, Rischio e responsabilitá oggettiva. "Il referente normativo in tema di colpevoleza si rinviene nelli art $42 \mathrm{cp}$, la dore è data e vincerla in presenza di negligenza, imprudenza o imperizia, o altrimenti per inosservanza di leggi, diregolamenti, ordini o discipline”. Código Civil italiano, Giovani Perlingieri, Edizioni, op cit, pag. 2607.
}

${ }^{59}$ Mazeaud, H "La faute objetive", "Aprécier la faute $<<$ in concreto $>>$, c'est examiner liétat d'ame de l'agent, chercher si sa consciencelui reproche quelque chose".

"On démarque nettemente cette responsabilité dela responsabilité morale; on $<<$ déculpabilise $>>$ la fautecivil".

"La falta objetivo "Apreciar la falta $<<$ en concreto $>>$ es examinar el estado de ánimo del agente, buscar si su conciencia le reprocha alguna cosa".

"Se distingue que claramente esta responsabilidad de la responsabilidad moral se $<<$ desculpabiliza $>>$ la falta civil”. Ma Luisa Atienza Navarro, opc cit, pag 513 notas 16, 17 y 18. 
discernimiento, la culpa civil y la responsabilidad del art ${ }^{\circ} 1.382$ Code civile.

Esta teoría de la culpa objetiva o abstracta, ha dado lugar a muchas polémicas en la doctrina francesa, siendo al principio pocos los tratadistas partidarios de ella, hasta llegar a ser mayoría, mientras que en la actualidad existen dudas a la hora de aplicarla, por considerar que no se debe prescindir totalmente de la capacidad de discernimiento como establece el artículo 1382 del Code.

Por la Ley del 3 de enero de 1968, se modificó el art $^{\circ} 489.2$ del Code civil en el sentido de exigir responsabilidad civil a los enfermos mentales, lo que dio lugar a poder deducirse que de igual forma se puede exigir responsabilidad a los menores que no tengan capacidad intelectiva y volitiva $^{60}$. La Court de Cassatión, ha condenado en muchas sentencias a menores a resarcir el daño ocasionado, sin tener suficiente capacidad intelectiva y volitiva para estimar o ponderar las consecuencias del acto dañoso, aplicando la culpa in abstracto u objetiva.

\subsection{LA IMPUTABILIDAD CIVIL EN EL CODICE CIVILE ITALIANO}

En el Derecho italiano se sigue el mismo sistema que en el Derecho español, en el que no se responde de los hechos dañosos si no se tiene la capacidad de responder y de querer. Su artículo 2.046 así lo contempla, al decir que no se responde de las consecuencias del hecho dañoso, si no tiene la capacidad de entender y de querer en el momento de su comisión a no ser que el estado de incapacidad derive de su propia culpa ${ }^{61}$.

En las últimas décadas se da prioridad a indemnizar a la víctima con

\footnotetext{
${ }^{60} \mathrm{Art}^{\circ}$ 489.2 Code civil "Celui qui a causé un dommage á autri alors qu'il etait sous l'empire d'un trouble mental, n'en est pas moins obligé á reparatoón”.

Art ${ }^{\circ}$ 489.2 Código civil francés. "Quien haya causado un daño a otro hallándose bajo el efecto de un transtorno mental no estará, por ello, menos obligado a repararlo.
}

$\left.{ }^{61}\right) \mathrm{Art}^{\mathrm{O}} 2.046$ Codice civile italiano. "Nonrisponde delle conseguenze del fatto dannosochi non aveva la capacitá d'intendere o di volere al momento in cui lo ha commesso, a meno che lo stato d'incapacità derivi da sua colpa". 
lo que se está objetivando la responsabilidad, "sin embargo, mientras sigamos con el sistema actual del Cc, la imputabilidad seguirá siendo el elemento subjetivo de la culpa, por lo que los sujetos civilmente inimputables no podrán realizar conductas negligentes o dolosas, a los efectos del art $^{\mathrm{O}} 1.902 \mathrm{Cc}$, sino sólo objetivamente negligentes o dolosas ${ }^{62}$.

Si se aplica el $\operatorname{art}^{\circ} 1.902$ ante una conducta negligente, se aplicará a personas con capacidad natural de entender y de querer, pero si se aplica a menores que no tienen esta capacidad natural de entender y de querer estamos ante una conducta objetivamente negligente, por lo que para exigir la responsabilidad a su autor será necesario que una ley expresamente lo permita. Es lo que ha hecho el legislador francés con el artículo 489.2 Code civil; el italiano en el $\mathrm{art}^{\circ}$ 2.047.II Códice civile;

$\mathrm{El} \operatorname{art}^{\mathrm{O}}$ 2.047, 2 del Códice civile dice: "En el caso en que el dañado no haya podido obtener el resarcimiento por quien es tenido a cargo de la vigilancia del menor, el juez, en consideración a las condiciones económicas de las partes puede condenar al autor del daño a una indemnización equitativa" ${ }^{63}$. Quiere decir este artículo que, en el caso de que la víctima no haya podido obtener el resarcimiento, porque los encargados de su vigilancia no pudieron evitarlo y por ello no fueron responsables, no existan como tales o sean insolvente, el juez de forma discrecional, puede condenar al menor a pagar una indemnización equitativa, pero no al resarcimiento del daño causado, según las circunstancias del caso y la situación económica de las partes.

Para aplicar este artículo, la conducta del menor inimputable tiene que ser objetivamente antijurídica, es decir, contraria a derecho, pues, de lo contrario no se puede aplicar por no poder exigirse la correspondiente

\footnotetext{
62 Atienza Navarro, la resp. Op cit, pag. 522

${ }^{63} \mathrm{Art}^{\mathrm{O}}$ 2.047.2 Códice divile "Nel caso in cui il danneggiato non abbia potuto ottenere il resarcimiento da chi étenvto alla sorveglianza, il giudice, in considerazione delle condizioni economiche delle parti, puo condannare liautore del danno a un'equa indennità".
} 
responsabilidad. Tiene que ser objetiva, por no tenerse en cuenta la imputabilidad del menor su capacidad de entender y querer y además subsidiaria al no poder responsabilizar a los encargados de su vigilancia.

En estos casos la figura central es el juez, el cual tiene que valorar las circunstancias del caso, en especial la situación económica de las partes, si el menor es o no insolvente, lo normal es que lo sea, pero puede disponer de un patrimonio, por lo que habrá de analizar su cuantía, o la víctima puede ser una persona con un poder económico considerable. Por todo ello, el juez, según esas circunstancias, hará lo que estime más conveniente para las partes en la regulación de la indemnización.

$\mathrm{Al}$ igual que el $\operatorname{art}^{\mathrm{o}}$ 2.047.2 del Códice civile en el Código penal de 1973, en el apartado segundo, de la regla primera se podría hacer responder al menor con sus propios bienes, si no hay persona que los tenga bajo su potestad o guarda legal o fuera ésta insolvente, pero fue derogada por la disposición final quinta de la LORPM, por lo que hay que estar a lo que dispone el $\operatorname{art}^{\mathrm{o}} 3$ de esta Ley.

\section{LA RESPONSABILIDAD CIVIL DEL MENOR CIVILMENTE} IMPUTABLE

\subsection{EL ARTÍCULO 1.902 EN RELACIÓN CON EL 1.104 PARA DETERMINAR LA NEGLIGENCIA DEL MENOR.}

En la aplicación del $\operatorname{art}^{\mathrm{o}} 1.902$ hay que tener en cuenta si el menor tiene la capacidad natural de entender y de querer, si tiene suficiente capacidad intelectiva y volitiva para comprender el alcance del acto que da lugar a la responsabilidad. Un menor actúa negligentemente si ha adquirido la suficiente madurez intelectiva y volitiva, habiendo podido actuar de una manera distinta al hecho cometido.

El encargado de averiguar si el menor ha actuado de forma negligente es el juez, el cual, deberá averiguarlo caso por caso, atendiendo al 
grado de discernimiento del menor en cuestión.

Para averiguar si el menor ha actuado de forma negligente, el juez tiene que emplear un modelo de referencia propio de su edad, quiere ello decir, que no puede emplear el de una persona adulta, pues el menor tiene menor grado de discernimiento que un adulto, por lo que si se aplicara ese modelo de referencia o de conducta sería notoriamente injusto y el menor resultaría desprotegido.

Según el artículo 1.104, habla de las "circunstancias de las personas, del tiempo y del lugar", por lo que habrá de tener en cuenta la edad del menor y como consecuencia de ello su capacidad intelectiva y volitiva correspondiente a las franjas de edad en que se pueda encuadrar al menor ${ }^{64}$.

La negligencia es lo contrario de diligencia, o la falta de ella, ser una persona diligente significa obrar con cautela, cuidado, atención, reflexión, prudencia, raciocinio o perseverancia, que un menor debe tenerla con un grado de desarrollo adecuado a su edad. El $\operatorname{art}^{\circ} 1.104$ al tratar de la negligencia es por tanto aplicable a la culpa extracontractual de los artículos 1.902 y 1.903.

Igualmente el artículo 1.103 es aplicable a la culpa extracontractual y sirve para que los Tribunales moderen la suma indemnizatoria, valorando la culpa del obligado u otras personas involucradas en el caso de que se trate. ${ }^{65}$

\subsection{TIPO DE RESPONSABILIDAD DEL MENOR CIVILMENTE IMPUTABLE}

La responsabilidad de un menor puede ser directa o subsidiaria

\footnotetext{
${ }^{64} \mathrm{Art}^{\mathrm{O}}$ 1.104: “La culpa o neglegencia del deudor consiste en la omisión de aquella diligencia que exija la naturaleza de la obligación y corresponde a las circunstancias de las personas, del tiempo y del lugar. Cuando la obligación no exprese la diligencia que ha de prestarse en su cumplimiento, se exigirá la que correspondería a un buen padre de familia".
}

$65 \mathrm{Art}^{\mathrm{O}}$ 1103: "La responsabilidad que proceda de negligencia es igualmente exigible en el cumplimiento de toda clase de obligaciones; pero podrá moderarse por los Tribunales según los casos”. 
según sea culpable el menor o las personas que le tengan bajo su guarda o custodia tales como padres, tutores, acogedores, profesores o titulares de centros docentes. La doctrina se encuentra dividida sobre ello.

Para unos autores la responsabilidad es subsidiaria, y según ellos el menor responderá conforme al $\operatorname{art}^{\circ} 1902$ en ausencia o defecto de sus padres, tutores o titulares de centros, acogedores, etc.

Según otros, afirman que el perjudicado puede accionar directamente contra el menor por el $\operatorname{art}^{\circ} 1.902$, sin perjuicio de que otras personas, padres, tutores, etc, puedan ser llamados igualmente a responder, de acuerdo con el art ${ }^{\circ} 1.903 \mathrm{Cc}$.

Esta última es la posición más correcta y que sigue la mayoría de la doctrina.

Los artículos 1.902 y 1.903 no se excluyen el uno al otro, sino que son complementarios: un menor puede ser responsable conforme al art 1.902 frente a la víctima del daño y del mismo modo esa víctima puede demandar a los padres, tutores y titulares de centros docentes según los casos, en virtud del $\operatorname{art}^{\mathrm{o}} 1.903$. De esta forma se ven involucrados en el acto dañoso varias personas, de una parte el menor y de otra, los padres, tutores, etc, todos ellos deberán responder de forma solidaria, que es la forma que resulta más adecuada para indemnizar a la víctima.

Por otra parte, en el Proyecto de Código Civil de García Goyena de 1851, en su artículo 1.901 antecedente del 1.903 actual, se mostró favorable al carácter subsidiario de la responsabilidad del padre y de la madre viuda, respecto a los hijos que tiene bajo su potestad y viven en su compañía; los tutores lo son de los menores que están bajo su autoridad y habiten en su compañía; los dueños o directores de un establecimiento o empresa, respecto de los perjuicios causados por sus domésticos en el servicio de los ramos en que los tuvieren empleados y por último, los maestros o directores de artes y oficios en cuanto a los perjuicios causados por sus alumnos o aprendices, mientras permanezcan bajo su custodia. De ello se infiere que la 
responsabilidad directa corresponde al causante directo del daño, es decir, al menor.

De igual forma en el artículo 1.900 del mencionado Proyecto de García Goyena, es el antecedente del artículo 1.902 en el que se contempla la responsabilidad civil directa del menor, por lo que se demuestra que el legislador no quiere eliminar la responsabilidad directa del menor.

\subsection{LEGISLACIÓN NACIONAL E INTERNACINAL EN RELACIÓN CON}

\section{LA RESPONSABILIDAD DE LOS MENORES}

En las últimas décadas se ha operado un cambio importante en relación con la responsabilidad de los menores al reconocérseles una mayor libertad y autonomía para el libre desarrollo de su personalidad. La responsabilidad de una persona viene dada en función de su libertad de acción y autonomía, por ello, parece lógico que si un menor dispone de mucha autonomía, igualmente se le debe exigir una mayor responsabilidad.

La legislación internacional sigue el principio de reconocer mayor grado de libertad a los menores, para asegurar el libre desarrollo de su personalidad, como se halla contemplado en el artículo 26.2 de la Declaración Universal de Derechos del Hombre de la Asamblea de la ONU de 10 de diciembre de 1948; así como en el $\operatorname{art}^{\circ} 16.1$ de la misma, en la que se reconoce a los hombres y las mujeres a contraer matrimonio cuando lleguen a la edad núbil. Igualmente se reconoce este derecho en el $\operatorname{art}^{\mathrm{o}} 12 \mathrm{del}$ Convenio Europeo de Derechos Humanos de 4 de noviembre de 1950, el cual dice: "A partir de la edad núbil, el hombre y la mujer tienen derecho a casarse y a fundar una familia según las leyes nacionales que rijan el ejercicio de este derecho".

Por lo que se refiere a la legislación española se ha ido adaptando progresivamente a la legislación internacional como se puede contemplar en el $\operatorname{art}^{\circ}$ 10. 1 CE que dice: "La dignidad de la persona, los derechos inviolables que le son inherentes, el libre desarrollo de la personalidad, el respeto a la ley y a los derechos de los demás son fundamente del orden 
político y de la paz social”.

El código civil reconoce en varios artículos el libre desarrollo de la personalidad del menor. En el $\mathrm{art}^{\circ} 154$ los padres ejercen la patria potestad "Si los hijos tuvieren suficiente juicio deberán ser oídos siempre antes de adoptar decisiones que les afecten”; el art 159 dice que el juez podrá decidir al cuidado de que progenitor quedarán los menores de edad con suficiente juicio y en todo caso a los que fueran mayores de doce años; el art 162 exceptuando a la patria potestad: $1^{\circ}$ los actos relativos a derechos de la personalidad u otros que el hijo, de acuerdo con las leyes y con sus condiciones de madurez, pueda realizar por sí mismo, $2^{\circ}$ aquellos en que exista conflicto de intereses entre los padres y el hijo, $3^{\circ}$ los relativos a bienes que estén excluidos de la administración de los padres.

De igual forma en el art ${ }^{\circ} 164.3$ sobre la administración de los bienes del menor, permite al hijo menor, mayor de dieciséis años administrar los bienes que hubiera adquirido con su trabajo o industria, es decir, su administración ordinaria, necesitando el consentimiento de sus padres para los que excedan de ella. Por el $\mathrm{art}^{\mathrm{o}} 663$ el mayor de catorce años de uno y otro sexo puede otorgar testamento, excepto el testamento ológrafo que se requiere para efectuarlo la mayoría de edad en virtud del $\operatorname{art}^{\circ} 688$.

Por todo lo anterior, se deduce que al menor se le concede una amplia libertad para tomar decisiones en sus propios negocios y en su vida diaria, al mismo tiempo que queda protegido como menor; lo que da lugar a que se le puedan exigir las responsabilidades pertinentes de acuerdo con el $\operatorname{art}^{\circ} 1.902$, al tratarse de un menor con capacidad de entender y querer, así como de comprender el alcance de sus propios actos.

Se puede ser responsable de acuerdo con el $\operatorname{art}^{\circ} 1.902$ por ser capaz de entender y de querer, también lo es cuando cause daños en el colegio, en sus actividades escolares, extraescolares y complementarias, de acuerdo con el $\mathrm{RD} \mathrm{n}^{\circ}$ 732/1995, de 5 de mayo, BOE $\mathrm{n}^{\circ} 131$ de 2 de junio, en el que se trata de los derechos y deberes de los alumnos, así como las normas de 
convivencia de los centros.

El mencionado Real Decreto señala en su introducción como el deber más importante de los alumnos "el de aprovechar positivamente el puesto escolar que la sociedad pone a su disposición, por lo que el interés por aprender y la asistencia a clase, es decir, el deber del estudio es la consecuencia del derecho fundamental a la educación. En su artículo 17 dispone que: "Todos los alumnos tiene derecho a que se respete su integridad física y moral y su dignidad personal, no pudiendo ser objeto, en ningún caso, de tratos vejatorios o degradantes"; lo cual tiene importancia en estos tiempos en que alumnos con capacidad de entender y de querer realizan actos de acoso a otros, con consecuencias muy graves para los afectados.

Con el fin de enmendar las conductas de los alumnos contrarios a las normas establecidas en este Real Decreto, en virtud de sus artículos 48d y 53a, ${ }^{66}$ se les puede obligar a realizar tareas para mejorar y desarrollar las actividades del centro, así como a reparar el daño causado a las instalaciones, el material del centro o a las pertenencias de otros miembros de la comunidad educativa; pues según el art 39 "los alumnos deben cuidar y utilizar correctamente los bienes muebles y las instalaciones del centro y respetar las pertenencias de otros miembros de la comunidad educativa".

Además de lo establecido en este RD, el alumno que sea insolvente

\footnotetext{
$66 \mathrm{Art}^{\mathrm{O}}$ 48d RD 732/1995: "Las conductas contrarias a las normas de convivencia del centro podrán ser corregidas con:

d) Realización de tareas que contribuyan a la mejora y desarrollo de las actividades del centro, si procede, dirigidas a reparar el daño causado a las instalaciones o al material del centro o a las pertenencias de otros miembros de la comunidad educativa".
}

Art ${ }^{\circ}$ 53a RD 732/1995: "Las conductas enumeradas en el art anterior podrán ser corregidas con:

a) Realización de tareas que contribuyan a la mejora y desarrollo de las actividades del centro o si procede, dirigidas a reparar el daño causado a las instalaciones o al material del centro o alas pertenencias de otros miembros de la comunidad educativa. Estas tareas deberán realiarse en horario no lectivo. 
puede ser obligad a reparar el daño o a la restitución, si no puede indemnizar, de acuerdo con el $\operatorname{art}^{\mathrm{o}} 110 \mathrm{Cp}$ en sus apartados $1^{\circ}$ y $2^{\circ}$.

\section{LA RESPONSABILIDAD CIVIL DEL MENOR CIVILMENTE INIMPUTABLE}

En nuestro código civil, no hay ninguna referencia al dato biológico de la edad para poder determinar la inimputabilidad civil. El código penal establece en su art $^{\circ} 13$ que los menores de dieciocho años no son responsables con arreglo a este código. En la LORPM en su $\operatorname{art}^{\circ} 11$ donde se considera a los mayores de catorce años y menores de 18, responsables por la comisión de hechos tipificados como delitos o faltas en el código penal o las leyes penales especiales.

En los ordenamientos extranjeros nunca se considera imputable al menor de siete años como en el $\operatorname{art}^{\circ}$ 828.BGB y en el $\operatorname{art}^{\circ} 488.2$ del código civil portugués. Entre los siete y los diez años, es donde más dudas existen para saber si en este periodo de tiempo, los menores son capaces de entender y de querer así como de medir el alcance y las consecuencias de sus actos. Es a partir de los diez años cuando se suele considerar al menor con suficiente madurez para entender y querer, como dispone el $\operatorname{art}^{\circ}$ 921del código civil argentino.

De lo que se trata para obligar a indemnizar al menor inimputable es el tratar de que la víctima no quede sin indemnización, en defecto de los padres, tutores, etc, que son los responsables de los daños producidos por los menores que se encuentren a su cargo.

La doctrina para resolver este problema se encuentra dividida, opinando unos autores que en el caso de menores de muy corta edad, se equipare al caso fortuito o fuerza mayor, mientras que otros opinan lo contrario.

Si se trata de un niño de muy corta edad, la liberación paterna 
significará que la víctima se quedará sin resarcimiento, por muy solvente que sea el niño. Tratándose de niños o jóvenes con capacidad de discernimiento es necesario que sean culpables para responder. Si el menor carece de discernimiento, la víctima, a falta de persona que pueda responder por él, habrá de soportar el daño, pues el hecho sólo podrá calificarse de fortuito, como lo son los fenómenos de la naturaleza ${ }^{67}$.

Rivero Hernández, La Cruz Berdejo, opinan de otra manera en lo relativo a caso fortuito y fuerza mayor y dicen: $<\mathrm{El}$ obrar de un loco o de un niño no puede equipararse a un hecho de la naturaleza o el de un animal sin dueño ni guardador, pues el niño o el loco son personas, seres humanos provistos de un patrimonio y gravados con unas obligaciones sociales que no tienen el lobo que mata al ganado o el río que inunda la finca. Recae sobre ellos una "responsabilidad por existir" con que nace cada hombre y que indistintamente nos lleva a pensar en la elección entre el causante del daño y el perjudicado es aquel quién - teniendo fortuna personal - debe soportar las consecuencias económicas salvo si emplea la diligencia $\operatorname{debida}^{68}>$.

Estas afirmaciones sobre el caso fortuito se basan en datos históricos, como en el Derecho Romano (D- 9-2-5-2) ya tratados en el apartado correspondiente por lo que no insistiré más sobre ello.

Una sentencia ilustrativa sobre el caso fortuito es la de fecha 21 de noviembre de 1990 (RJ 1990/9014), en la que trata de un niño que saca el ojo a otro en el comedor de una guardería. Un menor de seis años de edad, mientras comían, agredió a otro con un tenedor sacándole el ojo izquierdo.

El padre del menor demanda a la guardería infantil en la persona de

\footnotetext{
${ }^{67}$ López Beltrán de Heredia, La responsabilidad civil, Mª Luisa Atienza Navarro, op cit pag. 546, nota 93.

${ }^{68}$ Rivero Hernández, La Cruz Berdejo, Elementos de Derecho civil, en $M^{a}$ Luisa Atienza Navarro, op cit pag 547, nota 93.
} 
su directora. Los resultados de la prueba establecen que en el momento de los hechos se encontraban en el comedor veinticinco escolares, vigilados convenientemente por la profesora encargada del grupo, no sugiriendo del comportamiento del menor una atención especial al mismo. El hecho aconteció de manera súbita e inopinada.

En su fundamento tercero afirma que ni el $\operatorname{art}^{\circ}$ 1902, ni el relacionado 1.903, en especial aplicable a este caso, en cuanto conviene a la responsabilidad por hecho ajeno, supuesto concreto de los educadores, pueden interpretarse, con olvido del propio concepto de culpa, como fondo remanente de los mismos; lo que obliga a considerar si un suceso de tales características era previsible, dentro de un orden cotidiano o normal y a valorar la imposibilidad de evitarlo. De los datos probados no se puede imputar a los guardadores una conducta negligente, por la rapidez con que el hecho se desarrolló, por la ausencia de antecedentes del niño, ni por el carácter infrecuente e improbable del caso.

La profesora se hallaba cumpliendo sus cometidos propios de su empleo en el comedor, por lo que cumplió con la diligencia debida que se exige a los padres y educadores de estar pendientes de los niños durante las comidas.

Por su fundamento cuarto califica el hecho como fortuito, al darse la circunstancia de imprevisibilidad, y produce indemnidad en los términos señalados en el artículo 1.105 del Código civil ${ }^{69}$.

En consecuencia, al tratarse de un niño de muy corta edad, la rapidez e imprevisibilidad de los hechos, el hallarse la profesora presente en el comedor ala hora de la comida, todo ello da lugar a que no se le pueda imputar a la guardería ni a la profesora ningún tipo de negligencia, por lo que se desestima la demanda y produce indemnidad del $\operatorname{art}^{\circ} 1.105 \mathrm{Cc}$ al ser

\footnotetext{
${ }^{69} \mathrm{Art}^{\circ} 1.105$ Código civil: "Fuera de los casos expresamente mencionándose en la ley, y de los que así lo declare la obligación, nadie responderá de aquellos sucesos que no hubieran podido preverse, o que previstos, fueran inevitables".
} 
calificado el caso fortuito, quedándose el demandado sin indemnización.

\subsection{ARGUMENTOS PARA EXIGIR RESPONSABILIDAD A UN MENOR INIMPUTABLE.}

Para exigir responsabilidad a alguien es preciso que sea subjetivamente imputable, quiere ello decir que tenga voluntad libre y capacidad de entender y de querer, pues en caso contrario, no se podrá hablar de culpa o negligencia al realizar una determinada conducta.

Si un menor es inimputable por ser menor o incapaz, responden de él sus padres, tutores, guardadores o acogedores, pero puede darse el caso de que estos no existan ${ }^{70}$ demuestren que emplearon la diligencia debida para prevenir el daño del artículo 1903 in fine, o resulten ser insolventes. En estos casos en que no haya persona responsable para responder por otro con su patrimonio, será el propio menor o inimputable el que tenga que indemnizar a la víctima de forma subsidiaria, para lo que se pueden emplear varios argumentos que se analizan a continuación:

Argumento de la equidad. Las leyes se dictan siempre con carácter general, es decir, previendo los casos que ordinariamente se presentan en la realidad, por lo que no se pueden tener en cuenta las circunstancias especiales del caso concreto, con lo que al aplicarse la ley general, sin modulación ni adecuación a esas circunstancias, podría producir un resultado injusto. Para evitarlo, el juez debe aplicar la ley con equidad, esto es, teniendo en cuenta las peculiaridades propias del caso, como haría el

\footnotetext{
${ }^{70} \mathrm{Art}^{\mathrm{O}} 228$ Código civil: "Si el Ministerio Fiscal o el Juez competente tuvieran conocimiento de que existe en el territorio de su jurisdicción alguna persona que deba ser sometida a tutela, pedirá el primero y dispondrá el segundo, incluso de oficio, la constitución de la tutela"
}

Art 229 Código civil: "Estarán obligados a promover la constitución de la tutela, desde el momento que conocieren el hecho que la motivare, los parientes llamados a ella y la persona bajo cuya guarda se encuentre el menor o incapacitado, y si no lo hicieren, serán responsable solidarios de la indemnización de los daños y perjuicios causados". 
legislador mismo, quien "si estuviera presente, admitiría el caso y de haberlo previsto, lo hubiera previsto en la propia ley" ${ }^{\text {"71 }}$. La equidad ha sido invocada por la doctrina siendo a veces más justo que el menor, conforme al artículo 1902, cargue con el resarcimiento a que la víctima quede sin indemnizar ${ }^{72}$.

Consiste este argumento en que el juez puede dictar una condena de equidad sobre el propio menor según las circunstancias del caso y la situación económica de las partes, sin abarcar o comprender la totalidad de los daños causados. Se puede considerar que este argumento no tiene peso suficiente, por impedir el $\operatorname{art}^{\mathrm{o}} 3.2 \mathrm{Cc}$ que las resoluciones judiciales descansen de manera exclusiva en la equidad si no hay ley que expresamente lo permita, y en el Código Civil español no se da tal ley, al contrario de otros extranjeros ${ }^{73}$. Hay que tener en cuenta lo que dice el artículo $3.2 \mathrm{Cc}$, "La

\footnotetext{
${ }^{71}$ Aristóteles se ocupa de la equidad al final del libro quinto de la ética a Nicómaco. Para él la equidad no es un elemento corrector de la Ley, sino integrador de la misma, completándola en el momento de su aplicación al caso concreto mediante su adaptación a las circunstancias del supuesto de hecho, cuyo símil era la "vara lesbia", que consistías en una regla de plomo empleada por los arquitectos de la isla de Lesbos, la cual por ser maleable, medía las superficies amoldándose a las formas de las piedras (Blanco González y otros, Filosofía del derecho, UNED, Unidad Didáctica, Madrid 1997, pags 45 y 46)

72 Atienza Navarro Maria Luisa, op cit, pag 533.

${ }^{73} \mathrm{Art}^{\mathrm{o}} 829$ BGB, 2047 italiano, 54 del Código suizo de las Obligaciones, 1187 venezolano, 1140 del peruano y1386 bis del belga.
}

- Art 829 BGB “ en tanto el resarcimiento del daño no pueda ser reclamado de un tercero con deber de vigilancia, si la equidad, según las circunstancias, especialmente la relación de las partes, exige una indemnización, siempre y cuando éste no se vea privado de los medios requeridos para su razonable sustento ni para cumplir con sus obligaciones legales de alimentos".

- Art $^{\circ} 54$ del Código suizo de las Obligaciones, "Si la equidad lo exige, el Juez puede condenar a una persona incapaz de discernimiento a la reparación total o parcial del daño que ella ha causado. El que adolece de una incapacidad pasajera de discernimiento, está obligado a reparar el daño que causó en tal estado si no prueba que cayó en él sin su culpa".

- Art" 1386 bis belga, "Cuando una persona se encuentra en un estado de demencia, trastorno mental grave o retraso mental, haciéndole incapaz de controlar sus acciones, causa daño a otro, el Juez puede exigir la reparación total o parcial, como si ella tuviera el control de sus acciones.

El Juez determinará en equidad teniendo en cuenta las circunstancias del caso y la situación de las partes". 
equidad habrá de ponderarse en la aplicación de las normas", por ello se podrá aplicar equitativamente el artículo 1902. De lo que se trata es de si existe un patrimonio que pueda compensar a la víctima por los daños causados por un inimputable, como por ejemplo, un menor cuyos padres han fallecido recientemente, dejándole como heredero de una considerable fortuna, sin haberse constituido el organismo tutelar, ni haber guardador de hecho. Si este menor ha cometido un hecho dañoso, su patrimonio habrá de indemnizar a la víctima, pues lo que el código civil impide, es utilizar de forma exclusiva la equidad sin ley, pero no la equidad al servicio de la ley, no sólo lo permite sino que lo exige mediante la expresión "habrá de ponderarse" del mencionado artículo 3.2 Cc. ${ }^{74}$.

Argumento del derogado párrafo segundo del art. 32 del C.c que decía lo siguiente: "La menor edad, la demencia o imbecilidad, la sordomudez, la prodigalidad y la interdicción civil, no son más que restricciones de la personalidad jurídica. Los que se hallen en alguno de esos estados son susceptibles de derechos, y aún de obligaciones cuando estás nacen de los hechos o de relaciones entre los bienes del incapacitado y un tercero".

Este párrafo segundo fue suprimido por la Ley de 24 de octubre de 1983 y sirve para demostrar que las personas que se encuentren en ese estado son susceptibles de obligaciones, por lo que si cometen un acto dañoso, no habiendo persona que responda por ellos, se podrá exigir que respondan con su patrimonio ante una tercera persona. Pero a pesar de esta reforma de lo que no hay duda es que, los menores y los incapacitados son susceptibles de derechos y de obligaciones.

El art. 32 actual dice, "La personalidad civil se extingue por la muerte de las personas". La minoría de edad o la incapacidad no afectan a la

\footnotetext{
${ }^{74}$ Yzquierdo Tolsada, Mariano, (2001)Sistema de Responsabilidad Civil Contractual y Extracontractual, Dykinson, Madrid, pag 230.
} 
capacidad jurídica, pues ser persona para el derecho consiste en ser susceptible de derechos y obligaciones, por lo que con el art. 32 es suficiente para exigir obligaciones a estas personas. "Este es el postulado inicial y básico del derecho de la persona”. Mientras la personalidad jurídica exista, y existe mientras no se produzca el fallecimiento, pueden nacer obligaciones en el patrimonio de toda persona, tenga esta la más precoz inteligencia o sea un profundo oligofrénico o un demente furioso ${ }^{75}$.

El haber suprimido el párrafo segundo del artículo 32 y quedado redactado en su sencilla forma actual, es suficiente para poder exigir a un menor o discapacitado, sin padres ni tutores, la correspondiente indemnización por los daños originados a la víctima.

Como último argumento a emplear es el de la relación de especialidad que guardan los artículos 1903 y 1905 a 1910 en relación con el 1902. El artículo 1903 trata de la responsabilidad de las personas que tienen con el menor una relación de dependencia por razones de familia, tutoría, enseñanza, etc. Los artículos 1905 a 1910 tratan de la responsabilidad de los animales y cosas inanimadas que uno tiene bajo su guarda. Por ello puede entenderse que cuando no se puede exigir responsabilidad por el hecho ajeno, al no existir padres, tutores, etc, o ser estos insolventes, hay que recurrir al artículo 1902 como norma general para hacer responder al menor o incapaz por sus propios actos.

Al haber sido aprobada la LORPM 5/2000 para exigir responsabilidad a los menores hay que aplicar su $\operatorname{art}^{\circ} 61.3$ que dice: "Cuando el responsable de los hechos cometidos sea un menor de dieciocho años, responderán solidariamente con el de los daños y perjuicios causados sus padres, tutores, acogedores y guardadores legales o de hecho, por este orden". Se refiere según su $\operatorname{art}^{\mathrm{o}} 1$ (LORPM) a los menores de edades comprendidas entre catorce y dieciocho años por los daños causados por una conducta tipificada como delito o falta.

75 Ibidem, op cit, pag 232. 
Independientemente de la LORPM se puede exigir responsabilidad a un menor autor material del daño y a la persona que lo tiene bajo su guarda o custodia. Será una responsabilidad solidaria del menor susceptible de culpa y de sus padres ${ }^{76}$.

Cualquiera de las personas enumeradas en el artículo 1903 es responsable en un caso concreto de los actos de un menor, ello no impide que él mismo pueda estar obligado a responder directamente de acuerdo con el artículo 1902. Son dos responsabilidades directas, diferentes y sujetas a sus propios presupuestos ${ }^{77}$.

Para hacer responder a los inimputables que lo son por razones de anomalías psíquicas, o alteraciones graves de la conciencia de la realidad hay que estar a lo que dispone el artículo 118, 1 del C.P. "son también responsables por los hechos que ejecutan los declarados exentos de responsabilidad penal quienes los tenga bajo su potestad o guarda legal o de hecho, siempre que haya mediado culpa o negligencia por su parte y sin perjuicio de la responsabilidad civil directa que pudiera corresponder a los imputables". Esta regla es poco clara por no poderse saber a quien se refiere con la expresión "y sin perjuicio de la responsabilidad civil directa que pudiera corresponder a los imputables". En la regla $1^{\text {a }}$ del $\operatorname{art}^{\circ} 20$ del C.P. de 1973 estaba claro que respondían de manera directa los guardadores y los autores materiales del hecho sólo lo hacía de forma subsidiaria ${ }^{78}$. En el nuevo código esas personas que denomina imputables debería llamarlas inimputables para exigirles responsabilidad civil $^{79}$.

\footnotetext{
76 Diaz Alabart, la responsabilidad civil por los actos ilícitos, dañosos de los sometidos a patria potestad o tutela, ADC, 1987, pag 877 (Yzquierdo Tolsada op cit, nota 22 de la pág. 231)

77 Gómez Calle, La responsabilidad civil del menor, cit, pag 96,97 (Yzquierdo Tolsada, op cit, nota 23, pag 231). 78 Art $^{\mathrm{o}}$ 20, $1^{\text {a }}$ C.P. 1973, "No habiendo persona que los tenga bajo su potestad o guarda legal, o siendo aquella insolvente, responderán con sus bienes las propias personas a que hace referencia el párrafo anterior (enajenados, menor de dieciséis años, alteración en la percepción), dentro de los límites que para el embargo de bienes señalan las leyes de enjuiciamiento civil y criminal".

${ }^{79}$ López Garrido y García Aran, El Código Penal de 1995 y la voluntad del legislador, Madrid 1996, pag 79 (Yzquierdo Tolsada, op cit, pag 231).
} 
En resumen: existen en nuestro C.c. argumentos para exigir responsabilidad a los autores materiales del daño, de muy corta edad o con anomalías psíquicas, cuando no haya personas encargadas de su guarda o estas sean insolventes. Pero los jueces estos hechos los asimilan al caso fortuito de acuerdo con la tradición romanista, por lo que a veces la víctima puede quedar sin indemnización; mientras que en otros códigos de orientación germánica contemplan expresamente la responsabilidad del menor y atienden fundamentalmente a que la víctima no quede sin indemnización. 


\section{GENERALIDADES}

En los últimos decenios se han ido operando cambios importantes en el derecho de familia, por la Ley 11/1981 de 13 de marzo que modificó el código civil en materia de filiación, patria potestad y régimen económico matrimonial, que ha supuesto una mayor autonomía del hijo, al dar prioridad al libre desarrollo de la personalidad, lo que va en detrimento de la autoridad de los padres.

Al configurarse el estado como social, y en particular en nuestra constitución se da prioridad al perjudicado para que no quede sin reparación. Nuestros legisladores del siglo XIX al redactar el código civil, dieron más importancia a la culpa que a la garantía, pero con el paso del tiempo se ha ido evolucionando en sentido contrario, "nuestros Tribunales lo que han hecho ba sido ir cargando sobre la idea de garantía, al tiempo que iban quitando peso a la culpa". Ambos criterios fueron tenidos en cuenta por los legisladores decimonónicos, pero dominando la culpa frente a la garantía; algo que por otra parte, era coherente con el orden social burgués. La clase burguesa y el liberalismo económico no podían tener frenos a la hora de implantar sus ideas, no en vano se habla del triunfo de la burguesía. Por ello sólo serán susceptibles de indemnización aquellos daños en los que interviene culpa o negligencia en el comportamiento de quien lo causa. Con la configuración del estado como social, el legislador y los Tribunales prestan una especial atención a los perjudicados. Si la norma jurídica que regula la responsabilidad civil, tiene en cuenta dos sujetos, el perjudicado y el que ha de hacer frente al perjuicio, en un estado social, la norma y su interpretación prestan más atención al primero que al segundo, buscando principalmente que el perjudicado sea satisfecho ${ }^{80}$.

Los padres son responsables de la educación de los hijos, teniendo

\footnotetext{
${ }^{80}$ Bonilla Correa, op. cit, pag 222.
} 
por objeto esta educación, el que sean autónomos cuando alcancen la mayoría de edad y puedan defenderse por la vida de forma satisfactoria.

Educar hoy día a un hijo menor de edad es muy complicado debido a múltiples factores, tales como la permisividad a la conducta de estos menores, el progresivo debilitamiento de la autoridad paterna, la falta de valores de la educación actual, el desprestigio de todo tipo de autoridad, el haberse implantado entre los menores una cultura de dedicarse a la vida de disfrute y placeres, sin ningún sacrificio como exige la educación y preparación para el futuro. Todo ello hace que los padres tengan muchos problemas a la hora de controlar y educar a los hijos.

Las relaciones entre padres e hijos al igual que entre profesores y alumnos, suponen desigualdad, de tal forma que un padre no puede ser el amigo, el compañero o el colega de su hijo; el padre no es igual que el hijo, son distintos en su forma de comportarse. El hijo tiene que obedecer a su padre, cumplir sus indicaciones, orientaciones y consejos que le dé y a su vez el padre tiene la obligación de dar ejemplo, así como exigirle que sea diligente en su comportamiento y en los estudios, inculcarle valores éticos y morales de acuerdo con los usos sociales.

Ha resultado en estos tiempos muy mermada la autoridad paterna por la evolución de la sociedad actual, al estar los padres separados de sus hijos al trabajar ambos cónyuges, al considerar que los hijos deben gozar de gran libertad, autodeterminación y desarrollo de su personalidad de esta forma, "vamos abocados a una sociedad totalmente permisiva en la que el fenómeno de los niños maltratadores, fruto de una educación que no conoce límites, va en aumento, encontrándose los padres sin herramientas educativas para el buen desarrollo de las facultades que engloban la patria potestad". ${ }^{81}$

Todo ello ha dado lugar a que "haya cada vez más padres que

\footnotetext{
81 Paños Pérez, Alba (2010) La Responsabilidad civil de los padres por los daños causados por menores e incapacitados, Ed.Atelier, Barcelona, pag 67.
} 
declare que tiene temor a sus hijos por denuncias, incluso a agresiones físicas, habiendo renunciado muchos de estos padres a su labor educativa por excesiva tolerancia o indiferencia". 82

Por la Ley 54/2007, de 28 de diciembre, de adopción internacional, ha sido suprimida la facultad de corrección que se hallaba contemplada en el artículo $154 \mathrm{Cc}$, in fine, que decía "podrán también corregir razonable y moderadamente a los hijos". Vemos por tanto que un recurso que los padres tenían para imponer su autoridad a los hijos que no observaban buen comportamiento, ha sido suprimido por lo que el problema se agrava, pues "el tipo de educación excesivamente permisiva que se está dando a los menores genera unos caracteres explosivos, que ha dado lugar a lo que los psicólogos denominan niño tirano o niño maltratador". Así las fiscalías españolas califican de alarmante el incremento en los últimos años de la agresiones de los hijos a los padres y que señalan que el maltrato familiar fue el delito que más creció entre los adolescentes en 2007. Se ha constatado que cada vez son más los progenitores que presencian denuncias contra sus hijos, aunque son muchos los que luego se niegan a declarar contra ellos, el número de delitos de este tipo se ha multiplicado por siete en cuatro años ${ }^{83}$. Todo ello pone de manifiesto la gravedad del problema de las relaciones paterno-filiales lo que influye de manera decisiva a la hora de delimitar la responsabilidad extracontractual de los padres por los hechos de los hijos, con lo que se debería exigir una mayor responsabilidad a los menores al disponer estos de una mayor libertad.

\section{PRINCIPIOS DE DERECHO EUROPEO DE LA RESPONSABILIDAD CIVIL. (EUROPEAN GROUP ON TORT}

\footnotetext{
82 Ibiden, pag 66, nota $n^{\circ} 132$

${ }^{83}$ Ibiden, pag 67, nota $n^{\circ} 237$
} 


\section{LAW)}

Art' 4: 101 Culpa: "Una persona responde con base en la culpa por la violación intencional o negligente del estándar de conducto exigible $\$$. Este artículo se corresponde con el 1902 del código civil español, y aunque con distintas palabras viene a decir lo mismo. La expresión "violación intencional" es equiparable a la culpa de nuestro artículo 1902, puesto que intencional implica la voluntad de causar daño. La culpa incluye el dolo y la negligencia, en el sentido de que la palabra intencional implica dolo y dolo es la intención de causar un mal a alguien; implica maldad o mala fe, mientras que negligencia es falta de diligencia, previsión, de habilidad para prevenir el daño y se suele considerar como modelo la que debe de tener un buen padre de familia.

La culpa es el criterio que se emplea para imputar un daño a alguien por su propia conducta, es algo subjetivo, del individuo de que se trate. Mientras que la responsabilidad objetiva, en la que no se tiene en cuenta la conducta o comportamiento de un individuo; siendo lo decisivo la relación de la persona con la actividad de riesgo.

Este artículo se relaciona igualmente con el artículo 1382 del code civil francés que dice: "cualquier hecho del hombre que cause daño a otro obliga a aquel por cuya culpa sucedió, a repararlo”. De igual forma se relaciona con el artículo 2043 del Códice italiano, el cual dice: "cualquier acto doloso o culposo, que ocasiona a otros un daño injusto, obliga al que ha cometido el hecho a resarcir el daño ${ }^{85}$. El estándar de conducta exigible

${ }^{84} \mathrm{Art}^{\mathrm{o}} 4101$ Fault: "A person is liable on the basis of fault for intentional or negligent violation of the required standard of conduct."

European Group tort law, Thomson, Aranzadi; traducido por Miguel Martin Casals, Ed. Aranzadi, 2008, pag 108.

$85 \mathrm{Art}^{\mathrm{O}} 1382$ del Code Civile: “ Tout fait quelconque de l’home, qui cause á autrui un dommage, obligue celui para la faute duquel il est arrilvé, a le reparrer".

Art $^{\circ} 2043$ del Codice civile italiano (Risarcimento per fatto illecito). "Qualunque fatto doloso o colposo, che 
se halla contemplado en el artículo 4.102 y dice: (1) "el estándar de conducta exigible es el de una persona razonable que se halle en las mismas circunstancias y depende, en particular, de la naturaleza y el valor del interés protegido de que se trate, de la peligrosidad de la actividad, de la pericia exigible a la persona que la lleva a cabo, de la previsibilidad del daño, de la relación de proximidad o de especial confianza entre las personas implicadas, así como de la disponibilidad y del coste de las medidas de precaución y de los métodos alternativos".

(2) "El estándar anteriormente indicado puede adaptarse cuando debido a la edad, a la discapacidad física o psíquica o a circunstancias extraordinarias no sea exigible que la persona de que se trate lo cumpla"

(3) "Al establecer el estándar de conducta requerido deben tenerse en cuenta las normas que prescriben o prohíben una determinada conducta". 86

La expresión "persona razonable” es algo variable y depende en gran medida de la formación o preparación técnica de la persona en cuestión, y es diferente para un experto en la materia que para alguien que no lo es, como por ejemplo un ingeniero industrial tendrá un estándar mayor de responsabilidad que un titulado en formación profesional, pues el ingeniero

cagiona ad altri un danno ingiusto, obliga colui che ha commesso il fatto a risarcire il danno".

${ }^{86} \mathrm{Art}^{\circ} 4.102$ Required Standard of conduct.

1) The required standard of conduct is that of the reasonable person in the circumstances, and depends, in particular, on the nature and value of the protected interest involved, the dangerousness of the activity, the expertise to be expected of a person carrying it on, the foreseeability of the damage, the damage, the relationship of proximity or special reliance between those involved, as well as, the availability and the costs of precautionary or alternative methods.

2) The above standard may be adjusted when due to age, mental or physical disability or due to extraordinary circumstances the person cannot be expected to conform to it.

3) Rules which prescribe or forbid certain conduct have to be considered when establishing the required standard of conduct. 
tiene una mayor preparación y sus exigencias tienen que ser por tanto mayores. En cuanto a "la naturaleza y el valor del interés protegido de que se trate" significa que cuanto más importante sea el interés a proteger, mayor será la exigencia para prevenir el daño, por lo que la diligencia será más elevada como puede ser cuando se refiera a la vida o a la integridad física de las personas.

Por lo que se refiere a la "peligrosidad de la actividad", la persona encargada tiene que tener las actitudes necesarias para realizarla, en caso contrario debe de abstenerse de llevarla a cabo; debe de tener la titulación requerida y demostrar la pericia necesaria, pues en caso contrario se le puede exigir responsabilidad por impericia o negligencia.

En la previsibilidad del daño puede variar el estándar de conducta, pues hay veces que aunque la persona haya sido muy diligente, el daño ha podido ser imprevisible, como por ejemplo en un comedor de una guardería un niño de muy corta edad produzca a otro una agresión con un tenedor en un ojo, con la correspondiente pérdida de visión del mismo; a pesar de que la cuidadora se encontrara presente, la agresión se haya producido de forma súbita, nadie puede por ello evitarlo, lo que daría lugar a un caso fortuito, quedando exonerada la cuidadora y la guardería, pues el estándar de conducta de los responsables ha sido correcto.

Como causas extraordinarias del apartado 2, del $\operatorname{art}^{\mathrm{o}} 4$ : 102, son de varias clases, dependiendo de la edad, grado de discernimiento, circunstancias peculiares del suceso, y otras en que se tienen que analizar caso por caso. El Juez teniendo en cuenta el caso de que se trate deberá establecer el grado de responsabilidad de los implicados pudiendo llegar a exonerar a los responsables. Pensemos en menores que comenten imprudencias con instrumentos peligrosos, o en lugares con mucho tráfico, en los que se debe redoblar la prudencia, a la vez que esos menores tienen el discernimiento suficiente; en estos casos sus padres pueden ser exonerados, pues los que no han cumplido con el estándar de conducta exigible han sido 
los propios menores.

El cumplimiento de las normas vigentes es determinante para poder imputar a alguien una culpa. En la mayoría de los ordenamientos, el no haber cumplido lo que establece una norma, es suficiente para culpar al infractor, siempre que se dé una relación directa, un nexo causal, entre el incumplimiento de la norma y la producción del daño, en caso contrario, ese incumplimiento sería irrelevante.

Este cumplimiento de las normas de $\operatorname{art}^{\mathrm{o}}$ 4: 102 apartado 3 del estándar de conducta exigible no sólo abarca las normas que emanan de los poderes públicos, sino que, llega hasta las instrucciones técnicas de organismos privados, empresas, y otros entes en los que se deben tener en cuenta, pues en caso contrario se viola el mínimo de estándar de conducta exigible y como consecuencia de ello se incurre en responsabilidad. Tengamos en cuenta unos menores de 12 o 13 años que vean un cartel de "prohibido el paso o no tocar peligro de muerte" y a pesar de ello se produce un accidente por no respetarlo; ello daría lugar a ser ellos responsables por tener el suficiente discernimiento y la empresa haber cumplido con las normas de seguridad.

$\operatorname{Art}^{\circ}$ 6.101 Responsabilidad por los menores o por discapacitados psíquicos. "La persona que tiene a su cargo otra persona que es menor o sufre discapacidad psíquica responde por el daño causado por esa otra persona a menos que demuestre que ella misma cumplió con el estándar de conducta que le sea exigible en su supervisión ${ }^{87}$.

Este artículo se corresponde con el 1903 de nuestro código civil en

\footnotetext{
${ }^{87}$ Chapter 6 Liability for others.

Art $^{\circ}$ 6.101 Liability for minors or mentally disabled persons.

A person in charge of another who is a minor or subject to mental disability is liable for damage caused by the other unless the person in charge shows that he has conformed to the required standard of conduct in supervision.
}

European Croup tort Law, Thomson, Aranzadi, op. Cit, pag 159. 
sus apartados, primero, segundo, tercero, quinto y sexto, en el que se refiere a quien tiene a cargo otra persona, padres, tutores, personas o entidades, de un centro de enseñanza no superior y que también pueden ser exonerados si emplearon la diligencia de un buen padre familia.

Aunque en el artículo 1903 no hace referencia a la discapacidad psíquica se sobreentiende que quedan incluidos los discapacitados, sobre los que por sus circunstancias especiales se debe redoblar, extremar o intensificar la vigilancia sobre ellos.

Menor de edad es la persona menor de 18 años de acuerdo con el artículo 12 de nuestra constitución en que establece la mayoría de edad a los 18 años. En la mayor parte de los ordenamientos de nuestro entorno, la mayoría de edad se establece igualmente a los 18 años.

Persona que lo tiene a cargo puede ser física o jurídica, puede tratarse de padres o tutores o alguna institución que lo tenga a cargo. No incluye sin embargo a la persona que los tiene a cargo por un corto periodo de tiempo, como pueden ser los tíos o los abuelos; los que sólo pueden responder en caso de negligencia.

En cuanto al alcance de la responsabilidad no se da por el acto culposo o negligente del menor, sino por no haber observado la obligación de vigilar, culpa in vigilando, al igual que sucede en nuestro código civil.

Los menores de cierta edad pueden ser ellos mismos culpables si tienen el discernimiento suficiente. No serían culpables los menores de 7 años, pero si a partir de los doce y desde luego a partir de los catorce como señala el $\operatorname{art}^{\circ} 1.1^{\circ}$ de nuestra LORPM.

Padres e hijos pueden ser solidariamente responsables, cuando se trate de menores cercanos a la mayoría de edad, los denominados grandes menores (grande minori) del derecho civil italiano y los padres no consigan probar su propia diligencia y por tanto no queden exonerados. En la jurisprudencia española resulta muy difícil que los padres queden exonerados, dando lugar a una responsabilidad objetiva o cuasiobjetiva. 
Para resolver los casos de responsabilidad por los daños causados por los menores, existen tres formas de realizarlo en los ordenamientos de nuestro entorno:

En Austria e Inglaterra no se estable ninguna regla especial para estos casos, de forma que la victima tiene que probar el daño causado por el menor, la culpa de los padres y el nexo causal con ese daño.

Otro grupo de países como Alemania y Suiza, se presume la negligencia de los padres o cuidadores, que sin embargo pueden tratar de exonerarse probando su propia diligencia en la vigilancia y educación de los menores.

El tercer grupo a considerar es el formado por Francia e Italia en que perteneciendo al segundo grupo mencionado, se fueron progresivamente a este tercero en el que la responsabilidad es objetiva. A él pertenece España en el que la responsabilidad es igualmente objetiva, al resultar muy difícil ser exonerado como se dijo anteriormente.

Como consecuencia de estas formas de resolución de la responsabilidad de los daños ocasionados por los menores el European Group on tort Law ha establecido una presunción de responsabilidad por los padres o guardadores, presunción que cede ante la prueba de que se había ejercitado adecuadamente el deber de supervisión sobre esos menores ${ }^{88}$.

Esta presunción de responsabilidad es la misma que la establecida en el $\operatorname{art}^{\circ} 1903$ in fine, con la diferencia que en nuestra jurisprudencia es muy difícil de probar el haber ejercitado adecuadamente el deber de supervisión de los menores. Son pocas las sentencias en que los padres queden exonerados de responsabilidad por los daños causados por sus hijos menores, pues nuestra jurisprudencia protege más al perjudicado, tratando siempre de que sea resarcido.

Se da una inversión de la carga de la prueba, esto es, que si el

\footnotetext{
${ }^{88}$ European Group on tort Law op. cit. pags 159 y 160.
} 
demandante o actor es quien normalmente debe probar lo que demanda, en este caso, es el padre quien debe de probar o demostrar que ejerció adecuadamente el deber de supervisión o que empleó la diligencia debida para prevenir el daño.

\section{RESPONSABILIDAD DE LOS PADRES EN EL CÓDIGO PENAL}

Para estudiar este tipo de responsabilidad hay que tener en cuenta lo dispuesto en los artículos 20, 118 y 120 del código penal.

$\mathrm{El}$ artículo 20 en sus apartados primero y tercero dice: están exentos de responsabilidad: " ${ }^{\circ}$ el que al tiempo que cometer la infracción penal, a causa de cualquier anomalía o alteración psíquica, no puede comprender la ilicitud del hecho o actuar conforme a esa comprensión.

El trastorno mental transitorio no eximirá de pena cuando hubiere sido provocado por el sujeto con el propósito de cometer el delito o hubiera previsto o debido prever su comisión.

$3^{\circ}$ El que, por sufrir alteraciones en la percepción desde el nacimiento o desde la infancia, tenga alterada gravemente la conciencia de la realidad".

Por lo que se refiere al artículo $1181^{\circ}$ del CP dice: "en los casos de los números primero y tercero son también responsables por los hechos que ejecuten los declarados exentos de responsabilidad penal, quienes los tengan bajo su potestad o guarda legal o de hecho, siempre que haya mediado culpa o negligencia por su parte y sin perjuicio de la responsabilidad civil directa que pudiera corresponder a los imputables".

En cuanto al $\operatorname{art}^{\circ}$ 120.1 CP dice: "son también responsables civilmente, en defectos de los que lo sean criminalmente: $1^{\circ}$ los padres o tutores, por los daños y perjuicios causados por los delitos o faltas cometidas por los mayores de 18 años sujetos a su patria potestad o tutela y que vivan en su compañía, siempre que haya por su parte culpa o 
negligencia".

Los declarados exentos de responsabilidad de $\operatorname{art}^{\circ} 20$, números 1 y 3, son personalmente responsables civiles y puede exigírseles responsabilidad si disponen de patrimonio y en determinadas circunstancias, como ya fue expuesto anteriormente, por lo que no insistiré más sobre ello.

Son responsables civiles directos las personas que los tengan bajo su potestad o guarda legal o de hecho, pero siempre que haya intervenido por su parte culpa o negligencia, de la que regula el artículo 1104 del código civil, según la naturaleza de la obligación de persona, tiempo y lugar, que por lo general es la que correspondería a un buen padre de familia. Es la que correspondería en los Principios Europeos de la Responsabilidad Civil en sus artículos 4.101 y 4.102 que denomina estándar de conducta exigible.

$\mathrm{Al}$ aparecer los términos "culpa o negligencia" quiere ello decir que el motivo de la responsabilidad se encuentra en la culpa o negligencia y si estos no existen los padres no tendrán que responder. En este caso la culpa o la negligencia tendrá que ser probada por el perjudicado y se trata por ello de un sistema subjetivo, al contrario de lo que sucede en el artículo 1903 del código civil en que es un sistema objetivo y a los padres corresponde probar que obraron con la diligencia de un buen padre de familia para prevenir el daño, lo que no resulta nada fácil ante un tribunal.

Esta responsabilidad civil, independiente de la penal, pues aunque no exista responsabilidad penal puede existir responsabilidad civil o a pesar de existir ambas, se hace una pieza separada de responsabilidad civil, se fundamenta en la relación de dependencia que existe entre los padres y los hijos sometidos a su cuidado, lo que da lugar a un deber de control de los padres sobre los hijos, tratándose de faltas "in vigilando" o "in educando".

En estos supuestos la responsabilidad civil se exige a personas que no han participado en el delito, pero tienen una relación o vinculación con los participes del hecho que da lugar a una responsabilidad civil subsidiaria o de segundo grado, que surge por defecto total o parcial de la principal (la 
que comete el hijo) por lo que debe responder el padre.

\section{RESPONSABILIDAD DE LOS PADRES EN EL CÓDIGO CIVIL}

La responsabilidad de los padres en el código civil se contempla en los artículos 1902 y 1903, el primero trata de la responsabilidad por actos u omisiones propios, por culpa o negligencia mientras que el segundo es complementario del anterior, pues en su apartado primero dice: "la obligación que impone el artículo anterior es exigible no sólo por los actos u omisiones propios, sino por los de aquellas personas de quienes se debe responder." Y las personas de las que se debe responder las exponen los apartados siguientes, dedicando el primero de ellos a los padres, a los que señala como los responsables de los daños causados por los hijos que se encuentren bajo su guarda.

El artículo 1902 dice: "el que por acción u omisión cause daño a otro, interviniendo culpa o negligencia, está obligado a reparar el daño causado, "lo que trata de un sistema subjetivo puro por culpa o negligencia. Mientras que el artículo 1903 es un sistema de responsabilidad subjetiva objetivada por la inversión de la carga de la prueba de su último apartado en el que dice: "la responsabilidad de que trata este artículo cesará cuando las personas en él mencionadas prueben que emplearon toda la diligencia de un buen padre de familia para prevenir el daño".

Normalmente la carga de la prueba recae sobre el demandante o actor, en nuestro caso es el perjudicado, pero por el último apartado del artículo 1903 visto anteriormente, la carga de la prueba se invierte y recae sobre los padres del menor, que deben demostrar que actuaron con la diligencia de un buen padre de familia para prevenir el daño, lo que da lugar a una objetivación de la responsabilidad. 


\subsection{OBJETIVACIÓN DE LA JURISPRUDENCIA}

$\mathrm{Al}$ redactar el código en 1889 se da en el último inciso del Art. 1903 una inversión de la carga de la prueba, con lo que se consigue una objetivación de la responsabilidad, la cual aumentará más a través de la jurisprudencia.

El motivo principal de la objetivación jurisprudencial es el tratar de indemnizar a la víctima sobre cualquier otra consideración. Con la inversión de la carga de la prueba se consigue indemnizar a la víctima, pero no es suficiente y se necesitan argumentos para involucrar a los padres por culpa in vigilando o in educando, para evitar la exoneración y que la víctima cargue con el daño, al ser los menores personas en la mayor parte de los casos insolventes.

Para exigir responsabilidad a los padres es necesario que ellos puedan vigilar y educar o corregir a sus hijos, pero en la actualidad se establece una prioridad a la idea de libertad y libre desarrollo de la personalidad del menor, con lo que su capacidad de vigilar y educar se quedan disminuidas de forma considerable.

No se trata de fijarse en la culpa del sujeto que causa el daño, lo que importa es asegurar la reparación o indemnización a la víctima del daño que ésta ha sufrido, que no tiene la obligación de soportarlo y que se debe de buscar la forma de asegurar esa reparación.

Cuanto mayores sean los poderes de los padres, es decir, de la patria potestad mayores responsabilidades se les podrá exigir por los actos dañosos de sus hijos. En sentido contrario, si a los hijos se les permite una mayor libertad, autonomía, libre desarrollo de la personalidad, etc, debería exigirse mayor responsabilidad a los hijos y menor a los padres; pero esto tiene el inconveniente de que el menor suele ser insolvente y entonces daría lugar a no poder garantizarse el cobro del perjudicado, que es lo que se trata fundamentalmente que quede garantizado.

Todo ello da lugar a que se produzca un contrasentido entre la 
excesiva libertad de los hijos y la exigencia de responsabilidad a los padres, así como, el que los tribunales no exoneren de responsabilidad a los padres, cuando estos no hayan actuado culposamente.

Esta situación es debida a que el código civil no se ha modificado con el paso del tiempo, de acuerdo con la evolución de los cambios sociales, por lo que han sido los tribunales los que han tenido que dar respuesta a las nuevas realidades sociales, para conformar la responsabilidad de los padres por los hechos de sus hijos. ${ }^{89}$

\subsection{RESPONSABILIDAD POR HECHO AJENO}

Nuestro código civil en su $\operatorname{art}^{\circ} 1903$ contempla la obligación de reparar el daño causado por otro en su apartado primero que dice: "la obligación que impone el artículo anterior es exigible no sólo por los actos u omisiones propios, sino por los de aquellas personas de quienes se debe responder".

Se trata de una responsabilidad por hecho ajeno o responsabilidad por el hecho de otro, ya que la responsabilidad por hecho propio se regula en el $\operatorname{art}^{\circ} 1902$ y los dos artículos se complementan.

En esta responsabilidad por hecho ajeno el que comete el hecho dañoso es el menor, es el que lo realiza materialmente, pero el que responde es el padre, tutor, etc, por darse una negligencia por su parte, in vigilando o in educando, de acuerdo con la expresión "no sólo por los actos u omisiones propios, sino por los de aquellas personas de las que se debe responder", es decir, los padres tienen el deber de vigilar y educar a sus hijos y si sus hijos comenten hechos daños ellos resultan culpables de forma directa como si ellos mismos los hubieran realizado. A no ser que probaran que emplearon la diligencia de un buen padre de familia para prevenir el daño, en cuyo caso serán exonerados. Si no logran probar esa diligencia, la responsabilidad pasa a ser cuasi-objetiva y tendrán que indemnizar por los

${ }^{89}$ Bonilla Correa, op. cit 217 y ss. 
daños causados.

La jurisprudencia ha continuado objetivando la culpa, aunque existen algunas sentencias en que los responsables de los menores quedan exonerados como en la STS de 28 de diciembre de 2001 (RJ 2000/3094), en ella en su fundamento primero se dice que las niñas de 5 años que estaban jugando a la comba, al soltarla se dio a la otra niña en un ojo, por lo que perdió la visión en el mismo, debido a un fatal accidente, de un juego que es calificado de totalmente inocuo, practicado por la mayor parte de las niñas y que se encontraban vigiladas en todo momento por una profesora del centro. Las niñas de una conducta moral sin carácter conflictivo.

Por su fundamento segundo se exculpa a los padres de Patricia, que fue la niña que soltó el extremo de la comba y produjo el hecho fatal, que es la comba un juego inocuo y se encuentra bajo la vigilancia de una profesora y por ello no se puede exigir responsabilidad a esos padres.

$\mathrm{Su}$ fundamento tercero contempla la exoneración del colegio por hallarse los alumnos vigilados por la profesora que atendió a la pequeña en los primeros momentos, no pudiéndose por ello imputar al colegio una responsabilidad culposa omisiva. La carga de la prueba se efectuó sobre los demandados, con lo que se dio una inversión de la carga de la misma, habiendo ellos demostrado que obraron con la debida diligencia, y el accidente se debió a un caso fortuito, por la falta de previsibilidad de un resultado como el que se produjo. Por todo ello en su fundamento cuarto se desestimó el recurso de casación, imponiendo el pago de las costas a la parte recurrente.

Otra sentencia sobre negligencia de los padres, es la STS de 24 de mayo 1996 (RJ 1996/3915), en ella se aprecia falta de diligencia del padre por lo que es condenado. Los hechos consisten en que un menor toma la pistola de su padre que guardaba en un porta folios dentro de su coche, de marca Mercedes, dentro de cuya rueda de repuesto se hallaba un cargador de munición, que vio su hijo en una descarga del maletero, por lo que 
algunas veces cogía la pistola del coche con las llaves de su padre; la noche del 25 de mayo 1985, en unión de otros menores, siendo víspera de fiesta tuvieron unas palabras con otro grupo de tres personas mayores a los que disparó produciéndoles la muerte.

No habla la sentencia de la edad del menor, pero se supone que sería un adolescente próximo a la mayoría de edad, que tendría capacidad de discernimiento para prever el alcance de sus actos y su trascendencia.

La pistola marca Start, I, de 7,62 mm la tenía el padre sin la guía de pertenencia, ni licencia de uso, por tanto se trataba de un arma ilegal, lo que dio lugar a ser condenado en vía penal.

El Juzgado y la Audiencia no han considerado que el padre actuó con negligencia, lo que corregirá posteriormente el Tribunal Supremo. Ello da lugar a un error jurídico producido por las sentencias de instancia en las que se afirma "que no ha quedado demostrado que el demandado actuase sin la diligencia debida", cuando es el demandado a quién corresponde demostrarlo, pues la inversión de la carga de la prueba así lo exige, en el último inciso del $\operatorname{art}^{\mathrm{o}} 1903$.

De los hechos se deduce que el padre no obró con la diligencia debida, al no tomar las medidas de precaución necesarias para que su hijo no consiguiera tomar la pistola y su correspondiente munición, de ello se infiere que no justificó el último inciso del art $^{\circ}$ 1903. Por otra parte, de los hechos cometidos por los menores responden los padres que los tienen bajo su guarda, por ello el TS casa la sentencia, estima en parte la demanda y condena a los demandados a indemnizar sendas cantidades de 5 millones de pesetas a los actores, padres de los respectivos hijos fallecidos.

\subsection{LA RESPONSABILIDAD DE LOS PADRES EN LA LORPM}

La LORPM en su artículo primero, apartado 1, dice que se aplicará para exigir la responsabilidad de las personas mayores de 14 años y menores 
de 18, por la comisión de hechos tipificados como delitos o faltas en el código penal o las leyes penales especiales.

En su artículo 3 dice que cuando el autor sea menor de 14 años, no se le exigirá responsabilidad con arreglo a la presente Ley, sino que se le aplicará lo dispuesto en las normas sobre protección de menores prevista en el código civil y demás disposiciones vigentes.

La franja de los 14 años que se ha establecido, obedece a que al llegar a ella el menor en circunstancias normales, tiene el suficiente discernimiento para calibrar el alcance y trascendencia de sus actos. Por debajo de la franja de los 14 años se entiende que le falta el suficiente discernimiento por lo que el legislador le aplica lo dispuesto en las normas de protección de menores previstas en el código civil y demás disposiciones vigentes. Para aplicarle la presente Ley, el menor tiene que tener una edad de más de 14 años y menor de 18, siendo así por tener a los 14 años la enseñanza básica, con un grado de madurez aceptable y lo que se pretende es no mezclarle con adultos, ni tampoco aplicarle ese tipo de legislación como establece el artículo 19 del código penal.

Por el $\operatorname{art}^{\circ} 61.3$ de la LORPM se exige la responsabilidad civil a los padres, tutores, acogedores y guardadores legales o de hecho y dice lo siguiente: "Cuando el responsable de los hechos cometidos sea un menor de 18 años, responderán solidariamente con el de los daños y perjuicios causados su padres, tutores, acogedores y guardadores legales o de hecho, por este orden. Cuando estos no hubieren favorecido la conducta del menor con dolo o negligencia grave, su responsabilidad podrá ser moderada por el Juez según los casos".

Así se establece un sistema de responsabilidad civil objetivo y solidario, asignando su competencia al Juzgado de Menores, establece la responsabilidad solidaria del menor de 18 años y de sus padres, tutores, acogedores y guardadores legales o de hecho por este orden; sin exigir que se dé alguna otra circunstancia, como vivir en su compañía, culpa, 
negligencia, etc y sin perjuicio de que la responsabilidad pueda ser moderada por el Juez, cuando no hubieren favorecido la conducta del menor con dolo o negligencia grave. La moderación se refiere a un tanto por ciento de la indemnización, sin que pueda llegar a ser una exención total o completa.

Por el $\operatorname{art}^{\circ} 61.3$ los Juzgados de Menores son competentes para tratar de las demandas dirigidas contra una Administración Pública, cuando sea tutora, acogedora o guardadora de un menor, que tiene el cometido de control y vigilancia sobre esos menores, por ser una institución pública encargada de ellos para exigir la responsabilidad patrimonial de la Administración Pública originada por el funcionamiento normal o anormal de sus servicios, se aplica el artículo 61.4 de la LORPM. Se utilizará el art ${ }^{\circ}$ 145 de la Ley 30/1992 LRJAP y PAC y la Ley 35/1995 de ayudas y asistencia a las víctimas de delitos violentos y contra libertad sexual y sus disposiciones complementarias.

La acción para exigir la responsabilidad civil corresponde al Ministerio Fiscal, excepto si el perjudicado renuncia a ella, la ejercita por si mismo en el plazo de un mes desde que se le notifique la apertura de pieza separada de responsabilidad civil $\left(\operatorname{art}^{\circ}\right.$ 61.2), o bien se la reserve para ejercerla ante el orden de la jurisdicción civil.

Si los hechos cometidos por el menor no son típicos penalmente su régimen jurídico es el del $\operatorname{art}^{\mathrm{o}} 1903$ y ss. del CC. Si el menor es de edad inferior a 14 años, aunque sean típicos penalmente, se someten a lo previsto en el CC. En consecuencia, se someten a la LORPM, cuando el menor es mayor de 14 años y menor de 18, sus hechos son típicos penalmente y el perjudicado no se reserva las acciones civiles.

El carácter objetivo de la responsabilidad tiene un respaldo mayoritario en la doctrina hay autores que la califican de cuasi objetiva por la posibilidad de moderación por el Juez, pero esta moderación no es preceptiva y además no llegará nunca a excluir la obligación de responder.

Bonilla Correa la califica de acuerdo con la doctrina "como objetiva, 
al margen de la culpa. Los padres van a responder con independencia de haber o no incurrido en culpa o negligencia, incluso probando que fueran enteramente diligentes. No obstante, la existencia de dolo o culpa grave tiene consecuencias; impedir la moderación "'?0.

Los tribunales califican en unas ocasiones de cuasi objetiva y en otras de objetivas, pero la tendencia general es a la objetivación, como se puede ver en la S.A.P de Badajoz de 25 de enero de 2005 (AC- 2005/333), en ella se da una responsabilidad objetiva y solidaria de los padres.

En su fundamento de derecho tercero apartado 3, la LORPM establece un modelo de responsabilidad de carácter objetivo independiente del contemplado en el Código Civil y en el Código Penal. Se trata de un modelo o sistema de mayor alcance y severidad en el que se consigue por una parte proteger mejor a la víctima al liberarle de tener que probar la culpa del responsable civil, así como de proteger igualmente contra la insolvencia de los menores infractores, asegurándolo con un sistema objetivo, sin fisuras ni excusas la indemnización de daños a tales víctimas, sin que puedan liberarse de su responsabilidad aunque prueben la diligencia debida de último inciso del $\operatorname{art}^{\circ} 1903$; y por otra parte, conseguir una mayor implicación del padre y demás responsables en el proceso de socialización de los menores imponiéndoles las consecuencias civiles de las infracciones que estos cometan por la transgresión del conjunto de deberes que tienen sobre ellos.

Su apartado cuarto hace referencia al artículo 61.3 de la LORPM en el que señala a los propios menores como sujetos pasivos obligados en primer lugar a la responsabilidad civil y en segundo lugar, pero solidariamente con el propio menor, a sus padres, tutores, acogedores o guardadores legales o de hecho, por este orden. El menor desde luego es el principal responsable civil, pues ya tiene discernimiento suficiente por su edad, pero en ningún caso se va a poder exonerar a los responsables

${ }^{90}$ Ibidem, op cit pag 232 y 233. 
solidarios que le tiene a su cargo, ni aunque acrediten haber actuado con la máxima diligencia, lo único que pueden conseguir es una moderación de la responsabilidad, si no han favorecido la conducta del menor con dolo o negligencia grave; siempre que el Juez, lo considere oportuno no de forma obligatoria, sino facultativa.

El apartado 5 considera la responsabilidad como objetiva, independiente de la culpa civil, prescindiendo totalmente de los criterios de imputación subjetiva, teniendo estos en cuenta para la moderación de la responsabilidad si el juez lo estima conveniente, de los responsables por hechos ajenos. Para la exigencia de responsabilidad sólo es necesaria la vinculación del menor con alguna de las personas que contempla el $\operatorname{art}^{\mathrm{o}} 61.3$ de la Ley, padres, tutores, etc. Esta responsabilidad se fundamenta además de en el deber de guarda, en el deber de educación, así como en las facultades de corrección de los padres, tutores y acogedores o guardadores que se hallen sometidos a su guarda.

Por el apartado 7 se analizan las circunstancias particulares del caso según el informe elaborado por el equipo técnico del Juzgado de Menores de Badajoz, deduciéndose de él, se trata de unos padres separados, lo que influyó sobre el menor. La madre se buscó un empleo en el servicio doméstico, para hacer frente a los gastos generales de la casa, así como que su hijo pudiera continuar sus estudios, lo que hizo hasta que los dejó para integrarse en el mundo laboral, siendo ella la que mantuvo las normas y horarios del hijo, ya próximo a la mayoría de edad. El padre por su parte se desentendió por completo del menor, dejando el hogar familiar, rompiendo todos los lazos afectivos con el menor, despreocupándose de la asistencia y educación de dicho menor.

En el apartado 8, la sentencia ha de confirmarse en el sentido de hacer responsable al padre solidariamente con el menor del importe total de la indemnización. La madre merece en atención a su comportamiento y actitud, que su responsabilidad sea moderada reduciéndose en un 50\%. 
Vemos que no hay exoneración para nadie, dándose solo la moderación, lo que conforma una responsabilidad de carácter objetivo en que se atiende fundamentalmente a la indemnización de la víctima.

En el artículo 62 LORPM sobre la extensión de la responsabilidad civil dice: "la responsabilidad civil a la que se refiere el Artículo anterior se regulará en cuanto a su extensión, por lo dispuesto en el Capítulo I del Título $5^{\circ}$ del Libro Primero del Código Penal vigente". Este capítulo 1 abarca de los Artículos 109 a 115 del CP. El Artículo 109 CP habla de que se obliga a reparar, en los términos previstos en las leyes, los daños y perjuicios causados y los daños en la forma prevista en las leyes. La sentencia penal que condena por un delito no presupone sin más la existencia de responsabilidad civil, dado que esta nace de la producción de un daño, y este daño unos delitos pueden producirlo y otros no. No es cierto, por tanto, que toda responsabilidad criminal conlleve necesariamente la civil. Las únicas infracciones penales susceptibles de engendrar responsabilidad civil son aquellas en las que el hecho además del daño criminal a ellas inherente, producen un daño civil, generador de daño de esta naturaleza, a cuyo resarcimiento se encamina la acción civil correspondiente (STS 936/06 de 10-10 RJ 2006/7705). La sentencia debe contener una determinación del daño, en la medida de lo posible, como si de una acción civil se tratara, ejercida con independencia de lo penal; por cuanto la acción civil "ex delicto", no pierde su naturaleza civil por el hecho de ser ejercitada en un proceso penal. La estimación de la concreta cuantía objeto de la condena ha de ser razonada en los supuestos en que la motivación sea posible, y si no lo es o alcanza a veces dificultades insuperables, explicar la indemnización por daño moral, difícilmente sujeta a normas preestablecidas. Comprende también los intereses legales del $\operatorname{art}^{\circ} 576$ LEC, pues si hay una cantidad líquida, esta devengará los intereses desde que se dicta en primera instancia hasta la ejecución. La fijación del "quantum" es potestad del Tribunal de Instancia; siendo en casación impugnables sólo las bases sobre 
las que se asienta. La cuantía sólo es revisable cuando la cifra fijada por el Juez o Tribunal rebase, exceda o supere la reclamada o solicitada por las partes acusadoras y la sentencia sólo lo será cuando no fije, o lo haga defectuosamente las bases correspondientes. La indemnización comprende los perjuicios materiales (que han de estar probados) y los morales que no son susceptibles de prueba, cuando su existencia se infiere inequívocamente de los hechos.

El $\mathrm{Art}^{\circ} 11.2$ del CP dice: "deberá restituirse siempre que sea posible, el mismo bien, con abono de los deteriores y menoscabos que el Juez o Tribunal determinen. La restitución tendrá lugar aunque el bien se halle en poder de terceros y este lo haya adquirido legalmente y de buena fe, dejando a salvo su derecho de repetición contra quien corresponda y, en su caso, el de ser indemnizado por el responsable civil del delito o falta". Restituir es volver una cosa a quien la tenía antes, esta acción, hay que entender que es sólo susceptible de imponerse jurídicamente en casos de ilegitima posesión, cuando esta recae sobre objetos perfectamente identificables, que subsisten como tales, por lo que el dinero se restituye devolviendo una cantidad igual. Si existe la misma cosa de que el perjudicado hubiera sido desposeído, es imperativa la devolución de la misma. En los delitos que tienen por objeto la incorporación al propio patrimonio de una cosa ajena (hurto, robo, apropiación indebida, estafa) ha de considerarse de aplicación preferente la restitución de la cosa respecto de la indemnización de perjuicios. Lo propio en el delito de apropiación indebida ha de ser la devolución del objeto en cuestión. La indemnización será con carácter subsidiario en caso de que no fuera posible la sustitución de la cosa. Si la acusación pide la indemnización y no la restitución del objeto indebidamente apropiado, se concederá aquella y no la restitución. (STS 1709/03-19-12 RJ 2003/9314). Fuera de los casos anteriores el derecho de cualquier perjudicado se concreta en recibir una suma de dinero.

Dice al $\mathrm{Art}^{\mathrm{O}} 112 \mathrm{CP}$ sobre la reparación: "la reparación del daño 
podrá consistir en obligaciones de dar, de hacer, o de no hacer que el Juez o Tribunal establecerá atendiendo a la naturaleza de aquel y a las condiciones personales y patrimoniales del culpable, determinando si han de ser cumplidas por el mismo o pueden ser ejecutadas a su costa". La cuantificación de la indemnización es competencia del Tribunal que dicta la sentencia, para lo que debe obrar de forma ponderada y razonable así como dentro de los parámetros máximos (STS 481/02,15-3 RJ 2002/4603). Los criterios que se emplean son el de explicar la causa de la indemnización, no imponer una cantidad superior a la que pide la acusación y dentro de la discrecionalidad de que se haya facultado el Tribunal debe aplicar el principio de razonabilidad (STS 89/03,23-1 RJ 2003/962). La reparación abarca todo el daño causado, lo que se traduce en que la víctima tiene derecho a una indemnización adecuada, de acuerdo con los daños y perjuicios causados (STS 195/05,17-2 RJ 2005/3059). El daño es el menoscabo de la cosa y el perjuicio es el menoscabo económico derivado de ese daño (STS 722/99,6-5 RJ 1999/4963). Los daños han de ser probados por quien intente percibirlos (STS 722/99,6-5 RJ 1999/4963). Por daños materiales sólo proceden reputarse perjudicados los que sufran un daño patrimonial efectivo, por lo que hay que excluir los dudosos (STS 589/99,21-4 RJ 1999/2786).

El Art 113 CP dice: "la indemnización de perjuicios materiales y morales comprenderá no sólo los que se hubieren causado al agraviado, sino también los que se hubieren irrogado a sus familiares o a terceros”. Según la actual doctrina y jurisprudencia, cuando la entidad aseguradora tenga concertado un contrato de seguro con el perjudicado por el delito, al ser esta entidad un tercero y haber satisfecho las cantidades del contrato, puede reclamar frente al responsable penal en el seno del proceso penal que se siga contra el mismo, como actora civil, subrogándose en la posición del perjudicado (STS 199/07,1-3 RJ-2007/1808).

Por el $\mathrm{Art}^{\mathrm{O}} 114 \mathrm{CP}$ que dice: "si la víctima hubiere contribuido con 
su conducta a la producción del daño o perjuicio sufrido, los Jueces o Tribunales podrán moderar el importe de su reparación o indemnización". Si la víctima ha favorecido con su negligencia la comisión del delito el Juez está facultado para moderar la indemnización, pudiendo actuar con discrecionalidad para acordar o no esa moderación, con mayor motivo si el perjudicado ha obrado con negligencia.

Dice el Art $^{\circ} 115$ CP: "los Jueces y Tribunales, al declarar la existencia de responsabilidad civil, establecerán razonadamente en sus resoluciones la bases en las que fundamenten la cuantía de los daños e indemnizaciones, pudiendo fijarlas en la propia resolución o en el momento de su ejecución “. La competencia para la cuantificación de las indemnizaciones es de los Tribunales de Instancia, dentro de los parámetros máximos que determinen las peticiones acusatorias, con ponderación discrecional, por lo que no se tiene que revisar el montante de las responsabilidades civiles, excepto en los caso en que se dé arbitrariedad y desproporción manifiesta; en el caso en que se dé infracción de este artículo 115 sí se puede cuestionar en casación las bases de las indemnizaciones.

\section{DOLO O NEGLIGENCIA GRAVE DEL ART ${ }^{\circ}$ 61.3 LORPM}

El $\mathrm{Art}^{\circ}$ 61.3 LORPM dice que cuando los padres, tutores, acogedores y guardadores legales o de hecho, no hubieren favorecido la conducta del menor con dolo o negligencia grave, su responsabilidad podrá ser moderada por el Juez según los casos.

Este sistema de responsabilidad es de carácter objetivo, pues para nada se emplea el criterio de la culpa, aunque esta no exista a ninguno de los responsables enumerados se les exonera de responsabilidad, sólo se puede moderar, siempre y cuando no haya existido dolo o negligencia grave, en cuyo caso tampoco se daría la moderación. La Ley concede al Juez la facultad de moderar esa responsabilidad, sin que exista obligación de imponerla, es sólo facultativo para el Juez, sólo en el caso de que no se dé 
negligencia se podrá aplicar la moderación.

Es pues, suficiente la vinculación jurídica del menor con el responsable civil de las instituciones del $\operatorname{Art}^{\circ}$ 61.3, para que se dé la responsabilidad objetiva, ajena a la noción de culpa civil, para quienes responden por hechos ajenos prescindiéndose por completo de los criterios de imputación subjetiva, los cuales sólo se tienen en cuenta, para dejar al arbitrio del Juez la moderación de la responsabilidad ${ }^{91}$.

La expresión dolo o negligencia grave empleada por el legislador ha sido criticada por inducir a error, por entender que como está redactado el precepto tiene unas connotaciones más penales que civiles, pues en el caso de haber contribuido con su conducta los responsables de los menores enumerados en el precepto, deberían de responder no sólo civilmente, sino también criminalmente, por lo que se habría de haber empleado otros términos como diligencia o cuidado, más propios del derecho civil, como es el caso del $\mathrm{Art}^{\circ} 1904$ del CC al regular la acción de regreso en materia de centros docentes de enseñanza no superior ${ }^{92}$.

En cuanto a la expresión de "según los casos" para moderar la responsabilidad hay que tener en cuenta que el dolo o negligencia grave se da en el caso de no haberse observado la diligencia de un buen padre de familia, se trata de un caso en que se ha dado una negligencia notable por lo que se debe desestimar la moderación. Para el caso de que fuera una diligencia leve tampoco se habría observado una diligencia normal por lo que no se darían las circunstancias propias para la moderación. La diligencia para la moderación tiene que ser la que observa un padre de familia responsable, previsor y cuidadoso.

\subsection{CONCEPTO DE DOLO O CULPA GRAVE}

Culpa equivale a falta de diligencia y diligencia es la obligación de

\footnotetext{
${ }^{91}$ Gómez Ribero, Maria del Carmen, (2007) Comentarios a la Ley Orgánica de Responsabilidad de los menores, Ed. Iustel, Madrid, pag 474.

${ }^{92}$ Bonilla Correa, op, cit, pag 251
} 
evitar el daño por todos los medios posibles al alcance de alguien. Se dan tres clases de culpa, culpa grave o culpa lata, culpa leve y culpa levísima.

Culpa lata o culpa grave consiste en el descuido o desprecio absoluto en la adopción de las precauciones más elementales para evitar un mal o daño ${ }^{93}$. Es algo extenso amplio o dilatado al incurrir en la culpa; aquella culpa en que incurre el encargado de un asunto que lo descuida por completo. Se considera la falta de toda diligencia, el no poner el cuidado que el hombre menos diligente pone en sus negocios.

La culpa simple o culpa leve es la falta de la diligencia ordinaria, tomando como modelo la de un buen padre de familia en general, la que un hombre pone en sus propios negocios.

Culpa levísima es la falta de diligencia del hombre más diligente, del mejor de los padres de familia.

La distinción entre estos tres tipos de culpa, sólo tiene importancia en las obligaciones contractuales, según lo que se estipule en las mismas. En las obligaciones extracontractuales no tiene ningún interés toda vez que el autor del acto ilícito responde siempre del daño, cualquier que sea el grado de la falta de diligencia que se pueda identificar en el supuesto de hecho. En este sentido el $\mathrm{Art}^{\circ} 1089$ dice: "en que intervenga cualquier género de culpa o negligencia”, por lo que es indiferente el grado de culpa a la hora de responder el causante del daño. Los tribunales deberán apreciar la falta de diligencia, teniendo en cuenta las circunstancias del caso concreto, conforme a la interpretación analógica del Art ${ }^{\circ}$ 1104, según las circunstancias de personas tiempo y lugar ${ }^{94}$.

El dolo consiste en engaño, fraude, simulación o mentira y es un medio empleado para perjudicar. Supone el dolo la intención de dañar. La doctrina distingue tradicionalmente entre actuación dolosa de una parte y culposa, o sea, negligente, de otra. La distinción se concreta en la intención

\footnotetext{
93 Cabanellas de Torres, Guillermo, Diccionario Jurídico, editorial Eliasta S.R.L. Buenos Aires 1988.

${ }^{94}$ Lasarte Carlos, principios de Derecho Civil, Tomo II 17 edición, Marcial Pons, 2013, pag 277.
} 
con que se realiza el acto dañoso: el dolo presupone la de conseguir el efecto perjudicial, y la culpa no.

Una actitud dolosa es la voluntad de realizar un acto antijurídico con conocimiento de su ilegalidad, sabiendo que puede ser dañoso a los demás; pero sin necesidad de que el agente haya previsto o podido prever todos y cada uno de sus posibles efectos. No es preciso la intención de dañar, basta la voluntad de infringir el deber; la mala fe, la conciencia de que se realiza un acto ilícito. En relación con el daño el dolo presupone el conocimiento de su producción, al menos probable, como consecuencia de esa acción querida por el agente ${ }^{95}$.

La culpa lata es equiparable al dolo, pero no es dolo propiamente dicho, pues a la culpa lata le falta la intención, por ello no es igual la culpa lata o grave que el dolo. La máxima"culpa lata dolo equiparatur" quiere decir, que una negligencia extrema debería acarrear para el agente las consecuencias del dolo o al menos presumirse.

El Art 1107 sobre daños y perjuicios, habla de los que responde el deudor de buena fe, que son los previstos o que se hayan podido prever al tiempo de constituirse la obligación y en su apartado segundo dice: "en caso de dolo responderá el deudor de todos los que conocidamente se deriven de la falta de cumplimiento de la obligación", con lo que se da una equiparación, pero es sólo equiparación, pues como dice Yzquierdo Tolsada "una cosa es que tradicionalmente se haya establecido la equiparación entre culpa lata y dolo a fin de sentar unos criterios mínimos de imputación de la responsabilidad y otra que corresponda establecer como regla general la equiparación de efectos jurídicos"96.

Los artículos 1902 y 1903 hablan sólo de la responsabilidad por culpa o subjetiva y no se hace mención alguna al dolo, pero ha de incluirse en los mismos la conducta dolosa o intencional. El dolo habrá de

\footnotetext{
${ }^{95}$ Lacruz Verdejo, Jose Luis Derecho de obligaciones II tercera edición, Dikinson Madrid 2005, pag 446.

${ }^{96}$ Yzquierdo Tolsada, Mariano, Sistema, op.cit pag 237.
} 
identificarse con la conducta deliberada y consciente dirigida a producir daño a otro y, por tanto, reviste una gravedad mucho mayor que la culpa en sentido estricto; por lo que el término culpa de estos artículos tiene que englobar necesariamente no sólo la culpa, también y con mayor motivo el dolo.

Si la culpa es el no prever o no evitar lo que pudo y debió preverse, el dolo consiste en no evitar el daño que se previó. El agente actúa con dolo si es consciente de que su comportamiento provoca o puede provocar un daño y no toma las medidas pertinentes encaminadas a evitarlo, por lo que de esa forma se constituye en responsable de los daños ${ }^{97}$.

\subsection{CONCEPTO DE NEGLIGENCIA}

El Art $^{\circ}$ 61.3 LORPM no dice nada sobre lo que debe entenderse por negligencia, ni hace referencia a ningún tipo de ella. En sentido genérico negligencia es la falta de diligencia, el no haber empleado todos los medios necesarios para prevenir o evitar un daño.

El Art ${ }^{\circ} 1903$ CC en su último apartado habla de la diligencia de un buen padre de familia. Al no decir nada el Art 61.3 LORPM hay que estar a lo que dispone el $\mathrm{Art}^{\circ} 1104$ CC que dice: "la culpa o negligencia del deudor consiste en la omisión de aquella diligencia que exija la naturaleza de la obligación y corresponda a las circunstancias de las personas, del tiempo y del lugar. Cuando la obligación no exprese la diligencia que ha de prestarse en su cumplimiento, se exigirá la que correspondería a un buen padre de familia". Este artículo que mide la diligencia exigible es variable para cada caso según su naturaleza.

La negligencia referida a este caso es la del cumplimiento de un

\footnotetext{
${ }^{97}$ Castán Tobenas José, Derecho Civil Español común y foral Tomo IV, 15 Edición, Reus S.A Madrid 1993, pag 963.

Díez Picazo, Luis y Antonio Gullón, Sistema de Derecho Civil, Tomo II, $7^{a}$ Edición, Editorial Tecnos, Madrid, pag 609 .

Lasarte, Carlos, op.cit, pag 277.
} 
deber de vigilancia sobre menores, en que los encargados de realizarlo incumplieran sus deberes, actuando de una forma no correcta. No se trata de ver si los padres, tutores, etc, han cometido infracción de su deberes, sino de ver si existe un nexo de causalidad entre el daño causado por el menor y el posible incumplimiento de los deberes de vigilancia y control sobre el menor.

Para determinar si hubo negligencia en el cuidado de los menores por parte de los padres tutores etc. hay que tener en cuenta las costumbres de lugar, la conducta del menor y de los encargados de su vigilancia.

LORPM en su $\operatorname{Art}^{\circ} 61.3$ no hace referencia alguna a las circunstancias del menor por lo que el Juez será el que haya de establecer caso por caso si ha habido o no negligencia, lo que es para él facultativo de acuerdo con la expresión "podrá" "según los casos". Si no hubo negligencia por parte de los encargados de su vigilancia el Juez tendrá la facultad de aplicar la moderación para exigir responsabilidades.

Las personas encargadas de la vigilancia y control de los menores pueden ser personas físicas o jurídicas, siendo su obligación efectuar correctamente la vigilancia o control sobre el menor, por lo que la diligencia exigible a unos y otros ha de ser la misma.

En cuanto a las circunstancias personales de los encargados de los menores, deben ser valoradas por el Juez o Tribunal, si se trata de un matrimonio separado, si le tienen o no en su compañía, con quien está en el momento de producirse el hecho dañoso, a cargo de quién le ha sido asignado su guarda u otras circunstancias análogas.

De igual forma deben ser tenidas en cuenta las circunstancias personales del menor, tales como su edad, pues no es igual un menor de edad próxima a los 14 años que a los 18. Los hábitos del menor, sus antecedentes de conducta, si es o no agresivo, si padece alguna enfermedad, su desarrollo físico y grado de madurez, así como sus cualidades intelectuales y volitivas. 
Todas estas circunstancias personales, las costumbres y usos sociales del lugar, el ser o no reprochable socialmente la conducta, sirven al Juez o Tribunal como elementos de juicio para moderar la indemnización a la víctima.

\subsection{CONCEPTO DE LA DILIGENCIA DE UN BUEN PADRE DE FAMILIA}

La diligencia de un buen padre de familia es un concepto que se configura como abstracto, que se adapta de forma elástica a cualquier tiempo, lugar y a distintos supuestos. Es una expresión de gran fortuna por su empleo en muchos códigos extranjeros y en el código civil español, al mismo tiempo de que existen tantos tipos de buen padre de familia, de hombres diligentes, como sean las condiciones sociales y las industrias y profesiones de los hombres.

Para unos autores el criterio del buen padre de familia peca de excesiva indeterminación, por ser demasiado elástico y variado, un concepto nebuloso que se presta a deformaciones de todo género, que puede dar lugar a resultados absurdos. Según otros la noción de elasticidad es una valoración de esta figura, su característica más importante, la que le da sentido, la que hace que se pueda aplicar a muy diversas situaciones que nos ofrece la vida de relación, en la época moderna al relacionar el capital con el trabajo.

El magistrado no tiene que encontrarse encasillado por rígidas e inflexibles reglas jurídicas, tiene que observar el lado práctico de la relación, con una libertad de juicio y de apreciación completa de la realidad. Dada la elasticidad del concepto del buen padre de familia, puede darse el caso de que los jueces al ser sus mentes y hábitos igualmente elásticos pueden tener sobre un mismo supuesto de hecho criterios distintos; por lo que puede dar lugar a que dos jueces con criterios distintos pueden, pronunciar dos sentencias distintas sobre un mismo supuesto de hecho.

Se adapta bastante lo expuesto sobre el buen padre de familia un 
comentario sobre el "Guardasigilli" del código civil italiano de 1942: "la diligencia del buen padre de familia es una de aquellas fórmulas elaboradas por la jurisprudencia romana y por la tradición romanística cuyo contenido se infiere de las condiciones dominantes en la convivencia social y que, por su adaptabilidad a la situaciones de hecho, responde de modo excelente a las necesidades de la vida de relación. La figura del "bonus pater familias" no se resuelve en el concepto de hombre medio, extraído por la práctica de la media estadística; sino que es un concepto deontológico que es fruto de una valoración expresada por la conciencia social. Es el modelo de ciudadano y de productor que es ofrecido a cada uno por la sociedad en que vive; modelo que por su naturaleza es variable según los tiempos, las costumbres sociales, las relaciones económicas y el clima político" 98.

Esta figura jurídica la contemplan diversos códigos entre ellos el Francés en su artículo 1137 que trata sobre la conservación de la cosa, obliga al encargado de su conservación en su apartado primero, a realizarlo con la diligencia de un buen padre de familia. El código civil italiano en su artículo 1176, apartado primero, exige esa diligencia para el cumplimiento de la obligación. Lo mismo puede decirse del Portugués de 1966 en su artículo 487, apartado segundo ${ }^{99}$. Por lo que se refiere al código civil alemán se aparta del buen padre de familiar y lo sustituye en su artículo 276 apartado segundo, en el que dice: “actúa negligentemente quien no observa la diligencia exigible en el tráfico”. Aunque por otra parte los civilistas alemanes después de haber empleado otras fórmulas como "vida de relación", "necesidades del tráfico", han terminado por confesar que en sustancia no hay diferencia entre el criterio romano y el del $\mathrm{BGB}^{100}$.

\footnotetext{
98 Beltran de Heredia y Onis, Pablo, Libro homenaje al profesor Don José Beltrán de Heredia y Castaño, 1984, Ediciones Universidad de Salamanca, Salamanca, pag 72 y ss.

99 Ibidem, pag 76

100 Código Civil Portugués Artigo 487, $2^{\circ}$ Culpa.

2) A culpa é apreciada, na falta de ontro criterio legal, pela diligencia en un bon pai de familia, emplace das circunstancias de cada caso".
} 
En nuestro código civil son muchos los artículos que se refieren a la diligencia del buen padre de familia, en el Art ${ }^{\circ} 1104$ sobre culpa contractual por el que se exige una diligencia media; el 1903 sobre la culpa extracontractual se pide una diligencia exigente por las palabras "toda" y “prevenir". El 1801 sobre juego, 1889 gestión de negocios ajenos, 270 tutela, 164 patria potestad y muchos otros, por lo que vemos que se le ha prestado bastante atención en el articulado del código, pero poca en la doctrina. Puede decirse que en la gran cantidad de artículos que en el código civil se refieren a la diligencia del buen padre de familia sus funciones se refieren a gestionar, administrar, cuidar y conservar. ${ }^{101}$

Los artículos 1104 y 1903 son los más generales que hablan sobre el buen padre de familia, el 1104 sobre la responsabilidad contractual y el 1903 sobre responsabilidad extracontractual en que trata sobre padres, tutores, dueños o directores de un establecimiento, centros docentes, hacen que el buen padre de familia sea considerada una figura jurídica abstracta y generalizada, constantemente empleada como referencia por los jueces y tribunales.

\subsection{LA CULPA EN LOS PETL}

El grado de culpa se halla contemplado en el Artículo 4.101 PETL en el que establece que, "una persona responde con base en la culpa por la violación intencional o negligente del estándar de conducta exigible”. En el apartado siguiente 4.102 define lo que es el estándar de conducta exigible y dice

1) " el estándar de conducta exigible es el de una persona razonable que se halle en las mismas circunstancias y depende, en particular de la naturaleza y el valor del interés protegido de que se trate, de la peligrosidad de la

\footnotetext{
Codigo civil italiano $\operatorname{art}^{\circ} .1 .1176,1$ (Diligenza nell, adempimento)
}

1) Nell, adempiere l'obligazione il debitore debe usare la diligenza del buon padre di famiglia". ${ }^{101}$ Beltran de Heredia y Onis op.cit pag 78. 
actividad, de la pericia exigible a la persona que la lleva a cabo, de la previsibilidad del daño, de la relación de proximidad o de especial confianza entre las personas implicadas, así como de la disponibilidad y del coste de las medidas de precaución y de los métodos alternativos.

2) El estándar anteriormente indicado puede adaptarse cuando debido a la edad, a la discapacidad física o psíquica o a las circunstancias extraordinarias no sea exigible que la persona de que se trate lo cumpla.

3) $\mathrm{Al}$ establecer el estándar de conducta requerido deben tenerse en cuenta las normas que prescriben o prohíben una determinad conducta".

El Artículo 4.101 establece que una persona es culpable si su manera de obrar, de comportarse ante una determinada situación no se halla de acuerdo con lo que podía esperarse razonablemente de ella. Es por ello una clausula basada en la culpa que se halla de acuerdo con lo establecido en otros códigos como el francés, Holandés, Austriaco, Italiano, el artículo 1902 Español, el de las obligaciones Suizo, BGB Alemán en sus artículos 823 y 276 (exigencia diligente en el tráfico), así como el Common Law.

Con la expresión "violación intencional o negligente" quiere decir, que abarca al dolo, pues si hay intencionalidad es una acción dolosa, mientras que si es negligente falta la intencionalidad por lo que sería simplemente culpa.

La responsabilidad por culpa hace referencia al criterio de imputación basado en una responsabilidad originada por el comportamiento o conducta de una persona. Por el contrario en la responsabilidad objetiva se fundamenta no en la conducta de la persona, sino en el riesgo o el peligro, por lo que una persona que obtiene beneficios de una actividad tiene necesariamente que asumir los riesgos (cuius commoda, eius incommoda) que esa actividad comporta.

En el artículo 4.102 apartado 1, se enumeran el conjunto de factores que se han de tener en cuenta al definir el estándar de conducta exigible. La expresión "persona razonable" debe considerarse con el buen padre de 
familia visto anteriormente, en que se trata de un hombre o una mujer que tiene que preocuparse de su familia, no sólo de él o ella sino de los que se encuentran a su alrededor, velar por su bienestar, cuidarlos y atender a sus intereses y necesidades.

"Persona razonable", sufre variaciones según la categoría o lo complejo de las actividades de que se trate, como por ejemplo un director general de una empresa tiene un estándar de conducta más exigente que un Jefe de una Sección de la misma; será más riguroso el estándar de un profesor de educación física que el alumno que se limita a recibir las clases de deporte.

"La naturaleza y el valor del interés protegido que se trate", quiere decir que cuando el interés protegido es muy valioso como puede ser la integridad física o psíquica hay que redoblar el esfuerzo y la diligencia encaminados a proteger esos bienes jurídicos.

Sobre la "peligrosidad de la actividad" y de la "pericia" de la persona que la lleva a cabo, hay que asegurarse de que uno es capaz, que está suficientemente formado y preparado para realizar esas actividades que entrañan peligro. Hay que tener las titulaciones necesarias, o conocimientos tanto teóricos como prácticos, encaminados a poder realizar esos cometidos con las garantías necesarias, para no causar mayores peligros. Si alguien no tiene los conocimientos necesarios para desarrollar esa actividad peligrosa, si no es un experto, lo mejor es que se abstenga de realizarla, pues en caso contrario incurre en impericia o negligencia y se le puede exigir las pertinentes responsabilidades. Se trata de actividades que requieren unas aptitudes mayores que las de cualquier persona normal.

El estándar de diligencia en estos casos se debe incrementar y hay que observar la "regla de peligro" que dice: "quien crea o mantiene una situación de peligro para otros debe adoptar todas las medidas apropiadas para evitar que tal peligro se materialice en forma de daño”. Esta regla se emplea para delimitar la culpa de una persona que debería haberse dado 
cuenta del riesgo que entraña su actividad para los demás y sirve para determinar si se trata de una acción antijurídica. El Juez puede por esta regla establecer si se habían adoptado las medidas necesarias para prevenir el daño y si se da o no una causalidad entre la conducta observada y el daño producido.

Otro factor a considerar es el de la "previsibilidad del daño", si la persona en cuestión puede ser considerada responsable, si por su comportamiento a pesar de haber obrado con la diligencia debida, era imposible prever el daño. La previsibilidad puede ser de tipo objetivo, que es la que adoptan estos Principios, aunque según las circunstancias que se consideren extraordinarias, se puede aplicar alguna corrección y llegar a la exoneración.

Un elemento a considerar en el estándar de conducta es el de la "relación entre las personas implicadas", pues a una mayor proximidad entre unos y otros actores puede dar lugar a una mayor confianza, así como a prestar una atención más intensa a sus propios intereses en presencia, sobre todo en el campo de la prestación de servicios especializados de asesoramiento a empresas o particulares. Si una persona posee amplios y profundos conocimientos sobre materias que sirvan a ese asesoramiento o que aparenta poseerlos, debe necesariamente responsabilizarse frente a aquellas personas que confiaron en él.

Por último en la expresión sobre "la disponibilidad y el coste de las medidas de precaución y de los métodos alternativos", se refiere a que cuando se persiguen unos determinados objetivos, hay que estudiar los métodos apropiados de acuerdo con los principios de la proporcionalidad y de la buena fe, con el fin de no perjudicar a terceras personas, es decir, elegir el camino menos peligroso. De igual forma se deben analizar cuidadosamente los métodos empleados, en orden a que no resulten económicamente demasiado costosos, que no sean económicamente inviables, que superen los costes a los beneficios, en cuyo caso no se deben 
seguir, pues podrían superar el valor de las primas del seguro para la cobertura, por lo que deberían en ese caso rechazarse.

El apartado 2 del Art. 4:01 sobre la adaptación del estándar ordinario a circunstancias extraordinarias, se tiene que considerar el no adoptar un estándar de conducta totalmente objetivo para no producir injusticias al exigir responsabilidades. Por ello hay que aplicar la responsabilidad por culpa teniendo en cuenta esas circunstancias extraordinarias, tales como la exoneración, la edad del causante del daño y su capacidad de discernimiento.

Los principios en cuanto a la edad no marcan límites, sino que emplean un criterio flexible, por lo que hay que analizar por parte del Juez caso por caso, para ver su grado de discernimiento, el empleo de instrumentos peligrosos, lugares en que transitan muchos vehículos y personas, por lo que en niños de corta edad son conscientes del grado de peligro que entraña el estar en ellos. Todo ello hace que según las circunstancias que concurran en la producción del daño puede dar lugar a una disminución de la responsabilidad e incluso a llegar a la exculpación según los casos.

En el apartado 3 de Art. 4:102 sobre los deberes normativos como indicios de culpa, indica que deben cumplirse las normas que contienen mandatos o prohibiciones específicas, que imponen o prohíben determinadas conductas.

Según el ordenamiento de que se trate se distingue entre antijuridicidad y culpa, la cuestión se tratará desde el punto de vista de la antijuridicidad, por la relación que existe entre el daño producido y la norma infringida, pues antijuridicidad es lo contrario a la norma, la no observancia de la norma o la conducta contraria al derecho. Mientras que en los ordenamientos en que la culpa y la antijuridicidad son indistintos como en los Principios, en ellos se atiende a la relación de culpabilidad.

Las normas a que se refiere no son solamente las que aprueban los 
poderes públicos, sino las de otros organismos ya sean públicos, semipúblicos y privados; las directivas, principios deontológicos, corporaciones y organizaciones técnicas o profesionales. El no cumplir estar normas o mandatos positivos, prohibiciones, etc, constituyen por si mismos indicios de culpa, pensemos por ejemplo en mandatos o indicaciones que digan "prohibida la entrada", "no tocar", "peligro de muerte", "material inflamable", "no fumar", el no cumplirlos es motivo más que suficiente para exigir responsabilidad, pues ello puede dar lugar a graves accidentes y causar grandes males, no sólo para el infractor, sino también para otros. ${ }^{102}$

\section{LA RELACION DE CAUSALIDAD}

Entre la conducta del agente y el daño ha de existir una relación de causalidad. La lectura del art 1902 evidencia que entre la acción u omisión del agente y el daño inferido a la víctima debe existir un nexo causal, una relación de causa a efecto que, doctrinalmente, se conoce con el nombre de relación de causalidad. ${ }^{103}$

Este requisito de la relación de causalidad se da en el art 1902 con el verbo causar y en el art 1903 con el de derivar; también el art $^{\mathrm{o}} 109$ del C.P habla de daños y perjuicios causados y el art $^{\circ} 113$ causado. La víctima del daño, pues, habrá de demostrar tal relación, mientras que el agente podrá defenderse probando que no existe. ${ }^{104}$

El art 902 dice que el que causa un daño a otro está obligado a reparar el daño causado y ese daño ha de ser causado por determinados comportamientos humanos. En la jurisprudencia del Tribunal Supremo se ha mantenido de modo constante la tesis de que la existencia de una relación de causalidad entre la conducta del agente y el daño constituye un requisito necesario para que se origine la responsabilidad. Este problema

\footnotetext{
102 Principios del Derecho Europeo de la Responsabilidad Civil, op. cit, pag 108 y ss.

${ }^{103}$ Lasarte Carlos, Principios, op.cit, pag 279.

${ }^{104}$ Lacruz Verdejo, José Luis, Elementos de Derecho Civil, Tomo II, Tercera Edición, Ed. Dykinson, Madrid 2005, pag 462 .
} 
es muy complejo, pese a su formulación simple. Ello es debido a que todo hecho no está precedido por un solo antecedente sino por varios, por lo que hay que decidir cuál de ellos revistes o merece el papel de causa. Para resolver esta cuestión se han formulado en la doctrina diferente construcciones teóricas en el campo del Derecho Penal, limitándose la doctrina civil a recibirlas y a aplicarlas al de la responsabilidad de esta indole. ${ }^{105}$

En parecidos términos se expresa Castán Tobeños al afirmar: "La prueba de la relación de causa a efecto entre la falta cometida por una persona y el daño sufrido por otra, es una de las más grandes dificultades que presentan en la práctica las cuestiones de responsabilidad por culpa. Las circunstancias de hecho, que son casi siempre complejas, suelen hacer muy delicada la apreciación de éste vínculo; Y, sin embargo, es imposible condenar por daños si no se demuestra cumplidamente esta relación. Confírmalo así nuestra jurisprudencia en la práctica totalidad de los fallos”"106.

Entre el hecho del agente y el daño producido debe existir como se ha dicho anteriormente una relación de causa a efecto y ello es debido a que un daño no suele provenir de una sola causa, sino de múltiples. Por ello se ha dicho siempre que este tema es el que mayores problemas, controversias y confusiones ha originado en el derecho de daños.

Para el estudio de la causalidad hay que distinguir entre causalidad de hecho y alcance de la responsabilidad (causalidad jurídica o imputación objetiva) ${ }^{107}$. La causalidad se refiere a las circunstancias de producción del hecho en sí, a las causas que le han originado, para lo cual se dan varios tipos como equivalencia de las condiciones, causalidad próxima, adecuada, etc, que se analizarán seguidamente. Mientras que el alcance de la responsabilidad (causalidad jurídica o imputación objetiva y subjetiva) trata de ver en función de las teorías de la causalidad, qué criterio o criterios son más adecuados para imputar a alguien la responsabilidad del hecho dañoso. La causalidad de

\footnotetext{
105 Díez Picazo Luis y Antonio Gullón, Sistema, op.cit, pags 603 y 604.

106 Castán Tobeñas, José, Derecho Civil, op.cit, pag 965.

107 Asociación de Profesores de Derecho Civil (APDC), Cuestiones Actuales en Materia de Responsabilidad Civil, XV Jornadas de la APDC, A Coruña, 8 y 9 de Abril de 2011, Editum Ediciones de la Universidad de Murcia 2011, Catedrático de Derecho Cilvil D. Miguel Martín-Casal, pags44 y45.
} 
hecho se realiza en los Tribunales de Instancia, pero no en casación, lo contrario sucede en la causalidad jurídica o imputación objetiva que sólo se pueden revisar en casación. La causalidad jurídica abarca la imputación objetiva y también la imputación subjetiva, o análisis de la negligencia, el dolo o el factor de atribución que corresponda.

Los juicios de causalidad y de imputación se tienen que distinguir pero tratarse a la vez. Esto es debido a que los distintos matices de la relación causal no pueden hacerse de forma neutra y objetiva, basada en el desarrollo cronológico de los acontecimientos, sino de forma simultánea, de las circunstancias subjetivas de las que se encuentren involucrados en el hecho dañoso. Si se da por ejemplo un accidente de tráfico o ferroviario o de cualquier otra índole, en el que intervienen varias personas, no es suficiente el averiguar que tal o cual cosa ha sido el origen del accidente, hay que tratar al mismo tiempo el grado de negligencia e intencionalidad de esas personas implicadas o relacionadas con ese accidente ${ }^{108}$.

\subsection{TEORÍAS SOBRE LA CAUSALIDAD \\ 6.1.1. TEORÍA DE LA EQUIVALENCIA DE LAS CONDICIONES.}

Fue expuesta en 1860 por el penalista alemán Maximilian Von Buri, dando comienzo al tratamiento de este problema, basándose en las ideas del empirismo inglés, viene a sostener que si desde el punto de vista filosófico todas las fuerzas tienen alguna eficacia para el movimiento del fenómeno también en lo jurídico hay que entender que todas las condiciones son equivalentes, por lo que la llama equivalenztheorie. Por ello no hay que hacer distinciones: Todas son indispensables, y si faltase alguna el suceso no habría acaecido, por lo que también se llama teoría de la "conditio sine qua non". Cada una de las condiciones puede ser considerada al mismo tiempo como causa de todo el desenlace final.

Este criterio es excesivo filosófica y jurídicamente considerado, pues al hacer responsable a la persona de todas las consecuencias, se llega a consecuencias irracionales y absurdas, perdiendo prestigio en Alemania, después de haberse impuesto como

\footnotetext{
108 Izquierdo Tolsada,Mariano, op. cit, pag 188.
} 
dominante en el país de nacimiento, por lo que fue olvidándose al igual que en países como Noruega, Italia y Brasil, en cuyas legislaciones penales había sido admitida. Fue criticada por Binding de forma que quedó demostrado que era inviable por culminar afirmando que todos son responsables de todo: sería por ejemplo autor de adulterio, junto al varón que yace con la mujer casada con otro hombre, el carpintero que hizo la cama.

El Tribunal Supremo ha hecho uso de la equivalencia de las condiciones, como en la sentencia de 10 de febrero de 1959 (RJ-1959/1483) ${ }^{109}$.

\subsubsection{TEORÍA DE LA CAUSALIDAD PRÓXIMA.}

Esta teoría consiste en que hay que considerar la causa inmediata (proximoe cause), como la que da lugar a la imputación, sin tener en cuenta otros más remotos o distantes (too remote). Su formulación se remonta al filósofo inglés del siglo XVI Francis Bacon, el cual en un pasaje de sus Maxims of law, sostuvo que sería para el Derecho una tarea infinita detenerse en las causas de las causas y las influencias de unas sobre otras, en una concatenación interminable. Sólo se debe reconocer relevancia a la causa más próxima en el tiempo, esto es, a la inmediatamente anterior a la producción del daño. Las demás tienen que considerarse sin trascendencia a los efectos jurídicos.

La teoría es más precisa y completa que la anterior, aunque ha tenido críticas, por el hecho de que no siempre el antecedente temporal más próximo, es el relevante y da lugar a la responsabilidad dentro de toda la cadena causal. El ser más inmediato tiene que

\footnotetext{
109 El caso trata de una vaca que escapó de una finca y vino a morir en otra contigua. Para evacuar el animal fueron avisados unos operarios que cargaron y transportaron el animal. Al sospecharse que la vaca habría muerto de hidrofobia, se sometieron todos ellos a un tratamiento antirrábico. Uno de los operarios comenzó a tener síntomas de parálisis, quedando finalmente paralítico e incapacitado para toda clase de trabajo. Por ello demandó al dueño de la vaca D. Leoncio G DE G ante el Juzgado de Primera Instancia de Llerena, basándose en el art ${ }^{\circ}$ 1905 del C.C. Al realizarse el informe pericial del veterinario se demostró que la hidrofobia no existía, con lo que la culpa no era del dueño del animal, siendo de la reacción al tratamiento de los sueros, con lo que se rompe el nexo causal. No obstante la sentencia condenatoria fue confirmada por la Audiencia y El Supremo.
} 
ser más razonable que meramente cronológico. ${ }^{110} \mathrm{El}$ caso que se aplica a esta teoría es el de la sentencia del Tribunal Supremo de fecha 21 de marzo de $1950{ }^{111}$ (RJ-1950/394).

\subsubsection{TEORIA DE LA CAUSALIDAD ADECUADA}

Esta teoría fue fundada en 1888 por el fisiólogo de Friburgo Von Kries. Es más satisfactoria que las anteriores, pero tiene el inconveniente de su propia abstracción. Puede que la regla de la experiencia asigne a un determinado antecedente la calificación de causa ordinariamente adecuada, pero nadie puede asegurarnos que en la producción del daño no haya podido ser otra la decisiva en la producción del daño.

Según esta teoría, no todos los acontecimientos que preceden a un daño tienen la misma relevancia, pero tampoco ha de ser siempre el más próximo en el tiempo el que se deba escoger: el daño debe asociarse con el antecedente que según el curso normal de los acontecimientos, ha sido la causa directa e inmediata. Del conjunto de hechos antecedentes cabe considerar como causa en sentido jurídico sólo aquellos hechos de los cuales quepa esperar a priori, la producción de un resultado. Se basa en las estadísticas y en los juegos de probabilidad de Von Kries. Hay situaciones en las que un hecho es consecuencia de otro, en otros el resultado es probable y por el contrario otras en que es improbable. Atendiendo a este criterio de probabilidades del conjunto de hechos antecedentes habrá de considerar como causas en sentido jurídico, para la imputación del daño, sólo aquellos hechos de los cuales quepa esperar "a priori” y según criterios razonables de seguridad o de verosimilitud estadística, la producción de un resultado dañoso.

El juez debe establecer un pronóstico retrospectivo de probabilidad, preguntándose si la acción que se juzga era por sí sola apta para provocar normalmente esa consecuencia. En el caso singular no hay causalidad, es decir, para que se de

\footnotetext{
110 Izquierdo Tolsada. M. op.cit, pag 190 y 191. Castán Tobeñas,J, op. cit,pags 966 y 967 .

111 Demandados unos cirujanos en la Audiencia de Barcelona, por una operación de cirugía estética en la que no se consiguieron los resultados deseados, no fue por impericia o negligencia de los médicos, pues ello fue debido a una infección no atribuible a los demandados. La responsabilidad no nace de la causa remota de la operación, sino de la próxima y eficiente que es la infección.
} 
causalidad el caso tiene que contemplar varias causas para poder elegir la o las adecuadas.

Un caso ilustrativo de esta teoría es la Sentencia de 22 de febrero de 1946(RJ 1946/253), llamado Caso Peñaranda. ${ }^{112}$

\subsubsection{TEORIA DE LA CAUSA EFICIENTE}

Es una variante de la causalidad adecuada, por lo que son muy similares. Esta teoría se basa en que el hecho más eficiente es el decisivo, aunque las opiniones sobre su eficiencia son discrepantes, pues unas se basan en el hecho más activo (Birkmeyer), o en el que tiene en sí mismo la fuerza determinante para producir el daño tal y como se ha dado (KOHLER). ${ }^{113}$

Una sentencia ilustrativa de esta teoría es la sentencia de 5-11-88 (RJ-1988/1961), en la que se dice sobre la culpa extracontractual, la determinación del nexo causal entre la conducta del agente y el daño producido debe inspirarse en la valoración de las condiciones o circunstancias que el buen sentido señale en cada caso como índice de responsabilidad, dentro del infinito encadenamiento de causas y efectos, con abstracción de todo exclusivismo doctrinal y concretamente de las dimensiones filosóficas que agrupan de un lado, a los partidarios de causa eficiente y, de otro, a los que más bien se apoyan en el principio de razón suficiente, ni adoptar una postura intermedia a favor de la "condictio si ne quanon" o del efecto predominante de la circunstancia principal o de

\footnotetext{
${ }^{112}$ Se trata de un caso seguido ante el Juzgado de Peñaranda de Bracamonte y la Audiencia de Valladolid, en el que unos trabajadores fallecieron por la explosión de un polvorín que se encontraba en las inmediaciones de la empresa donde trabajaban los fallecidos. El motivo del recurso de los demandantes lo basan en que la empresa había transgredido la legislación sobre descanso dominical. El Tribunal Supremo desestima el recurso por no darse relación de causa a efecto entre el motivo de descanso dominical y la explosión del polvorín. Las normas sobre descanso dominical no son suficientes para imputar al empresario, por perseguir el fin de descanso, no de seguridad. Estos obreros no murieron porque el empresario incumpliera el precepto del descanso dominical, sino por la explosión de un polvorín cercano, que además produjo otras víctimas en la misma localidad.
}

Izquierdo Tolsada. Mariano, op cit, pags 193 a 195.

-Castán Tobeñas José, op cit, pag 968.

Reglero Campos Fernándo, Lecciones de Responsabilidad Civil, Aranzadi, Navarra 2002, pags 92 y 96.

${ }^{113}$ Díez Picazo, op, cit, pag 605. 
cualquier otro elemento.

Hay que optar decididamente por soluciones y criterios que le permitan valorar en cada caso si el acto antecedente que se presenta como causa tiene virtualidad suficiente para que del mismo se derive, como consecuencia necesaria, el efecto dañoso producido. Exige la causalidad eficiente la determinación de si la conducta del autor del acto es generalmente apropiada para producir un resultado de la clase dada y solamente en el supuesto de que la contestación sea afirmativa, cabrá apreciar la existencia de un nexo causal.

Otra sentencia aplicable a la doctrina de la causa eficiente es la de 22 de octubre de 1948 (RJ-1948/1212), en ella se trata de un caso de atropello de automóvil seguido ante el Juzgado de $1^{\mathrm{a}}$ Instancia de Segovia y la Audiencia de Madrid. En ella se condena a un conductor que sufrió un accidente de automóvil por rotura de la barra de la dirección, el cual no disponía de carnet o autorización oficial para conducir. El hecho de no disponer de carnet es una infracción administrativa que en este caso no tiene que ver nada con el accidente, aunque se trate de algo imprudente o negligente; en el supuesto caso de que hubiera tenido el carnet desde mucho tiempo, el hecho de romperse la barra, hubiera producido los mismos efectos, a pesar de su antigüedad con el carnet. Dice la sentencia que, para que pueda ser apreciada la culpa extracontractual ha de inspirarse en la valoración de las condiciones y circunstancias que el buen sentido señale al examinar el caso; pues no se aprecia buen sentido ni valoración de las condiciones y circunstancias, sino todo lo contrario, se le condena por no disponer de carnet, lo cual no constituye negligencia, pues es algo imprevisible que se rompa la barra de la dirección. El Juzgado le había absuelto, pero la Audiencia le condenó y confirmó la sentencia condenatoria el Tribunal Supremo.

Ni la Audiencia ni el Tribunal Supremo deberían haber condenado al conductor por tratarse de un caso fortuito del $\mathrm{art}^{\mathrm{o}} 1105$ CC que dice; "Fuera de los casos expresamente mencionados en la ley, y de los que así declare la obligación, nadie responderá de aquellos sucesos que no hubieran podido preverse, o que previstos fueran inevitables". Por ello el conductor debería de haber sido absuelto. 


\subsubsection{CRITERIOS DE LA IMPUTACON OBJETIVA}

En la relación de causalidad se dan dos cuestiones que hay que distinguir: una cuestión de hecho y una cuestión de derecho. La cuestión de hecho es la causalidad y la cuestión de derecho es la imputación objetiva.

A la hora de resolver un caso, en el que existen varias causas concurrentes, hay que averiguar cuál de ellas ha de ser tenida en cuenta para establecer qué patrimonio ha de responder.

Una vez decidido que existe relación causal, hay que ver entre todos los que intervienen en la acción, quien o quienes tienen que responder y de cuantas consecuencias. Para ello podremos servirnos del criterio de la equivalencia de las condiciones, de la causa próxima o cualquier otro; pero este ya no es un problema de causalidad, o una cuestión de hecho, aquí se trata de un problema de imputación objetiva, es decir, una questio iuris.

La imputación objetiva al ser una quesito iuris, no se deja en exclusiva al Tribunal de instancia, sino al Tribunal Supremo para que se dé un tratamiento uniforme.

La primera parte de la secuencia, es decir, la causalidad física, se gobierna por la ley física, desde el orden natural o del curso lógico de las cosas; sólo después viene el jurista para introducir los términos jurídicos de la imputación objetiva.

Pantaleón Prieto es el que ha sugerido la introducción de los criterios de la imputación objetiva en la dogmática civil, como viene haciendo la justicia penal, como viene ocurriendo en Alemania y en el Derecho angloamericano. Estos criterios son los siguientes:

$\left.1^{\circ}\right)$ Riesgo general de la vida "Allgemeinem Lebensrisiko", según el cual no es imputable a un tercero un resultado dañoso que constituya la manifestación de un riesgo que cabría considerar como cotidiano o propio de la vida social. Un ejemplo sería que alguien que provoca el que un viajero no pueda tomar un determinado vuelo, no se le pueda imputar que al estrellarse el siguiente avión y muriera el perjudicado, pues eso es un riesgo que va unido al hombre que vive en sociedad.

$\left.2^{\circ}\right)$ Prohibición de regreso "Regressverbot", por el que se prohíbe o impide retroceder en la cadena causal desde que se verificó una intervención dolosa o 
gravemente negligente de un tercero. El ejemplo que ilustra este criterio es el de la Sentencia del T.S de 11 de marzo de 1988 (RJ 1988/1961) conocida como del Hotel "Corona de Aragón" en el que a través de una freiduría o churrería del mencionado hotel se propagó un peligrosísimo incendio. Si el incendio era leve en un principio y no habría tenido relevancia, si no hubiera sido por la introducción por unos desconocidos de una peligrosa y abundante substancia explosiva, al parecer napalm o pirogal. La sentencia absolvió al propietario del establecimiento, al haberse interrumpido el nexo causal por la intervención de terceros (desconocidos) que colocaron el explosivo, al tratarse de una intervención dolosa o intencionada y no estar determinada por la del agente inicial.

Este criterio no se podría aplicar cuando la conducta dolosa o gravemente negligente de un tercero, es favorecida por la negligencia del primer agente causal, o por incumplir normas de seguridad y custodia.

$3^{\circ}$ ) El criterio de la provocación (Herausforderung), trata de los daños causados en un estado de necesidad, por el cumplimiento de un deber o en el ejercicio de la legítima defensa. Son supuestos en que existe una provocación por parte de un tercero. En el ámbito penal, la legítima defensa, tanto propia como ajena, el cumplimiento de un deber, son causas de exención de la responsabilidad penal y civil, que se hallan contemplados en el $\operatorname{art}^{\circ} 20$ números $4^{\circ}$ y $7^{\circ}$ del CP, así como en el $\operatorname{art}^{\circ} 118.1$ CP. Un ejemplo de este criterio es la STS de fecha de 3 de octubre de 1996 (RJ 1996, 7011) en la que un vigilante de seguridad nocturno persigue a un menor de dieciséis años que había entrado hacia los doce de la noche en el almacén de carritos del supermercado dedicándose a jugar con ellos y hacer ruidos, por lo que el vigilante le persiguió al menor, cayéndose éste por un talud, produciéndose la pérdida de un riñón y movilidad en la muñeca derecha. El vigilante no debió perseguirle por el peligro que se originaba. La sentencia condena al menor con el $80 \%$ de la indemnización y al vigilante nocturno el $20 \%$. Se da por tanto una moderación de la responsabilidad en el vigilante por actuar en el ejercicio de un oficio o cargo en el que se excedió en el cumplimiento de su obligación.

$4^{\circ}$ ) El fin de protección de la norma fundamental de la responsabilidad 
(Schutzwech der Haftungsbergrüdenen Norm). Este caso quiere decir que sólo se da imputación causal cuando la situación que genera un daño es el origen de una transgresión o conculcación por parte del demandado de una norma de obligación o seguridad. Por ello no habrá imputación causal cuando la norma conculcada o transgredida tenga una finalidad diferente. Para que exista relación de causalidad tiene que ser consecuencia de la norma de seguridad. Dos casos ya vistos son el "Caso Peñaranda "en que la norma que se vulnera es la del descanso dominical, que no tiene que ver nada con la explosión del polvorín cercano y el "Caso de la Barra de la Dirección "en el que se condena al conductor que no tiene carnet de conducir, cuando es debido a la rotura de la barra de la dirección.

$5^{\circ}$ ) El criterio denominado de incremento del riesgo (Risikoerhöhung). Según este principio un acto o una omisión no se puede considerar como causa de un suceso si éste se hubiera producido de igual forma sin la existencia de aquel acto u omisión. Un caso aplicable a este criterio es el de la Sentencia del Tribunal Supremo de 17-02-2000 (RJ 2000/1161) en el que trata de un enfermo internado en un hospital psiquiátrico, sujeto a vigilancia visual y terapia ocupacional, se fuga y se arroja a una ría en la que perece ahogado. El recurso queda desestimado por haber cumplido el hospital con su deber genérico de vigilancia sobre el interno en vigilancia visual y terapia ocupacional, como había señalado el médico en su informe.

$\left.6^{\circ}\right)$ Criterio de la adecuación, por el que se permite excluir la imputación cuando al relacionar el daño con la conducta del autor, es muy remoto y sería descartado como motivo para la imputación por una persona experimentada y con conocimientos similares al autor. Una sentencia aplicable a este criterio es la de 22 de mayo de 1999 (EDE 12022 RJ-1999/4582), en ella se trata de que los trabajos a que hace referencia no son un caso fortuito o de fuerza mayor, ni de la intervención de tercero. Lo que sucede es que se contrata a esta empresa y los trabajos que se realizaron consisten en soldaduras, las cuales producen chispas que dan lugar a la combustión de materias inflamables, por lo que el motivo es el no haber adoptado por la empresa las medidas de seguridad adecuadas para evitar esos daños.

Estos criterios de la imputación objetiva que provienen normalmente de la 
dogmática y de la jurisprudencia penal, han sido adoptados por la jurisprudencia civil, para determinar la existencia del nexo causal y si procede o no imputar al encausado. ${ }^{114}$

\subsection{INTERFERENCIA DE CIRCUNSTANCIAS EXTRAÑAS EN EL NEXO CAUSAL}

En la aplicación del requisito de la causalidad, hay ocasiones en que la responsabilidad no puede atribuirse en exclusiva a la acción del sujeto, por haber contribuido, coadyuvado o favorecido a su causación elementos extraños tales como son el caso fortuito o la fuerza mayor, el hecho de un tercero o la acción de la propia víctima. Al darse alguno de estos elementos extraños, determinará en el autor del daño una exoneración total o parcial, al concurrir un acontecer ajeno entre la conducta del agente y el resultado dañoso, al interferir entre la voluntad de este agente en que desvía o al menos influye en el curso causal desatado por el acto originario.

\subsubsection{EL CASO FORTUITO Y LA FUERZA MAYOR.}

Tanto la fuerza mayor como el caso fortuito son circunstancias que dentro del curso causal del hecho dañoso, dan lugar a que el demandado quede exonerado de responsabilidad.

El caso fortuito y la fuerza mayor han sido históricamente de efectos idénticos, liberando de responsabilidad al demandado. En la actualidad existe interés en diferenciar ambas figuras al considerarse en los sistemas objetivos de responsabilidad, que la fuerza mayor libera al deudor o al dañante, mientras que no sería así en el caso fortuito. Esta teoría procede de Exner y su tesis consiste en diferenciar caso fortuito y fuerza mayor, según el criterio de interioridad o exterioridad. Caso fortuito sería todo acontecimiento que sucede dentro del círculo interno del sujeto, mientras que la fuerza mayor se da externamente, fuera de ese círculo.

\footnotetext{
114 Izquierdo Tolsada, op .cit, pag 194 a 196

Reglero Campos, Fernando, op. cit, pag 94 a 97.
} 
La jurisprudencia considera que la doctrina científica moderna basada en teorías subjetivas y objetivas, son conceptos distintos al caso fortuito y la fuerza mayor, el Derecho español los regula con uniformidad, la jurisprudencia identifica una y otra figura, al liberar ambas al deudor del cumplimiento de la obligación.

El caso fortuito es todo suceso no culposo imposible de prever, o que previsto sea inevitable y, por ello se realiza sin culpa del agente, por lo que la relación de causalidad no se produce entre el acontecimiento y el daño producido. En la jurisprudencia los casos fortuitos se refieren con frecuencia a casos en los que intervienen en juegos, niños de corta edad, sin intervención de factores extraños o peligrosos, en los que las reacciones de estos niños son imprevisibles, a pesar de la atenta vigilancia de sus cuidadores (STS-8-3-1999 RJ-1999/2249).

La primera sentencia que se inclina por la distinción entre caso fortuito y fuerza mayor es la STS de 30-9-83 (RJ-1983/4688) en la que detalla las distintas posiciones doctrinales sobre ello.

En cuanto a la fuerza mayor es un acontecimiento imprevisible e inevitable o irresistible (vis cui resisti non potest). En el Consorcio de Compensación de Seguros se refiere a los fenómenos de la naturaleza de carácter extraordinario, tales como inundación, terremoto, erupción volcánica, tempestad ciclónica atípica (ciclones violentos de carácter tropical y borrascas frías intensas), caídas de cuerpos siderales y aerolitos, hechos derivados de terrorismo, motín o tumulto popular, y hechos o actuaciones de las Fuerzas Armadas o de las Fuerzas y Cuerpos de Seguridad del Estado en tiempos de paz. ${ }^{115}$ En el art $1908,3^{\circ}$ Cc, dice que responderán los propietarios de los daños causados, por la caída de árboles colocados en sitios de tránsito, cuando no sea ocasionado por fuerza mayor, quiere ello decir, que si se cayera por un fuerte viento, tormenta, etc el propietario quedará exonerado de responsabilidad por tratarse de fuerza mayor.

En el ámbito de la responsabilidad del Estado, la Ley 30/1992, de 26 de

\footnotetext{
115 RD 2022/1986, de 29 de agosto, por el que se aprueba el Reglamento de cobertura por el Consorcio de Compensación de Seguros de los Riesgos Extraordinarios sobre las Personas y los Bienes, art ${ }^{\circ} 1$.
} 
noviembre, Régimen Jurídico de las Administraciones Públicas y del Procedimiento Administrativo Común, en su $\operatorname{art}^{\circ} 139$ dispone que "los particulares tendrán derecho a ser indemnizados por las Administraciones Públicas correspondientes de toda lesión que sufran en cualquiera de sus bienes y derechos, salvo en los casos de fuerza mayor". La sentencia de 31 de mayo de 1999 (RJ-1999/6154) en su fundamento quinto, apartado A, dice que "en el caso fortuito hay indeterminación e interioridad; indeterminación porque la causa productora del daño es desconocida; interioridad, además, del evento en relación con la organización en cuyo seno se produjo el daño, y ello porque está directamente conectado al funcionamiento mismo de la organización, es decir, evento interno, intrínseco, inscrito en el funcionamiento interno de los servicios públicos, producido por la misma naturaleza, por la misma consistencia de sus elementos, con causa desconocida".

La fuerza mayor, en cambio, "hay determinación irresistible y exterioridad; indeterminación absolutamente irresistible, en primer lugar, es decir, aun en el supuesto de que hubiera podido ser prevista; exterioridad, lo que es tanto como decir que la causa productora de la lesión ha de ser ajena al servicio y al riesgo que le es propio: en el sentido de aquellos hechos que, aún siendo previsibles sean inevitables, insuperables e irresistibles, siempre que la causa que los motive sea extraña e independiente del sujeto obligado".

Una sentencia sobres un caso de fuerza mayor es la STS de 15 de diciembre de 1996 (RJ-1996,8979), en la que un pastor D. Juan-José M.F.se produjo la caída de unos cables de alta tensión sobre el mencionado pastor , que resultó electrocutado; pero ello no fue debido a un defectuoso mantenimiento o conservación de la línea por parte de sus usuarios, sino que se atribuye al extraordinario e imprevisible temporal de fuerte viento e intensas lluvias que, en los días 21 y 22 de noviembre de 1989, descargó sobre el término municipal de Córdoba, que recogieron los medios de información de la ciudad, con lo que se trata de un caso de fuerza mayor y por ello excluye la responsabilidad de los demandados usuarios de la línea, resultando exonerados en virtud del $\operatorname{art}^{\circ} 1105$ del Código Civil. ${ }^{116}$

116 Reglero Campos Fernando y otros, op. cit, pag 102 y ss. 


\subsection{EL HECHO DE UN TERCERO}

Cuando un tercero interviene en el proceso causal, da lugar a que su intervención exonere de responsabilidad al agente material del daño, siempre que tal conducta no venga predeterminada por ese autor material del daño o sea un mero instrumento suyo $^{117}$. Esto quiere decir que no tienen que estar conectados el tercero con el agente material del daño, en cuyo caso serian coautores y responsables solidarios. Si están conectados no se rompe el nexo causal, pero si se da el caso contrario sí se rompe y el autor material queda exonerado de responsabilidad.

El criterio de la prohibición de regreso (regressverbot) impide retroceder en el curso causal cuando en él ha interferido la conducta dolosa de un tercero. En el caso Banca Catalana STS de 16 de noviembre de 1983 (RJ-1983/6116), aunque el banco pagó el talón queda exonerado, ya que el daño no proviene de la operación bancaria, sino de la conducta maliciosa del Secretario de la entidad actora Ignacio A,N., que abusando de la confianza que se había depositado en él, se apropió de un dinero ilegalmente obtenido, sin estar conectada la actuación de él con la conducta dolosa del tercero. Lo mismo puede decirse del caso Corona de Aragón, visto anteriormente, en el que el propietario de freiduría quedó exonerado, al haber introducido napalm unos terceros desconocidos, por lo que no se puede retroceder en la secuencia de los hechos, dando lugar a que se rompa el nexo causal.

Se tienen que dar dos condiciones para aplicar el criterio de la prohibición de regreso:

$\left.1^{\circ}\right)$ La intervención del tercero tiene que ser dolosa o con negligencia graves. Si no se da este tipo de conducta, será responsable el que inicia el proceso causal. Esto podemos verlo en el "caso de la vaca" (RJ-1959/1483, 10 de febrero de 1959) en que se hizo retroceder y hacer responsable al dueño de la vaca, cuando el motivo fue el deficiente estado de los sueros que le causaron la parálisis al operario, con lo que él no tenía que ver nada; ni tampoco la intervención de los médicos había sido dolosa ni

\footnotetext{
${ }^{117}$ Izquierdo Tolsada, op,cit.pag 203. Igualmente Castán Tobeños, op,cit. Pag 970.
} 
gravemente culposa, con lo que se rompe el nexo causal y D. Leoncio como propietario de la vaca no se le deberían haber exigido responsabilidades.

$2^{\circ}$ ) La conducta dolosa del tercero no tiene que haber sido favorecida de forma apreciable o determinante por el demandado. Estas conductas se dan frecuentemente por incumplimiento de normas de seguridad y custodia, como por ejemplo la STS de 17 de mayo de 2000 (JUR 2000/3933), en la que en un banco la secretaria se había quedado con más de veintiséis millones de pesetas, rellenando varios talones, con una firma estampillada, sin emplear la original, ello vulnera el $\operatorname{art}^{\circ} 107$ de la Ley Cambiaria y del Cheque, el cual dispone que el documento no se considera cheque si carece de alguno de los presupuestos del $\mathrm{art}^{\circ} 156$, por lo que resulta responsable el Banco Bilbao Vizcaya, S.A, ya que la entidad bancaria está obligada a verificar que el título está correctamente firmado, de manera que ha de realizar una labor de comprobación de los requisitos intrínsecos y extrínsecos del cheque, con lo que el banco queda condenado, basándose en los artículos 156 y157 de la Ley Cambiaria y del Cheque como norma fundamental de la responsabilidad.

\section{2. 3. LA CONDUCTA DEL PERJUDICADO}

La norma habla de culpa del perjudicado, en el $\operatorname{art}^{\circ} 1.1$ de la Ley de Responsabilidad Civil y Seguro en la Circulación de Vehículos de Motor y en el $\operatorname{art}^{\circ} 9$ de la Ley de Productos Defectuosos; el art ${ }^{\circ}$ 45,II de la Ley Reguladora de la Energía Nuclear habla de la persona que sufrió los daños, o en el $\operatorname{art}^{\circ} 25$ de la Ley de Consumidores y Usuarios donde se refiere a la culpa del consumidor. Pero de lo que no habla es del término víctima para designar a quien sufrió los daños como participante causal en el suceso dañoso.

La culpa de la víctima es alegada con gran frecuencia por los demandados, lo que da lugar a bastantes sentencias absolutorias por darse una quiebra o ruptura del nexo causal.

En general, puede decirse que cuando la culpa es exclusiva de la víctima, se produce una total exoneración de responsabilidad del demandado y su apreciación corresponde al Tribunal que tiene asignada la resolución del caso. Las condiciones que se 
tienen que dar para que la culpa exclusiva de la víctima exonere al demandante son los de que sea única, total y exclusivamente la originadora del daño.

Para determinar si en un hecho dañoso debe ser o no indemnizada la víctima, se deben tener en cuenta circunstancias tales como su edad, condiciones físicas o mentales, exposición al riesgo, papel que desempeña en la producción del hecho dañoso .Hay casos en que el daño no puede ser imputado a su autor, por poder tratarse de alguien que no sea subjetivamente imputable. El problema se da cuando se trata de ancianos, dementes, disminuidos físicos, menores que sean inimputables y sufran el daño, y lo sufre por haber participado en el hecho de forma decisiva en el curso causal. Esta participación del imputable tiene gran importancia en un sistema objetivo, mientras en uno subjetivo tiene poca relevancia al no poder imputársele subjetivamente el daño.

El legislador francés ha seguido esta línea en la ley tendente a mejorar la situación de las víctimas de los accidentes de circulación, de 5 de julio de 1985, "llamada Ley Badinter", en la que se prevé como regla general la excepción de la culpa inexcusable de la víctima, excluyéndose de ella los supuestos en los que la edad de la víctima sea inferior a los 16 años o superior a los setenta, o cuando tenga declarada una incapacidad permanente o invalidez de al menos el $80 \%$, a no ser que haya buscado voluntariamente el daño. De igual forma la Ley Belga de 13 de abril de 1995 protege a las víctimas menores de 14 años en el caso de que hubieran participado culpablemente en el accidente $^{118}$.

Un caso de culpa del perjudicado se da en la STS de 31 de mayo de 1993 (RJ1993/4056) en el que trata de un menor que se columpió entre dos columnas de hormigón, unidas por una cadena de hierro, construidos por el demandado para que no pudieran entrar a aparcar coches en la finca de su propiedad. El menor murió al columpiarse en las cadenas. Los muros y las cadenas no fueron construidos con el fin de utilizarse como columpios. Por ello se desestima el recurso y se declara culpable en exclusiva al menor.

\section{2. 4. LOS PETL EN LA RELACIÓN DE CAUSALIDAD}

\footnotetext{
${ }^{118}$ Reglero Campos F. y otros op, cit, pags 106 y ss.
} 
La relación de causalidad comienza en los PETL en su $\operatorname{art}^{\mathrm{o}}$ 3-101 que trata de conditio sine qua non y dice lo siguiente:

"Una actividad o conducta (en adelante actividad) es causa del daño de la víctima si, de haber faltado tal actividad, el daño no se hubiera producido"119.

Lo primero que hay que preguntarse es los perjuicios que origina la actividad y si los debe soportar la persona responsable, para ello es preciso analizar las causas que se dan en el hecho dañoso o la actividad de que se trate y ver si faltando alguna el daño se hubiera o no producido. Si se comprueba que de no haberse dado esa actividad el suceso no se hubiera producido, estamos ante algo relevante, que es la causa necesaria para el hecho dañoso; en caso contrario se trataría de algo irrelevante que no se debe tener en cuenta.

$\operatorname{Art}^{\circ} 3102$ Causas Concurrentes.

"En caso de una pluralidad de actividades, si cada una de ellas hubiera causado el daño por sí sola al mismo tiempo, se considerará que cada actividad es causa del daño de la víctima".

En este caso se considerará la existencia de un daño en un único momento. Si cada actividad hubiese causado el daño, con independencia de las otras, los responsables de las distintas actividades lo son plenamente. Es irrelevante si las actividades se dieron o no al mismo tiempo. Esto se puede mostrar con el ejemplo de dos ladrones que van realizar un robo, uno de ellos llega antes que el otro, mientras va preparando el terreno para llevarlo a cabo, mientras que al incorporarse el siguiente cometen el robo los dos juntos al mismo tiempo ${ }^{120}$.

\footnotetext{
119 Chapter 3. Causation.
}

Section 1. Conditio sine qua non and qualifications.

$\operatorname{Art}^{\mathrm{o}}$ 3:101. Conditio sine qua non.

An activity or conduct (hereafter : activity) is a cause of the victim's damage if, in the absence of the activity, the damage would not have occurred.

$120 \mathrm{Art}^{\circ}$ 3: 102 Concurrent causes.

In case of multiple activities, where each of them alone would have caused the damage at the same time, each activity is regarded as a cause of the victim's damage. 
$\mathrm{Art}^{\mathrm{O}} 3106$ Causas Inciertas en la Esfera de la Víctima.

"La víctima tiene que cargar con la pérdida sufrida en la medida correspondiente a la probabilidad de que pueda haber sido causada por una actividad, acontecimiento o cualquier otra circunstancia perteneciente a su propia esfera".

Una causa se encuentra dentro de la esfera de la víctima si es causada por su actividad. Los acontecimientos naturales como tormentas, enfermedades, ataques cardíacos, pueden considerarse dentro de la esfera de la víctima. Estos daños tienen que ser soportados por ella. Hay casos en los que media tanto culpa de la víctima como del demandado, siendo en este caso necesario determinar la proporción entre uno y otro de los que intervienen para distribuir entre ellos la correspondiente responsabilidad.

\section{LA MODERACIÓN}

\subsection{ART $^{\circ} 114$ DEL CÓDIGO PENAL}

El $\operatorname{art}^{\circ} 114$ del Código Penal dice:"Si la víctima hubiere contribuido con su conducta a la producción del daño o perjuicio sufrido, los Jueces o Tribunales podrán moderar el importe de su reparación o indemnización”

Este artículo trata de la concurrencia o compensación de culpas con el fin de determinar la proporción en que cada uno de los responsables ha contribuido al resultado final. Se encuentra directamente relacionado con el $\operatorname{art}^{\circ} 61.3$ de la LORPM aunque son diferentes, pues este no habla de culpa de la víctima, ni que esta haya contribuido a la producción del daño; y si no habla de ello es debido a que se trata de una responsabilidad cuasi objetiva. La responsabilidad de los obligados solidarios no requiere culpa, teniéndose en cuenta la no existencia de culpa grave, solamente para la reducción del quantum de la indemnización de esos responsables solidarios.

\footnotetext{
$\operatorname{Art}^{\mathrm{o}}$ 3:106 Uncertain causes within the victim's sphere.
}

The victim has to bear his loss to the extent corresponding to the likelihood that it may have been caused by an activity, occurrence or other circumstance within his own sphere. 
La culpa del $\operatorname{art}^{\circ} 114$ es una culpa penal de la que se deriva una culpa civil, en la que se tienen en cuenta los criterios de la importación subjetiva, es en definitiva, una responsabilidad civil de carácter subsidiario, de padres y tutores respecto de los daños y perjuicios derivados de delito o falta cometidos por menores que se encuentren sujetos a patria potestad o tutela, que vivan en su compañía y que haya mediado culpa o negligencia en el ejercicio de los deberes inherentes a la patria potestad o tutela.

Por la LORPM se ha introducido un sistema de responsabilidad civil de mayor alcance y severidad con una doble finalidad: en primer lugar amparar mejor los derechos de las víctimas al liberarles de tener que probar la culpa del responsable civil, protegiéndola también frente a la insolvencia del menor, asegurándoles así mediante un sistema objetivo, sin fisuras ni excusas, la indemnización de los daños sufridos por tales víctimas, y en segundo lugar, conseguir una mayor implicación de los padres y demás responsables en el proceso de socialización de los menores imponiéndoles las consecuencias civiles de las infracciones que estos cometen por la transgresión del conjunto de deberes que tienen sobre ellos (SAP, Alicante, de 26-06-2006, JUR/2007/8026).

En conclusión, la norma del $\operatorname{art}^{\circ} 61$ LORPM trata de supuestos diferentes que no se contemplan en el $\operatorname{art}^{\circ} 114$, pues éste tiene en cuenta la imputación subjetiva, mientras que el otro trata de un sistema objetivo.

\subsection{ART $^{\circ}$ 1.103 DEL CÓDIGO CIVIL}

$\mathrm{El} \operatorname{art}^{\circ} 1.103$ que se refiere a la moderación dice: "La responsabilidad que proceda de negligencia es igualmente exigible en el incumplimiento de toda clase de obligaciones; pero podrá moderarse por los Tribunales según los casos"

Comparando este artículo con el 61.3 LORPM se observa iguales términos como "podrá" y "la responsabilidad podrá ser moderada según los casos". Existen diferencias como en el Código civil en que dice la responsabilidad que "proceda de negligencia" y es exigible en toda clase de obligaciones; por el contrario la LORPM se refiere a los responsables solidarios (no el menor o menores), que no hubieren favorecido la conducta del menor con dolo o negligencia grave. 
Existe diferencia en cuanto a los sujetos de la moderación, en la LORPM afecta únicamente a los responsables solidarios (no al menor o menores), mientras que el Código Civil no tiene limitación alguna. $\mathrm{El} \mathrm{art}^{\mathrm{o}}$ 61.3 LORPM contempla otra diferencia en el sentido de que la negligencia se tiene en cuenta sólo si es grave, en cuyo caso no se daría o podría aplicarse la moderación, mientras que el $\operatorname{art}^{\circ} 1.103$ CC habla de "la responsabilidad que proceda de negligencia". La otra diferencia se da en el tipo de negligencia, ya que el Código Civil no menciona ninguna en especial, la LORPM habla de dolo o negligencia grave.

En consecuencia, el $\operatorname{art}^{\mathrm{o}} 1.103$ se refiere a una moderación de toda clase de obligaciones, mientras que el $\operatorname{art}^{\circ}$ 61.3 LORPM se refiere a la responsabilidad civil por los menores de edad comprendida entre catorce y dieciocho años, por lo que son distintas de los responsables solidarios que los tengan a su cargo en cuanto a su contenido y soluciones que ofrecen.

\subsection{DISCRECIONALIDAD DE LA MODERACIÓN}

La discrecionalidad del $\operatorname{art}^{\mathrm{o}} 61.3$ sobre la moderación se contempla en la expresión "su responsabilidad podrá ser moderada por el Juez según los casos", al emplear la palabra "podrá" establece una facultad de la que podrá hacer o no uso el Juez según las circunstancias del caso de que se trate. Aunque sea una facultad del Juez, tiene que motivarla tanto si la concede como si la niega, en la misma resolución.

Esta facultad de moderación no puede entenderse como arbitraria pues tiene límites en dolo o negligencia grave de los responsables solidarios como padres, tutores, etc. Si existe dolo o negligencia grave no puede aplicarse la moderación, pues ello daría lugar a la quiebra de la responsabilidad objetiva; ni tampoco se puede aplicar con carácter restrictivo, por lo que hay que estar al caso concreto.

Un ejemplo de moderación se aprecia en la SAP de Badajoz de fecha 25 de enero de 2005 (AC/2005/333), ya vista anteriormente, en sentido positivo en el que a la madre se le modera su responsabilidad en un $50 \%$, por haber cuidado y atendido al menor, procurándose un trabajo en el servicio doméstico para hacer frente a los gastos de los estudios del menor y es la que mantiene unas normas y horarios; por el contrario, el 
padre se ha desentendido por completo del menor y, tras dejar el hogar familiar, rompiendo todos los lazos afectivos con su hijo, se ha despreocupado de la educación y asistencia del menor, por lo que en su fundamento de derecho tercero, apartado octavo se condena al padre a responder solidariamente con el menor del importe total de la indemnización, sin embargo, la actitud de la madre merece que su responsabilidad sea moderada, reduciéndose en un 50\%. Otra sentencia, ésta en sentido negativo, es la de la SAP de Sevilla de 3 de junio de 2005 (JUR72005/238714) se trata de una responsabilidad civil derivada de delito, en la que se desestima el recurso por no haber dato alguno que permita aplicar la moderación solicitada, al constar que el menor tenía 17 años al cometer los hechos, que en su domicilio tenía una bolsa conteniendo 12 tabletas de hachís que dedicaba en parte a la venta de terceras personas; también que llevaba una navaja que era suya en la cintura de $20 \mathrm{~cm}$ de longitud, hechos estos que debían ser conocidos por los padres y que debieron hacerles tomar las medidas oportunas y ejercer las facultades de corrección que los padres ejercen sobre sus hijos.

\subsection{SUJETOS A LOS QUE SE APLICA LA MODERACIÓN}

La moderación se aplica a los responsables solidarios del $\operatorname{art}^{\circ}$ 61.3 LORPM, es decir, padres, tutores, acogedores y guardadores legales o de hecho, que responden con el menor. Este queda por tanto fuera de la moderación.

Por el instituto de la moderación puede quedar la víctima sin recibir una satisfacción completa por el perjuicio causado, pues la deuda contraída por el menor, una parte de ella será satisfecha por los responsables solidarios, mientras que la otra correrá a cargo del propio menor. Se considera por ello que la moderación rompe el principio de reparación de todos los daños causados, pues cuanto mayor cuota de moderación se aplique, menos dinero cobra la víctima, esto se contempla en la S.A.P. de Córdoba de 20 de febrero de 2004 (JUR/2004/105382) en ella se condena solidariamente a la madre y al hijo a pagar 468 euros a la víctima, la madre recurre la sentencia y obtiene una moderación del 50\% de su responsabilidad solidaria por lo que la víctima recibe finalmente 234 euros, es decir, la mitad de lo reclamado. 
A veces se dan casos en que intervienen una pluralidad de responsables, padre, madre, varios tutores, por lo que hay que analizar detalladamente el comportamiento individual de cada uno de ellos, para establecer con precisión a quien se puede aplicar la moderación por haber sido diligente y a quien no.

Una sentencia ilustrativa sobre pluralidad de responsables es la SAP de Asturias de fecha 27 de abril de 2006 (JUR 2006/166775), en la que al Organismo que ostentaba la guarda y custodia se le modera la cuantía en un 30\%, al padre que estaba en un Centro Penitenciario en el momento de ocurrir los hechos un 50\%, y a la madre no se la admite moderación, por entender que su conducta ha contribuido de manera determinante a la producción de los hechos, esta es la distribución de la cantidad, que excede del 50\%, lo que no suele ser frecuente ${ }^{121}$.

\subsection{CUANTÍA DE LA MODERACIÓN}

La moderación la aplica el Juez de forma discrecional, fundamentando la resolución, pero lo que no puede hacer es exonerar, pues exonerar es distinto a moderar.

Cuando un menor comete un hecho dañoso, hay que buscar una persona física o jurídica que sea responsable de indemnizar a la víctima o perjudicado, pues el menor es en la mayor parte de los casos insolvente. Para ello se recurre a los responsables solidarios o terceras personas que los tienen a cargo, tales como, padres, tutores, acogedores, guardadores legales o de hecho, personas que han actuado correctamente, con la debida diligencia, pero en virtud del vínculo que les une con el menor, por tratarse de un institución tuitiva, son obligados a responder de forma solidaria con el menor responsable. En estos casos la moderación podrá alcanzar hasta la mitad.

No se puede emplear la exoneración completa, pues ello daría lugar a la quiebra del sistema, al quedar la víctima sin indemnización. De igual forma tampoco se permite una moderación en que se imponga a los responsables solidarios una cantidad

121 Bonilla Correa, Jesús Ángel, op. cit, pag 268 y 269 
testimonial, consistente en muy poca cantidad de dinero, que en la práctica equivaldría a una exoneración.

Los Tribunales han aplicado desde un $20 \%$ a un $50 \%$ en la mayor parte de las sentencias. En algún caso excepcional se ha llegado a las dos terceras partes de la indemnización que correspondería al menor. ${ }^{122}$

\subsection{FUNDAMENTO Y OBJETO DE LA MODERACIÓN}

El fundamento de la moderación es garantizar a la víctima una indemnización, como consecuencia de una acción delictiva definida en el Código Penal, cometida por un menor de dieciocho años y mayor de catorce. Este menor en la mayor parte de los casos será insolvente, por lo que habrá que recurrir a los responsables solidarios, para garantizar el reparo a la víctima o perjudicado.

La Ley establece un mecanismo corrector para los responsables solidarios que han actuado diligentemente en relación con los menores de quienes son responsables. Este mecanismo es la moderación. En los casos en que no existe dolo ni negligencia grave de los responsables solidarios, que no tienen culpa, han educado y formado al menor de forma satisfactoria, si se ha controlado y vigilado bien al menor, es por lo que la norma disminuye la cuantía de la moderación.

Para aplicar la moderación hay que tener en consideración el comportamiento de los padres, el que hayan mostrado diligencia en el cumplimiento de sus obligaciones tuitivas, pues en caso contrario no hay moderación. Una sentencia apropiada a este caso es la S.A.P de Lugo de 23 de octubre de 2001 (JUR 2001/332000) en ella no se aprecia en los padres conducta dolosa o negligente de ningún tipo, pues intentaron mantener a su hijo dentro de unos parámetros de conducta y educación perfectamente socializables, intentando mantener a su hijo escolarizado hasta que resultaba completamente imposible, por lo que le posibilitaron el acceso al trabajo. Por todo ello se moderó su responsabilidad pasando de 3.069 .000 a 2.069.000 pesetas.

122Bonilla Correa, Ibidem, pag 269 y 275 
En cuanto al objeto de la moderación es asegurar la reparación a la víctima del hecho cometido por el menor y para ello lo que se trata es de favorecer la reparación del daño como elemento de conciliación entre la víctima y el menor infractor.

El tipo de responsabilidad del $\operatorname{art}^{\circ}$ 61.3 LORPM es de tipo objetivo, es decir, que no se tienen en cuenta la noción de culpa civil, ni los criterios de imputación subjetiva, pero la facultad moderadora no cambia en modo alguno su carácter objetivo, puede parecer que no concuerda la moderación con la responsabilidad objetiva, pero es que no nos encontramos ante una verdadera responsabilidad, sino ante una garantía para la víctima o perjudicado que se da como consecuencia de la relación que existe entre el menor y los responsables solidarios. ${ }^{123}$

\section{LA RESPONSABILIDAD DE LOS PADRES}

\subsection{FUNDAMENTO}

En la responsabilidad criminal, no se puede responder penalmente por otro. Es necesario al mismo tiempo la existencia de culpa para que se pueda dar el delito o falta, de lo que se deduce que no hay responsabilidad criminal sin culpa. Lo que sí existe es responsabilidad civil que derive del delito cometido por otro.

En nuestro Código Civil el art $^{\circ} 1.902$ se refiere a los casos en que una persona responde de sus propios actos; mientras que el art ${ }^{\circ} 1.903$ trata de los casos en que tiene que responder una persona distinta, debido a una relación de carácter especial en que se encuentra respecto al responsable material del daño.

La responsabilidad del $\operatorname{art}^{\mathrm{o}} 1.903$ se denomina "por hecho ajeno" y se refiere a una relación familiar o cuasi familiar sobre los padres y tutores. Este artículo ha sufrido varias modificaciones como consecuencia de la necesidad de adaptarse a los principios de la C.E. En su redacción anterior decía: "El padre y, por muerte e incapacidad de éste la madre, son responsables de los perjuicios causados por los hijos menores de edad que vivan en su compañía”. Este artículo se encontraba en desacuerdo con el $\operatorname{art}^{\circ} 32$ C.E que dice en su apartado $1^{\circ}$ : "El hombre y la mujer tienen derecho a contraer matrimonio con

123 Ibidem, pag 271 y ss 
plena igualdad jurídica". Esas modificaciones tienen por objeto materializar la igualdad entre los cónyuges, para lo que la madre se equipara al padre ejerciendo ambos cónyuges la patria potestad de forma conjunta. Esta igualdad se contempla en el apartado segundo del $\operatorname{art}^{\circ} 1.903$ que dice: "Los padres son responsables de los daños causados por los hijos que se encuentren bajo su guarda".

El párrafo primero del $\operatorname{art}^{\circ} 1.903$ dice: "La obligación que impone el artículo anterior es exigible, no sólo por los actos u omisiones propios, sino por los de aquellas personas de quienes se debe responder" exponiendo a continuación los distintos titulares de la responsabilidad por hecho ajeno o por hecho de otro, que se da cuando la ley obliga a reparar el daño causado por la acción u omisión de una persona a otra distinta.

Para que una persona responda por otra tiene que darse una especial relación de dependencia familiar, cuasi familiar, educativa, guarda, custodia, etc, entre el responsable por hecho ajeno y el autor material del daño. Es una relación especial en que a diferencia de lo que sucede en el artículo 1.902, en el 1.903 se presume la culpa. Por lo que puede decirse que el 1.903 es una prolongación del 1.902, como sucede con el $\operatorname{art}^{\circ} 1.384$ del Código Francés; si en el 1.902 se halla la culpa in operando, en el 1.903 se trata de culpa in vigilando, in eligendo o in educando. ${ }^{124}$

Esta responsabilidad por hecho ajeno se fundamenta en la culpa que esas personas tienen "in vigilando" por no controlar debidamente a las personas que tienen bajo su dependencia, al no haber podido evitar el daño causado a otros. De igual forma se da culpa "in educando" cuando no se ha sabido inculcar los valores y virtudes necesarios en el menor para evitar los daños que éste haya ocasionado a la víctima.

La prueba de la culpa no ha de ser probada por la víctima, como sería lo normal, sino que se da una inversión de la carga de la prueba, debiendo ser probada por el responsable del menor, por lo que se entiende que si el menor ha dañado habrá sido por que los padres no le han vigilado o educado con la diligencia de un buen padre de familia y les corresponde a ellos probar que lo vigilaron y educaron correctamente, de acuerdo con lo que establece el inciso último del $\operatorname{art}^{\circ} 1.903$ que dice: "La responsabilidad

${ }^{124}$ YzquierdoTolsada, op, cit, pag 254 
de que trata este artículo cesará cuando las personas en el mencionadas prueben que emplearon toda la diligencia de un buen padre de familia para prevenir el daño".

El fundamento en la culpa no es real y se puede ver en las sentencias del Tribunal Supremo en que es muy difícil encontrar alguna en que los padres lograron demostrar que emplearon la diligencia de un buen padre de familia. Cada día la responsabilidad por culpa o subjetiva, va cediendo cada vez más ante la responsabilidad objetiva. Esto es debido a que cada vez se tiende más a la socialización o garantía de la víctima, para poder asegurar la reparación del daño, pues en la mayor parte de los casos, los menores autores materiales de los daños resultan ser insolventes, por ello es conveniente asegurar que el patrimonio de los padres responda a la indemnización del perjudicado.

Para los distintos supuestos del artículo 1.903 se dan dos requisitos comunes a ellos, el primero es la idea de garantía para resarcir a la víctima en virtud del principio pro damnato; y el segundo, es la relación de dependencia, jerarquía o subordinación que permiten dar a otro órdenes, instrucciones, indicaciones o mandatos para que obedezca, ya sean de carácter familiar o docente. Por lo que la responsabilidad por otros se fundamenta en la culpa in vigilando e in educando y se justifica por un doble interés, el interés de la víctima facilitándose por la ley el resarcimiento y en el interés del menor o incapaz, que al ser inimputable no puede responder, por lo que responderá su representante legal, que aunque sea responsable por hecho ajeno lo hace por culpa propia, al hallarse ligado por relación de dependencia con el menor ${ }^{125}$.

Parece que es la patria potestad el criterio que une la responsabilidad con aquel que la ostenta, y esto es así porque si un menor causa un daño es porque no le vigiló ni educó correctamente. Se culpa al padre por el hecho de ser el padre, independientemente de cualquier otra consideración. No se atiende a la culpa, es una responsabilidad cuasi objetiva u objetiva, y ello lo podemos ver en que casi todas las sentencias del Tribunal Supremo, son de carácter objetivo, y que como dice YzquierdoTolsada "los tribunales han confundido a los padres con una compañía de seguros"126. Es muy raro encontrar

\footnotetext{
125 Paños Pérez, Alba. La responsabilidad civil de los padres por los daños causados por menores e incapacitados. Atlelier, libros jurídicos, Barcelona 2010, pag 20 y ss.

${ }^{126}$ YzquierdoTolsada, op. Cit, pag 257
} 
una sentencia que exonere a los padres, como la STS de 5 de marzo de 1997 (RJ 1997/1650), en ella se exonera a los padres del hijo mayor de edad, José, esquizofrénico paranoide, el cual disparó con una pistola matando a tres menores. Los demandantes solicitan la declaración de responsabilidad de los demandados por no haber solicitado la incapacidad de su hijo. Pero se daba la circunstancia de que el médico no había informado a los padres de la gravedad de la enfermedad de su hijo, por lo que los padres desconocían esa gravedad; que José había mejorado de su enfermedad y no presentaba signos externos de violencia; que a la vista de estos antecedentes los padres carecían de la información necesaria para incapacitar a su hijo, ni tampoco para internarlo en un centro psiquiátrico, cosa que nadie, ni el médico les había indicado. Por ello dice en su Fundamento Segundo que de existir alguna responsabilidad sería del facultativo que no comunicó la clase de enfermedad que José padecía, ni tampoco aconsejó su ingreso en el centro, no compartiendo la Sala el criterio de que el médico no está obligado a informar según la Ley de Sanidad. Si en algún caso hay obligación de informar, es en el supuesto de las enfermedades psiquiátricas, por la propia idiosincrasia de tales enfermedades, los riesgos que conlleva y la necesidad de ayuda que tales enfermedades requieren, nada de lo cual puede hacerse, si quien puede no informa. Por todo ello el recurso quedó desestimado y los padres exonerados de responsabilidad.

En cuanto a la enumeración de responsables del $\operatorname{art}^{\mathrm{O}} 1.903$ es una relación taxativa o de números clausus, no admitiéndose la analogía para hacer responsables a otros parientes, tales como abuelos o tíos e incluso a la mujer por los daños por el marido o el novio por lo hecho por la novia, por lo que no se puede dar ningún tipo de ampliación ${ }^{127}$. La práctica totalidad de la doctrina defiende que se trata de numerus clausus y el Tribunal Supremo adoptó este criterio, en la sentencia de 30 de abril de 1969 (RJ 1969/2411), pues se trata de una obligación de ocuparse de menores, por la relación de filiación y por la relación de dependencia, que no se dan en otros parientes.

127Ibidem, pag 254 


\subsection{LA RESPONSABILIDAD DE LOS PADRES EN EL DERECHO COMPARADO.}

\subsubsection{DERECHO FRANCÉS}

La responsabilidad extracontractual en el derecho francés se halla contemplada en el capítulo II del título IV del libro III del Código Civil francés, que comprende de los artículos 1.382 a 1.386. La responsabilidad por hecho propio se da en los artículos 1.382 y 1.383, que se corresponden con nuestro artículo 1.902. El artículo 1.384 trata de la responsabilidad por hecho ajeno y se corresponde con nuestro artículo 1.903.

En la redacción inicial del $\operatorname{art}^{\mathrm{o}} 1.384$ decía "el padre, y la madre tras el fallecimiento del marido, son responsables del daño causado por sus hijos menores que habiten con ellos"; este artículo fue modificado por la Ley n ${ }^{\circ} 70-459$ de 4 de junio de 1970 para que la responsabilidad de los padres por los daños causados por sus hijos menores de edad sea solidaria. En su redacción inicial la responsabilidad de la madre era subsidiaria al decir "el padre, y la madre tras el fallecimiento del marido", con esta modificación el párrafo tercero queda redactado de la forma siguiente: "Los padres, mientras ejerzan la patria potestad, son solidariamente responsables del daño causado por sus hijos menores que vivan con ellos"128. De esta forma los cónyuges quedan equiparados respondiendo los dos de forma solidaria y no quedando la mujer subordinada al marido, sino en un plano de igualdad.

En su párrafo sexto contiene una cláusula exonerativa, si logran demostrar " que no pudieron impedir el hecho que dio lugar a esta responsabilidad". Pero a pesar de esta cláusula la tendencia de la jurisprudencia de la Cour de Cassation es hacia una objetivación de la responsabilidad de los padres.

Tradicionalmente se ha fundamentado la responsabilidad de los padres por los hechos dañosos de sus hijos menores en la vigilancia y educación de los mismos, con la posibilidad de poder quedar exonerados si podían demostrar que actuaron con la diligencia debida y que no pudieron evitar el daño. Con el paso del tiempo, por los cambios que operan en la sociedad, la autoridad de los padres se ha debilitado de forma

128' 'Le pére et la mére, en tant qu'il sexercent l'autorité parentale, sont solidairement responsables du domage causé par leurs enfants mineurs habitant avec eux" 
notoria, la legislación internacional trata de dar mayor libertad e independencia a los menores, la dispersión de la familia, el incremento de juguetes peligrosos, la proliferación de seguros, la multiplicación de familias con un solo progenitor, han dado lugar a que los principios anteriores basados en la autoridad y los padres, y en el concepto de culpa, ya no se tengan en cuenta, pasando a una responsabilidad objetiva, con el fin de que sea una garantía para indemnizar a la víctima ${ }^{129}$.

Respecto a las personas responsables por hecho ajeno enumerados en el $\operatorname{art}^{\mathrm{o}} 1.384$ la relación es limitada, pues la patria potestad no es transmisible, por lo que una persona que sea encargada de cuidar menores, no queda exonerada de responsabilidad al ser titular de la patria potestad; con lo que esa persona será responsable de acuerdo con los artículos 1.382 y $1.383^{130}$ pero no con el 1.384. Para aplicar este artículo a personas distintas de los enumerados en el mismo la Asamblea Plenaria de la Corte de Casación, en sentencia de 29 de marzo de 1991, conocida como sentencia Blick, estableció que se podría aplicar a otras personas siempre que se "tuviera la obligación de organizar y controlar a título permanente el modo de vida de la persona". Quiere ello decir que se puede aplicar ese tipo de responsabilidad por hecho ajeno a los abuelos y tíos, a establecimientos médicos o educativos, pero dándose esa circunstancia de que se trate de un período de tiempo largo en el que se "organice y controle a título permanente el modo de vida de la persona". En caso contrario si se trata de un menor que pasa unas vacaciones con los abuelos, o unos amigos en un fin de semana, etc, no se puede aplicar lo dispuesto en el $\operatorname{art}^{\mathrm{o}} 1.384$, sino el $\operatorname{art}^{\mathrm{o}} 1.382$ y 1.383 en que se da una responsabilidad por hecho propio.

Los requisitos que se deben dar para la aplicación del $\operatorname{art}^{\mathrm{O}} 1.384$ son en general que se trate de un daño, pues sin daño no hay responsabilidad; que se dé una relación de

\footnotetext{
${ }^{129}$ López Sánchez, Cristina op.cit, pag 99 y ss 130 (130) $\operatorname{Art}^{\mathrm{o}} 1.382$ y 1383 Code civil
}

Art 1382 Code civil: "Cualquier hecho del hombre que cause daño a otro obliga a aquel por cuya culpa sucedió, a repararlo". "Tout fait quelconque de l'homme qui cause a autrui un dommage, obligue celui par la faute du quel il est arrivé a le reparer".

Art 1.383 Code civil: “Cada uno es responsable del daño que cause, no sólo por su acción, sino también por su negligencia o su imprudencia". "Chacun est responsable du dommage qu'il a cause non seulement par son fait, mais encoré par sa négligence ou par son impurdence”. 
causa o efecto entre la acción y omisión y el daño, lo que se llama relación de causalidad; que el acto sea culposo, es decir, antijurídico o contrario a derecho. $Y$ en particular que el autor del daño sea menor de edad, viva con sus padres y estos lo tengan bajo su guarda.

La menor edad se entiende al menor que no haya cumplido los dieciocho años, de acuerdo con el $\mathrm{art}^{\circ}$ 488. Cuando haya alcanzado la mayoría de edad o el menor sea emancipado cesará la responsabilidad de los padres.

En cuanto a la cohabitación o convivencia entre padres e hijos, no es necesario que sea constante y puede alterarse en ausencias justificadas. Se requiere igualmente que los padres tengan al hijo bajo su patria potestad. El problema sobre la convivencia y la patria potestad se complica cuando no se da el caso de una familia unida y tradicional, sino que se trate de una familia desestructurada, con padres separados, en la que el hijo se halla con uno de los progenitores. En este caso, cuando uno de los padres tiene asignada la patria potestad, puede darse el caso de que éste fuera el único responsable, e incluso lo seguiría siendo en los casos en que el menor cometiera el acto dañoso, encontrándose en régimen de visitas con el otro progenitor; por lo que al no tener la guarda éste no respondería por el $\operatorname{art}^{\mathrm{o}} 1.348 \mathrm{y}$ el otro progenitor que tiene asignada la guarda, al no cohabitar con él tampoco responde por ese artículo. Para resolver este problema la Corte de Casación en sentencia de 19 de febrero de 1997 (Sentencia Bertrand) estableció que se abandonaba el requisito de la cohabitación o convivencia para poder aplicar el $\operatorname{art}^{\circ} 1.384$. En el caso de esta sentencia se trataba de un menor de diecisiete años, hijo de padres divorciados, su guarda había sido encomendada a la madre, el menor causó daños a un automóvil que previamente había sido robado, durante el periodo que el joven se encontraba con su padre. Por el $\operatorname{art}^{\circ} 1.384$ la madre no podía quedar obligada por no darse el requisito de la cohabitación, quedando sólo la interposición de una demanda contra el padre basada en el $\operatorname{art}^{\circ}$ 1.382. La sentencia Samda de la Cour de Cassation de 19 de febrero de 1997 dijo que:"el ejercicio de un derecho de visita y alojamiento no hace cesar la condición de cohabitación del menor con el padre que ejerce la guarda" por lo que también la madre era responsable.

Además de la sentencia anterior, la llamada Bertrand de 19 de febrero de 1997 en 
la que la Corte de casación sustituyó definitivamente la presunción de culpa de los padres por una responsabilidad objetiva, por lo que en el momento que un menor cause daño a otra persona, no podrán sus padres librarse de responder de dicho daño. De igual forma el requisito de la cohabitación no tiene sentido al haber admitido la responsabilidad objetiva de los padres, pues exista o no cohabitación, los padres van a seguir respondiendo. Por todo ello aunque figure en el $\mathrm{art}^{\circ} 1.384$, la jurisprudencia ha prescindido de este requisito.

Los padres aunque logren demostrar que no hubo culpa por su parte seguirán respondiendo, por lo que sólo podrán ser exonerados al romperse el nexo causal por contribuir la víctima de forma culposa a la producción del daño o en caso de fuerza mayor.

Por la sentencia Bertrand se han unificado las soluciones jurisprudenciales, dándose seguridad jurídica y evitando el desorden que imperaba antes de su aplicación; de igual forma se ha podido con ello garantizar la indemnización de las víctimas por su sistema de responsabilidad de carácter objetivo ${ }^{131}$.

\subsubsection{DERECHO ALEMÁN}

En el Código civil alemán en su $\operatorname{art}^{\circ}$ 828-1 el menor de siete años no responde en ningún caso de los daños que pudiera ocasionar. En contra el menor que ha cumplido los siete años de edad, pero no ha llegado a los diez, no es responsable del daño causado a otro, si se trata de un accidente de automóvil, ferrocarril o funicular, siempre que la lesión no se haya producido dolosamente. Mientras que si supera los siete años y es inferior a dieciocho podrá responder, si en el momento de la comisión del hecho ilícito se demuestra que tenía capacidad de discernimiento suficiente ${ }^{132}$. En el primer supuesto

\footnotetext{
${ }^{131}$ López Sánchez, Cristina, op.cit, pag 103 y ss

$132 \mathrm{Art}^{\mathrm{O}} 828$ BGB MENORES DE EDAD

1)"Quien no ha cumplido los siete años de edad, no es responsable de un daño que causa a otro"

2)"Quien ha cumplido los siete años de edad pero no los diez no es responsable del daño causado a otro por un accidente de automóvil, ferrocarril o funicular. Ello no rige si la lesión se ha producido dolosamente"

3)"Quien todavía no ha cumplido los dieciocho años de edad no es responsable por los daños que causa
} 
se trata de un caso indiscutible, pero en el segundo y tercer supuesto nos encontramos ante situaciones que admiten prueba en contrario, hay que analizar en el segundo supuesto si el menor ante esos tipos de accidentes actuó o no dolosamente y en el tercero si tenía o no la capacidad de comprender el alcance de sus actos, por lo que el Juez deberá analizarlo caso por caso.

En el art $^{\mathrm{o}}$ 828.II se delimita la edad de la incapacidad, a partir de la cual ya se puede ser responsable en determinados casos. Trata de la responsabilidad ante determinados accidentes en una franja de edad comprendida entre los siete y los diez años en que se exonera la responsabilidad al menor involucrado en los mismos, siempre y cuando no haya actuado dolosamente; con la palabra "dolosamente" se hace referencia a la intencionalidad, al haber obrado con mala fe o mala voluntad, en cuyo cao si sería imputado. Del art ${ }^{\mathrm{o}}$ 828.III, se infiere que si el menor en cuestión comprende la injusticia de la acción que comete, de la ilicitud de su hecho dañoso entonces resulta imputable. Ello quiere decir, si tiene discernimiento para comprender la injusticia de su acción en relación a otras personas y de la obligación de responder ante ellos de las consecuencias de su acción; supone la capacidad de diferenciar entre el bien y el mal para lo que es necesario tener condiciones de madurez, en las que haya suficiente capacidad intelectiva y volitiva en orden a calibrar la trascendencia de sus actos, así como del peligro de los mismos.

La responsabilidad de las personas encargadas de la vigilancia del menor se contempla en el artículo 832 BGB en el que se exige a toda persona encargada de la vigilancia de otra que deberá hacerse cargo del daño que ésta cause a terceros. Este artículo se refiere fundamentalmente a los padres y se corresponde con el 1.903 de nuestro Código civil. El guardador tiene una doble obligación en el sentido que tienen que vigilar al menor y si se produce un hecho dañoso responsabilizarse de que la víctima no quede sin indemnización.

El art 832 BGB expone en su apartado primero una obligación de carácter legal como es la de padres, tutores, etc, sobre un menor o incapaz, mientras que en su causante del daño no poseía el necesario discernimiento para comprender la responsabilidad". 
apartado segundo trata de una responsabilidad de tipo contractual, en el sentido de que se trata de una persona que mediante una remuneración se encarga de vigilar al menor o incapaz.

La doctrina manifiesta que la vigilancia a ejercer sobre el menor no debe coartar su libertad, por lo que se habrá de tratar de encontrar un equilibrio entre esa vigilancia y el libre desarrollo de la personalidad del menor, de acuerdo con la legislación internacional sobre menores.

En cuanto a los requisitos para aplicar este artículo, el acto tiene que ser ilícito o antijurídico, es decir, contrario a derecho y además tiene que darse una relación de causalidad entre la infracción del deber de cuidado del menor y los daños ocasionados por él ${ }^{133}$.

Para llevar a cabo la indemnización a la víctima existe una responsabilidad solidaria de acuerdo con el artículo 840 BGB en sus apartados I y II, mediante los cuales se dan unas relaciones internas, así como una responsabilidad conjunta cuando son varias personas las involucradas en la responsabilidad.

En el apartado 840.I BGB se da la responsabilidad solidaria entre los distintos responsables y si los guardadores son los padres, entre ellos la responsabilidad es igualmente solidaria.

Por el artículo 840.II BGB si el menor tiene capacidad delictual, es decir, si tienen más de siete años y menos de dieciocho con capacidad de discernimiento, sería él el único responsable de la reparación del daño; en este caso si el encargado de la vigilancia pagó la indemnización podrá ejercer su derecho de regreso contra el menor ${ }^{134}$.

$133 \mathrm{Art}^{\circ} 832$ BGB RESPONSABILIDAD DEL OBLIGADO A LA VIGILANCIA

1)"Quien por disposición legal está obligado a ejecutar la vigilancia sobre una persona que por su minoría de edad o por sus circunstancias psíquicas o físicas requiere tal vigilancia, está obligado al resarcimiento del daño que esta persona causa antijurídicamente a un tercero. El deber de resarcimiento no se da si cumplió el deber de vigilancia o si el daño se hubiera producido igualmente pese a la observancia de la vigilancia"

2) La misma responsabilidad incumbe a quien asume mediante contrato la ejecución de la vigilancia. $134 \mathrm{Art}^{\circ} 840$ BGB RESPONSABILIDAD DE VARIOS

$\mathrm{Art}^{\circ} 840$ I BGB 1) "Si para el daño que resulta de un acto ilícito son responsables varias personas conjuntamente, estos responden como deudores solidarios"

$\mathrm{Art}^{\circ} 840$ II BGB 2) "Si junto con quien, de acuerdo con los artículos 831 y 832, está obligado a resarcir el daño 
El Código civil alemán en materia de responsabilidad civil extracontractual se basa en el principio general de la culpa y se da una ponderación entre la protección del menor y la víctima. Pero se puede dar la circunstancia de que la víctima del daño no pueda responsabilizar al autor material por ser incapaz de acuerdo con el artículo $828 \mathrm{BGB}$, ni tampoco a la persona encargada de la vigilancia, por resultar exonerada en virtud del artículo 832 BGB; para evitar esta situación irregular o anómala se emplea el $\operatorname{art}^{\circ}$ 829BGB que trata de la equidad, por la que se puede obligar al menor, en determinadas circunstancias a responder de sus propios actos ${ }^{135}$.

\subsubsection{DERECHO ITALIANO}

La responsabilidad extracontractual en el Código civil italiano de 1.942 se encuentra contemplada en el Libro IV "Delle obbligazioni", título noveno con la denominación "Dei fatti illiciti". Los artículos que comprende son del 2.043 al 2.059. Por lo que se refiere a la imputabilidad del menor y a la responsabilidad de los vigilantes se regulan en los artículos 2.046 a 2.048.

El artículo 2.046 dice que aquel que en el momento de la comisión de un hecho dañoso no tenga la capacidad suficiente de entender y de querer, no responde de las consecuencias del hecho dañoso. Si un menor de dieciocho años es capaz de distinguir entre lo lícito y lo ilícito, puede ser obligado a responder de sus propios actos ${ }^{136}$. La capacidad de entender y de querer requiere una madurez física y psíquica, para ser capaz de comprender el alcance y las consecuencias de sus actos. No será imputable el menor que en el momento de cometer el acto dañoso no comprenda la trascendencia y

causado por otro es también responsable del daño del otro, en su relación recíproca es responsable sólo del otro, y en el caso del artículo 829 sólo el obligado a la vigilancia”

135 López Sánchez, Cristina, opcit, pag 154 y 155

136 Artículo 2.046 Codice civile: Imputabilidad del hecho dañoso.

"No responde de las consecuencias del hecho dañoso quien no tenga capacidad de entender y de querer en momento en que lo ha cometido, a menos que el estado de incapacidad derive de su propia culpa"

Articolo 2.046 Codice civile: Imputabilitá del fatto dannoso.

"Non responde delle consequenze del fatto dannoso chi non aveva la capacitá d'intendere o di volere al momento in cui lo ha commesso, a meno che lo stato d'incapacitá da sua colpa" 
significado de sus actos. Para poder apreciar el grado de discernimiento o de madurez del individuo en cuestión, ha de realizarlo el Juez, analizando caso por caso, para ver si es incapaz y como consecuencia de ello inimputable, pues el código italiano no dice a partir de qué edad se adquiere la madurez o capacidad de entender y querer en cada individuo.

El Juez para determinar la imputabilidad o no imputabilidad de un menor dispone de medios técnicos y personal especializado en las ramas científicas necesarias, para lo que además deberá tener en cuenta las circunstancias personales del menor tales como estudios de que dispone, entorno social en el que se halla inmerso, tipo de hecho ilícito, desarrollo intelectivo y volitivo, y tipo de personalidad.

En el $\mathrm{art}^{\circ} 2047.1$ del Códice regula la responsabilidad del vigilante del incapaz que es de carácter directo del vigilante, mientras que en su apartado 2 se da la propia responsabilidad del incapaz, en que responde con carácter subsidiario para que la víctima no quede sin indemnización, cuando no pueda ser exigida al vigilante. El motivo de la culpa en este caso es una culpa in vigilando y la prueba de no haber podido impedir el hecho supone no haber mantenido un control constante sobre el incapaz. Se da una inversión de la carga de la prueba, al tener que demostrar el vigilante que no tuvo ninguna culpa y que no pudo impedir el hecho dañoso; al mismo tiempo que tiene que haber una causalidad o relación de causa o efecto entre la vigilancia sobre el incapaz y el hecho dañoso que el menor produce. Por ello el vigilante tiene que demostrar que aunque hubiera empleado la diligencia debida, el daño de todas formas se hubiera producido $^{137}$.

El apartado segundo de este artículo ha tenido muy poca aplicación por la jurisprudencia, pues es muy difícil que se den casos de esta índole, al resultar los menores insolventes y los jueces tratar de proteger a los menores incapaces, como ya se vio anteriormente en el capítulo relativo a los menores responsables.

Por el contrario el apartado primero, si ha sido aplicado en reiteradas ocasiones, dando lugar a una consolidada jurisprudencia ${ }^{138}$, que considera que es la responsabilidad

\footnotetext{
137 López Sánchez, Cristina, pag 136 y ss

138 "Consolidata giurisprudenza ritiene essere la responsabilitá che ricade in capo al sorvegliante di persona
} 
que recae en el encargado de la vigilancia de la persona incapaz que ha provocado un daño injusto, y no sin embargo que sea el incapaz el que quede a cargo con la responsabilidad ${ }^{139}$.

El artículo 2.048 al contrario que el 2.047 está dirigido a los menores que sin haber alcanzado la mayoría de edad, tienen el suficiente discernimiento para comprender el alcance y significado de sus actos, por lo que pueden ser considerados imputables. La responsabilidad de este artículo es concurrente y solidaria, quiere ello decir, que los menores son imputables y responden conjuntamente con sus padres de forma solidaria. Al hallarse varias personas involucradas en el hecho dañoso, se da una responsabilidad de carácter solidario, con lo que se puede ejercitar la acción de derecho de regreso en relación con la responsabilidad correspondiente a la otra parte. Los padres en este artículo para quedar exonerados han de probar que por su parte no ha habido culpa in vigilando, ni tampoco culpa in educando.

El menor responde por la culpa del artículo $2.043^{140}$, por tratarse de un hecho

incapace che ha provocato un danno ingiusto e non viceversa qualora sia stato l'incapace a subire il danno" (Cass. 18 luglio 2003, no 11.245, ivi, 2003, voce Responsabilitá civile no 222 Repertorio GeneraleAnuali, Foro Italiano, Perlingieri Giovanni, op.cit, pag 2633)

139 Art 2047 Códice Civile: "Daño causado por el incapaz"

2047.1 "En caso de daño causado por una persona incapaz de entender y de querer, el resarcimiento es debido por quien está obligado a la vigilancia del incapaz, salvo que pruebe que no pudo impedir el hecho"

2047.2 "En caso de que el perjudicado no haya podido obtener el resarcimiento de quien está obligado a la vigilancia, el Juez, en consideración de las condiciones económicas de las partes, puede condenar al autor del daño a una indemnización equitativa"

Art $^{\circ} 2047$ (Danno cagionato dall'incapace)

"In caso di danno cagionato da persona incapace di intendere o di volere, il resarcimento e dovuto da chi e tenuto alla sorveglianza dell'incapace, salvo che provi di non aver potuto impediré il fatto".

"Nell caso in cui il dannegiato non abbia potuto ottenere il resarcimento da chi e tenuto alla sorveglianza, il giudice, in considerazione delle condizione economiche delle parti, puo condannare l'autore del danno a un'equa indennita"

${ }^{140} \mathrm{Art}^{\mathrm{o}} 2043$ Codice Civile (Resarcimiento por hecho ilícito)

"Cualquier hecho doloso o culposo, que cause a otro un daño injusto, obliga a quien haya cometido el hecho a resarcir el daño"

$\mathrm{Art}^{\circ} 2043$ (Resarcimento por fatto illecito)

"Qualun quefatto doloso o colposo, che cagiona ad altri un danno ingiusto, obliga colni che ha commeso il fatto 
ilícito y ser capaz para comprender el alcance y significado de sus actos, por lo que tiene el discernimiento suficiente para resultar imputable. Para que los padres sean responsables el hijo necesariamente ha de ser menor de edad, no este emancipado y además tiene que cohabitar con ellos; pues si no se dan estas circunstancias los padres podrán exonerarse de responsabilidad. El perjudicado puede dirigirse contra el menor, contra los padres o contra cualquiera de ellos y si resultan exonerados los padres el deber de indemnizar recaerá en exclusiva sobre el menor ${ }^{141}$.

Al aplicar este artículo se pueden dar circunstancias especiales tales como que los cónyuges se encuentren separados y los menores convivan con uno solo de los cónyuges de forma habitual y en los fines de semana o vacaciones según disponga el convenio regulador, el cónyuge que no conviva con el menor tendrá asignados unos días para tener a su hijo ${ }^{142}$.

Por la Ley de 8 de febrero de $2006{ }^{143}$ se ha previsto el acogimiento compartido, en base al cual ambos padres son conjuntamente responsables de la vigilancia y de la educación de la prole. Por ello si un menor comete un hecho dañoso, en primer lugar se podrá exigir responsabilidad al cónyuge con el que convive o cohabita, pero de igual forma se podrá exigir al otro cónyuge por culpa in educando, si se demuestra que el hecho se produjo por una defectuosa educación por su parte ${ }^{144}$.

\footnotetext{
a risarcire il danno"

141 López Sánchez, Cristina, op.cit, pag 139 y ss

Paños Pérez, Alba, op.cit, pag 81 y ss

${ }^{142}$ En estos casos responde generalmente el cónyuge que en el momento de producirse el hecho dañoso tenga al menor a su cargo (Paños Pérez, Alba, op.cit, pag 130)

143 "Si fatta ipotesi di responsabilitá, con la previsione delli affido congiunto, non e destinata piu a muttare. A seguito di separazione la L.8 febbraio 2006, $\mathrm{n}^{\mathrm{o}} 54$ ha previsto l'affido condiviso in base al quale entrambi $\mathrm{i}$ genitori sono congiuntamente responsabili della sorveglianza e dell'educazione della prole. Proprio rifaendosi a tale lege, ve chi in dottrina ha ritenuto appliciabile l'art 2048 ad ambe due i genitori (A. Greco, La responsabilitá civil en ell'affidamento condiviso, Responsabilidade Civile e Providenza, 2006, pag 731 ss, Perlingieri, Giovanni, op, cit pags 2636

144 "In presenza di illecito, perpetrato di minore capace d'intendere e di volere al momento della sua commissione, i genitori possono essere chiamati a responderé insieme al minore" (Cass, 3 marzo 1995, n 2.463, in Repertorio Generale Anuali Foro Italiano, 1.995, voce Responsabilitá civile, no 106, ibídem, pag 2.637).
} 
Se puede por tanto exigir responsabilidad a ambos cónyuges o a cada uno de ellos por separado, según las circunstancias del caso que se considere, pues pueden ser responsables los dos, o solamente con el que convive o solamente con el que no convive, pues aunque no haya convivencia entre ellos, cualquiera puede haber influido de forma negativa en la educación del menor ${ }^{145}$.

\subsection{EL ARTÍCULO 1903.2 DEL CÓDIGO CIVIL}

La responsabilidad de los padres se regula en el art 1903.2 del Código Civil y dice: "Los padres son responsables de los daños causados por los hijos que se encuentren bajo su guarda". Este apartado segundo ha sido modificado varias veces, la primera fue por la Ley 11/1.981 de 13 de mayo, de modificación del Código Civil en materia de filiación, patria potestad y régimen económico del matrimonio, para cumplir los principios constitucionales entre el hombre y la mujer, con el fin de que la mujer quedara igualada al padre.

Por la redacción anterior se decía: "El padre y, por su muerte e incapacidad de éste la madre, son responsables de los perjuicios causados por los hijos menores de edad que viven en su compañía", vemos en la dicción "por muerte e incapacidad de éste la madre", que se produce una grave discriminación de la mujer con respecto al hombre, incompatible con los artículos 14 y 32 de la Constitución. Ha sido modificado de igual forma en los códigos civiles de nuestro entorno como se vio en el epígrafe anterior relativo al derecho comparado.

En la expresión "hijos menores de edad que viven en su compañía", al sustituirla

\footnotetext{
145 "Prima ancora della recente reforma codicistica, taluno in dottrina, ha ritenuto estensible la responsabilitá anche al coniuge non affidatario quando il danno provocato sia consequenziale ad un attivitá permessa al minore per via di concorde decisione dei genitore overo ad un attivitá che risulti in contrasto con gli interessi del minore stesso, ma che non sia stata in concreto ostacolata dal genitore non affidatario. Parimenti si puó ravvisare, in ragione della valutazione delle circostanze nelle quali il danno é stato commesso, la responsabilitá del convivente del coniuge separato o divorziato con el cuale il minore si trova a coabitare (P. Morozzo DELLA ROCCA, la r.c. dei genitori, tutori, maestri, p.49. Ibidem, pag 2.637)
} 
por la de "hijos que se encuentren bajo su guarda", el concepto de guarda es más amplio, con unas connotaciones jurídicas que no las poseen los términos compañía o convivencia, por lo que este término se encontraría dentro de las facultades o derechos que configuran la patria potestad, mientras que la compañía o convivencia sería una base fáctica, no siempre imprescindible para el ejercicio de la misma"146.

Este término guarda se utiliza para dar respuesta a las nuevas situaciones que se crean al modificarse el artículo por la Ley 11/1.981, como los casos de crisis matrimonial en los que la patria potestad la tienen los dos progenitores, pero se encuentra desmembrada por no convivir los cónyuges, lo que da lugar a que el que tiene la guarda asignada, es el principal responsable sobre todo "in vigilando", aunque en algunos casos la jurisprudencia ha exigido al cónyuge que no tiene asignada la guarda la responsabilidad "in educando".

Pensemos en situaciones de menores emancipados, o mayores de edad con la patria potestad prorrogada o rehabilitada; menores bajo tutela, acogimiento, guarda legal o de hecho, ya sea en instituciones privadas o públicas, en estos casos la guarda tiene la función de delimitar la responsabilidad. En la patria potestad prorrogada o rehabilitada, los padres seguirán respondiendo del mayor de edad debido a su incapacitación. Por lo que se refiere a los menores emancipados está claro que los padres no responderán de esos menores, por no tener la guarda sobre ellos. Para el resto de casos como guardadores y demás la responsabilidad recaerá sobre la persona física o jurídica a quien se hubiere asignado la guarda del menor.

De la patria potestad se derivan una serie de obligaciones sobre los menores, que se basan en la culpa in vigilando o in educando, aunque se hable de culpa, es algo meramente formal, en realidad se trata de una responsabilidad de carácter objetivo en la que se responde por el mero hecho de ser padres, con el fin de encontrar un patrimonio lo suficientemente solvente para que la víctima quede indemnizada. El artículo 154 del Código Civil es el que recoge los deberes de la patria potestad. Ha sufrido diversas modificaciones, siendo la más importante de ellas la de la Ley 11/1.981 de 13 de mayo, de modificación del Código Civil en materia de filiación, patria potestad y régimen

146 Bonilla Correa, op. Cit, pag 287 
económico del matrimonio, en la que se dan dos principios fundamentales para informar el cumplimiento de los deberes y facultades que integran la patria potestad y que son: el beneficio de los hijos y la personalidad del menor. En la redacción anterior a la citada reforma, que era la originaria se decía:

"El padre, y en su defecto la madre, tienen potestad sobre sus hijos legítimos no emancipados; y los hijos tienen la obligación de obedecerles mientras permanezcan en su potestad, y de tributarles respeto y reverencia siempre.

Los hijos naturales reconocidos, y los adoptivos menores de edad, están bajo la potestad del padre o de la madre que los reconoce o adopta y tienen la misma obligación de que habla el artículo anterior."

Tras la modificación se atribuyó la patria potestad al padre y a la madre de forma conjunta a ambos progenitores, quedando redactado de la siguiente forma:

"Los hijos no emancipados están bajo la potestad de los padres. La patria potestad se ejercerá siempre en beneficio de los hijos, de acuerdo con su personalidad, y con respeto a su integridad física y psicológica.

Esta potestad comprende los siguientes deberes y facultades:

$1^{\circ}$ Velar por ellos, tenerlos en su compañía, alimentarlos, educarlos y procurarles una formación integral.

$2^{\circ}$ Representarles y administrar sus bienes.

Si los hijos tuviesen suficiente juicio deberán ser oídos siempre antes de adoptar decisiones que les afecten.

Los padres podrán, en el ejercicio de su potestad, recabar el auxilio de la autoridad.

La Ley 13/2005, de 1 de julio, por la que se modificó el Código Civil para contraer matrimonio personas del mismo o distinto sexo, con plenitud e igualdad de derechos y obligaciones cualquiera que sea su composición. Por lo que según su disposición adicional primera, sobre su aplicación en el ordenamiento dispone lo siguiente: "Las disposiciones legales y reglamentarias que contengan alguna referencia al matrimonio se entenderán aplicables con independencia del sexo de sus integrantes". Esta Ley modificó el párrafo primero del artículo 154CC que pasó de decir "los hijos no 
emancipados están bajo la potestad del padre y de la madre" a "los hijos no emancipados están bajo la potestad de sus progenitores".

Otra modificación sobre varios artículos del Código Civil, fue la Ley 54/2007, de 28 de diciembre, sobre la Adopción internacional, que lo dejó de la siguiente forma: "los hijos no emancipados están bajo la potestad de los padres". La patria potestad del art 154 CC se define como: "el conjunto de derechos que la ley confiere a los padres sobre las personas y sobre los bienes de sus hijos no emancipados, constituyendo a la par un conjunto de deberes que, como inherentes a dicha patria potestad, deben asumir y cumplir los padres respecto de sus hijos. La patria potestad se configura en los tiempos actuales más como una función que como un poder, denominándose por la doctrina “deber función”, constituyéndose de esta manera como uno de los más inexcusables deberes que tienen que cumplir los padres ${ }^{147}$.

En su apartado segundo del mencionado artículo dice que la patria potestad se ejercerá siempre en beneficio de los hijos, de acuerdo con su personalidad, exponiendo después los deberes y facultades que comprende. Al decir de acuerdo con la personalidad del hijo, viene a significar que tendrá que adaptarse a las cualidades de éste, sobre todo en lo que se refiere a su educación.

De los deberes y facultades que comprende en primer lugar dice que tienen que velar por ellos, tenerlos en su compañía, alimentarlos, educarlos y procurarlos una formación integral. En cuanto a la palabra velar viene del latín "vigilare" y significa permanecer despierto, seguir trabajando por la noche, vigilar, cuidar en especial de noche a un enfermo ${ }^{148}$. Se refiere a unos deberes de carácter general propios de la patria potestad, tales como vigilar al menor para que no cometa actos que pueden perjudicar a su salud física y mental como a la de otros terceros. De igual forma la palabra guarda en su acepción primera se refiere al que tiene a su cargo el cuidado de algo y en su acepción segunda, a la observancia y cumplimiento de lo mandado. La palabra guardar, viene del germano wardon (warda) que equivale a atalaya y quiere decir conservar, tener cuidado y evitar, conceptos así como el de velar por los hijos se relacionan de forma estrecha con

\footnotetext{
147 Paños Pérez, Alba, op.cit, pags 54 y 55

148 Diccionario Anaya de la Lengua, Madrid 1.981
} 
el concepto de guarda mencionado ${ }^{149}$.

La doctrina ha criticado la imposición a los padres de demostrar su ausencia de la culpa in vigilando e in educando, por lo difícil que resulta encontrar la prueba y sobre todo el nexo causal entre el hecho dañoso del hijo y la culpa in educando del padre. El concepto de educación es demasiado amplio, abarcando la formación de tipo personal y al mismo tiempo espiritual, de tal forma que le sirvan para valerse por la vida, respetando a los demás, con el respeto a los principios democráticos.

Hay autores como Cavanillas Mugica, Casas Planes y García Vicente que entienden que los supuestos considerados como culpa in educando son subsumibles dentro de la culpa in vigilando, por entender que no se trata de que sean responsables por educar mal, sino por vigilar insuficientemente a quien se sabe que tiene un defecto o particularidad de carácter. Ni tampoco que la culpa pueda alegarse como criterio autónomo de imputación sino que sirve para concretar la culpa in vigilando de los padres, en el sentido de que "a mayor educación menos vigilancia y más autonomía, y viceversa". Otro argumento que emplea la doctrina es el de que la culpa in educando surgió paralela a la in vigilando, no tiene justificación hoy día por dos razones: de una parte la debilitación de la autoridad paterna y por otra las inevitables y crecientes influencias que interfieren en la educación de los padres. Por todo ello no considera válido invocar la culpa in educando ${ }^{150}$.

Aunque hoy día se da una crisis importante de la autoridad paterna, la educación de los padres a los hijos basada en principios de la propia responsabilidad, de respeto a los demás, de reglas morales, etc, tienen una gran influencia en el desarrollo y comportamiento posterior de los menores y aunque la doctrina crea que se puede prescindir de la culpa in educando, la jurisprudencia por el contrario ha dictado bastantes sentencias, basadas precisamente en la culpa in educando de sus padres. Un ejemplo lo tenemos en la S.A.P de Córdoba de 23 de enero de 2009 (JUR 2009/199.267), en la que, después de finalizar un partido de fútbol, un menor le agredió a otro en una disputa produciéndole traumatismo craneoencefálico, rotura del labio

\footnotetext{
149 Ibidem

150 Paños Pérez, Alba, op.cit, pag 55
} 
superior y pérdida de dos piezas dentales, en su Fundamento Jurídico Tercero, el Juez dice que el fundamento de la responsabilidad se encuentra no sólo en el deber de guarda, sino también en el deber de educación y en el adecuado uso de las facultades de corrección que los padres, tutores, acogedores y guardadores, tienen sobre sus hijos, pupilos, acogidos o sometidos a su guarda. No es por lo tanto falta de vigilancia de los responsables del partido de fútbol, sino a la carencia formativa del menor en aspectos básicos de la convivencia que propicia groseros comportamientos lesivos de derechos básicos ajenos, correspondiendo promover esa formación básica para evitarlos, a los padres. De los hechos se deduce que no se trata de culpa in vigilando de los organizadores del partido de fútbol, pues éste ya había acabado, aunque se encuentre bajo la autoridad de los responsables del equipo federado, lo decisivo no es la falta de vigilancia, sino que se trata de omisión de corrección de los padres sobre el menor, pues esa conducta violenta y excesiva significa que las tareas educativas de los padres no han causado efecto en el menor, seguramente por la laxitud al inculcárselas o en haber tolerado pasivamente esas manifestaciones violentas, siendo por ello responsables los padres por culpa in educando.

En general puede decirse que las funciones de la patria potestad se reducen a la expresión de "el deber de velar por los hijos", abarcando todas esas funciones incluyendo el deber de educación, así lo ha venido considerando la doctrina.

En el número dos del apartado segundo dice que deberán "representarlos y administrar sus bienes", por lo que los padres pueden sin autorización judicial, realizar actos de aplicación de dinero o capitales de los sometidos a patria potestad en la adquisición de bienes inmuebles ${ }^{151}$.

Los padres tienen el deber de oír a sus hijos al tomar decisiones que les afecten si tuvieren suficiente juicio, para ello deben ser mayores de siete años, por regla general, que tengan uso de razón, por lo que dependerá de su desarrollo psicológico. Si se les presentaran problemas que no pudieran resolver por sí mismos, en el ejercicio de la patria potestad, podrán recabar el auxilio de la autoridad, estas situaciones se suelen dar en casos extremos, tales como que hubiesen perdido el trabajo y no pudieran atender a

\footnotetext{
${ }^{151}$ Resolución de la Dirección General de los Registros y del Notariado de 7/7/98)
} 
los gastos de la familia, problemas de drogas de los hijos, etc; por lo que en estos casos tienen la obligación de solicitar el auxilio de la autoridad, para que les faciliten una institución de cuidado de menores y poder atenderle en forma debida.

Este $\operatorname{art}^{\mathrm{o}} 154$ como se ha dicho anteriormente fue modificado de forma sustancial por la Ley 54/2007, por lo que se eliminó la dicción final del artículo: “podrán también corregir razonable y moderadamente a los hijos". Con ello se debilita de forma notoria la autoridad de los padres. Si a ello añadimos que al niño se le reconoce el libre desarrollo de su personalidad, a los padres habrá de exigírseles una menor vigilancia sobre los menores.

El motivo de suprimir esa facultad de corregir moderadamente a los hijos se justifica en el segundo apartado del punto cuarto de la exposición de motivos de la ley, por la preocupación del Comité de Derechos del Niño, en el sentido de que haya posibilidad de que la facultad de corrección moderada reconocida a los padres y tutores pueda contravenir el artículo 19 de la Convención sobre los Derechos del Niño de 20 de noviembre 1989. Este derecho de corrección sobre los niños no trataba de amparar malos tratos, consistía en un deber relacionado con la obligación de educar que corresponde a los padres, para lo que era necesario dar una torta, azote en las nalgas, ante comportamientos violentos o agresivos que algunos adolescentes cometen, que no constituyen infracción penal ni civil, y que la jurisprudencia ha dado la razón al padre fundándose en los deberes implícitos de la patria potestad entre los que se encontraba esa facultad de corrección moderada. ${ }^{152}$

Actualmente no se permiten castigos físicos como medida de corrección. Si antes cuando era reconocida esa facultad del padre de corregir razonable y moderadamente a los hijos, se refería a castigos muy leves, hoy día, después de haberse suprimido ese derecho de corrección es impensable el pegar a un hijo o aplicarle castigos físicos, con lo que corregir significa, rectificar, reprender, moderar, enmendar, reparar, retocar,

$152 \mathrm{Art}^{\mathrm{o}} 19.1$ de la Convención de Derechos del Niño de 20/11/1.989.

"Los Estados Partes adoptarán todas las medidas legislativas, administrativas, sociales y educativas apropiadas para proteger al niño contra toda forma de perjuicio o abuso físico o mental, descuido o trato negligente, malos tratos o explotación, incluido el abuso sexual, mientras el niño se encuentre bajo la custodia de los padres, de un representante legal o de cualquier otra persona que lo tenga a su cargo" 
modificar, amonestar, templar, disminuir, conceptos todos ellos que implican el tratar de que el niño observe una buena conducta, se porte bien y sea educado ${ }^{153}$. De acuerdo con el artículo 153 del Código Penal, cualquier daño físico o psíquico cometido contra un menor que conviva en el domicilio familiar, constituye delito y por ello se aplicará la correspondiente sanción.

Los padres de acuerdo con el artículo 155 del Código Civil, tienen derecho a ser obedecidos y respetados por los hijos mientras permanezcan bajo su potestad. Deben los hijos de contribuir, según sus posibilidades, al levantamiento de las cargas familiares, mientras convivan en ella. El deber de obediencia proviene de la patria potestad y el de respeto por la filiación. El deber de contribuir al sostenimiento de las cargas familiares es un deber de justicia, pues si se trata de un menor de dieciséis años por ejemplo y realiza algún trabajo lo lógico y justo es que ayude a su familia y no pretenda disponiendo de recursos económicos vivir sin aportar nada. En consecuencia por este artículo, los hijos deben ayudar económicamente a sus padres y manifestarles respeto y reverencia.

La legislación española protege al menor en el artículo 39 de la Constitución en su apartado segundo en el que dice. "Los poderes públicos aseguran, asimismo, la protección integral de los hijos, iguales estos ante la ley con independencia de su filiación, y de las madres, cualquiera que sea su estado civil. La ley posibilitará la investigación de la paternidad”. El apartado tercero se refiere a las obligaciones de los padres sobre los hijos y dice: "Los padres deben prestar asistencia de todo orden a los hijos habidos dentro o fuera del matrimonio, durante su minoría de edad y en los demás casos en que legalmente proceda". Con ello se establecen criterios para la protección de los hijos declarándose la igualdad entre todos ellos, por lo que no tiene que haber distinciones entre ellos, como existían antes denominándose hijos, naturales, ilegítimos, etc. Lo único que debe distinguirse entre los hijos es a los que presenten situaciones de minusvalía.

En su apartado cuarto dice: “Los niños gozarán de la protección prevista en los acuerdos internacionales que velan por sus derechos". Los acuerdos internacionales que velan por los derechos de los niños, son fundamentalmente los promovidos por la

153 Viene del latín corrigere, Diccionario Anaya de la Lengua, op.cit 
UNICEF o fondo de las Naciones Unidas para la Infancia. Siendo la más importante la Convención sobre los Derechos de Niño de 20 de noviembre de 1.989. En su artículo segundo trata de la no discriminación del niño, en el tercero se refiere al interés superior del niño, en las medidas que tomen las instituciones públicas o privadas, el compromiso de su cumplimiento de los Estados Parte, obligando estos a sus instituciones a que cumplan las normas establecidas en materia de seguridad y sanidad. Corresponde por ello al Estado garantizar protección y cuidado, cuando los padres u otras personas responsables, no tengan los medios necesarios para poderlo cumplir ${ }^{154}$.

De acuerdo con esta Convención nuestra Ley Orgánica 1/1.996 de 15 de enero sobre Protección Jurídica del Menor, en su artículo 2, trata de los Principios Generales en materia de menores, en el que manifiesta la primacía del interés del menor, las medidas educativas y las limitaciones a la capacidad de obrar del menor, que se interpretarán de forma restrictiva.

\subsection{CONDICIONES QUE SE HAN DE CUMPLIR PARA EXIGIR RESPONSABILIDAD A LOS PADRES}

Las condiciones, presupuestos o requisitos que han de darse para exigir responsabilidad a los padres son: causación directa de un daño por el hijo, la relación de causalidad entre la acción u omisión del agente y el daño, el hijo tiene que hallarse bajo la guarda de sus padres y ha de ser menor de edad.

154 Artículo 3 de la Convención sobre los Derechos del Niño de 20/11/1.989

1) En todas las medidas concernientes a los niños que tomen las instituciones públicas o privadas de bienestar social, los tribunales, las autoridades administrativas o los órganos legislativos, una consideración primordial a que se atenderá será el interés superior del niño.

2) Los Estados Partes se comprometen a asegurar al niño la protección y el cuidado que sean necesarios para su bienestar, teniendo en cuenta los derechos y deberes de sus padres, tutores u otras personas responsables de él ante la ley y, con ese fin, tomarán todas las medidas legislativas y administrativas adecuadas.

3) Los Estados Partes se asegurarán de que las instituciones, servicios y establecimientos encargados del cuidado o la protección de los niños cumplan las normas establecidas por las autoridades competentes, especialmente en materia de seguridad, sanidad, número y competencia de su personal, así como en relación con la existencia de una supervisión adecuada. 


\subsubsection{CAUSACIÓN DIRECTA DE UN DAÑO POR EL HIJO}

El resultado dañoso es el primer elemento de cualquier responsabilidad civil y constituye la razón de ser de este tipo de responsabilidad, el reparar el daño causado.

La jurisprudencia tradicionalmente exige que el daño sea cierto y probado, lo que quiere decir que no sea imaginario y pueda ser probado por quien lo alega. Debe ser directo y personal, es decir que afecte de modo directo al perjudicado al ser consecuencia directa del evento dañoso ${ }^{155}$.

El daño o resultado dañoso ha de causarse a otro que, precisamente por ello resulta perjudicado en su persona o en sus bienes. Este requisito se encuentra claramente indicado en el propio artículo 1.902 al decir que "el que por acción u omisión cause daño a otro", y constituye un presupuesto ineludible de la responsabilidad civil extracontractual, el precisar la alteridad entre el sujeto agente y el sujeto perjudicado.

Cuando el menor comete un hecho dañoso sus padres se verán obligados a repararlo, independientemente de que el hijo sea también responsable del daño de acuerdo con el artículo 1.902, ni que sea o no inimputable. De igual forma tampoco importa la capacidad de discernimiento del menor. Los padres van a responder porque así lo dispone el artículo 1.903, al hacerles responsables de los daños causados por sus hijos. Siempre que el menor causa un daño a un tercero, la jurisprudencia hace responsables a los padres de forma directa, pues no tiene en cuenta para nada los elementos subjetivos de la culpa, al tratarlo como una responsabilidad objetiva.

\subsubsection{RELACIÓN DE CAUSALIDAD}

Para que exista nexo causal entre el acto inicial y el resultado dañoso es necesaria una relación de causalidad, conforme a los conocimientos normalmente aceptados, debiéndose valorar si el actuar antecedente que se presenta como causa, tiene virtualidad suficiente, para que del mismo se derive la consecuencia necesaria del efecto lesivo producido, no siendo suficiente las simples conjeturas ni los datos facticos; con lo que tiene que darse una relación de prueba terminante entre la conducta del agente y la

\footnotetext{
155 Paños Pérez, Alba, op.cit, pag 97 y ss
} 
producción del daño, para que se haga patente la culpabilidad que obliga a repararlo (STS de 2 de marzo de 2000- RJ-2000/1304).

En la responsabilidad por hecho ajeno referida a los padres hay que distinguir si el nexo causal se refiere a la acción u omisión del menor, o de la omisión de los padres. Hay autores que sostienen la necesidad del nexo causal entre los padres y el hijo, además del daño cometido por el menor con la víctima.

Al ser una responsabilidad de carácter objetivo en la que los padres responden siempre, no se analiza en la jurisprudencia la relación de causalidad sobre la omisión de los padres por culpa in vigilando o in educando. Esta relación es muy difícil de demostrar, pues es muy complicado saber el grado de discernimiento del menor y si existe o no la culpa in educando, pues es enormemente difícil relacionar en un caso la culpa del menor con un defecto en la educación por parte de los padres. Lo que se analiza en la mayoría de los casos es la relación causa -efecto entre el acto del menor y la víctima.

En todos los casos de daños causados por un menor, en virtud de la relación de filiación y de la patria potestad, los padres responden siempre que se de ese nexo causal entre el menor y la víctima.

Existen situaciones que interrumpen el nexo causal, el caso fortuito y la fuerza mayor, la intervención de terceros y la culpa de la propia víctima que han sido tratados anteriormente por lo que no insistiré más sobre ellos.

\subsubsection{EL HIJO BAJO LA GUARDA DE SUS PADRES}

El artículo 1.903 contempla la necesidad de que los menores "se encuentren bajo su guarda”, en su párrafo segundo. La guarda se halla inmersa dentro del concepto de patria potestad del artículo 154 del Código Civil, en el que en su apartado segundo punto primero se habla de "tenerlos en su compañía", asignándola conjuntamente al padre y a la madre en su párrafo primero.

Este concepto de guarda y de tener a los hijos en su compañía se relaciona con el deber de los padres de mantener a los hijos en el domicilio familiar, para que se dé una relación de convivencia entre el menor y los progenitores, para poder formarse 
debidamente, cumplirse las funciones de la patria potestad, con lo que se desarrolle correctamente el menor y pueda actuar por la vida de forma independiente al llegar a la mayoría de edad.

Los padres responden de los daños cometidos por menores no emancipados, por ser los que se hallan bajo la patria potestad y por tanto bajo su guarda. El emancipado responde con su propio patrimonio. Los padres pueden conceder la emancipación de acuerdo con el apartado tercero del artículo 314. Puede darse la circunstancia de que los padres tuvieran que responder por los hechos de un menor emancipado, si se demuestra un nexo causal entre el acto dañoso de ese menor y el haber concedido los padres la emancipación del menor de forma precipitada, sin estar el menor preparado para ello ${ }^{156}$. Responden con su propio patrimonio los que hubieran obtenido el beneficio de la mayoría de edad y el menor con vida independiente ${ }^{157}$.

El concepto de guarda es más amplio que el de convivencia, cohabitación, vivir en su compañía, y está pensado para responder a los casos de crisis conyugales. La patria potestad se impondrá independientemente de que exista o no convivencia entre los padres y el menor. En la STS de 30 de abril de 1.969 (RJ 1969/2411) se condena a la madre a pesar de que el hijo vivía con su abuelo materno, que lo cuidaba como si fuera su hijo a todos los efectos, y es condenada la madre por ser titular de la patria potestad, sin tener en cuenta la convivencia ${ }^{158}$.

En los casos de matrimonios separados o divorciados se plantea el problema de si deben responder ambos cónyuges, puesto que la patria potestad continua siendo compartida. En estos casos el responsable de los daños causados será aquel con quien conviviera. Ahora bien si el daño se produce durante el transcurso del derecho de visita el responsable es el otro cónyuge, es decir, el que recibe la visita del menor.

La patria potestad normalmente es compartida pero pueden darse casos en que se

\footnotetext{
${ }^{156}$ Ibidem, pags 101 y 102

157 Artículo 319 del Código Civil: "Se reputará para todos los efectos como emancipado al hijo mayor de dieciséis años que con el consentimiento de los padres viviere independiente de estos. Los padres podrán revocar este consentimiento".

158 Paños Pérez, Alba pag 103

YzquierdoTolsada, Mariano, op.cit, pag 257
} 
puede privar de la misma como establece el artículo 92, apartado $3^{\circ}$ que dice: "En la sentencia se acordará la privación de la patria potestad cuando en el proceso se revele causa para ello"159.

Cuando los progenitores no cumplen con sus funciones de la patria potestad, entre ellos la función de guarda, pueden ser privados de esa patria potestad, como en la sentencia que a continuación se comenta ${ }^{160}$. Trata de un matrimonio que se separan encontrándose la madre en estado de gestación, realizándolo de común acuerdo según se expresa en su Fundamento de Derecho Primero. El marido demandado se desentendió de su futura prole, sin que se fijara régimen de visitas, ni pensión alimenticia. No asistió ni al nacimiento, ni al bautizo de la hija. Tampoco ya nacida intentó el cumplimiento de sus deberes paterno filiales. Fallecida la madre que padecía una grave enfermedad, la menor continuó conviviendo con sus tíos que se hicieron cargo de ella y de las atenciones y cuidados requeridos por ésta. Al poco tiempo del fallecimiento de la madre el padre recabó el ejercicio de sus derechos sobre su hija que había cumplido ya dos años. En su Fundamento de Derecho Tercero se califica la conducta del padre de la niña como de grave, por no haber cumplido sus funciones de patria potestad; la niña se encuentra plenamente integrada en la familia compuesta por la hermana y cuñado de la madre, los cuales la atienden en todo lo que necesita y la niña ni siquiera conoce a su padre. Por otra parte el hallarse separado de su mujer no exime de las funciones de patria potestad de acuerdo con el artículo 92 del Código Civil en su apartado primero que dice: "La separación, la nulidad y el divorcio no eximen a los padres de sus obligaciones para con los hijos". Por todo ello se desestima el recurso del padre por no haber cumplido los deberes de la patria potestad y en atención al interés del menor se dispone que continúe con sus tíos por ser la mejor forma para que sea atendida debidamente.

\subsubsection{EL HIJO HA DE SER MENOR DE EDAD}

Dentro de la minoría de edad hay que distinguir distintas franjas de edad, por representar cada una de ellas, distintos grados de madurez, lo que debe tenerse en cuenta

\footnotetext{
159 YzquierdoTolsada, Mariano, op.citpag 257

160 STS de 23 de febrero de 1.999 (RJ-1999/1130)
} 
para exigir responsabilidad a los padres. En primer lugar hay que distinguir la infancia que comprende hasta los siete años en el que los menores son completamente incapaces, no resultando imputables por ello. En segundo lugar los menores de edad mayores de siete años, para los cuales es el Juez el que se encarga de determinar su capacidad, según la edad del menor y su grado de desarrollo intelectivo y volitivo. En tercer lugar los menores de edad desde los doce años hasta la mayoría de edad, en que tienen una madurez similar a una persona adulta.

En el Código Civil holandés se ha establecido la responsabilidad de los padres según la edad que tenga el menor. De esta forma la responsabilidad civil de los padres de un menor de catorce años se realiza con carácter objetivo (artículo 1.691, Libro VI del CC). Si el menor tiene entre catorce y dieciséis años, responden el padre o la madre o el tutor, pero según criterios subjetivos, ya que podrían quedar exentos de responsabilidad si prueban que su actuación fue diligente (artículo 169.2, Libro VI, Cod. Civil). A partir de los dieciséis años es responsable el propio menor a pesar de no haber alcanzado la mayoría de edad, que se fija en los dieciocho años (artículo 233, Libro I, Código Civil) ${ }^{161}$.

La mayoría de edad en la mayor parte de los códigos, así como en las constituciones de nuestro entorno se obtiene a los dieciocho años. En el artículo primero de la Convención de los Derechos del Niño, entiende por niño a todo menor de dieciocho años. En la Carta Europea de los Derechos del Niño de 21 de septiembre de 1.992, en su punto dos, entiende por niño al menor de dieciocho años; así como en las Reglas de las Naciones Unidas para la protección de los menores privados de libertad de 14 de diciembre de 1.990 en su artículo 11, apartado a, se establece la mayoría de edad a los dieciocho años ${ }^{162}$.

Una excepción importante es la del Código Civil de Japón, que la establece a los veinte años cumplidos en su artículo cuarto. Según su artículo 731 no podrán contraer matrimonio el varón que no haya cumplido los dieciocho años de edad, ni la mujer que no haya cumplido los dieciséis. En su artículo 753 dispone que el menor que haya

\footnotetext{
161 Paños Pérez, Alba, pag 74, nota no 257 referida a Navarro Michel

162 De igual forma la mayoría de edad se establece a los dieciocho en el artículo 488 del Code Civil francés, artículo 2 del BGB alemán, artículo 315 del Código Civil español y artículo 12 de la Constitución española.
} 
contraído matrimonio se tendrá por mayor de edad ${ }^{163}$.

Antes de llegar a la mayoría de edad se reconoce al menor una cierta capacidad de actuación en determinadas edades, como en el art ${ }^{\circ} 2.2$ de la Ley de Protección Jurídica del menor en la que se dice que "las limitaciones a la capacidad de obrar del menor se interpretarán de forma restrictiva”. Por ello en el artículo 154 del Código Civil dice que “ si los hijos tuvieren suficiente juicio deberán ser oídos siempre antes de tomar decisiones que les afecten"; en el artículo 160 se dice que a los menores "no podrán impedirse sin justa causa las relaciones personales del hijo con sus abuelos y otros parientes y allegados"; por el artículo 162 se le permiten al menor actos relativos a derechos de la personalidad u otros que el hijo de acuerdo con las leyes pueda realizar por sí mismo, en aquellos que existan intereses entre los padres y el hijo o bienes que estén excluidos de la administración de los padres.

A partir de los doce años de acuerdo con el artículo 177.1 dice que "habría de consentir la adopción, en presencia del Juez, el adoptante o adoptantes y el adoptado mayor de doce años". Por los artículos 20 y 21 se les permite obtener la nacionalidad española por opción o residencia con asistencia del representante legal. Por el artículo 663.1 podrá hacer testamento, excepto el ológrafo del artículo 688, para el que se requiere la mayoría de edad. Puede de acuerdo con el artículo 48 contraer matrimonio con dispensa, así como por el artículo 1.329 puede otorgar capitulaciones matrimoniales, con el concurso y consentimiento de sus padres o tutor, sobre que se limite a pactar el régimen de separación o el de participación.

A partir de los dieciséis años puede consentir su emancipación según el artículo 317 , solicitarla por artículos 320 y 321; puede administrar los bienes que haya adquirido con su trabajo o industria según el artículo 1164.3.

La Constitución Española en su artículo 10.1 le reconoce el derecho al libre desarrollo de la personalidad como derecho fundamental. De igual forma el artículo 9 de la Ley Orgánica 1/1.996 de 15 de enero, de Protección Jurídica del Menor, le otorga el derecho a ser oído, tanto en el ámbito familiar como en cualquier procedimiento

\footnotetext{
163 Barberán Francisco y Domingo Rafael, Código Civil Japonés, Edición Bilingüe actualizada a 30/09/2006,
} Thomson, Aranzadi. The Global Law Collection, Navarra, 2006 
administrativo o judicial en que esté directamente implicado y que conduzca a una decisión que afecte a su esfera personal, familiar o social.

En la responsabilidad extracontractual sobre menores se da una situación en que por una parte el menor dispone de una gran libertad de acción, promoción social, el fomento de su autonomía, lo que supone que a partir de los catorce años puedan conducir ciclomotores de poca cilindrada de acuerdo con el Código de la Circulación, con un simple permiso o autorización administrativa, lo que constituye una fuente de innumerables peligros por los accidentes a que da lugar; mientras que por otra parte responden de estos actos los padres, con responsabilidad cuasi objetiva u objetiva, cuando deberían de ser los propios menores los que respondieran de forma directa de acuerdo con el artículo 1.902, al disponer de mucha libertad y gozar de tantos derechos.

Esto ha empezado a cambiar con la entrada en vigor de la LORPM en la que se puede imputar al menor de edad mayor de catorce años y menor de dieciocho. Con ello al menor comprendido dentro de dicha edad se le puede exigir responsabilidad civil extracontractual, de acuerdo con el artículo 61.3 de la mencionada Ley. Ya hay sentencias que condenan al menor solidariamente con sus padres, al tener una edad próxima a los dieciocho años, con suficiente capacidad volitiva e intelectiva para comprender la gravedad y trascendencia de sus actos.

Por lo que se refiere a la edad cada vez se le da más importancia, por las repercusiones que tiene en lo que concierne a la responsabilidad de los padres, por cuanto menos discernimiento posean, mayor ha de ser la vigilancia de los padres sobre ellos. La capacidad intelectiva y volitiva se va afianzando a partir de los siete años, de tal forma que al llegar a los doce ya son plenamente conscientes de la importancia y trascendencia de sus acciones. Es a esta edad de doce años la edad a partir de la cual se tiene en consideración las opiniones de los menores, en las que tienen que ser oídos y pueden consentir en la adopción del artículo 177.1 visto ya anteriormente, dicha edad es considerada por muchos autores la edad mínima para establecer la imputabilidad civil.

La edad de catorce años ha establecido la LORPM como barrera mínima a partir de la cual el menor es plenamente consciente del alcance de sus actos, se trata de un límite de edad que alcanza hasta la edad próxima a la mayoría de edad, a la que se 
denomina grandes menores, en italiano grande minori. Para determinar la capacidad intelectiva y volitiva de este tipo de menores, es el Juez el que la establece, observando caso por caso, teniendo en cuenta no sólo el criterio biológico de la edad, también el psicológico para poder calibrar su verdadero grado de madurez.

La doctrina entiende que si cada vez se da más autonomía a los menores, una mayor libertad, que no sólo la conceden los padres, sino hasta las propias normas, privándoles hasta a los padres de su potestad correctora, si los menores tienen una cierta edad y madurez; parece lógico que toda la responsabilidad no ha de recaer sobre los padres, mediante la objetivación de la culpa por el principio pro damnato para indemnizar a la víctima. Por ello la responsabilidad de los padres debe de moderarse e incluso resultar exonerados.

Se ha llegado a decir que los "tribunales han confundido a los padres con una compañía de seguros" como se dijo anteriormente ${ }^{164}$. Un sector doctrinal ha llegado a proponer la imposición de un seguro obligatorio de responsabilidad por los actos dañosos de los hijos menores de edad, para poder satisfacer los intereses de todos los afectados. Carmen Calle, ha realizado un detallado análisis sobre esta cuestión, sobre las consecuencias que produciría la imposición del seguro obligatorio. López Beltrán de Heredia se ha mostrado a favor de esta solución. En Italia se está tratando de imponer este tipo de seguro ${ }^{165}$.

\subsection{REGIMEN DE LA SOLIDARIDAD, DEL ART ${ }^{\circ}$ 61.3 LORPM}

La responsabilidad solidaria aparece mencionada en el artículo 61.3 de la LORPM que dice: "Cuando el responsable de los hechos cometidos sea un menor de dieciocho años, responderán solidariamente con él de los daños y perjuicios causados sus padres, tutores, acogedores y guardadores legales o de hecho...". También contempla la solidaridad en la Exposición de Motivos en su punto octavo. De igual forma el artículo 1.903 CC, así como el artículo 116 del Código Penal, tratan de responsabilidad solidaria.

\footnotetext{
164 Paños Pérez, Alba, op.cit, pag 79

Yzquierdo Tolsada, Mariano, op.citpag 257

165 Paños Pérez, Alba, op.cit nota 57 pag 79
} 
Al decir en la Exposición de Motivos, apartado 8, que "la Ley introduce el principio en cierto modo revolucionario de la responsabilidad solidaria con el menor responsable de los hechos de sus padres, tutores, acogedores o guardadores, si bien permitiendo la moderación judicial de la misma", lo de "revolucionaria", no debe de ser por la solidaridad, que ya se contempla en el artículo 1.903 CC y en el $116 \mathrm{CP}$, será por lo relativo a la responsabilidad objetiva.

Cuando hay varias personas responsables del mismo daño, es necesario determinar el régimen jurídico que ha de aplicarse para indemnizar a la víctima o perjudicado. Puede aplicarse el régimen de solidaridad o de mancomunidad. El régimen de solidaridad consiste en que cada acreedor puede pedir y cada deudor debe cumplir la totalidad de la obligación o deuda de una sola vez, sin perjuicio del ajuste posterior de cuentas entre los acreedores y deudores, para la justa percepción o contribución de cada cual. Mientras que la mancomunidad trata de pagar una deuda u otra obligación pero diferenciando las partes o prestaciones de cada una.

La posición dominante de la doctrina es la solidaridad, indicando que en ella no se pueden individualizar los respectivos comportamientos o los concretos daños atribuibles a cada uno de los sujetos. La jurisprudencia se inclina clara y mayoritariamente a favor de la solidaridad.

Existe un debate doctrinal entre la solidaridad y la mancomunidad, siendo minoritaria esta última.

Los partidarios de la solidaridad emplean los siguientes argumentos:

Los artículos 1.137 y 1.138 del CC sobre mancomunidad sólo son aplicables a las obligaciones derivadas de contrato, no a los resultantes del ilícito civil. Ello se deduce de las palabras finales del artículo $1.137 \mathrm{CC}$ y de las iniciales del artículo siguiente. ${ }^{166} \mathrm{El}$

\footnotetext{
166 Artículo 1.137 dice: "La concurrencia de dos o más acreedores o de dos o más deudores en una sola obligación no implica que cada uno de aquellos tenga derecho a pedir, ni cada uno de estos deba prestar íntegramente los casos objeto de la misma. Sólo habrá lugar a esto cuando la obligación expresamente lo determine, constituyéndose con el carácter de solidaria".

Artículo 1.138 dice: "Si del texto de las obligaciones a que se refiere el artículo anterior no resulta otra cosa, el
} 
artículo $116 \mathrm{CP}$ es aplicable por analogía a la responsabilidad civil extracontractual derivada de ilícito no punible, pues no hay razón para circunscribirlo a la derivada de delito. Por el principio pro damnato el sistema de la solidaridad asegura el resarcimiento del perjudicado ante la posible insolvencia de los deudores y además le evita el tener que acreditar la parte de daño atribuible a cada uno para condenarle a indemnizar.

Frente a los partidarios de la solidaridad se encuentran sus detractores partidarios de la mancomunidad, para lo que emplean unos argumentos totalmente contrarios a los anteriores y son los siguientes:

Los artículos 1.137 y 1.138 CC se refieren a obligaciones en general, por lo que son aplicables también a los procedentes de actos ilícitos. No cabe aplicar el artículo 116 $\mathrm{CP}$, por haberse querido tratar con más rigor a los autores del acto dañoso por ser punible y además, porque hay ley aplicable al caso como es el artículo 1.137 CC, lo que excluye la aplicación de la analogía. El beneficio para el perjudicado "pro damnato" se realiza a costa de los deudores, los cuales pueden alegar el principio "pro debitoris", además de que no existe razón para proteger más al acreedor por daños que a otro tipo de obligación y con respecto a la posible insolvencia de deudores, puede suceder en cualquier clase de deuda ${ }^{167}$.

\subsubsection{EFECTOS DE LA SOLIDARIDAD}

En una obligación solidaria el acreedor puede solicitar a cada deudor el cumplimiento integro de la prestación. El deudor solidario, en las reclamaciones podrá utilizar todas las excepciones que se deriven de la naturaleza de la obligación así como que le sean personales (artículo 1.148 CC).

Desde el punto de vista procesal, las acciones ejercitadas contra cualquiera de los deudores solidarios perjudicarán a todos ellos (artículo 1.141 CC) lo que supone, de un lado que a todos les hace incurrir en mora, y de otro, que la sentencia obtenida en un

\footnotetext{
rédito a la deuda se presumirán divididos en tantas partes iguales como acreedores o deudores haya, reputándose créditos o deudas distintos unos de otros".

${ }^{167}$ Reglero Campos, Fernando y otros. Lecciones de Responsabilidad Civil, op.cit, pag 121

YzquierdoTolsada, Mariano, op.cit, pags 401 y ss
} 
pleito contra un deudor solidario tiene efectos de cosa juzgada frente a los demás ${ }^{168}$.

Conviene distinguir en la solidaridad la relación interna de la obligación y la relación externa entre los deudores y el acreedor.

En la relación interna el deudor que haya pagado tiene derecho a reclamar del resto de los deudores solidarios la parte de la deuda que a cada uno le corresponda, con los intereses del anticipo; esto es lo que se denomina acción de regreso. El pago hecho por uno de los deudores extingue la obligación. La falta de cumplimiento de la obligación por insolvencia del deudor solidario será suplida por sus codeudores, a prorrata de la deuda de cada uno (artículo 1.145 CCC).

Por lo que se refiere a la relación externa de la obligación cada deudor está obligado al cumplimiento integro de la prestación, por lo que el acreedor, puede dirigirse contra cualquiera de los deudores solidarios o contra todos ellos simultáneamente. Si el acreedor reclama contra uno solo de los deudores solidarios y no resulta cobrada la deuda, ello no es obstáculo para los que posteriormente se dirijan contra los demás, hasta que la deuda sea cobrada por completo (artículo 1.144CC).

\subsubsection{LA RESPONSABILIDAD DE LOS OBLIGADOS SOLIDARIOS}

El sistema de la solidaridad ha sido establecido como ya se dijo anteriormente, para la garantía o protección de los intereses del perjudicado, como se aprecia en la Exposición de Motivos de la LORPM, en su apartado octavo. Por lo que se atiende a este principio "pro damnato" de protección de la víctima, para lo cual el mejor modo de asegurarlo es mediante el régimen de la solidaridad.

Por el artículo 1.137 de nuestro Código Civil se establece el principio de mancomunidad, quedando el de solidaridad como una excepción, aunque la doctrina y la jurisprudencia han seguido este último para favorecer a la víctima, por ser más efectivo.

En el régimen de solidaridad puede haber distintas cuotas y la obligación ser de esta naturaleza como dispone la STS de 27 de mayo de $1.997^{169}$, siendo este tipo de solidaridad establecido por este Tribunal, por razones de interés social para proteger al

\footnotetext{
168 Bonilla Correa, op.cit, pag 204

169 STS 27 de mayo de 1997 (RJ-1997/4142)
} 
perjudicado; ya que la ventaja principal de este régimen está en poder exigir el pago íntegro de la indemnización a cualquiera de los corresponsables.

Cuando se dan varios responsables solidarios como padres, tutores, etc, pueden responder por igual cuantía o por el contrario se modera la responsabilidad de forma independiente. Si se establece la moderación implica fijar límites, con lo que quiebra la solidaridad. Al introducir el sistema de culpa y no ser una culpa igual a otra, tampoco lo será la indemnización que corresponda al perjudicado. En estos casos la solidaridad existirá respecto a la cantidad a que haya sido condenado el progenitor que menos culpa o negligencia haya tenido, respecto al resto no hay solidaridad, y ello afecta no sólo a la relación interna sino también a la externa de cara al perjudicado. Existirá por tanto solidaridad en cuanto los implicados responden con igual cantidad, pero si la cantidad es distinta no habrá solidaridad, lo que implica fraccionar la responsabilidad civil por conductas diferentes. Por ello se trataría de una responsabilidad impropia del artículo 1.140 del CC. Una sentencia que trata sobre esta problemática es la de Badajoz de 25 de enero de $2005^{170}$.

Con respecto al propio menor en relación con sus responsables solidarios la problemática es mayor, pues el menor normalmente es insolvente por lo que si el perjudicado se dirige contra el menor no cobrará la indemnización. Con ello disminuye la eficacia del instituto de la solidaridad, al ser necesario dirigirse el perjudicado contra los padres, etc, responsables solidarios y no contra el menor que no tiene solvencia, por ello no puede dirigirse contra cualquiera de los dos y por el total de la deuda. Si la solidaridad es una garantía para el perjudicado, consiste en poder dirigirse contra cualquiera de los responsables solidarios por el total de la deuda; si el menor no es solvente, sólo se dirige contra los padres y si la responsabilidad de estos puede moderarse con una disminución de su importe, se puede decir que quiebra el instituto de la solidaridad, por lo que la víctima no cobrará el total del valor de los daños que le han sido causados ${ }^{171}$.

\footnotetext{
${ }^{170}$ Ya se vio anteriormente, en ella se modera la responsabilidad de la madre en un 50\%, no así la del padre por haberse desentendido del menor

${ }^{171}$ Bonilla Correa, Jesús Ángel, op.cit, pags 206 y 207
} 


\subsection{ESTUDIO DE LA EXPRESION “POR ESTE ORDEN” DEL ARTÍCULO 61.3 DE LA LORPM}

El artículo 61.3 dice: "Cuando el responsable de los hechos cometidos sea un menor de dieciocho años, responderán solidariamente con él de los daños y perjuicios causados sus padres, tutores, acogedores y guardadores legales o de hecho por este orden. Cuando éstos no hubieren favorecido la conducta del menor con dolo o negligencia grave, su responsabilidad podrá ser moderada por el Juez según los casos".

Este artículo indica que el menor de edad comprendido entre 14 y 18 años es imputable penalmente y de igual forma civilmente. Por otra parte el menor tiene que responder civilmente y con él una serie de personas, que lo hacen de forma solidaria.

La expresión "por este orden" ha generado muchas controversias sobre las personas que han de responder conjunta y solidariamente de los daños y perjuicios causados por un menor infractor que realiza un hecho dañoso.

Se plantea la duda de que según el orden de preferencia que se enumera como por ejemplo los padres, impide exigir responsabilidad a quien le sigue en la lista como los tutores o acogedores.

Hay dudas de si al actuar sobre un responsable, es o no exigible que tenga al menor bajo su guarda.

Es necesario saber si se puede exigir responsabilidad civil a varios de los responsables enumerados o sólo a uno.

En los debates parlamentarios se realizó una interpelación al Senador Sr. Cañellas Fons en la que manifestó lo siguiente: "Su Señoría decía que le espantaba esa solidaridad que se impone en el artículo. Señoría, solidaridad de todos estos "insta modum" que dicen los canonistas, porque dice: solidariamente los padres, los tutores, los guardadores, por este orden, no todos a la vez y en el mismo saco. Juntos pero no revueltos, para decirlo en términos más coloquiales. Primero los padres, luego los tutores -que vienen a hacer las veces de los padres- y en último extremo, los guardadores legales o de hecho, 
que son los menos responsables ${ }^{172}$. . Esta expresión que emplea el legislador, se habrá de tener en cuenta, aunque no contribuye a resolver las dudas que existen sobre la mencionada expresión, además de contribuir a generar una mayor confusión.

Las distintas posiciones doctrinales han sido sistematizadas por Carrera Domenech en las siguientes tesis:

1) Tesis del orden excluyente: el legislador ha establecido un orden de prelación, de manera que la existencia de sujetos de una clase previamente nombrada, excluye la responsabilidad de los sujetos de una clase posterior.

2) Tesis del orden acumulativo: el legislador no ha querido establecer un orden excluyente. La existencia de sujetos integrados en más de una de las categorías nombradas, no excluye la posibilidad de establecer una responsabilidad solidaria de todos ellos.

3) Tesis de la gestión efectiva del proceso educativo: el orden establecido por el legislador debe interpretarse de forma flexible, haciendo responder a quienes en el momento de sucederse los hechos se hallaban gestionando efectivamente el proceso educativo del menor, y ello con independencia de que existan sujetos que preceden en el orden literal de la norma ${ }^{173}$.

\subsubsection{TESIS DEL ORDEN EXCLUYENTE}

Si consideramos la tesis del orden excluyente puede dar lugar a producirse resultados injustos, como por ejemplo si se hace responder a unos padres privados de patria potestad y se exonera a unos guardadores legales. Los padres responderán en la medida en que tengan las obligaciones como tales. En todos aquellos casos en que han sido privados de la patria potestad, y habiéndose atribuido las funciones de los mismos a una Entidad o persona física o jurídica, los padres dejarán de responder. Lo importante es la efectividad del vínculo, mostrada a través del ejercicio o la posibilidad de ejercerlo. Si se dan una pluralidad de figuras, debemos ver la efectividad de la relación para atribuir la responsabilidad a uno de ellos, como por ejemplo la figura del tutor es

\footnotetext{
${ }_{172}$ Diario de Sesiones del Pleno del Senado. Legislativa VI, BOCG n ${ }^{\circ}$ 156, de 26 de diciembre de 1.999, pag 7658

${ }^{173}$ De la Rosa Cortina, José Miguel, op.cit, pag 58, nota 75
} 
incompatible con la de los padres en cuanto al ejercicio de sus funciones, por ello, sólo uno de estos deberá responder y lo hará el que efectivamente ejerce como tal ${ }^{174}$.

\subsubsection{TESIS DEL ORDEN ACUMULATIVO}

$\mathrm{Al}$ considerar la tesis del orden acumulativo, no se sigue el orden excluyente, por lo que si se dan más de una categoría de las nombradas, se puede exigir la responsabilidad a todos ellos. Puede defenderse esta tesis por la naturaleza objetiva de la responsabilidad, en la que presenta la ventaja de reforzar las posibilidades de cobro de la víctima, pero también presenta el inconveniente de atribuir responsabilidad a quienes pueden no tener el menor contacto con el infractor. Para aplicar esta tesis, hay que tener en cuenta el haz de facultades que comprende las obligaciones de educación, guarda, vigilancia o educación; si se encuentran dispersos entre distintos responsables, cabrá condenarlos conjuntamente entre sí y con el menor infractor ${ }^{175}$.

\subsubsection{TESIS DE LA GESTIÓN EFECTIVA DEL PROCESO EDUCATIVO}

En cuanto a la tesis de la gestión efectiva del proceso educativo, trata de establecer un criterio para seleccionar entre los responsables solidarios que respondan en cada caso. Conde Pumpido entiende que se deben emplear unos criterios correctores de la expresión "por este orden", debido a las dudas que plantea; por lo que hay que fijarse en quien desempeña de forma efectiva el deber de guarda y cuidado del menor, la posibilidad de control y su relación con los hechos delictivos. Emplea este autor un segundo argumento basado en el principio de causalidad, necesario para que surja incluso una responsabilidad de naturaleza objetiva; tiene necesariamente que darse una relación causa-efecto entre la conducta del responsable solidario y el hecho dañoso, lo cual puede producirse indistintamente por acción u omisión, con lo que la responsabilidad se traslada a quien ejerce el deber de guarda. En el caso de que sean varias personas las que tengan asignado el deber de guarda se debe seguir el orden del

\footnotetext{
174 Bonilla Correa, Jesús Ángel, op.cit, pag 404 y 405

175 De la Rosa Cortina, op.cit, pags 60 y 68
} 
artículo 61.3 LORPM $^{176}$.

El orden establecido lo defiende Carmen Calle y establece en otro supuesto que los nombrados con posterioridad, pese a existir figuras anteriores, llegan a responder, por lo que si no hay padres responderán los tutores, y así hasta el final con lo que se busca satisfacer al perjudicado a toda costa, lo que es excesivo; este planteamiento sirve para evitar situaciones injustas a las personas que deben responder. Se debe respetar el orden establecido dentro de ciertos límites, debiendo responder el que tenga asignado el haz completo de facultades de la guarda, así si la tienen los padres responderán ellos, si la tiene una Entidad o persona física, será ella quien responda, dejando de responder los padres $^{177}$.

\subsubsection{LA EXPRESIÓN “POR ESTE ORDEN” EN LA JURISPRUDENCIA}

En la práctica de las Audiencias se está imponiendo la tesis de la gestión del proceso educativo junto a la de responsabilidad acumulada. Ello es debido a la enorme confusión que ha originado la expresión "por este orden", por dar lugar a diversas interpretaciones, con lo que se ha prescindido de la mencionada expresión, admitiéndose la posible condena solidaria de distintas categorías de responsables, involucrados en la responsabilidad de la educación del menor.

Una sentencia en la que se considera la imposibilidad de responsabilidad acumulada de distintos responsables con orden excluyente es la S.A.P de Lleida de 11 de marzo de $2002{ }^{178}$. En ella trata de un menor interno en una Entidad de Atención de Menores de la Generalidad, que agredió a su profesora con un cuchillo, en una clase de cocina, tratándose de un menor conflictivo, con lo que se da una responsabilidad civil derivada de un ilícito penal. En su Fundamento de Derecho Tercero, dice que el artículo 61.3 de la LORPM establece la responsabilidad solidaria del menor de dieciocho años y de sus padres, tutores, acogedores y guardadores legales o de hecho, por este orden, sin exigir que concurra ninguna otra circunstancia y sin perjuicio de que la responsabilidad

\footnotetext{
176 Bonilla Correa, Jesús Ángel, op.cit, pags 401, 402 y 403

177 Bonilla Correa, ibídem, pag 404

178 S.A.P de Lleida de 11 de marzo de 2002 (JUR 2002/118 814)
} 
pueda ser moderada por el Juez cuando no hubiese favorecido la conducta del menor con dolo o negligencia grave. No se contempla en esta Ley la posibilidad de concurrencia de varios responsables a que alude la recurrente sino que, por el contrario, la prelación es "por este orden", que bien podría considerarse excluyente y no acumulativo, desde el momento en el que no se exige el requisito de la convivencia ni el incumplimiento de deberes inherentes al ámbito de competencia de cada uno de ellos. Por tanto la profesora demandante no puede ser considerada como guardadora de hecho a los efectos del artículo 61.3. La responsable es la Generalidad como titular de la tutela, guarda, custodia y formación del menor que desempeña por Ministerio de la Ley, siendo evidente que la clase que impartía la profesora lo hacía sometida a las instrucciones, supervisión, dirección y vigilancia de quien tiene asumida la tutela, por lo que no es admisible que esa responsabilidad se pueda trasladar a un tercero, en este caso la profesora. Por ello se desestima el recurso y se condena a la Generalidad a indemnizar a la profesora mencionada.

Un ejemplo de responsabilidad de orden acumulativo lo constituye la S.A.P de Asturias de 27 de abril de $2006^{179}$, en ella se condena a la Administración del Principado de Asturias y a los padres; en su Fundamento Primero la madre solicita una moderación de su responsabilidad civil de un 50\%. Por su Fundamento Tercero no se puede acceder a lo solicitado por parte de la recurrente, pues el hecho delictivo tuvo lugar cuando el menor disfrutaba de un permiso de fin de semana, estando por tanto en compañía de su madre, con lo que impide apreciar una negligencia grave en el actuar de la Administración del Principado de Asturias, quien en aquella época ostentaba la guarda y custodia del menor, por ello se moderó su responsabilidad en un 30\% y del padre del menor en un 50\% al encontrarse éste último al producirse los hechos interno en el Centro Penitenciario de Villalona. Respecto a la madre se considera que ha mostrado muy poco interés y apoyo hacia el menor durante el cumplimiento de la medida de internamiento que le fue impuesta por el Juzgado de Menores, lo que consta documentalmente acreditado y que ha contribuido en gran parte a favorecer tal conducta. Por ello no se puede moderar la conducta de la recurrente, quedando su

179 S.A.P de Asturias de 27 de abril de 2006 (JUR 2006/166775) 
recurso desestimado. En esta sentencia se puede apreciar que se condena a varios de los responsables por encontrarse dividida la totalidad o haz de facultades que integran la patria potestad, por ello la Administración del Principado de Asturias es la titular de la guarda y custodia del menor; al mismo tiempo su padre aunque se encuentra internado en el Centro Penitenciario de Villalona, por ser el padre, tiene responsabilidad in educando y la madre que le tiene al menor en un permiso de fin de semana le corresponde por ser la madre una responsabilidad in vigilando e in educando, lo que da lugar a un orden acumulativo de la responsabilidad.

La S.A.P de Valladolid de 22 de noviembre de 2002 (JUR-2003/19730) es un ejemplo de responsabilidad por la gestión efectiva del proceso educativo, trata de un menor con ausencia de figuras parentales, cuya infancia ha pasado con su abuela materna y dos tías suyas, consume drogas de forma habitual y va notablemente retrasado en los estudios ante los que muestra una actitud pasiva. Se encontraba bajo la tutela de la Gerencia de los Servicios Sociales de Valladolid, ingresado en el Centro Zambrano de dicha ciudad en virtud de una medida de internamiento dictada por el Juzgado de Menores. Habiéndose fugado de dicha institución cometió un hecho delictivo. En su Fundamento de Derecho Tercero se refiere al orden del artículo 61.3, dice: “ una interpretación lógica y sistemática ha de conducir a entender que lo que el legislador ha pretendido es que la responsabilidad de orden civil recaiga, de entre aquellas personas que en el artículo 61.3 se enumeran, en la que en el momento de causarse los daños por el menor ejerciera sobre el mismo los contenidos de la patria potestad, siendo evidente que , como también razona el juez a quo, otra interpretación conduciría al absurdo, por ejemplo, de atribuir a unos padres a quienes se les hubiera privado de la patria potestad la obligación de responder por los daños causados por un hijo, cuya guarda y custodia se hubiera encomendado a un tutor".

En la Sentencia intervienen varias personas sin que se mencionen por parte del Juez de Instancia, ni la Sala, a los padres, de los que sólo se dice "ausencia de figuras parentales", con lo que seguramente habrán abandonado sus deberes de patria potestad, ni tampoco a la abuela y tíos del menor, que son los que le han cuidado antes de su ingreso en el Centro de Menores. 
El Juez de Instancia y la Sala no se plantean una responsabilidad conjunta o acumulativa. Lo decisivo es quien desempeña de forma exclusiva el haz total de facultades que informan las funciones de la patria potestad, por ello prescinde de la expresión "por este orden" y se fija en el ejercicio efectivo de esos poderes de patria potestad, que realiza la Gerencia de Servicios Sociales de Valladolid.

\subsection{OBLIGACIÓN DE INDEMNIZAR DE LOS PADRES SEGÚN LAS SITUACIONES FAMILIARES}

Conviene distinguir, para estudiar las situaciones familiares con claridad en su exposición, si se trata de matrimonios que viven junto con sus hijos lo que es una situación convencional, de otras situaciones no convencionales o familias desestructuradas como la separación de hecho, separación judicial, divorcio o nulidad del matrimonio y como los padres que no se encuentran casados entre sí.

Dentro de las situaciones convencionales se dan los regímenes de separación de bienes, gananciales, participación y lo relativo a las capitulaciones matrimoniales. De igual forma se analizan las relaciones internas entre los cónyuges y las internas entre deudores y perjudicado.

\subsubsection{SITUACIONES CONVENCIONALES}

En estas situaciones los padres se encuentran unidos en matrimonio y ejercen la patria potestad de forma conjunta de acuerdo con el artículo 156 Código Civil y son responsables solidarios según lo dispuesto por el artículo 1.903 del mencionado código.

Los tres tipos de régimen económico matrimonial son la sociedad de gananciales, la separación de bienes y la participación. Se da también la posibilidad de que los cónyuges establezcan un régimen particular en las llamadas "capitulaciones matrimoniales" de acuerdo con el artículo 1.325 del Código Civil. 


\subsubsection{REGIMEN DE GANANCIALES}

En el régimen de gananciales intervienen tres patrimonios que se pueden emplear para responder de los hechos dañosos de los hijos y que son el ganancial y los dos patrimonios privativos de cada uno de los cónyuges. Gananciales son los bienes que se ganan o aumentan durante el matrimonio por el trabajo de los cónyuges, por los productos de los bienes privativos o comunes o por otra actividad legal.

Hay que distinguir las relaciones internas y externas a la hora de pagar la indemnización, o lo que es lo mismo, el responder frente a un tercero que ha sufrido el daño y de otra parte cómo se realiza la distribución entre los cónyuges del pago de la misma.

La deuda del artículo 1.903, de las personas responsables de los menores, es con cargo a la sociedad de gananciales, en ello está de acuerdo la doctrina, en lo que no hay acuerdo es en la norma en que se ha de basar, para unos sería el artículo 1362.1 del Código Civil ${ }^{180}$, para otros sin embargo, se basaría en el artículo 1.366 que dice: "Las obligaciones extracontractuales de un cónyuge consecuencia de su actuación en beneficio de la sociedad conyugal o en el ámbito de la administración de los bienes, serán de la responsabilidad y cargo de aquella, salvo si fuesen debidos a dolo o culpa grave del cónyuge deudor". El beneficio de la sociedad de gananciales se ha de entender en sentido amplio como ventaja para la familia, por lo que necesariamente tienen que incluirse la responsabilidad civil derivada de los hechos dañosos causados por los hijos; además de señalar la doctrina científica que la imputabilidad de la obligación del cónyuge puede deberse a responsabilidad por riesgo o incluso a una acción u omisión ilícita culpable, propia o de las personas por quienes se debe responder ${ }^{181}$.

\footnotetext{
180 Artículo 1362.1 del Código Civil: "Serán de cargo a la sociedad de gananciales los gastos que se originen por alguna de las siguientes causas:

$\left.1^{\circ}\right)$ El sostenimiento de la familia, la alimentación y educación de los hijos comunes y las atenciones de previsión acomodadas a los usos y a las circunstancias de la familia.

$2^{\circ}$ ) La alimentación y educación de los hijos de uno sólo de los cónyuges correrá a cargo de la sociedad de gananciales cuando convivan en el hogar familiar. En caso contrario, los gastos derivados de estos conceptos serán sufragados por la sociedad de gananciales, pero darán lugar a reintegro en el momento de la liquidación”. ${ }^{181}$ SAP de Pontevedra de 8 de octubre de 2002 (JUR 2003/23356)
} 
La expresión “actuación en beneficio de la sociedad conyugal”, se refiere no sólo a un sentido económico o patrimonial, abarca el tema de la responsabilidad de los padres por los hechos ilícitos de los hijos, con lo que hay que incluir la vigilancia y educación de los mismos. Por ello la mencionada expresión ha de ser entendida en un sentido amplio, como es en general actuar en interés de la familia, en todos los aspectos.

En cuanto a la otra expresión del mencionado artículo que dice "salvo si fuesen debidos a dolo o culpa grave del cónyuge deudor", se refiere a la culpa grave que se asimila o equipara al dolo (culpa lata dolo equiparatur), por lo que hay que tener en cuenta el tipo de culpa de que se trata ya que la Ley atribuye unas consecuencias diferentes a uno u otro tipo de culpa. Hay que distinguir si el dolo o culpa grave afecta al aspecto interno o externo de la relación. Si afecta tanto al aspecto interno como externo de esa sociedad de gananciales, ésta no responderá, de ahí se deriva que el acreedor deba dirigirse directa y exclusivamente contra el cónyuge que actuó con dolo o culpa grave. En sentido contrario, si afecta al aspecto interno, pero no al externo, el acreedor podrá dirigirse contra la sociedad de gananciales, y ésta responderá en todo caso; pero se dará un derecho de repetición de la sociedad de gananciales contra el cónyuge que actuó con dolo o negligencia grave, ahora bien, este derecho de repetición cesa cuando el cónyuge no haya actuado con dolo o negligencia grave.

Bonilla Correa entiende que la postura más correcta es aplicar el artículo 1.366 CC, tanto a efectos internos como externos, y que en el caso de existir esa responsabilidad por uno sólo de ellos se tendría que aplicar el artículo 1.373 CC $^{182}$.

Cuando la obligación de responder recae sobre los dos cónyuges, que ejercen conjuntamente la patria potestad, al ser una obligación contraída de forma conjunta, responderán los bienes gananciales de acuerdo con el artículo 1.367 CC que dice: "Los bienes gananciales responderán en todo caso de las obligaciones contraídas por los dos cónyuges conjuntamente o por uno de ellos con el consentimiento expreso del otro". El acreedor también puede dirigirse contra los bienes privativos de cada uno de los cónyuges deudores por lo establecido en el artículo 1.369. En este caso si uno de los cónyuges hubiera aportado bienes privativos para saldar la deuda ganancial, tendrá

182 Bonilla Correa, op.cit, pag 306 y 307 
derecho de regreso contra el patrimonio común de acuerdo con el artículo 1.364 CC, que dice: "El cónyuge que hubiere aportado bienes privativos para los gastos o pagos que sean de cargo de la sociedad tendrá derecho a ser reintegrado del valor a costa del patrimonio común".

\subsubsection{RÉGIMEN DE SEPARACIÓN DE BIENES}

En el régimen de separación de bienes cada uno de los consortes tiene sus propios bienes y su propio patrimonio, por lo que no existe ningún tipo de unión o de confusión, ni de comunidad. Tampoco existe participación de cada esposo en la actividad económica del otro, por lo que los vínculos económicos entre ambos cónyuges son los de su vida en común, lo que consuman en común, así como las obligaciones familiares de cada uno de ellos y a la prole. Por ello se define este régimen de separación de bienes como aquel en que cada uno de los cónyuges mantiene la propiedad, disfrute, administración y disposición de sus bienes y derechos.

El régimen de separación de bienes es de carácter supletorio con respecto al de gananciales, que es más empleado, por lo que hay que estar a lo que dispone el artículo 1.435 CC, que dice: "Existirá entre los cónyuges separación de bienes: $1^{\circ}$ ) cuando así lo hubieren convenido, $2^{\circ}$ ) cuando los cónyuges hubieren pactado en capitulaciones matrimoniales que regirá entre ellos la sociedad de gananciales, sin expresar las reglas por que hayan de regirse sus bienes, $3^{\circ}$ ) cuando se extinga, constante matrimonio, la sociedad de gananciales o el régimen de participación, salvo que por voluntad de los interesados fuesen sustituidos por otro régimen distinto.

Conviene diferenciar los casos en que hayan sido condenados y por tanto deban responder ambos cónyuges o por el contrario haya sido condenado uno solo de ellos.

Para el caso en que se condene a ambos cónyuges, la contribución será proporcional a la capacidad económica de uno y otro cónyuge de acuerdo con el artículo 1.438 que dice: "Los cónyuges contribuirán al sostenimiento de las cargas del matrimonio. A falta de convenio lo harán proporcionalmente a sus respectivos recursos económicos. El trabajo para la casa será computado como contribución a las cargas y dará derecho a obtener una compensación que el Juez señalará, a falta de acuerdo, a la 
extinción del régimen de separación". Lo expuesto en este artículo hay que analizarlo desde el punto de vista interno y externo de la relación. Desde el punto de vista interno, se da una división de la deuda por tratarse de separación de bienes, lo que se considera una carga del matrimonio por el deber de guarda sobre los hijos, es un gasto extraordinario, con lo que responderán ambos cónyuges en proporción a su capacidad económica. En el aspecto externo de la relación, por ser una deuda de carácter solidario de los cónyuges, al perjudicado o víctima le es indiferente el régimen económico de los contrayentes, por lo que podrá dirigirse contra uno u otro o contra ambos para el cobro de la deuda.

Por lo que se refiere a la moderación se puede aplicar a uno solo de los cónyuges, siempre que se pueda "individualizar las conductas de cada uno de ellos".

En cuanto al caso en que se condene a uno solo de los cónyuges la deuda será de su propia cuenta por lo que habrá que aplicar lo que dispone el artículo 1440.1 CC que dice: "Las obligaciones contraídas por cada cónyuge serán de su exclusiva responsabilidad".

De todas formas, la condena de uno solo de los cónyuges es muy remota, "sobre todo si atendemos a la redacción de la LORPM en donde el establecimiento de responsables obedece a un determinado título con la única finalidad de hacer posible el cobro del perjuicio causado a la víctima, donde la moderación existe pero no la exoneración, por lo que la condena de uno solo de los cónyuges no se llegará a producir, sin perjuicio de la moderación" 183 .

\subsubsection{RÉGIMEN DE PARTICIPACIÓN}

En este régimen cada uno de los cónyuges adquiere derecho a participar en las ganancias obtenidas por su consorte durante el tiempo en que dicho régimen haya estado vigente (artículo $1.411 \mathrm{CC}$ ). Se han de aplicar las normas del régimen de separación de bienes de acuerdo con el artículo 1.413 .

Es en definitiva una comunidad en la que los patrimonios permanecen separados durante la vida conyugal, dando lugar en el momento de liquidarse a una participación en

183 Ibidem, pag 309 
las ganancias obtenidas por los mismos.

Cuando uno de los cónyuges hubiese abonado una indemnización que debía haber sido satisfecha, en parte, por su cónyuge, le reconoce un crédito contra éste, que se asignará al final al patrimonio del cónyuge acreedor, deduciéndose por tanto del patrimonio del deudor, de acuerdo con lo establecido en el artículo 1.426 CC que dice: "Los créditos que uno de los cónyuges tenga frente al otro, por cualquier título, incluso por haber atendido o cumplido obligaciones de aquel, se computarán también en el patrimonio final del cónyuge acreedor y se deducirán del patrimonio del cónyuge deudor".

\subsubsection{LAS CAPITULACIONES MATRIMONIALES}

Los contrayentes gozan de una amplia libertad de contratación, por lo que pueden pactar diversas formas para hacerse cargo de las deudas asignadas por los actos dañosos de los hijos que estén a su cargo, para lo que hay que estar a lo que establece el artículo 1.323 CC que dice: "El marido y la mujer podrán transmitirse por cualquier título bienes y derechos y celebrar entre sí toda clase de contratos".

Aunque los cónyuges dispongan por éste artículo una considerable libertad de contratación, esta no puede ser tan amplia que afecte a los derechos del perjudicado o a otro de los cónyuges, por lo que habrá que distinguir una vez más entre el aspecto interno y externo de la relación.

En el aspecto interno si un cónyuge se encarga del pago de las deudas originadas por los actos dañosos de los hijos, será el que realizará ese pago, pero al mismo tiempo surgirá un derecho de repetición contra el cónyuge que haya quedado exonerado, aunque la exoneración no podrá ser total de acuerdo con el artículo 1.328 CC, que establece: "Será nula cualquier estipulación contraria a las leyes o a las buenas costumbres o limitativa de la igualdad de derechos que corresponde a cada cónyuge".

La igualdad del artículo 1.328 es una igualdad en donde los cónyuges tienen derecho a participar en la vida familiar, en la dirección de la familia, que tiene que ver con el principio de igualdad y no discriminación establecido en la CE, como en el artículo $66 \mathrm{CC}$, por lo que se refiere más a temas personales o familiares que a 
patrimoniales. Por ello, en los aspectos internos, no debe existir sobre todo en aspectos patrimoniales, límites a la autonomía de la voluntad"184.

En el aspecto externo de la relación, las capitulaciones matrimoniales no pueden oponerse frente al perjudicado en virtud de los artículos 1.255 CC y 1.328 CC ${ }^{185}$, pues se tratan de limitaciones de carácter interno, no oponibles al acreedor perjudicado.

\subsubsection{SITUACIONES FAMILIARES NO CONVENCIONALES}

Las situaciones familiares no convencionales, en contraposición a las convencionales vistas anteriormente, son cada vez más frecuentes en estos tiempos en que vivimos, como consecuencia de haberse alterado de forma sustancial los esquemas tradicionales de relaciones familiares. Así, el modelo de familia tradicional está dando paso a familias desestructuradas o construidas sobre la base de una pauta atípica ${ }^{186}$.

El niño para el pleno y armonioso desarrollo de su personalidad ha de crecer en el seno de la familia, en un ambiente de felicidad, amor y comprensión, en el que debe de prevalecer el interés del menor.

Los padres se preocupan fundamentalmente de satisfacer las necesidades físicobiológicas de sus hijos, encargándose de atender las necesidades de alimentación, temperatura, higiene, sueño, actividades físicas, con lo que proporcionan a sus hijos lo que creen que es mejor para ellos. Pero los niños han de crecer con límites y con referencias claras, no sólo consiste en proporcionarles cosas y elementos materiales. Ello no es suficiente, es necesario inculcarles valores morales y espirituales, que les hagan ser responsables. Los niños han de tener padres, no amigos, ni colegas. A los padres les cuesta trabajo mantener la autoridad, pues es poco grato hacerlo, es más cómodo dejar que el niño haga lo que quiera. Y eso es así, debido a que por la vida laboral u otras

\footnotetext{
184 Ibidem, pags 310 y 311

185 Artículo 1.255: "Los contratantes pueden establecer los pactos, cláusulas y condiciones que tengan por conveniente, siempre que no sean contrarios a las leyes, a la moral ni al orden público”

Artículo 1.315: “El régimen económico del matrimonio será el que los cónyuges estipulen en capitulaciones matrimoniales, sin otras limitaciones que las establecidas en este Código"

186 Paños Pérez, Alba, op.cit, pag 128
} 
circunstancias se pasa poco tiempo con ellos. No saben los padres muchas veces a qué atenerse, por no estar a lo que hay que estar, por venirles grande la carga de educar. Ello da lugar a que el niño se comporte como un pequeño tirano, demasiado protegido, que decide todo lo que la familia ha de hacer, como y cuando lo ha de hacer. Para evitar estas situaciones no hay que confundir tutela con opresión y lograr un equilibrio entre esa tutela y la autonomía que deba de tener un niño de acuerdo con su edad, así como de su grado de madurez.

Los niños al principio son desvalidos y frágiles, pero van cambiando y cada vez tienen una mayor autonomía y madurez. Tienen grandes potencialidades que necesitan desarrollarse, por lo que los padres no deben fallarles, procurando el desarrollo para que esas potencialidades lleguen a materializarse. Ello hace necesario que en los primeros años de la vida aumenten y se refuercen los mecanismos de protección sobre el menor, quedando pospuestos o postergados los derechos de autonomía e independencia, hasta poder ejercerlos plenamente cuando llegue a ser adulto.

La familia ha sufrido grandes cambios en las últimas décadas, con lo que se dan muchos casos de separaciones y divorcios, llegándose a varias y sucesivas uniones de padres y madres. Estas uniones son más inestables, menos duraderas y no resuelven los problemas de la vida diaria de una familia. Con ello se incumplen los preceptos constitucionales de su artículo 39, de protección social, económica y jurídica de la familia, así como lo establecido sobre ella en el Código Civil, todo ello, afecta directamente a la familia en general y en particular a las madres y a los hijos, ello incide de forma decisiva en la posterior evolución de la sociedad, en orden a la conservación de la especie humana como es la procreación, crianza, protección y educación de los menores.

A los progenitores sólo les preocupa la afectividad y su felicidad con lo que viven aventuras amorosas, creando familias que se esfuman rápidamente; por ello se habla de poligamia secuencial, monogamia en serie, familias extremas, familias recompuestas, biparentales compuestos, etc. Este tipo de uniones suelen ser transitorias o de poca duración dando lugar a que los niños se vean obligados a convivir con otros niños que no conocen, y a los que han de tratar como hermanos; deben de igual forma compartir 
habitación, juegos y el afecto de padre o madre con otros menores. Ello va en contra de la seguridad y estabilidad de que debe de gozar un menor. Además estos menores tienen que acostumbrarse a querer y a vivir con el novio de su madre o la novia del padre, conformándose con ello, pues toda situación por desfavorable que sea es susceptible de empeorar.

Las crisis matrimoniales pueden ser amistosas o no, o pueden empeorar siendo amistosas y derivar en no amistosas. Estas desavenencias del matrimonio dan lugar a que los hijos se vean envueltos en "una guerra sin cuartel" entre sus padres y utilizados como moneda de cambio o arma arrojadiza entre ellos, con lo que causarán sufrimientos psicológicos a los menores. Los hijos no pueden estar soportando conflictos continuos entre sus padres por nimiedades y trivialidades, así como aguantando sus presiones colocándoles contra el otro, por lo que si esto se produce dará lugar a que sufran secuelas afectivas y psicológicas traumáticas para el resto de su vida ${ }^{187}$.

\subsubsection{SEPARACIÓN DE HECHO}

Se da la separación de hecho cuando los padres no conviven entre sí. Puede deberse a motivos extraconyugales tales como laborales o de salud, o ser una pareja no casada, con lo que no necesariamente tiene que tratarse de una crisis matrimonial.

La separación de hecho se produce por decisiones personales de los cónyuges sin someterse al conocimiento judicial, con lo que se halla contrapuesta a la separación judicial en que se requiere un proceso y la correspondiente sentencia ${ }^{188}$. Puede ser convencional cuando los dos cónyuges están de acuerdo o unilateral cuando la provoca uno solo de ellos.

Una separación de hecho equivale a una separación judicial y no tiene que tener consecuencias distintas de cara a la responsabilidad sobre los hijos, pues se trata de responsabilidad objetiva en la LORPM y cuasi objetiva en el Código Civil. La patria potestad la siguen ejerciendo ambos progenitores, pero al quedarse los hijos con uno de ellos será éste el que la ejerza materialmente, en este caso, la atribución de ella no es de

\footnotetext{
187 Beneito Berenguer, Remigio, La Protección del Menor, Tirant lo Blanch, Valencia 2009, pags 57 a 64

188 Lasarte Carlos, Principios de Derecho Civil VI, Marcial Pons, 7ªedición, pag 92
} 
carácter judicial; sino que se acuerda entre los cónyuges o uno sólo de ellos ${ }^{189}$.

La Ley 15/2005 de 8 de julio ha modificado varios artículos del Código Civil y de la Ley de Enjuiciamiento Civil para actualizarlas ya que como dice en la Exposición de Motivos: "Estas disposiciones han estado en vigor un cuarto de siglo, tiempo durante el que se ha puesto de manifiesto de modo suficiente tanto sus carencias como las disfunciones por ellas provocadas. Sirvan sólo a modo de ejemplo los casos de procesos de separación o de divorcio que, antes que resolver la situación de crisis matrimonial, han terminado agravándola o en los que su duración ha llegado a ser superior a la de la propia convivencia conyugal”. Dice igualmente, que la reforma pretende garantizar la libertad que como valor superior de nuestro ordenamiento jurídico, tenga su más adecuado reflejo en el matrimonio, así como el respeto al libre desarrollo de la personalidad, de acuerdo con el artículo 10.1 CE, justifica reconocer mayor trascendencia a la voluntad de la persona cuando ya no desea seguir vinculado con su cónyuge. En consecuencia, la Ley lo que pretende es agilizar los trámites de separación y divorcio, para que la crisis matrimonial dure lo menos posible y se garanticen la libertad y el libre desarrollo de la personalidad.

Cuando la separación de hecho la provoca uno solo de los cónyuges hay que estar a lo que dispone el artículo 156 sobre la patria potestad en el que dice en su último inciso: "Si los padres viven separados, la patria potestad se ejercerá por aquel con quien el hijo conviva". La separación a que se hace referencia puede tratarse de una separación judicial con su correspondiente sentencia o bien cualquier otra como la separación de hecho unilateral, en cuyo caso se presume el consentimiento del cónyuge que abandona el hogar familiar, para que el otro cónyuge siga ejerciendo las funciones inherentes a la patria potestad, de acuerdo con el artículo 156.1 que dice: "La patria potestad se ejercerá conjuntamente por ambos progenitores o por uno sólo con el consentimiento expreso o tácito del otro". La segunda parte del último inciso del artículo 156 concede al progenitor no conviviente solicitar al Juez, en interés del hijo, atribuirle la patria potestad para que la ejerza conjuntamente con el otro progenitor o bien distribuir entre el padre y la madre las funciones inherentes a sus ejercicio.

${ }^{189}$ Bonilla Correa, Jesús Ángel, op.cit, pag 323 
El hecho de encontrarse separados los cónyuges, el que no convive con el menor, tiene obligaciones básicas con el mismo, por lo que no puede eludir sus responsabilidades. Los padres tienen sobre el menor el doble requisito de la patria potestad y de la guarda del menor, con lo que si se hallan separados, no justifica que el no conviviente pueda desentenderse de las obligaciones inherentes a la patria potestad. Por ello deben responder ambos cónyuges por los hechos de sus hijos, actuando ambos en interés del menor y al mismo tiempo se consigue una mayor garantía de pago frente al tercero perjudicado. Aunque se encuentren separados los progenitores, de acuerdo con el artículo 1903.2 CC no se precisa el requisito de la convivencia, pero subsiste el de la patria potestad, por lo que ambos progenitores son responsables.

En cuanto al régimen económico del matrimonio "el llevar separado más de un año por acuerdo mutuo o por abandono del hogar" es causa suficiente por decisión judicial y a petición de uno de los cónyuges para la disolución de la sociedad de gananciales o cualquier otro régimen económico de acuerdo con lo establecido en el artículo 1393.3 del CC. Para el caso en que uno de los cónyuges fuera menor o incapacitado y se diera la situación de separación, el otro cónyuge no podría ser tutor (artículo 234.2) ni curador (artículo 291).

Si la separación de hecho se hace de acuerdo entre ambos cónyuges, es decir, de forma convencional, los pactos que establezcan sobre sus hijos, régimen económico, etc, que se hacen a veces en escritura pública y ante notario han sido reconocidos como validos por la doctrina. Todo ello siempre que estén de acuerdo con la igualdad entre los cónyuges, no resulten perjudiciales o contrarios a los intereses de los hijos, ni resulten contrarios al orden público ${ }^{190}$.

\subsubsection{SEPARACIÓN JUDICIAL, DIVORCIO Y NULIDAD DE MATRIMONIO}

En los procesos de separación judicial, divorcio y nulidad de matrimonio, se suspende la vida en común de los cónyuges, por lo que se alteran los derechos y deberes inherentes a la patria potestad, asignándose la guarda y el cuidado a uno solo de los

190 Lasarte Carlos, op.cit, pag 93 y 55 
progenitores. El procedimiento tiene que ser de carácter judicial, en el que tiene que intervenir el Juez dictando la correspondiente sentencia.

La guarda y custodia se establece en un convenio regulador que deben realizar los cónyuges con la aprobación del Juez, en caso contrario en que no se pusieran de acuerdo, será el propio Juez el que lo establezca por decisión judicial. De acuerdo con el artículo 90 CC, apartado a, el convenio regulador que establecen los artículos 81 y 86 CC, tiene que determinar el cuidado de los hijos sujetos a la patria potestad de ambos, a cargo de quien de los dos cónyuges quedan los hijos, el ejercicio de la misma, régimen de comunicación y estancia de los hijos con el progenitor que no viva habitualmente con ellos. De forma excepcional podrán ser encomendados a los abuelos, parientes y otras personas que así lo consintieren y, de no haberlos a una institución idónea confiriéndoles las funciones tutelares que ejercerán bajo la autoridad del Juez ( $\left.\operatorname{art}^{\circ} 103, a\right)$.

La separación, la nulidad o el divorcio, de acuerdo con el artículo 92 CC, no eximen a los padres de sus obligaciones para con los hijos y las medidas que se tomen judicialmente sobre su custodia, educación, etc, tendrán que ser en su beneficio, debiendo velar el Juez por su derecho a ser oídos. En el apartado cuarto se establece que los padres pueden acordar en el convenio regulador o el Juez podrá decidir, en beneficio de los hijos, que la patria potestad se atribuya exclusivamente a uno de ellos, o bien que la guarda y custodia sea ejercida por ambos de forma compartida.

Lo normal es que se atribuya la guardia y custodia a uno de los progenitores, mientras que el otro tendrá un derecho de visitas de acuerdo con lo establecido en el artículo $94 \mathrm{CC}$, en que le permite visitar a sus hijos, comunicarse con ellos y tenerlos en su compañía. Este derecho de visitas no se debe de interpretar de forma restrictiva, pues su fundamentación se encuentra en la necesidad de reanudar las relaciones entre los padres y los hijos, para evitar que las rupturas se transformen en muy prolongadas o definitivas; sólo debe restringirse si se dan circunstancias que supongan peligro para la salud física, psíquica o moral del menor. Constituye este derecho de visitas del progenitor que no convive con los hijos, al mismo tiempo un deber, para poder ejercer la patria potestad y un derecho de los hijos para poder comunicarse con sus padres y 
tenerlos en su compañía ${ }^{191}$.

El Juez puede privar a uno de los cónyuges de la patria potestad, en la sentencia de nulidad, separación o divorcio, cuando en el proceso se revele causa para ello (artículo 92.3).

Respecto al deber de alimentar a los hijos, recae sobre los padres independientemente de que ostenten o no sobre ellos la patria potestad, de acuerdo con el artículo 92.1 CC, por lo que se encarga a la autoridad judicial que en la sentencia que declare la separación, nulidad o divorcio fije las medidas para la asignación de los alimentos, de acuerdo con el apartado primero del artículo 93 CC que dice: "El Juez, en todo caso, determinará la contribución de cada progenitor para satisfacer los alimentos y adoptará las medidas convenientes para asegurar la efectividad y acomodación de las prestaciones a las circunstancias económicas y necesidades de los hijos en cada momento".

La pensión de alimentos es necesario actualizarla periódicamente por influir sobre ella la inflación. De igual forma la evolución de los hijos con el aumento de la edad, aumentarán de igual forma las necesidades, por lo que habrá que aumentar la cuantía. Por otra parte, el cónyuge que no convive con los hijos, puede tender a no cumplir con esta obligación, sobre todo cuando aumente con el paso del tiempo, o a no estar de acuerdo con la cuantía de la misma, para subsanar estos inconvenientes hay que estar a lo que dispone el artículo 91 CC que comprende la prestación de alimentos y las garantías para asegurarla.

Una vez que se ha producido la separación, nulidad o divorcio y asignado la guarda del menor o menores a uno sólo de los progenitores hay que delimitar a quién de ellos se le puede exigir la obligación de responder, a no ser que se haya establecido una guarda compartida, en cuyo caso responden ambos progenitores.

191 Paños Pérez, Alba, op.cit, pag 132. Ver igualmente Lacruz Verdejo, op. Cit, pags 101 y 102 donde dice: “Es un derecho que a los padres reconoce, aunque no ejerzan la patria potestad para relacionarse con sus hijos menores, que se fundamenta en el Derecho natural, calificado por la doctrina de derecho-deber o de derecho función, de carácter personalísimo, irrenunciable, inalienable, imprescriptible, con subordinación al interés del hijo y concedido con independencia de los motivos que dan lugar a la separación o el divorcio" (RIVERO HERNANDEZ) 
En el caso más frecuente en que la custodia se asigna a uno solo de los progenitores, ambos siguen conservando la titularidad de la patria potestad, por decisión judicial si no se hallan de acuerdo o por aprobación judicial del convenio en caso contrario. Para la imputación de la responsabilidad se precisa la patria potestad y la guarda del menor, la obligación de responder recaerá entonces en el que ostente la titularidad de la guarda. ¿Pero qué sucede cuando el menor se encuentra en el derecho de visita con el cónyuge que no tiene asignada la guarda, es decir, con el cónyuge no custodio?. Aquí es donde surgen los problemas, pues si nos atenemos a la necesidad de la guarda, el progenitor que tenga solamente el derecho de visitas no resultará nunca responsable. La doctrina considera que esto sería injusto y que ello conculcaría los principios de igualdad de los cónyuges y del orden público que son los que informan la responsabilidad de los padres.

Para resolver la cuestión se puede emplear el criterio de la culpa in educando, en la exigencia de la responsabilidad de los padres, respondiendo los dos progenitores, independientemente de quien ostenta la guarda del menor, solamente por el hecho de haber participado los dos en la educación del menor.

La culpa in educando es difícil de aplicar, por la dificultad de la prueba, sino también para determinar que existe nexo causal entre la educación que ha recibido de sus padres el menor y la producción del hecho dañoso por éste ${ }^{192}$. Es difícil probar ese nexo causal, sólo en casos muy especiales en que se demuestre que el progenitor permitiera al menor el uso de objetos o instrumentos peligrosos, o casos parecidos, sería recomendable emplear la culpa in educando para la exigencia de responsabilidad.

La forma más correcta de resolver el modo de imputar la responsabilidad en estos casos es exigirla al progenitor que tenga la guarda del menor en el momento en que se produce la comisión del hecho dañoso. Para ello se emplea la llamada "teoría del traspaso de responsabilidad", que supone entender que el derecho de visitas transfiere la guarda del menor durante los periodos de tiempo que dura el mismo. De esta forma se emplea el criterio de la culpa in vigilando, por lo que para ello hay que estar a lo que

\footnotetext{
192 Paños Pérez, Alba, op.cit, pag 133. Bonilla Correa dice que esta teoría de la culpa in educando "plantea problemas de indefinición y dificultades para precisar su alcance" (Bonilla Correa, op.cit, pag 319)
} 
dispone la sentencia judicial donde se establece el régimen de visitas y además se tiene que comprobar si realmente se ha producido el traspaso del menor de un cónyuge a otro. Esto tiene importancia, ya que puede darse la circunstancia de que el cónyuge con derecho de visita no haya querido recibir al menor, es decir, que se ausente y no le reciba cuando tiene obligación de hacerlo y en ese tiempo que lo tenga el cónyuge custodio, el menor cometa el hecho dañoso; en este caso deberá responder este cónyuge custodio, pero entonces conserva la acción de repetición contra el que ostenta el derecho de visita.

Si la responsabilidad se traspasa con el menor, tiene que responder el progenitor que tenga consigo al mismo en el momento en que comete el acto dañoso, por lo que prevalece el que tiene la guarda de forma efectiva frente a la guarda legal; o lo que es lo mismo, guarda y custodia del menor o guarda permanente y derecho de visita o guarda momentánea. En definitiva de lo que se trata es que se cumpla con precisión el régimen de visitas, para atribuir la responsabilidad al cónyuge o progenitor con quien se encuentra el menor en el momento de producirse el hecho dañoso ${ }^{193}$.

Para el caso en el que una sentencia establezca la guarda y custodia conjunta, no es necesario aplicar la teoría del traspaso de la responsabilidad, por lo que es indiferente con quien se encuentre el menor en el momento de cometer el acto dañoso; al tener ambos progenitores la guarda jurídica compartida, responderán ambos progenitores.

\subsubsection{PADRES NO CASADOS ENTRE SI}

El artículo 156.1 CC atribuye la patria potestad conjuntamente a ambos progenitores, por lo que no tiene ninguna relevancia el que se encuentren o no casados.

Si ambos progenitores viven juntos con sus hijos, los dos tendrán la guarda jurídica y los

\footnotetext{
193 Yzquierdo Tolsada, Mariano, op.cit, pags 257-258 dice: "No está demás por todo ello, preferir entonces como criterio de atribución al doble requisito patria potestad- guarda del menor, de tal modo que haya de ser responsabilizado quien, teniendo la patria potestad, se halle con el menor en el momento del daño, excluyéndose así la responsabilidad del que ostenta la patria potestad pero no tiene la guarda en el momento concreto" Bonilla Correa, op. Cit, pags 319-320 dice: "Supone entender que se ha producido el traspaso de la guarda durante las visitas, ya que sería injusto cargar la responsabilidad sólo contra el progenitor que en virtud de resolución judicial tiene atribuida la guarda"
} 
dos serán responsables. Si la guarda jurídica se atribuye a uno solo de ellos por resolución judicial, sólo él será responsable.

Por ello se aplican las mismas soluciones para los padres casados de manera convencional que viven con sus hijos, como los referidos a situaciones familiares no convencionales, que viven separados y el hijo vive bajo la guarda de un progenitor y en las visitas con el otro.

En consecuencia, para exigir la responsabilidad del artículo 1903.2 del CC, da igual que los progenitores se encuentren o no casados.

\subsubsection{LA JURISPRUDENCIA ANTE LAS DISTINTAS SITUACIONES} FAMILIARES

En la S.A.P de Baleares de 25 de marzo de 2009, trata de unos menores que se introducen en un hotel que se encontraba cerrado, provocando el incendio del mismo. Los daños que se ocasionan son abonados a los propietarios del hotel por Seguros Catalana Occidente S.A.

En su Fundamento de Derecho Primero, la parte actora Catalana Occidente ejercita la acción de repetición contra los padres de los menores autores del incendio, por entender que ha existido falta de atención y cuidado por parte de quienes ostentaban la patria potestad de los menores.

Por su Fundamento de Derecho Segundo se exponen los criterios para justificar la aplicación del artículo 1903 CC: "La responsabilidad civil de los padres por los actos ejecutados por los hijos constituidos "in potestas", se justifica, tradicional y doctrinalmente por la transgresión del deber de vigilancia que a los primeros compete, omisión de la obligada diligencia in custodiando o in vigilando, que el legislador contempla partiendo de una presunción de culpa concurrente en quien desempeña los poderes y los deberes integrantes de la patria potestad, de forma que puede ser configurada como una responsabilidad por riesgo a cuasi objetiva, con la consiguiente inversión de la carga de la prueba, de manera que la demostración del empleo de las

precauciones adecuadas para impedir el evento dañoso, según lo establecido en el párrafo final de tal artículo, ha sido entendida por la jurisprudencia de marcada 
severidad, exigiéndose una rigurosa prueba de la diligencia empleada, atemperándose a las circunstancias de tiempo y lugar del caso concreto y según lo que antecede, no compete al actor la carga de acreditar la negligencia de los demandados.

Su Fundamento de Derecho Tercero demuestra el nexo causal entre el incendio del Hotel y la participación de los hijos de los demandados: "Esta Sala comparte los razonamientos de la resolución recurrida y llega a la conclusión de que existen datos que acreditan la participación de los hijos de los demandados en el incendio del Hotel con la existencia de un enlace preciso y directo que prueba su participación, según las normas del criterio humano, pues consta que el origen del incendio se localizó en el mostrador donde los menores habían dejado unas velas encendidas, que en el citado mostrador no existía conducción eléctrica alguna que hubiera podido ocasionar el incendio por cortocircuito, sin que exista prueba alguna de la que pueda deducirse la presencia de terceras personas dentro del indicado recinto".

En el Fundamento de Derecho Quinto no se exonera de la responsabilidad a José Ángel padre del menor Abilio, participante en los hechos, por no hallarse separado de su mujer Felisa en el tiempo en que los menores incendiaron el Hotel: "Tal exoneración ha de producirse en el caso de que la guarda del menor la ostente exclusivamente de forma temporal uno de los progenitores en virtud de lo dispuesto en el convenio regulador aprobado por la sentencia en procedimiento matrimonial, en cuyo caso aquel que estuviere privado de dicha guarda y custodia no le alcanza la responsabilidad derivada del artículo 1903, párrafo $2^{\circ}$ del CC si el daño causado se hubiere producido cuando el menor estuviera bajo la ordinaria guarda y custodia de aquel que la tiene concedida.

Ahora bien, en el caso de autos la sentencia de divorcio de 9 de julio de 2007, que aprueba el Convenio Regulador de las partes sobre la guarda y custodia de los hijos de 28 de junio de 2007 es muy posterior a los hechos enjuiciados (14 de abril de 2006), no constando la existencia de una sentencia judicial que al tiempo del incendio atribuyera la guarda del menor Abilio únicamente a la madre".

Por el Fundamento de Derecho Sexto no exonera el Tribunal a los demandados por no haber observado la diligencia debida del artículo 1903, párrafo último CC. "Los padres responden del daño causado por sus hijos, salvo prueba que evidencia que no 
incurrieron en falta de diligencia en su labor de supervisión o educación del menor de edad, imponiendo la Ley a los padres la obligación de educarles y procurarles educación integral".

En el caso hoy enjuiciado consta acreditado que los hijos de los demandados entraron reiteradamente en propiedad ajena, sustrayendo repetidamente objetos que se llevaron a sus respectivas casas y finalmente prendieron unas velas que dejaron encendidas provocando un incendio que causó importantes daños a la propiedad.

Frente a ello no existe ninguna prueba en los autos que acredite que los padres de los menores adoptaran alguna diligencia concreta o medida necesaria oportuna y adecuada para conocer los lugares que frecuentaban sus hijos y las actividades que realizaban, para prevenir y evitar la producción del resultado dañoso.

Los razonamientos hasta aquí expuestos determinan la estimación del recurso de apelación interpuesto por Catalana Occidente y la condena de los demandados al abono de la cantidad reclamada en la demanda ( S.A.P Baleares, de 25 de marzo de 2009, AC 2009/776)

La S.A.P de Córdoba de fecha 23 de enero de 2009 trata de un caso de culpa in educando, en el que un menor al terminar un partido de futbol, que formaba parte de un equipo federado de la Federación Andaluza, golpeó a otro produciéndole traumatismo cráneo encefálico y caída de piezas dentales: "En su Fundamento Jurídico Tercero, el juzgador de instancia se basa en una culpa in educando, que determina la obligación de los padres de indemnizar los daños causados por sus hijos menores en atención a un déficit de formación personal a ellos imputable por establecerse una presunción de falta de aplicación en sus labores educativas, cuya apreciación anularía, incluso, la virtualidad del supuesto previsto en el artículo 1903.5 del CC, sobre la responsabilidad de los titulares de centros educativos y en los a ellos asimilados.

Por el artículo 61.3 LORPM se considera que el fundamento de la responsabilidad civil se encuentra no sólo en el deber de guarda sino también en el deber de educación y en el adecuado uso de las facultades de corrección que los padres, tutores, acogedores o guardadores tienen sobre sus hijos, pupilos, acogidos o sometidos a su guarda (S.A.P Sevilla de 3 de junio de 2005, JUR-2005/238714). 
A tenor de dicha doctrina y teniendo en cuenta que el $\operatorname{art}^{\circ}$ 61.3 LORPM establece un sistema propio de responsabilidad civil, alejado de los artículos 1.903 y $120 \mathrm{CP}$, el motivo ha de ser desestimado, pues aun reconociendo que el daño producido por el menor lo ha sido en el transcurso de un partido de fútbol, aun cuando recién terminado, en cuyos momentos se encuentra bajo la autoridad de los responsables del equipo federado, lo decisivo no es la falta de vigilancia en ese momento concreto, dificultada por demás por la complejidad y tumultuosidad de los acontecimientos en los que medió una invasión del campo por parte de personas distintas de los jugadores, sino, conforme expresa la sentencia citada y la mayor parte de la doctrina y jurisprudencia, la carencia formativa del menor en aspectos básicos de la convivencia que propicia groseros comportamientos lesivos de derechos básicos ajenos, por mucho que sea cierto que la práctica del deporte no solamente afecta al desarrollo físico del menor y atiende también a la plenitud de su personalidad mediante la adquisición de otros valores adyacentes al meramente deportivo, que han de ser incluidos por el equipo en cuya disciplina se inserta, resultando por ello meridianamente claro que no corresponde a sus responsables promover esa formación básica de la personalidad sino en el presente caso a los padres.

En su Fundamento de Derecho Cuarto se concede una minoración de un veinte por ciento a los padres del menor: "En esta tesitura, sin embargo, no puede olvidarse las circunstancias concretas en que acaecen los hechos, ya descritos somera pero suficientemente, ni que entonces el menor estaba sujeto a una disciplina que, momentáneamente, excluía las facultades concretas de vigilancia y control de los padres respecto de su hijo, por lo que no puede sustentarse que la conducta particular de aquél, constitutiva del ya mencionado delito, sea debida al dolo o la negligencia grave de los progenitores, por cuya razón es pertinente hacer uso de aquella facultad y aminorar la indemnización a cargo de los padres en un veinte por ciento, con estimación parcial del recurso".

Esta sentencia como vemos es ilustrativa de un caso de culpa in educando sobre un menor de carácter violento, al que sus padres no han corregido ese comportamiento, resultando por ello condenados a indemnizar a los perjudicados y que sólo se concede el aminorar esa indemnización en un veinte por ciento al no haber favorecido la conducta 
del menor con dolo o negligencia grave ${ }^{194}$.

En la S.A.P de Zaragoza de fecha 3 de abril de 2009, trata del caso de un menor que provoca un incendio, cuando se encuentra bajo la guarda de su padre, en la localidad de Quinto de Ebro, en el Colegio Fernando el Católico de dicha localidad, por lo que la Euromutua Seguros y Reaseguros, formula demanda contra la madre, después de haber indemnizado al Ayuntamiento de Quinto de Ebro, la madre recurre dicha demanda en que se condena al padre en su Fundamento de Derecho Tercero, que dice lo siguiente: "No es discutido que al tiempo de los hechos el menor se hallaba en compañía de su padre en la localidad de Quinto de Ebro, en donde no reside la madre, que lo tiene en guarda por sentencia de separación matrimonial. Ello provoca la cuestión a que hace referencia el recurso, y que el juzgador de primer grado resuelve extendiendo la responsabilidad del artículo 1.903 CC a los dos progenitores al padre por incumplimiento del deber de vigilancia del menor que tenía en su compañía y a la madre por dejación en su labor educativa y de formación integral que le correspondía con base al artículo 154 CC.

Ciertamente la cuestión que plantea la responsabilidad de los padres en los supuestos de crisis matrimonial con atribución de las facultades de guarda sobre los menores a uno de los esposos, con un régimen de visitas para el otro ha dado lugar a soluciones doctrinales diversas, si bien la doctrina mayoritariamente se decanta por excluir al cónyuge que no lo tiene en su compañía en el momento del suceso, aunque sea el custodio, y tal posición ha sido acogida por la STS de 11 de octubre de 1.990 (RJ1990/9014), de constante cita en la doctrina mayoritaria a la que nos referimos, en la que se condena al padre de un menor que causó unos daños a otro como consecuencia de un accidente de circulación, a pesar de que, aunque no ostentaba habitualmente la guarda, si la tenía en el momento en que ocurrió el accidente. La argumentación del Supremo es la siguiente: "Dice el recurrente que el texto legal vigente establece que los padres son responsables de los daños causados por los hijos que se encuentren bajo su guarda y que el menor hijo del recurrente, por separación judicial de sus progenitores, quedó según convenio regulador, bajo la guarda de la madre. Siendo ciertas estas afirmaciones del

194 SAP de Córdoba de 23 de enero de 2009 (JUR 2009/199 267) 
recurrente, no se puede ignorar el carácter flexible del concepto "bajo su guarda", que admite situaciones transitorias derivadas del derecho de visita o del propio convenio, pues en el presente, dada la edad del menor, 17 años, se le autorizaba a acudir y permanecer según su voluntad en las esferas de relación paterna y materna. Y la sentencia recurrida ha declarado hecho probado que el accidente se produjo cuando el hijo estaba bajo custodia del padre. En consecuencia, procede la estimación del motivo $^{195}$.

Por la S.A.P de Huelva de 18 de octubre de 2004, se resuelve un caso en que una madre tiene asignada la guarda y custodia del menor Inocencio, pero el hecho dañoso que comete el menor, se produce en un periodo de visita bajo la guarda y custodia efectiva del padre, por lo que es condenado. En su Fundamento de Derecho Primero dice lo siguiente: "El Juzgador tras la valoración de todas las pruebas practicadas concluye que a estos efectos es preciso distinguir entre la guarda y custodia legal y la guarda y custodia efectiva del menor y ciertamente esta Sala comparte plenamente tal conclusión de modo que es necesario concretar en esa fecha, 18 de Octubre de 2002, quien de ambos progenitores que se hallaban divorciados ejercía de manera real la custodia del menor. Resultando que si bien es cierto que desde el punto de vista estrictamente legal dicha función tutelar estaba atribuida a la madre, no lo es menos que Inocencio en aquel tiempo convivía con su padre quien de manera efectiva ejercitaba su guarda y custodia y esta aseveración no queda desvirtuada por la ausencia de un procedimiento de Modificación de Medidas, pues era el padre a quien incumbía el cumplimiento de ese deber de vigilancia y cuidado del menor del que deriva la acción de responsabilidad civil que se ejercita por el demandante, no constando en modo alguno que el padre hubiese probado conforme al artículo 1903 del Código Civil su diligencia en el ejercicio de este deber, como tampoco puede desvirtuarse por el criterio de la solvencia o insolvencia económica, esto es, la responsabilidad debe recaer en quién ejercía dicho deber independientemente de que sea solvente o insolvente a efectos económicos.

No hallamos pues el error denunciado en la valoración de las pruebas por el Juez

195S.A.P de Zaragoza de fecha 3 de abril de 2009 (JUR 2009/220 677) 
a quo, se han analizado las distintas declaraciones de las partes litigantes, se han estudiado las diversas pruebas documentales aportadas, estimándose, es de insistir, que en aquel tiempo, octubre de 2002, el menor Inocencio se encontraba bajo la efectiva guarda y custodia de su padre, el cual en el acto del Juicio reconoció y admitió que su hijo vivía con él en ese tiempo y por ello ha resultado condenado en la Sentencia criticada.

En la presente Sentencia se trata de un menor cuyos padres se encuentran divorciados con la guarda y custodia sobre el menor de forma compartida, siendo la responsabilidad civil del padre del menor por ostentar esa guarda y custodia de forma efectiva sobre el menor en el momento en que ocurrieron los hechos, correspondiéndole por ello la obligación de indemnizar. No consta como se dice en la Sentencia que el padre hubiera probado de acuerdo con el artículo 1903 CC su diligencia en el ejercicio del deber de cuidado y vigilancia sobre el menor, cuestión esta muy difícil de demostrar por tratarse de una responsabilidad cuasi objetiva ${ }^{196}$.

La S.A.P de Zaragoza de 31 de marzo de 2003 trata de un caso en el que unos menores incendian unas pacas de paja, el menor Javier es hijo de padres divorciados, a los que en la sentencia de divorcio se establece una guarda y custodia de forma conjunta o compartida, por lo que no se admite la teoría del traspaso de la responsabilidad y por tanto la exoneración del cónyuge que no se hallaba con el menor en el momento de los hechos, por lo que hay que estar a lo dispuesto en el convenio regulador, como se expone en el Fundamento de Derecho Segundo apartado cuarto que dice: "En el caso, sin embargo, no hay cuestión, pues la estipulación primera del convenio regulador aprobado por la sentencia de separación señala que "Javier queda en custodia de ambos progenitores, conviviendo con cada uno de ellos durante el período de un curso escolar". El padre, pues, era en julio de 1999 titular de una guarda compartida y no puede eludir las responsabilidades que el artículo 1903.2 CC le impone, ni siquiera por la razón esgrimida de estar en el día de los hechos realizando un traslado de domicilio, pues la responsabilidad de que se trata se configura bajo un régimen de objetivación, no pudiendo exonerarse los padres por encontrarse trabajando en el momento en que el 
hecho dañoso se produce. La responsabilidad establecida por este artículo contempla una responsabilidad por riesgo o cuasi objetiva" ${ }^{\text {"197. }}$.

\subsubsection{LAS SITUACIONES FAMILIARES NO CONVENCIONALES EN EL DERECHO COMPARADO}

\subsubsection{DERECHO FRANCÉS}

El Derecho francés es muy similar al español. Al tratar de la patria potestad el artículo 371 Code Civile dice que: "El hijo, a cualquier edad, debe honra y respeto a sus padres", lo que se corresponde con nuestro artículo 155.1 CC. De igual forma el artículo 371.1 Code Civile dice: "La patria potestad es un conjunto de derechos y de obligaciones que tienen como fin el interés del hijo", al igual que nuestro artículo 154 CC. El padre y la madre hasta la mayoría de edad o la emancipación del hijo tienen la obligación de velar por su salud, moralidad, seguridad, educación de tal forma que se desarrolle de forma satisfactoria con el respeto debido a su persona. Deben además informar al hijo en las decisiones que le conciernen de acuerdo con su edad y grado de madurez.

Cada uno de los padres debe de contribuir al sustento y educación de los hijos según los recursos propios y del otro cónyuge así como de las necesidades que precise el hijo, todo ello hasta que el menor llegue a la mayoría de edad (artículo 371.2 Code Civile), como establecen los artículos $143.2^{\circ}$ y $154.1^{\circ}$ del CC).

El hijo no puede abandonar el domicilio familiar sin el permiso de sus padres, y sólo puede ser alejado de él en los casos de necesidad que la ley establezca (artículo 371.3 Code Civile), que corresponde al $155.1^{\circ}$ CC. Tiene derecho a mantener relaciones personales con sus ascendientes, pudiendo impedir este derecho solamente motivos graves (artículo 371.4 Code); se corresponde con el 90 B del CC que dice sobre el convenio regulador: "Si se considera necesario, el régimen de visitas y comunicación de los nietos con sus abuelos, teniendo en cuenta siempre el interés del aquellos", el Juez de familia en interés del hijo, señalará el modo en que haya de relacionarse con un tercero,

197 S.A.P de Zaragoza de 31 de marzo de 2003 (AC 2003/1801) 
sea pariente o no (artículo 371.4, párrafo $\left.2^{\circ}\right)^{198}$.

No debe de ser separado el hijo de sus hermanos, salvo que las circunstancias aconsejen otra cosa, por lo que el Juez si es aconsejable regulará las relaciones personales entre los hermanos (artículo 371.5 Code). En nuestro artículo 92.4 CC dice: "Podrá también acordarse, cuando así convenga a los hijos, que la patria potestad sea ejercida total o parcialmente por uno de los cónyuges o que el cuidado de ellos corresponda a uno u otro procurando no separar a los hermanos" ${ }^{" 199}$ con lo que se puede ver que son muy similares.

El artículo 372 del Code dice que: "El padre y la madre ejercerán conjuntamente la patria potestad", con lo que se corresponde con nuestro artículo $156 \mathrm{CC}^{200}$. El artículo 372 del Code en su apartado $3^{\circ}$ dice: "No obstante, la patria potestad podrá ejercerse en común, en caso de declaración conjunta del padre y de la madre ante el Secretario Jefe del Tribunal de Gran Instancia o por decisión del Juez de Familia", mientras que en nuestro artículo 156.1 habla de "o uno sólo con el consentimiento expreso o tácito del otro", además de decir que serán válidos los actos que realice uno de ellos conforme al uso social y a las circunstancias o en situaciones de urgente necesidad.

Respecto a terceros de buena fe el acto realizado por un cónyuge se presume que cada uno de ellos está de acuerdo con el otro, en lo relativo a la persona del hijo (artículo 372.2 Code), lo cual es determinante al exigir responsabilidades por los hechos dañosos de los menores, expresándose casi en idénticos términos el apartado 3 de nuestro artículo 156 CC. Los artículos 373 y 373.1 del Code tratan de la ausencia, incapacidad o imposibilidad de uno de los padres de ejercer la patria potestad, la ejercerá el otro como establece el apartado cuarto de nuestro artículo 156 ya mencionado.

Cuando los padres se separen no tiene que repercutir sobre las reglas de atribución del ejercicio de la patria potestad. Cada uno de los padres debe mantener

\footnotetext{
198 Se corresponde de igual forma con el $94.2^{\circ}, 103.1^{\circ} ; 160.2^{\circ}$ y $3^{\circ}$ y 161 CC

199 Ver igualmente $103.1^{\circ}, 149.2^{\circ}$ y 159 CC

200 Por la Ley de 4 de enero de 1970, se sustituyó la palabra puissance paternelle, referida a la autoridad del padre sobre los hijos por autorité parentale, con lo que se consiguió la igualdad entre el marido y la mujer. En el Derecho español se ha llevado a cabo esa misma igualdad, aunque se ha conservado la denominación de patria potestad.
} 
relaciones personales con el hijo. Se puede privar a uno de los padres de la patria potestad si las circunstancias lo exigen, para lo que se encuentra facultado el Juez. En general los artículos 373.2, 373.2.1, 373.2.2 y 373.2.7 del Code Civile ${ }^{201}$, regulan la patria potestad que se corresponden con los artículos 92, 93, 94, 154 y 160 de nuestro CC.

En las separaciones hay que atender fundamentalmente el interés del menor como establecen las legislaciones estatales e internacionales, tanto de la ONU como europea, para evitar que el menor que es la parte más débil de los que intervienen en la separación

201 Artículo 373.2 Code civile: "La separación de los padres no repercute en las reglas de atribución del ejercicio de la patria potestad.

Cada uno de los padres debe mantener relaciones personales con el hijo y respetar los vínculos que éste tenga con el otro padre.

Cualquier cambio de residencia de uno de los padres, cuando modifique la forma de ejercicio de la patria potestad, deberá notificarse previamente, y en tiempo hábil, al otro padre. En caso de desacuerdo, el padre más diligente acudirá al Juez de Familia, que resolverá conforme a lo que exija el interés del hijo. El Juez distribuirá los gastos de desplazamiento y modificará en consecuencia la cuantía de la contribución por sustento y educación del hijo".

Artículo 373.2.1 Code Civile: "Si el interés del hijo lo exige, el Juez podrá confiar el ejercicio de la patria potestad a uno de los padres. No se podrá negar el otro padre el ejercicio del derecho de visita y el de tener en su compañía al hijo, sino por motivos graves.

Ese padre conservará el derecho y el deber de cuidar del sustento y educación del hijo. Habrá de ser informado de las decisiones importantes relativas a la vida de éste último. Y deberá respetar las obligaciones que le impone el artículo 371.2".

Artículo 373.2.2 Code Civile: "En caso de separación de los padres, o de estos respecto del hijo, la contribución a su sustento y educación tomará la forma de una pensión alimenticia pagadera según el caso, por uno de los padres al otro o a la persona a la que haya sido confiado el hijo.

La forma y las garantías de esta pensión alimenticia se fijarán en el convenio aprobado a que se refiere el artículo 373.2.7, o en su defecto, por el Juez.

Esta pensión puede adoptar, en todo o en parte, la forma de una asunción directa de los gastos mencionados en beneficio del hijo.

La misma puede pagarse, en todo o en parte, en forma de derecho de uso y habitación"

Artículo 373.2.7 Code Civile: "Los padres podrán acudir al Juez de Familia para que apruebe el convenio en el que establezcan la forma de ejercicio de la patria potestad, y en el que fijen su contribución al sustento y educación del hijo.

El Juez aprobará el convenio, salvo que le conste que no preserva suficientemente el interés del hijo o que el consentimiento de los padres no se ha prestado libremente". 
quede en una situación precaria con sus derechos básicos menoscabados por las tensiones que se originan entre los cónyuges para establecer el convenio. Por ello el Code en su artículo 373.2.7, exige la aprobación del Juez, para evitar esas complicaciones, al igual que lo establece el artículo 156.2 de nuestro CC. El consentimiento de los padres se ha de prestar libremente, sin que uno de ellos pueda imponerle al otro condiciones que entrañen desigualdad, por ello se exige la aprobación del Juez, ya que en caso contrario se vulneraría la Ley 4 de enero de 1970 en que se modificó el artículo 371.1 Code para que se diera una igualdad entre los padres para la educación y protección de los hijos.

\subsubsection{DERECHO ALEMÁN}

En el Derecho alemán se dan la disolución del matrimonio, la separación de hecho y el divorcio como en nuestro Código Civil. De la disolución trata en el Libro Cuarto, Sección Primera, Título Tercero en los artículos 1313 al 1318 del B.G.B.

Del divorcio trata en el Título 7, subtítulo 1, artículos 1564 a 1568, en los que se hace mención a la separación de hecho de los cónyuges y para llegar en determinadas circunstancias al divorcio.

El divorcio sólo es posible mediante sentencia judicial ${ }^{202}$. Para la obtención del divorcio es necesario que se dé un fracaso del matrimonio al cesar la vida en común de los cónyuges para lo que se exige como mínimo un año, con la solicitud de ambos o asintiéndolo el demandado. Si llevan separados menos de un año, el divorcio es posible si representa para el cónyuge demandante un perjuicio inexigible, por culpa del otro cónyuge. El plazo de un año o menos si se da un "perjuicio inexigible" es más largo que el de tres meses que establece el artículo 81 del Código Civil. En cuanto a la dicción "perjuicio inexigible" entiendo que se refiere a una situación insoportable para el cónyuge demandante, que entrañe riesgos graves para él o para los hijos, que se corresponde con el apartado segundo del artículo 81 del Código Civil en el que dice que

\footnotetext{
202 Artículo 1564 BGB: "El divorcio de un matrimonio sólo es posible mediante sentencia judicial a instancia de uno o de ambos cónyuges. El matrimonio se disuelve con la firmeza jurídica de la sentencia. Los presupuestos bajo los cuales puede solicitarse el divorcio resultan de las disposiciones siguientes".
} 
"no será preciso el plazo de tres meses para la interposición de la demanda cuando se acredite la existencia de un riesgo para la vida, la integridad física, la libertad, la integridad moral o libertad e indemnidad sexual del cónyuge demandante o de los hijos de ambos o de cualquiera de los miembros del matrimonio"; con lo que el Código Civil es más explícito que el artículo 1565 del BGB ${ }^{203}$.

Se presume fracasado el matrimonio si viven separados durante un año y los dos cónyuges solicitan el divorcio o uno de ellos con el asentimiento del otro y sobre todo si viven separados desde hace tres años, con lo que el plazo es superior al del Código Civil que establece tres meses como se vio anteriormente por la reforma de la Ley 15/2005 de 8 de julio. En cuanto a la vida separada se da cuando entre ellos no existe comunidad doméstica, al rechazarla uno de ellos. Se contempla igualmente el caso en que los cónyuges viven separados dentro de la vivienda conyugal, caso bastante frecuente en la actualidad por no disponer de medios económicos para adquirir otro inmueble.

En su artículo 1568 trata de la cláusula de inconveniencia en virtud de la cual, existiendo el fracaso del matrimonio, no se concede el divorcio por motivos especiales en atención a los hijos menores de edad del matrimonio, o de grave perjuicio para el otro cónyuge $^{204}$.

203 Artículo 1565 BGB: “1) Puede obtenerse el divorcio en caso de fracaso del matrimonio. El matrimonio se considera fracasado cuando cesa la comunidad de vida de los cónyuges y no puede esperarse que los cónyuges la reestablezcan.

2) Si los cónyuges todavía no viven separados durante un año, el divorcio del matrimonio sólo es posible si la continuación del matrimonio representase para el cónyuge demandante, por motivos imputables a la persona del otro cónyuge, un perjuicio inexigible".

${ }^{204}$ Artículo 1566 BGB: “1) Se presupone de manera irrefutable el fracaso del matrimonio si los cónyuges viven separados desde hace un año y ambos cónyuges solicitan el divorcio o el demandado asiente el divorcio.

2) Se presupone de manera irrefutable el fracaso matrimonial si los cónyuges viven separados desde hace tres años"

Artículo 1567 BGB: “1) Los cónyuges viven separados si entre ellos no existe una comunidad doméstica y es evidente que un cónyuge no quiere establecerla, porque rechaza la convivencia conyugal. Tampoco existe ya una comunidad doméstica si los cónyuges viven separados dentro de la vivienda conyugal.

2) La vida en común durante un breve periodo con el fin de servir a la reconciliación de los cónyuges no interrumpe ni suspende los plazos establecidos en el artículo 1566"

Artículo 1568 BGB: "No debe decretarse el divorcio, pese al fracaso del matrimonio, si y en tanto que la 
La patria potestad se regula en el BGB en el Libro Cuarto, Sección Segunda, Parentesco, Título Cinco, artículos de 1626 al 1698b. El artículo 1626 BGB trata del contenido de la patria potestad, por lo que, se corresponde con el artículo 154 CC. Habla de forma más general que el artículo 154 CC, al decir que tienen la obligación y el derecho de cuidar de su hijo menor, cuidar de su persona y de su patrimonio, tomar en consideración su cuidado y educación, la capacidad y necesidades crecientes, lo que se corresponde con el apartado segundo, puntos $1^{\circ}$ y $2^{\circ}$ del artículo 154 CC, cuando dice: "velar por ellos, tenerlos en su compañía, alimentarlos, educarlos y procurarlos una formación integral; representarlos y administrar sus bienes".

Dice que discutirán con el hijo, en tanto su nivel de desarrollo lo permitan, las cuestiones relativas a la patria potestad y promoverán la adopción de acuerdos, mientras que el artículo 154 CC dice que si los hijos tuvieran suficiente juicio deberán ser oídos siempre antes de adoptar decisiones que les afecten. Siempre estas cuestiones tanto en uno como en el otro código tienen que orientarse en interés del hijo ${ }^{205}$.

Para el caso de que los padres no se encuentren casados entre sí ostentan la patria potestad, si manifiestan que quieren asumirla o contraen matrimonio entre sí. En caso contrario y con carácter subsidiario la madre será la que ostente la patria potestad ${ }^{206}$.

subsistencia del matrimonio es necesaria, excepcionalmente, por motivos especiales en interés de los hijos menores de edad del matrimonio, o si en tanto que el divorcio representaría para el cónyuge demandado que no lo consiente un perjuicio tan grave, derivado de circunstancias extraordinarias, que aconseja excepcionalmente la subsistencia del matrimonio, incluso teniendo en cuenta el interés del cónyuge demandado”

205 Artículo 1626 BGB: “1) Los padres tienen la obligación y el derecho de cuidar de su hijo menor de edad (patria potestad). La patria potestad comprende el cuidado de la persona del menor (guarda de la persona) y de su patrimonio (administración del patrimonio).

2) Los padres toman en consideración, en su cuidado y educación, la capacidad y necesidades crecientes del menor tendentes al comportamiento responsable independiente del mismo. Discutirán con el hijo, en tanto su nivel de desarrollo lo permita, las cuestiones relativas a la patria potestad y promoverán la adopción de acuerdos.

3) El trato con ambos progenitores responde, como regla general, al bienestar del hijo. Lo mismo rige para el trato con otras personas con las cuales el hijo posee vínculos, si el mantenimiento de los mismos es favorable para su desarrollo".

206 Artículo 1626 a BGB : “1) Si los padres, en el momento del nacimiento del hijo, no están casados entre sí, ostentan la patria potestad conjunta, si ellos 
Los padres ostentan la patria potestad y la tienen que ejercer en interés del menor, por lo que deben intentar llegar a un acuerdo si surgen divergencias. Si no logran ponerse de acuerdo en algún asunto que sea de gran importancia para el hijo, uno de los cónyuges podrá solicitar al juzgado de familia, para que interceda entre ambos y señale a uno de ellos para decidir lo más conveniente, todo ello, con las debidas prevenciones. Este ejercicio de la patria potestad se corresponde con el artículo 156.2 en el que dice que cualquiera de los dos progenitores podrán acudir al Juez, quien, después de oír a ambos y al hijo si tuviera suficiente juicio y, en todo caso, si fuera mayor de doce años, atribuirá sin ulterior recurso la facultad de decidir al padre o a la madre, lo que quiere decir que el Juez, asignará el derecho a decidir a uno de ellos, que sea el que actué de una forma razonable en interés del hijo. La principal diferencia es que el BGB no habla de oír al hijo, ni de la edad de doce años ${ }^{207}$.

La patria potestad comprende la representación del hijo, cuyos padres le representan conjuntamente, estando legitimado cualquiera de los padres en caso de peligro inminente para ejercitar todas las acciones legales que sean necesarias para el bienestar del hijo, debiendo ser informado sin dilaciones el otro cónyuge (artículo 1629.1 BGB). De igual forma el apartado primero del artículo 156 CC establece que serán válidos los actos que realice uno de los cónyuges conforme al uso social y a las circunstancias o en situaciones de urgente necesidad, así como que la ejercen conjuntamente o uno de ellos con el consentimiento del otro, por lo que son casi idénticos si exceptuamos la dicción de "uno de ellos con el consentimiento del otro".

1- declaran que quieren asumir la patria potestad conjunta o

2- contraen matrimonio entre sí

2) En otro caso, la madre ostenta la patria potestad.

207 Artículo 1627 BGB: "Los padres ostentan la patria potestad de forma responsable y la ejercitan mediante acuerdos recíprocos favorables al bienestar del menor. En caso de diversidad de opiniones, deben intentar llegar a un acuerdo".

Artículo 1628 BGB: "Si los padres no pueden ponerse de acuerdo en un asunto concreto o en un determinado tipo de asuntos que conciernen a la patria potestad, cuya ordenación es de considerable significado para el hijo, el juzgado de familia, a petición de uno de los padres, puede ceder el derecho de decidir a uno de ellos. La cesión podrá ir acompañada de limitaciones o de modos. 
El artículo 1631 BGB establece el contenido y límites de la guarda de la persona, que abarca el deber y el derecho a cuidar, educar, vigilar y asignar residencia al hijo. No se puede emplear violencia en su educación, ni castigos corporales, ofensas morales u otros tratos o medidas degradantes. Pueden los padres en casos especiales solicitar el apoyo del juzgado de familia. En el artículo 154 CC, párrafo último, podrán los padres recabar el auxilio de la autoridad y fue suprimido por la Ley 54/2007 de 28 de diciembre, la expresión del artículo 154 inciso final, que decía, "podrán también corregir razonable y moderadamente a los hijos" ${ }^{\prime 208}$.

Los padres tienen una responsabilidad limitada frente a los hijos diciendo que : "deben responder frente al hijo de la misma diligencia que emplean en los propios asuntos", por lo que a mi juicio hay que entender la diligencia que observa un buen padre de familia del artículo $1104.2^{\circ}$ CC. Si ambos progenitores son responsables, deben responder como deudores solidarios, al igual que el artículo 1903.2 del CC y del artículo 61.3 LORPM. ${ }^{209}$

Para el caso de que se halle en peligro el bienestar del hijo, ya sea corporal, psíquico o moral, de su patrimonio, por descuido de los encargados de la patria potestad, el juzgado de familia tiene que intervenir adoptando las medidas necesarias para evitar esos males; en particular, cuando no se respeta la obligación de alimentos o la administración del patrimonio. El artículo 158 CC apartado $1^{\circ}$ dice que:" El Juez de oficio o a instancia del propio hijo, de cualquier pariente o del Ministerio Fiscal, dictará,

208 Artículo 1631 BGB: “1) La guarda de la persona comprende, en particular, el deber y el derecho de cuidar del hijo, de educarlo, de vigilarlo y de determinar su residencia.

2) Los hijos tienen derecho a una educación sin violencia. Son ilícitos los castigos corporales, ofensas morales y otras medidas degradantes.

3) El juzgado de familia debe apoyar, en supuestos especiales, a los padres a petición suya, en el ejercicio de la guarda de la persona."

Artículo 1631a BGB: "En asuntos concernientes a la formación y al oficio los padres deben tomar particularmente en consideración la aptitud y las preferencias del hijo. En caso de duda debe pedirse el consejo de un maestro o de otra persona idónea".

209 Artículo 1664 BGB: “1) En el ejercicio de la patria potestad los padres sólo deben responder frente al hijo de la misma diligencia que emplearon en los propios asuntos.

2) Si ambos progenitores son responsables de un daño, responden como deudores solidarios" 
$1^{\circ}$, las medidas convenientes para asegurar la prestación de alimentos y proveer a las futuras necesidades del hijo, en caso de incumplimiento de este deber por sus padres". De igual forma el artículo $164.1^{\circ} \mathrm{CC}$ establece que: "Los padres administrarán los bienes de los hijos con la misma diligencia que los suyos propios, cumpliendo las obligaciones generales de todo administrador y las especiales establecidas en la Ley Hipotecaria"210.

Cuando los padres viven separados y ostentan la patria potestad, cada uno de ellos puede solicitar al juzgado de familia que se le ceda total o parcialmente la patria potestad. La solicitud se debe estimar si el otro progenitor la consiente, a no ser que el hijo haya cumplido catorce años y no la consienta. De igual forma se debe estimar en el caso de que la supresión de la patria potestad conjunta y la cesión al solicitante sea lo mejor para el hijo. No debe estimarse esa solicitud, si la patria potestad, de acuerdo con otras disposiciones, deba regularse de forma diferente. Nuestro artículo $156.5^{\circ}$ es más escueto que el alemán y no habla del mayor de catorce años, se limita a decir que la patria potestad la ejerce el cónyuge con el que convive, que a instancia del otro progenitor, el Juez, podrá en interés del hijo, atribuir al solicitante la patria potestad para ejercerla conjuntamente, o distribuir entre el padre y la madre las funciones inherentes a su ejercicio $^{211}$.

210 Artículo 1666 BGB: “1) En caso de puesta en peligro del bienestar corporal, psíquico o moral del hijo o de su patrimonio por ejercicio abusivo de la patria potestad, por descuidar al hijo, por una negativa no culpable de los padres o por el comportamiento de un tercero, el juzgado de familia debe adoptar las medidas necesarias para evitar el peligro cuando los padres no quieren o no están en disposición de evitarlo.

2) Como regla general se considera que el patrimonio del hijo se pone en peligro cuando el titular de la administración vulnera su obligación de alimentos frente al hijo o las obligaciones inherentes a su cargo administrador o no sigue las órdenes del juzgado en relación con la administración del patrimonio.

3) El juzgado puede sustituir las declaraciones del titular de la patria potestad.

4) En asuntos relacionados con la guarda de la persona el juzgado puede acordar medidas frente a terceros"

211 Artículo 1671 BGB: “1) Si los padres que ostentan la patria potestad conjunta viven separados no sólo de forma temporal, cada uno de ellos puede solicitar que el juzgado de familia le ceda total o parcialmente la patria potestad.

2) Debe estimarse la solicitud en tanto que

1- el otro progenitor la consiente, a no ser que el hijo haya cumplido catorce años y no esté de acuerdo con la cesión, o

2- sea esperable que la supresión de la patria potestad conjunta y la cesión al solicitante sea lo mejor para el 
La madre puede ostentar de forma subsidiaria cuando los padres no están casados entre sí, como dispone el ya visto artículo $1626^{a}$, apartado 2 , el padre puede en este caso solicitar al juzgado de familia que le ceda total o parcialmente la patria potestad, pudiéndose estimar la solicitud si ello contribuye al bienestar del hijo. En este caso la patria potestad corresponde a ambos padres, si el juzgado de familia estima que ello no perjudica al menor (artículo 1672 BGB).

Cuando uno de los padres es incapaz de obrar se le suspende del ejercicio de la patria potestad. De igual forma sucede con el que tiene limitada o restringida la capacidad de obrar. La guarda del hijo en este caso, la ostenta él junto con el representante legal del hijo, es decir, se trata de un padre menor de edad en el que se dan algunas limitaciones y por tanto no está autorizado para la representación del hijo. Si se dan discrepancias entre el padre menor de edad y el representante legal del hijo (tutor o curador) se da preferencia al padre menor de edad. En caso contrario se aplica el artículo 1627.2 y 1628 BGB, ya vistos anteriormente, por no ponerse de acuerdo padre, menor y representante legal, con lo que resuelve lo que proceda el juzgado de familia ${ }^{212}$. En el artículo 157 CC establece lo mismo al decir que "el menor no emancipado ejercerá la patria potestad sobre sus hijos con la asistencia de sus padres, y a falta de ambos de su tutor; en caso de desacuerdo o imposibilidad, con la del Juez". Aunque el hijo menor queda emancipado al contraer matrimonio, necesita la asistencia de sus padres o tutor y a falta de estos por el Juez, sobre todo para determinados actos que sean trascendentes.

Si el juzgado de familia comprueba que durante un largo tiempo uno de los padres no puede ejercer la patria potestad por cambio de trabajo u otras causas, la patria potestad de ese padre se suspende. Durante el tiempo que la patria potestad se encuentra en suspenso el progenitor queda deslegitimado para su ejercicio. De igual forma cuando

bienestar del hijo.

3) No debe estimarse la solicitud en tanto que la patria potestad, conforme a otras disposiciones, deba regularse de forma diferente".

212 Artículo 1673 BGB: “1) La patria potestad de uno de los padres se suspende cuando éste es incapaz de obrar.

2) Lo mismo rige si tiene limitada la capacidad de obrar. La guarda de la persona del hijo es ostentada por él junto con el representante legal del hijo. En caso de discrepancia de criterio tiene preferencia la opinión del padre menor de edad, si el representante legal del hijo es un tutor o un curador; en otro caso se aplican los artículos 1627.2 y $1628 . "$ 
el juzgado de familia comprueba que la causa o causas que originaron la suspensión han desaparecido, vuelve a ser ejercida por el progenitor que la tenía suspendida ${ }^{213}$. En el artículo $156 \mathrm{CC}$, apartado $4^{\circ}$ dice que por "defecto o por ausencia, incapacidad o imposibilidad de uno de los padres, la patria potestad será ejercida exclusivamente por el otro"; en igual forma el artículo $1678.1^{\circ}$ BGB dice que si la misma se suspende, corresponde su ejercicio al otro progenitor y si es con carácter permanente el juzgado de familia la cederá al otro, cuanto interese al hijo.

En el derecho alemán al igual que en el español el hijo tiene derecho a relacionarse con cada uno de sus padres y los padres a su vez con el hijo. Los padres deben facilitar las relaciones del hijo con el otro progenitor o con la persona que tenga la guarda, pues el no hacerlo así, da lugar a que ello cause malestar al hijo haciéndole sufrir innecesariamente. Las relaciones de los padres con los hijos quedan siempre supeditadas al bienestar del hijo por lo que es el juzgado de familia el que se encarga de su regulación. Si la prohibición de relacionarse con el hijo es muy prolongada, sólo se puede adoptar para no poner en peligro el bienestar del hijo. Se puede ordenar por parte del juzgado de familia que la relación se lleve a cabo en presencia de un tercero, que puede ser una institución de ayuda a la juventud (artículo 1684 BGB).

Los abuelos tienen derecho al igual que los hermanos a relacionarse con el hijo si conviene a los intereses de éste. De igual forma puede hacerlo con otras personas próximas de su entorno familiar con los que tienen alguna responsabilidad material con él. En caso de problemas y discrepancias señalará el juez de familia lo más conveniente para el menor (artículo 1685 BGB). El artículo 160 CC dice que el padre o la madre, aunque no ejerzan la patria potestad, tienen el derecho a relacionarse con sus hijos menores; los abuelos y otros parientes y allegados tienen derecho a relacionarse con el hijo y sólo puede ser impedido mediando justa causa. Si hay discordias o controversias,

213 Artículo 1674 BGB: “1) La patria potestad de uno de los padres se suspende si el juzgado de familia comprueba que, durante largo tiempo, no puede ejercitar de hecho la patria potestad.

2) La patria potestad renace cuando el juzgado de familia comprueba que la causa de la suspensión ha desaparecido".

Artículo 1675 BGB: "Mientras la patria potestad está en suspenso, el progenitor no está legitimado para ejercitarla" 
el Juez a petición del menor, abuelos, parientes y allegados resolverá como tenga como más conveniente a los intereses del menor, teniendo en cuenta que esas relaciones no puedan conculcar las resoluciones judiciales que regulen esas relaciones.

Cada progenitor puede solicitar del otro, información sobre la situación personal del hijo, cuando se dé un interés legítimo y no resulte perjudicial para él. Cuando los padres viven separados no de forma temporal, se necesita el acuerdo de ambos en la toma de decisiones que sean relevantes y trascendentes para el hijo; en los asuntos relativos a la vida diaria del hijo, asuntos que no sean trascendentes, es suficiente con las decisiones que tome el progenitor con el que convive el hijo, para estos casos si se dan discrepancias serán resueltas por el juez de familia.

Si se trata del cónyuge de un progenitor, que ostenta en exclusiva la patria potestad, y que no es padre o madre del hijo, está autorizado, con el acuerdo del que ostenta la patria potestad, para tomar decisiones en asuntos de la vida diaria del hijo. De igual forma en caso de peligro inminente el cónyuge está legitimado para ejercitar todas las acciones legales que sean necesarias para proteger el bienestar del hijo; el progenitor que ostenta la patria potestad debe ser informado sin demora. En estos casos el juzgado de familia podrá limitar o excluir estas autorizaciones, si conviene al interés del hijo.

\subsubsection{EL DERECHO ITALIANO}

En el derecho italiano el artículo 2.048 exige la convivencia del menor con el progenitor, con lo que da lugar a que la responsabilidad recaiga solamente en el cónyuge que convive con el menor, lo que constituye una notoria injusticia, al recaer sobre él la responsabilidad del daño que ocasione el menor no emancipado.

Para poder exigir responsabilidad al cónyuge con el que no convive habitualmente el menor hay que estar a lo que dispone el artículo 155 del Códice que trata sobre los distintos aspectos del ejercicio de la patria potestad y en concreto en su apartado tercero en que exige que las decisiones más importantes de mayor interés para los hijos se han de tomar conjuntamente por ambos progenitores. Por ello se puede exigir responsabilidad al cónyuge no conviviente con el menor, por culpa in educando, al ser los dos responsables por haberle consentido al menor un acto ilícito, sobre el que los dos 
cónyuges habían tratado en conjunto; de igual forma se puede exigir responsabilidad al cónyuge no conviviente cuando haya tolerado al menor una actividad contraria a sus propios intereses.

Cuando se da el caso de convivencia temporal en el derecho de visita en que el menor se encuentra con el cónyuge no custodio se resuelve como si se tratara de un matrimonio normal, al exigirse responsabilidad al cónyuge custodio aunque el menor se halle con el otro cónyuge no custodio y a éste se le permite la cohabitación, por lo que se exige una responsabilidad solidaria entre ambos cónyuges. Con ello se consigue que el cónyuge no custodio continúe ocupándose del menor, así se trata de una solución distinta a la que establecen nuestros Tribunales al exigir la responsabilidad al cónyuge con el que se encuentra el menor en el momento de producirse los hechos que dan lugar a la responsabilidad.

En el caso de separación personal de los padres el hijo menor tiene el derecho de mantener una relación equilibrada y continua con cada uno de ellos, de recibir cuidado, educación e instrucción de ambos. Para realizarlo el juez que pronuncia la sentencia de separación de los cónyuges adopta y provee todo lo relativo a la prole, a cuál de los cónyuges es confiado, determina el tiempo de las visitas, fija la medida y el modo en que cada uno de ellos ha de contribuir al mantenimiento, cuidado, a la instrucción y a la educación de los hijos. De acuerdo con lo establecido por los padres, el juez aprueba lo expuesto anteriormente, si no es contrario a los intereses de los menores.

La patria potestad de los padres es ejercitada por ambos. Las decisiones de mayor interés para los hijos relativos a la instrucción, a la educación y a la salud son asunto de común acuerdo teniendo en cuenta la capacidad, las inclinaciones naturales y las aspiraciones de los hijos. En caso de desacuerdo la decisión se encarga al juez. El juez puede establecer que en lo relativo a las decisiones de ordinaria administración, los padres ejerzan la patria potestad separadamente.

Salvo acuerdos distintos libremente suscritos por las partes, cada uno de los padres provee al mantenimiento de los hijos en la medida proporcional a su propia renta. La asignación se adapta periódicamente a los índices de precios al consumo, en defecto de otros parámetros indicados por las partes o por el juez. Para comprobar los datos 
económicos de las partes el juez puede efectuar peticiones a la policía financiera.

En nuestro Código Civil en su artículo 160.1, contempla de igual forma el que el padre y la madre aunque no ejerzan la patria potestad tienen el derecho a relacionarse con sus hijos menores. Para la prestación de alimentos el artículo 158 CC dice que el Juez de oficio o a instancia del propio hijo, de cualquier pariente o del Ministerio Fiscal, dictará las medidas convenientes para asegurar la prestación de alimentos y proveer las futuras necesidades del hijo, en caso de incumplimiento de este deber por sus padres; con lo que dice lo mismo que el artículo 155 del Códice de forma más genérica. El artículo 146 CC establece que la cuantía de los alimentos será proporcionada al caudal o medios de quien los da y a las necesidades de quien los recibe, lo mismo que el Códice ${ }^{214}$.

${ }^{214}$ Artículo 155 Códice: (Provvedimenti riguardo ai figli).

"Anche in caso di separazione personale dei genitori il figlio minore ha il diritto di mantenere un rapporto equilibrato e continuativo con ciascuno di essi, di ricevere cura, educazione e instruzione da entrambi e di conservare rapporti significativi con gli ascendenti e con i parenti di ciascun ramo genitoriale.

Per realizare la finalitá indicata dal primo comma, il giudice che pronuncia a separazione personale dei coniugi adotta i provvedimenti relativi alla prole con exclusivo riferimento all'interese morale e materiale di essa. Valuta prioritariamente la possibilitá che i figli minori restino affidati a entrambi i genitori oppure stabilisce a quale di essi i figli sono sffidati, determina i tempi e le modalitá della loro presenza presso ciascun genitori, fissando altresi la misura e il modo con cui ciascuno di essi deve contribuire al mantenimento, alla cura, all'instruzione e all'educazione dei figli. Prende atto, se non contrari all'interesse dei figli, degli accordi intervenuti tra i genitori. Addota ogni altro provvedimento relativo alla prole.

La potestá genitoriale é esercita da entrambi i genitori. Le decisioni di maggiore interesse per i figli relative all'istruzione, all'educazione e alla salute sono assunte di comune accordo tenendo conto delle capacitá, dell'indinazione naturale e delle aspirazione dei figli. In caso di disaccordo la decisione é rimessa al giudice. Limitadamente alle decisioni su questioni di ordinaria administrazione, il giudice puó estabilire che i genitori esercitino la potestá separadamente.

Salvo accordi diversi liberamente sotto critti dalle parti, ciascuno dei genitori provvede al mantenimento dei figli in misura proporcionale al proprio reddito; il giudice stabilisce, ove necessario, la corresponsione di un assegno periodico al fine di realizare il principio di proporcionalitá, da determinare considerando:

1) le attuali esigenze del figlio;

2) il tenore di vita goduto dal figlio in costanza di convivenza con entrambi i genitori;

3) i tempi di permanenza presso ciascun genitori;

4) la valenza economica dei compiti domestici e di cura assunti da ciascun genitori.

L'asseguo é automaticamente adequato agli indici ISTAT in difetto di altro parametro indicato dalle parti o dal giudice. Ore le informazioni di carattere economico fornite dai genitori non risultino sufficientemente 
La relación del niño con los abuelos y otros parientes y allegados se reconoce en el artículo 160.2 del CC, al igual que en el artículo 155.1 Códice ya visto, en el que se reconoce el derecho del menor a relacionarse con sus ascendientes y parientes de cada uno de sus padres (conservare rapporti significativi con gli ascendenti e con i parenti di ciascun ramo genitoriale).

Este aspecto del menor a relacionarse con sus ascendientes y parientes es particularmente característico de la reforma del Códice, ya sentida desde hacía bastante tiempo por la doctrina italiana que lamentaba la ausencia de una norma que atribuyese la necesaria relevancia a las relaciones abuelos-nietos (nono - nipoti); aunque ahora no haya normas que reconozcan la debida relevancia a esas relaciones en el ámbito de la familia unida, es previsible que en el futuro se configuren normas para un derecho de los abuelos a relacionarse con los nietos, encontrando un soporte favorable en esta disposición del artículo 155.1 Códice $^{215}$.

El juez puede disponer la guarda del menor a uno solo de los padres cuando la guarda con el otro sea contraria a los intereses del menor. Cualquiera de los padres puede pedir la guarda del menor cuando se dan las circunstancias anteriores (artículo 155 bis Códice). En el artículo 170 CC se contempla la posibilidad de privar total o parcialmente de su patria potestad, por sentencia fundada en el incumplimiento de deberes propios de la misma o dictada en causa criminal o matrimonial al padre que no cumpla con esos deberes de asistencia de todo orden al menor, por ser una función al servicio de los hijos y lo que cuenta es siempre el interés superior del niño al tratarse de

documentate, il giudice dispone un accertamento della policia tributaria sui redditi e sui beni oggeto della contestazione, anche se intestati a soggetti diversi."

215 Altro aspetto particolarmente caratterizante la riforma é la previssione del diritto del minore di conservare rapporti significativi con gli ascendenti e con i parenti: da tempo infatti, la dottina lamentava l'assenza di una norma che attibuisse l'adequata rilevanza e tutela ai rapporti noni-nipoti. Al riguardo, si rileva che, sebbene (paradossalmente) ancora nessuna norma contempli la rilevanza di tali rapporti nell'ambito della famiglia unita, la tesi favorevole a configurare un diritto dell'avo a frequentare i nipoti trova ora un sopporto ulteriore e insupeabile nella disposizione in commento." (S. Patti, L'affidamento condiviso dei figli in FPS, 2006, p 300 ss, Giovanni Perlingieri, op.cit, pag 678) 
la persona más débil que interviene en el ejercicio de la patria potestad, con lo que se puede privar al progenitor que no lo cumpla al igual que el artículo 155 bis del Códice.

Los padres tienen derecho a pedir en cualquier momento la revisión de las disposiciones concernientes a la custodia de los hijos, la atribución del ejercicio de la patria potestad sobre ellos y de las eventuales disposiciones relativas a la medida y a la modalidad de la contribución (artículo 155 ter Códice Civile) ${ }^{216}$

Todas las disposiciones relativas a las relaciones entre padres e hijos ya sean de carácter personal como la custodia y atribución de la patria potestad, o patrimonial como el tipo y cuantía de la ayuda o la asignación de la casa familiar, pueden ser modificados en cualquier momento con la previsión adoptada por el tribunal a petición de los padres, si se dan cambios en relación con las condiciones establecidas en el tiempo o en la fecha en que fueron establecidos.

Uno de los motivos más importantes en orden a la revisión de las disposiciones originales se da en el artículo 155.4 apartado 2 del Códice que considera el cambio de residencia o del domicilio de uno de los cónyuges como un motivo más que suficiente para la justificación de modificar acuerdos de carácter económico por parte del otro cónyuge. Esta norma, está orientada a evitar o dificultar, una posible fuga del padre con el que el hijo convive o un alejamiento para comprometer la relación con el otro padre; con lo que al ser el cambio de domicilio un derecho constitucional, la solicitud de cambio en las condiciones de los acuerdos se ha de interponer cuando pueda afectar a las modalidades de la custodia ${ }^{217}$.

En el artículo $158.2^{\circ} \mathrm{CC}$, el Juez de oficio o a instancia de parte del propio hijo, de cualquier pariente o del Ministerio Fiscal, dictará: Las disposiciones apropiadas a fin de evitar a los hijos perturbaciones dañosas en los casos de cambio de titular de la potestad

216 Artículo 155 ter del Códice Civile: "I genitori hanno diritto di chiedere in ogni tempo la revisione delle disposicioni concernenti l'affidamento dei figli, l'attribuzione dell'esercizio della potestá su di essi e delle eventuali disposizioni relative alla misura e alla modalitá del contributo"

217 Giovanni Perlingieri, op.cit, pag 682

Artículo 155 quarter, apartado $2^{\circ}$ : “Nel caso in cui uno dei coniugi cambi la residenza o il domicilio, l'altro coniuge puó chiedere, se il mutamento interferisce con le modalitá dell'affidamento, la redefinizione degli accordi o dei provvedimenti adottati, ivi compresi quelli economici . 
de guarda, con lo que se da equivalencia con el 155 quarter, $2^{\circ}$ del Códice. Estas medidas del artículo $158.2^{\circ}$ se amplían a todo tipo de situaciones que excedan a las meramente paterno-filiales, cuando cambien las circunstancias, se pueden revisar, además de cumplir lo establecido en la LO 1/96 de Protección Jurídica del Menor, así como lo relativo a las Convenciones Internacionales suscritas por España.

El juez de acuerdo con el artículo 155 Códice, puede asumir de oficio o a instancia de parte medios de prueba y dispone además, la posibilidad de escuchar al menor que haya cumplido doce años, incluso aunque no haya alcanzado esta edad, si tiene la suficiente capacidad de discernimiento ${ }^{218}$. Lo mismo dispone el artículo 156.2 CC para el caso de desacuerdo entre el padre y la madre sobre la patria potestad.

Los hijos deben respetar a los padres así como contribuir en relación con su patrimonio o capital y renta al mantenimiento de la familia mientras convivan con ella ${ }^{219}$. El artículo 155 del CC habla de "obedecer a sus padres mientras permanezcan bajo su potestad y respetarles siempre", mientras que el Códice no habla de obedecer en su artículo 315. En su apartado segundo el artículo 155 CC dice que los hijos tienen que contribuir equitativamente según sus posibilidades, al levantamiento de las cargas de la familia mientras que convivan con ella, al igual que lo hace el artículo 315 Códice.

La modificación más importante en lo que se refiere a la reforma del derecho de familia ha sido a través de la Ley de 19 de mayo de 1975, número 151 que ha introducido el principio de paridad e igualdad moral y jurídica entre los dos cónyuges, profunda en cuanto a los fundamentos de innovación normativa, la cual ha transformado la patria potestad en potestá dei genitori, por entender que patria potestad se refiere sólo al padre y no a la madre, con lo que el padre estaría en un plano de superioridad sobre la madre; por el contrario con la expresión potestá dei genitori el plano entre padre y madre es de igualdad. Con ello los cónyuges son titulares de extensos derechos, el uno con el respeto

\footnotetext{
218 Artículo 155 sexies Códice Civile: "Prima dell'emanazione, anche in via provvisoria, dei provvedimenti di cui all'articolo 155, il giudice dispone, inoltre, l'audizione del figlio minore che abbia compinto gli anni dodici e anche di etá inferiore ove capace di discernimento"

219 Artículo 315 Códice (Doveri del figlio verso i genitori)

"Il figlio deve rispettare i genitori e debe contribuiré in relacione alle proprie sostanze e al proprio veddito, al mantenimento della familia finché convive con essa”
} 
del otro, como de igual forma son obligados recíprocamente por los extensos deberes y sobre la base de similares principios jurídicos de igualdad son vinculados a la potestad en el exclusivo interés de la prole ${ }^{220}$.

La Constitución italiana de 1948 sin duda ha influido sobre la nueva formulación de las relaciones jurídicas entre cónyuges y entre padres e hijos. En realidad es necesario referirse a los artículos 29 y 30 de la Constitución para poder individualizar la sugerencia normativa al futuro legislador de la reforma del año 1975, o sea el sustancial principio de igualdad sancionado en el artículo 29 de la Constitución el cual establece la igualdad de los cónyuges en el deber de mantener, educar e instruir a la prole.

El instituto familiar a través de la Constitución, asume así la fisonomía de una sociedad natural en la que la igual dignidad moral y jurídica de los cónyuges garantiza la tutela también de la prole no porque sea necesariamente de una relación conyugal, sino en cuanto más simplemente por haber procreado las dos personas a la prole, en el mantenimiento, la educación y la instrucción de los hijos debe prescindirse de la presencia de una relación conyugal, por lo que la Constitución ${ }^{221}$ impone tales deberes a

220 Sicuramente, la modifica piú importante dell'istituto é intervennta attraverso la Riforma del diritto di familia, con la L 19 maggio 1975, n⿳ 151, che ha introduto il principio di paritá ed iguaglianza morale e giuridica fra i due coniugi, profonda quanto fondamentale innovazione normativa la cuale ha del pari trasformato l'espressione "patria potestá" in "potestá dei genitori" (artículo 316)

In tale contesto, i coniugi sono titulare degli stessi diritti, l'uno nei riguardi dell'altro, come sono obbligati reciprocametne per gli stessi doveri e sulla base di simile principio giuridico di uguaglianza sono vincolati all'ufficio della potestá nell'interesse exclusivo della prole. (A.e.M. Fino cchiaro, Diritto di familia, p.1982)

221 Constitución Italiana:

Artículo 2: "La República reconoce y garantiza los derechos inviolables del hombre, ora como ciudadano, ora en el seno de las formaciones sociales donde aquel desarrolla su personalidad y exige el cumplimiento de los deberes inexcusables de solidaridad política, económica y social”.

Artículo 29: "La República reconoce los derechos de la familia como sociedad natural basada en el matrimonio.

El matrimonio se regirá sobre la base de la igualdad moral y jurídica de los cónyuges, con los límites establecidos por la ley en garantía de la unidad de la familia”

Artículo 30: "El deber y derecho de los padres a mantener, instruir y educar a los hijos, incluso a los habidos fuera del matrimonio.

En los casos de incapacidad de los padres, la ley dispondrá lo necesario para que sea cumplida la misión de los mismos. 
quienes han procreado, tutela la relación de filiación en cuanto tal, independientemente de la presencia de una relación conyugal; con ello el nuevo principio constitucional revoluciona así la atribución del poder de decisión dentro de la familia e impone normativamente la responsabilidad de los padres ${ }^{222}$.

El hijo está sujeto a la patria potestad de los padres si no ha alcanzado la mayoría de edad ni está emancipado. La potestad se ejerce de común acuerdo entre ambos padres. En caso de desacuerdo en cuestiones de particular importancia cada uno de los padres puede recurrir al juez sin formalidad alguna indicando la adopción de medidas más idóneas. Si existe un inconveniente peligroso de un grave perjuicio para el hijo, el padre puede adoptar la toma de medidas urgentes e impostergables.

El juez, escuchados los padres y el hijo, si es mayor de catorce años, sugiere la determinación de lo que considere más útil a los intereses del hijo y de la unidad familiar. Si la controversia o disputa continua, el juez atribuye el poder de decisión a aquél de los padres que, individualmente, crea el más idóneo para cuidar de los intereses del hijo (artículo 316 Códice). Este artículo se corresponde con el 154.1 del CC donde dice que estarán bajo la potestad del padre y de la madre. Por el artículo 156.1 el padre que realice un acto conforme al uso social será válido y en circunstancias o en situaciones de urgente necesidad. En el artículo 156.2 se contempla el caso en el que si se dan desacuerdos entre los padres, éstos podrán acudir al juez, quien oirá a ambos y al hijo si tuviera suficiente juicio y en todo caso si fuere mayor de doce años. Esto contrasta con el 316.5 en el que establece que el menor sea de como mínimo catorce años, que es la diferencia en cuanto a la edad, mientras que el Códice no dice nada de que estas medidas no podrán durar más de dos años como establece el 156.2 CC $^{223}$.

La ley garantiza a los hijos nacidos fuera del matrimonio plena protección jurídica y social, en la medida compatible con los derechos de los miembros de la familia legítima.

La ley dictará las normas y límites de investigación de la paternidad.

222 F. Prosperi. La familia “non fundata sul matrimonio”, p. 134 y E. QUADRI, La rilevanza constituzionale della familia, in RFP, 1983, p.1128

223 Artículo 316 Códice: (Esercizio della potestá dei genitori)

Il figlio é soggetto alla potestá dei genitori sino all'etá maggiore o all'emancipazione.

La potestá é esercitata di comune accordo da entrambi i genitori. In caso di contrasto su questioni di particolare importanza ciascuno dei genitori puó ricorrere senza formalitá al giudice indicando i provvedimenti 
En el apartado tercero del artículo 316 Códice, se contempla la posibilidad de que los padres puedan recurrir al juez, cuando se dan controversias entre ellos por no encontrar soluciones en sus relaciones internas de familia, ello puede representar un síntoma de que las relaciones entre los padres no atraviesan por un buen momento, por lo que puede dar lugar a una reclamación o solicitud de separación.

Esto prueba el limitado uso de este instrumento en la jurisprudencia, la cual considera superfluo tal recurso al juez puesto que, en el momento mismo que se dirige para resolver la cuestión, la relación entre los cónyuges es ya comprometida. Quiere ello decir que muy pocas parejas recurren al juez normalmente para resolver sus controversias y cuando lo hacen es por motivos muy serios en los que ya la situación se ha deteriorado de tal forma que se da la separación ${ }^{224}$.

El artículo 317 del Códice contempla los casos en que por ausencia, incapacidad o cualquier otro impedimento que haga imposible a uno de los padres ejercer la patria potestad, ésta será ejercida por el otro cónyuge ${ }^{225}$.

La patria potestad de los padres no cesa cuando después de la separación, disolución o anulación del matrimonio, el hijo en estos casos es confiado a uno de ellos.

che ritiene piú idonei.

Se sussiste un inconbente pericolo di un grave pregiudizio per il figlio, il padre puó adottare i provvedimenti ed indifferibile.

Il giudice, sentiti i genitori ed il figlio, se maggiore degli anni quattordici, suggerisce le determinazioni che li tiene piú nell'interesse del figlio e dell'unita familiare. Se il contrasto permane, il giudice attribuisce il potere de decisione a quello dei genitori che, nel singolo caso, ritiene il piú idóneo a curare l’interese dil figlio.

224 Appare anche ipotizzabile la circonstanza secondo la cuale il ricorso al giudice por un contrasto che non trovi la sua solucione all'interno del rapporto familiare, possa representare un sintomo, un indicio di una fase patológica che la relazione sta attraversando e che potrebbe anche dar luogo alla richiesta di una separazione.

Ció prova il limitato utilizzo nella realtá prática dello strumento di cui all'art 316, coma 3, considerando superfluo tale ricorso al giudice poiché, nel momento in cui al medesimo ci si rivolge per risolvere la cuestione, il rapporto fra i genitori-coniugi é giá compromesso. (Tribunal de Florencia).

Trib.min. Firenze, 11 marzo 1986 in DFP, 1986, p.1085

Trib. min. Firenze, 6 giugno 1983, ivi, 1983, p.1067

225 Artículo 317.1 Códice Civile (Impedimento di uno dei genitori)

"Nel caso di lontananza, di incapacitá o di altro impedimento che renda impossibile ad uno dei genitori l'esercizio della potestá, questa é esercitata in modo exclusivo dell'altro" 
Para su regulación en estos casos hay que estar a lo que dispone el artículo 155 del Códice, ya visto anteriormente.

En el artículo 156.4 CC se dice lo mismo que en el artículo 317.1 Códice: "En defecto o por ausencia, incapacidad o imposibilidad de uno de los padres, la patria potestad será ejercida exclusivamente por el otro. Vemos que no hay variaciones, pues las expresiones son equivalentes en uno y otro idioma, como "lontananza" que es ausencia en español.

El apartado primero del artículo 317 del Códice disciplina el impedimento del ejercicio de la patria potestad debido a la ausencia de uno de los padres, pero manteniendo la titularidad entre ambos.

Esto se produce en cuanto, materialmente, uno de los padres no está presente para asumir por sí mismo las decisiones cotidianas, sea de carácter excepcional para guardar la vida del menor y por tanto la ley ha previsto que todos los poderes y deberes inherentes a la patria potestad se concentren sobre el padre que permanece operativo, con el fin de mantener y salvaguardar los intereses del menor en todas las más variadas facetas $^{226}$.

La ausencia se debe presentar con la característica al menos de la temporalidad y por tanto no definitiva, prolongada en el tiempo y sin la certeza sobre el momento en el cual el impedimento podrá venir a menos ${ }^{227}$.

El artículo 317 bis Códice, dice que el padre que ha reconocido al hijo natural ostenta la patria potestad sobre él. Si el reconocimiento se hace por ambos padres, el ejercicio de la potestad lo ostentan conjuntamente ambos en el caso de que sean conviventes. Se aplica lo dispuesto en el artículo 316. Si los padres no conviven el ejercicio de la potestad lo ostenta el padre con el cual el hijo convive, o sea, si no convive con alguno de ellos, será el primero que le haya reconocido. El juez, en el exclusivo interés del menor, puede disponer distintas soluciones; puede también excluir de la patria potestad a los padres, disponiendo el nombramiento de un tutor.

\footnotetext{
226 A e M. FINOCHIARO, Diritto di familia, p.2020

227 Tribunal de Bari, 30 de diciembre de 1953, in RFI, 1954, voce patria potesá, nº 7; App. Florencia (Firenze), 12 gennaio 1959, in Git, 1959, pag 180
} 
El padre que no ejercita la patria potestad tiene el poder de vigilar su instrucción, su educación o las condiciones de vida del menor ${ }^{228}$.

Este artículo 317 bis Códice regula el ejercicio de la patria potestad de los padres naturales, atribuyendo la titularidad de la misma a aquellos que tienen reconocido con acto voluntario un hijo propio natural y la norma se considera aplicable también en la hipótesis de relación de filiación aunque pueda surgir por estimación judicial ${ }^{229}$.

Es evidente que este artículo es una traducción en precepto del principio de igualdad de los cónyuges por la unión de lo dispuesto en los artículos 3 (que es equivalente al 14 de nuestra Constitución del año 1978) y 30 de la Constitución de 1 de enero de 1948, en que es significativa la intención del legislador italiano de 1975 de establecer la paridad o igualdad entre los hijos legítimos y los naturales ${ }^{230}$.

Por analogía en materia de patria potestad la filiación legítima al equipararse a la ilegítima o natural, conduce a considerar que la norma en materia de ausencia o impedimento de uno de los padres, se puede aplicar lo dispuesto en el apartado 1 del artículo 317 Códice.

En el último apartado del artículo 317 bis reconoce al padre natural, el cual no ejercita la patria potestad, el derecho de vigilar sobre la instrucción, la educación y sobre las condiciones de vida del hijo menor, no asegurando, sin embargo, un derecho de participar en las decisiones de mayor interés para el menor, salvo la posibilidad de recurrir al juez en caso de que el padre considere que se trata de algo decisivo contrario a

\footnotetext{
228 Artículo 317 bis (Esercizio della Potestá)
}

$\mathrm{Al}$ genitore che ha reconosciuto il figlio naturale spetta la potestá su di lui. Se il riconoscimento é fatto da entrambi i genitori, l'esercizio della potestá spetta congiuntamente ad entrambi qualora siano conviventi. Si applicano le disposicioni del articolo 316. Se i genitori non convivono l'esercizio della potestá spetta al genitore col quale il figlio convive overo, se non convive con alcuno di essi, al primo che ha fatto il reconoscimento. Il giudice, nell'esclusivo interesse del figlio, puó disporre diversamente; puó anche escludere dall'essercizio della potestá entrambi i genitori, provvedendo alla nomina di un tutore.

Il genitore che non esercita la potestá ha il potere di vigilare sulla istruzione, sull'educazione e sulle condizioni di vita del figlio minore.

${ }^{229}$ L.FERRI, potestá dei genitore, p.52

${ }^{230}$ F. PROSPERRI, “La familia non fundata sul matrimonio”, p 135 ss 
los intereses del hijo ${ }^{231}$.

El juez puede privar a los padres de la patria potestad en interés del hijo como dice al final del apartado segundo, con lo que se corresponde con el artículo 170 CC.

El hijo no puede abandonar la casa de los padres o la del padre que tiene sobre él la patria potestad ni la morada de aquellos a quienes haya sido confiado.

En caso de que se aleje sin permiso, los padres pueden reclamarlo, si fuera necesario al juez tutelar (artículo 318 Códice) ${ }^{232}$.

Este artículo se relaciona con el artículo $154 \mathrm{CC}$ en su apartado $1^{\circ}$ en que se establecen los deberes y facultades sobre los hijos en el que dice: "velar por ellos y tenerlos en su compañía", por lo tanto si el menor se ausenta o abandona el hogar sin permiso de sus padres, está vulnerando la obligación que tiene de estar junto a ellos. Por otra parte, además, incumpliría el deber de obedecer siempre a sus padres que contempla el artículo 155 CC, con lo que estos dos artículos 154.1 CC y 155.1 CC, son los que se equiparan con el 318 del Códice italiano.

El más completo y correcto el cumplimiento de la patria potestad si se realiza mediante la convivencia cotidiana del hijo con los padres, algo imprescindible al cual el ordenamiento lo ha tenido en cuenta en más normas o, mejor lo ha identificado como elemento esencial para proteger o amparar y actuar en el interés moral y material de los hijos así como de un correcto desarrollo de su personalidad.

Este artículo es otro ejemplo de elección legislativa, en la cual se prevé a cargo del hijo menor la obligación de no abandonar la casa de los padres, también para poder cumplir por parte del hijo los deberes de colaboración y de compromiso en el cuidado de la familia según el artículo 315, y de todas maneras para hacer más fácil, en concreto más factible el deber de la patria potestad por parte de los padres ${ }^{233}$.

El juez conserva una esfera de discrecionalidad a los fines de poder valorar en

\footnotetext{
231 M. FINOCHIARDO, Diritto di familia, p.2037

232 Artículo 318 Códice (Abbandono della casa del genitore)

Il figlio non puó abandonare la casa di genitori o del genitore che esercita su di lui la potestá ne la demora da essi assegnatagli. Qualora se ne allontani senza permesso, i genitori opssono richiamarlo ricorrendo, se necesario, al giudice tutelare.
}

233 A. GORASSINI, L’allontanamento volontario del minore, p.14 
cada caso concreto, para comprobar, si bajo el alejamiento injustificado del hijo, no se halle una posible denuncia de una situación intolerable de agobio sobre este menor y luego el abandono sea en realidad el ejercicio de libertad personal dentro de sus propios límites ${ }^{234}$.

En caso de que sea verdad la existencia de circunstancias perjudiciales para el menor, que justificaran su voluntario alejamiento, el juez no puede disponer su regreso coactivo en consideración a los intereses propios de dicho menor y de las exigencias de desarrollo de su personalidad ${ }^{235}$.

\subsubsection{DERECHO PORTUGUES}

La mayor parte de los artículos del Código Civil portugués sobre la patria potestad han sido redactados por la Ley 496/77 de 25 de noviembre de 1977. Después la Ley 84/95 de 31 de agosto de 1995, ha modificado los artículos 1887 y 1905, añadiendo un artículo 1887A sobre relaciones de los hijos con sus hermanos y ascendientes; el artículo 1905 sobre separación judicial de personas y bienes, declaración de nulidad o anulación de casamiento.

Los hijos están sujetos a la patria potestad hasta la mayoría de edad o su emancipación (artículo 1877). Los padres en interés de los hijos, deben velar por su seguridad, salud, alimentarlos, dirigir su educación, representarlos, incluso a los todavía no nacidos (nascituros) y administrar sus bienes. Los hijos a su vez deben obediencia a los padres, los cuales de acuerdo a la madurez de los hijos deben tener en cuenta sus opiniones en los asuntos familiares más importantes y reconocerles un cierto grado de autonomía. Ello se encuentra de acuerdo con lo establecido en la legislación internacional de menores ${ }^{236}$.

\footnotetext{
234 M. GIORGIANI, Della potestá dei genitori, p.341

235 Tribunal, min, Trieste, 21 giugno 1998, in DFP, 1988, p.1412

236 Artigo 1878 (Contenido do poder paternal)

1) Compete a os país, no interesse dos filos, velar pela seguranca e saude destes, prover a seo sustento, dirigir a sua educacao, representa-los, ainda que nascituros, e administrar os seus bens.

2) Os filos deven obediencia a os país; estes, porén, de acordó com a maturidade dos filos, devem ter em conta a sua opiniao nos asuntos familiares importantes e reconhecerles autonomía na organizacáo da propia vida.
} 
Si los hijos no han completado su formación al llegar a la mayoría de edad o su emancipación, los padres deberán facilitar a los hijos durante un tiempo razonable, el poder seguir recibiendo su formación profesional hasta que la finalicen (artículo 1880). Los padres de acuerdo con sus medios económicos deben procurar a sus hijos una formación física, moral e intelectual, sobre todo en especial a los disminuidos físicos y mentales; esta formación o instrucción ha de ser tanto general como profesional, de acuerdo con sus posibilidades y teniendo siempre en cuenta las aptitudes e inclinaciones de los menores. Esto se corresponde con el artículo 154 CC español en el punto $1^{\circ}$ del apartado segundo en el que habla de educarles y procurarles una formación integral.

En lo que se refiere a la educación religiosa, la deciden los padres hasta que tienen la edad de dieciséis años ${ }^{237}$.

Los menores no pueden abandonar la casa paterna. La patria potestad pertenece a ambos padres, ejerciéndola de común acuerdo y de no existir este acuerdo pueden recurrir al Juez, que tratará de llegar a ponerles de común acuerdo; pero si tampoco fuera posible, el Juez oirá antes de decidir al hijo mayor de catorce años, excepto si lo desaconsejan circunstancias graves. En el artículo 156 CC, apartado segundo, dice que cuando hay desacuerdo se puede acudir al Juez, después de oír a ambos y al hijo si tuviera suficiente juicio y en todo caso si fuera mayor de doce años con lo que nuestro Código adelanta la edad de escuchar al hijo, basándose en la capacidad de discernimiento del menor y en todo caso a los doce años, con lo que adelanta dos años sobre el artículo 1901 del Código portugués que lo hace a los catorce.

Cuando uno de los padres no puede ejercer la patria potestad por ausencia, incapacidad u otro impedimento, será ejercida por el otro cónyuge (artículo 1903); de igual forma sucede cuando fallece uno de los cónyuges, ejerciéndola el cónyuge que

237 Artigo 1885 (Educacáo)

1) Cabe aos país, de acordó com as suas posibilidades, promover o desenvolvimento físico, intelectual e moral dos filos.

2) Os país deven proporcionar aos filos, em especial aos disminuidos física e mentalmente, adecuada instrucáo geral e profissional, correspondente, na medida do possivel, as aptidóes e inclinacóes de cada um.

Artigo 1886 (Educacáo religiosa)

Pertenece aos país decidir sobre a educacáo religiosa dos filos menores de dezasseis annos. 
sobrevive, es decir, el que queda viudo, se encarga de ejercerla (artículo 1904). Estos dos artículos dicen lo mismo que el artículo 156, apartado cuarto de nuestro Código Civil.

En los casos de divorcio, separación judicial de personas y bienes, declaración de nulidad de matrimonio, los alimentos debidos al hijo y la forma de su prestación serán regulados por acuerdo de los padres, todo ello sujeto a la aprobación judicial, que podrá ser recurrida si no respeta los intereses del menor por ser la parte más débil de la relación, la cual tiene preferencia sobre otros intereses. Ello incluye el derecho a mantener una relación, directa, fluida y frecuente con el cónyuge al que no le haya sido confiada la guarda (en portugués grande proximidade). La guarda se puede confiar a cualquiera de los padres y si se dan circunstancias graves en que peligren la salud, educación, o la formación moral del menor, podrá encomendarse la guarda a una tercera persona o establecimiento de asistencia y reeducación, apropiado para el menor (artículo 1905).

Los padres no pueden injustificadamente privar a los hijos de convivencia con los hermanos y ascendientes. Los hermanos en los casos de separación se ha de procurar que permanezcan unidos, si ello es posible pues en caso contrario se les hace sufrir al separarles de sus otros hermanos, por ello en el artículo 92, $4^{\circ}$ Código Civil dice que el cuidado de los hijos corresponda a uno u otro (de los cónyuges) procurando no separar a los hermanos. De igual forma sucede con los abuelos, y a su vez los abuelos sufren al no poder relacionarse con sus nietos como todo abuelo desea; por ello el artículo 160.2 Código Civil dice que "no podrán impedirse sin justa causa las relaciones personales del hijo con sus abuelos y otros parientes y allegados". Con lo que coincide lo establecido en nuestro Código Civil con el artículo 1887A del Código portugués, reformado por la Ley 84/95 de 31 de agosto en la que se permite a los dos padres en condiciones de igualdad el ejercicio de la patria potestad ${ }^{238}$.

\footnotetext{
${ }^{238}$ Por la Ley 84/95 de la Asamblea de la República se añadió el artículo 1887 A para la convivencia entre menores, hermanos y ascendientes. Se modificó el artículo 1905 para ejercer en igualdad de condiciones la patria potestad por ambos cónyuges y el artículo 1906 para aplicar esa igualdad a quienes no hubieran contraído matrimonio.

Artígo 1905 Código Civil (divorcio, separacáo judicial de pessoas e bens, declaracáo de nulidade ou anulacáo do casamento)
} 
Si el hijo es entregado a una tercera persona o a un establecimiento de asistencia y educación, pasan a estas personas o establecimientos los derechos y deberes que ostenten los padres, para poder realizar correctamente sus funciones tutelares. El Tribunal decide cuál de los dos progenitores ejerce la patria potestad en la parte de funciones no transferidas en el punto anterior (Artículo 1907 Código Civil portugués). El artículo 172 del Código Civil español dice en su apartado primero que "la asunción de la tutela atribuida a la entidad pública lleva consigo la suspensión de la patria potestad o de la tutela ordinaria", aunque a la entrega de la guarda se hace por escrito y se recuerda a los padres las responsabilidades que siguen manteniendo respecto del hijo.

Cuando los progenitores no se encuentran unidos por matrimonio, después de nacer el menor la patria potestad la ejerce el progenitor que tiene la guarda del hijo. A los efectos del apartado anterior se presume que la madre tiene la guarda del hijo, lo que puede rebatirse judicialmente. Si los progenitores conviven maritalmente, el ejercicio de la patria potestad pertenece a ambos cuando declaren delante de un funcionario del Registro Civil ser esa su voluntad (artículo 1911 Código Civil portugués)

Los padres tienen obligación de cumplir con los deberes inherentes a la patria potestad y si no lo hacen, quiere decir que se da una dejación de esos deberes, con lo que se pone en peligro la seguridad, la salud, la formación moral o la educación del menor. En estas circunstancias el Tribunal a petición del Ministerio Público o de cualquier pariente del menor, tomará las disposiciones necesarias para confiar al menor a una tercera persona o a un establecimiento de educación apropiado. En este caso los padres

1) Nos casos de divorcio, separacáo judicial de pessoas e bens, declaracáo de nulidade ou anulacáo do casamento, o destino do filho, os alimentos a este devidos e forma de os prestar seráo regulados por acordó dos país, sujeito a homologacáo do tribunal; a homologacáo será recusada se o acordó náo corresponde ao interesse do menor, incluido o interesse deste em manter con aquelle progenitor a quem nao seja confiado una relacáo de grande proximidade.

2) Na falta do acordo, o Tribunal decidirá de harmonía com o interesse do menor, incluindo o de manter una relacáo de grande proximidade com o progenitor a quem náo seja confiado, podendo a sua guarda caber a qualquer dos país, ou quando se verifique alguna dos circunstancias previstas no artigo 1918, a terceira pessoa on estabelecimento de reeducacáo on assisténcia.

Artigio 1887 A (Convivo com irmáos e ascendentes)

Os país náo podem injustificadamente privar os filos do convivio com os irmáos e ascendentes. 
pueden ejercer su patria potestad en todo aquello que no se oponga a lo establecido por el tribunal.

Al confiar la guarda del menor a otra persona o a un establecimiento los padres tendrán derecho a un régimen de visitas para relacionarse con el menor, siempre y cuando no perjudique los intereses del mismo ${ }^{239}$. Ello se corresponde con el artículo 1584 que dice que "el Juez dictará las demás disposiciones que considere oportunas, a fin de apartar al menor de un peligro o de evitarle perjuicios" y de igual forma con el artículo $160.1^{\circ}$ que dice: "El padre y la madre, aunque no ejerzan la patria potestad, tienen el derecho a relacionarse con sus hijos menores..."

En consecuencia, en el derecho comparado, francés, alemán, italiano y portugués, las disposiciones relativas a la patria potestad, son muy similares a las del derecho español y ello es debido a que a partir de los años setenta, se ha operado un cambio en los ordenamientos para equiparar a la madre con el padre en igualdad de condiciones, al igual que se ha hecho en España por la Ley 11/1981, de 13 de mayo, de modificación del código civil en materia de filiación, patria potestad y régimen económico del matrimonio.

239 Artigo 1918 (Perigo para aseguranca, saude, formacao moral e educacáo do filho)

Quando a seguranca, a saude, a formacáo moral ou a educacáo de un menor se encontren em perigo e náo seja caso de inibicáo do exercicio do poder paternal, pode o tribunal a requerimento do Ministerio público ou de qualquer das pessoas indicadas do $\mathrm{n}^{\mathrm{o}} 1$ do artigo 1915, decretar as providencias adequadas designadamente confía-lo a terceira pessoa ou a estabelecimento de educacáo ou assisténcia.

Artigo 1919 (Exercicio do poder paternal)

1) Quando tiver sido decretada alguna dos providencias referidas no artigo anterior, os país conservan o exercicio do poder paternal em tudo o que come la se nao mostre inconciliável.

2) Se o menor tiver sido confiado a terceira pessoa on a estabelecimento de educacáo on asistencia, será estabelecido um regime de visitas a os país, a menor que, excepcionalmente, o interesse o filho o desaconselle.

Los artículos y jurisprudencias del epígrafe 8.7.7.3 se han obtenido del Códice Civile, Giovanni Perlingieri, Edizioni Scientifiche Italiane. 


\subsubsection{ESTATUTO DEL CÓNYUGE DEL PROGENITOR EN LA LEGISLACIÓN EUROPEA}

En los tiempos actuales se da cada vez un mayor número de familias recompuestas o reconstituidas, en las que de los nuevos esposos, uno de ellos tiene hijos menores a su cargo de su anterior unión, respecto de los cuales el cónyuge no progenitor realiza sobre ellos funciones tuitivas o de patria potestad que no están a veces reconocidas y reguladas por el Derecho. En Francia, actualmente conviven uno de cada diez menores con un padrastro o una madrastra, que es la persona que sin vínculos de paternidad o maternidad han venido siempre desarrollando funciones de padre o madre, respecto de su consorte.

Cuando cesan las relaciones entre una pareja en la que hay hijos comunes, si después se constituye una nueva pareja ya sea mediante matrimonio o pareja de hecho, da lugar a lo que se denomina una pareja reconstituida, en la que uno de los antiguos cónyuges de la anterior pareja se une con un tercero que es el llamado padrastro o madrastra. Ello da lugar a unas nuevas relaciones entre el padrastro o madrastra y el hijastro, relaciones en las que hay que determinar si existen o no derechos y obligaciones entre unos y otros; en el caso de haberlos deben ser regulados jurídicamente en determinado grado de extensión y contenido.

En los ordenamientos civiles de nuestro entorno el belga, el italiano y el español no tienen nada previsto en las relaciones entre el padrastro y el menor. La ley británica permite al padrastro compartir la patria potestad con los progenitores, sin tener en cuenta la orientación sexual de la pareja, ni su estatuto jurídico. Con respecto a los derechos alemán, danés y holandés, la participación del padrastro en la patria potestad, es posible, sólo en el caso de que sea ejercida por uno sólo de los progenitores. El Derecho sueco sólo reconoce al padrastro esa posición jurídica para el caso de menores inmersos en el seno de parejas homosexuales. Para el Derecho suizo sólo considera al padrastro como un mero auxiliar del progenitor ${ }^{240}$.

${ }^{240}$ Lasarte Carlos, Relaciones Paterno-Filiales, Congreso IDADFE 2011, Vol II, Madrid 2014, pag 127 y ss, Estatuto del Cónyuge del Progenitor en la Legislación Europea, artículo de D. Iñigo Mateo Vila. 


\subsection{SITUACIÓN EN FRANCIA}

En Francia se admite una intervención del padrastro en el ejercicio de la patria potestad en dos disposiciones del Código Civil. Una de ellas se contempla en el artículo 377 del Código llamada "delegación voluntaire", que le permite al padrastro ejercer total o parcialmente la patria potestad sobre el menor. La otra disposición se llama "delegatión partage", en la que se le permite a dicho padrastro participar en el ejercicio de la patria potestad junto con uno de los progenitores y hasta con los dos de acuerdo con lo establecido en el artículo 377.1 del Código.

Estas disposiciones no son específicas para el padrastro o madrastra, sino que se pueden incluir a ellos o simplemente a terceros, o instituciones, pues el Código no dice nada sobre derechos de personas que convivan con el cónyuge, sobre los hijos.

La délégation voluntaire de los progenitores a un tercero se regula en el artículo 377, apartado primero del Código, en que se prevé que el juez pueda delegar total o parcialmente el ejercicio de la patria potestad en algún allegado de confianza a petición de los padres, de forma conjunta o separada cuando las circunstancias lo exijan.

La délégation-partage, introducida por la Ley no 2002-305, de 4 de marzo de 2002, relativa a la patria potestad, se contempla en el artículo 377.1 del Código, en ella la delegación total o parcial de la patria potestad ha de hacerse en sentencia dictada por el Juez de Familia. La sentencia de delegación podrá prever, para las necesidades educativas del hijo, que sus padres o uno de ellos, compartan todo o parte del ejercicio de la patria potestad con el tercero delegado. Este reparto requiere el consentimiento del padre o de los padres en cuanto que ellos ejerzan la patria potestad. Esta disposición es más amplia que la delegación voluntaria al permitir al padrastro o madrastra participar en el ejercicio de la patria potestad sin que ninguno de los progenitores pierda sus prerrogativas.

El artículo 371 fue introducido igualmente por la Ley n ${ }^{\circ}$ 2002-305 de 4 de marzo, y ha contribuido a regular la familia recompuesta al reconocer el derecho a tener y conservar por parte del menor, relaciones personales con un tercero ya sea o no pariente, con lo que se puede incluir al padrastro. El modo de realizarlo lo señala el Juez de Familia de acuerdo con el apartado segundo de dicho artículo que dice; "Si fuere de interés del hijo, el Juez de Familia señalará el modo en que haya de relacionarse con un 
tercero, sea pariente o no".

La Cour de Cassation, por resolución de 24 de febrero de 2006, autorizó la delegación parcial de la patria potestad a una madre a favor de su compañera, a la que se encontraba unida como pareja de hecho. Se basa la resolución en el artículo 377, párrafo primero, que dice: "El padre y la madre, conjunta o separadamente, y cuando las circunstancias lo exijan, podrán acudir al Juez a fin de delegar, en todo o en parte, el ejercicio de la patria potestad en un tercero, miembro de la familia, allegado digno de confianza, institución autorizada para acoger a menores o Servicio Departamental de Ayuda Social a la Infancia"; con lo que vemos que no se opone a que esa madre, al ser única titular de la patria potestad delegue su ejercicio en todo o en parte, en la persona con la que convive en unión estable y continua, cuando las circunstancias lo exijan y la medida sea conforme al interés superior del menor. Esta sentencia es importante y de tener en cuenta por haber reconocido la Cour de Cassation, la figura de la madrastra en el interior de la pareja homosexual.

En Francia se ha tratado sobre la elaboración de un "Estatuto del cónyuge del progenitor" que debería de haber entrado en vigor en 2009, para dar solución a la problemática que origina el alto número de familias recompuestas, con la posición jurídica que ocupa el nuevo cónyuge o conviviente del progenitor ya sea padrastro o madrastra, en francés beau-parent. La relación del beau-parent con el menor suscita problemas, pues la ley si le da un mayor protagonismo, el otro cónyuge no conviviente con el menor quedaría marginado, lo que vulnera la legislación que concede el derecho a conservar lazos afectivos con el menor a los dos progenitores. Por otra parte, si un padrastro sucede a otro, ello originaría para el menor una situación de precariedad e inestabilidad, totalmente contraria a la estabilidad que el menor necesita para un desarrollo armónico de su personalidad. Para solucionar este problema, la única forma es aplicar un tipo de relación más estable que la que contemplan los artículos 377 y 377.1 del Códe Civil, con el instituto de la adopción, en que no se da la temporalidad por ser irrevocable.

La doctrina considera que el padrastro o madrastra sólo deben tener responsabilidades sobre los menores en casos realmente excepcionales y en beneficio del 
menor, como pueden ser los siguientes:

- Cuando los progenitores se nieguen a escolarizar al menor o a intervenirle quirúrgicamente de urgencia.

- Para poder recoger al menor del centro educativo, bastando que el progenitor hubiera dado el nombre de su nuevo cónyuge o conviviente.

- Para que el Juez de Familia pueda confiar al padrastro o madrastra la guarda del hijo del cónyuge o conviviente fallecido, siempre teniendo en cuenta el interés del menor $^{241}$.

\subsection{SITUACIÓN EN EL REINO UNIDO}

En el Reino Unido, a partir de una ley de 1989 (Children Act 1989) que entró en vigor en 1991, el padrastro (stepfather) puede, basándose en que ocupa la misma vivienda habitual del menor, dirigirse al Juez para solicitar que le sea adjudicada conjuntamente con los progenitores la patria potestad (parental responsibility). Esta atribución es automática e independiente del estatuto jurídico y de la orientación sexual de la pareja reconstituida.

La otra ley que existe es la de Adoption and Children Act 2002, mediante la cual se permite al padrastro la adquisición de la patria potestad sobre el menor en el caso de parejas reconstituidas homosexuales y siempre que exista inscripción de ella en el registro correspondiente. Se requiere un acuerdo con los titulares de la patria potestad sobre el menor y la aprobación del Juez.

El tercero que consiga la patria potestad, sus obligaciones y derechos son análogos a los de los progenitores, con lo que será ejercida la patria potestad por las tres personas simultáneamente.

En estos casos el menor debe de ser consultado para que conozca, en la forma apropiada a su edad, el alcance de la decisión, llegando su duración hasta que el menor cumpla la edad de dieciséis años, pudiendo ser prorrogada en casos extraordinarios, por causas justificadas.

241 Ibidem pag 129 y ss 
El padrastro ha de tener necesariamente regulada su relación con el progenitor por matrimonio o pareja de hecho, no puede ser cualquier otro tercero, se exige esta formalidad. Debe además demostrar hallarse involucrado en la vida del menor y comprometerse en el interés del menor. La asignación de la patria potestad a un tercero, no tiene necesariamente que representar una disminución de la de los progenitores, pudiendo en algunos supuestos previstos legalmente, el no requerirse la intervención del progenitor para adjudicar la patria potestad al padrastro o a un tercero.

\subsection{SITUACIÓN EN ALEMANIA, DINAMARCA Y PAISES BAJOS}

En estos países existe una norma específica relativa al ejercicio por parte del padrastro de la patria potestad, hallándose supeditada a que sea ejercida por uno solo de los progenitores, de suerte que se concede prioridad a la filiación biológica, con lo que se limita el acceso de aquel a este ejercicio.

En Alemania, desde el año 2001 el padrastro tiene otorgado por ley una forma limitada de patria potestad. La ley de pareja de hecho registrada (eingetrangene Lebenspartnerschaft) que entró en vigor el 1 de agosto de 2001, concede al padrastro que constituya pareja de hecho registrada, la patria potestad reducida sobre el menor, con la condición de que el progenitor que forme pareja con él sea el único titular de la patria potestad.

El padrastro no puede ser titular de la patria potestad reducida en dos casos: Primero, si no está casado con el cónyuge progenitor ni vinculado a éste por una pareja de hecho registrada; Segundo, si la filiación del menor estuviera fijada respecto de ambos padres dado que aunque éstos se encuentren separados, ejercerán conjuntamente la patria potestad. El padrastro puede decidir ordinariamente sobre asuntos de la vida cotidiana del menor y en asuntos de gravedad puede realizar actos jurídicos que sean necesarios y afecten al menor, en cuyo caso tendrá que informar de forma inmediata al progenitor. El Juez de familia puede decidir sobre este ejercicio de la patria potestad, cuando las circunstancias lo aconsejen y siempre en interés del menor. La patria potestad finalizará cuando concluyan las relaciones de la pareja formada por el cónyuge y el progenitor. 
En Dinamarca desde 1985, los padres biológicos pueden acordar el transferir la patria potestad al padrastro, tanto si éste está casado como si no, pero no se permiten las parejas reconstruidas de homosexuales. Para que este acuerdo sea válido hay que comunicarlo a la administración local.

En los Países Bajos, desde el 1 de enero de 1998, las parejas independientemente de su tipo, casadas o no y homosexuales, pueden obtener del Juez la titularidad de la denominada autoridad común que no es otra cosa que la patria potestad. Es necesario que la patria potestad se ejerza por uno sólo de los cónyuges o progenitores en el momento de la solicitud; que el padrastro que vaya a ejercer la patria potestad del menor mantenga relaciones personales con él; y que los dos miembros de la pareja reconstituida se encarguen del menor al menos un año.

Este tipo de relación se hará siempre en beneficio del menor, el cual deberá ser escuchado aunque tenga menos de doce años y sin que sus relaciones con el otro progenitor se vean perjudicadas.

Si el otro progenitor vive, el Juez deberá asegurarse de que el que opte por la patria potestad haya atendido al menor durante un año y que el progenitor ejerciente de la patria potestad la haya ostentado, como mínimo durante tres años.

Desde el 1 de enero de 2002 se atribuye la patria potestad común de forma automática a las parejas reconstituidas, ya se traten tanto de heterosexuales como homosexuales, casados o parejas de hecho en los casos siguientes: Primero, que el menor haya nacido durante la vida de pareja reconstituida; Segundo, que la filiación se encuentre referida a un solo progenitor ${ }^{242}$.

\subsection{SITUACIÓN EN SUIZA}

En Suiza la situación del cónyuge del progenitor se encuentra regulada en el artículo 299 de su Código Civil, siendo su régimen idéntico para las parejas del mismo o distinto sexo.

El cónyuge del progenitor es un auxiliar o asistente de forma que no ostenta

242 Ibidem, pags 133 y ss 
ningún derecho ni deber directo sobre el menor, pudiendo sólo tener la posibilidad de representar al progenitor en el caso de que "las circunstancias lo exijan".

Por Ley Federal de 18 de junio de 2004, se aplica el mismo artículo 299 a las parejas del mismo sexo ${ }^{243}$.

\subsection{SITUACIÓN EN BÉLGICA}

Las legislaciones belga, española e italiana excluyen a terceras personas del ejercicio de la patria potestad, con lo que no contemplan de ningún modo la figura del cónyuge del progenitor, al que consideran un tercero sin ningún poder sobre el menor.

En Bélgica el padre y la madre ejercen la patria potestad aunque no vivan juntos, por lo que al cónyuge del progenitor se le considera un tercero sin que tenga ningún vínculo ni derecho, ni deber sobre el menor.

Desde el año 2001 se han presentado propuestas para la creación de un estatuto del parentesco o de la paternidad social, para asignar derechos y deberes al cónyuge del progenitor e incluso en determinados casos a terceros, sin relación de filiación con el menor, para poder ejercer la patria potestad. Para ello se exige la existencia de un vínculo ejecutivo con el menor, en interés de éste, el haberse encargado de su educación durante tres años como mínimo, siendo la extensión de esta atribución de la patria potestad variable según el caso de que se trate.

El Gobierno belga, a través del Consejo de familia, en los años 2003 y 2004 se pronunció en contra de fragmentar la titularidad de la patria potestad, por lo que consideró necesario seguir sin la concesión de un estatuto jurídico al cónyuge del progenitor y que la patria potestad sea conjunta para ambos progenitores aunque se encuentren separados.

No obstante el Tribunal Constitucional se está pronunciando a favor de definir de qué forma, en qué condiciones y según qué procedimiento la patria potestad podría en interés del menor, extenderse a otras personas que no tengan un vínculo de filiación con el mencionado menor, todo ello manifestado en la sentencia de 8 de octubre de 2003.

243 Ibidem, pag 135 
Por la Ley de 18 de mayo de 2006, la única institución para que el cónyuge del progenitor ostente algún deber o derecho o representación sobre el menor, es la adopción, independientemente de que cónyuge y adoptante sean matrimonio o pareja de hecho, homosexuales o heterosexuales ${ }^{244}$.

\subsection{SITUACIÓN EN ITALIA}

Italia sigue con el régimen de que los progenitores ejercen conjuntamente la patria potestad, aunque vivan separados, por lo que si uno no la ejerce, será ejercida por el otro.

La adopción es la única forma que tiene el cónyuge del progenitor o adoptante, para formar una relación jurídica con el adoptado ${ }^{245}$.

\subsection{SITUACIÓN EN ESPAÑA}

En España por los artículos 154 y 156 en sus apartados primeros no se reconoce la intervención de terceros ajenos a los progenitores en el ejercicio de la patria potestad sobre el menor, aunque tampoco se excluye esa posibilidad. Sólo se contempla por tanto a los progenitores y si existe desacuerdo entre ellos, se recurrirá al Juez.

Para que un tercero sea introducido en el ejercicio de la patria potestad en nuestro Derecho Civil, la única forma de hacerlo es recurrir a la adopción, para ejercer la patria potestad sobre el adoptado, de acuerdo con el artículo $44.2^{\circ}$ del Código Civil que dice: "El matrimonio tendrá los mismos requisitos y efectos cuando ambos contrayentes sean del mismo o de distinto sexo". Este párrafo segundo del artículo 44 CC fue introducido por la Ley 13/2005 en que se reconoce el derecho a contraer matrimonio a personas del mismo sexo. En los países en que no se reconoce ningún derecho al cónyuge del progenitor, están cambiando progresivamente, de tal forma que el cónyuge del progenitor que convive con el menor, al mantener relación con él, habrá de tener algún poder sobre dicho menor.

\footnotetext{
244 Ibidem, pags 137 y 138

245 Ibidem, pag 138
} 
Es necesaria una regulación sobre este asunto, pues el cónyuge del progenitor al convivir con el menor, tendrá que llevarle al colegio, al médico, etc; tendrá que tomar decisiones que le afecten, sobre todo en situaciones de urgencia o gravedad. Como consecuencia de ello, debe de establecerse un marco jurídico estable en el que se sepan con claridad sus derechos y obligaciones en relación con el hijo del progenitor ${ }^{246}$.

\subsubsection{LA PATRIA POTESTAD PRORROGADA Y REHABILITADA}

La patria potestad prorrogada y rehabilitada se regula en el Capítulo IV De la extinción de la patria potestad, del Título VII. De las relaciones paterno filiales del Libro I, De las personas, en el artículo 171.

La Ley 11/1981, de 13 de mayo, de modificación del Código Civil en materia de filiación, patria potestad y régimen económico del matrimonio, introdujo la novedad de la previsión de una patria potestad sobre los hijos mayores de edad, en ella dice en su inciso primero "la patria potestad sobre los hijos que hubieren sido incapacitados por deficiencias o anomalías psíquicas o por sordomudez, quedará prorrogada por ministerio de la Ley al llegar aquellos a la mayoría de edad...". Este texto fue modificado por la Ley 13/1983, de 24 de octubre, de reforma del Código Civil en materia de tutela, la cual suprimió la dicción "por deficiencias o anomalías psíquicas o por sordomudez”, en su artículo cuarto. La redacción se hizo por la LO 1/1996 de 15 de enero, de protección jurídica del menor, en la que se suprimió del artículo 171, las palabras "no se constituirá la tutela, sino que" y al final del último párrafo del mismo artículo se agrega la frase "o curatela, según proceda" 247 .

Este artículo ha supuesto una innovación por simplificar y facilitar el ejercicio de la patria potestad a los padres del menor, que son los más indicados para ejercerla, con lo que se le causa menores trastornos. Al mismo tiempo no es necesario recurrir al instituto de la tutela, como sucedía en el régimen anterior, en que la patria potestad se extinguía al llegar a la mayoría de edad, sin otra alternativa posible.

En el derecho de los países de nuestro entorno, tenemos un precepto equivalente

\footnotetext{
246 Ibidem, pags 139 y 142

247 BOE n $^{\circ} 15$, de 17 de enero de 1996, pag 1236
} 
a nuestra patria potestad prorrogada en el artículo 416 del Códice Civile italiano, por el que se puede inhabilitar a un menor no emancipado en el último año de su minoría de edad, empezando a tener efectos a partir del día que adquiera la mayoría de edad ${ }^{248}$, si se trata de un mayor de edad en general produce efectos a partir del día de la publicación de la sentencia.

Por lo que se refiere al Derecho alemán en el BGB se contempla la figura del asistente legal y se da cuando un mayor de edad como consecuencia de una enfermedad psíquica o de una discapacidad física, psíquica o mental no puede cuidar total o parcialmente de sus asuntos, el juzgado de tutelas, a petición suya o de oficio, le nombra un asistente legal. Su regulación comprende de los artículos 1896 al 1908 y es una institución intermedia entre la tutela y la curatela. En su artículo 1908 se regula el establecimiento del asistente legal para un menor de diecisiete años de edad, al que se suponga que será necesaria esa asistencia cuando llegue a la mayoría de edad, siendo eficaces esas medidas cuando llegue a dicha edad ${ }^{249}$.

El artículo 171 CC amplía la vigencia de la patria potestad más allá del límite de la mayoría de edad, pues si la patria potestad se da como una obligación de vigilancia y control sobre el menor de edad no emancipado, a la que se pone término cuando el hijo alcanza la mayoría de edad, en la patria potestad prorrogada o rehabilitada los padres mantienen esas obligaciones de vigilancia y control aunque el hijo sea mayor de edad.

Contempla este artículo dos figuras diferentes, aunque al decir "La patria potestad

\footnotetext{
248 Artículo 416 Códice Civile italiano (Interdizione e inabilitazione nell'ultimo anno di minore etá)

"Il minore non emancipato puó essere interdetto e inabilitato nell'ultimo anno della sua minore etá. L'interdizione o l'inabilitazione ha effeto dal giorno in cui il minore raggiunge l'etá maggiore"

Artículo 421 Códice Civile italiano (Decorrenza degli effetti dell'interdizione e dell'inabilitazione)

“L'interdizione e l'inabilitazione producono i loro effetti dil giorno della pubblicazione della sentenza, salvo il caso previsto dell'articolo 416"

249 Artículo 1908 a del BGB (Nombramiento de asistente legal y ordenación de la reserva de consentimiento, de manera preventiva, para un menor de edad)

“Las medidas establecidas en los artículos 1896 y 1903 pueden ser adoptadas incluso para un menor de edad que ha cumplido los diecisiete años de edad, siempre que sea de suponer que al llegar a la mayoría de edad serán necesarias. Las medidas no serán eficaces hasta que se alcance la mayoría de edad”
} 
prorrogada en cualquiera de estas dos formas", lo que no es correcto pues la prorrogada es para menores de edad y la rehabilitada para mayores de edad, lo que trata de dos instituciones diferentes que responden a situaciones distintas. La patria potestad prorrogada se refiere al caso en que un menor de edad, es incapacitado durante esa minoría de edad, continua incapacitado al llegar a cumplir la mayoría de edad directamente sin ninguna otra formalidad. En cuanto a la patria potestad rehabilitada tiene lugar cuando el hijo mayor de edad es incapacitado, con la exigencia de que sea soltero y viva en compañía de sus padres o de uno de ellos, pues en caso de que fuera casado cesará de acuerdo con el punto $4^{\circ}$, artículo 171 CC.

La patria potestad prorrogada o rehabilitada no es la misma que la que se da en un menor de edad sin discapacidad, sino que habrá que estar a lo que disponga la sentencia de incapacitación, de acuerdo con lo dispuesto en el artículo $171.1^{\circ}$ CC. De igual forma hay que tener presente lo que previene el artículo 760.1 de la Ley de Enjuiciamiento Civil, según la cual la sentencia de incapacitación determinará la extensión y los límites de ésta, así como el régimen de tutela o guarda a que haya de quedar sometido el incapacitado, y se pronunciará en su caso, sobre la necesidad de internamiento, sin perjuicio de lo dispuesto en el artículo 763.2.

El juez puede fijar el alcance que vaya a tener el régimen de prórroga o rehabilitación de la patria potestad, el titular que se vaya a encargar de ejercer esas funciones, su contenido personal o patrimonial o sobre su duración ${ }^{250}$. De todo lo que

${ }^{250}$ La Ley 1/2000, de 7 de enero, de Enjuiciamiento Civil, deroga los artículos 202 al 214 CC dejándolos sin contenido, y redactó el artículo 760 de la misma como sigue:

“1) La sentencia que declare la incapacitación determinará la extensión y los límites de ésta, así como el régimen de tutela o guarda a que haya de quedar sometido el incapacitado, y se pronunciará en su caso, sobre la necesidad de internamiento, sin perjuicio de lo dispuesto en el artículo 763.

3) En el caso a que se refiere el apartado 2 del artículo anterior, si el tribunal accede a la solicitud, la sentencia que declare la incapacidad o la prodigalidad nombrará a la persona o personas que, con arreglo a la ley, hayan de asistir o representar al incapaz y velar por él.

4) 3) La sentencia que declare la prodigalidad determinará los actos que el pródigo no puede realizar sin el consentimiento de la persona que deba asistirle"

Artículo 763.2 L.E.C. "El internamiento de menores se realizará siempre en un establecimiento de salud mental adecuado a su edad, previo informe de los servicios de asistencia al menor” 
no haya previsto la sentencia de incapacitación las normas generales serán de aplicación, con lo que subsidiariamente, se aplicarán las normas de la patria potestad ordinaria.

Para que se dé la patria potestad prorrogada o rehabilitada es necesario que la incapacitación haya sido declarada judicialmente.

El mayor incapacitado se encontrará bajo la patria potestad de sus padres, de acuerdo con lo dispuesto en el artículo 1903.2, para lo que habrá que ver lo que dispone la sentencia de incapacitación al respecto. Por ello sus padres deberán realizar las labores de guarda con mayor puntualidad y desvelo que si se tratara de un menor de edad.

\subsubsection{PATRIA POTESTAD PRORROGADA}

La patria potestad prorrogada se da cuando un hijo menor no emancipado es declarado incapaz durante su minoría de edad y con ello se da como previsible que el origen o causa de la incapacidad subsistirá durante la mayoría de edad. Al darse esa circunstancia de incapacidad, tiene que continuar la patria potestad, ejercida por sus padres mientras no se modifique la declaración de incapacidad.

El menor de edad es incapacitado cuando padece una enfermedad física o psíquica que le impide valerse o gobernarse por sí mismo, por lo que en este caso se procede a su incapacitación de acuerdo con los artículos 201 y 202 CC $^{251}$, de manera que el menor al cumplir los dieciocho años, los padres continuarán ejerciendo la patria potestad, por ministerio de la ley y en su virtud lo hacen de manera automática.

Si el artículo 171 CC no hubiera previsto lo relativo a la patria potestad prorrogada, el menor al llegar a la mayoría de edad, tendría que ser sometido a tutela o curatela según correspondiese, de acuerdo con lo establecido en la sentencia de incapacitación, lo que daría lugar a distorsiones y complicaciones para el incapacitado. Con ello el artículo 171 CC, facilita y simplifica los casos al hacer que continúe de

\footnotetext{
251 Artículo 200 CC: "Son causas de incapacitación las enfermedades o deficiencias persistentes de carácter físico o psíquico, que impidan a la persona gobernarse por sí misma" Artículo 201: "Los menores de edad podrán ser incapacitados cuando concurra en ellos causa de incapacitación y se prevea razonablemente que la misma persistirá después de la mayoría de edad"
} 
manera ininterrumpida la patria potestad que es lo más útil y provechoso para el menor.

El requisito fundamental de la patria potestad prorrogada es el de que se trate de un menor y además no se encuentre emancipado ni sujeto a tutela, pues si está sujeto a tutela lo que se prorrogaría no sería ya la patria potestad, sino la tutela ${ }^{252}$.

El artículo 171 CC enumera las causas de extinción de la patria potestad prorrogada y rehabilitada.

La primera es la muerte o declaración de fallecimiento de ambos padres o del hijo, lo que concuerda con el artículo 169.1 CC.

La segunda es la adopción del hijo, que también concuerda con el artículo 169, en su apartado $2^{\circ}$ CC. Por ello con la adopción se produce una extinción de la patria potestad vigente y se constituye una nueva que pasan a desempeñar los adoptantes, por ello subsistirá en estos adoptantes la titularidad de la patria potestad prorrogada en las mismas condiciones que tenían los padres por naturaleza.

La tercera de las causas es la cesación de la incapacidad, en cuyo caso ya no serán necesarias las medidas de protección al haber alcanzado la salud física o mental el sometido a ese régimen de protección.

Como causa final o causa cuarta es la de haber contraído matrimonio el incapacitado. En este caso el otro cónyuge ejerce las funciones tutelares sobre el cónyuge incapacitado, por ser preferido sobre los padres de acuerdo con el artículo $234.2^{\circ}$ que dice: "Para el nombramiento de tutor se preferirá el cónyuge que conviva con el tutelado". Para contraer matrimonio válidamente se precisa prestar el consentimiento, con lo que puede parecer raro que un incapacitado pueda contraer matrimonio, pero debemos tener en cuenta que no todos los supuestos de incapacitación producen los mismos efectos. Pensemos por ejemplo en que las deficiencias físicas no tienen

252 Artículo 276 CC: "La tutela se extingue":

$1^{\circ}$ ) Cuando el menor de edad cumple los dieciocho años, a menos que con anterioridad hubiera sido judicialmente incapacitado

$2^{\circ}$ ) Por la adopción del tutelado menor de edad

$\left.3^{\circ}\right)$ Por fallecimiento de la persona sometida a tutela

$\left.4^{\circ}\right)$ Por la concesión al menor del beneficio de la mayor edad"

Artículo 278 CC: Continuará el tutor en el ejercicio de su cargo si el menor sujeto a tutela hubiese sido incapacitado antes de la mayor edad, conforme a lo dispuesto en la sentencia de incapacitación. 
necesariamente que suponer la imposibilidad de prestar el consentimiento para contraer matrimonio; de igual forma las deficiencias psíquicas a veces no son impedimento para contraer matrimonio, como contempla el artículo 56.2 CC que dice: "Si alguno de los contrayentes estuviere afectado por deficiencias o anomalías psíquicas, se exigirá dictamen médico sobre su aptitud para prestar el consentimiento", con lo que hay que estar a lo que disponga el dictamen del médico forense sobre su edad mental y capacidad de discernimiento, si de ello resultare apto para el matrimonio, se contraerá válidamente y el otro cónyuge ejercerá la función tutelar sobre el incapacitado.

Un último caso de extinción de la patria potestad prorrogada o rehabilitada se podría añadir a los ya citados, y que se da cuando los padres o el padre que ostenta la patria potestad la pierde, se le priva de ella o se le suspende ${ }^{253}$. Esta sentencia de Burgos

${ }^{253}$ Paños Pérez, Alba, op.cit, pag 96 y lo fundamenta con la S.A.P de Burgos de 14 de julio de 2005 (JUR 2005/218 946), que dice lo siguiente:

En su Fundamento de Derecho Segundo "Si bien, tal y como establece el artículo 171 del Código Civil la patria potestad prorrogada se extingue por la muerte o declaración de fallecimiento de los padres o del hijo, la adopción de éste, por cesar la causa de la incapacitación o por matrimonio del incapaz; no ha de existir obstáculo alguno para que se pueda, en determinados casos, privar a los padres de la patria potestad prorrogada por incumplimiento de los deberes inherentes a la misma de conformidad con lo dispuesto en el artículo 170 del Código Civil.

Si la patria potestad ordinaria, la que naturalmente ostentan los padres sobre sus hijos menores de edad, se configura como un derecho supeditado al cumplimiento de la función para que fue instituida, cuanto más la prorrogada o rehabilitada, a favor del mayor de edad declarado incapaz, que no es sino una forma de tutela o curatela, y por lo tanto, la razón de su establecimiento se encuentra en la necesidad de suplir en beneficio e interés de la incapaz su falta de capacidad. Si los padres no cumplen los deberes que conlleva su ejercicio, resultará procedente la privación de la patria potestad, pues esta medida, prevista en el artículo 170 del Código Civil, se concibe más que como una sanción al progenitor como una medida de protección al incapaz; pues si en su beneficio exclusivo se estableció, cuando por la forma en que se ejercita, el incapaz no resulta suficientemente tutelado, es evidente que procederá la adopción de otra medida que realmente cumpla las funciones tutelares perseguidas.

Por su Fundamento Jurídico Tercero, en su apartado tercero y siguientes dice: "De la prueba obrante en las actuaciones, informe de la trabajadora social del CEAS, resulta que los apelantes, los padres de la incapaz $\mathrm{D}^{\mathrm{a}}$ Laura, no obstante haber sido oportunamente informados por los servicios sociales de la conveniencia y necesidad de que su hija (con una minusvalía reconocida del 44\% diagnosticada de oligofrenia leve y valorada como Retraso Intelectual ligero), realizará actividades de formación, educación y ocupación, no han solicitado plaza en los Centros especializados recomendados, no obstante incluso haberse comprometido a hacerlo con los 
de 14 de julio de 2005, ilustra bien de los problemas que implica la patria potestad rehabilitada, en que una mujer con deficiencias tiene unos progenitores demasiado rígidos y autoritarios que no son adecuados para ejercer la patria potestad sobre una mujer con ese tipo de personalidad.

Los padres no se preocupan de internarla en una institución adecuada a sus características, sino que permanece en su domicilio recibiendo una educación demasiado rígida, no apropiada en modo alguno a su situación, en la que imperan los castigos. La madre tiene también deficiencias, con lo que se pone de manifiesto que los progenitores no reúnen las condiciones necesarias para cumplir con los deberes inherentes a la patria potestad.

La joven cuando se encuentra internada en el establecimiento apropiado a su condición, progresa adecuadamente al cumplir regularmente los horarios y actividades

trabajadores Sociales de PROSAME y del CEAS, determinando que las deficiencias de Laura se alarguen y se cronifiquen, lo que evidentemente supone el incumplimiento del deber de velar por el incapaz.

Teniendo en cuenta que su madre $\mathrm{D}^{a}$ Alejandra, que según el informe psicosocial obrante al folio 1294 , de los dos progenitores el "que más influye en su hija y con la que más conflictos desarrolla", tiene reconocida una incapacidad del $66 \%$ por trastorno límite de la personalidad y problemas físicos; que las pautas educativas de los progenitores, que se describen en el informe psico-social como rígidos y autoritarios, no son los más adecuados, ha de valorarse estos incumplimientos de los deberes de formación y educación, que dadas las deficiencias de la incapaz, resultan de especial trascendencia como de falta de aptitud para el desempeño de la patria potestad rehabilitada (aún sin ignorar la dificultad que el ejercicio de estas funciones entrañan dada la personalidad de Doña Alejandra).

Si a todo lo expuesto se añade que Doña Laura "ha mejorado ostentosamente desde que abandonó el domicilio familiar, adquiriendo habilidades sociales, pautas adecuadas de comportamiento y resolución de conflictos, concentración y adecuación a la responsabilidad diaria en los talleres que realiza" (folio 131) según se indica en el informe psicosocial, de fecha 21 de mayo de 2004; constando que desde enero de 2004 hasta la actualidad viene siendo usuaria de los servicios de orientación asesoramiento y apoyo psicológico, acudiendo en horario de mañana al taller de Habilidades de la Asociación PROSAME, resulta procedente no interrumpir la dinámica de mejoría paulatina en la evolución de la incapaz, valorando como contrario a los intereses de la incapaz el regreso a una relación caracterizada por los graves enfrentamientos y disputas, como fue la existente con sus padres con motivo de la rehabilitación de la patria potestad que no fue ejercitada en su beneficio por la incapacidad de los progenitores para controlar la difícil personalidad de Laura consecuencias de sus limitaciones, dados los también escasos recursos personales de sus progenitores. 
programadas por la dirección del Centro, con lo que mejora paulatinamente de forma ostensible, de acuerdo con lo que manifiestan el personal encargado y recomiendan que siga en esa situación o de lo contrario si vuelve a la casa de sus padres su situación empeorará. Por ello en el interés de la incapaz debe de seguir en esa institución, sin que los padres ejerzan la patria potestad al ser perjudicial para ella.

\subsubsection{PATRIA POTESTAD REHABILITADA}

Se da la rehabilitación de la patria potestad cuando un menor alcanza la mayoría de edad, pero posteriormente al ser incapacitado de forma sobrevenida, se hace necesario rehabilitar la patria potestad en sus padres, siempre que sea soltero y viva en compañía de ellos.

El incapacitado puede quedar bajo la patria potestad del padre o de la madre o de ambos progenitores, lo que supone que no se le nombre tutor o curador que es más complicado y menos efectivo. Al nombrarle a sus progenitores le resulta al incapacitado más fácil y llevadera la patria potestad de sus padres, con lo que no se produce ningún trauma para él.

Para poder rehabilitar la patria potestad se precisa la declaración de incapacitación del hijo mayor de edad, debe ser además soltero y vivir en compañía de los padres o de uno de ellos, según corresponda de acuerdo con lo preceptuado en el artículo 171 CC $^{254}$.

\footnotetext{
subsidiariamente, en las reglas del presente título

La patria potestad prorrogada terminará:

$1^{\circ}$ ) Por la muerte o declaración de fallecimiento de ambos padres o del hijo

$2^{\circ}$ ) Por la adopción del hijo

$3^{\circ}$ ) Por haberse declarado la cesación de la incapacidad

$\left.4^{\circ}\right)$ Por haber contraído matrimonio el incapacitado
}

254 Artículo 171 CC: "La patria potestad sobre los hijos que hubieran sido incapacitados, quedará prorrogada, por ministerio de la Ley, al llegar aquellos a la mayor edad. Si el hijo mayor de edad soltero que viviere en compañía de sus padres o de cualquiera de ellos fuere incapacitado se rehabilitará la patria potestad, que será ejercida por quien correspondiere si el hijo fuera menor de edad. La patria potestad prorrogada en cualquiera de estas dos formas se ejercerá con sujeción a lo especialmente dispuesto en la resolución de incapacitación y,

Si al cesar la patria potestad prorrogada subsistiere el estado de incapacitación, se constituirá la tutela o curatela según proceda. 
El requisito de vivir en compañía se ha de entender en sentido amplio, sin demasiada rigidez, con flexibilidad, sin que sea necesario vivir bajo el mismo techo, es suficiente con el cuidado y vigilancia de los padres sobre el hijo, y que éste tenga respecto de ellos una dependencia física y económica. Pensemos en casos en que el hijo se encuentre internado en Colegios o Instituciones de protección de menores, por cuyo motivo no se puede privar a los padres de su patria potestad al no existir convivencia con el hijo. No sólo la doctrina exige flexibilidad, también lo hace la jurisprudencia como la S.A.P de Toledo de fecha 28 de noviembre de 2002 y otras ${ }^{255}$.

La sentencia presente trata de un caso de patria potestad rehabilitada en demanda interpuesta por el Ministerio Fiscal, que declara la incapacidad total de $\mathrm{D}^{\mathrm{a}}$ Pilar R.M, en que se rehabilita la patria potestad en la persona de su madre $\mathrm{D}^{\mathrm{a}}$ Clementa M., contra la cual se alza un hermano de $\mathrm{D}^{a}$ Pilar el cual solicita la constitución de la tutela que habría de recaer en el propio recurrente.

En su Fundamento de Derecho Primero, la pretensión es rechazada y se fundamenta en que conforme al artículo $759.2^{\circ}$ L.E.C, será en la demanda de incapacitación donde se habrá de pedir el nombramiento de persona o personas que hayan de asistir o representar al incapaz, siendo en este caso presentada la demanda no por el hoy recurrente, sino por el Ministerio Fiscal, quien propuso la prórroga de la patria potestad en la persona de la madre.

Por otro lado, el recurrente aduce que la incapacitada no convive con la madre, pues la misma pasa la mayor parte del tiempo ingresada en un centro adecuado, pasando con la madre únicamente los períodos de vacaciones.

Sin embargo, el requisito de la convivencia del artículo 171 del CC, no puede ser entendido en su sentido literal, pues ello dejaría fuera de la posibilidad de prórroga, precisamente los casos más graves de incapacidad, es decir, aquellos como el presente, en que el sujeto, por su grave estado de retraso o enajenación, requiera de su internamiento en centro adecuado. Evidentemente el sentido del requisito de la convivencia se refiere a que el incapacitado no conviva con otra persona distinta de sus

\footnotetext{
255 S.A.P de Toledo de 28 de noviembre de 2001 (JUR 2002/28544)
} 
padres (por ejemplo con un hermano, con una pareja de hecho, etc), supuestos en los que la rehabilitación podría no tener sentido, pero sin duda se comprenden en el precepto los incapaces que ingresados en un centro han convivido entonces con sus padres, pues si no, prácticamente quedaría desprovisto de contenido.

Se alega por último que la madre es persona mayor, aquejada de sordera y ceguera casi total, con la movilidad limitada y que la incapaz se muestra agresiva con ella. Las primeras circunstancias, que están suficientemente acreditadas, no son causa que pueda ser invocada por quien pretende ser tutor, sino por analogía con el artículo $251 \mathrm{CC}$, por quien pretende excusarse del cargo, es decir, la propia madre, si es que fuera concebible excusarse de la patria potestad, lo que no parece posible como veremos.

El hecho de que la incapaz se muestre agresiva con su madre, se trataría de una circunstancia preexistente al momento actual, en el que como el propio recurrente aduce, las vacaciones las pasas precisamente con su madre, lo que no tiene por qué alterarse pese a la constitución de la tutela.

Fundamento de Derecho Segundo: Además de todo lo anterior entiende la Sala que en realidad el recurrente, hermano de la incapacitada, carece de legitimación para pretender ser nombrado tutor frente a la decisión judicial que acuerda la rehabilitación de la patria potestad, y sólo al padre o madre rehabilitados, les corresponde alegar las causas por las que entendieran que no se ha de rehabilitar la patria potestad. Y aún ello es más que discutible, pues como ya hemos apuntado más atrás, no parece posible la excusa para el ejercicio de la patria potestad rehabilitada o prorrogada, pues ésta se rige por normas y principios diferentes a los de la tutela, pues el propio artículo 171 señala que la misma se ejercerá con sujeción a lo dispuesto en la sentencia de incapacitación y subsidiariamente por la regla del presente título, es decir, el Título VII del libro Primero relativo a las relaciones paterno filiales, en tanto que la tutela se regula en el Título X. Y así como no es concebible que un padre se excuse del ejercicio de la patria potestad por razones de edad, enfermedad o difícil convivencia con sus hijos menores, pues la misma no es un derecho sino un deber, del mismo modo, la patria potestad prorrogada o rehabilitada, que se rige por las mismas normas, por ser también un deber de derecho de familia, entendemos que resultaría inexcusable. 
La S.A.P de Toledo de 28 de noviembre de 2001, da prioridad a la patria potestad rehabilitada frente a la tutela por entender que si ya antes habían tenido los padres la patria potestad es lógico que la continúen ejerciendo en la rehabilitación. Para ello hay que estar a lo que disponga la sentencia de incapacitación que será lo más idóneo para el incapacitado, pues el Juez dispone del personal especializado para que le asesore y tener elementos de juicio para disponer lo conveniente. La convivencia se entiende en sentido amplio y flexible, dándose aún en el caso de que el incapacitado se encuentre internado en un establecimiento apropiado a su condición, pues aunque no esté con sus padres les visitará en tiempo de vacaciones, mensualmente o fines de semana, con lo que sigue dandose una convivencia aunque sea interrumpida y no constante.

La tutela es una institución subsidiaria respecto a la patria potestad, lo que quiere decir que si viven los padres se debe de establecer en primer lugar la patria potestad ya sea en versión prorrogada o rehabilitada, para ello aunque el incapacitado se encuentre internado en establecimiento ello no impide ejercer la patria potestad, con lo que se asimila a los mayores de edad que residen por motivos de estudios en localidad distinta de sus padres, sin ser independientes económicamente, por ello también se da convivencia en el caso de padres que ejercen patria potestad sobre hijos internados en establecimientos especiales, como dispone la S.A.P de Valencia de 28 de octubre de $2005^{256}$.

En relación con el otro requisito de la patria potestad rehabilitada, esto es, el ser

256 S.A.P de Valencia de 28-10-2005 (JUR 2005/23.028) FUNDAMENTO DE DERECHO SEGUNDO "La Sala considera en beneficio del hijo declarado incapaz que procede rehabilitar a sus padres en la patria potestad por considerar esta institución prioritaria a la constitución de la tutela, entendiendo que el requisito de la convivencia con los padres debe interpretarse de la misma forma que se interpreta ésta en el supuesto de alimentos debidos a los hijos mayores de edad que conviven con el cónyuge y no gozan de independencia económica, -artículo 93.2 CC- esto es, como dependencia de éstos, sin necesidad de que materialmente se conviva con los mismos, sino que residiendo en aquél caso por motivos de estudios en otra localidad y en el caso de autos en un centro específico para el tratamiento de su enfermedad, se sigue dado el sentido de convivencia en el domicilio paterno pues todas las salidas del centro bien por recuperación del mismo, bien por señalarse periódicamente visitas semanales o mensuales se efectuarían en el domicilio familiar, y en aquél centro se encuentra bajo la supervisión de sus padres". 
soltero, pues en el caso de haber contraído matrimonio sería el otro cónyuge, el que se encargaría de su guarda; pues el otro cónyuge tiene preferencia sobre los padres a la hora de asignar la patria potestad de acuerdo con lo establecido en el artículo 234.2 del Código Civil.

Si el incapacitado contrae matrimonio, fallece su cónyuge o declaración de fallecimiento, matrimonio nulo, divorcio o separación de los cónyuges, no se podría aplicar el artículo 234.2 y como consecuencia de ello pasaría a ser de nuevo soltero, pues es inconcebible que si es divorciado o separado el otro cónyuge se hiciera cargo de él. Por todo ello los padres al quedar incapacitado y ser soltero tendrían que volver a ejercer la patria potestad sobre él aunque sea mayor de edad. Al no existir cónyuge al que corresponda la tutela de forma legal, se rehabilita en los padres, pues rehabilitar, es restablecer a una persona o cosa a su antiguo estado.

\section{RESPONSABILIDAD DE LOS TUTORES}

\subsection{LOS TUTORES EN EL CÓDIGO CIVIL}

El artículo 1903.3 dice que: "Los tutores son responsables de los perjuicios causados por los menores o incapacitados que estén bajo su autoridad y habiten en su compañía".

Son por tanto necesarias dos exigencias para hacer responsables a los tutores: que los menores se encuentren bajo su autoridad y que vivan en su compañía. Para encontrarse bajo su autoridad es preciso que se constituya formalmente la tutela, designando al tutor o tutores encargados del menor. De igual forma se exige que el menor viva en compañía de los tutores, cosa que no hace el apartado segundo del mencionado artículo en el que habla de "que se encuentren bajo su guarda".

En el artículo 269 CC se contemplan las obligaciones que tienen los tutores sobre el tutelado, las cuales consisten en velar por él, alimentarle, educarle y darle una formación integral, con el fin de que se pueda insertar correctamente en la sociedad. Al tratarse la tutela de una institución destinada a proteger a los menores o incapaces que no pueden gobernarse por sí mismos, tiene que darse en las relaciones entre tutores y 
tutelados una orientación general en interés del menor, que es la base sobre la que descansan las instituciones que tratan sobre los menores ${ }^{257}$. Estas obligaciones del tutor sobre el menor se encuentran de acuerdo con el artículo 39 de nuestra Constitución, así como su artículo 10.1 sobre derechos de la persona (dignidad y libre desarrollo de la personalidad), y el artículo 27 relativo al derecho a la educación. En nuestro ordenamiento interno se debe destacar la LO 1/1996 de 15 de enero sobre la protección jurídica del menor, que se publicó para cumplir con lo establecido en la Convención de los Derechos del Niño, de 20 de noviembre de 1989, ratificada por España el 30 de noviembre de 1990.

Se dan polémicas en la doctrina sobre si es necesaria o no la convivencia para poder exigir responsabilidad al tutor. Para unos autores es necesario el requisito de la compañía basándose en que el artículo 269 CC, recoge el deber de velar por el tutelado, para lo que se requiere el deber de tenerlo en su compañía; el deber de control o vigilancia, necesario para exigir responsabilidad, se debe de apoyan en el requisito de la compañía, pues si no se da no es posible exigir esa responsabilidad. Para otros autores no existe el requisito de la compañía por existir entidades que prestan la función tutelar, a los cuales no se les puede exigir ese requisito; otro argumento es el del artículo 234 en su inciso final que dice: "se considera beneficiosa para el menor la integración en la vida de familia", con lo que se puede interpretar que la convivencia no tiene carácter obligatorio; por último si el menor se encuentra a cargo de otra persona, será ella la responsable, como sucede en el derecho de visita.

De ello se deduce que el requisito de la compañía se da como necesario en un sistema basado en la culpa, mientras que en el basado en la idea de garantía, el tutor debe

\footnotetext{
257 Artículo 269 CC: " El tutor está obligado a velar por el tutelado y en particular:

$\left.1^{\circ}\right)$ A procurarle alimentos

$2^{\circ}$ ) A educar al menor y procurarle una formación integral

$3^{\circ}$ ) A promover la adquisición o recuperación de la capacidad del tutelado y su mejor inserción en la sociedad

$4^{\circ}$ ) A informar al Juez anualmente sobre la situación del menor o incapacitado y rendirle cuenta anual de su administración
} 
responder aunque no tenga al menor en su compañía 258 .

El artículo 228CC obliga al Ministerio Fiscal y al Juez a la constitución de la tutela, cuando tuvieran conocimiento de que en el territorio de su jurisdicción hubiera alguna persona que necesitara ser sometida a esta institución tuitiva.

El artículo 229 CC, impone la obligación de promover la constitución de la tutela, a los parientes llamados a ella, o a la persona bajo cuya guarda se encuentre el menor, haciéndoles responsables de los daños y perjuicios que se causen por su inactividad, desde el momento en que tuvieran conocimiento de los hechos que la motivaron. Esta responsabilidad alcanza de igual forma al Ministerio Fiscal y al Juez que no la hubieran constituido, teniendo conocimiento de la existencia de alguna persona necesitada de esa tutela.

Pueden ser tutores tanto personas físicas como personas jurídicas. En el artículo 241 CC, establece las condiciones necesarias para ser tutor, que son el encontrarse en el pleno ejercicio de sus derechos civiles y que no concurran causas de inhabilitación, con lo que no pueden serlo los menores de edad, los incapaces, los sometidos a tutela ni los comprendidos en causas de inhabilitación de los artículos 243, 244 y 245 CC. Las personas jurídicas de acuerdo con el artículo 242 CC, pueden ser tutores si no tienen finalidad lucrativa y entre cuyos fines figure la protección de menores e incapacitados.

El Juez para nombrar tutor, nombrará a las personas relacionadas en el artículo 234 CC, pero si éstas no existieran o existiendo las considerase no idóneas, designará tutor a quien por sus relaciones con el tutelado, y en beneficio de éste, considere más idóneo, de acuerdo con el artículo 235 CC.

Normalmente la tutela se ejercerá por un solo tutor, pero en circunstancias especiales pueden concurrir varios tutores sobre un solo tutelado, cuando lo lógico es que exista un solo tutor por menor tutelado. La existencia de varios tutores sobre un tutelado da lugar a que haya que considerar quien de ellos es el responsable o si deben de hacerlo todos de manera conjunta.

Si hay más de un tutor con división de funciones, como es el caso en que un tutor

\footnotetext{
258 Bonilla Correa, Jesús Ángel, op.cit, pags 335, 336 y 337.
} 
se encarga de la persona del tutelado y el otro de sus bienes, parece lógico que cada uno se encargue de lo relativo a sus funciones. Con ello se hará responsable el encargado de la persona del menor, mientras que no se exigirá responsabilidad sobre el menor al encargado de los asuntos patrimoniales. Ello es debido a que sería injusto hacer responder al tutor de los bienes del menor, cuando no tiene sobre él ningún control sobre su educación y vigilancia.

Para el caso de que se den varios tutores sin división de funciones, todos ellos responderán de la parte tanto personal como patrimonial y han de hacerlo de forma conjunta, la responsabilidad ha de ser también conjunta, como establece el artículo 237 CC.

Por último si hay varios tutores y uno solo de ellos tiene asignada la convivencia con el tutelado será a éste al que se exija la responsabilidad, al fundamentarse en la culpa como establece el Código Civil, por el deber de control y vigilancia sobre el menor.

Respecto a los tutores que sean personas jurídicas, pueden ser de carácter privado o público. Las personas jurídicas privadas cuando tienen por objeto funciones tuitivas responden como si se tratara de una persona física, pero no hay que confundirla con la responsabilidad de los empresarios del artículo $1903.4^{\circ}$; aquí se trata del artículo $1903.3^{\circ}$ en que se actúa en beneficio de dicho menor, mientras que en la responsabilidad empresarial se trata de obtener beneficios bajo una organización.

El tutor persona jurídica se contempla en el artículo 239 CC que trata de la situación de desamparo que se da cuando de hecho a causa del incumplimiento o del imposible o inadecuado ejercicio de los deberes de ejercicio de la patria potestad le incumben al menor de conformidad a las leyes, cuando este menor quede privado de la necesaria asistencia moral y material. El párrafo primero del artículo mencionado dice que: "La tutela de los menores desamparados corresponde por ley a la Entidad a que se refiere el artículo 172". Y esa entidad no es otra que la que se encuentra en cada demarcación territorial para la protección de los menores.

La situación de desamparo supone por tanto que los padres por una u otra razón incumplen las obligaciones inherentes a la patria potestad y que además no existe un guardador de hecho que los sustituya. 
Por ello la Administración ante la situación de desamparo resolverá declarando la tutela provisional del menor, a la espera de nombrar bien a la propia Entidad como tutora definitiva o bien a una persona física o jurídica privada. Esta institución es de carácter subsidiario, pues si hay alguna otra persona que se pueda encargar del menor, no habría situación de desamparo.

\subsection{LOS TUTORES EN LA LORPM}

En la LORPM no se exige para que haya responsabilidad del tutor el requisito de que los menores habiten en su compañía, como hace el párrafo tercero del artículo 1903 CC, ya visto anteriormente. Esta responsabilidad es directa y cuasi objetiva de los tutores, es directa por ser el encargado de su vigilancia y educación, por lo que aunque no haya causado el hecho dañoso, responderá el tutor, al tener que responder por otro; es cuasi objetiva por atender fundamentalmente a la garantía frente a un tercero.

La responsabilidad en la LORPM se basa en el criterio de la garantía, en relación a la víctima, por ello el requisito de la convivencia deja de tener significado, de tal forma que el tutor deberá responder pese a no existir esa compañía. La compañía o convivencia sólo se tiene en cuenta a los efectos de la moderación, pero no a la exención total de responsabilidad ${ }^{259}$.

Cuando se nombren varios tutores, responderán todos ellos de forma solidaria, independientemente de que tuvieren o no al menor en su compañía. Este dato de la compañía del menor sólo se tendrá en cuenta para la moderación, siendo necesario considerar si se trata de culpa in vigilando o in educando. Si el tutor lo es solamente de los bienes del tutelado no responderá de los daños causados por éste ${ }^{260}$.

De acuerdo con el artículo 242 CC, ya visto anteriormente, "podrán ser también tutores las personas jurídicas que no tengan finalidad lucrativa y entre sus fines figure la protección de menores e incapacitados". Por otra parte las Comunidades Autónomas por el artículo 148, 1,20 de la C.E. tienen atribuidas competencias de asistencia social,

\footnotetext{
259 Ibidem, pag 337

260 Ibidem, pag 339
} 
con lo que abarca el cuidado y asistencia a los menores en situaciones de desamparo. Además tras la última reforma de la Ley de Extranjería por la Ley Orgánica 2/2009, de 11 de diciembre, estas personas jurídicas del artículo 242 CC, pueden asumir y de hecho asumen la tutela de los menores inmigrantes no acompañados Para ello la Administración General del Estado y las Comunidades, conforme al artículo 35, apartado 11, podrán establecer convenios con organizaciones no gubernamentales, fundaciones y entidades dedicadas a la protección de menores, con el fin de atribuirles la tutela ordinaria de los menores extranjeros no acompañados.

Cada convenio especificará el número de menores cuya tutela se compromete a asumir la entidad correspondiente, el lugar de residencia y los medios materiales que se destinarán a la atención de los mismos.

Estará legitimada para promover la constitución de la tutela la Comunidad Autónoma bajo cuya custodia se encuentre el menor. A tales efectos, deberá dirigirse al juzgado competente que proceda en función del lugar en que vaya a residir el menor, adjuntando el convenio correspondiente y la conformidad de la entidad que vaya a asumir la tutela.

El régimen de la tutela será el previsto en el Código Civil y en la Ley de Enjuiciamiento Civil. Además serán aplicables a los menores extranjeros no acompañados las restantes previsiones sobre protección de menores recogidos en el Código Civil y en la legislación vigente en la materia.

Estas organizaciones no gubernamentales, fundaciones y entidades dedicadas a la protección de menores, parece lógico que deban asumir la responsabilidad sobre los menores y quedar las Comunidades Autónomas exoneradas, por lo que se deberá de fijar en el convenio de forma clara, para su exigencia ante el posible hecho dañoso del menor ${ }^{261}$.

\footnotetext{
261 De la Rosa Cortina, José Miguel, op.cit.pags 144 y ss
} 


\subsection{LOS ABUELOS COMO TUTORES}

Las relaciones entre abuelos y nietos han tenido en el Código Civil un tratamiento muy exiguo, para subsanarlo se ha promulgado la Ley 42/2003, de 21 de noviembre, para proteger esas relaciones. Con esta Ley los abuelos tienen derecho a relacionarse con sus nietos mediante derecho de visitas y en determinadas situaciones la custodia ordinaria e incluso las funciones de tutela sobre los nietos.

La protección de estas relaciones se hallan contempladas en el artículo 39 de la Constitución Española, de igual forma en la Ley Orgánica 1/1996, de 15 de enero, de Protección Jurídica del Menor, en su artículo $2^{\circ}$ dice que: " en la aplicación de la presente Ley primará el interés superior de los menores sobre cualquier otro interés legítimo que pudiera concurrir". En la legislación internacional la Convención de Naciones Unidas sobre los Derechos del Niño de 20 de noviembre de 1989 en su Preámbulo dice que el niño para el pleno y armonioso desarrollo de su personalidad, debe crecer en el seno de la familia, en un ambiente de felicidad, amor y comprensión; en su artículo 3.2 dice: "Los Estados Partes se comprometen a asegurar al niño la protección y el cuidado que sean necesarios para su bienestar, teniendo en cuenta los derechos y deberes de sus padres, tutores u otras personas responsables de él ante la ley y, con este fin, tomarán todas las medidas legislativas y administrativas adecuadas.

En su Exposición de Motivos la Ley 42/2003 dice que los abuelos desempeñan un papel fundamental de cohesión y transmisión de valores en la familia, que es el agente de solidaridad por excelencia de la sociedad civil. Cabe entender que los abuelos, ordinariamente ajenos a las situaciones de ruptura matrimonial, pueden desempeñar un papel crucial para la estabilidad del menor, contrarrestando situaciones de hostilidad o enfrentamiento entre los progenitores y dotar al menor de referentes necesarios y seguros en su entorno, con lo que pueden neutralizar o aminorar los efectos negativos y traumáticos de una situación de crisis.

Con esta modificación legislativa se pretende un doble objetivo. En primer lugar, singularizar desde un aspecto sustantivo, de forma más explícita y reforzada, el régimen de relaciones entre los abuelos y los nietos, tanto en caso de ruptura familiar, como en el caso de simple dejación de obligaciones por parte de los progenitores. En segundo lugar, 
se atribuye a los abuelos una función relevante en el caso de dejación por los padres de las obligaciones derivadas de la patria potestad.

Para conseguir los objetivos propuestos han sido modificados en esta Ley 42/2003, los artículos 90, 94, 103, 160 y 161 del Código Civil, así como, el artículo 250 de la Ley 1/2000, de 7 de enero, de Enjuiciamiento Civil.

Hay que tener en cuenta que "en la sociedad en que vivimos se producen situaciones en las que los padres abandonan sus obligaciones en relación con sus hijos, o mantienen una cierta ausencia en la vida de éstos. En tal caso los abuelos de nuevo mantienen una situación privilegiada para que puedan desempeñar unas funciones que los padres no van a ejercer por unas u otras razones, y en este sentido la Ley viene a priorizar la posición de los abuelos frente a otras alternativas de más escasa referencia en la estimación de los menores"262.

La interrupción ilegítima entre los abuelos y los nietos, obedece a alguno de los motivos siguientes: por ruptura del matrimonio o pareja de los padres, por fallecimiento de alguno de los progenitores o por diferencias personales entre los abuelos y los progenitores de los menores.

Las rupturas del matrimonio o pareja de los padres afectan en la época actual a un $52 \%$ de las uniones, con lo que se trata de un grupo considerablemente numeroso. Al producirse la ruptura de una pareja el cónyuge que se considera víctima de esa relación, pretende luchar y vengarse contra el otro y sus padres, es decir, los abuelos, para tratar de causarles daño, impidiendo que los abuelos se relacionen con sus nietos, de esta forma hace sufrir a los abuelos y al otro cónyuge.

Al producirse esta situación, en que se impide relacionarse a los abuelos con los nietos, si se prolonga en el tiempo, da lugar a que sean los abuelos para los nietos unos desconocidos, olvidándose de los intereses y sentimientos de los menores, que no tienen ninguna culpa de las desavenencias conyugales, ni de las diferencias entre los adultos, ni de ese fracaso matrimonial.

La persona que desea que cesen o desaparezcan las relaciones entre abuelos y nietos tratará de ganar tiempo para que se vayan diluyendo esos lazos afectivos, hasta

\footnotetext{
262 Acevedo Bermejo, Antonio. Las Relaciones Abuelos - Nietos, Tecnos, Madrid, 2006, pag 23
} 
llegar a un punto de no retorno, en que ya sea tarde para volver a restablecer esas relaciones, que nunca se deberían de haber roto o deteriorado. Esta situación hace que los abuelos sufran, pues a cualquier abuelo le gusta estar con sus nietos, pero es sobre todo muy dolorosa para los nietos que por su menor edad, no saben asimilar este problema; con lo que se encuentran entre la espada y la pared, por una parte ellos desean ver a sus abuelos y por otra el progenitor que presiona y hace todo lo posible para que esas relaciones no se produzcan.

Con la nueva Ley estos problemas se resuelven al darse una protección legal a esas relaciones que el progenitor de forma ilegítima trata de romper ${ }^{263}$.

Cuando se produce el fallecimiento de uno de los cónyuges, para el que sobrevive, la familia del cónyuge fallecido es un asunto que no desea recordar mucho, para no perpetuar el luto y poder aliviarse de los sufrimientos ocasionados, especialmente si encuentra otra persona con la que pueda rehacer su vida.

Este progenitor sobreviviente tratará que las relaciones abuelos-nietos se diluyan lo más posible e incluso que desaparezcan, sobre todo para no molestar a su nueva pareja.

Para los menores los abuelos padres del cónyuge fallecido son la referencia que les queda de su progenitor fallecido, por lo que son una referencia constante de sus valores y recuerdos, de la unión con los miembros de la familia del difunto, por lo que si no se corrige esa situación, llegando a cortarse toda relación abuelos nietos, el daño para los menores sería muy grande por abarcar un gran número de personas para ellos queridas, como tíos, primos y otros parientes.

Se pueden solicitar medidas cautelares en la nueva Ley, para que no pueda perpetuarse esa situación por parte del progenitor que obstaculiza esas relaciones, mediante la interposición de recursos para dilatar el momento en que se restablezcan las relaciones. Por ello con esas medidas cautelares se evita la interrupción de esas relaciones desde el primer momento, que para los menores constituiría una mutilación por la

263 Ibidem, pags 25 y 26 
pérdida de unos familiares de referencia, cercanos y entrañables ${ }^{264}$.

Otra causa de ruptura de relaciones entre abuelos - nietos se da cuando surgen desavenencias entre los abuelos y los propios hijos, padres de los menores, con lo que se impide las relaciones y contactos mutuos.

A veces se producen por diversos motivos, relaciones conflictivas entre los padres de uno de los miembros de la pareja y el otro miembro de ésta, dando con ello lugar a que llegue a trascender hasta los nietos, interrumpiendo toda relación con los abuelos.

Cuando se producen este tipo de situaciones, los abuelos al igual que los nietos sufren una gran angustia e impotencia, pues se llega por parte de los padres a impedir incluso los contactos de tipo telefónico entre ellos, lo que es a todas luces notoriamente injusto, ya que en interés de los niños, los padres no deben impedir esas relaciones, de lo que ellos no son en modo alguno culpables.

En los tres casos que hemos visto, separación, fallecimiento del cónyuge y desavenencias entre padres y cónyuges; siempre los abuelos van a tratar de mantener, conservar o restablecer la relación con sus nietos mientras que los padres de los menores se van a negar a que la relación permanezca. Ante esta tesitura los abuelos después de tratar de restablecer esas relaciones por la vía amistosa, deberán recurrir a los medios que les ofrece la Ley 42/2003 para que por vía judicial el Juez les asigne el derecho de visitas a que tienen derecho, si preciso es por la vía de apremio.

La parte demandada tratará con diferentes subterfugios de escamotear esas relaciones, tratando de justificarse afirmando que son los abuelos los que no quieren relacionarse, o que no quieren los nietos, que los abuelos son perjudiciales a los nietos, etc, pero lo que es cierto es que si los abuelos han recurrido al Juez es por no encontrar otro modo de poder relacionarse con sus nietos. La Ley establece que las relaciones entre abuelos y nietos no podrán impedirse sin justa causa, con lo que el Juez deberá averiguar en cada caso para que estos problemas puedan ser subsanados, quedando restablecidas las relaciones abuelos - nietos ${ }^{265}$.

${ }^{264}$ Ibidem, pag 26 y 27

265 Ibidem, pag 27 y ss 


\subsection{EL DERECHO DE VISITAS ABUELOS - NIETOS}

El artículo 90 CC fue modificado por la Ley 42/2003 para que a los abuelos se les reconozca el derecho a relacionarse con sus nietos de forma concreta, durante un determinado tiempo, cosa que antes no contemplaba ninguna norma.

Para ello en el Convenio Regulador que los cónyuges establecen en el momento de su separación, nulidad o divorcio, al tratar sobre el sistema de visitas, tienen que fijar las comunicaciones y estancias de los abuelos con sus nietos, con la certeza de que serán cumplidas, lo que habrá de ser aprobado por el Juez.

En el régimen de visitas del Convenio Regulador, tiene que constar con claridad el régimen de visitas ente los abuelos y los nietos para después de la separación, por lo que los cónyuges de mutuo acuerdo tienen que fijar los días y las horas de las visitas, tanto en fines de semana, como en vacaciones escolares, para que los menores puedan permanecer en compañía de los abuelos; de igual forma deberá fijarse el lugar y la hora a la que los abuelos recogerán a los menores, así como la hora y lugar en que deberán entregarlos al término de la visita.

Si no se da acuerdo entre los cónyuges, sobre el derecho de visitas entre abuelos y nietos, cosa que por otra parte suele ser relativamente frecuente, será el Juez quien establezca y regule este derecho teniendo en cuenta el grado de vinculación existente entre abuelos y nietos, para que no se pierdan esas relaciones. Independientemente de que haya o no acuerdo entre los cónyuges, el régimen establecido en el Convenio Regulador, tienen que ser respetado, y si no lo es, será exigido por vía de apremio, pero si a pesar de ello alguien dificulta o impide este derecho, los abuelos al denunciarlo, el Juez podrá conminar o compeler a su cumplimiento.

$\mathrm{Al}$ producirse la separación, nulidad o divorcio, uno de los progenitores o incluso los dos, pueden tratar de que los menores no se relacionen con sus abuelos, pero en este caso, siempre habrá un cónyuge que no conviva con los menores y tenga un derecho a régimen de visitas. Los abuelos de acuerdo con el artículo $90 \mathrm{CC}^{266}$, tendrán su

266 Artículo 90 del Código Civil 
correspondiente derecho de visitas que como es lógico tendrá que ser inferior al de sus progenitores.

En este derecho de visitas, al tener los nietos dos parejas de abuelos, si viven todos ellos, al tener éstos derecho de visita por Ley, se da la circunstancia de que entre las visitas al progenitor con el que no conviven y los abuelos, el tiempo libre de los menores queda notablemente disminuido, con lo que se les causa trastornos y se vulnera el principio del interés del menor, que es junto con el de los abuelos, el objeto que protege la Ley.

En el futuro seguramente aumentará el número de abuelos que se encontrarán separados entre sí, exigiendo además cada uno de ellos su correspondiente derecho. Para poder resolver los problemas que origina esta situación, deberá el Juez tener en cuenta los intereses de todos los implicados, armonizándolos, siempre para proteger al menor y fraccionando los tiempos de visita de cada uno. La extensión del derecho de visitas tiene que ser superior en el padre separado o divorciado a la de los abuelos, al ser un grado de parentesco mayor, sin que desde luego pueda llegar a excluirse a los abuelos.

Por lo general el tiempo del régimen de visitas entre abuelos y nietos suele ser de un tercio del asignado al progenitor no conviviente con los menores, pudiéndose estimar que será un fin de semana al mes, dos o tres días en Navidad, dos días en Semana Santa y hacia diez días en verano.

Para este régimen de contactos se ha de tener en cuenta el grado de relación o

B) Si se considera necesario, el régimen de visitas y comunicación de los nietos con los abuelos, teniendo en cuenta, siempre, el interés de aquellos.

Los acuerdos de los cónyuges, adoptados para regular las consecuencias de la nulidad, separación o divorcio serán aprobados por el Juez, salvo si son dañosos para los hijos o gravemente perjudiciales para uno de los cónyuges. Si las partes proponen un régimen de visitas y comunicación de los nietos con los abuelos, el juez podrá aprobarlo previa audiencia de los abuelos en la que éstos presten su consentimiento. La denegación de los acuerdos habrá de hacerse mediante resolución motivada y en este caso los cónyuges deben someter a la consideración del juez nueva propuesta para su aprobación, si procede. Desde la aprobación judicial, podrán hacerse efectivos por la vía de apremio.

Las medidas que el Juez adopte en defecto de acuerdo o las convenidas por los cónyuges, podrán ser modificadas judicialmente o por muevo convenio cuando se alteren sustancialmente las circunstancias.

El Juez podrá establecer las garantías reales o personales que requiera el cumplimiento del convenio. 
proximidad existente entre abuelos y nietos, su relación afectiva, cercanía, como puede ser haber vivido juntos, haberlos cuidado, llevado al colegio u otras actividades parecidas, deberán tener un régimen de visitas más extenso que con otros abuelos que hayan tenido relación menos cercana.

Cuando se trata de menores hijos del cónyuge fallecido, los abuelos que reclamen la visita de sus nietos, deben tener un tiempo de visitas más extenso, llegando a los fines de semana alternos y la mitad de las vacaciones escolares, como si se tratara de padres o madres separados; con ello se consigue que los menores se relacionen no sólo con los abuelos, sino también con sus tíos y primos.

Las relaciones abuelos - nietos se deben reforzar en el caso de que el cónyuge sobreviviente inicie una nueva relación sentimental, para que no se pongan en peligro esas relaciones de los menores con la familia del progenitor fallecido.

El derecho de los abuelos a visitar a sus nietos, así como a tenerlos consigo, no tiene que limitarse a poco tiempo, ello dependerá de la extensión que determine el Juez en el Convenio Regulador, pudiendo incluir pernocta de los menores en el domicilio de los abuelos, según dispone la STS de 28 de junio de 2004(RJ-2004/4321) ${ }^{267}$.

\subsubsection{LOS ABUELOS EN LA CUSTODIA ORDINARIA DE LOS NIETOS}

Los abuelos en circunstancias excepcionales pueden desempeñar las funciones de guardia y custodia sobre sus nietos menores, de acuerdo con lo preceptuado en el artículo $103 \mathrm{CC}^{268}$. Tienen prioridad los abuelos sobre otros parientes que pudieran reclamar el derecho de guarda y custodia sobre los menores y sobre todo frente a una institución.

Al decir con carácter de excepción que los abuelos puedan asumir la guarda y custodia sobre los menores, se refiere a los casos de ausencia de los padres, de drogodependencia, toxicomanías y reclusión de los progenitores en establecimientos

\footnotetext{
${ }^{267}$ Acebedo Bermejo, Antonio, op.cit, pag 29 y ss

268 Artículo 103 CC, $1^{\mathrm{a}}$ medida, apartado 2: "Excepcionalmente, los hijos podrán ser encomendados a los abuelos, parientes u otras personas que así lo consintieren y de no haberlos, a una institución idónea, confiriéndoseles las funciones tutelares que ejercerán bajo la autoridad del juez".
} 
penitenciarios, con lo que en estas circunstancias extremas se hace materialmente imposible el que los progenitores puedan ejercer esas funciones, y antes de ponerlos en manos de otros parientes o de una institución apropiada, el legislador ha querido que los abuelos sean prioritarios en esa asignación.

Cuando los abuelos se hacen cargo de la custodia de los menores, pasan éstos a convivir con sus abuelos en un mismo domicilio, ejerciendo sobre dichos menores las responsabilidades que implica esa custodia.

En este caso los progenitores, aunque se haya asignado a los abuelos la guarda y custodia, mantendrán el ejercicio de la patria potestad sobre los menores, lo que implicará la facultad de tomar decisiones sobre su salud, formación y educación. Quiere ello decir que "los abuelos custodios de sus nietos no podrán decidir el centro escolar al que los niños asistan, el proyecto educativo al que se los piense someter o el especialista médico que deba atenderlos en una determinada dolencia, que serían cuestiones trascendentes cuya decisión deberá ser adoptada por los padres, quedando los abuelos facultados para tomar otras decisiones más secundarias, que afectarán a la vida cotidiana de los nietos"269.

Al asumir los abuelos la custodia de los nietos, comporta una serie de gastos originados por atenderlos, los cuales deben ser asumidos por los progenitores entregándolos a los abuelos. Estos gastos son en concepto de alimentos, necesarios para el sustento, habitación, vestido, asistencia médica, educación e instrucción, mientras sea menor de edad y después cuando sea mayor de edad, si no ha terminado su formación por causa que no le sea imputable, de acuerdo con lo establecido en el artículo 142 CC. Esta obligación de pagar los alimentos depende en gran medida de las posibilidades económicas de los progenitores, será pagado por el tiempo que los menores permanezcan guardados por los abuelos y dichos menores no dispongan de medios económicos propios para hacer frente a dichos gastos.

La cantidad de dinero que los abuelos deben recibir de los progenitores, en concepto de alimentos, tiene que figurar en el Convenio Regulador, determinada en su cuantía, además de fijar la fórmula para su actualización periódica, generalmente anual,

269 Acevedo Bermejo, Antonio, op.cit, pag 33 
de acuerdo con lo preceptuado en el artículo 93 del CC. Según el artículo 144 CC los abuelos no tienen obligación de compartir esos gastos con los progenitores, por el orden de prelación establecido en el mencionado artículo. En el Convenio Regulador deberá constar esa cuantía a pagar por los progenitores, el consentimiento de los abuelos como encargados de la custodia, se tendrá que someter al dictamen del Ministerio Fiscal, para que después sea aprobado por el Juez.

Para establecer la fórmula de actualización de la pensión de alimentos existen dos fórmulas principales, una es según el Índice de Precios al Consumo IPC que hace público el Instituto Nacional de Estadística y la otra trata de adecuar la prestación de los obligados al pago, según sus rendimientos económicos del año anterior. La fórmula del IPC es la de más fácil aplicación, la más sencilla por basarse en datos oficiales y al alcance de todos, por lo que es de más frecuente aplicación. Por la otra fórmula mencionada de adaptación de la pensión a las variaciones de salarios de los obligados al pago, es más justa, pero resulta de muy complicada aplicación, pues es necesario recabar esos datos de las empresas, o a veces el Juez tiene que averiguarlo por otros procedimientos, lo que origina retrasos, por ello es menos empleada ${ }^{270}$.

\subsubsection{LOS ABUELOS COMO TUTORES SOBRE LOS NIETOS}

Por el mencionado artículo 103 los abuelos pueden asumir las funciones tutelares sobre los menores, con exclusión de los padres y con mejor derecho en determinadas situaciones especiales como ausencia de los padres, incapacidad de éstos para ejercer las responsabilidades propias de la patria potestad, drogodependencias, toxicomanías graves o reclusión en establecimientos penitenciarios.

Al darse estas situaciones anormales o irregulares, los abuelos gozan de privilegio o prioridad para que el Juez les asigne la tutela de los menores antes que a otros parientes que también tengan derecho a ello. Si se diera la circunstancia de que estos parientes tales como abuelos, tíos $u$ otros no existieran o no prestaren su consentimiento, esas funciones tutelares pasarían a ser ejercidas por una institución adecuada a los menores.

270 Ibidem, pags 32 y ss 
Cuando asumen los abuelos las funciones tutelares, deben percibir la pensión de alimentos a cargo de los padres, siempre que existan y se encuentren en situación de abonarla, de acuerdo con lo establecido en el artículo 143 CC. Para el caso de que los progenitores no estén en condiciones de cumplir la obligación alimenticia han de satisfacer alimentos a los menores de edad escolar los abuelos que cuenten con medios de fortuna.

El Juez al encomendar a los abuelos la tutela sobre los nietos con carácter excepcional, tienen que cumplir con ello las obligaciones del artículo 154 del CC, es decir, reemplazar a los padres en sus funciones de velar por ellos, tenerlos en su compañía, alimentarlos, educarlos, procurarlos una formación integral, representarlos y administrar sus bienes.

Por la Ley 42/2003, al dar nueva redacción al artículo 103 CC en que dice: "que ejercerán bajo la autoridad del Juez", quiere decir que esas funciones tutelares sobre los nietos tienen necesariamente que llevarse a cabo supervisadas por el Juez. El Juez controlará periódicamente el ejercicio de esta responsabilidad, revisando las cuentas y la gestión de su patrimonio para comprobar que las funciones tutelares se desarrollan correctamente. $^{271}$

\subsubsection{LAS FUNCIONES TUTELARES DE LOS ABUELOS EN LA} JURISPRUDENCIA

La STS, Sala 1a , de 28 de junio de 2004, trata de unos abuelos que desean tener derecho de visitas con sus nietos, que se encuentran custodiados por su madre. Los menores nacidos el 1 de febrero de 1990 y 22 de noviembre de 1995 no tienen padre por haber fallecido éste el día 15 de diciembre de 1995, un mes después de haberse separado judicialmente de su mujer.

La madre pretende que los abuelos puedan visitar a los nietos y tenerlos en su compañía domingos alternos desde las 17:00 horas hasta las 20:30 del mismo día. El Ministerio Fiscal informó que se debería de establecer el régimen siguiente: un fin de

${ }^{271}$ Ibidem, pags 35 y 36 
semana completo con pernocta al mes, una de las fiestas de Navidad, entendiéndose por tal la Nochebuena y el día de Navidad, la Nochevieja y el día de Año Nuevo o la noche y el día de Reyes a elección de la madre, cuatro días en Semana Santa y quince días en verano. Este tipo de régimen de visitas es el más normal, el más justo y el que se suele adoptar con más frecuencia.

El progenitor custodio de los menores (la madre) pretende que los menores vean a sus abuelos los domingos durante tres horas y media, de las 17:00 a las 20:30 horas lo que es a todas luces insuficiente, de igual forma se opone a que los menores pernocten con sus abuelos, cuando el mayor ya lo habría hecho en el tiempo en que vivía su padre, el menor no por ser de muy corta edad. Tampoco desea la madre que convivan con los abuelos una temporada.

Las pretensiones de la madre no tienen fundamento jurídico por vulnerar la Ley $42 / 2003$ y la $1 / 1996$, pues se debe tener en cuenta el interés de los menores, así como el de los abuelos, por ser las partes más débiles de la relación familiar. Se debe considerar que el régimen de visitas del Ministerio Fiscal es el correcto, por no ser excesivo ni perturbar a los menores, con mayor motivo al tratarse de hijos de un progenitor fallecido que si viviera tendría derecho de visita, con lo que lo ocupan ahora sus hijos, siendo además el único modo que tienen los menores de relacionarse y mantener el recuerdo de su padre, con sus abuelos y familiares paternos.

Su Fundamento de Derecho Primero, dice que la Sentencia del Juzgado de $1^{\text {a }}$ Instancia no 22 de Madrid de 28 de abril de 1997, establece que el régimen de visitas será el que acuerden la madre y los abuelos. Si no se pusieran de acuerdo se aplicará el de tenerlos un fin de semana al mes, con pernocta, comenzando por el inmediato posterior a la presente resolución, desde las 18:00 horas los viernes hasta las 21:00 horas del domingo, una de las fiestas de Navidad, considerando por tal la Nochebuena y el día de Navidad o Nochevieja y el día de Año Nuevo, o la noche y el día de Reyes, tres días en Semana Santa y quince días seguidos en verano, siendo estos periodos elegidos por la madre.

En el final de su Fundamento de Derecho Segundo dice que procede acordar que en ejecución de sentencia, con audiencia de los interesados, de los menores y del 
Ministerio Fiscal, se establezca un régimen de visitas entre abuelos y nietos, que puede ser el mismo hasta ahora establecido u otro diferente, debiendo ponderarse la razonabilidad de las opiniones de los menores, lo que no significa que quepa identificar lo expresado por ellos con su interés, pues en todo caso debe prevalecer el beneficio de los mismos en orden a su formación integral e integración familiar y social.

La sentencia de la Audiencia Provincial de León, Sección 2a n no 343/1999, de fecha 21 de julio (AC-1999/7346) trata de un caso de divorcio en que la menor queda bajo la custodia de la madre, con un régimen de visitas para el padre, en relación a su hija, los fines de semana alternos desde las 11:00 horas del sábado a las 20:30 horas de los domingos, así como la mitad de las vacaciones de verano, Semana Santa y Navidad, eligiendo los periodos el padre los años impares y la madre los pares. Para recoger a la menor irá el padre a la vivienda materna, lo mismo que para reintegrarla y si el padre no pudiera realizarlo por motivos laborales, serán los abuelos paternos quienes se encargarán de hacerlo en el mencionado domicilio, pudiendo dichos abuelos paternos tenerla consigo en los periodos de visita que correspondan al padre.

El padre contribuye a la alimentación de su hija menor con la cantidad de 35.000 pts al mes, actualizándose todos los años en el mes de enero de acuerdo con el Índice de Precios al Consumo que publica el Instituto Nacional de Estadística u otro organismo equivalente, debiéndose pagar dicha cantidad dentro de los cinco días primeros de cada mes.

La madre recurre la sentencia basándose en que la menor no puede pernoctar sólo con los abuelos paternos, cuando no pueda hacerlo por razón de trabajo, además de considerar que los abuelos no gozan de buena salud. El Juez considera que la abuela se encuentra en un estado y aspecto adecuado para cuidar a la menor por lo que el recurso queda desestimado.

Lo más importante de esta sentencia se encuentra en que los abuelos pueden tener la custodia de la nieta cuando las circunstancias lo exigen, como es el este caso por motivos laborales del padre, además de que los abuelos tienen derecho de visita sobre los nietos independientemente de los progenitores de acuerdo con los artículos 90, 94 y 160 CC. 
La Sentencia de la Audiencia Provincial de Barcelona, Sección 18, de 28 de diciembre de 2000 (JUR-2001/113069), trata de dos niñas cuyos padres fallecieron, por lo que se encuentran bajo la tutela de su abuelo paterno. La sentencia es recurrida por los abuelos maternos que desean un régimen de visitas más amplio, a lo que se opone el abuelo paterno basándose en que no hay condiciones higiénicas y el ejemplo que reciben no es el adecuado para las menores.

De su Fundamento de Derecho Segundo queda demostrado que las niñas tienen nueve y ocho años y quedaron bajo la tutela del abuelo paterno, al haber fallecido ambos padres. El abuelo materno desea tener a sus nietas en su compañía fines de semana alternos, vacaciones y otras fiestas.

El demandado manifiesta que ha habido buena relación con los abuelos maternos y los tíos e incluso que él las llevaba, que recibían muchas atenciones de los abuelos, pero que el ejemplo que recibían las niñas no era el adecuado porque las tías de las menores se acostaban con los novios en la casa cuando estaban allí las niñas.

De informe del S.A.T (Servei d'Assessorament tecnic i d'Atenció a la Victima) se deduce que según manifiesta la hermana mayor no ve a sus abuelos maternos desde hace tiempo, cuando hacía las visitas dormía con la abuela, lo que no le gustaba porque estaba muy sucio debajo de las camas, la gustaría volver sin quedarse a dormir y dice que le han comprado una litera para que duerma con su tío y con su tía. Antes, su hermana dormía en la misma cama con su tío y su tía; a su prima de diecisiete años, el tío y la tía, así como su abuela, la pegaban con una vara para que hiciera las faenas de la casa, lo que vio en dos o tres ocasiones, cuando contaba entre cinco y siete años de edad.

La hermana menor que tienen ocho años, dice que no ve a los abuelos porque andan mal de salud y no la vienen a ver, que antes si los veían cuando iban las dos a su casa, quedándose algunas veces a dormir. Ella dormía en la cama de la abuela, el abuelo dormía solo en otra habitación, el tío materno dormía con su novia; ella misma había dormido en la habitación con su tío en una litera, por lo que desea ir de visita un fin de semana, pero no dormir, porque tiene que hacerlo en una litera con su hermana en la misma habitación que su tío y su tía.

Esta sentencia es ilustrativa de que no se respeta el interés de los menores, que 
debe ser el principio fundamental de las funciones tutelares; al mismo tiempo, no se dan condiciones higiénicas en la vivienda donde residen en las visitas a los abuelos y familiares maternos. Por otra parte reciben un mal ejemplo al pernoctar en una habitación con sus tíos, al no disponer para ellos de una habitación individual y sobre todo al ver los malos tratos tanto de palabra como de obra que recibe su prima de diecisiete años, lo que resulta para ellas muy desagradable y guardarán malos recuerdos para el resto de su vida. Desean ellas relacionarse con su familia materna, además de los abuelos con sus tíos y especialmente con su prima, por lo que constituye un ejemplo de que los menores deben relacionarse con los abuelos, pero hay que considerar también las relaciones con sus tíos y primos porque tienen gran importancia. Las niñas desde luego desean relacionarse con su familia materna, pero no pernoctar en su domicilio por lo anteriormente expuesto.

La Sala entiende que debe en parte tenerse en cuenta el recurso de apelación de la parte demandada, limitando las visitas durante el curso escolar (para no interferir en el desarrollo de las actividades de las menores, de orden escolar o complementario) a sábados alternos de 10 a 20 horas más dos días de libre elección, de mutuo acuerdo entre ambas familias, de las vacaciones de Navidad, uno de cada mitad del periodo vacacional, y uno del periodo de Semana Santa con el mismo horario y sin pernocta, más un día inter-semanal de la siguiente semana a elegir de mutuo acuerdo, y en su defecto el miércoles.

En la Sentencia de la Audiencia Provincial de Santa Cruz de Tenerife (Sección 1ª) $\mathrm{n}^{\circ}$ 145/2002, de 18 de marzo (JUR-2002/182735), se da un régimen de visitas de los abuelos maternos que se considera excesivo, pues no se trata de subrogar a la abuela materna en el lugar de la madre fallecida, lo que se pretende es la continuación de los lazos afectivos entre los nietos y la familia materna.

Por su Fundamento de Derecho Primero, se concede a los abuelos maternos un régimen de visitas de un mes de estancia durante las vacaciones de verano, la mitad de las vacaciones de Navidad y Semana Santa y un régimen de visitas de un fin de semana cada tres; este régimen se considera excesivo por ser más propio de un progenitor que de unos abuelos. En su Fundamento de Derecho Segundo, dice que las relaciones 
personales entre abuelos y nietos no pueden tener la misma duración que las que se establecen en el artículo 160.2 del CC para los progenitores; ni tampoco las relaciones tienen que limitarse a un simple régimen de visitas, como desea la parte apelante, con mayor motivo al tratarse de unos menores de madre fallecida, por lo que se trata de mantener las relaciones abuelos - nietos lo más fluidas posible. Como consecuencia de

ello, el Juez establece un nuevo régimen de visitas en el que prevalecerá el acordado entre el padre y los abuelos maternos, en defecto del cual será el siguiente:

En lo relativo a visitas la abuela materna podrá tener a sus nietos un sábado o domingo, el que ella elija comunicándolo con suficiente antelación al padre, desde las diez a las veintiuna horas. Este sábado o domingo será uno de cada cuatro fines de semana. De igual forma la abuela podrá tener a sus nietos los días 25 de diciembre y 7 de enero en igual horario de las diez a las veintiuna horas.

Por lo que se refiere a las estancias la abuela podrá tener a los menores dos semanas durante las vacaciones de verano escogiendo el padre el periodo concreto de dichas estancias de los menores, teniendo que reintegrarlos al domicilio paterno antes de las veintiuna horas del último día de cada periodo de estancias.

\section{RESPONSABILIDAD DE LOS ACOGEDORES}

\subsection{DEFINICIÓN Y CARACTERÍSTICAS}

El acogimiento se contempla en el artículo 172.3 del Código Civil que dice: "La guarda asumida a solicitud de los padres o tutores o como función de la tutela por ministerio de la Ley, se realizará mediante el acogimiento familiar o el acogimiento residencial. El acogimiento familiar se realizará por la persona o personas que determine la entidad pública. El acogimiento residencial se ejercerá por el Director del centro donde sea acogido el menor".

La primera característica es la referida al tipo de acogimiento que puede ser familiar o residencial. El familiar puede ser normal o profesionalizado, siendo en este último de un mayor nivel de exigencia. Para el residencial puede ser en institución 
pública o de carácter privado. Con lo que el acogimiento puede realizarse tanto por personas físicas como personas jurídicas.

Como segunda característica tenemos la provisionalidad de esta institución, en la que una vez cesen las causas que la motivaron, volverá el menor con sus padres o tutores como se encontraba inicialmente.

La tercera característica es la separación entre la guarda y su ejercicio, lo que da lugar a que varias personas puedan ser responsables como consecuencia de los daños ocasionados por un menor. Ello depende del modo en que se llegue a la situación de acogimiento, como puede ser que los padres no hayan cumplido con sus deberes inherentes a la patria potestad y hayan sido privados de ella, por lo que la entidad asumirá la tutela legal del menor; o bien, se trate de unos padres que se encuentren en una situación de imposibilidad de cuidar del menor, en tal caso la entidad se hará cargo de dicho menor.

\subsection{ACOGIMIENTO FAMILIAR}

En el acogimiento familiar la Entidad pública encargada de la protección o el Juez asignan a determinadas personas las obligaciones de cuidar, alimentar, educar y formar integralmente al menor, dentro de la nueva familia, teniéndole en su compañía como un nuevo miembro, pasando de la familia natural a la de acogida. Estas obligaciones son las propias de la patria potestad que se encuentran contempladas en el artículo 154.1 del Código Civil, ya expuesto.

El requisito de la compañía es necesario para cumplir con los deberes de la patria potestad, para poder velar por ellos, con lo que se plantea el problema en el derecho de visitas, que tienen los padres del menor, en cuyo caso mientras el menor permanezca con sus padres, en el ejercicio de este derecho de visitas, la familia de acogida quedará exonerada de responsabilidad, al no tener al menor bajo su guarda, en el caso de que éste produzca un hecho dañoso.

Por lo que se refiere a la responsabilidad en el acogimiento familiar, hay que considerar si se puede incluir dentro del artículo 1903, si es números clausus o números apertus. Sobre ello se encuentra dividida la doctrina, en que para algunos como 
Yzquierdo Tolsada, es números clausus y no se puede incluir más que a los que se contemplan en el artículo; mientras que Santos Briz considera que se pueden incluir a otras personas no enunciadas en el artículo y de igual forma piensa De la Rosa Cortina que se puede incluir a guardadores y acogedores ${ }^{272}$.

De acuerdo con el artículo 172.3 del C.C dice: "El acogimiento familiar se ejercerá por la persona o personas que determine la entidad pública”, por lo que se trata de personas físicas como es la familia, que no tiene personalidad jurídica propia, pero sí la tiene la entidad pública que la designa.

El acogimiento se ha de realizar por escrito como dispone el artículo 173.2 C.C en el que se precisa además el consentimiento de la entidad pública, de las personas que reciban al menor y de éste si tuviera doce años cumplidos, por ello sólo se ha de considerar acogedores a las personas que menciona el documento en que se formaliza el acogimiento.

Los requisitos del acogimiento familiar que se realizan por escrito comprenden los consentimientos necesarios, la modalidad y duración del mismo; derechos y deberes de cada una de las partes y dentro de éstos, la periodicidad de las visitas por parte de la familia del menor acogido, el sistema de cobertura por parte de la entidad pública o de otros responsables civiles de los daños que sufra el menor o de los que pueda causar a terceros y la asunción de los gastos de manutención, educación y atención sanitaria. El contenido del seguimiento que en función de la finalidad del acogimiento, vaya a realizar la entidad pública, y el compromiso de colaboración de la familia acogedora al mismo. La compensación económica que en su caso vayan a recibir los acogedores. Si los acogedores actúan con carácter profesionalizado o si el acogimiento se realiza en un hogar funcional, se señalará expresamente. Se necesita además un informe de los servicios de atención a menores.

El documento con el contenido expresado debe ser remitido al Ministerio Fiscal por disposición expresa de este precepto en concordancia con el artículo 174.2 del C.C.

Si los padres o el tutor no consienten o se oponen al mismo, el acogimiento sólo podrá ser acordado por el Juez, en interés del menor. La propuesta de la Entidad pública

\footnotetext{
272 De la Rosa Cortina, José Miguel, op.cit, pags 35 y 36
} 
contendrá todas las menciones expresadas anteriormente.

No obstante, la entidad pública podrá acordar en interés del menor, un acogimiento familiar provisional, que subsistirá hasta tanto se produzca resolución judicial.

La entidad pública, una vez realizadas las diligencias oportunas, y concluido el expediente, deberá presentar la propuesta al Juez de manera inmediata y, en todo caso, en el plazo máximo de quince días ${ }^{273}$.

Finalmente el acogimiento familiar puede adoptar tres tipos atendiendo a su finalidad, contemplados en el artículo 173 bis del C.C introducido por la LO 1/1996 de Protección Jurídica del Menor, que son el simple, el permanente y el pre adoptivo. El primero, es transitorio y dura hasta la reinserción en la propia familia o hasta que se establezca una medida de protección más estable. El segundo opera en función de la necesidad de medidas más estables, atribuyendo a la familia acogedora medidas de tutela, necesarias para el interés del menor. En cuanto al tercero, es decir, el pre adoptivo, se da en una situación previa a la adopción por la familia acogedora cuando ha sido presentada por la entidad pública ante la autoridad judicial la propuesta de adopción hasta que ésta se produzca, o bien, cuando sea necesario un periodo previo a la adopción, de adaptación del menor a la familia adoptiva.

\subsection{ACOGIMIENTO RESIDENCIAL}

El acogimiento residencial se contempla en el apartado 3, del artículo 172 CC donde dice: "El acogimiento residencial se ejercerá por el Director del centro donde sea acogido el menor".

En el acogimiento residencial se dan similitudes con el acogimiento familiar pues se trata en definitiva de atender al menor, cumpliendo las funciones que establece el artículo 154 C.C para los padres y tutores. Pero de igual forma se dan diferencias entre uno y otro tipo de acogimiento. En primer lugar puede tratarse de un acogimiento

\footnotetext{
${ }^{273}$ Disposición adicional sexta de la Ley Orgánica 1/1996, de 15 de enero, sobre Protección Jurídica del Menor.

- Consulta 8/1997, de 8 de octubre de la Fiscalía General del Estado
} 
residencial ejercido por una institución de carácter público o privado, con lo que la formalización mediante documentos será menor en una Entidad pública que en una privada; en una pública depende de otra Entidad pública superior por ello no es necesaria demasiada documentación, al contrario que en una privada, con la que hay que distribuir claramente la responsabilidad entre una y otra.

El ejercicio de la guarda en lo que se refiere al requisito de la compañía tiene que ser más amplio y flexible que en el acogimiento familiar, pues no está el menor dentro de una familia, sino de una residencia atendido por su personal y en compañía de otros menores.

Por último, con respecto a la guarda, se atribuye al director de la residencia donde se encuentre internado el menor, distinguiéndose su responsabilidad de la del resto de empleados que formen la plantilla de dicha residencia.

En cuanto a la responsabilidad sobre el menor hay que considerar quien es el que detenta la patria potestad sobre el menor, pues puede tratarse de una tutela ex lege por parte de la Entidad o bien coexistir esa tutela ex lege con la patria potestad de los padres o tutores. La vigilancia sobre el menor la tiene el Centro residencial en el que se encuentra interno, por lo que es responsable de llevar la vigilancia y control sobre dicho menor. Si el menor comete un hecho dañoso, el responsable es el acogedor residencial, por no haberle controlado debidamente y como consecuencia de ello debe responder el Director del Centro por tratarse de una persona jurídica, no los empleados que se encuentran bajo su autoridad ${ }^{274}$.

\subsection{EL ACOGIMIENTO EN LA JURISPRUDENCIA}

En la S.A.P de Burgos, sección $1^{\mathrm{a}} \mathrm{n}^{\mathrm{o}}$ 230/2009, de 20 de octubre (JUR2009/476974) se declara la responsabilidad acumulativa de acogedores y de la Entidad Pública de Protección de Menores, por un delito cometido por un menor en desamparo, en acogimiento profesionalizado y prolongado por un año.

Este acogimiento no ha dado buenos resultados, pues el menor ha sido

274 Bonilla Correa, pag 353 y ss 
condenado penalmente en cinco ocasiones, incluida la de la presente Sentencia, con lo que parece que el acogimiento de casi un año se ha agravado o al menos consolidado su tendencia al delito. Los acogedores no sólo tienen que proporcionar al menor un código de conducta adecuado, le tienen que dar normas e imponerle una cierta disciplina, sino que también tienen que cuidar o controlar que esas normas se cumplan, y además tienen o deben tener un control directo de la persona del menor, lo que implica control rígido de actividades y horarios. Y si se tiene en cuenta lo expuesto a la vista de su historial delictivo, y además de que el menor fue detenido sobre las 0:00 horas del día 2 de noviembre cuando se dirigía a su domicilio siendo portador de un bolso ajeno, conducta por la cual ha sido condenado, que sin duda procede lo expuesto. Y ello por cuanto esta Sala no desconoce que los acogedores llevaban un año de acogimiento con el menor, sino que se trataba de un acogimiento profesionalizado, lo que implica un mayor nivel de exigencia para los acogedores.

La peculiaridad de esta Sentencia es que los acogedores no han controlado correctamente al menor, al permitirle estar solo a altas horas de la noche, tratándose de una persona conflictiva; dichos acogedores eran los responsables de su educación social y de la inculcación de valores morales, éticos y cívicos, por lo que a tenor del razonamiento de la Juez, no puede recaer únicamente la responsabilidad sobre la Junta de Castilla y León, como entidad que tenía asumida la tutela legal, por la situación de desamparo. La responsabilidad tiene que darse también sobre los acogedores por lo anteriormente expuesto, sin que estos puedan alegar en su descargo la existencia de un contrato administrativo de acogida con la referida entidad pública, por cuanto se trata de una responsabilidad ex lege, que no puede ser soslayada por un contrato inter-partes, en perjuicio de los derechos de terceros, máxime cuando se trata de una responsabilidad nacida ex delicto.

La S.A.P de Santa Cruz de Tenerife, sección $5^{\circ}$ n $^{\circ} 542 / 2009$ de 2 de noviembre (JUR-2010/78554), declara igualmente responsabilidad solidaria entre Entidad Pública como tutor y los acogedores. Se trata de un sistema de responsabilidad civil solidaria, pero con un orden de prelación que cabría calificar de excluyente, lo que da lugar a contradictio in terminis. Ese orden de prelación se contempla en el artículo 61.3 de la 
LORPM que dice: "responderán solidariamente con él de los daños y perjuicios causados sus padres, tutores, acogedores y guardadores legales o de hecho por este orden". Esta expresión de "por este orden", que ya fue analizada en el apartado correspondiente, se puede interpretar como que si hay padres o tutores, no se puede exigir responsabilidad a los acogedores o guardadores; pero lo decisivo o relevante en un sistema solidario de responsabilidad no sería el orden de prelación establecido, sino las efectivas facultades que los diversos responsables tuvieran atribuidas y ejercidas sobre el menor en el momento de acaecer los hechos que determinen su responsabilidad. Siendo pues una responsabilidad objetiva, la misma vendría a fundamentarse en la vinculación de deberes de control y vigilancia que los padres, tutores o guardadores han de tener sobre los menores sujetos a su cargo en función de la relación de filiación o de la protección jurídica del menor. En el presente caso no se discute que la Dirección General de Protección del Menor y la Familia de la Comunidad Autónoma de Canarias tuviera la tutela del menor responsable, conservando facultades de supervisión y vigilancia, pues no se trata de una renuncia o desvinculación del menor cuando se da en acogimiento, sino de una delegación que favorezca el ejercicio de las funciones sin que implique una exención de toda responsabilidad sobre el menor. En consecuencia, si parte de las facultades se delegan manteniendo una facultad superior de vigilancia y cuidado, lo propio es compartir responsabilidades debiendo responder de forma solidaria $^{275}$.

En la S.A.P de Lérida de 11 de marzo de 2002, Sección 2a, (JUR 2002/118814), trata de un menor acogido residencialmente en el Centro Educativo de Atención a la Infancia, bajo la tutela de la Generalitat de Cataluña, en el que el menor agredió a la profesora con un cuchillo en una clase de cocina, que se impartía en el mencionado centro.

La sentencia admite que la LORPM establece una responsabilidad al margen de la culpa, pero condena a la Generalitat basándose precisamente en la culpa. No considera a la profesora guardadora de hecho, pues la guarda de hecho se da en circunstancias especiales del artículo 303 C.C, ni que la ejerza materialmente, correspondiendo esa

${ }^{275}$ De la Rosa Cortina, José Miguel, op.cit, pags 147 y 148 
titularidad al Centro y en concreto sería su Director. Tampoco se admite una responsabilidad acumulativa.

El menor se encuentra bajo la tutela de la Administración de la Generalitat de Cataluña, quien ejerce sus funciones a través del Centro de Atención a la Infancia en régimen de acogimiento. Para exigir responsabilidad no se hace sobre el Centro, es decir, su Director, pues en ese caso, respondería la Generalitat; para evitarlo trata de cargar esa responsabilidad sobre la profesora, con lo que trata de exonerarse culpando a la perjudicada, que es la profesora bajo la que se encontraba el menor en el momento de producirse los hechos.

El Juez no considera a la profesora una guardadora de hecho, ni se puede considerar responsable de la mala conducta del alumno, al tratarse de un sistema de responsabilidad al margen de la culpa; por todo ello se condena al menor junto con la Generalitat de Cataluña $^{276}$.

\subsection{EL ACOGIMIENTO EN EL DERECHO PORTUGUÉS}

\subsubsection{GENERALIDADES}

El día 11 de septiembre de 2009 fue publicada la Ley portuguesa no 103/2009 que aprobó un nuevo régimen jurídico de apadrinamiento civil el cual es equiparable a nuestro acogimiento, para lo que se procedió a la alteración del Código Civil, el Código de Registro Civil, el Código de Impuesto sobre el Rendimiento de las Personas Singulares y la Ley de Organización y funcionamiento de los Tribunales Judiciales. Esta Ley entró en vigor el día siguiente a la publicación del Decreto Ley n 121/2010, de 27 de octubre, que tiene por objeto su reglamentación.

La institución del apadrinamiento civil es de muy reciente creación en el derecho civil portugués, por lo que se trata de una materia muy poco estudiada por la doctrina, desconocida por la jurisprudencia y de la que apenas han hecho uso de ella las familias. Está por descubrir todavía como opción entre los propios padrinos y afiliados, así como, entre los profesionales con responsabilidades en el proceso de apadrinamiento.

\footnotetext{
276 Bonilla Correa, op.cit pag 359
} 
El legislador portugués lo que pretende es introducir en el ordenamiento jurídico una relación, tendencialmente con un carácter de estabilidad y permanencia entre un niño o un joven menor de edad y una persona singular o una familia que ejerza los poderes y deberes propios de los padres, estableciendo con ellos unos lazos de carácter afectivo que no se consiguen en otro tipo de acogimiento como el residencial, pretendiendo contribuir al bienestar y desarrollo del menor, pues para ello no hay nada mejor que realizarlo en el ámbito familiar.

Para su constitución es precisa la homologación o decisión judicial y sujeta al Registro Civil.

Esta nueva institución jurídica ha sido calificada por algunos como relación "para familiar", "casi familiar" y que según otros será una nueva relación familiar que complementará a las otras previstas en el Código Civil. Pretende situarse entre la tutela y la adopción, como se dice en la Exposición de Motivos que precede a la Proposición de Ley $n^{\circ}$ 253/X en la que aclara: "un padrino es más que un tutor y menos que un adoptante estricto" ${ }^{277}$. De hecho, en los términos de los reformulados artículos 1921, n³ y 1961, al, g del Código Civil, no habrá lugar a tutela siempre que se constituya una relación de apadrinamiento civil, haciendo esto cesar a la tutela previamente establecida. En cuanto a los requisitos, una nueva relación de apadrinamiento es menos exigente que una adopción estricta, tanto para su constitución, como para su cesación, finalización o interrupción, para no desencadenar devoluciones sucesivas entre los involucrados.

Así parece ser la idea del legislador portugués al introducir el apadrinamiento como una "tercera vía", con el fin de integrar a los menores en un ambiente familiar que de otra forma permanecerían en instituciones, como sucede con un gran número de menores que les resulta muy difícil volver a la familia o a la adopción. Para lograr ese propósito se han flexibilizado las medidas intermedias necesarias para rehacer las soluciones de acogimiento de menores, que han sido solicitadas en la Relación de demandas de acogimiento, protección, tutela y crianza de jóvenes, ante la Subcomisión

\footnotetext{
277 "O padrino é mais do que um tutor, e é menos do que um adoptante restrito". Relaciones Paterno Filiales, Congreso IDADFE 2011, Prof Lasarte, Carlos, Ed Tecnos, Madrid 2014. Capítulo II O Novo Regime Portugués do "Apadrinamento Civil" Lei no 103/2009, de Da María Raquel Guimaraes, Professora Universidade do Porto y de la Universidade de Valladolid, Espanha, pag 35 y ss
} 
de Derechos Libertades y Garantías de la Asamblea de la República ${ }^{278}$.

\subsubsection{LOS AHIJADOS CIVILES}

El apadrinamiento es presentado como una solución que responde a las necesidades de los menores que por una u otra razón se encuentran apartados o separados de sus familias, siendo preferible esta solución antes que recurrir a las exigencias de una adopción o lo que es todavía peor el recurrir a ser internado en una institución residencial. Esta institución no puede ser considerada como un atajo hacia la adopción, porque para los menores los requisitos de la adopción no deben ser encaminados hacia el apadrinamiento civil.

Un menor, mayor de doce años puede iniciar un procedimiento de apadrinamiento civil, pudiendo llegar a designar la persona o familia que pueda apadrinarle, para lo que se precisa el consentimiento del propio menor mayor de doce años.

$\mathrm{Al}$ tratarse de menores, aunque sean mayores de doce años es necesario que sea supervisado el procedimiento por la comisión de menores y jóvenes o tribunal que entienda del proceso relativo al menor o Ministerio Público, como de igual forma se establece para el acogimiento regulado en el Código Civil español. El procedimiento se aplica a los menores portugueses así como a los menores extranjeros que residan en el territorio de Portugal. Puede ser una vía para obtener la nacionalidad portuguesa, aunque de forma restrictiva, para lo que hay que tener en consideración la nacionalidad del menor que seguramente se encontrará de forma irregular, por ello se deberá de estudiar las normas de conflicto para ver si permiten la adquisición de la nacionalidad. De todas formas al tratarse de una ley nueva habrá que esperar a que el tiempo ponga de manifiesto los problemas que puedan surgir para que el legislador introduzca las alteraciones necesarias para la adquisición de la nacionalidad ${ }^{279}$.

\footnotetext{
278 En el año 2007 se encontraban 11362 menores en instituciones en solicitud de apadrinamiento, Ibidem, pag 37 nota $^{\circ} 8$

${ }^{279}$ Ibidem, pags 39, 40 y nota 18
} 


\subsubsection{PADRINOS Y MADRINAS CIVILES}

Los padrinos y madrinas de acuerdo con el Decreto Ley portugués no 121/2010, de 27 de octubre, establece una edad mínima de veinticinco años y teniendo en cuenta la esperanza media de vida no permite el apadrinamiento a las personas mayores de sesenta años, por lo que no pueden rebasar este límite de edad. El legislador portugués ha considerado que para desempeñar correctamente los deberes del apadrinamiento tienen que tener una edad comprendida entre veinticinco años como mínimo y no superar los sesenta.

La Ley permite el apadrinamiento singular, es decir, por una sola persona o el realizado por una familia, para lo que habrá que tener en cuenta la idoneidad y forma de vida de los posibles padrinos. No existe impedimento de la Ley para que los padrinos puedan ser una pluralidad de personas, ni siquiera casados como pueden ser dos o más hermanos, o por un padre y un hijo, o un casado y sus hijos, pero a grupos más numerosos que los expuestos no parece que sea recomendable por las dificultades que originaría en la práctica. Se permite la extensión del apadrinamiento al cónyuge que vive en unión de hecho con el padrino o madrina, es decir, en una pareja de hecho, por el artículo 6 de la Ley se contempla esta hipótesis. Lo que sí prohíbe la Ley es la existencia de varios apadrinamientos sobre un mismo ahijado.

En lo que se refiere al apadrinamiento por personas casadas del mismo sexo la doctrina se encuentra dividida, para unos si se permite mientras que para otros no. El dilema se centra en el $n^{\circ} 4$ del artículo $3^{\circ}$ del Decreto Ley $n^{\circ}$ 121/2010 en el que unos dicen que la certificación necesaria deberá ser cautelosa en el caso de matrimonio de personas del mismo sexo, a pesar de no estar prohibida; mientras que para otros está prohibida.

El certificado de idoneidad para el apadrinamiento versa sobre las condiciones que deben ponderar los técnicos responsables del mismo, que se contemplan en el $n^{\circ} 1$ del artículo 3 del mencionado Decreto Ley, siendo éstos la personalidad, naturalidad, capacidad afectiva, estabilidad emocional, capacidades educativas y relacionales, condiciones de higiene y habitabilidad, situación económica, profesional y familiar, etc. Pues bien, unos interpretan que al realizar el certificado deberán ser especialmente 
cautelosos - a pesar de no estar prohibida- ante una solicitud por matrimonio de personas del mismo sexo; mientras que otros creen que esa posibilidad queda apartada por el $\mathrm{n}^{\mathrm{o}} 4 \mathrm{del}$ artículo $3^{\circ}$, esta es pues la división que existe sobre las parejas del mismo $\operatorname{sexo}^{280}$.

\subsubsection{LAS RELACIONES DE APADRINAMIENTO CIVIL}

El contenido de la relación de apadrinamiento civil depende de los contornos concretos que formen el compromiso de apadrinamiento y de la decisión judicial. El régimen de esta relación es el establecido en los artículos 1878 y ss del Código Civil portugués, con las limitaciones de los artículos 1936 a 1941 de dicho Código referidos a la tutela, teniendo en cuenta que las alteraciones a esas reglas tienen que ser admitidas por decisión judicial.

Los padrinos tienen la obligación, según lo dispuesto por el legislador de prestar alimentos al ahijado, siempre que los padres de éste no se encuentren en las condiciones necesarias de poder cumplirlo. El menor apadrinado al llegar a la mayoría de edad habrá de permitírsele completar sus estudios profesionales si no lo hubiera hecho en su minoría, para que pueda encontrar trabajo, de acuerdo con el artículo 1880 del Código Civil portugués; que se corresponde con el artículo 142, apartado 2 del Código Civil español el cual dice: "Los alimentos comprenden también la educación del alimentista mientras sea menor de edad y aún después, cuando no haya terminado su formación por causa que no le sea imputable".

Por el artículo 1878 del Código Civil portugués, en su apartado primero trata de la seguridad de los hijos, su salud, sustento, dirigir su educación, representarle y administrar sus bienes, que se relaciona con el artículo 154, apartado segundo del Código Civil español; de la misma forma el apartado $2^{\circ}$, contempla la obligación de los hijos de obedecer a sus padres, como en el artículo $155.1^{\circ}$ Código Civil español, así como el deber de escuchar a los mayores de doce años, al igual que lo hace el 156.2 y 159 Código Civil Español. Vemos por tanto que se aplican al menor apadrinado las disposiciones de

280 Ibidem, pag 40 y ss, así como nota no 37 
los menores en general y que son muy parecidas las disposiciones de uno y otro código.

En la relación de apadrinamiento, el legislador intenta aproximar al padrino y madrina con el tutor en lo que se refiere a las responsabilidades parentales, pero se da la diferencia en cuanto a la duración, que mientras se trata de la tutela se termina con la minoridad del pupilo y en el apadrinamiento tiene carácter permanente, sobreviviendo a la mayoría de edad del ahijado ${ }^{281}$.

\subsubsection{LOS PADRES}

Los padres en una relación de apadrinamiento civil siguen teniendo vínculos con el menor, pasando a ser digamos terceros en la nueva relación, en el sentido de que no son partes en ella.

En el proceso de apadrinamiento los padres tienen facultades para iniciar la designación de las personas que pretendan ser padrinos y además debiendo ser oídos a la hora de esa elección. Si no han sido privados del ejercicio de la patria potestad, los padres deben prestar su consentimiento en la constitución de la relación de apadrinamiento, suscribiendo el compromiso de la misma.

Tienen los padres la obligación de prestar alimentos al menor, siempre que sus condiciones económicas lo permitan y con prioridad ante los padrinos.

Sobre los padrinos recaen las responsabilidades parentales de acuerdo con lo establecido en el compromiso del apadrinamiento o la sentencia judicial según se trate. Tienen los padres unos derechos reconocidos en el artículo 8 de la Ley, siempre que no se encontraren incursos en un incumplimiento de sus deberes para con el menor, para que sin perjuicio de lo dispuesto en el compromiso del apadrinamiento, ser informados del local de residencia del hijo, acompañarle, contactar con el menor, recibir alguna imagen del mismo e incluso un derecho de visita.

Debe existir alguna relación entre los padres y el menor, para lo que habrá que estar a lo que disponga el compromiso de apadrinamiento y la opinión del Juez. Para ello hay que analizar caso por caso, pues, habrá situaciones que no aconsejen esas relaciones,

281 Ibidem, pags 46 y 55 
bien por no convenir al desarrollo del menor o por comprometer esa relación de apadrinamiento. En otras circunstancias podrán ser consideradas beneficiosas para el menor, por lo que serán permitidas e incluso estimuladas. Los padres deben contribuir a que las relaciones entre los padrinos y el ahijado se consoliden, por ello deben cooperar de forma positiva para que su hijo se integre en la nueva familia.

Los padres deben respetar y preservar la intimidad de la vida privada y familiar, así como el buen nombre y reputación de los padrinos. Los padrinos tienen el mismo deber hacia los padres del ahijado o menor. El hecho de realizar una relación de apadrinamiento no disminuye su personalidad jurídica con su hijo.

No hay duda de que los padres y padrinos están obligados a respetar y preservar la intimidad de la vida privada y la honra del menor apadrinado. Un menor es una persona en riesgo que al ser apadrinada se encuentra bajo las responsabilidades paternales de alguien que él desconoce, aunque ello no disminuye en nada sus derechos como persona, se le coloca en una situación que es especialmente vulnerable de cara a posibles violaciones de sus derechos.

Al establecer una nueva relación de apadrinamiento deben intervenir los padres, además del propio menor y el Juez. Se debe establecer una habilitación de los padrinos, para comprobar que reúnen condiciones de personalidad, idoneidad, socio-económicas, de orden práctico, motivaciones y posibilidades de cooperar con los padres en orden a asegurar el correcto desenvolvimiento del ahijado.

El menor o en su caso sus padres, pueden haber establecido alguna relación entre el menor y algún adulto o familia que puedan ser sus futuros padrinos; con lo que sería esta la mejor solución para habilitar a los padrinos y conseguir una buena relación de apadrinamiento. En el caso de que no se dé ninguna relación entre el ahijado o sus padres con los futuros padrinos, hay que recurrir para la habilitación a una "bolsa" de posibles padrinos, en que figuran los nombres de las personas y familias que desean ser padrinos, siendo proporcionada esta lista de nombres de la bolsa por los servicios de atención a los menores. Este procedimiento de habilitación es menos idóneo que el anterior pues en él no se da ninguna relación previa entre el menor y sus futuros padrinos. 
Como conclusión de esta institución reciente del legislador portugués es muy original, siendo desconocido su resultado práctico desde su introducción en el ordenamiento nacional, con lo que se puede especular sobre las soluciones que aportará en el futuro. Desde luego ha servido para colmar lagunas en el ejercicio de los poderes paternales por personas distintas a los padres $^{282}$.

\section{GUARDADORES LEGALES Y DE HECHO}

\subsection{GUARDADORES LEGALES}

Para llegar a la situación de guarda legal, pueden darse por varias causas: tutela ex lege, por resolución judicial y por guarda convencional. Estas situaciones se contemplan en los artículos 239 y 172 del Código Civil.

La tutela ex lege se da cuando el menor se encuentra en situación de desamparo que contempla el artículo 239 CC y que remite al artículo 172 en que definen a la misma como aquella en que "se produce de hecho a causa del incumplimiento o del imposible o inadecuado ejercicio de los deberes que le incumben de conformidad a las leyes, cuando éstos queden privados de la necesaria asistencia moral y material". En este caso la entidad pública del respectivo territorio que tenga encomendada la tutela de los menores o incapaces se hará cargo de los mismos, responsabilizándose de los daños que puedan causar.

Por resolución judicial se contempla en el artículo 172 in fine en el que dice: "se asumirá la guarda por la entidad pública cuando así lo acuerde el Juez en los casos que legalmente proceda". Se trata de una situación de carácter transitorio por causa legal o por el interés del menor. Se extingue cuando cesen las causas que la motivaron o se llegue a tutela ex lege o a la adopción.

En cuanto a la guarda convencional se da cuando los padres o tutores solicitan a la Administración que asuma las funciones de guarda por el tiempo necesario al concurrir circunstancias graves que les impidan cuidar del menor. Este tipo de guarda se

282 Ibidem, pag 49 y ss 
realiza mediante la petición de los padres o tutores ante la Administración, es decir, la entidad pública, al darse circunstancias graves, por las que no se pueda atender debidamente al menor. Se tiene que formalizar por escrito, haciendo constar que los padres o tutores han sido informados de las responsabilidades que siguen manteniendo respecto del hijo, así como de la forma en que la guarda será ejercida por la Administración. Cualquier variación posterior en cuanto a la forma del ejercicio de la guarda por parte de la Administración tiene que ser fundamentada y comunicada a los padres y tutores, así como al Ministerio Fiscal ${ }^{283}$.

De acuerdo con el artículo 61 de la LORPM se refiere a los guardadores legales, entre otros, como posibles responsables solidarios y para establecer quién es responsable hay que ver quién tiene encomendada la dirección del proceso educativo, así como si los hechos se pueden considerar culpa in educando o in eligendo.

La jurisprudencia menor suele responsabilizar a la Entidad Pública, como la S.A.P de Valladolid secc $2^{\mathrm{a}}, \mathrm{n}^{\mathrm{o}} 758$, de 22 de octubre de 2002 (JUR-2002/284904) en la que la Entidad Pública recurrente, alega que deben responder civilmente la menor y sus padres, en ningún caso la Entidad Pública que sólo tenía la guarda de la menor, mientras que la Audiencia declara que la guarda asumida por la Gerencia de Servicios Sociales "supone el ejercicio de las facultades de control y vigilancia del menor que, en tales circunstancias, sus padres no pueden ejercer en modo alguno, de forma que esta situación se asemeja a una suspensión de hecho de las facultades de los padres de llevar a cabo dichas funciones mientras estén bajo dicha guarda institucional, salvo los casos, por ejemplo, situaciones de visitas y permisos de salidas con los padres en que éstos se hacen cargo, aunque fuere transitoriamente, de los menores. En el caso actual, sólo la entidad pública que ejercía la guarda del menor tenía facultades y posibilidad, en el momento en que

\footnotetext{
${ }^{283}$ Artículo 172.2 Código Civil: Cuando los padres o tutores, por circunstancias graves, no puedan cuidar al menor, podrán solicitar de la entidad pública competente que ésta asuma su guarda durante el tiempo necesario.

La entrega de la guarda se hará constar por escrito, dejando constancia de que los padres o tutores han sido informados de las responsabilidades que siguen manteniendo respecto del hijo, así como de la forma en que dicha guarda va a ejercerse por la Administración.
}

Cualquier variación posterior de la forma de ejercicio será fundamentada y comunicada a aquéllos y al Ministerio Fiscal. 
acaecen los hechos, para vigilar y controlar la actuación del menor, y no sus padres, por lo que a ella le alcanza la responsabilidad civil solidaria recogida en el artículo 61.3 LORPM".

El que se constituya una guarda legal por la Entidad Pública de Protección de Menores, en sustitución o por delegación de los padres, no exime a éstos de responsabilidad; en este sentido la S.A.P de Alava, secc $2^{a} n^{\circ} 50$, de 10 de febrero de 2004 (ARP-2004/226) así lo dispone “ la guarda asumida por la madre y realizada mediante acogimiento residencial no extingue la patria potestad de aquella sobre el menor (artículo 169 y ss del Código Civil); que, el propio tenor del primer inciso del artículo 61.3 no excluye la responsabilidad de los padres por la mera existencia de acogedores y guardadores legales". Puede decirse que cuando se da acogimiento o se encomienda la guarda a una familia se tiende a liberarles en la medida de lo posible de responsabilidad, para no desincentivar estas instituciones en que el menor pueda vivir en un ambiente familiar que siempre será mejor para él, antes que hacerlo en una institución residencial $^{284}$.

\subsection{GUARDADORES DE HECHO}

Esta figura jurídica que aparece tras la reforma de 24 de octubre de 1983, se contempla en el Capítulo V del Título X del Libro I del Código Civil en su artículo 303 que dice: "Sin perjuicio de lo dispuesto en los artículos 203 y 228, cuando la Autoridad judicial tenga conocimiento de la existencia de un guardador de hecho podrá requerirle para que informe de la situación de la persona y los bienes del menor o del presunto incapaz y de su actuación en relación con los mismos, pudiendo establecer asimismo las medidas de control y vigilancia que considere oportunas".

Aunque el Código Civil no da un concepto de la guarda de hecho, se trata de una serie de situaciones fácticas que se caracterizan por la ausencia del procedimiento legal para el desarrollo de las funciones que se ejercitan, lo que quiere decir es que se dan los requisitos para la existencia de un órgano tutelar, pero esa protección al menor o incapaz

284 Bonilla Correa, op cit, pag 345 y ss. Igualmente ver De la Rosa Cortina, José Miguel, op.cit. pag 151 y ss 
se realiza sin el trámite correspondiente ${ }^{285}$.

Al no darse una definición de la guarda de hecho es necesario saber si se puede incluir en el artículo 1903, 2 y 3 del CC como los padres y tutores o recurrir al artículo 1902. Esta cuestión la resolvió la S.A.P de Asturias de 18 de julio de 2001 (JUR2001/309599) en la que se desestimó la demanda al no ser probado que el demandado fuese el tutor del menor causante de los daños. Frente a dicha resolución, el apelante manifiesta que si bien no se demuestra que el demandado sea el tutor del menor, de lo que no existe duda, es que sí es guardador de hecho. La Audiencia entiende que "aun cuando la reclamación hubiese sido hecha con base en la condición de guardador de hecho del demandado por el artículo 1902 CC, tampoco podría prosperar pues no es predicable de tal tipo de responsabilidad el carácter cuasi objetivo que se proclama de la que surge en los casos del artículo 1903".

La LORPM, al contrario que el CC, menciona a los guardadores de hecho, pero lo hace en último lugar, al ser su vinculación con el menor de segundo grado, pues antes se encuentran los padres y tutores. Ahora bien, aunque se encuentren en la escala de responsabilidad del artículo 61.3, no significa que no tengan que asumir sus responsabilidades cuando el menor cometa un hecho dañoso encontrándose a su cargo. $\mathrm{Al}$ contemplarse en el artículo anterior la expresión "por este orden", hay que determinar cómo se resuelven los casos en que se encuentren inmersos padres o tutores con guardadores de hecho. Este caso se planteó y resolvió en la S.A.P de Asturias, secc $2^{\mathrm{a}}, \mathrm{n}^{\mathrm{o}}$ 379/2004, de 16 de diciembre (JUR-2005/36761), en ella trata de "unos padres que hacen una dejación total de funciones tutelares correspondientes a los padres, habiendo sido el menor atendido por la abuela ante la falta de cuidado y atención prestados, no existiendo respecto de dicho menor a diferencia de sus hermanos, que fueron encontrados en desamparo y tutelados por la Administración, resolución judicial alguna declarando esa situación de desamparo, y que evidencie que los padres no tenían su guardia y custodia, por lo que ostentando aquellos la patria potestad de su hijo, y no acreditándose la imposibilidad de ejercer las funciones inherentes a la misma es evidente que procede la íntegra confirmación en este punto de la sentencia recurrida, pues el

285 Ibidem, pag 366, nota 207 
deber de vigilancia, control y custodia permanece a favor de la persona o entidad a la que se le ha encomendado esta labor y no puede trasladarse la responsabilidad a otra persona diferente, por lo que los citados recurrentes deberán responder solidaria y conjuntamente con su hijo Esteban de los daños y perjuicios ocasionados como consecuencia de su comportamiento. Por todo ello se condena a los padres y se exonera a la abuela guardadora de hecho. "En este caso la dejación y abandono de los padres sobre el menor, más el intento de cargar su responsabilidad a la abuela, que es la única que se ha preocupado del menor, es por lo que el Tribunal condena a los padres, pues, en caso contrario sería tolerar y estimular la incuria o indolencia de los progenitores.

La S.A.P de Cáceres de 5 de abril de 2005 (JUR-2005/99769) resuelve un caso de concurrencia de varias personas condenando al menor, junto con sus representantes legales que eran sus padres y la Junta de Extremadura. El menor había sido ingresado por orden judicial en un centro de protección de la Junta días después de ocurrir los hechos; la Junta recurre, pero la Audiencia entiende que al encontrarse en el Centro de Acogida supone que la Administración asume la guarda de hecho y como consecuencia de ello debe responder.

La S.A.P de Asturias de 27 de abril de 2006 (JUR-2006/166775) trata de un supuesto en el que se distribuye la responsabilidad entre varios responsables, como son la Administración del Principado de Asturias y los padres. Los hechos ocurren cuando el menor se encuentra en un permiso de fin de semana en compañía de la madre. La Administración del Principado en el momento de los hechos tenía la guarda y custodia del menor. El Juez en la Sentencia rebaja la cuantía del padre en un 50\% por encontrarse al ocurrir los hechos en situación de internado en un Centro Penitenciario, pero a la madre no se le rebaja la cuantía por el escaso interés mostrado por el menor y por haber favorecido la mala conducta del mismo.

Se dan dentro de la guarda de hecho situaciones en las que de forma transitoria se permite que un menor pase un fin de semana en casa de un amigo, en compañía de un familiar o casos parecidos; a ello se denomina delegación temporal de guarda. Ante estos casos la doctrina se encuentra dividida ante la idea de exigir responsabilidad a estos guardadores momentáneos por los posibles hechos dañosos del menor. Font Serra es 
partidario de exigirla a los padres y a los guardadores, mientras que otros como Diaz Alabart se muestran partidarios de excluir la responsabilidad en estos supuestos de delegación temporal de guarda.

De la Rosa Cortina dice que debe estarse a las circunstancias del caso concreto, sin perjuicio de la responsabilidad de los padres, para lo que se ha de considerar el tiempo durante el que se delegó la guarda, edad del menor y otras circunstancias parecidas. Parece injusto exigir responsabilidad civil a un guardador provisional que ha tenido al menor durante poco tiempo. Tratándose de menores mayores de catorce años lo normal es que respondan los padres como gestores del proceso de socialización y no los delegados, que no se les puede responsabilizar de la educación ni vigilancia de este tipo de menores ${ }^{286}$.

\section{LAS COMUNIDADES AUTÓNOMAS ANTE LA RESPONSABILIDAD PENAL DE LOS MENORES.}

\subsection{LEGISLACIÓN ESPAÑOLA SOBRE COMUNIDADES AUTÓNOMAS EN RELACIÓN CON LA RESPONSABILIDAD DE LOS MENORES}

La C.E. en su título VIII, Artículo 148. 1.20, sobre las Competencias de las Comunidades Autónomas, asigna a éstas la competencia en materia de asistencia social, entre las que se encuentra la específica sobre protección de menores, incluidos los que no sean de nacionalidad española, por el hecho de encontrarse dentro de su territorio autonómico.

El artículo 149.1.8 establece la competencia exclusiva del Estado en materia de legislación civil, sin perjuicio de la conservación, modificación y desarrollo por las Comunidades Autónomas de los derechos civiles, forales o especiales, allí donde existan. Por otra parte en el mismo artículo 149, en su apartado tercero dice: "Las materias no

286 De la Rosa Cortina, Jose Miguel, op.cit pag 154 y ss

Bonilla Correa, op, cit pag 365 y ss 
atribuidas expresamente al Estado por esta Constitución podrán corresponder a las Comunidades Autónomas, en virtud de sus respectivos Estatutos. La competencia sobre las materias que no se hayan asumido por los Estatutos de Autonomía corresponderá al Estado, cuyas normas prevalecerán, en caso de conflicto, sobre las de las Comunidades Autónomas en todo lo que no esté atribuido a la exclusiva competencia de éstas. El derecho estatal será, en todo caso, supletorio del derecho de las Comunidades Autónomas". Vemos en este artículo 149 que el Estado tiene en exclusiva la legislación civil, pero no en materia social que es de las Comunidades Autónomas por el artículo 148.1.20, quiere ello decir que el Estado puede legislar en materia civil, aunque será la Comunidad Autónoma la que legisle, trate la protección de menores y la que en definitiva dirigirá esa protección a través de las Entidades encargadas de dicha función ya sean públicas o privadas.

De acuerdo con la disposición final vigésimo segunda de la Ley Orgánica 1/1996, de 15 de enero, de Protección Jurídica del Menor, las Comunidades Autónomas y de las Ciudades de Ceuta y Melilla son competentes para la ejecución de las medidas adoptadas por los Jueces de Menores. Para ello dichas entidades públicas llevarán a cabo la creación, dirección, organización y gestión de servicios, instituciones y programas adecuados para la ejecución de las medidas previstas en esta Ley (Art ${ }^{\mathrm{o}}$ 45.1 LORPM).

Las Comunidades Autónomas y Ciudades de Ceuta y Melilla serán las responsables de la ejecución de las medidas en relación con los menores, donde se ubique el Juzgado de Menores que haya dictado la sentencia, sin perjuicio de lo dispuesto en el apartado 3 del artículo siguiente (Art ${ }^{\circ} 45.2$ LORPM) ${ }^{287}$.

\footnotetext{
${ }^{287}$ Artículo 46.3 LORPM: "Recibidos por la entidad pública el testimonio y la liquidación (informes técnicos que abren en la causa) de la medida indicada en el apartado anterior, aquella designará de forma inmediata un profesional que se responsabilizará de la ejecución de la medida impuesta, y, si ésta fuera de internamiento, designará el centro más adecuado para su ejecución de entre los más cercanos al domicilio del menor en los que existan plazas disponibles para la ejecución por la entidad pública competente en cada caso. El traslado a otro centro distinto de los anteriores sólo se podrá fundamentar en el interés del menor de ser alejado de su entorno familiar y social y requerirá en todo caso la aprobación del Juzgado de Menores competente para la ejecución de la medida. En todo caso, los menores pertenecientes a una banda, organización o asociación no podrán cumplir la medida impuesta en el mismo centro, debiendo designárseles uno distinto aunque la elección del mismo suponga alejamiento del entorno familiar o social.
} 
El artículo 45.3 de la LORPM dice: "Las Comunidades Autónomas y las Ciudades de Ceuta y Melilla podrán establecer los convenios o acuerdos de colaboración necesarios con otras entidades, bien sean públicas, de la Administración del Estado, Local o de otras Comunidades Autónomas, o privadas sin ánimo de lucro, para la ejecución de las medidas de su competencia, bajo su directa supervisión, sin que ello suponga en ningún caso la cesión de la titularidad y responsabilidad derivada de dicha ejecución". Al permitir la ejecución de estas medidas por entidades privadas sin ánimo de lucro, algunos autores consideran que entraña peligro, sobre todo en lo que se refiere a internamiento de menores. Este supuesto peligro, al tratarse de entidades privadas sin ánimo de lucro, unido a que la responsabilidad queda en manos de las C.C.A.A, lo disminuyen de forma considerable. El emplear entidades privadas sin ánimo de lucro es propio del derecho anglosajón y ha sido acogido por la Fiscalía General del Estado, por permitir con ello contar en el proceso con mayores medios materiales y humanos de carácter diverso, existentes en la sociedad civil.

Las Entidades administrativas tienen que elaborar un programa individualizado de la ejecución de las medidas que debe aprobar el Juez de Menores, de oficio o a instancia del Ministerio Fiscal o del letrado del menor ( $\operatorname{art}^{\circ} 44.2 \mathrm{c}$ ). Apertura de un expediente individual del menor que contenga todas las resoluciones judiciales y toda la documentación general ( $\operatorname{art}^{\circ}$ 48). Elaboración de informes periódicos sobre su evaluación personal, que se remitirán al Juez de Menores, Ministerio Fiscal de forma preceptiva y al letrado del menor si lo solicita ( $\left.\operatorname{art}^{\mathrm{o}} 49\right)$. Ejercer régimen disciplinario sobre los menores ( $\mathrm{rrt}^{\circ} \mathrm{60}$ ). Una vez cumplida la medida, la entidad pública tienen que elaborar el informe final, más los realizados anteriormente ( $\operatorname{art}^{\circ}$ 49.1) que se remitirá al Juez de Menores, el cual dictará auto acordando lo que proceda sobre el archivo de la causa; dicho auto será notificado por el secretario judicial al Ministerio Fiscal, al letrado del menor, a la entidad pública y a la víctima.

Hay que tener en consideración que para cumplir con las medidas de esta Ley, es necesaria la creación, dirección, organización y gestión de los servicios necesarios, lo que comporta unos gastos en infraestructuras que no todas las C.C.A.A pueden asumir. Para ello es necesario que las leyes de financiación de las Comunidades Autónomas, así como 
el Consejo de Política Fiscal y Financiera realicen una evaluación de esos gastos para dotarlos de los fondos necesarios para hacer frente a esas necesidades y poder cumplir con esas funciones ${ }^{288}$.

\subsection{LA PROBLEMÁTICA DE LAS COMUNIDADES AUTÓNOMAS EN RELACIÓN CON LOS MENORES INMIGRANTES NO ACOMPAÑADOS.}

El menor inmigrante no acompañado es una persona menor de dieciocho años que se encuentra separada de ambos padres y no está bajo el cuidado de ningún adulto que por ley o costumbre esté a su cargo ${ }^{289}$. Cada vez es mayor el número de menores extranjeros indocumentados no acompañados que hay en España, habiéndose observado este fenómeno a finales de la década de los noventa. Se trata de unos menores que han tenido que vivir en unas condiciones sociales y familiares en sus países de origen de gran precariedad, dando ello lugar a separarse de su familia, viviendo solos y sin ninguna protección.

Estos menores sujetos a una inmigración prematura se encuentran sin arraigo en un sistema educativo, por hallarse de un lado para otro, sin rumbo fijo, tratando de encontrar un lugar de acogida y poder mejorar sus condiciones de vida. Por ser menores tienen derecho de acceso al sistema educativo español, aunque se da escasez de medios materiales y humanos para formarlos debidamente. Un menor en esta situación se escolariza durante el tiempo que se encuentra bajo la tutela de la administración, en sus centros para la guarda de menores o en situación de acogimiento en una familia. Al tratarse de un extranjero que normalmente se encontrará indocumentado, se añaden mayores dificultades para integrarle en el sistema educativo general, sobre todo si procede de un país que no es de habla española, para ello será necesario encontrar personal que se pueda comunicar con él en su propia lengua, además de averiguar su edad, origen y otros datos para ver si se puede contactar con sus familiares.

\footnotetext{
${ }^{288}$ Gomez Rivero, Ma del Carmen, Comentario a la Ley Penal del Menor, op.cit, pags 352 y ss.

${ }^{289}$ Los Menores Extranjeros no Acompañados en los Sistemas de Protección a la Infancia de las Comunidades Autónomas, Cabello Mallal Vicente, Cloquel Loazano Alexis, Tirant Loblanc, Monografías, artículo de Josep María Felip y Sardá, Valencia 2010, pag 224 y ss.
} 
En general puede decirse que estos menores proceden de países de Asia y de África, en que se han producido guerras y consecuentemente familias desestructuradas, con la necesidad de trasladarse de forma clandestina a través de las fronteras, bajo unas condiciones de gran violencia ${ }^{290}$.

Para España las Comunidades Autónomas que sufren y deben resolver estos problemas son las de Andalucía e Islas Canarias por su proximidad con el continente africano, que es del que llegan estos menores bien por ser originarios del mismo o por haberlo atravesado desde Asia. Al mismo tiempo estos menores al llegar a estas Comunidades mencionadas a veces se trasladan a otras como Madrid, Barcelona o Valencia, por creer que en ellas encontrarán una vida mejor; con ello el problema se extiende a casi todo el territorio nacional, lo que da lugar a que algunas comunidades se encuentren desbordados para hacer frente al problema.

\subsubsection{LA UNIÓN EUROPEA}

Con el fin de hacer frente a este problema el 6 de mayo de 2010 la Comisión Europea presentó una comunicación al Parlamento y al Consejo Europeo con el objetivo de que se aprobase un Plan de Acción de la Unión Europea sobre menores extranjeros no acompañados (MENA).

\footnotetext{
${ }^{290}$ Existen casi veinticinco millones de niños desarraigados en el mundo. Sólo en la Europa Occidental hay más de 100.000 niños separados de sus padres y alrededor de unos 20.000 menores no acompañados presentan solicitudes de asilo cada año en Europa, Norteamérica y Oceanía. La mayoría de los que huyen de sus hogares lo hacen por causa de las guerras, pensemos en Libia, Egipto, Siria, Irak, etc. En la última década, las guerras han producido la muerte de dos millones de niños y han dejado un millón de menores huérfanos. Más de 300.000 niños, muchos de ellos menores de diez años, sirven actualmente como soldados en todo el mundo. En este caso si son niñas las someten a esclavitud sexual.
}

En el año 2000 un millón doscientos mil niños fueron vendidos u objeto de tráfico de seres humanos. Un centenar de países permiten en su legislación azotes en las escuelas. En treinta países, las sentencias penales contra niños se traducen en sanciones ejercidas mediante látigos o varas. Sólo 16 países en todo el mundo prohíben de modo absoluto cualquier tipo de castigo corporal sobre los niños (esto es, sólo el $2.4 \%$ de la población mundial infantil está protegida contra todo tipo de maltrato físico).

Ibidem, pags 223 y 224

Ver igualmente : La Protección del Menor, CEU Universidad Cardenal Herrera, Tirant Lo Blanch, cap 13, n 375 , Susana Sanz Caballero, Valencia 2009 
Este plan de Acción se fundamentaba en que numerosos menores de 18 años llegaban a territorio de la UE sin estar acompañados o que dejaban de estarlo al entrar en territorio europeo, por lo que se hizo necesaria una acción coordinada por parte de los países de la Unión.

No se conoce exactamente el número de estos menores, aunque se conocen algunos datos relativos al año 2008, en que se habían producido 11.292 solicitudes en 22 Estados miembros; para 2009 fueron 10.960 dichas solicitudes.

El Plan consta de tres vías: La prevención de la migración insegura de los Mena, la protección de los Mena cuando son identificados como tales y la generación de soluciones duraderas.

La prevención trata de conocer las razones de que estos menores abandonen sus países de origen, llegando a la conclusión de que el motivo es la pobreza, el subdesarrollo, procediendo su mayor parte de los países del Magreb por los acontecimientos de guerras y revueltas de los últimos tiempos. De igual forma las catástrofes naturales, el empeoramiento de las condiciones ambientales, las discriminaciones étnicas, la acción de las redes de explotación sexual y laboral, la decisión de las familias de enviarlos a la emigración para lograr una vida mejor y el encontrarse con algún miembro de su familia, que resida en territorio de la Unión, han contribuido a la agravación del problema. Para resolverlo la UE trata de colaborar con los países de origen y tránsito, programas de cooperación regional, y acuerdos con terceros países.

Las labores de protección empiezan cuando el menor es detectado en la frontera o el territorio de un país de la UE., para lo que hay que designarle un representante que se encargue de facilitarle lo que precise en su periodo de adaptación. Hay que alojarlo adecuadamente con separación de los adultos y proceder a su identificación. Averiguar su edad, contactar con su familia si es posible, todo ello con las debidas garantías procesales y jurídicas, así como de protección de datos. Tratar de identificar, perseguir y condenar a las organizaciones contrabandistas, traficantes, redes mafiosas o de explotación sexual de niños. No se debe de recurrir a la detención, salvo en casos excepcionales y por el tiempo más breve posible. 
Por lo que se refiere a las soluciones duraderas se deben de atender caso por caso, protegiendo siempre el interés del menor. Se debe de procurar que el menor pueda retornar voluntariamente a su país de origen (siempre que se haya podido localizar a su familia) para que pueda volver a vivir en su propio entorno familiar y cultural. Este retorno no se producirá si se demuestra que existen riesgos de que pueda ser perseguido en su país de origen, por lo que en este caso será considerado como un menor refugiado y asilado, gozando de una protección especial; para lo que la UE se compromete a financiar programas para integrar a estos menores que hayan sido objeto de violencia o de trata de personas. La UE, si se da el caso de un país de la Europa mediterránea que acoja a gran cantidad de menores refugiados no acompañados, podría disponer de medidas de reasentamiento en otros países de la Unión, con las debidas garantías de dignidad y en el interés del menor ${ }^{291}$.

\subsubsection{LA PRACTICA ESPAÑOLA CON LOS MEORES NO ACOMPAÑADOS}

El Plan de Acción fue impulsado por España durante su presidencia rotatoria de la UE, al ser precisamente uno de los países con mayor flujo migratorio de menores no acompañados. Las leyes españolas garantizan la protección de los menores en general y muy especialmente de los menores extranjeros no acompañados. España ha realizado un gran esfuerzo para garantizar a los menores extranjeros inmigrantes no acompañados unas condiciones de igualdad con los menores españoles y extranjeros acompañados, considerándolos menores en condiciones de gran vulnerabilidad, por lo que se les atiende en el derecho a la educación, la asistencia sanitaria y demás servicios públicos.

Para resolver los problemas sobre estos menores se recurre a la Ley Orgánica 4/2000 de 11 de enero y sobre todo a su Reglamento de desarrollo en el Decreto 2393/2004, de 30 de diciembre, en su artículo 111, en el que se dice que se debería crear en la Dirección General de la Policía un registro de menores no acompañados a efectos únicamente de identificación. En este registro ya se han empezado a recoger datos tales como, el nombre y los apellidos del menor, nombre de los padres, último lugar de

\footnotetext{
${ }^{291}$ Los Menores Extranjeros no Acompañados, op.cit, pag 208 y ss
} 
residencia que han tenido en el país de procedencia, huellas dactilares, fotografía, centro de acogida donde reside, si tiene la prueba médica de determinación de la edad y otros datos que tengan relevancia en orden a su protección.

Al haberse encomendado a las Comunidades Autónomas la protección de esos menores a través de sus instituciones no se da una unificación u homogeneización en su tratamiento por lo que éste no coincide entre unas y otras.

Para facilitar el funcionamiento de los servicios encargados de la protección de menores, deben comunicar a la policía los datos de éstos que se encuentren en situación de desamparo, con el fin de que a través del registro se pueda saber el número de menores no acompañados que haya en el territorio nacional y su situación. Este registro tiene por objeto la identificación y la protección, sin que pueda emplearse para otros fines. Con el mismo se permite centralizar la información, evitar que al trasladarse de una comunidad a otra se vuelva a repetir las pruebas sobre la edad o si se han adoptado medidas de protección sobre el menor.

Los avances en materia de protección española han sido importantes al haberse firmado acuerdos con Senegal (adoptado el 8 de diciembre de 2006) y con Marruecos (de 6 de marzo de 2007), en los que se protege a los menores no acompañados de igual forma que a los nacionales españoles de acuerdo con el Convenio de los derechos del niño. La cooperación por parte española ha llegado al mismo Marruecos al crear centros de formación profesional y fomento del desarrollo local en las zonas de procedencia de menores no acompañados. De esta forma la denominada Estrategia de la Cooperación Española de Atención, Protección, Formación e Inserción de los Menores Vulnerables de Marruecos la AECIS que ha abierto centros de capacitación en Nador y Beni Mellal; Cataluña ha abierto uno en Tánger y la Comunidad de Madrid cuatro en Tánger, Ben Guerir, Tagramut y Fats Anjra respectivamente.

Un problema de concentración por su proximidad a los países emisores o de transito se da en Ceuta, Melilla, Islas Canarias y Andalucía; para paliarlo el gobierno central ha promovido acuerdos con las ciudades autónomas y comunidades mencionadas para mejorar la situación en los centros de acogida, además de haber creado un Programa especial para el traslado y atención de esos menores no acompañados 
desplazados desde Canarias que cuenta con un Fondo de Apoyo y acogida para la integración de los inmigrantes ${ }^{292}$.

Una de las Comunidades Autónomas que mayores problemas tienen en relación con los menores no acompañados es la de Andalucía. Para las autoridades encargadas de protección de menores, consideran de vital importancia la operatividad de un registro único en materia de menores extranjeros no acompañados, con el fin de tener un conocimiento rápido y fiable de la identidad y situación de cada menor, así como de su paso a través de otras Comunidades Autónomas. De igual forma sirve para que cuando uno de estos menores haya cumplido la mayoría de edad, pueda evitarse que se traslade a otra Comunidad Autónoma y entre de nuevo en su sistema de protección como menor indocumentado.

La determinación de la edad es fundamental para que no se de cohabitación entre mayores y menores en los centros de protección, pues ello será perjudicial para los realmente menores por recibir ejemplos poco apropiados para su edad, dificultar su integración y programa educativo. Resulta difícil averiguar la edad del menor ya que las pruebas óseas en que se basan los fiscales tienen bastante margen de error y por otra parte la fecha de nacimiento que figura en su documentación aunque sea legal existen dudas sobre si es cierta la información que contiene y más tratándose de unos menores que habrán llegado a través de organizaciones de tráfico de personas o de falta de registros seguros en sus países de origen.

Los menores extranjeros no acompañados se encuentran atendidos por personal especializado en los centros de acogida inmediata, en los que se les atiende en sus necesidades básicas, se les informa de su situación, la atención prestada se realiza en su propio idioma, con respeto de su cultura y religión ${ }^{293}$. En cuanto al número de menores extranjeros atendidos oscila entre 337 en 2005 hasta 1298 en 2010, por lo que tiende a aumentar, lo que supone un gran problema que necesita una importante asignación de medios materiales y humanos para atenderlo debidamente ${ }^{294}$, este personal comprende

\footnotetext{
292 Ibidem pags 214 y ss

293 Ibidem, pag 131 y ss; Artículo de la Sra Vazquez Murillo, Subdirectora General de la Consejería para la Igualdad y Bienestar de la Junta de Andalucía.

294 Ibidem pag 136 y ss
} 
menores con medidas de protección que cumplen 16 años hasta que incluso rebasan la mayoría de edad, se les atiende en centros de día orientándoles para integrarse en el mundo laboral y comprende a tutelados y ex tutelados, denominándose Programa P+18.

\subsection{LA LORPM EN RELACION CON LA RESPONSABILIDAD CIVIL DE LOS MENORES EN LAS COMUNIDADES AUTÓNOMAS.}

Existe una polémica doctrinal al exigir la responsabilidad de los menores, pues hay autores que sostienen que se debe exigir esa responsabilidad a través de la Jurisdicción contencioso-administrativa basándose en el artículo 61.4 LORPM que dice: “En su caso, se aplicará también lo dispuesto en el artículo 145 de la Ley 30/1992, de 26 de septiembre, de Régimen Jurídico de las Administraciones Públicas y del Procedimiento Administrativo común, y en la Ley 35/1995 de 11 de diciembre, de ayudas y asistencia a las víctimas de delitos violentos y contra la libertad sexual, y sus disposiciones complementarias". Este apartado debe interpretarse en relación con el anterior (es decir 61.3) en el sentido de que cabe deducir la responsabilidad civil contra la Administración Pública ante el Juzgado de Menores, a través de la pieza de responsabilidad civil, pero cuando dicha Administración se encuentre en alguna de estas situaciones legales: tutor, acogedor o guardador legal o de hecho respecto del menor causante de los daños o perjuicios. No cabe confundir o identificar esta responsabilidad con la responsabilidad patrimonial de la Administración por funcionamiento anormal de los servicios públicos, ya que aquella presenta un origen ex delicto (ilícito penal) y se extiende a las personas indicadas en el citado apartado $\operatorname{art}^{\circ} 61.3$ de la LO 5/2000 en función del deber de control y vigilancia que los padres, tutores, o guardadores han de

\begin{tabular}{|l|l|l|l|l|l|l|}
\hline \multicolumn{6}{|l|}{ COMUNIDAD AUTÓNOMA DE ANDALUCÍA PROGRAMA P+18 / JÓVENES ATENDIDOS } \\
\hline AÑOS & 2005 & 2006 & 2007 & 2008 & 2009 & 2010 \\
\hline $\begin{array}{l}\text { CHICOS } \\
\text { INMIGRANTES }\end{array}$ & 298 & 553 & 736 & 987 & 1187 & 1217 \\
\hline $\begin{array}{l}\text { CHICAS } \\
\text { INMIGRANTES }\end{array}$ & 39 & 71 & 70 & 78 & 80 & 81 \\
\hline TOTAL & 337 & 624 & 806 & 1065 & 1267 & 1298 \\
\hline
\end{tabular}


tener sobre los menores a su cargo ya sea por virtud de la relación filial ya por los mecanismos de protección jurídica del menor previstos en el código Civil. Por ello se trata de una responsabilidad equiparable a la del artículo 1903 del Código Civil, que es una responsabilidad por los actos del otro, para los padres o tutores por los actos de los hijos menores derivada de la comisión de un ilícito penal cometido por éstos ${ }^{295}$. Como podemos ver no es necesario recurrir a la jurisdicción contencioso-administrativa para la responsabilidad civil de las Comunidades Autónomas, es suficiente basarse en el artículo 61.3 LORPM, pues por el artículo 172.1 CC son tutores de un menor que se encuentre en desamparo, por lo que en este caso se equipara al tutor del Derecho Privado, siendo además una responsabilidad solidaria junto con el menor que comete el hecho dañoso. De igual forma la CCAA que asume la guarda de un menor, de acuerdo con el artículo 172.2 CC, se convierte en guardador legal, incluyéndose entre los responsables civiles del artículo 61.3 LORPPM.

Las declaraciones de desamparo y lo relativo a la tutela automática son tratados por la jurisdicción civil y no por la contenciosa, a pesar de que sean declarados por actos administrativos y ello es por aplicación del artículo 172.6 que dice: "Las resoluciones que aprecien el desamparo y declaren la asunción de la tutela por ministerio de la Ley serán recurribles ante la jurisdicción civil sin necesidad de reclamación administrativa previa ${ }^{296}$, lo que representa un argumento más a favor de la jurisdicción de menores.

La S.AP de Tarragona $\mathrm{n}^{\mathrm{o}}$ 397/2005 explica con claridad la preferencia de la jurisdicción de menores sobre la contencioso administrativa, empleando tres argumentos para justificarlo: $1^{\circ}$ ) La norma especial es de aplicación preferente a la norma general; específicas son las normas contenidas en el título VIII, sobre responsabilidad civil, de la Ley 5/2000, donde se atribuye la competencia a la jurisdicción de menores; genéricas son las normas de la Ley 30/92 sobre Régimen Jurídico de la Administración Pública; 2ª En el aspecto temporal la Ley penal del menor 5/2000 es posterior a la Ley 30/92. $3^{\circ}$ ) La colisión entre dichas normas debe resolverse de modo que los guardadores legales o

\footnotetext{
295 S.A.P Valladolid $n^{\circ}$ 933/2002, de 23 de diciembre (JUR-2003/34960). En el mismo sentido, la S.A.P de Valladolid, secc $2^{a} n^{o} 840 / 2002$ de 22 de noviembre (JUR-2003/19730). S.A.P Alava, secc $2^{a} n^{\circ}$ 149/2003, de 31 de julio (JUR-2003/214024); S.A.P de Valladolid no 758/2002, de 22 de octubre (JUR-2002/284904).

${ }^{296}$ De la Rosa Cortina, op.cit, pags 164 y ss
} 
de hecho del menor, sean públicos o privados, respondan solidariamente con él y la jurisdicción competente sea la de Menores, según el artículo 64; esta responsabilidad puede concurrir y es compatible con la responsabilidad patrimonial de la Administración Pública originada por el funcionamiento normal o anormal de sus servicios, dado que el artículo 61.4 dice que "En su caso, se aplicará también lo dispuesto en el artículo 145 de la Ley sobre Régimen jurídico de la Administración Pública”297.

Por la aplicación de la LORPM se ha exigido una responsabilidad de carácter objetivo a las Comunidades Autónomas, llegándose a responsabilizarlas por hechos cometidos por menores internados en sus centros, contra el propio personal encargado de la guarda de estos menores. La razón de ello se encuentra en tratar de socializar los daños que originan estos menores, por hallarse generalmente faltos de recursos económicos para hacer frente a la indemnización de la víctima; con ello se hace responder a la Entidad que es la que se encuentra en mejor situación de asumir los costes de dicha indemnización.

\subsection{LA RESPONSABILIDAD DE LAS COMUNIDADES AUTÓNOMAS EN LA JURISPRUDENCIA}

12.4.1 RESOLUCIONES QUE ADMITEN LA CONDENA DE LAS ENTIDADES PÚBLICAS Y DE LOS PADRES.

Los padres de un menor declarado en desamparo pueden ser responsables solidarios junto con una Entidad Pública de Protección de menores, aunque tengan la patria potestad suspendida y el menor no se encuentre en su compañía, si se debe al incumplimiento de sus obligaciones paternas o por la mala educación que recibió el menor. Para ello se precisa la relación de causa a efecto, entre el abandono de los padres o esa deficiente y defectuosa educación con los hechos dañosos cometidos por el menor. Pero desde luego lo que no se puede hacer es excluir la responsabilidad de los padres sin motivo justificado.

Lo que en estos casos se hace es condenar a los padres junto a la CC.AA al

297 Ibidem pags 167 y 168 (SAP Tarragona no 397/2005 de 12 de abril) (JUR-2005/123453) 
considerar el artículo 61.3 LORPM que la responsabilidad de unos no excluye la de los otros, pues ambos la tienen ya sea in vigilando o in educando.

Un caso ilustrativo ${ }^{298}$ es el de un menor que cometió los hechos después de haberse fugado de un centro concertado con la Generalitat Valenciana, donde se encontraba cumpliendo una medida de internamiento semiabierto, por el que se condena a los padres junto a la CC.AA, basándose en que los progenitores han incurrido en mala o deficiente educación. La Sentencia dice: “el hecho de que el menor se encontrase ingresado en un centro público, no excluye la responsabilidad de los padres, máxime cuando éstos no han sido privados de la patria potestad. Es obligación de los padres educar a los hijos y procurarles una formación integral. Una mala o deficiente educación, que en algunos casos explica la situación marginal en la que se encuentra el menor y el origen delictivo, es más relevante que el simple defecto en el ejercicio del deber de guarda".

En otra, la S.A.P de Asturias de 24 de febrero de 2005 (JUR-2005/90958) se condena de igual forma a los padres por haber dejado a su hijo en situación de desamparo, al no observar los deberes propios de la patria potestad. El menor se encontraba al producirse los hechos delictivos bajo la tutela de una entidad pública de la Consejería de Servicios Sociales del Principado de Asturias, pero el encontrarse bajo esa tutela tiene su origen en el incumplimiento por parte de los padres de los deberes de patria potestad, no solo con el menor, también con sus hermanos. Por ello no se puede eximir de responsabilidad a los padres, ni tampoco moderar su responsabilidad, con lo que se condena a los padres junto con la CC.AA ${ }^{299}$.

\subsubsection{RESOLUCIONES QUE CONDENAN EXCLUSIVAMENTE A LAS ENTIDADES PÚBLICAS.}

Las Comunidades Autónomas deben de responder de los menores que se encuentren en situación de desamparo, siempre que tengan conocimiento de la situación, quiere ello decir que tiene que promover la declaración de desamparo, aunque no haya

\footnotetext{
298 S.A.P Alicante, secc $3^{\mathrm{a}}, \mathrm{n}^{\mathrm{o}}$ 521/2007, de 26 de septiembre (JUR-2008/129484)

299 S.A.P de Asturias, secc $2^{\mathrm{a}}$, $\mathrm{n}^{\mathrm{o}} 73 / 2005$, de 24 de febrero (JUR-2005/90985)
} 
sido formalmente declarado. De no hacerlo así, debe de ser condenada civilmente, por dar lugar a un fraude de ley al tener encomendada la protección de menores la Comunidad Autónoma. Ello se basa en lo dispuesto en los artículos 229 y 172 del CC que tratan de la responsabilidad en que incurren quienes tienen la obligación de promover la tutela y no lo hacen, pues tienen que adoptar las medidas de protección en interés del menor, a la mayor brevedad posible y además ponerlo en conocimiento del Ministerio Fiscal.

La S.A.P de Valladolid $n^{\circ} 933 / 2002$ de 23 de diciembre (JUR-2003/34960) contempla el caso de un menor bajo la guarda de la Entidad Pública, considera responsable al menor solidariamente con la Comunidad Autónoma y exonera a los padres con los argumentos siguientes: "en el momento de producirse los hechos correspondía a la Gerencia de Servicios Sociales exclusivamente, y no a los padres, ejercer el derecho-deber de control y vigilancia del menor en virtud de la guarda legal asumida sobre el mismo en cuanto sujeto a la medida de internamiento en un Centro de menores por resolución judicial. Esta situación produce la suspensión de hecho de las facultades de los padres para llevar a cabo las mencionadas funciones tutelares mientras el menor estuviera bajo esa guarda institucional. De ahí que los padres ninguna posibilidad de control tenían sobre su hijo en tales circunstancias, y por lo tanto, no puede atribuírseles esta responsabilidad civil del artículo 61.3 de la Ley de responsabilidad penal de los menores, sino que la misma debe recaer en la Administración demandada al ostentar, con exclusión de los padres, las funciones de tutela (obligación de la vigilancia y control) del menor en el momento de los hechos, en virtud de la guarda legal".

En el mismo sentido la S.A.P de Jaén, secc $1^{\mathrm{a}}$, no 236/2010, de 15 de noviembre (JUR-2011/129237), declara la responsabilidad de la CC.AA, en un supuesto de hurto cometido por un menor internado en un Centro de Protección, excluyendo a sus padres, siguiendo el mismo criterio mantenido por otras Audiencias Provinciales, por el que "la Junta de Andalucía es responsable civil solidaria por los hechos cometidos por el menor que a la fecha de su comisión se encontraba en situación de desamparo y sus padres privados de la patria potestad, asimilándose así la entidad pública a la figura del tutor y 
guardador de hecho, pasando el menor a depender de los órganos designados por la Comunidad Autónoma, encontrándose bajo su directa supervisión y dependencia como se desprende del artículo 45 LORPM. En consecuencia, el menor se encontraba en una situación de dependencia de la Comunidad, al estar privados los padres de su patria potestad, viniendo la misma a sustituir a éstos en los deberes de protección establecidos por las leyes para la guarda de los menores (artículo 172 CC). Por ello, las Audiencias Provinciales han venido reconociendo la responsabilidad de las Comunidades Autónomas por los actos delictivos ejecutados por los menores que se encuentren bajo su guarda, autoridad o en situación de desamparo, recogiendo así el deseo del legislador de proteger a las víctimas, que se manifiesta al establecer un sistema de responsabilidad civil objetiva de padres, tutores, acogedores y guardadores legales o de hecho a los que responsabiliza de las consecuencias pecuniarias de tales acciones (artículo 61.3 LORPM), ya sea de forma aislada o acumulativa, al tratarse de una responsabilidad solidaria. No puede declararse que la Entidad Pública responda de los daños causados solidariamente con el menor, pero con carácter subsidiario respecto de sus padres, ya que éstos privados de la patria potestad, no tenían ninguna autoridad sobre el menor, ni por tanto tampoco obligaciones de vigilancia, educación o cualquier otro inherente a la patria potestad. Por todo ello la Junta de Andalucía asumió su tutela, al ser ella responsable solidaria por el artículo 61.3 de la Ley, el cual no establece una responsabilidad subsidiaria en cascada como pretende la parte apelante, sino una responsabilidad solidaria con el menor, quedando excluidos los unos o los otros, de tal forma que si existen padres pero no ejercen como tales por encontrarse privados de la patria potestad, se pasa a los tutores, luego los acogedores y guardadores legales y de hecho, por este orden como señala el precepto, por lo que la Junta de Andalucía, al no ejercer las funciones tutelares los padres, tutores o acogedores, es ella la que las ejerce como guardadora legal del menor" 300 .

300 De la Rosa Cortina, op,cit, pag 193 y ss 


\subsubsection{RESOLUCIONES QUE CONDENAN A LA CC.AA POR HECHOS COMETIDOS POR MENORES SOMETIDOS A MEDIDAS DE PROTECCIÓN O REFORMA.}

La jurisprudencia menor, es decir, de las Audiencias Provinciales declaran la responsabilidad de las CC.AA, por hechos de los menores sometidos a medidas de protección o reforma, aunque se encuentren fugados del centro, en permisos con sus familiares, en centros privados o cuando las agresiones se produzcan contra los profesores, empleados o vigilantes de su centro de internamiento.

En la S.A.P de Zaragoza, secc $1^{a} n^{\circ}$ 174/2004, de 25 de abril (ARP-2004/251) se contempla el caso de un menor al cuidado de la Comunidad Autónoma en régimen semiabierto, cometiendo el hecho cuando estaba fuera del centro y dice: "no puede olvidarse que en realidad el sistema de protección del menor, con las medidas establecidas en la ley, supone un cauce para su reeducación por la institución pública correspondiente, cauce que se entiende fracasado si el tutelado comete una infracción tipificada, siendo responsable la Comunidad Autónoma.".

Por la S.A.P de Santa Cruz de Tenerife no 388 de 3 de julio de 2009 (JUR2009/439536), se trata un caso en el que un menor tutelado por la CC.AA comete un delito y ésta trata de exonerarse basándose en que la Administración que ejercía las competencias relativas a la ejecución de las medidas de amparo era el Cabildo Insular, además porque el menor estaba en acogimiento por la Entidad Colaboradora que gestiona el Centro de Menores, bajo la responsabilidad de su Director, y también porque la Entidad que gestiona el Centro de Menores tenía concertada una póliza de seguro de responsabilidad civil. La sentencia considera que en tanto la CC.AA sigue teniendo facultades de control y supervisión debe responder. "En el presente caso no se discute que la Dirección General de Protección del Menor y la Familia de la Comunidad Autónoma de Canarias tuviera la tutela del menor responsable, conservando facultades de supervisión y vigilancia, pues no se trata de una renuncia o desvinculación del menor cuando se da en acogimiento, sino de una delegación que favorezca el ejercicio de las funciones sin que implique una exención de toda responsabilidad sobre el menor. En consecuencia, si parte de las facultades se delegan manteniendo una facultad superior de 
vigilancia y cuidado, lo propio es repartir responsabilidades debiendo responder de forma solidaria. Este es el espíritu del artículo 45.3 de la LORPM. De otro lado vista la fase procesal en que se encuentra la causa, el Cabildo Insular, la entidad colaboradora y la entidad aseguradora no constan llamadas al proceso, y por ello no pueden ser condenadas quebrantando su derecho a audiencia y defensa, lo que no obsta al derecho de repetición que la parte apelante ostenta al ser responsable civil solidario".

Lo que viene a decir esta sentencia es que la CC.AA, aunque tenga convenio con una entidad inferior o de tipo privado, tiene responsabilidad de poder supervisar y controlar, así como in eligendo por haberla seleccionado. Al mismo tiempo la CC.AA puede repercutir sobre esas entidades lo pagado si fueran culpables, pero primero tienen que indemnizar a la víctima por tratarse de una responsabilidad objetiva.

Un ejemplo en el que la CC.AA resulta responsable por los hechos cometidos por menores tutelados ingresados en un centro de protección, en el que recibe el daño un empleado de la Comunidad encargada de velar por el menor, se da en la S.A.P de Valladolid, secc $2^{\mathrm{a}} \mathrm{n}^{\mathrm{o}} 758 / 2002$, de 22 de octubre de 2002 (JUR-2002/289904), en la que se dice: " no puede afirmarse que el daño producido entraña en el caso de autos un perjuicio que tiene el deber jurídico de soportar la educadora que cumple su función, ya que precisamente en los servicios cuyo ejercicio entraña mayor riesgo, a la Administración corresponde poner a disposición del empleado público los medios adecuados y suficientes para evitar aquel daño o perjuicio, y cuando como en el caso presente sucede, esos medios se revelan insuficientes o inadecuados para prevenirlo o evitarlo con ello se patentiza que faltaba algo por prever o prevenir, siendo procedente la declaración de responsabilidad en los términos indicados. Así pues la educadora tenía el deber jurídico de realizar las actividades con los menores pero no el de soportar el daño que sufrió en desarrollo de esa actividad". Esta sentencia manifiesta que la Administración tiene que proporcionar los medios materiales y humanos suficientes para el desarrollo de sus funciones, por lo que si se producen deficiencias en su funcionamiento, cuando los empleados cumplen correctamente con sus cometidos, estos no tienen obligación de soportar los perjuicios y en consecuencia será la propia Administración la que deba indemnizar a esos empleados perjudicados, por no haber 
prevenido o evitado esas carencias ${ }^{301}$.

${ }^{301}$ De la Rosa Cortina, op.cit, pag 173 y ss 


\section{PARTE SEGUNDA}

\section{LA RESPONSABILIDAD DE LOS MENORES EN \\ LOS CENTROS DE ENSEÑANZA NO \\ UNIVERSITARIOS.}

\section{CAPÍTULO PRIMERO: LA RESPONSABILIDAD DE LOS PROFESORES.}

\section{1- LA EDUCACIÓN EN ESPAÑA A PARTIR DE 1850}

En la segunda mitad del siglo XIX la enseñanza pública primaria era financiada por los municipios, obligatoria de los seis a los nueve años, gratuita para quienes no pudieran pagarla. Si se disponía de medios económicos suficientes se estaba obligado al abono de su importe. Se trataba de una enseñanza primaria poco desarrollada y escasamente generalizada en que se enseñaba a leer, escribir, nociones básicas de aritmética, geometría, lengua castellana y otras materias básicas, en general cosas muy elementales.

La enseñanza media o segunda enseñanza comprendía dos ramas paralelas que eran los “estudios generales" y “de aplicación”, impartidas en los institutos costeados por las diputaciones provinciales, tratándose de unos estudios dirigidos a un sector reducido que capacitaban para recibir una formación universitaria dirigida a la élite.

Por lo que se refiere a la enseñanza privada, era necesario para ejercerla, el régimen de autorización gubernamental expresa y exigencia de unos requisitos determinados al empresario, sobre el edificio o los profesores ${ }^{302}$.

Ante este sistema educativo, el profesor tenía gran autoridad ante los alumnos y podía tener amplio control sobre los mismos, pues no existían apenas actividades

\footnotetext{
${ }^{302}$ La Educación en la España Contemporánea, Ediciones SM, Fundación Santa María, Dr. Esquerdo, 125, Madrid, 1994, pags 261 y ss.
} 
extraescolares y complementarias. Su actividad se reducía a impartir sus enseñanzas a unos alumnos de corta edad en un aula, o a lo sumo en las inmediaciones de la escuela, lo que facilitaba su vigilancia y control sobre ellos. En estas circunstancias se le podía exigir responsabilidad al profesor, al contrario de lo que sucede al avanzar el siglo XX en el que la enseñanza es más compleja con muchas actividades, dirigida a toda la población, con lo que se masifica y resulta difícil controlar a los alumnos.

Para la época de la Restauración en el último tercio del siglo XX, se da una tasa de analfabetismo de un $72 \%$ para 1877 y de un 63\% para 1900, con lo que la enseñanza primaria tiene gran demanda y profundas carencias, sigue dependiendo de las juntas locales, con presupuesto a cargo de los ayuntamientos y a partir de 1901 se amplía la edad escolar obligatoria hasta los doce años. La escolarización total fue imposible por la falta de escuelas y de maestros, lo que daba lugar a que quedara el 50\% de menores sin escolarizar ${ }^{303}$.

La enseñanza media se impartía en los institutos desde el año 1845, dividiéndose en provinciales y locales. En los provinciales se cursaba el bachillerato completo, mientras que en los locales se cursaba solamente el bachillerato elemental. El profesorado de estos centros procedía de los estudios universitarios. En 1875 había 51 centros provinciales y 13 locales, llegando en 1921 los primeros a 58. Su financiación era de carácter provincial hasta la Ley de 1890 en que se reconoció la obligación del Estado de hacerse cargo de sus gastos. Se daba igualmente una enseñanza privada, e incluso doméstica que dependía de los institutos oficiales, la cual obtenía unos resultados mejores, pues sus índices de aprobados eran muy superiores a la pública. Al encargarse el Estado de su sostenimiento, controlaba sus normas de funcionamiento y gestión organizativa, a través de rectores, así como de los gobernadores que actuaban como delegados del gobierno ${ }^{304}$.

\footnotetext{
${ }^{303}$ La Ley que regula la enseñanza en España es la llamada Ley Moyano de 9 de septiembre de 1857 vigente hasta la Ley General de Educación de 1970.

${ }^{304}$ La Educación en la España Contemporánea, op cit, pags 275 y ss
} 


\subsection{LA EDUCACIÓN EN LAS CONSTITUCIONES: LA CONSTITUCIÓN REPUBLICANA DE 1931.}

Al comenzar el siglo XX la educación fue entendiéndose como un derecho social en el que el Estado tenía que hacerse cargo de los gastos que originara y al mismo tiempo extenderlo al mayor número posible de personas, de tal forma que llegara a toda la población e incluso a los adultos que la necesitaran. Para ello el Estado tiene que incrementar dichos gastos de forma considerable para poder asignar recursos materiales y humanos con el fin de poder materializar esa demanda que la sociedad precisa para progresar.

Será en la segunda década del siglo XX cuando sea contemplada por primera vez en los textos constitucionales la educación como un derecho social. La primera constitución en el mundo en contemplar el derecho a la educación es la de Méjico de 5 de febrero de $1917^{305}$. En ella la educación primaria era obligatoria y la de carácter público gratuita. Se permitía la enseñanza privada con autorización del Estado, pudiendo revocarla si no cumplían las normas los centros privados a los que denomina "planteles". Remite a leyes posteriores del Congreso su financiación y el régimen de los funcionarios encargados de implantarla ${ }^{306}$.

La otra Constitución en contemplar el derecho a la educación como derecho social es la Constitución Alemana de Weimar de 11 de agosto de $1919^{307}$. Lo relativo a la educación y enseñanza comprende del artículo 142 al 149, ambos inclusive, en los que se trata de la enseñanza pública y privada como en la Constitución de Méjico vista anteriormente. La enseñanza pública empieza con la escuela pública primaria que dura

\footnotetext{
305 Constituciones Españolas y Extranjeras, Tomo II, Taurus Ediciones, Madrid, 1977, pag 447.

${ }^{306}$ Artículo 3, apdo 5 : “ El Estado podría retirar discrecionalmente, en cualquier tiempo, el reconocimiento de validez oficial a los estudios hechos en planteles particulares”

Artículo 3, apdo 6: “La educación primaria será obligatoria”

Artículo 3, apdo 7: “Toda la educación que el Estado imparta será gratuita”

Artículo 3, apdo 8: “ El Congreso de la Unión, con el fin de unificar y coordinar la educación en toda la República, expedirá las leyes necesarias destinadas a distribuir la función social educativa, entre la Federación, los Estados y los Municipios, a fijar las aportaciones económicas correspondientes a este servicio público y a señalar las sanciones aplicables a los funcionarios que no cumplan o no hagan cumplir las disposiciones relativas, lo mismo que a todos aquellos que las infrinjan” (Ibidem, pag 448).

${ }^{307}$ Textos Constitucionales españoles y extranjeros, Editorial Atheneum, Zaragoza, 1930.
} 
ocho años y la escuela secundaria, a la que llama complementaria de perfeccionamiento y llega hasta los dieciocho años de edad. Por lo que a las escuelas privadas se refiere, necesitan la autorización del Estado y quedan sometidas a las leyes de los Estados Federados a los que llama Países. La responsabilidad del funcionario con respecto a una tercera persona recae en primer lugar sobre el Estado o la Corporación, quedando reservada la acción de regreso contra dicho funcionario, al igual que sucede hoy día en que en la enseñanza pública se exige la responsabilidad al titular del centro y si ha actuado con dolo o culpa grave se da la acción de regreso contra el profesor ${ }^{308}$.

Al reconocerse el derecho a la educación se dará un aumento grande de alumnos, de tal forma que la enseñanza se masificará, no habrá maestros y profesores suficientes para tanto alumno, con unas instalaciones insuficientes, incompletas o no adecuadas para tanto personal. Por otra parte, en épocas anteriores en que la educación se dirigía a pocos alumnos, el tiempo de escolarización era corto y el profesor podía tener control sobre sus alumnos, se le podía exigir responsabilidades; ahora bien al cambiar esta situación el profesor ya no podrá controlar a tanto alumno, ni tendrá él la culpa de las instalaciones insuficientes, ni redacta él las normas educativas. De ello se infiere que sería manifiestamente injusto el que recayera sobre el profesor la responsabilidad por los hechos dañosos de sus alumnos menores de edad. Para evitar esta situación de injusticia, se traspasó la responsabilidad al Estado en lugar de al profesor, pudiéndose exigirla a éste en determinados casos.

Será en Francia por primera vez cuando se exija responsabilidad al Estado en vez de al profesor en la enseñanza pública con la Ley de 20 de julio de 1899, como consecuencia de la presión de los sindicatos de enseñanza y la opinión pública al darse casos en que el motivo del daño era debido a casos fortuitos ante los que el profesor

308 Constitución Alemana de Weimar

$\mathrm{Art}^{\mathrm{o}} 131$ "Si un funcionario, en el ejercicio del cargo que le está encomendado, infringe su deber profesional con respecto a tercera persona, la responsabilidad recaerá primariamente sobre el Estado o la Corporación a cuyo servicio se halle el funcionario, quedando reservada la acción contra éste. No podrá ser excluida la vía judicial ordinaria. Las leyes correspondientes determinarán los detalles complementarios.

$\mathrm{Art}^{\mathrm{o}} 145$ “Existe una obligación general escolar. Para cumplirla existe, en primer término, la escuela pública primaria, con ocho años como mínimo de estudios, y después la escuela complementaria de perfeccionamiento hasta los diez años de edad cumplidos. En las escuelas primarias y complementarias son gratuitas la enseñanza y los medios de estudio. 
nada podía hacer por evitarlos. Esta Ley fue derogada por la de 5 de abril de 1937 para aplicarla a los profesores de la enseñanza privada, estableciendo una equiparación entre ambos tipos de educación.

En España será la Constitución de la República de 1931 la primera en contemplar en su articulado la enseñanza primaria como obligatoria ${ }^{309}$.

Lo primero que trató el nuevo régimen fue luchar contra el analfabetismo con lo que se dio prioridad a la organización y promoción de la escuela primaria. Para ello se edificaron 7000 escuelas de nueva planta, cuyo número era escaso para las necesidades reales; la plantilla del magisterio nacional fue aumentada, se consiguió un buen funcionamiento de las escuelas normales, se perfeccionó la preparación académica de los maestros, pero su número continuó siendo escaso ${ }^{310}$. En el artículo 48 de la Constitución de 1931 se fijan los principios de la educación, que ha de ser sobre todo laica, la enseñanza primaria será obligatoria y gratuita; para el resto de grados la financia el Estado, pudiendo limitarse solamente por la aptitud y la vocación del alumno; los profesores y catedráticos de la enseñanza oficial son funcionarios públicos, además atribuye el servicio educativo al Estado. La enseñanza privada no la contempla ${ }^{311}$.

\footnotetext{
309 Su antecesora la Constitución de 30 de junio de 1876, en su artículo 12, habla de libertad de elegir la profesión, de fundar y sostener establecimientos de educación; sobre los establecimientos de instrucción pública costeados por el Estado, las provincias o los municipios. Pero no dice nada de obligatoriedad y las reglas que desarrollen la enseñanza las remite a una ley posterior (Constituciones Españolas, Fernando González Doria, Editorial Cometa, Madrid, 1986, pag 406).

310 La Educación en la España Contemporánea, Ediciones SM, op cit, pag 807 y ss.

${ }^{311}$ Art $^{\circ} 48$ Constitución de 1931. "El servicio de la cultura es atribución esencial del Estado, y lo prestará mediante instituciones educativas enlazadas por el sistema de la Escuela Unificada”.
}

La enseñanza primaria será gratuita y obligatoria.

Los maestros profesores y catedráticos de la enseñanza oficial son funcionarios públicos. La libertad de cátedra queda reconocida y garantizada.

La República legislará en el sentido de facilitar a los españoles económicamente necesitados el acceso a todos los grados de enseñanza, a fin de que no se halle condicionado más que por la aptitud y la vocación.

La enseñanza será laica, hará del trabajo el eje de su actividad metodológica y se inspirará en ideales de solidaridad humana.

Se reconoce a las Iglesias el derecho, sujeto a inspección del Estado, de enseñar sus respectivas doctrinas en sus propios establecimientos. 


\section{2- LA RESPONSABILIDAD DEL PROFESOR EN EL DERECHO COMPARADO.}

\subsection{FRANCIA.}

\subsubsection{LEY DE 20 DE JULIO DE 1889.}

Las enseñanzas privada y pública estaban asimiladas en el siglo XIX, se trataba de una enseñanza liberal en el ámbito municipal, subvencionadas por el Estado; en las que el maestro tenía bastante poder sobre los alumnos, a los que en determinados casos podía reservarse la admisión o su rechazo. Este panorama sufre grandes cambios en el último tercio del siglo, sobre todo en la década de 1880 en que se aprobaron leyes de educación donde se da entrada a todos y se concibe como un servicio público.

Ante esta situación los miembros de la enseñanza presionan para que se les diera un tratamiento distinto a los de la enseñanza privada, por lo que propugnaban una reforma en la que por su condición de funcionarios deberían ser tratados como otros cuerpos profesionales, donde se tenía a efectos de responsabilidad solamente en cuenta sus faltas personales y no sus faltas de servicio, de las que debería de responsabilizarse el Estado $^{312}$.

La jurisprudencia demostró que los juicios eran demasiado rigurosos, sobre todo en la década de 1890, lo que demostraba que la garantía del inciso final del artículo 1384, que eximía de responsabilidad al profesor que hubiera actuado con diligencia, era algo ilusorio, que no sucedía nunca. Al profesor en estas circunstancias se le presume la culpa, porque no puede eludir su responsabilidad al no poder demostrar su diligencia ante el hecho dañoso. Ante ello las asociaciones y convenciones de profesores denunciaron estos agravios y se enviaron informes ante el Parlamento.

\footnotetext{
${ }^{312}$ En derecho francés el término faute tiene un significado mucho más amplio y objetivo que el término culpa. Faute de service es una falta de servicio de la que es responsable el ente público por su funcionamiento ya sea normal o anormal. Mientras que faute personnelle es una falta personal del funcionario por su comportamiento culposo o doloso, en la que es identificado como autor material del daño por lo que podrá ser obligado a responder frente al perjudicado o será el ente público después de haber indemnizado a la víctima el que podrá hacerlo por vía de regreso contra dicho funcionario.
} 
En el informe que presenta el Sr. Savary a la Cámara se dice que "se trata de una sustitución, no de una supresión de la responsabilidad", por lo que se refiere a que el Estado sustituya al profesor cuando sea una falta de servicio imputable al mismo y sólo se exija responsabilidad cuando se trate de falta personal del profesor en cuestión.

Por otra parte, el Sr. Thezard, ponente en el senado, tuvo en cuenta la jurisprudencia y la práctica con lo que vio que era imposible para el profesor salir sin responsabilidad, además el Estado en jurisdicciones distintas de la educación pública, se le considera responsable por las personas que emplea. La responsabilidad civil impuesta a los profesores de las escuelas públicas la considera una anomalía y lo que propone es que a la responsabilidad del Estado se aplique la ley común, y dijo lo siguiente: “¿Cuál debe ser la persona responsable, ya que parece imposible salir sin responsabilidad y sin indemnización a las víctimas de accidentes? Esta persona sólo puede ser el Estado. Los profesores son sólo funcionarios, probablemente responsables de su mala conducta, pero no hay razón que permita a los funcionarios el hacerles responder por la culpa de otro".

Finalmente Samary presentó otro informe ante la Cámara en el que manifestó que "la enseñanza pública en la época de la publicación del Código era muy distinta a la de finales del siglo XIX, pues las escuelas municipales eran libres, a las que el Estado concedía una subvención; los padres daban un salario al profesor, libremente acordado con ellos, por lo que las circunstancias habían cambiado de forma notoria”313.

El descontento de los profesores iba en aumento por la severidad exigida por los tribunales para exonerar de culpa al profesor al aplicar el apartado $5^{\circ}$ del artículo 1384. Poco después se produjeron dos condenas manifiestamente injustas, que pusieron de manifiesto la gravedad del problema por tratarse de casos fortuitos en los que al profesor le era totalmente imposible de prever el daño por las circunstancias en que se produjeron.

El primer caso fue el denominado asunto Leblanc, en el que un alumno menor de edad, de la escuela Fontenoy - Sus- Bois falleció por una peritonitis causada por un

\footnotetext{
313 Juan Antonio Moreno Martínez, Responsabilidad de centros docentes y profesorado por daños causados por sus alumnos, Monografías, Ciencias Jurídicas, Madrid, 1996, pag 63.
} 
puntapié que recibió en una riña entre alumnos, durante un periodo de descanso entre clases. El Tribunal correccional del Sena condenó al director Sr. Leblanc, declarándolo civilmente responsable a pesar de resultar imposible evitar los golpes dados a la víctima, afirmando en la sentencia "que de acuerdo con el artículo 1384 CC el director Leblanc debía de ser declarado civilmente responsable del delito con independencia de su vigilancia habitual, su honorabilidad reconocida y la imposibilidad para impedir los golpes dados a la víctima, por el sólo hecho de producirse en el interior de la escuela".

Esta sentencia condenatoria del director le afectó de tal forma que tuvo que ser ingresado en un hospital psiquiátrico, cuya causa fundamental fue el descrédito de su honor en el sector educativo. El Ministerio Público recurrió la sentencia ante la Sala de Apelaciones de París, reformándola el 31 de mayo de 1892; aunque esta reforma no afectó al director, que perdió la razón por el juicio, lo que le impidió interponer apelación dentro de los plazos señalados por la ley. La Corte de París reconoció que la vigilancia era efectiva, que los alumnos no presentaban problemas de carácter que exigieran una mayor vigilancia; ninguna discusión se produjo con anterioridad, los hechos se desarrollaron con gran rapidez siendo por ello imposible evitarlos, todo ello por tanto demostró la no existencia de falta en la conducta del Sr. Leblanc.

El segundo caso es el conocido como asunto Guillot y se produce en el patio de la escuela de Santerraine (Creuse). En el patio de la mencionada escuela, se perforaron unos agujeros de gran profundidad para plantar árboles. Para evitar accidentes el director prohibió a los alumnos acercarse a dichos agujeros, designando a un profesor que vigilara el recreo e impidiera a los alumnos acercarse a los mismos. A pesar de todas estas prevenciones, un niño aprovechando que un profesor le daba la espalda, empujó a otro arrojándole a uno de tales hoyos, lo que le produjo la invalidez.

El Tribunal de Gueret, en sentencia de 18 de diciembre de 1894, declaró la culpabilidad del profesor, siendo confirmada esta sentencia por el Tribunal de Limoges en sentencia de 1 de mayo de 1895. Este caso como el del Sr. Leblanc, eran imposibles de prever por la rapidez con que se produjeron y la condena de los profesores ponía de manifiesto que se debía realizar una reforma en la exigencia de responsabilidad de los docentes. 
Estos casos provocaron una gran inquietud en el sistema educativo, iniciando una campaña en los medios periodísticos, así como el solicitar a los diputados una modificación de la responsabilidad de los docentes. Como consecuencia de ello la Cámara de los Diputados el 21 de marzo de 1898, añadió al último párrafo del artículo 1384 el texto siguiente: "No obstante, la responsabilidad civil del Estado sustituye a la de los miembros de la enseñanza pública" ${ }^{314}$.

Después en el Senado se acuerda añadir un artículo más para la regulación de la competencia judicial, pero sin incorporarlo al artículo 1384 del Código civil, que dice: "La acción de responsabilidad contra el Estado, en el caso previsto por la presente Ley, se tramitará ante el Tribunal civil o el juez de paz del lugar en que el daño se haya causado, y será dirigido contra el prefecto del departamento"315. Estos artículos 1 y 2 (el 2 sin añadir al artículo 1384), aprobados por el Senado y la Cámara de Diputados constituyen la Ley de 20 de julio de $1899^{316}$.

\subsubsection{LA LEY DE 5 DE ABRIL DE 1937}

Poco tiempo después de la aprobación de la Ley de 20 de julio de 1899 se empezaron a observar problemas en su aplicación, resultando poco efectiva de cara a la protección del profesorado de los centros públicos.

En primer lugar, en la práctica de la jurisprudencia para proteger a la víctima en casos dudosos se demandaba al mismo tiempo al Estado por la Ley de 1899 y al profesor por los artículos 1382 y 1383 del Código civil ${ }^{317}$, con ello los profesores

\footnotetext{
314 Texte de la Loi du 20 JUILLET 1899:”toutefois la responsabilité civile de l’Etat est substitués a celle des membres de lenseignement public”.

315 L’article 2 de la meme loi stipule que “L’action en responsabilité contre l’État será portée devant le tribunal civil ou le juge de paix du lieu oú le dommage aura été causé et dirigée contre le préfet du departement”.

316 Juan Antonio Moreno Martínez, la responsabilidad, op cit, pags 62 y ss.

317 Artículo 1382; “Cualquier hecho del hombre que cause daño a otro obliga a aquel por cuya culpa sucedió, a repararlo".

Artículo 1383; “Cada uno es responsable del daño que cause, no sólo por su acción, sino también por su negligencia o su imprudencia”.
} 
pensaron que la ley no les protegía suficientemente, al aumentar de forma extraordinaria los casos de demandar conjuntamente al Estado y al profesor.

Otro problema que se dio fue la insuficiente sustitución del Estado sobre los profesores ante posibles daños del alumnado, al quedar excluidos de la responsabilidad del Estado los daños causados a los alumnos por un tercero o por el propio profesor e incluso los que el propio alumno pueda causarse a sí mismo.

En cuanto a las actividades extraescolares de igual forma estaban excluidos los daños producidos en actividades extraescolares, lo que estaba en contra de la idea educativa del Estado que las fomentaba o estimulaba, pero si se producían fallos o accidentes no se hacía cargo de la indemnización de ellos resultante.

Finalmente los miembros de la enseñanza privada alegaron su agravio comparativo con los de la enseñanza pública al no darse con ellos la sustitución por el establecimiento de enseñanza privada en la responsabilidad por los hechos dañosos de sus alumnos.

Para subsanar estos problemas se aprobó la Ley de 5 de abril de 1937, formada por dos artículos, en el primero de ellos se suprime en el apartado $7^{\circ}$ del artículo 1384, la referencia a los profesores en la relación de personas sobre las que recae una presunción de culpa, quedando redactado como sigue: "La anterior responsabilidad tiene lugar salvo que los padres o los artesanos prueben que no pudieron impedir el hecho que dio lugar a esta responsabilidad".

La otra modificación del artículo primero trata del último párrafo del artículo 1384 y queda redactado del modo siguiente: "En lo que concierne a los profesores, la culpa, imprudencia o negligencia invocada contra ellos como causantes del evento dañoso deberá probarse en juicio por el demandante, conforme al Derecho común". De esta forma no se da inversión de la carga de la prueba, con lo que el profesor resulta protegido y será el demandante el encargado de demostrar la culpabilidad del profesor.

El apartado relativo a la responsabilidad de profesores y artesanos del artículo 1384, queda sin modificación y dice: "Los profesores y artesanos, son responsables del 
daño causado por sus alumnos y aprendices durante el tiempo que permanezcan bajo su vigilancia" 318 .

El artículo segundo de la Ley de 5 de abril de 1937 da una protección mayor a los profesores de la enseñanza pública, a los que va dirigido, sus disposiciones no figuran en el artículo 1384 del Código civil y además derogó la Ley de $189{ }^{319}$.

El texto del artículo regula el régimen de sustitución del Estado cuando se interpongan acciones judiciales contra los profesores y lo hace dándoles una protección muy superior a la que daba la Ley de 1899. La cobertura del Estado es mayor abarcando no sólo las actividades escolares, también las extraescolares.

En los apartados primero y segundo trata de la sustitución del Estado y dicen lo siguiente: $1^{\circ}$ ) "En todos los casos en que la responsabilidad de los miembros de la enseñanza pública sea exigible a consecuencia o con ocasión de un acto dañoso cometido, ya sea contra los niños o los jóvenes que le son confiados por razón de sus funciones, ya sea contra esos niños o jóvenes en las mismas condiciones, la responsabilidad del Estado sustituirá a los miembros de la enseñanza, que no podrán ser emplazados nunca, ante los tribunales civiles, por la víctima o sus representantes", $2^{\circ}$ )'Sucederá así cuantas veces, durante la escolaridad o fuera de ella, dentro de una finalidad de educación moral o física, no prohibida por los reglamentos, los niños o jóvenes confiados así a los miembros de la enseñanza pública se encontraran bajo la vigilancia de éstos”.

Del apartado primero, se deduce el tratar por todos los medios que el profesor no comparezca judicialmente, para que no puedan involucrarle en la exigencia de responsabilidad, que para ello le sustituye el Estado y en el segundo abarca todas las actividades de la enseñanza ya sean escolares o extraescolares o de otra naturaleza siempre que se hallen bajo la vigilancia de los profesores, con lo que abarca diversas actividades por ello dice "que no estén prohibidos por los reglamentos", con lo que se consigue una educación completa, de otra forma, se reduciría la enseñanza al no quedar cubiertas todas sus necesidades por temor a incurrir en responsabilidad.

\footnotetext{
318 Juan Antonio Moreno Martínez, op.cit, pag 67 y ss

${ }^{319}$ Henry Mazeaud, Lecciones de Derecho Civil, Vol II, trad de Luis Alcalá Zamora y Castillo, Ediciones Jurídicas Europa - América, Buenos Aires, 1960, pag 203
} 
Por el apartado tercero, se hace referencia a la acción de repetición, que el Estado puede dirigir contra el profesor para reparar el daño causado por la falta in vigilando de éste y dice:" La acción de repetición podrá ser ejercitada por el Estado, ya sea contra el maestro, ya sea contra los terceros, conforme al derecho común". Puede pensarse que con esta protección del Estado sobre el profesor, éste queda exento de responsabilidad, pero no es así, pues el Estado puede repetir contra el profesor cuando éste haya faltado a sus deberes de vigilancia en relación con los alumnos, lo que sucede es que el Estado no suele ejercitar la acción de regreso contra los profesores. El Estado queda en libertad para repetir o no. De manera que, casi siempre, la responsabilidad la soporta el Estado, y no el profesor público, con lo que se produce una cierta laxitud de los profesores en su deber de vigilancia ${ }^{320}$.

Su régimen jurídico se regula en el apartado 5 , con mayor amplitud y precisión de la que lo hacía en la Ley de 1899 en lo que a la competencia de los tribunales se refiere: "La acción de responsabilidad interpuesta por la víctima, sus parientes o causahabientes, intentada contra el Estado cuando así sea responsable de los daños, será tramitada ante el tribunal civil o el juez de paz del lugar en que se haya causado el daño y será dirigida contra el prefecto del departamento". Y sobre la prescripción de la acción dice en su apartado $6^{\circ}$ : "En lo que concierne a la reparación de los daños previstos por la presente ley, la prescripción se ganará a los tres años, a partir del día en que se haya cometido el hecho dañoso."

Se han producido polémicas sobre si la acción de repetición del Estado se da por falta personal o falta de servicio. La Corte de Casación aplica la Ley de 1937 y el Consejo de Estado recurre a las leyes de responsabilidad administrativa. El Tribunal de Conflictos ha dado la razón a la Corte de Casación que aplica la Ley de 1937 tanto por falta personal como de servicio, no siendo posible en ninguno de los dos casos que la víctima pueda demandar al profesor, pues ello sería privar de todo alcance a la sustitución establecida por la Ley. Mazeaud afirma que si la Ley de 1937 se hubiera limitado a la culpa personal del profesor, toda repetición del Estado habría sido imposible en caso de

\footnotetext{
${ }^{320}$ Ibidem, pag 250

Ver igualmente Juan Antonio Moreno Martínez, op.cit, pag 73
} 
simple falta de servicio, por no concederse en derecho común administrativo la repetición por falta de servicio ${ }^{321}$.

La Ley de 1937 ha resuelto el problema de los profesores de la enseñanza pública $^{322}$, pero para el sector privado se ha tenido que aplicar la Ley de 31 de diciembre de 1959, la llamada Ley Debré. Por esta ley se permite a las escuelas privadas relaciones de unión con el Estado, pero conservando el carácter de establecimiento privado.

Para ello se establecen dos tipos de contratos, el contrato simple y el contrato de asociación. El contrato simple se reserva para los establecimientos de enseñanza primaria, en el que la actividad del Estado consiste en un control pedagógico y financiero que incluye la remuneración de los profesores afectados, quedando como profesores asalariados de Derecho privado sometidos a un convenio colectivo. En cuanto al contrato de asociación es más extenso, abarcando a la enseñanza primaria y secundaria, la implicación con el Estado es mayor, llegando éste a responsabilizarse de los gastos de funcionamiento, la remuneración de casi todos los profesores, considerándolos funcionarios del Estado sujetos a un estatuto de Derecho público.

Por lo que se refiere a los accidentes ocurridos en las escuelas con contrato de asociación, en virtud del artículo 10 del Decreto de 22 de abril de 1960, la

${ }^{321}$ Mazeaud, op cit, pags 203 y ss

Juan Antonio Moreno Martínez, op cit, pags 74 y ss

${ }^{322}$ Art $^{\circ} 2$ Ley de 1937: La Loi du 20 juillet 1899 est abrogée et reemplacée par les dispositions suivantes:

“Dans tous les cas oú la responsabilité des membres de l’ensegnament public est engagée a la suite ou á l'occasión d’un fait domageable commis, soit par les enfants ou jeunes gens qui leur sont confies a raison de leurs fonctions, soit á ces enfants ou jeunes gens dans les mémes conditions la responsabilité de l’Etat será substituée á celle desdits membres de lenseignement, qui ne pourront jamais étre mis en cause devant les tribunaux civils par la victime ou ses representants”. “Il en será ainsi toutes les fois que, pendant la scolarité ou en dehors de la scolarité dans un but d’éducation morale ou physique, non interdit par les reglaments, les enfants ou jeunes gens confies ainsi membres de l'enseignement public se trouveron sous la survillance de ces derniers".

“L’action recursoire pourra étre exercée par l’Etat, soit contre l'instituteur, soit contre les tiers, conformément au droit commun”.

“L’action en responsabilité exercée par la victime, ses parents ou ses ayants droit, intentée contre l’Etat ainsi responsable du dommage, será portée devant le tribunal civil ou le juge de país du lieu ou le dommage a été causé et dirigée contre le prefet du departement”.

“La prescription en ce qui concerne la reparation des dommages préveus par la presente loi será acquise par trois années á partir oú le fait dommageable a été commis”.

(DALLOZ CODE CIVIL, LIBRERIE DALLOZ, RUE soufflot 11, PARIS 1951 pag 495) 
responsabilidad de esos accidentes se someten a las normas de la Ley de 5 de abril de 1937.

Esta Ley ha sido criticada por la doctrina al afirmarse que la víctima o sus parientes quedan desprotegidos, al no poder probar la falta del profesor, pues es el único que puede informar para esclarecer el hecho. Para subsanar este problema se ha aconsejado acudir al seguro obligatorio para indemnizar esos daños, aunque todavía no se exige como obligatorio, se ha implantado bastante ${ }^{323}$.

Mazeaud ha criticado esta Ley por los mismos motivos y preguntándose si se ha considerado que el régimen de culpa para los padres y artesanos es el óptimo ¿por qué no lo es para los profesores? Con ello se produce un agravio comparativo con los padres y artesanos a los que se refuerza su responsabilidad al resultarles difícil conseguir la exoneración de su responsabilidad ${ }^{324}$.

\subsection{ALEMANIA}

\subsubsection{PROFESORES DE LA ENSEÑANZA PÚBLICA}

Para la exigencia de responsabilidad a los profesores de la enseñanza pública hay que tener en cuenta el artículo 839.1 del BGB que dice: "Si un funcionario viola dolosa y negligentemente el deber oficial que le incumbe frente a un tercero debe resarcir al tercero el daño que de ello resulta. Si al funcionario sólo le es imputable negligencia, únicamente puede ejercitarse frente a él la reclamación si el perjudicado no puede obtener el resarcimiento de otra forma". Al mismo tiempo hay que relacionarlo con el artículo 34 de la Ley Fundamental de Bonn ${ }^{325}$ que trata de la violación de los deberes de la función pública con respecto a un tercero. Por el contenido de estos dos artículos el

\footnotetext{
323 Juan Antonio Moreno Martínez, op cit, pags 76 y ss

${ }^{324}$ Mazeaud, op.cit, pag 205 y ss

${ }^{325} \mathrm{Art}^{\mathrm{O}} 34$ L.F. de Bonn: "Cuando alguien, en ejercicio de una función pública que le fuera confiada, violare los deberes que la función le imponga con respecto a un tercero, la responsabilidad recae en principio, sobre el Estado o el órgano a cuyo servicio se encuentre. En caso de dolo o negligencia grave queda reservado al recurso contencioso administrativo. Para la reclamación de daños y perjuicios, así como para el recurso contencioso-administrativo, no podrá excluirse la vía judicial ordinaria”. (Constituciones Españolas y Extranjeras, op.cit, pag 566).
} 
Estado quedará obligado si lo está el profesor de acuerdo con el artículo 839 BGB, al interponer la demanda el perjudicado. En este caso el Estado indemnizará al perjudicado, pero le queda la facultad de poder accionar por vía de regreso contra el funcionario en los casos en que hubiera actuado con dolo o negligencia grave.

Con estas normas los funcionarios de la enseñanza pública quedan protegidos al no poder ser demandados judicialmente por el perjudicado, pues de esta forma son sustituidos en su responsabilidad por el Estado, aunque a éste le quede la posibilidad de repetir contra el profesor por dolo o negligencia grave, algo que en la práctica es muy poco frecuente. Con estas disposiciones los profesores de la enseñanza pública gozan de una posición privilegiada en comparación con los de la privada.

El artículo 839 BGB protege al profesor en su apartado primero, al exigir al perjudicado demandar en último caso al profesor, o lo que es lo mismo, si existe alguna otra persona que pueda ser declarada responsable, será a ella a la que deberá dirigirse en primer lugar. Por el apartado segundo, el profesor se puede exonerar, si el daño se ha producido por culpa del alumno. Finalmente por el apartado tercero, no hay deber de resarcimiento si el perjudicado ha omitido dolosa o negligentemente la posibilidad de evitar el daño mediante el ejercicio de un medio legal.

\subsubsection{PROFESORES DE ENSEÑANZA PRIVADA}

La exigencia de responsabilidad a los profesores de enseñanza privada se contempla en el artículo 832.1 BGB, que dice: “Quien por disposición legal está obligado a ejecutar la vigilancia sobre una persona que, por su minoría de edad o por sus circunstancias psíquicas o físicas requiere de tal vigilancia, está obligado al resarcimiento del daño que esta persona causa antijurídicamente a un tercero. El deber de resarcimiento no se da si cumplió el deber de vigilancia o si el daño se hubiera producido igualmente pese a la observancia de la vigilancia".

Para la exigencia de responsabilidad del profesor es necesario que el menor se encuentre bajo la vigilancia del profesor y además el daño que cause el alumno tiene que ser antijurídico, es decir, contrario a derecho. De lo que se trata en este artículo es de 
proteger a los terceros perjudicados por los menores, por el deber de vigilancia que los profesores tienen sobre sus alumnos, sobre los que recae la responsabilidad. El tercero perjudicado puede ser miembro de la comunidad educativa, tales como alumnos, personal administrativo, como de fuera de dicha comunidad y los daños pueden ser personales o materiales (cosas). Es irrelevante el que en el menor se dé o no la culpabilidad, pues el inimputable aunque no recaiga sobre el la culpabilidad, había que exigírsela a los que tienen el deber de vigilancia sobre él; si es inimputable será mayor la atención de control y vigilancia que deban realizar sobre él.

En los casos en que tanto el profesor como el alumno sean responsables deben responder de forma solidaria de acuerdo con el artículo $840.1^{\circ}$, que dice: "Si para el daño que resulta de un acto ilícito son responsables varias personas conjuntamente, éstos responden como deudores solidarios". De esta forma el profesor y el alumno quedan obligados a indemnizar al perjudicado. Por sus relaciones internas, si el profesor indemnizó al perjudicado tendrá la facultad de repetir contra el alumno según el artículo $840.2^{\circ} \mathrm{BGB}^{326}$. Hay que tener en cuenta que según el artículo $828 \mathrm{BGB}$, el menor podrá ser responsable si tiene una edad superior a siete años y posea el discernimiento suficiente para darse cuenta del alcance de sus actos.

La responsabilidad del titular de un centro docente se contempla en el artículo 831 BGB: "Quien encarga a otro una actividad está obligado al resarcimiento del daño que el otro causa antijurídicamente a un tercero en la ejecución de la actividad. No se da el deber de resarcir si el dueño del negocio, en la elección de la persona encargada y, si debe suministrar dispositivos o medios materiales o está obligado a la dirección de la actuación, en el suministro o en la dirección, ha observado la diligencia exigible en el tráfico, o si el daño incluso con la observancia de dicha diligencia se hubiera producido igualmente".

Para la exigencia de responsabilidad se apela más al artículo 831 que al 832 al ser más solvente el establecimiento educativo que el profesor. El titular del centro docente o establecimiento educativo se asimila al dueño de un negocio, al que le incumbe la

\footnotetext{
${ }^{326}$ Artículo 840.2 ${ }^{\circ}$ BGB: "Si junto con quien de acuerdo con los artículos 831 y 832, está obligado a resarcir el daño causado por otro es también responsable del daño el otro, en su relación recíproca es responsable sólo el otro, y en el caso del artículo 829 sólo el obligado a la vigilancia”.
} 
elección del personal, las normas de organización, las instrucciones sobre la forma de impartir la educación y el control de tales deberes; por ello su responsabilidad se basa en la culpa in eligendo e in vigilando. De esta forma si el titular del centro docente y el profesor resultan ser responsables, al realizar el docente un acto antijurídico, los dos responderían solidariamente ante la víctima. En sus relaciones internas el titular del centro docente, una vez que ha indemnizado a la víctima, puede repetir contra el docente.

El profesor puede exonerarse de responsabilidad por el último inciso del artículo 832.1: "si cumplió el deber de vigilancia o si el daño se hubiera producido igualmente pese a la observancia de la vigilancia”. Para exigir responsabilidad al profesor es preciso que se dé una relación de causalidad entre la vigilancia sobre el alumno y el daño cometido por éste. Si el profesor observa la diligencia y vigilancia debida no se da la relación causa a efecto entre su conducta y el hecho dañoso del alumno, por lo que ese profesor quedará exonerado. Pueda el profesor recurrir a otras causas de exoneración como la culpa del alumno, del artículo 254 BGB, así como el 829 BGB $^{327}$.

\subsection{ITALIA}

\subsubsection{PROFESORES DE LA ENSEÑANZA PRIVADA}

En la responsabilidad de los profesores de la enseñanza privada en general conviene distinguir los casos en que el menor sea o no imputable.

Para los alumnos no imputables por carecer de discernimiento y voluntad hay que aplicar el artículo 2047 que dice en su párrafo 1: "En caso de daño ocasionado por persona incapaz de entender o de querer, la indemnización deberá ser atribuida a aquel que tiene la guarda del incapaz, salvo que pruebe no haber podido impedir el hecho"; y en el párrafo 20:'Que en el caso en el que el perjudicado no hubiera podido obtener el resarcimiento del que tuviera su guarda, el juez, en consideración de las condiciones

\footnotetext{
${ }^{327}$ Moreno Martínez, Juan Antonio, op. Cit, pags 88 y ss.

Código Civil Alemán, Traducción de Lomarca Marqués Albert, Moreiol Pons, op. Cit.
} 
económicas de las partes, puede condenar al autor del daño a una indemnización equitativa".

En cuanto al alumno que produce el hecho dañoso sea imputable por encontrarse con capacidad de discernimiento y voluntad, se rige la exigencia de responsabilidad por el artículo 2048.2": "Los preceptores y aquellos que enseñan un arte u oficio son responsables del daño ocasionado por el acto ilícito de sus alumnos y aprendices en el tiempo en el cual estén bajo su vigilancia". Y en su párrafo $3^{\circ}$ dice: "Las personas indicadas en los apartados anteriores se hallan liberadas de su responsabilidad sólo si prueban no haber podido impedir el hecho".

La responsabilidad del artículo 2048, es de carácter solidario, por la culpa del docente que no ha podido evitar el daño producido por el menor imputable. El acto dañoso se ha producido por el comportamiento consciente del propio menor, así como, por la culpa in vigilando del profesor.

En el artículo $2055.1^{\circ}$ se contempla la responsabilidad solidaria que dice: "Si el hecho dañoso es imputable a varias personas, todas están obligadas solidariamente al resarcimiento del daño". El perjudicado podrá dirigirse para obtener la indemnización por los daños sufridos, contra el profesor y alumno o contra cada uno de ellos. En este caso el profesor y el alumno serán responsables, debiendo los dos indemnizar al perjudicado, cuando no sea posible establecer la parte que cada uno ha tenido en el evento dañoso, deberán contribuir en partes iguales ${ }^{328}$. Cuando sea posible individualizar la culpa de alguno, la indemnización se repartirá de manera proporcional al grado de participación $^{329}$.

En las relaciones internas la distribución de la indemnización se realizará según la gravedad de la respectiva culpa. Si existen dudas, sobre la culpa de cada uno, se

328 “Qualora non sia possibile stabilire l’incidenza causale delle singole azioni od omissioni (ie: le singole culpe) di ciascuno dei danneggianti che hanno cagionato il danno, esse si presumono in igual misura: ergo, il quantum damni é ripartito tra tutti in maniera equanime”

(M.FRANZONI, L’illecito, p.115, Perlingieri, Códice Civile annotato con la dottrina e la giurisprudenza, Art ${ }^{\circ}$ 2055, pag 2674)

329 “Qualora sia possibile individuare le colpe di ciascuno, il quantum damni é ripartito in maniera proporcionale in ragione del diverso grado di responsabilitá dei danneggianti” (Corte di Cass, 15 gennaio 1969, nº 70) Perlingieri, op cit, pag 2674. 
presumen iguales, de acuerdo con los apartados segundo y tercero del artículo $2055^{330}$, por ello el que paga la indemnización tiene derecho de regreso contra el otro u otros, según su grado de culpa. En el caso de que haya pagado el profesor y la culpa sea de ambos, tendrá derecho de repetición sobre el alumno, en la parte proporcional; para el caso que tenga la culpa el profesor, el deberá pagar la indemnización. Si la culpa es del alumno y pagó el profesor, será éste el que tenga derecho de repetición sobre el alumno. Para el caso de que en la relación interna, el que ha efectuado el pago total, tiene derecho de repetición contra el otro u otros, y si los demás no pagan devengarán intereses de mora por lo que ascienda su importe ${ }^{331}$.

\subsubsection{LOS PROFESORES DE LA ENSEÑANZA PÚBLICA}

Los profesores de la enseñanza pública son funcionarios y empleados del Estado como dispone el artículo 28 de la Constitución italiana de 27 de diciembre de 1947, el cual dice: "Los funcionarios y empleados del Estado y de las entidades públicas son directamente responsables, según las leyes penales, civiles y administrativas, de los actos que ejecuten violando los derechos de los ciudadanos. En tales casos la responsabilidad civil se extiende al Estado y a las entidades públicas ${ }^{332}$.

El anterior artículo es desarrollado por el Texto Único de 10 de enero de 1957, del que sus artículos 22 y 23 tratan la responsabilidad extracontractual de los funcionarios. El artículo 22.1' dispone: "El dependiente que en el ejercicio de las atribuciones conferidas por la ley o el reglamento, cause un daño injusto a otros en el sentido del artículo 23, está personalmente obligado a resarcirlo". En el artículo 23 define lo que es daño injusto y dice: "el derivado de cada violación de los derechos de los terceros que el

\footnotetext{
${ }^{330}$ Artículo 2055, $2^{\text {o: }}$ "Colui che ha risarcito il danno ha regresso contro ciascuno degli altri, nella misura determinata dalla gravitá della rispettiva colpa e dell'entitá delle conseguenze che ne sono derivate” Artículo 2055, 3:”Nel dubbio, le singole colpe si presumono uguali”.

331 “Il comma 2 prevedere l'azione di regresso verso ognuno degli altri corresponsabile per colui che, convenuto in giudicio della vittima (Cass, 16 Febbraio $1996 n^{\circ}$ 1199), ha risarcito integralmente il danno (M.FRANZONI, dei fatti illeciti, pag 747). Affinché decorrano gli interessi dovuti in ragione dell’adempimento effettuato per l'intero ammontare é necessaria la costituzione in mora degli altri corresponsabile” (Cass, 15 gennaio 1979, $\mathrm{n}^{\circ}$ 300, in RGI, 1979) Perlingieri, op cit, pag 2677.

${ }^{332}$ Constituciones españolas y extranjeras, op cit, pag 529.
} 
dependiente hubiere cometido por dolo o culpa grave, dejando a salvo las responsabilidades más graves previstas por las leyes vigentes". La repetición o derecho de regreso de la Administración contra el funcionario se contempla en el inciso final del artículo 22 al decir: "La Administración que habiendo resarcido al tercero del daño causado por el dependiente puede repetir contra este último según las normas de los artículos 18 y $19 "$ ".

La técnica del ordenamiento jurídico italiano para proteger a los profesores de la enseñanza pública es similar a la francesa y alemana. Ello ha dado lugar de igual forma a grandes polémicas por los agravios comparativos que origina en relación con la privada. Un sector mayoritario de la jurisprudencia y por un sector de la doctrina, estiman que a los profesores públicos se les debería aplicar los artículos 2043, 2047, 2048 y 2050 del Código Civil con sus respectivas responsabilidades en ellos contenidas. Otro sector mayoritario de la doctrina y minoritario en la jurisprudencia entiende que la regulación que contiene el Texto Único de 1957 es el único que debe dar protección legal a la responsabilidad de los profesores de la enseñanza pública por los hechos dañosos cometidos por los alumnos y así los distingue de la enseñanza privada como expone la Sentencia de 3 de junio de 1964 del Tribunal de Venecia, que dice: "La presunción de culpa establecida a cargo de los profesores y de quienes enseñan un oficio o actividad artesanal por el acto ilícito de sus alumnos no es aplicable en relación con los profesores de la escuela pública"333.

Una nueva Ley de 11 de julio de 1980 ha regulado la disciplina sobre la responsabilidad patrimonial del personal directivo, docente, educativo y no docente, con una nueva base retributiva funcional del personal civil y militar del Estado. Su título segundo contempla las normas que se refieren al personal de la enseñanza maternal, elemental y artística de las instituciones educativas y de las escuelas especiales del Estado. De esta Ley nos interesa de modo especial su artículo 61, en cuyo párrafo $1^{\circ}$ dice: "La responsabilidad patrimonial del personal directivo, docente y no docente de enseñanza maternal, elemental, secundaria y artística del Estado y de las instituciones educativas estatales por los daños directamente irrogados a la Administración en conexión con los

\footnotetext{
${ }^{333}$ Moreno Martínez, Juan Antonio, op cit, pag 82 y ss, así como notas 54 y 59.
} 
comportamientos de los alumnos, se limita a los casos exclusivos de dolo o culpa grave en el ejercicio de la vigilancia sobre los mismos alumnos". Este apartado es similar a lo establecido en los artículos 22 y 23 del Texto Único de 1957:

$\mathrm{El}$ apartado $2^{\circ}$ trata de la responsabilidad del personal dependiente, tanto docente como no docente, frente al Estado por los daños causados de forma indirecta y dispone: "La limitación prevista en el anterior apartado se aplica asimismo a la responsabilidad del mencionado personal hacia la administración que resarza al tercero por los daños sufridos por las conductas de los alumnos sujetos a vigilancia. El último inciso de este apartado $2^{\circ}$, contempla la subrogación de la Administración por el personal a su servicio, ante las acciones judiciales entabladas por terceros y dice: "Salvo indemnización en los casos de dolo o culpa grave, la Administración se subroga al personal en las responsabilidades civiles derivadas de acciones judiciales entabladas por terceros" ${ }^{\text {334 }}$.

Con la Ley de 1980 los profesores de la enseñanza pública no tienen que comparecer en juicio, por las acciones judiciales de los terceros perjudicados; será la Administración la que comparezca en juicio, evitando que el profesor se vea involucrado en la contienda judicial. Ello no quiere decir que el profesor se encuentre exento de responsabilidad, pues la Administración puede ejercer el derecho de regreso contra él, cuando haya actuado con dolo o culpa grave. El espíritu de esta Ley es dar una protección completa al profesorado, en el sentido que comprenda todas las actividades del sistema educativo con sus actividades escolares, extraescolares y complementarias.

Para poder exonerar de responsabilidad al profesor, se han tenido en cuenta como modelo la diligencia de un buen padre de familia, el criterio de la normalidad, la edad del menor y su grado de discernimiento. En algunos casos se han empleado criterios demasiado rigurosos para esa prueba exoneratoria del profesor, tanto en la enseñanza

\footnotetext{
${ }^{334}$ Artículo 61, Ley de 11 de julio de 1980: "La responsabilitá patrimoniale del personale direttivo, docente, educativo e non docente della scuola materna, elementare, secondaria ed artística dello stato e delle istituzioni educative statali per danni arrecati direttamente all'Admministrazione in connessione a comportamenti degli aluni é limitata ai soli casi di dolo o colpa grave nell'esercizio della vigilanza sugli alunni stessi.

La limitazione di cui al comma precedente si aplica anche alla responsabilitá del predetto personale verso l’Amministrazione che risarcisca il terzo dei danni subiti per comportamenti degli alunni sottoposti alla vigilanza. Salvo rivalsa nei casi di dolo o colpa grave, l’Amministrazione si surroga al personale medisimo nelle responsabilitá civil derivanti da azioni giudiziarie promosse da terzi”.
} 
privada como en la pública, lo que dio lugar a que se produjera un cierto malestar en el campo educativo, por lo que se llegaron a suspender ciertas actividades extraescolares para reducir los riesgos que pudieran ocasionar. Para subsanar estos problemas algunas regiones italianas, en virtud del artículo 117 de la Constitución ${ }^{335}$ que las reconoce competencia legislativa, han aprobado disposiciones encaminadas a asegurar posibles casos de daños originados por los alumnos en actividades escolares, extraescolares y de transporte.

Estas disposiciones no sólo tratan de garantizar la posible exoneración de los profesores para que impartan todo tipo de actividades incluidas las extraescolares, también constituir un seguro a favor del personal dependiente del centro docente, ante los daños que puedan causar los alumnos ${ }^{336}$.

\section{RESPONSABILIDAD DE LOS PROFESORES EN EL CÓDIGO CIVIL ESPAÑOL}

\subsection{LOS PROFESORES DE LA ENSEÑANZA PRIVADA}

La responsabilidad de los profesores fue modificada por la Ley 1/1991 de 7 de enero en la que se suprimió la expresa declaración de responsabilidad de los maestros por los daños causados por los alumnos sustituyéndolos en su lugar por el titular del centro. La modificación operada por la Ley fue consecuencia de las presiones de los sindicatos de la enseñanza por el malestar del ámbito educativo de los menores en los

\footnotetext{
335 Artículo 117 de la Constitución italiana de 1947: “La Región dictará normas legislativas en los límites de los principios fundamentales establecidos en las leyes del Estado, siempre que dichas normas no se opongan a los intereses nacionales y a los de las otras Regiones, en las siguientes materias:

- Instrucción artesana y profesional y asistencia escolar....

Las leyes de la República podrán atribuir a la Región el poder de dictar normas para su actuación”

Constituciones españolas y extranjeras, op. Cit, pag 544.

336 Moreno Martínez, Juan Antonio, op.cit, pag 82 y nota 53.
} 
que la responsabilidad recaía siempre en el profesor, incluso en casos fortuitos, en los que resulta imposible evitar los hechos dañosos de los alumnos.

El espíritu de la Ley es traspasar esa responsabilidad al director del centro y dejar a cargo del profesor sólo en algunos supuestos tasados o concretos, por eso dice la Exposición de Motivos: "El régimen de responsabilidad que para los profesores y maestros del artículo 1903 no se ajusta a la realidad de nuestros días. Se trata de normas con fundamento en la llamada culpa in vigilando, concebidas en momentos en que existía una relación de sujeción del alumno al profesor, en términos que hoy no se producen en el discurrir diario de la vida docente".

Para traspasar la responsabilidad al titular del centro docente se redacta el artículo 1903 V de la siguiente forma: "Las personas o entidades que sean titulares de un Centro docente de enseñanza no superior responderán por los daños y perjuicios que causen sus alumnos menores de edad durante los períodos de tiempo en que los mismos se hallen bajo el control o vigilancia del profesorado del Centro, desarrollando actividades escolares o extraescolares y complementarias". Por este artículo el centro responderá si es demandado.

Para el caso en que el profesor hubiera incurrido en dolo o culpa grave en el ejercicio de sus funciones que fuesen causa del daño el centro indemnizará al perjudicado, pero podrá repetir por el todo contra el profesor de acuerdo con el artículo 1904 II redactado por la Ley 1/1991 que dice: “Cuando se trate de centros docentes de enseñanza no superior, sus titulares podrán exigir de los profesores las cantidades satisfechas, si hubiesen incurrido en dolo o culpa grave en el ejercicio de sus funciones que fuesen causa del daño". Al decir "en el ejercicio de sus funciones que fuesen causa del daño", se refiere a que se tiene que dar una relación de causa a efecto entre la actividad realizada por el profesor y el hecho dañoso cometido por el alumno, pues en caso contrario el profesor no puede ser imputado. El profesor en este caso tiene que haber contribuido con su conducta dolosa o gravemente culposa a la causación material del daño.

El artículo 1904 II al decir que "sus titulares podrán exigir de los profesores las cantidades satisfechas, si hubiesen incurrido en dolo o culpa grave", supone liberar al 
centro de las consecuencias de su propia culpa, por ello hay autores que defienden que el regreso no es "por el todo" sino en proporción a las propias culpas. Yo creo que debe analizarse caso por caso y el Juez establecer la proporción del centro, así como el profesor, en su debida proporción.

En otro orden de cosas, existe la duda de si en el artículo 1904 II el perjudicado puede demandar directamente al profesor y parece que sí, pues no hay razón para que él no pueda hacerlo. Puede realizarlo el perjudicado ante el centro o ante el profesor indistintamente ${ }^{337}$.

\subsubsection{PERSONAL DOCENTE}

El artículo $1903 \mathrm{~V}$ al hablar del profesorado se refiere a los encargados de impartir las distintas materias del programa del centro ya sean teóricas o prácticas, con la misión añadida de vigilancia y control sobre los alumnos. Sus actividades comprenden las escolares, extraescolares y complementarias. Ha de entenderse el concepto de profesor en sentido amplio, con lo que podemos denominar personal docente que abarca no sólo las funciones propiamente académicas, si no aquellas que tienen funciones o tareas de vigilancia o guarda sobre los alumnos. Comprende por tanto a vigilantes o educadores, monitores, instructores, personal auxiliar de una guardería, pedagogos, vigilantes del autobús escolar, ayudante y otros similares.

No hay que incluir aquellos que no realizan labores de enseñanza, guarda, o vigilancia sobre los alumnos por tratarse de personal no docente, tales como capellanes, letrados, médicos, psicólogos, bibliotecarios, administrativos, personal de limpieza, bedeles, etc. Este personal tiene un régimen distinto y se consideran simplemente empleados o dependientes, y se hallan comprendidos en el artículo 1903 IV. Para exigir responsabilidad a este grupo de personal no docente hay que aplicar el artículo 1904 I: "El que paga el daño causado por sus dependientes puede repetir de éstos lo que hubiese satisfecho". El titular del centro docente puede ejercer el derecho de regreso sobre ese personal por cualquier conducta culposa en que hayan incurrido, con ello responde

\footnotetext{
${ }^{337}$ Reglero Campos, Fernando, Lecciones de Responsabilidad, op.cit, pags 288 y ss.
} 
como empresario y constituye un perjuicio para estos dependientes, pues la conducta culposa no tiene que ser grave o dolosa, se trata simplemente de culpa.

Por el contrario el personal docente, que tiene funciones de vigilancia y guarda sobre los alumnos, se rige por el artículo 1904 II, en el que se restringe a las conductas dolosas o con culpa grave ${ }^{338}$.

\subsubsection{DOLO O CULPA GRAVE DEL PROFESOR}

El perjudicado ante un caso de dolo o culpa grave del profesor puede demandar indistintamente al profesor o al titular del centro docente, aunque lo normal es que se demande siempre conjuntamente a ambos.

Además del profesor en casos de dolo o culpa grave, pueden intervenir otras personas tales como el propio interesado, sus padres o tutores y el titular del centro docente. En estos casos la responsabilidad es solidaria, por ello el perjudicado puede reclamar la indemnización a cualquiera de los que se encuentren involucrados en esa responsabilidad, debiendo cualquiera de ellos pagar la indemnización, pudiendo después reclamar a cada uno la parte correspondiente.

Si el menor, concurre él mismo con su culpa a la producción del hecho dañoso, habrá que averiguar si en su conducta se puede apreciar esa culpa o negligencia para poder declararlo responsable, a él o a sus padres. Por ello, al dañarse a sí mismo habrá que reducir la indemnización a los otros responsables e incluso se puede apreciar culpa exclusiva de la víctima, quedando exentos los demás.

En estos casos de menores en que concurra su propia culpa hay que resolverlos caso por caso atendiendo a su grado de discernimiento. Desde luego no se puede declarar responsables a los menores de muy corta edad o incapacitados, con lo que la

\footnotetext{
338 - Lasarte Carlos, La responsabilidad civil en los Centros Docentes, op.cit, pag 75.

- Moreno Martínez, Juan Antonio, op.cit, pags 211 y ss.

- III Convenio Colectivo de Centros de Enseñanza Privada, BOE nº 43 de 19 de febrero de 1990

- VIII Convenio Colectivo de Centros de Enseñanza Privada, BOE nº 127 de 28 de mayo de 1991
} 
posibilidad de que lleguen a indemnizar si disponen de patrimonio es desde luego muy remota. No sucede lo mismo con los menores que sí son capaces de discernir, por tener edad y madurez suficiente, a estos sí se les puede hacer responder.

Los padres o tutores pueden ser de igual forma responsables junto al centro docente y profesores por los hechos dañosos de esos menores, pues aunque se encuentren dentro del colegio, en el horario escolar y bajo la vigilancia y control del profesorado, pueden incurrir en culpa in educando, por no haberles inculcado desde su más tierna edad valores basados en la tolerancia y respeto hacia los demás, impidiendo de esta forma conductas violentas o de acoso hacia otros alumnos. Esto se consigue llevando y recogiendo a sus hijos del colegio a tiempo para que estén vigilados, que no lleven objetos o instrumentos peligrosos con los que puedan causar daños y otras normas de conducta semejantes. Cuando se den estos casos de culpa in vigilando o in educando en padres y tutores, procederá la reducción de la indemnización de los centros docentes y profesores, respondiendo ellos en la parte que les corresponda ${ }^{339}$.

Para el caso en que sean responsables el titular del centro docente y el profesor de los daños causados por sus alumnos el sistema más empleado es el de la responsabilidad solidaria, que es la que más favorece a la víctima. Existe una corriente jurisprudencial no mayoritaria, que considera la aplicación de la solidaridad a los casos en que no se aprecien elementos suficientes para poder identificar o diferenciar el grado de participación de cada uno de los responsables.

El demandante puede dirigirse contra el titular del centro docente, contra el profesor o contra ambos conjuntamente como ya se vio. Si acciona contra el titular del centro, éste trata de exonerarse de acuerdo con lo establecido en el artículo 1903 VI, destruyendo la presunción de culpa que recae sobre él, así como también afirmando que no existe relación de causalidad o lo que es lo mismo que no se da relación de causa a efecto entre el daño que ha causado el menor y los medios materiales, humanos y organizativos del centro. Para poder exonerarse deberá demostrar que empleó la diligencia debida para impedir el hecho dañoso producido por el menor.

\footnotetext{
${ }^{339}$ Lasarte, Carlos, La Responsabilidad de los centros educativos, op.cit pag 76 y ss.
} 
Para el caso de que el demandado fuera el profesor, el que demanda, es decir, la parte actora tiene necesariamente que acreditar la conducta dolosa o culpa grave del profesor en el ejercicio de sus funciones docentes, lo que a veces no resulta fácil. El profesor para quedar responsabilizado por dolo o culpa grave tiene que tratarse de una situación de especial gravedad, como así desea el legislador. Al darse este tipo de gravedad hay que tener en consideración lo dispuesto en el artículo 1102 CC, aplicable a obligaciones contractuales y extracontractuales ${ }^{340}$ con lo que el profesor no puede quedar exonerado, debiendo ser responsable por el artículo 1902 CC $^{341}$.

\subsubsection{LA ACCIÓN DE REGRESO DEL ARTÍCULO 1904 II CC}

El que el titular del centro docente pueda ejercer el derecho de repetición contra el profesor en los casos de dolo o culpa grave, contemplado en el artículo 1904 II, supone un trato privilegiado con respecto al resto de personal dependiente de un establecimiento, comprendidos en el artículo 1904 I, cuyo derecho de regreso puede efectuarlo el empresario por cualquier tipo de culpa en que puedan incurrir. Supone una especie de patente de corso para el profesor con tal de que su descuido no sea muy grave y desde luego su justificación no está muy clara ${ }^{342}$.

Dar distinto trato a los profesores y a los dependientes tiene su origen en las presiones de los sindicatos de la enseñanza por el malestar en ese sector, como ya se vio anteriormente. El legislador como consecuencia de ello ha querido que se de esa diferencia, pues no es igual responder por hechos de terceros, es decir, de los alumnos, que responder por actos propios como sucede con los dependientes. La Ley 7/1991 así lo ha establecido, pues aunque se trate de una exclusión a la culpa del artículo 1902, no se rompe el principio de igualdad, además de ser mucho mayor la responsabilidad que recae sobre los profesores por hechos de sus alumnos que la de un empleado.

\footnotetext{
${ }^{340}$ Artículo 1102 CC : "La responsabilidad procedente de dolo es exigible a todas las obligaciones. La renuncia de la acción para hacerla efectiva es nula”

341 Moreno Martínez, Juan Antonio, op.cit, pag 215 y ss.

${ }^{342}$ Lasarte Carlos, La Responsabilidad Civil, op.cit, pag 74.
} 
El titular del centro docente al ser demandado por el perjudicado por haber incurrido en culpa o negligencia del artículo 1903 VI, debe responder en todo caso por lo que se trataría de una responsabilidad objetiva y no por culpa; pues al hablar el artículo 1904 II de cantidades satisfechas se da una responsabilidad de carácter objetivo en contra de la del 1903 VI que es culposa.

Si el titular del centro docente resulta culpable por los hechos dañosos de sus alumnos, al no haber acreditado la diligencia debida del artículo 1903 VI, no puede después repetir íntegramente las cantidades satisfechas contra el profesor, pues ello constituiría un enriquecimiento injusto en contra del profesor. Ello da lugar a una concurrencia de culpas entre el profesor por dolo o negligencia grave y el titular del centro docente por culpa de cualquier género, con lo que se da una relación solidaria entre ambos, cada uno de ellos pagará al realizarse el regreso lo que proporcionalmente le corresponda ${ }^{343}$.

Para realizar la acción de regreso es condición necesaria que el titular del centro docente haya efectuado la indemnización al perjudicado, en razón del vínculo de solidaridad que le une con el profesor, de acuerdo con el artículo 1145 I: “ El pago hecho por uno de los deudores solidarios extingue la obligación".

El titular del centro docente para repetir contra el profesor tiene en primer lugar que acreditar el dolo o culpa grave del profesor, a no ser que se hubiera determinado en el juicio principal con lo que ya no sería necesario repetirla. En segundo lugar, ese dolo o culpa grave ha de referirse a la falta de diligencia del profesor en la vigilancia sobre el alumno, que ha dado lugar al hecho dañoso cometido por éste y cuya relación de causalidad tiene que darse entre el acto del alumno menor sometido a la vigilancia del profesor y el daño causado ${ }^{344}$.

Otro aspecto del derecho de repetición a tener en cuenta se da cuando en actividades consistentes en excursiones, visitas a museos y otras de carácter análogo, se hubiera producido una conducta dolosa o con culpa grave de uno o varios profesores encargados de vigilar al alumnado sin que fuera posible determinar quién o quienes

\footnotetext{
343 Ibidem, pags 74 y 75.

344 Moreno Martínez, Juan Antonio, op.cit, pag 223.
} 
fueran responsables para poder atribuir el comportamiento negligente. Estamos ante un problema de daño causado por miembro indeterminado de un grupo, que las más modernas legislaciones, la doctrina y la jurisprudencia resuelven mediante la condena de todos los componentes del grupo, quienes quedan obligados a responder de forma solidaria frente al perjudicado. Lo ideal, desde luego, es poder determinar el nexo causal entre el daño y quién lo cometió, ello es fácil entre el alumno y el acto dañoso, pero no entre el grupo de profesores y el alumno vigilado; por lo que si no es posible encontrar el nexo causal entre profesores y alumno, se puede optar por que el perjuicio quede sin reparación, en contra del principio pro damnato para proteger a la víctima. La condena solidaria de los miembros del grupo es lo más conveniente que se puede hacer para evitar la injusticia que significaría que la víctima quedara sin reparación por el hecho de no poder probar cuál de todos ellos ha sido el autor del daño, existiendo la certeza de que el perjuicio causado proviene de ese grupo y que por tanto el autor debe pertenecer a él.

El fundamento jurídico de la solidaridad en estos casos se basa en la realización por parte de un grupo de una actividad llevada adelante en forma negligente y que causa un riesgo de daño, el que se verifica finalmente, y esa es la razón por la cual se estima que todos los miembros del grupo deben responder, ya que todos ellos han contribuido con su actitud a generar esa situación de riesgo ${ }^{345}$. Esta situación se contempla en el artículo 830 I BGB ya visto anteriormente sobre coautores y partícipes, en el que si varios han causado un daño ilícito realizado conjuntamente, cada uno de ellos es responsable del daño y lo mismo rige si no es posible determinar quién de ellos ha causado el daño.

El plazo para el ejercicio de la acción de repetición es el plazo general de quince años que establece el artículo 1964 CC, para las acciones personales que no tengan señalado plazo general de prescripción.

En cuanto a los seguros sobre responsabilidad civil, los centros deben contratar un seguro que ampare a sus empleados en el desarrollo y cumplimiento de sus

\footnotetext{
345 Barría Díaz, Rodrigo, El Daño causado por el miembro indeterminado de un grupo, Editorial La Ley, 1ª Edición, Madrid 2010, pag 73 y ss.
} 
obligaciones $^{346}$. En el VIII Convenio Colectivo de la Enseñanza Privada, señala en su artículo 75 que: "Todos los Centros deberán contar con dos pólizas de seguros que garanticen las coberturas de Responsabilidad Civil y Accidentes Individuales de todo el personal afectado por este Convenio". El mencionado artículo desarrolla todo el sistema de protección del personal tanto docente como no docente, así como las cifras máximas de cobertura para los distintos casos que puedan producirse en Responsabilidad Civil y Accidentes. De igual forma en el IX Convenio de 2011, dice que los centros deberán contratar un seguro de responsabilidad civil que ampare a sus empleados en el desarrollo y cumplimiento de sus obligaciones, como se ve en términos parecidos al III Convenio $^{347}$.

\subsubsection{LA RESPONSABILIDAD DE LOS PROFESORES DE ENSEÑANZA PRIVADA EN LA JURISPRUDENCIA.}

La jurisprudencia, para resolver los casos, los criterios que emplea son el de la negligencia del agente, la persona a la que se pueda exigir el cuidado sobre el menor para evitar el daño, el nexo causal que exista entre la acción u omisión y el daño producido, así como el de la previsión del daño. Este último es el criterio más utilizado y que además se encuentra contemplado en el artículo 1107 del CC aunque se refiera a la responsabilidad contractual es aplicable a la extracontractual ${ }^{348}$.

En la Sentencia de 14 de febrero de $2000^{349}$ se emplea el criterio de la previsibilidad para el establecimiento de responsabilidades, cuyos hechos son los siguientes: el Colegio de EGB “Quimbel” de Barcelona es explotado por la empresa Doceo S.L. que tiene un contrato de seguro con Winterthur Sociedad Suiza de Seguros. En su aula n ${ }^{\mathrm{o}}$ 1, ubicada

\footnotetext{
${ }^{346}$ III CONVENIO COLECTIVO NACIONAL DE CENTROS DE ENSEÑANZA PRIVADA SIN NINGÚN NIVEL CONCERTADO O SUBVENCIONADO, Segunda Disposición Final, BOE nº 43 de 19 de febrero de 1990, pag 4933. ${ }^{347}$ VIII CONVENIO COLECTIVO DE LA ENSEÑANZA PRIVADA, ARTÍCULO 75, BOE nº 127 de 28 de mayo de 1991, pag 17289 y IX CONVENIO, Disposición Final Tercera, BOE nº 125 de 26 de mayo de 2011.

${ }^{348}$ Artículo 1107 Código Civil: “Los daños y perjuicios de que responde el deudor de buena fe son los previstos o que se hayan podido prever al tiempo de constituirse la obligación y que sean consecuencia necesaria de su falta de cumplimiento".

${ }^{349}$ Sentencia del TS de 14 de febrero de 2000 (RJ/2000/675)
} 
en el séptimo piso del edificio, donde se impartían clases de plástica, la niña de doce años Pilar M, sobre las 15:45 horas del día 30 de abril, hallándose en clase ocupando un lugar junto a una de las tres ventanas, situadas a 68 centímetros del suelo y cuyos cierres carecían de mecanismos de seguridad, como asimismo de redes o mallas de protección, y a las que cabía acceder fácilmente desde encima del banco o pupitre, que se encontraba a una distancia del quicio o marco de aquellos de 24 y 13,5 centímetros respectivamente, que había abierto previamente, se subió a su pupitre y de ahí al alféizar de la ventana y, tras un impulso, se arrojó al vacío, y al caer sobre una terraza, a nivel del piso primero, resultó con lesiones gravísimas.

En su Fundamento de Derecho Primero don Enrique M.R, padre de la menor, demandó por los trámites de juicio declarativo de menor cuantía a la entidad "Doceo S.L", a Doña Josefina B.A. profesora del centro, y a la compañía "Winterthur Sociedad Suiza de Seguros", y, entre otras peticiones, interesó la condena solidaria a los litigantes pasivos a que le indemnicen, en nombre y representación de su hija, en la cantidad de veinte millones de pesetas.

El Juzgado acogió parcialmente la demanda, condenó a las entidades "Doceo S.L" y "Winterthur Sociedad Suiza de Seguros" a que pagaran solidariamente al actor la cantidad de diez millones de pesetas, absolvió a doña Josefina B.A., y su sentencia fue confirmada en grado de apelación por la Audiencia.

La compañía de seguros "Winterthur" ha interpuesto recurso de casación contra la Sentencia de la Audiencia.

En su Fundamento de Derecho Segundo, el motivo único del recurso es la infracción del artículo 1902 Código Civil, por cuanto, que según acusa, la Sentencia impugnada no ha valorado la inexistencia de culpa en la entidad "Doceo S.L", ya que no puede exigirse a esta sociedad una diligencia que vaya más allá de prever y evitar la posibilidad de daños derivados de circunstancias accidentales, y por dicha actuación, no ha generado el riesgo o peligro causante de los daños personales de la menor Pilar M.A., que fueron ocasionados por la propia voluntad de ésta, amén de que la voluntad de suicidarse ha sido la causa eficiente, principal y determinante del daño sufrido, de manera que se interfiere en la cadena causal y exonera de toda responsabilidad a aquella entidad 
por tratarse de un suceso imprevisible e inevitable y se desestima por las razones que se dicen seguidamente.

Aún desde la óptica de que la caída de la menor Pilar M.A. no se produjo por hallarse ésta en movimiento junto a una ventana abierta, sino que fue un acto voluntario y consciente de la misma, no hay duda de que dicha acción pudo evitarse si el colegio "Quimbel" hubiera adoptado las medidas de precaución posibles y socialmente adecuadas, en consonancia con las normas de seguridad del Departament d'Ensenyament de la Generalitat de Catalunya, donde se establece que la colocación de las ventanas debe efectuarse de forma que no existieran elementos practicables por debajo de 1,10/1,20 metros, medidos sobre cualquier elemento a que un niño pudiera subirse, como hizo con posterioridad al evento de manera que la argumentación de la resolución de instancia respecto a que "el reproche culpabilístico que se imputa al centro escolar propiedad de Daceo S.L. en la sentencia apelada, se centra en la previsibilidad del resultado dañoso, toda vez que las ventanas de las plantas altas del edificio en las aulas ocupadas por menores no se encontraban correctamente situadas ni protegidas, careciendo de toda medida de seguridad, al tiempo que eran fácilmente accesibles por los alumnos desde los pupitres colocados debajo y ello, con independencia del cumplimiento de las normas administrativas, que como bien recoge la Sentencia apelada tampoco se daba, y ya había sido puesto de manifiesto por el Consejo Escolar que en la reunión celebrada el 9 de abril del mismo año 1991 había acordado poner rejas en los tres últimos pisos para mayor seguridad de los alumnos (folio 42), por lo que es claro que el colegio no había adoptado las precauciones que correspondían a las circunstancias de personas, tiempo y lugar, y que por ello no cabe excluir su responsabilidad de las consecuencias dañosas del suceso", es irreprochable y se ajusta a evolución de la doctrina jurisprudencial de la culpa extracontractual, dispuesta en el artículo 1902 del Código Civil, asimismo recogida en la referida Sentencia, hacia un sistema que, acepta soluciones cuasi objetivas demandadas por el incremento de actividades peligrosas.

En verdad en el suceso objeto del debate, no medió la culpa exclusiva de la niña Pilar M.A., que determinara la ruptura del nexo causal, sino una conjunción de causas, 
ambas relevantes para la efectividad del hecho, sin que ninguna de ellas esté provista de eficacia suficiente para anular a la otra, por lo que esta Sala acepta el razonamiento de instancia con mención a que no pueda exigirse a los menores el mismo grado de madurez en su actuar que a una persona adulta, de donde resulta que no excluye por completo la responsabilidad del colegio, ni estima como única causa eficiente del evento la conducta de la niña, pues si las ventanas estuvieran dotadas de los debidos mecanismos de protección, el suceso hubiese podido ser evitado, por lo que la apreciación de concurrencia de culpas, en igual grado y con igual virtualidad, sirve para moderar la responsabilidad de los demandados.

Esta Sentencia condena a indemnizar a la empresa Daceo S.L., que explota el colegio Quimbel, por infracción del artículo 1902 del Código Civil por no haber adoptado las medidas de seguridad del Departament d'Ensenyament de la Generalitat, precisamente puesto de manifiesto por el Consejo Escolar veintiún días antes de que se produjera el hecho, en cuya reunión de nueve de abril se acordó instalar rejas en los tres últimos pisos. De igual forma se condena a la compañía de seguros Winterthur junto a la empresa Daceo S.L. expresada anteriormente a los que se hace responsables moderando su responsabilidad civil, por la culpa de la niña Pilar M.

La profesora doña Josefina B.A., queda absuelta por no tener responsabilidad alguna al tratarse de un hecho imprevisible y la niña de doce años tiene el grado de discernimiento suficiente para saber el alcance de sus actos, ya que se trata de un caso en que la causa principal es la voluntad de suicidarse.

La niña no es la causante en exclusiva del daño, por lo que no se da una ruptura del nexo causal, pues si el colegio hubiera instalado los mecanismos de seguridad adecuados, el hecho dañoso no se hubiera producido, por ello se aprecia una concurrencia de culpas, que sirve para moderar la indemnización de la empresa y la compañía de seguros. La empresa y la compañía de seguros tienen que indemnizar por un tipo de responsabilidad cuasi objetivas que se adaptan por el incremento de las actividades peligrosas, así como, por el principio de ponerse a cargo de quien obtiene provecho la indemnización del quebranto producido por tercero, pues si la empresa 
hubiera gastado el dinero en poner rejas o cierres de seguridad en las ventanas, el hecho dañoso no se hubiera producido y no habría dado lugar a la indemnización.

El caso que tratamos se adapta perfectamente a la tesis de la causalidad adecuada que acepta la doctrina jurisprudencial, en el que exige para apreciar la culpa del agente que el resultado sea una causa natural, adecuada y suficiente, lo que se da con claridad, pues el antecedente del hecho dañoso es la inexistencia de medidas de seguridad en las ventanas, que de haber existido el hecho dañoso no se podría haber producido.

La Sentencia T.S. de 31 de octubre de $1998^{350}$, trata de una visita de los alumnos de un colegio de religiosos a un parque zoológico, en el que se produce un ataque de un león a un niño de cuatro años y medio.

En su Fundamento de Derecho Segundo, la parte recurrente afirma que se ha infringido el artículo 1903 IV del Código Civil, que trata de la responsabilidad de los dueños o directores de un establecimiento o empresa respecto de los perjuicios causados por sus dependientes. Se trata de un caso de responsabilidad extracontractual directa del empresario, de tipo cuasi objetiva.

Como datos inexcusables se dan los siguientes: a) Que el niño atacado por el león tenía cuatro años y medio, b) Que cuando se visita un parque zoológico con fieras expuestas, hay que tener o desarrollar un "plus" de atención y cuidado, c) Que dicho niño lesionado estuvo totalmente descontrolado por parte de los profesores cuando ocurrió el accidente.

De todo lo cual se infiere la clara culpabilidad extracontractual del colegio en cuestión, que no ha logrado conseguir demostrar la existencia de una diligencia de su parte para evitar el accidente. En conclusión procede determinar la culpabilidad del centro de enseñanza recurrido en el resultado lesivo al menor en cuanto a la actuación de los profesores, que debe asumir en base al principio in eligendo - nexo y resultado lesivo.

De todo lo anterior se infiere que la Sala debe asumir la instancia, y en cuanto a la delimitación del "quantum" indemnizatorio, se habrá de tener en cuenta lo manifestado en el voto particular al respecto, pues no se puede desechar las secuelas que afectarían al

\footnotetext{
${ }^{350}$ STS de 31 de octubre de 1998 (RJ/1998/8359)
} 
menor durante toda su vida, su dificultad en la integración social y laboral por la deformidad que le ocasionan, así como su repercusión desde el punto de vista psicológico; y por ello parece lógica y aceptable la suma de diez millones de pesetas.

En la presente Sentencia se aplica el artículo 1903 IV, de responsabilidad del empresario, al tratarse de un colegio privado, que trata de obtener lucro por lo que se asimila a una empresa, en la que se da manifiesta falta de control sobre el menor por parte de sus dependientes, en este caso de los profesores. No han observado la diligencia debida al dejar solo a un niño de cuatro años y medio en el zoológico cuando le atacó el león, lo que quiere decir que no ejercían ningún control sobre él. Esto en si mismo considerado constituye una falta muy grave al haber hecho dejación de sus funciones de vigilancia y control sobre el menor.

El director del centro deberá pagar la indemnización a los padres del menor y puede repetir contra los profesores la cantidad satisfecha de acuerdo con el artículo 1904 I del Código Civil, por haber sido los profesores los causantes del daño, pues si le hubieran controlado adecuadamente, no le hubiera atacado el león. La acción para ejercitarla tiene un plazo de quince años del artículo 1964 Código Civil. Si no se sabe quién es la profesora directamente responsable, se deberá aplicar el régimen de la solidaridad y la que cumpla la obligación de indemnizar, tendrá acción contra los demás por la parte proporcional que corresponda.

La Sentencia T.S. de fecha 27 de septiembre de $2001^{351}$ trata de un caso en el que unos niños del Colegio Azkauri de Getxo (Bilbao), jugando al juego "tren chu chu" causan lesiones a la menor Ana Rebeca.

En su Fundamento de Derecho Segundo dice que sobre las trece horas del día 19 de abril de 1991, unos ciento veinte niños de edades aproximadas de seis años, se encontraban bajo la supervisión de dos personas no docentes, en un recinto cerrado de su colegio, por estar lloviendo entonces, en espera de acceder al comedor y en tal momento un grupo de aquellos niños jugaba al juego que denominaban "tren chu chu" y a causa de la fila que enlazados formaban para ello, se desploma Ana Rebeca, que

\footnotetext{
${ }^{351}$ Sentencia Tribunal Supremo de fecha 27 de septiembre de 2001 (RJ/2001/8155)
} 
formaba parte de la misma, se produce lesiones y de este resultado no se apercibieron las cuidadoras hasta que la niña se les acercó llorando y quejándose del brazo.

Ha de consignarse que dicha lesión consistió en fractura de codo derecho que requirió intervención quirúrgica y dejó secuelas medicamente especificadas y llevó a promover la demanda rectora con base en los artículos 1903 y 1902 Código Civil.

Por su Fundamento de Derecho Segundo, el juego que da lugar al presente litigio es inocuo en cuanto no necesita de elemento alguno, ni conlleva brusquedades, con lo que queda por determinar si se ha hecho correcta aplicación de lo dispuesto en el artículo 1903 V del Código Civil.

El recurrente habla de que "se desplomó", una "pequeña montaña de niños", una "cierta violencia" y que las cuidadoras no se apercibieron de las lesiones de Ana Rebeca en un primer momento, hasta que la niña se acercó llorando y quejándose del brazo, surgiendo todo esto en el curso natural del juego del que, por su inocuidad, no cabe esperar ni temer un resultado como el que se produjo para aquella niña sin que en la producción tuviese nada que ver el que las cuidadoras se hubieran o no apercibido "en un primer momento" de tales consecuencias.

En su Fundamento de Derecho Cuarto, la Sala establece que la consecuencia que para Ana Rebeca tuvo el juego de niños en el que participó no ha sido debido a una falta de vigilancia de las cuidadoras, pues lo cierto es que aquella consecuencia se produjo imprevisiblemente y de ello no puede derivarse, según resuelve la sentencia recurrida, responsabilidad ajena, sin cabida en aquel precepto invocado, valorando la diligencia en función de una culpa que no ha existido, lo que lleva aquí a la desestimación del motivo del recurso. Tratándose por ello de un caso fortuito.

El recurrente en esta Sentencia trata de demostrar que es un juego peligroso, con las palabras "se desplomó, una montaña de niños" y otras parecidas, pero lo cierto es que consiste en un juego inocuo. Al decir que la niña acudió llorando y quejándose del brazo, con ello quiere responsabilizar a las cuidadoras que han actuado diligentemente, pues las dos se encuentran presentes vigilando a los niños, de acuerdo con las normas que hayan recibido del director, por lo que no han vulnerado el artículo 1903 V Código 
Civil. El suceso es totalmente imprevisible, pues nadie puede evitar que una niña de seis años se caiga en esas circunstancias.

La única forma de evitar el suceso habría sido impedir a la niña toda actividad para que no sufriera accidentes, pero eso va en contra de los principios educativos que requieren una relación de distintas actividades con niños de su edad para que adquieran un desenvolvimiento correcto para el desarrollo de su personalidad.

La Sentencia de 10 de diciembre de $1996^{352}$, trata de la niña Oriana A.G. del Colegio Juana de Arco S.L. de San Sebastián, la cual en una discusión entre niños, clavó en un ojo al niño Ion B.J, un imperdible con chapa redonda, lo que le originó catarata traumática y edema estromal, para lo que hubo de practicársele operación quirúrgica, quedándole secuelas permanentes.

En su Fundamento de Derecho Tercero, se prueba en autos que las lesiones sufridas por el menor Ion B, lo fueron al clavársele en el ojo derecho el alfiler del broche o chapa que en forma de imperdible llevaba la niña Oriana A.G. al golpearle con él o arrojárselo, no son aceptables las razones que se exponen en la sentencia recurrida de que "se trata de niños de cuatro años y de una lesión causada mediante un broche, instrumento que no es por sí, ni se ha demostrado frente a ello que el de autos lo fuera, potencialmente peligroso, en el curso de una disputa súbita y en modo alguno atípica entre niños de esa edad, según aparece de lo actuado”, razonamiento que parece estar valorando la responsabilidad de los niños y no la de quienes los tenían confiados a su vigilancia durante su permanencia en el colegio. Traspasados al Colegio demandado, desde su entrada en el mismo, los deberes de vigilancia y cuidado sobre los menores, ha de apreciarse en el caso una omisión de ese deber de vigilancia en los profesores del centro, deber que, dada la edad de los alumnos (cuatro años), debió de ser extremada; tal omisión se produjo al permitir que la alumna llevase un broche de esas características compuesto de un elemento punzante que si, en poder de personas mayores, carece de peligrosidad no así en manos de un niño de cuatro años que con su actuación irreflexiva puede causarse lesiones a sí mismo o a un tercero, como así sucedió al surgir una disputa, no imprevisible, entre los niños y de la que las dos profesoras que estaban en la

\footnotetext{
352 Sentencia de 10 de diciembre de 1996 (RJ/1996/8975)
} 
clase ni siquiera se apercibieron aunque si otros alumnos. Por ello ha de afirmarse la existencia de una conducta negligente en las profesoras del Colegio demandado que tenían a su cargo a los menores, conducta que determina la responsabilidad del centro de enseñanza demandado de acuerdo con el artículo 1903 del Código Civil y la consiguiente obligación de resarcimiento de los daños causados al alumno Ion B, de ahí la necesaria estimación del motivo en tal aspecto.

Las profesoras han incurrido en negligencia según se desprende de los hechos relatados en la Sentencia, lo que obliga a indemnizar al director del colegio los cinco millones de pesetas que establece en el Fundamento de Derecho Cuarto. Una vez haya indemnizado esa cantidad a la madre de la víctima, por tratarse de un centro de enseñanza privada, el director podrá exigir la cantidad a las profesoras del colegio por negligencia grave, al haber omitido el deber de vigilancia, basándose en el artículo 1904 II que contempla la exigencia de responsabilidad por vía de regreso.

No obstante creo que podría haberse exigido responsabilidad a la madre por haber colocado a su hija en el vestido el mencionado broche con imperdible, habiendo contribuido con ello a la causación del daño, pues los padres pueden incurrir en responsabilidad si permiten o no evitan que los menores lleven consigo al colegio objetos que puedan resultar potencialmente peligrosos, como en el caso que nos ocupa. Pues si a la producción del daño contribuyeron tanto el centro docente o su personal en este caso las profesoras, como los padres del alumno, deben responder unos y otros, operando las reglas aplicables a los casos de concurrencia de varios responsables ${ }^{353}$.

\subsection{LA RESPONSABILIDAD DE LOS PROFESORES EN LA ENSEÑANZA PÚBLICA.}

Los profesores de la enseñanza pública son funcionarios por tratarse de personas incorporadas a la Administración por una relación de servicios profesionales y retribuidos, regulada por el Derecho Administrativo. La normativa que se aplica es la que

353 Reglero Campos, Fernando, Lecciones..... pag 289 
regula la responsabilidad patrimonial de la Administración, que se contempla en los artículos 139 a 146 de la Ley 30/1992 de Régimen Jurídico de las Administraciones Públicas y del Procedimiento Administrativo Común.

Para exigir responsabilidad a los profesores hay que hacerlo de acuerdo con el artículo 145.II de la LRJA.PAC ${ }^{354}$, que trata de la acción de regreso en los casos de dolo, culpa o negligencia grave. En esta acción de regreso se han de cumplir dos requisitos, que son: el primero, que el lesionado haya sido previamente indemnizado por la Administración y segundo, acreditar la existencia de dolo, culpa o negligencia grave en la conducta del personal al servicio de la Administración.

El particular no puede dirigirse directamente al profesor, tiene que hacerlo ante la Administración de forma directa, de acuerdo con el artículo 145 I LRJA. PAC., después en sus relaciones internas la Administración exigirá la responsabilidad a que hubiera lugar con el empleo de la vía de regreso.

El personal docente comprende los profesores propiamente dichos, como el resto de personal, tales como profesores auxiliares, cuidadores, vigilantes, monitores de deportes, y en general todos aquellos que realizan labores de guarda y vigilancia sobre los menores.

Del artículo 145 II al decir "podrá exigir de sus Autoridades y demás personal a su servicio", quiere decir que su potestad es discrecional y no obligatoria para la Administración, siendo su aplicación de carácter excepcional por las pocas veces que ha hecho uso de ese derecho. Ello ha dado lugar a que se hayan cometido abusos por la impunidad con que han actuado los funcionarios, lo cual ha sido criticado por la doctrina y se reclama una modificación de ese comportamiento administrativo haciendo más frecuente su utilización.

\footnotetext{
${ }^{354}$ Artículo 145 II LRJA.PAC: “La Administración correspondiente, cuando hubiere indemnizado directamente a los lesionados, podrá exigir de sus Autoridades y demás personal a su servicio la responsabilidad en que hubieran incurrido por dolo, culpa o negligencia grave, previa la instrucción del procedimiento que reglamentariamente se establezca.

Para la exigencia de dicha responsabilidad se ponderarán, entre otros, los siguiente criterios: El resultado dañoso producido, la existencia o no de intencionalidad, la responsabilidad profesional del personal al servicio de las Administraciones Públicas y su relación con la producción del resultado dañoso”.
} 
Por la reforma de la LRJA y PAC de 13 de enero de 1999 el ejercicio de la acción de regreso dejó de ser facultativo, pasando a tener carácter obligatorio, debiendo interponerse de oficio, aunque ello no ha dado lugar a una mayor frecuencia en su utilización cuando se trata de centros docentes públicos, siguiendo las cosas igual y como señalan algunos autores: "el funcionario quedará impune, el servicio seguirá funcionando mal y el erario público se verá gravado de nuevo innecesariamente" 355 .

En el artículo 145 II, en su apartado segundo, se concede una gran discrecionalidad a la Administración en la exigencia de responsabilidad a su personalidad, al decir "se ponderarán”, quiere decir que graduará esa responsabilidad según el resultado dañoso producido, la existencia o no de intencionalidad, la responsabilidad profesional del personal al servicio de las Administraciones Públicas y su relación con la producción del resultado dañoso.

Los criterios de ponderación sirven para fijar la cuantía de la indemnización y el grado de responsabilidad en cada caso, si hay lugar a dicha responsabilidad.

El resultado dañoso supone un incumplimiento de las obligaciones existentes entre la Administración y el personal a su servicio. Tiene que ser evaluable económicamente en dinero y ser antijurídica, es decir, contraria al Derecho. Sirve de forma directa para fijar la cuantía a indemnizar según la proporción entre el daño producido y la actividad realizada.

La existencia o no de intencionalidad, se refiere a si hay o no dolo, pues dolo es la intención de causar daño. Supone la existencia de dolo una mayor exigencia de responsabilidad, superior al culposo o de negligencia, aunque se trate de un tipo de negligencia o culpa grave.

En cuanto a la responsabilidad profesional del personal concierne a los funcionarios considerados en general, o lo que es lo mismo, el personal al servicio de las Administraciones públicas, con lo que hay que excluir a las autoridades. Hay que considerar en este criterio los conocimientos, la cualificación o preparación del funcionario, con lo que la titulación exigida, su competencia técnica, cuando sean más elevadas, será mayor el grado de responsabilidad exigida. Supone faltas de tipo técnico o

\footnotetext{
${ }^{355}$ Lasarte, Carlos, La Responsabilidad Civil en el Ámbito de los Centros Docentes, pag 73 y ss.
} 
profesional de carácter inexcusable, inadmisibles, de carácter muy grave, con un desconocimiento profesional manifiesto.

Finalmente ha de existir una relación entre la conducta del funcionario y el hecho dañoso producido, es decir, un nexo causal, una relación causa a efecto. Este requisito es necesario para la exigencia de responsabilidad, de tal forma que si no se da, no se puede exigir responsabilidad al funcionario. Se hace necesario sobre todo para determinar el grado de participación del funcionario en la producción del hecho dañoso, sobre todo cuando se hallan varios sujetos involucrados, tales como la propia víctima, terceros ajenos a la Administración u otros funcionarios.

Por lo que se refiere a la indemnización es necesario que sea satisfecha en primer lugar por la Administración y después se podrá efectuar la acción de regreso contra el funcionario. Lo que no puede hacerse es que primero se exija la indemnización al funcionario y la Administración pagar después al perjudicado, por eso dice el artículo 145.2 LRJA y PAC “cuanto hubiere indemnizado directamente a los lesionados, podrá exigir de sus Autoridades y demás personal a su servicio...."

De otra parte, la indemnización que paga la Administración no tiene que coincidir con lo que después se reclama al funcionario, pues aquella responde de forma objetiva, mientras que la responsabilidad del funcionario es subjetiva. Para eso se tienen en cuenta los criterios de ponderación, los cuales sirven para moderar la indemnización del funcionario, aunque pueden darse casos muy graves en los que a un funcionario altamente cualificado, con una conducta dolosa, le sea exigible todo lo abonado por la Administración.

Si se da el caso de que la Administración ejerce funciones privadas desvinculadas del servicio público, no se sigue este procedimiento, sino que en ese caso, el personal a su servicio, por el artículo 146.I LRJA y PAC, será demandado en vía civil como cualquier particular, por el artículo 1902 del Código Civil. 


\subsubsection{PROCEDIMIENTO PARA LA ACCIÓN DE REGRESO EN LA ENSEÑANZA}

PÚBLICA.

Para la exigencia de responsabilidad del artículo 145 II a los profesores de la enseñanza pública hay que estar a lo que disponen los artículos 19 y 21 del Real Decreto n 429/1993, de 26 de marzo, BOE 106. En su artículo 19 ordena que los particulares exigirán directamente a la Administración pública las indemnizaciones por los daños que les haya causado su personal; así como que una vez satisfechas esas indemnizaciones a los perjudicados, podrá exigir al personal a su servicio la responsabilidad en que hubieran incurrido por dolo o culpa o negligencia grave.

La acción de regreso se exige de oficio una vez satisfecha la indemnización por parte de la Administración y que haya una persona física reconocida como causante del daño o lesión al particular.

El desarrollo del procedimiento se encuentra contemplado en el artículo 21 mencionado. En su apartado primero el órgano competente notificará el acuerdo de exigir responsabilidad a los interesados, indicándoles los motivos del mismo, tales como nombres de los implicados, hechos por los que se imputa la responsabilidad, daños que se han producido a los particulares, criterios de ponderación tenidos en cuenta, cuantía que se exige, todo ello además concediéndoles un plazo de 15 días para que puedan aportar los documentos, informes y pruebas que consideren convenientes en orden a su defensa.

Se exige, por su apartado segundo, un informe al servicio en cuyo funcionamiento se haya ocasionado la presunta lesión indemnizable.

Una vez aportadas las pruebas, según el apartado tercero, en el plazo de 15 días se practicarán cuantas pruebas hayan sido admitidas y cualesquiera otras que el órgano competente considere oportunas.

Al ser instruido el procedimiento, se pondrá de manifiesto al interesado la decisión de exigirle responsabilidad, concediéndole un plazo de 10 días para que formule las alegaciones que estime convenientes. Creo que no solamente se debe de conceder este plazo, sino además informarle al interesado de todo el proceso administrativo desde el principio para que no pueda alegar indefensión del artículo 24 de la C.E. 
Después de concluido el trámite de audiencia, la propuesta de resolución será formulada en el plazo máximo de cinco días. Una vez concluido éste, el órgano competente resolverá en otro plazo máximo de otros cinco días.

$\mathrm{El}$ acto resolutorio tiene carácter ejecutivo, por lo que a partir de ese momento la Administración puede exigir al funcionario el abono de la cantidad establecida. Para llevarlo a cabo puede descontar o retener de la nómina del empleado las cantidades mensuales necesarias hasta completar el total de la indemnización. Si se da el caso de que el funcionario se encontrara en otra Administración o fuera de cualquiera de ellas, se puede utilizar la vía de apremio para hacer efectiva la cantidad demandada.

En lo que se refiere al plazo para incoar el procedimiento de ejercicio de la acción de regreso la Ley 30/1992 no dice nada, ni tampoco el Código Civil, por ello la doctrina está dividida. Para unos autores sería el plazo de un año para exigir la responsabilidad civil, que se contempla en el artículo 1968 II CC. Otros por el contrario, entienden que el plazo debe ser de cinco años establecido en el artículo 40 LGP para la prescripción de los derechos de la Hacienda Pública, al tratarse de hacer efectivo el derecho de crédito que la Administración tiene frente al empleado público por acción de regreso. Finalmente se considera otro plazo de quince años del artículo 1964 del Código Civil. Éste último plazo creo que es demasiado dilatado, pues en tanto tiempo puede haberse jubilado o haber fallecido el funcionario, lo que daría lugar a una dificultad o imposibilidad del cobro, desnaturalizando esta acción de repetición o resarcimiento ${ }^{356}$.

\subsubsection{RESPONSABILIDAD DE LOS PROFESORES DE LA ENSEÑANZA} PÚBLICA EN LA JURISPRUDENCIA.

En la STS de 29 de junio de $2000^{357}$ se trata de una niña de cuatro años, perteneciente al Colegio Teodosio El Grande de Coca, Segovia, se cae a un pozo en una

\footnotetext{
${ }^{356}$ Reglero Campos, Fernando, op.cit, pags 290, 291, 498 y ss.

Ver igualmente Moreno Martínez, Juan Antonio, op.cit, pag 224 y ss.

Ver igualmente Moreno Martínez, Juan Antonio, La Responsabilidad Civil y su Problemática Actual, coordinados, Ed.

Dikinson S.L. Madrid 2007, pags 208 y ss.

357 STS de 29 de junio de 2000 (RJ-2000/5916)
} 
salida al campo como actividad complementaria, aprobada al hacerse el programa anual del curso. El accidente se produjo el día 12 de noviembre de 1990 al caerse a un pozo situado a siete metros del camino por el que transitaba el personal de la excursión, logrando los profesores rescatarla con vida, falleciendo dieciocho días después el día 30 siguiente.

Por su Fundamento de Derecho Tercero, se establece la responsabilidad directa del Ministerio de Educación y Ciencia por aplicación de lo dispuesto en el artículo 1903 CC, puesto que los padres delegan las funciones de control y vigilancia de los alumnos en el centro de enseñanza desde el momento en que los menores acceden al mismo hasta que se produce su salida ordenada, sin que conste alterada esta situación por la práctica de la salida complementaria que se llevaba a efecto como actividad escolar, siendo por tanto el Colegio Público "Teodosio el Grande" de Coca, del Ministerio de Educación y Ciencia, por medio de su personal, el que tenía exclusivamente a su cargo el deber tuitivo de vigilancia sobre el alumnado, concretado en los profesores referidos, que debían de ser más exquisitos sobre niños de tan corta edad, como la menor fallecida.

De su Fundamento de Derecho Quinto se comprueba que el grupo de 57 alumnos, es un grupo excesivamente numeroso en la relación alumno profesor, que conlleva a pensar en una falta de diligencia provisoria imputable tanto a los profesores, como a la dirección demandada del Colegio Público e, incluso al propio Consejo Escolar que la aprobaron. El hecho de la caída al pozo de la niña no fue visto ni constatado por ninguno de los tres profesores hasta que lo comunicó otra pequeña, lo que es revelador de que las medidas de control y atención a los niños previstos no eran suficientes o no eran desarrollados convenientemente, y en consecuencia es evidente que tal valoración de los hechos supone estimar como civilmente culposa la conducta de los tres demandados, sin perjuicio de su calidad humana y profesional evidenciada tras producirse el hecho. En el presente caso los profesores demandados no han conseguido acreditar que obraran con toda la diligencia exigible en la vigilancia o en la adopción de las medidas suficientes de control respecto de la menor fallecida, no existiendo, por lo demás, ninguna duda acerca de la relación de causa a efecto entre ambos (hecho lesivo y conducta de los demandados). 
El comentario de esta Sentencia es que el recurso del Abogado del Estado se desestima, resultando acción de responsabilidad contra la Administración y contra la aseguradora. La Administración podrá accionar por vía de regreso contra los profesores por no haber obrado con la diligencia debida al no darse cuenta de que dos niñas se habían desviado de la ruta, cayéndose una de ellas al pozo. De igual forma se puede exigir responsabilidad al Director y Consejo Escolar del Centro, por no nombrar más personal para la vigilancia en la excursión de salida al campo, tales como profesores o padres de alumnos con lo que quizás se hubiera podido evitar el desgraciado accidente. En todo caso si se lleva a cabo acción de regreso contra los profesores habrá que moderar la cuantía, pues a pesar de su falta de diligencia, lograron sacarla con vida del pozo y además no fueron ellos solos los que planificaron la organización de esa actividad complementaria.

La Sentencia de la Audiencia Provincial de Barcelona de 25 de febrero de 1999, trata de unos alumnos del colegio "Pau Casals" de Barcelona que llegan de excursión a la playa Ribes Roges, en Vilanova y la Geltrú, vigilados por tres profesores pertenecientes al Departament d'Ensenyament de la Generalitat de Catalunya, maestros y funcionarios de dicho departamento, tutores de tercero, cuarto y quinto de ese centro escolar.

Al llegar a la playa los niños y los profesores dejaron sus pertenencias en la playa, extendieron las toallas y entraron en el mar. Algunos de los menores no sabían nadar, los profesores conocían que Esmeralda S.A. de nueve años no sabía nadar y desconocían los tres con seguridad si Nicolas G.G igualmente de nueve años sí sabía o no nadar.

Después de haberse introducido los niños en el agua, Nicolás y Esmeralda se estaban bañando sin control alguno de los profesores y fueron rescatados del agua por personas ajenas a la excursión al observar los signos de socorro que realizaba la niña con las manos, y procedieron ya en la arena a intentar reanimar a ambos, auxiliados por miembros de la policía local de la población, sin que los profesores se apercibieran de lo sucedido, pues se presentaron cuando se desarrollaban los primeros auxilios a los dos niños. El cuerpo de Nicolás fue avistado cuando ya era zarandeado por las olas y falleció por causa de la asfixia sufrida por la inmersión en agua salada, sobre las doce de la mañana de dicho día. 
Esmeralda S.A se salvó tras ser reanimada y atendida primeramente en el Hospital Comarcal San Antoni Abat de Vilanova y la Geltrú, donde ingresó presentando síntomas de ahogamiento y paro cardiorrespiratorio, siendo posteriormente trasladada al Hospital Sant Joan de Deu en Barcelona.

Los representantes legales de Nicolás G.G renunciaron expresamente a las acciones civiles correspondientes por haber sido ya indemnizados por la Compañía C.D, habiendo renunciado a cualquier indemnización los padres de Esmeralda S.A.

Fundamento de Derecho Primero. Los hechos declarados probados constituyen legalmente un delito de homicidio imprudente, previsto y penado en el artículo 142.1 del Código penal.

En la planificación de la excursión se respetaron las normas de la Resolución 116-1996 de organización y funcionamiento de los centros docentes públicos de Cataluña de Educación Infantil y Primaria y de Educación Especial para el curso 1996/97, las cuales establecen el número de acompañantes, al menos dos, uno de ellos como mínimo maestro, que deben acompañar a los alumnos en las salidas fuera del centro.

Por la declaración de testigos adultos, que no tenían ningún tipo de relación con la excursión o el colegio, han manifestado que "el mar estaba muy fuerte", "no estaba para meterse", "el mar era muy malo, no para bañarse", a lo que añadieron que había resaca en el mar lo que comprobaron al introducirse en el agua para rescatar a los menores, por lo que se considera y se deduce de las declaraciones de los cinco testigos que el estado del mar no era el más adecuado para que los 57 niños vigilados por tres adultos se bañaran.

Otro aspecto a considerar es que tuvieron que intervenir terceras personas ajenas a la excursión, sin que se apercibieran los tres tutores encargados de su vigilancia de las labores de reanimación sobre los menores, presentándose en el lugar de los hechos cuando esas labores se habían iniciado bastante antes. De igual forma deberían de haber impedido bañarse al alumno que no sabía nadar, con mayor motivo por el mal estado del mar; además deberían haber averiguado si el otro alumno sabía nadar, cosa de la que no estaban seguros. 
Fundamento Segundo. Son responsables del mencionado delito los tres acusados por la participación directa y voluntaria que tuvieron en su ejecución, pues los tres actuaron conjuntamente sobre los 57 alumnos, aunque cada uno fuera tutor de cada uno de los cursos participantes en la actividad.

Fundamento Tercero. En la realización del expresado delito no han concurrido circunstancias modificativas de la responsabilidad criminal.

Fundamento Cuarto. En orden a la pena a imponer, se estima adecuada por el Tribunal la de un año de prisión, la mínima legalmente prevista, a la que se añadiría la accesoria correspondiente, tipo de pena ésta que es de imperativa imposición a tenor de lo dispuesto en el artículo 56 del Código penal, accesoria que ha sido expresamente pedida por la acusación en los términos que comúnmente se solicita y se impone, la de inhabilitación especial para el empleo, cargo público, profesión un oficio, si éstos tuvieran relación directa con el delito cometido. El Tribunal ha valorado la contradicción que supondría imponer tal accesoria si la circunstancia de que el delito fue calificado de homicidio imprudente, por culpa simple y no profesional, pues se trata de culpa del profesional, pero no de una culpa profesional que implique impericia o incapacidad técnica para el ejercicio de la profesión.

Fundamento Quinto. Toda persona responsable criminalmente de un delito o falta lo es también civilmente y de las costas, según disponen los artículos 116 y 123 del Código penal, imponiéndose a los acusados estas últimas en la proporción de un tercio a cada uno de ellos. Señalándose que no procede realizar declaración alguna sobre la responsabilidad civil al haber renunciado a ella por haber sido ya satisfecha.

En esta sentencia se aprecia culpa o negligencia grave de los tres monitores encargados del control y vigilancia sobre los menores, al no haber averiguado los menores que sabían nadar. No debieron permitir bañarse a unos niños de tan corta edad, dado el estado del mar en ese día, e incluso aunque el mar se hubiera encontrado en buen estado tampoco, sobre todo a aquellos que no sabían nadar. Para permitir meterse a unos niños de esa edad, deberían haberse asegurado de que eran capaces de nadar y con un mayor número de vigilantes. Es un caso claro de negligencia grave. 
No existe dolo, pues los profesores no tuvieron intención de causar daño a los menores. Lo que si se da es una dejación de la vigilancia al haber intervenido terceras personas, sin que ellos se apercibieran hasta bien avanzadas las labores de reanimación, lo que da lugar a culpa o negligencia grave.

La compañía de seguros ha indemnizado por la responsabilidad civil, pero al tratarse de culpa grave, puede accionar contra el titular del colegio, en este caso la Generalitat de Cataluña, la que a su vez puede utilizar la vía de regreso, repetición o resarcimiento que así se conoce esta acción, contra los profesores ${ }^{358}$.

${ }^{358}$ Muñoz Naranjo, Alfredo (1999), Responsabilidad Civil de los Centros Docentes, Ed. Praxis, Barcelona, pag 154 y ss 


\section{CAPITULO II: LA RESPONSABILIDAD DE LOS CENTROS DOCENTES.}

\section{LOS CENTROS DE ENSEÑANZA EN GENERAL.}

Al presente trabajo interesan los centros de enseñanza no superior, los cuales responden de los daños que ocasionen los menores que tengan a su cuidado. En el caso de que asistan mayores de edad, deben de responder ellos mismos, por no poder aplicarles las instituciones de protecciones de los menores. Puede darse el caso de mayores de edad que se encuentren física o psíquicamente disminuidos, para lo que habrá que tener en cuenta lo que disponga la sentencia de incapacitación. Si se da el caso de menores de edad emancipados legalmente o que lleven vida independiente, se asimilan a los mayores de edad de acuerdo con lo dispuesto en el artículo 323 del Código Civil.

Los centros de enseñanza superior disponen de un alumnado mayor de edad con plena capacidad de discernimiento por lo que no se les puede exigir responsabilidad, excepto por propia culpa del artículo 1902 CC o por daños ocasionados por su propio personal del artículo 1903 IV CC.

El régimen que ha de aplicarse a los menores de los centros de enseñanza no superior, es el Código Civil, Código Penal y la LORPM, distinguiendo los centros de enseñanza privada a la que se asimilan los concertados, de los centros de enseñanza pública que se rigen por las leyes de la responsabilidad patrimonial de la Administración.

\subsection{LOS CENTROS DE ENSEÑANZA PRIVADOS.}

\subsubsection{TITULARIDAD DEL CENTRO DOCENTE.}

En la Ley 1/1991, de siete de enero se modificó el sistema de exigencia de responsabilidad por los menores, pasando del profesor al titular del centro docente, que es quien tiene las facultades de organización. La Exposición de Motivos de la Ley dice 
que el régimen de responsabilidad que se establece para los profesores y maestros no se ajusta a la realidad social de nuestros días, por fundamentarse en la llamada "culpa in vigilando", por lo que traslada esa responsabilidad al titular del centro docente. No hay que confundir al director del colegio con el titular del centro docente, pues el director es un profesor más al que le son encomendadas las funciones directivas, pero depende del titular.

De acuerdo con el artículo 10 de la LODE ${ }^{359}$ dice: "Se entiende por titular de un centro docente a la persona física o jurídica que conste como tal en el registro a que se refiere el artículo 13 de esta Ley”. Este registro depende de la Administración educativa competente, su objeto es la inscripción de los centros educativos, de cuyos asientos registrales tiene que dar traslado al Ministerio de Educación y Ciencia en el plazo máximo de un mes. Son centros privados aquellos cuyo titular sea una persona física o jurídica de carácter privado (Art $\left.{ }^{\mathrm{o}} 10.2\right)$.

Los requisitos necesarios para la creación y dirección de centros docentes privados se hallan contemplados en el capítulo tercero de la Ley, donde en su artículo 21 se permite libertad para su creación, organización y dirección, con las limitaciones que imponen la Constitución y la propia Ley. Se requiere una autorización administrativa en la que se exigen unos requisitos mínimos tales como titulación académica del profesorado, relación numérica alumno-profesor, instalaciones docentes y deportivas, así como el número de puestos escolares ( $\left.\operatorname{art}^{\mathrm{o}} 14\right)$.

Los centros gozan de libertad para establecer su régimen interno, la selección del profesorado de acuerdo con la titulación exigida por la legislación vigente, el procedimiento para la admisión de alumnos, establecer las normas de convivencia y su régimen económico ( $\left.\operatorname{art}^{\mathrm{o}} 25\right)$. Pueden de igual forma establecer en sus reglamentos de régimen interior órganos a través de los cuales se participe en la comunidad educativa.

Se concede a los titulares de los centros amplia libertad de organización en las actividades que realizan, para después poderles exigir responsabilidades por los menores y no a los directores y jefes de estudios que pueden adoptar medidas de organización,

\footnotetext{
${ }^{359}$ Ley Orgánica 8/1985 de 3 de julio, BOE nº 159 de 4 de julio, reguladora del Derecho a la Educación.
} 
pero que lo hacen sobre la base de las directrices marcadas por el titular del centro de enseñanza ${ }^{360}$.

En cuanto a los centros concertados, son aquellos centros privados sostenidos con fondos públicos ( $\left.\operatorname{art}^{\mathrm{o}} 10\right)$, los cuales se tienen que ajustar a lo que dispone el título cuarto de la $\mathrm{LODE}^{361}$. Para ello tienen que formalizar con la Administración un concierto en el que se establecen los derechos y obligaciones recíprocas, en cuanto al régimen económico, duración prórroga, extinción, número de unidades escolares y demás condiciones necesarias para impartir la enseñanza.

La responsabilidad de estos centros se rige por el Código Civil, pues aunque el concierto escolar se trate de una aportación económica muy importante de la Administración, no se impone la misma responsabilidad civil que a los centros públicos. Esta responsabilidad de los centros concertados es por culpa, aunque cuasiobjetiva y desde luego tiene que realizarse ante la jurisdicción civil, reclamando sólo al centro de acuerdo con los apartados $4^{\circ}$ y $5^{\circ}$ del artículo 1903, sólo al profesor por el artículo 1902 , aunque lo más normal es que se reclame a ambos. Sólo puede responder la Administración si se retrasa en el pago del dinero del concierto para el mantenimiento de instalaciones y se produjera alguna lesión en la que se dé una relación de causa a efecto entre dichas instalaciones y lesión, lo que obligaría a indemnizar por el mal funcionamiento del servicio público ${ }^{362}$. Las sentencias de los tribunales sobre este tipo de colegios se han resuelto por el Código Civil, por ello los centros privados y concertados se asimilan los unos a los otros considerándose privados.

\subsubsection{RESPONSABILIDAD DEL TITULAR DEL CENTRO DOCENTE POR EL} ARTÍCULO 1903 IV.

El titular de un centro docente privado al tratarse de una persona física o jurídica de carácter privado es un empresario al que se le puede exigir responsabilidad por sus

\footnotetext{
360 Atienza Navarro, María Luisa, op.cit, pag 42.

${ }^{361}$ Se regula de igual forma por lo dispuesto en la Ley Orgánica de Educación LO 2/2006, de 3 de mayo, BOE nº 106 de 4 de mayo.

${ }^{362}$ Lasarte, Carlos, La Responsabilidad Civil en el Ambito de los Centros Docentes, op.cit. pags 59 y 60.
} 
auxiliares por culpa in vigilando o in eligendo. Algunas sentencias del Tribunal Supremo han llegado a afirmar que la responsabilidad del artículo 1903 IV es una responsabilidad objetiva, fundada en la responsabilidad por riesgo y en la culpa "in vigilando" o "in eligendo", que lleva consigo la obligación de reparar el daño prescindiendo de la culpabilidad del autor del mismo (STS de 9-10-2000 RJ 2000/9184), otros más recientes, en cambio, dicen que la responsabilidad de ese artículo no tiene carácter objetivo, sino que se funda en el principio culpabilístico inherente al vicio "in eligendo" o "in vigilando" respecto de las personas por quienes se debe responder, como la STS de 6-22009 (RJ-2009/1369).

Se dan dos modelos de responsabilidad del principal por los hechos de los auxiliares que son: el modelo de responsabilidad por culpa presunta y el de responsabilidad vicaria.

El sistema de culpa presunta es el seguido por nuestro Código Civil en el que responde por culpa "in vigilando" e "in eligendo", propios de la época de su redacción, en que las relaciones entre el principal y los auxiliares eran de tipo jerárquico o vertical en el que era más fácil el control sobre el auxiliar. En este sistema el principal escoge, controla e instruye a sus dependientes, lo que no es posible en los tiempos actuales, al haber cambiado la organización empresarial moderna, en la que las relaciones son menos jerárquicas, más horizontales, menos definidas. Para superar estas dificultades se ha recurrido a admitir la responsabilidad por riesgo en la que se considera el daño una consecuencia o efecto de la empresa. Ante este panorama la jurisprudencia a pesar de afirmar que esta responsabilidad no tiene carácter objetivo, sino que se funda en el principio culpabilistico, en el que se da una presunción de culpa que desaparece cuando se pruebe haber empleado toda la diligencia de un buen padre de familia para prevenir el daño; la realidad es que al principal o empresario le resulta difícil probarlo, con lo que se ha llegado a un régimen de responsabilidad "cuasiobjetiva".

En cuanto al régimen de responsabilidad vicaria, se trata de un sistema en el que se impone al principal una responsabilidad de carácter objetivo por el daño que causen negligentemente los auxiliares. Este régimen es el que más se emplea en los países de nuestro entorno y se trata de una responsabilidad por hecho ajeno al no depender la 
responsabilidad del principal de su propia conducta, sino de la de sus propios auxiliares que emplea para el funcionamiento de su empresa.

Los motivos de que se emplee este sistema en la mayor parte de los países son varios. Uno de ellos es por las dificultades que se dan en la moderna organización empresarial para que los empresarios puedan aportar pruebas para demostrar su diligencia en las funciones de dirección sobre sus empresas. Desde el punto de vista de la organización es el empresario el que se encuentra en mejor situación para el control de los auxiliares, los riesgos, la formación del personal, renovación de equipos técnicos y sancionar las conductas o comportamientos peligrosos. En el aspecto económico tiene el principal capacidad para hacer frente a las indemnizaciones repercutiendo el precio sobre los productos y pagar una sola póliza aseguradora para proteger a sus auxiliares. Finalmente en relación con los padres y guardadores por hechos dañosos de sus hijos y pupilos, el exigir al principal una mayor exigencia de responsabilidad se justifica por ser su actividad económica generadora de riesgos, lo hace en su propio interés para obtener lucro, algo que no se da en los padres y guardadores, los cuales no obtienen lucro, es por lo que les es permitido exonerarse de responsabilidad si obraron con la diligencia debida del artículo 1903 VI CC 363 .

\subsubsection{PRESUPUESTOS DE APLICACIÓN DEL ARTÍCULO 1903 IV}

Entre el principal y el auxiliar tiene que darse necesariamente una relación de dependencia o subordinación, de tal forma que el auxiliar reciba órdenes o instrucciones del principal o que éste mande sobre el auxiliar, supervisando o controlando sus actividades. Para verificar si el auxiliar se encuentra realmente subordinado al principal hay que determinar si éste puede elegir o no al auxiliar, es decir, si puede contratarle o despedirle; el control sobre las tareas encomendadas; si el principal se lucra o beneficia del trabajo del auxiliar, quién sufre el riesgo de las pérdidas, la propiedad de los equipos, etc. Estos factores son determinantes en el mundo moderno, en el que las empresas

\footnotetext{
${ }^{363}$ La Responsabilidad Extracontractual del Principal por hechos de sus Auxiliares, Solé Feliu Josep, prólogo de Ricardo de Angel Yagüez, Editorial Reus S.A. Madrid 2012, pags 23 y ss.

Ver igualmente Atienza Navarro, Maria Luisa, op.cit pag 127 y ss.
} 
contratan y subcontratan a otros, lo que hace difícil establecer esas relaciones de dependencia o subordinación.

Otro presupuesto es que la actuación dañosa del auxiliar se ha de desarrollar en el cumplimiento de sus funciones. Quiere ello decir que la actuación ha de darse en el ámbito interno de la empresa donde se desarrollan las actividades de que se trate, ya sea una empresa, un colegio, etc. Tiene que existir un nexo causal entre la actuación del auxiliar y las funciones que le fueron encomendadas. La responsabilidad del principal, depende en gran medida, del grado del nexo causal, si ha sido muy estrecho o no, pues si la culpa es manifiesta del auxiliar en que ha cometido una falta muy grave puede el principal quedar exonerado; si se trata de un cumplimiento erróneo o negligente del auxiliar, deberá de responder el principal; si por el contrario el nexo causal es muy débil se puede entender que el auxiliar ha actuado fuera del ámbito de las funciones de la empresa, por lo que el principal no podrá ser responsable.

Finalmente, no es necesario identificar al auxiliar concreto que ha cometido el daño, para ello es más que suficiente demostrar que el daño se produjo dentro de la empresa sin relacionar que auxiliar cometió el acto culposo, como por ejemplo si se produce en un colegio un hecho dañoso en el que se encuentran presentes varios profesores, sin que se pueda imputar a ninguno de ellos la responsabilidad en concreto, por ello responderán junto con el titular de forma solidaria, sin perjuicio de las relaciones posteriores entre todos ellos. El perjudicado podrá reclamar al titular del centro, o contra el auxiliar o contra ambos conjuntamente, pues los fundamentos de la responsabilidad de cada uno de ellos son autónomos e independientes, por lo que puede utilizar cualquier opción para obtener la responsabilidad solidaria de ellos ${ }^{364}$.

\subsubsection{EL ARTÍCULO 1903 IV EN EL DERECHO COMPARADO}

El artículo 1903 IV y VI de nuestro Código Civil trata del mismo modelo que sigue el artículo 55 del Código Suizo de las obligaciones (CO) y el artículo 831 del BGB alemán, entre ellos al producirse y probarse la culpa del auxiliar autor del daño, se

\footnotetext{
${ }^{364}$ Solé Feliu Josep, La Resp. Extracontractual, op.cit, pag 64 y ss.
} 
presume la culpa del principal excepto si logra demostrar que empleó la diligencia debida en las funciones de selección dirección y control sobre sus auxiliares. En Suiza se ha pasado del sistema de culpa presunta en el que se exige responsabilidad por culpa "in eligendo", "in instruendo" o "in custodiando" a otro sistema en el que la responsabilidad se exige "in organizando" o lo que es lo mismo por defecto organizativo (Organisation shaftung), en el que debe de probar que ha organizado correctamente su actividad empresarial, para evitar causar daños a terceros. En este caso de Suiza, se han endurecido las condiciones del artículo 55 Código de las Obligaciones, para que el perjudicado no quede sin indemnización y al principal le resulte muy difícil el demostrar que empleó la diligencia debida, con ello se pasa de un tipo de responsabilidad por culpa presunta a otro de responsabilidad vicaria, o lo que es lo mismo, a un sistema de responsabilidad por culpa a otro cuasi objetivo u objetivo. ${ }^{365}$

Los tribunales alemanes han seguido un sistema similar pasando de aplicar el artículo 831 BGB a utilizar el artículo 823 BGB, con ello consiguen eludir las limitaciones del artículo 831 BGB, exigiendo al empresario un nivel de diligencia mucho mayor, no permitiéndole descargar su responsabilidad sobre los auxiliares. De esta forma cuando no se cumplen los presupuestos del artículo 831 BGB o se dan grandes posibilidades de exoneración del empresario se recurre al artículo 823 BGB por culpa o negligencia en la organización (Organisations verschulden), para que el dueño del negocio o posibles titulares de centros docentes no puedan exonerarse ${ }^{366}$.

La jurisprudencia alemana, para evitar el artículo 831 BGB y conseguir un régimen de responsabilidad objetiva reduciendo o eliminando las posibilidades exoneratorias del principal, recurre a utilizar el artículo 31 BGB que trata de la responsabilidad objetiva de

\footnotetext{
365 Artículo 55 (1) Código de las Obligaciones Suizo: L’employeur est responsable du dommage causé per ses travailleurs o uses autres auxiliaires dans l'accomplissement de leur travail, s'il ne prouve qu'il a pris tous les soins commandés par les circonstances pour détouner un dommage de ce genre ou que sa diligence n’eût pas empéché le dommage de se produire”.

Artículo 55 (1) Código de las Obligaciones Suizo: “El empleador es responsable por la pérdida o daño causado por sus auxiliares o empleados en el desempeño de su trabajo a menos que pruebe que empleó la diligencia debida para prevenir el daño o que éste se hubiera producido igualmente con el empleo de la máxima diligencia”.

${ }^{366}$ La Responsabilidad Extracontractual, Sole Feliu, Josep, op cit, pag 22 y ss.

La Responsabilidad de Centros Docentes, Moreno Martínez, Juan Antonio, op cit, pag 131 y ss.
} 
las personas jurídicas por hechos de sus representantes ${ }^{367}$. Otro mecanismo que emplea la jurisprudencia alemana para conseguir esos fines contrarios al artículo 831 BGB, es el de hacer uso del artículo 278 BGB que trata de la responsabilidad del deudor por terceros, con lo que extiende a supuestos de responsabilidad extracontractual lo establecido en responsabilidad contractual del deudor por hechos de sus auxiliares; para ello impone al deudor un régimen de responsabilidad objetiva que le impide aportar pruebas sobre su diligencia empleada en la elección, dirección o control de los auxiliares empleados en el cumplimiento de sus obligaciones.

Para aplicar el artículo 278 a la responsabilidad extracontractual se han usado figuras jurídicas tales como el contrato a favor de terceros, responsabilidad precontractual o deberes accesorios a la prestación principal ${ }^{368}$. Finalmente, los tribunales alemanes han atribuido al auxiliar una acción de regreso o repetición frente al principal, por responsabilidad civil de daños frente a terceros, hasta en casos en que se haya desestimado la responsabilidad de dicho principal de acuerdo con el artículo 831 $\mathrm{BGB}^{369}$.

En los países europeos de nuestro entorno el modelo que siguen es el de responsabilidad vicaria del principal, en el que se da una responsabilidad objetiva del principal por los daños causados de forma negligente por sus auxiliares en el desempeño de sus obligaciones. Es un sistema o régimen de responsabilidad por hecho ajeno, en el que no se tiene en cuenta su propia conducta, sino de la conducta culposa del personal que tiene a su disposición para el desenvolvimiento de su empresa.

En el Código Civil francés se contempla en el artículo 1384 (5) que dice: "Los dueños y patrones lo son del daño causado por sus dependientes y encargados en el ejercicio de las funciones en que estén empleados" ${ }^{\$ 70}$. Vemos que trata de

\footnotetext{
${ }^{367}$ Artículo 31 BGB: "La asociación es responsable de los daños que causa el órgano de gobierno, un miembro del órgano de gobierno u otro representante especial conforme a los estatutos, en ejecución de las actividades que les corresponden, por una acción frente a un tercero que obliga al resarcimiento de los daños causados”.

${ }^{368}$ Artículo 278 BGB: "El deudor debe responder de la culpa de su representante legal y de las personas de que se sirve para el cumplimiento de sus obligaciones con la misma extensión que de la culpa propia”.

${ }^{369}$ La Responsabilidad, Solé Feliu, op.cit, pags 25 y ss.

${ }^{370}$ Artículo 1384 (5) Code Civile: "Les maitres et les commettants, du dommage causé par leurs domestiques et préposés dans les fonctions ausquelles ils les ont employés"
} 
responsabilidad objetiva y no habla para nada de la culpa de los dependientes. La misma responsabilidad objetiva se da en el artículo 500 del Código Civil portugués. El artículo 1315 ABGB austriaco contempla una responsabilidad objetiva del empresario por los daños causados a un tercero, cuando el auxiliar designado es incompetente o una persona peligrosa para desempeñar las funciones asignadas ${ }^{371}$. El artículo 2049 del Códice Civile italiano trata de la responsabilidad por otros que se exige al empresario y que es de carácter objetivo.

El derecho inglés exige responsabilidad vicaria al principal por el hecho dañoso del auxiliar. Para ello el demandante sólo necesita probar que el auxiliar cometió un daño (tort), que era auxiliar del principal y que el daño se cometió en el curso o con ocasión del trabajo efectuado en la empresa (in the course of the employment), lo que da lugar a la exigencia de responsabilidad del principal como si él mismo hubiera cometido el daño. El mismo sistema se sigue en los Estados Unidos de América, en el que se exige responsabilidad objetiva o vicaria al principal, por la conducta del auxiliar cuando éste haya actuado en el ámbito de sus funciones en la empresa. Desde las primeras décadas del siglo XX se impuso este sistema en Estados Unidos para evitar las injusticias que se cometían con los empleados al endosárseles siempre la culpa a ellos (tort of negligence), la concurrencia de culpa de la víctima (contributory negligence), el sistema en cuestión se denomina responsabilidad empresarial (Enterprise liability) y consiste en un régimen de responsabilidad objetiva del empresario ajeno a la culpa por los daños de los trabajadores en accidentes laborales complementándolo todo ello con un seguro obligatorio. Su justificación se encuentra en que el empresario que obtiene beneficios de una determinada actividad debe de soportar los riesgos que de ella se puedan derivar, así como el encontrarse en mejor situación para hacer frente a los costes que origina su actividad y que abarcan la responsabilidad civil. De igual forma se considera que el empresario puede redistribuir los riesgos que origina su actividad mediante contratos de seguro o repercutiéndolo sobre el precio de los productos que fabrica ${ }^{372}$.

\footnotetext{
${ }^{371}$ Art $^{\mathrm{o}} 1315$ AGBG: "Uberhaup haftel derjenige, welcher sich einer untüchtigen oder wissentlich einer gefährlichen Person zur Besorgung seiner Angelegenheiten bedient, fur den Schaden, den sie in dieser Eigenschaft einem Dritten zufügt”.

${ }^{372}$ La Responsabilidad..... Solé Feliu, op cit, pag 31, 155 y ss.
} 


\subsubsection{EL ARTÍ́CULO 1903 IV EN EL DERECHO EUROPEO DE LA}

RESPONSABILIDAD CIVIL (PETL)

En los países de nuestro entorno el principal responde de forma vicaria frente a terceros por el daño causado por sus auxiliares en el ejercicio de sus funciones. Los Principios del Derecho Europeo de la Responsabilidad Civil (PETL) elaborados por el Grupo Europeo del Derecho de la Responsabilidad Civil (EGTL) se inclinan por la responsabilidad vicaria como modelo de responsabilidad por los auxiliares, por lo que dispone en su artículo 6:102 (1): “Una persona responde por el daño causado por sus auxiliares en el ejercicio de sus funciones siempre que éstos hayan violado el estándar de conducta exigible".

La mayoría de los ordenamientos sujetan a las personas jurídicas a la responsabilidad vicaria por los hechos cometidos por sus órganos, representantes y auxiliares. En ellos no se admiten causas de exoneración, al tratarse de una responsabilidad por los auxiliares responde la empresa con carácter objetivo. Se distingue entre sus órganos y representantes, de los auxiliares. En el caso de sus órganos y representantes es una responsabilidad originaria de la empresa como persona jurídica resulta directamente imputada. Si es el auxiliar el que comete el acto dañoso es un caso claro de responsabilidad por otro.

El uso del término auxiliar ha de entenderse en sentido amplio por lo que no se refiere sólo al mundo de los negocios sino también al ámbito doméstico lo que da lugar a que pueda ser tanto un empleado como cualquier persona que actúa con ánimo de ayudar y bajo la supervisión del demandado, en casos tales como echar una mano, ya sea de forma gratuita o no, trabajos de ayuda entre vecinos o de profesiones afines.

Se exige en la relación que el auxiliar se encuentre subordinado al principal o demandado, de tal forma que se halle integrado en la organización de la empresa, así como que lleve a cabo las tareas bajo la supervisión o control de aquel y no es necesario 
identificar al empleado que individualmente haya actuado, sino que basta con llegar a establecer que era parte del personal al servicio del empleador.

$\mathrm{El}$ auxiliar ha de actuar en el ejercicio de las funciones o en el desempeño de su empleo o servicio, lo que presupone que tiene que existir un nexo entre el empleo y el acto de que se trate. El mal uso del puesto de trabajo no es razón suficiente para que quede fuera del ejercicio de sus funciones. Lo difícil en estos casos está en determinar el grado de conexión entre la conducta del auxiliar que causó el daño y las tareas que le fueron asignadas, variando de unos ordenamientos a otros; desde el que considera esencial que el auxiliar haya actuado dentro del ámbito de las funciones, aunque las haya ejecutado mal, hasta otros muy rigurosos en que infrinja una prohibición o incumpla una orden del principal, queda fuera del ámbito de las funciones e impide la responsabilidad de dicho principal.

La responsabilidad vicaria por hechos de los auxiliares es compatible con un régimen de responsabilidad por culpa presunta para los padres y guardadores en relación con los daños causados por sus hijos menores o pupilos, como dispone el artículo 6:101 PETL; "La persona que tiene a su cargo otra persona que es menor o sufre discapacidad psíquica responde por el daño causado por esa otra persona a menos que demuestre que ella misma cumplió con el estándar de conducta que le era exigible en su supervisión". Este tipo de responsabilidad para los padres y guardadores se justifica en que tener hijos y cuidar personas discapacitadas constituye un gran beneficio para la sociedad, que debe de ser favorecido con un régimen cuasi-objetivo en el que permita la exoneración de responsabilidad cuando hubieran empleado la diligencia debida, por ello al ser los padres los que mejor pueden controlar a sus hijos no se debe imponer sobre ellos una carga demasiado pesada; de la misma forma hay que decir sobre los guardadores de incapaces. El cuidar a menores o incapacitados no reporta beneficios, es más una actividad de entrega a los demás que de recibir algo, por ello se justifica el asignar a estas personas un régimen de responsabilidad por culpa presunta que resulte menos rígido que el de responsabilidad vicaria, aplicado al principal o empresario, pues éste tiene como finalidad de sus actividades la obtención de lucro en su propio interés. Por otra parte el empresario puede repercutir sobre los precios de los productos las indemnizaciones o las 
primas de seguros, cosa que no pueden hacer los padres y guardadores. Finalmente, un empresario puede desvincularse de su auxiliar despidiéndole o no renovándole el contrato lo que no les es posible a los padres y guardadores, por todo ello no se da analogía entre padres y empresarios en cuanto al modelo de responsabilidad a exigir.

La responsabilidad empresarial se contempla en el artículo 4:202 (1) en el que dice: "La persona que se dedica de modo permanente a una actividad empresarial con fines económicos o profesionales y que emplea auxiliares o equipamiento técnico es responsable de todo daño causado por un defecto de tal empresa o de lo que en ella se produzca, a no ser que pruebe que ha cumplido con el estándar de conducta exigible". En estos Principios la responsabilidad de la empresa no es una responsabilidad objetiva, así lo ha manifestado el Grupo PETL, en que propone un régimen de culpa con inversión de la carga de la prueba. El perjudicado sólo necesita probar que la causa del daño se encuentra inmersa en el ámbito interno de la empresa, que es un defecto suyo, lo que da lugar a que sea ella la que demuestre que empleó la diligencia debida para prevenir el daño, o lo que es lo mismo, que observó el estándar de conducta exigible.

Esta responsabilidad del artículo 4:202 no implica que el auxiliar haya tenido que hacer algo mal y sea responsable, pues puede darse el caso de que haya producido un daño, sin haber violado el estándar de conducta exigible y resultar la empresa declarada responsable por no disponer de una adecuada organización que hubiera podido evitar esos daños.

La empresa no tiene por qué perseguir lucro, aunque si lo obtiene, es un dato muy significativo para que su actividad sea considerada como empresarial. Lo que se tiene en cuenta es que su actividad aunque no sea demasiado compleja tiene que implicar necesariamente una mínima organización del trabajo o de los recursos técnicos.

Por lo que se refiere al equipamiento técnico, se trata de material diverso, desde utillaje de lo más simple, hasta maquinaria cara y compleja, pasando por ordenadores. Pensemos por ejemplo en un colegio privado de formación profesional, donde se empieza a estudiar varios oficios desde lo más elemental hasta conseguir conocimientos de formación profesional de grado superior, para lo que se precisará equipos costosos, numerosos y diversos. 
El principal y el auxiliar pueden en ocasiones ser obligados a responder de forma solidaria ante la víctima, por ello el artículo 9:101 apartado 1,C dice: "Una persona es responsable por el daño causado por un auxiliar en circunstancias tales que también el auxiliar es responsable". En este apartado se refiere al aspecto externo de la relación entre los causantes del daño y la víctima que tiene que ser indemnizada. Si el daño es indivisible lo causan todos los involucrados en dicho daño, sin perjuicio de que después de haber indemnizado se pueda entre ellos hacer soportar a cada uno de ellos únicamente una parte de la pérdida. No se puede regular con detalle esta cuestión cuando el daño es indivisible, por lo que lo habrán de resolver los tribunales caso por caso.

En cuanto a las relaciones internas entre los causantes del daño se contempla en el artículo 9:102 (1) el cual dispone: "La persona sujeta a responsabilidad solidaria tiene derecho de regreso frente a cualquier otra persona que sea responsable ante la víctima por el mismo daño...". Los causantes solidarios pueden llamarse entre sí para distribuir la responsabilidad final entre ellos de acuerdo con su responsabilidad relativa. Puede darse el caso de que exista contrato entre los dos causantes que prevea la distribución de responsabilidad en caso de reclamación de un tercero, cuyas cláusulas deberán ser legales, pues si son abusivas habrán de tenerse por no puestas. Para distribuir la responsabilidad relativa será el tribunal el que lo haga, utilizando su amplio poder y atendiendo caso por caso $^{373}$.

\subsubsection{EL ARTÍCULO 1903 IV EN LA JURISPRUDENCIA.}

El artículo 1903 IV no ha cambiado de redacción desde que fue promulgado el Código Civil por ello no le ha afectado la reforma de la Ley 1/1991 de 7 de enero. Esta reforma se hizo para no transferir toda la responsabilidad derivada de los hechos dañosos cometidos por los alumnos menores de edad, estudiantes de los centros de

\footnotetext{
373 -Principios de Derecho Europeo de la Responsabilidad Civil, Martín Casals, Miguel, op cit.

- Responsabilidad Extracontractual del Principal.....Sole, Feliu Joseph.
} 
enseñanza no universitarios, sobre los profesores de los mismos. Lo que sí se ha modificado ha sido el artículo 1904 añadiendo un nuevo apartado en el que se dice que los titulares de centros docentes de enseñanza no superior podrán exigir de los profesores las cantidades satisfechas, si hubieren incurrido en dolo o culpa grave en el ejercicio de sus funciones que fuesen causa del daño. Para incluir la responsabilidad en el artículo 1903 IV CC supone que se trata de una responsabilidad del empresario, en el que éste responde por sus dependientes, en nuestro caso los profesores; mientras que si se incluye en el artículo 1903 V CC pueden intervenir el titular, el profesor y el $\operatorname{alumno}^{374}$.

Hay que tener en cuenta que si se incluye el supuesto de la responsabilidad en el artículo 1903 IV CC, el titular del centro docente podrá ejercer la responsabilidad por vía de regreso por cualquier grado de culpa del profesor de acuerdo con el artículo $1904.1^{\circ}$. Por el contrario si se incluye en el artículo $1903 \mathrm{~V}$ el derecho de regreso se reduce a los casos de dolo o culpa grave del profesor que se contempla en el artículo 1904.2

La jurisprudencia sobre el artículo 1903 IV es escasa y trata de culpa "in vigilando" o "in eligendo" de la entidad ya sea pública o privada y la culpa "in vigilando" del profesor o profesores de dicha entidad.

La STS de 29 de noviembre de $1998^{375}$ trata de una fiesta de fin de curso en un colegio en que se lanzaron globos al aire desde el patio del colegio, para lo que era necesario rellenarlos con una bombona de alcohol, con tan mala fortuna que al manipularse uno de ellos se inflamó el alcohol produciendo quemaduras graves a una niña dejándole secuelas.

Como consecuencia de ello los padres de la niña interpusieron demanda de responsabilidad civil extracontractual contra la Directora del Colegio, contra una compañía de seguros, contra la Asociación de Padres de Alumnos y contra el titular del centro docente.

En su Fundamento de Derecho Segundo el Tribunal Supremo desestimó el recurso del titular del centro docente por entender que a pesar de que debía aplicarse la

\footnotetext{
${ }^{374}$ Atienza Navarro. M ${ }^{\mathrm{a}}$ Luisa, La Resp. Op.cit, pag 81

${ }^{375}$ STS de 29 de noviembre de 1998 (RJ-1998/9980)
} 
normativa anterior a Ley 1/1991, “en la época actual cuando el alumno es confiado a un establecimiento propiedad de una persona jurídica, es ésta como director del establecimiento el que responde del acto de alguna de las personas físicas enseñantes". Su Fundamento de Derecho Cuarto, en su apartado primero el titular trata de denunciar la infracción del artículo 1105 CC por no ser aplicado para considerarlo caso fortuito y así exonerarse de responsabilidad por ruptura del nexo causal. Pero es desestimado, pues para apreciar la existencia del caso fortuito es necesario probarlo, lo que no ocurre en este caso y además no cabe en casación variar los elementos fácticos declarados en la sentencia de instancia.

El Tribunal Supremo estimó que la directora actuó de forma negligente al permitir el uso de globos con alcohol, por tratarse de una materia inflamable, en presencia de niños de corta edad, todo ello en un patio con una gran afluencia de personal al tratarse de una fiesta de fin de curso.

Esta conducta negligente de la directora es motivo suficiente para imputar la responsabilidad al titular del centro docente.

La STS de 3 de julio de $1998^{376}$ contempla el caso de un niño autista al que el director de su colegio manda que lleve una balda metálica la cual desequilibra la deambulación y se lesiona el ojo por el golpe contra dicha balda.

Su Fundamento de Derecho Primero describe el historial médico del menor, así como las características del colegio "Belvis de la Jara", donde se encuentra internado el menor Francisco Javier Z.M. El centro está destinado al internamiento de subnormales profundos en el que no se intenta que los internos aprueben asignaturas o aprendan un oficio ya que su nivel no lo permite por desgracia. Al tratarse de menores discapacitados el centro les asigna unos trabajos muy elementales para mantener su salud básica y mejoras psicológicas, con terapia de juegos y actividades muy sencillas para tratar de obtener un nivel de convivencia y sociabilidad bastante limitado, por lo que los trabajos que realizan tienen por objeto mantenerles ocupados.

El niño perjudicado tiene una edad de veintidós años, autista y con oligofrenia profunda, crónica e irreversible, es capaz de conocer a contadas personas sin posibilidad

\footnotetext{
376 Sentencia del Tribunal Supremo de fecha 3 de julio de 1998 (RJ/1998/5411)
} 
de hablar y valerse para las necesidades vitales propias. Ha tenido tendencia a autolesionarse durante años, habiendo perdido la visión total del ojo derecho a los once años de edad por autolesión. A los diecisiete años ingresó en el colegio, donde siguió tratamiento resultándole favorable, pues, perdió la tendencia a autoagresión.

El Juzgado había estimado la demanda por culpa extracontractual, al considerar probada la culpa, el daño y el nexo causal, pero la Audiencia por las circunstancias psíquicas y sociales de los alumnos y la preparación de los profesores, no cabe aplicar la inversión de la carga de la prueba, por ello no encuentra concatenación fáctica o relación causal entre el traslado del objeto y las gravísimas lesiones, que ni los peritos dieron explicación científica alguna que permitiera establecer el nexo causal.

En su Fundamento de Derecho Cuarto la Sala del Tribunal Supremo entiende que hubo nexo causal entre la caída y la lesión en el ojo, con la pérdida de visión del mismo, por atrofia del nervio ocular. No se puede negar que hubo traumatismo producido por la balda, que aunque no tenga elementos punzantes que puedan alcanzar el nervio óptico, sí que pueden las esquinas producir graves lesiones por el propio golpe sin necesidad de que se produzcan desgarros. Aunque la herida sólo se produjo en el párpado, para lo que requirió sutura, lo que sí es seguro es que produjo la atrofia del nervio óptico, lo que explicaría el que los facultativos no observasen la anormalidad o lesión del nervio óptico. De todo lo anterior se deduce que la culpa es del titular del centro docente por culpa "in eligendo" o "in vigilando", pues el director nunca debió mandar al niño autista que llevara la balda, al tratarse de un elemento potencialmente peligroso, que si en una persona normal no representa peligro, sí lo es en otra que anda de forma desequilibrada y con visión en un solo ojo. Podía haberle encargado otros cometidos inocuos para tenerle ocupado. No existe dolo por parte del director, pues no hay intención de dañar al interno, lo que sí puede considerarse que existe es falta de diligencia por su parte, pues el hecho podría haberse evitado si no se le hubiera hecho transportar la balda metálica. En estos casos la responsabilidad es de carácter objetivo o cuasi-objetivo, pues para exonerarse por el artículo 1903 VI, es necesario demostrar que se empleó la diligencia de un buen padre de familia para prevenir el daño, lo que no se da en el presente caso, y 
más tratándose de personas con muy escasa capacidad de discernimiento lo que obliga a redoblar o intensificar el cuidado y vigilancia sobre estos internos.

Por todo ello dice la Sentencia: "estimado el motivo, constando la culpa y el nexo causal, la responsabilidad por hecho ajeno, del párrafo $4^{\circ}$ del artículo 1903 del CC, abarca a la "Asociación de Padres de Niños Autistas", por "culpa in eligendo" o "in vigilando", al ser don Hipólito V.H. dependiente jerárquico suyo, siendo tal responsabilidad de matiz marcadamente objetiva. En cuanto a la indemnización, ponderando todas las circunstancias expuestas a través de esta sentencia, estima esta Sala que procede establecer una pensión vitalicia mensual a favor de Francisco Javier Z.M. de 100.000 pts, a satisfacer solidariamente por los demandados, entendiéndose que en dicha cantidad va incluido el daño moral para todos los perjudicados".

Al declarar la responsabilidad solidaria ambos demandados deberán hacer frente a la misma. El titular del centro "Asociación de Padres Autistas" como empresario que responde por sus dependientes debe de hacerse cargo de las pérdidas, de igual forma que cuando haya beneficios. El otro demandado es Hipólito V.H. dependiente jerárquico de dicha asociación en calidad de director. Entre ambos se dan unas relaciones internas en las que los dos tienen que efectuar los pagos de la pensión vitalicia, de tal forma que si uno no paga deberá de hacerlo el otro, quedándole a éste una acción de regreso contra el no pagador.

Otra S.T.S, ya tratada anteriormente en el Capítulo Primero sobre la responsabilidad de los profesores es la de 31 de octubre de $1998^{377}$, en ella un menor de cuatro años y medio, fue agredido en un parque zoológico al que el colegio realizaba una visita de sus alumnos, cuyas agresiones del león le produjeron secuelas que afectarán al menor durante toda su vida por la deformidad que le ocasionaron, con dificultad de integración social y laboral.

En su Fundamento de Derecho Segundo se dice que la responsabilidad concurrente de la dirección del colegio ha sido delimitada penalmente. De ello se infiere que la responsabilidad civil extracontractual deriva de un delito tipificado penalmente, lo que resulta indiferente para la exigencia de la responsabilidad civil que corresponda.

\footnotetext{
${ }^{377}$ Sentencia del Tribunal Supremo de 31 de octubre de 1998 (RJ-1998/8359)
} 
El titular del centro docente que es la Orden Menor de Frailes Franciscanos de Cartagena ha incurrido en responsabilidad civil extracontractual por culpa "in vigilando" e "in eligendo" por lo que tiene que hacer frente a la indemnización, de acuerdo con el artículo 1903 IV del Código Civil. Se trata de una responsabilidad directa por sus dependientes, en este caso los profesores, que no vigilaron correctamente al menor al que dejaron solo en el parque cuando ocurrió el accidente. La falta de vigilancia que da lugar al hecho dañoso es antijurídica, es decir contraria a derecho. El colegio ha cometido culpa "in eligendo" por la actuación de los profesores. Existe un nexo causal evidente entre la conducta de los profesores por falta "in vigilando" y el resultado lesivo. Entre los profesores y el titular del centro docente se da una relación jerárquica de dependencia, por hallarse encuadrados en la plantilla del mismo, condición necesaria para la exigencia de responsabilidades. Una vez que el titular indemnice a los padres del menor le queda la acción de regreso contra los profesores, como parte de las relaciones internas entre ellos.

En la STS de 10 de marzo de $1997^{378}$ se da la exoneración del titular del centro docente y del profesor al tratarse de un caso fortuito al resultar imposible prever la conducta dañosa del menor. Los hechos tratan de la niña Maria Flor RC, de seis años de edad, alumna del Colegio Nebrija, fue agredida en una clase de dibujo por el menor Israel IC con un lápiz o bolígrafo en el ojo izquierdo produciéndole graves lesiones y secuelas permanentes.

El motivo del recurso es tratar de exonerar de responsabilidad al centro y a la profesora del hecho dañoso producido, lo que es lógico en este caso por la rapidez con que se produjeron los hechos con alumnos de muy corta edad. No es posible imputar negligencia a la profesora que daba la clase de dibujo doña María Pilar F.I, ni por tanto al colegio, que dispuso de una alumna mayor en prácticas para reforzar la vigilancia de los escolares en la clase de dibujo, lo que pone de manifiesto por parte de la profesora y el centro el haber obrado con la diligencia debida ante alumnos de corta edad para prevenir el daño. Por ello en su Fundamento de Derecho Segundo de la sentencia dice: "Por mucho que se extreme la vigilancia de los alumnos de una clase, no puede alcanzar a

\footnotetext{
${ }^{378}$ Sentencia Tribunal Supremo de 10 de marzo de 1997 (RJ-1997/2483)
} 
prever que en un momento dado uno de ellos lance a otro un lapicero con tan mala fortuna. Falta pues claramente el nexo o enlace preciso que debe existir entre el hecho de que el accidente se haya podido producir en el ámbito colegial y que ya por este sólo hecho haya de presumirse la culpabilidad del profesorado y la responsabilidad del colegio".

En su Fundamento de Derecho Cuarto, la sentencia dice que la responsabilidad culposa extracontractual que se imputa al colegio demandado ha de regirse por lo dispuesto en el párrafo cuarto del artículo 1903 del Código Civil y, en cualquier caso, siempre sería aplicable el último párrafo del precitado artículo que exonera de responsabilidad a los que probasen que emplearon toda la diligencia de un buen padre de familia para prevenir el daño. Esta diligencia se pone de manifiesto al encontrarse la profesora presente en la clase en el momento de los hechos de los que le informaron inmediatamente después y además por la presencia de una alumna mayor en prácticas para reforzar la vigilancia de los escolares.

Por su Fundamento de Derecho Quinto, la sentencia establece que: “ El hecho tuvo que acontecer de manera rápida e inopinada, así como difícilmente previsible dentro de un orden cotidiano o normal, y reveladora también de la imposibilidad de imputar a la profesora y a su vez al colegio una indiciaria conducta negligente sin la cual no es dable primar la presunción culposa del artículo 1903 del Código Civil, con la correlativa exigencia de probar el empleo de toda la diligencia de un buen padre de familia". En consecuencia, no se puede exigir responsabilidad extracontractual ni a la profesora, ni tampoco al Centro, por el artículo 1903 CC, al tratarse de un hecho imprevisible, lo que constituye en mi opinión un caso fortuito del artículo 1105 CC.

Otra sentencia de caso fortuito es la de 8 de marzo de $1999^{379}$ en la que un menor de diez años de edad se cayó en un local de su colegio cuando jugaba a juegos normales, con niños de su edad, fracturándose la pierna derecha en el tercio proximal del fémur, habiéndole quedado un acortamiento del fémur de dos centímetros y medio.

En su Fundamento de Derecho Tercero se dice que: "es previsible que un niño pueda caerse, mas lamentablemente no siempre puede evitarse, pues, para ello sería

\footnotetext{
${ }^{379}$ Sentencia del Tribunal Supremo de 8 de marzo de 1999 (RJ/1999/2249)
} 
necesario no sólo su cuidado, sino que se le coartara toda libertad de movimientos". El accidente no se ha producido por la existencia de instrumentos o elementos peligrosos o que entrañen riesgos para la integridad física, sólo había niños jugando y el juego fue el causante del accidente, sin la concurrencia de ningún factor que pueda evidenciar una falta de diligencia por parte de los profesores o cuidadores.

En su Fundamento de Derecho Cuarto, los recurrentes argumentan que existe infracción de los artículos 1902 y 1903 del Código Civil, sosteniendo que por la inversión de la carga de la prueba, así como de la presunción de culpa en el agente, han de conducir a considerar negligente la conducta de los cuidadores, al no haber adoptado las debidas precauciones para evitar la caída del menor.

El motivo es desestimado a pesar de ello y de la teoría del riesgo, de tal modo que si de los hechos se deduce que no hubo ninguna culpa, ha de ser excluida la responsabilidad de los cuidadores, por ello dice la sentencia: "siendo éste el supuesto litigioso aquí contemplado, en el que aparece probado, y así lo declara la sentencia recurrida, que la caída del menor lesionado (de diez años de edad) se produjo única y exclusivamente como consecuencia de los juegos (normales en chicos de esa edad) con sus compañeros, durante el recreo en el colegio, sin intervención de ningún otro factor extraño o peligroso, que pudiera evidenciar la falta de la debida vigilancia por parte de sus cuidadores, cuya caída en tales circunstancias ha de ser conceptuada necesariamente como un evidente caso fortuito".

En la sentencia se aprecia que aunque los demandantes traten de involucrar a los cuidadores no les es posible, por tratarse de una caída del menor en que no ha mediado ningún agente externo, es una caída simple en un juego inocuo. Para evitar la caída habría que impedir el juego al niño, lo que impediría su correcto desarrollo, así como su libertad, vulnerando la legislación nacional e internacional en la que se exige plena libertad en el desarrollo de los menores. Al no existir culpa de los cuidadores no se les puede aplicar el artículo 1903 IV al titular del centro docente ni por tanto a los profesores a él subordinados. A pesar de las tendencias objetivadoras de la responsabilidad extracontractual y de la inversión de la carga de la prueba, de la responsabilidad por riesgo y demás, siempre en la responsabilidad por culpa queda 
alguna posibilidad de exonerarse cuando se empleó la diligencia debida a un buen padre de familia contemplada en el artículo 1903 VI, o no hubo ninguna responsabilidad del cuidador, por todo ello, este caso es fortuito del artículo 1105 CC y queda sin indemnización a los padres del menor por parte de la compañía de seguros.

A los titulares de centros docentes como se puede apreciar en estas sentencias, no se les puede exigir una responsabilidad totalmente objetiva por los daños causados por los alumnos, a ello ha contribuido la Ley I/1991. Aunque se exija responsabilidad por riesgo de empresa en los centros privados a los profesores de acuerdo con el artículo 1903 IV, no se puede decir lo mismo de un alumno que no es personal dependiente de la estructura empresarial, no es un empleado, es la razón de ser de la institución educativa de la cual se beneficia. Por todo ello el titular del centro docente se puede exonerar de responsabilidad cuando no tenga culpa por tratarse de un caso fortuito.

\subsubsection{RESPONSABILIDAD DEL TITULAR DEL CENTRO DOCENTE POR EL} ARTÍCULO $1903 \mathrm{~V}$.

\subsubsection{GENERALIDADES}

El artículo $1903 \mathrm{~V}$ se refiere a los daños causados por los alumnos menores de edad durante el tiempo en que los mismos se hallen bajo el control o vigilancia del profesorado del centro. En este artículo pueden intervenir con conductas negligentes el profesor, el titular del centro docente y el alumno, siendo éste el más relevante por causar directamente el hecho dañoso.

Este artículo fue modificado por la Ley 1/1991 en cuya Exposición de Motivos dice: "El régimen de responsabilidad para los profesores y maestros no se ajusta a la realidad social de nuestros días. Se trata de normas en la llamada "culpa in vigilando" concebidas en momentos en que existía una relación de sujeción del alumno al profesor, en términos que hoy no se producen en el discurrir diario de la vida docente". De ello se deduce que el legislador no desea que se tenga en cuenta ese tipo de culpa a la hora de exigir la responsabilidad. Pero después al redactar de nuevo el artículo sí que hace referencia al "control o vigilancia del profesorado del Centro, desarrollando actividades 
escolares o extraescolares y complementarias", lo que se contradice con la Exposición de Motivos, de donde parece deducirse que el titular del centro responde por los daños causados por los alumnos que no han sido controlados y vigilados de forma satisfactoria por los profesores. El último párrafo del artículo 1903 permite al titular exonerarse de responsabilidad si prueba que empleó la diligencia de un buen padre de familia para prevenir el daño ${ }^{380}$.

Si el profesor ha actuado con dolo o negligencia grave, el titular del centro, cuando haya indemnizado al perjudicado, puede exigirle por vía de regreso las cantidades satisfechas, de acuerdo con el artículo 1904 II.

La reforma de la Ley 1/1991 ha dado lugar a que la doctrina se encuentre dividida entre quienes consideran que la responsabilidad del titular del Centro docente del artículo $1903 \mathrm{~V}$ es subjetiva y los que la consideran de carácter objetivo.

La mayoría de los autores consideran que la responsabilidad del artículo $1903 \mathrm{~V}$ es de carácter subjetivo y en él caben dos hipótesis diferentes: los supuestos en que a la causación de un daño por el alumno ha contribuido la conducta negligente de un profesor y aquellos en que los profesores no han obrado con culpa, mientras que la causa indirecta del daño ha sido por defectos de organización.

\footnotetext{
${ }^{380}$ El artículo 1903 en lo relativo a la responsabilidad de los centros de enseñanza, su apartado IV, sobre los dueños o directores de un establecimiento o empresa respecto de los perjuicios causados por sus dependientes, no ha cambiado desde la publicación del Código Civil. Lo mismo puede decirse de su apartado VI, sobre la exoneración de las personas mencionadas en dicho artículo.
}

Los que sí han cambiado, han sido los apartados 5 y 6 de la redacción anterior a la Ley 1/1991, quedando un solo apartado, el V actual.

-Apartados 5 y 6 anteriores a la Ley 1/1991

*5) "El Estado es responsable en este concepto cuando obra por mediación de un agente especial; pero no cuando el daño hubiese sido causado por el funcionario a quien propiamente corresponda la gestión practicada, en cuyo caso será aplicable lo dispuesto en el artículo anterior”.

*6) “Son por último, responsables los maestros o directores de artes y oficios respecto a los perjuicios causados por sus alumnos o aprendices, mientras permanezcan bajo su custodia”.

- Apartado V actual: "Las personas o entidades que sean titulares de un Centro docente de enseñanza no superior responderán por los daños y perjuicios que causen sus alumnos menores de edad durante los periodos de tiempo en que los mismos se hallen bajo el control o vigilancia del profesorado del Centro, desarrollando actividades escolares o extraescolares y complementarias”. 
Para el caso en que la negligencia del profesor contribuya a la causación de un daño por el alumno, tienen que darse además una culpa "in vigilando" o "in eligendo" por parte del titular del centro, por la elección y control del profesorado, al ser el profesor un empleado suyo. El titular puede exonerarse si demuestra que empleó toda la diligencia de un buen padre de familia para prevenir el daño. Si se da el comportamiento negligente de un profesor, al titular le será muy difícil, por no decir imposible, el exonerarse.

Cuando se da una responsabilidad por hecho ajeno en sentido estricto, hay un acto dañoso del que su autor es responsable directo del artículo 1902 CC, que se extiende o transmite a la persona llamada a responder por él. Ahora bien, si se responde por una culpa propia del daño causado directamente por otra persona, no se tiene en cuenta o no es necesaria la culpa del artículo 1902 CC para la exigencia de responsabilidad, es suficiente demostrar que hubo negligencia en la prevención y evitación del daño por parte del causante del mismo.

En cuanto a la responsabilidad del empresario por los actos dañosos de sus dependientes, si el mencionado empresario responde por culpa propia es suficiente que el hecho del dependiente sea consecuencia de una conducta objetivamente negligente o intencional con capacidad de entender o de querer. Si la responsabilidad es por hecho ajeno, se hace necesario que el empleado obre con una conducta dolosa o culposa y que ésta se extienda o transmita al empresario.

Para que se aplique el artículo 1903 V CC, es necesario que la conducta del alumno haya sido objetivamente negligente o intencional, de lo contrario habría que aplicar el artículo 1903 IV, cuando hubiera negligencia en el profesor y no en el alumno. El titular del centro docente puede responder por los hechos dañosos de los alumnos cuando se trate de culpa de la organización, pues si ésta es deficiente, bastará con demostrar que existe nexo causal entre esa deficiencia y el daño producido, para aplicar el artículo 1903 V CC. Este es uno de los resultados positivos de la Reforma de 1991 al modificar ese apartado, de tal forma que la responsabilidad se traspasa al titular del centro docente, pues, gran parte de los hechos dañosos de los alumnos se producen por 
defectos organizativos, de los que el profesor no tiene culpa y antes de dicha Reforma, se imputaba a los profesores tanto por esos defectos como por casos fortuitos.

De acuerdo con el artículo 1903 VI, el titular del centro docente puede exonerarse de responsabilidad cuando demuestre que empleó toda la diligencia de un buen padre de familia para evitar el daño. Por ello si se demuestra que el hecho dañoso no ha sido por negligencia de la organización, ni a ello ha contribuido la culpa de algún profesor, el titular del centro quedará exonerado, como por ejemplo, en la STS de 8 de marzo de 1999, ya citada anteriormente, en la que un menor se cayó en un juego inocuo, fracturándose una pierna, "en el que no intervino absolutamente ninguna culpa por parte de aquellos a quienes se les imputa, sino que el mismo fue debido exclusivamente a un imprevisible acaecimiento de caso fortuito, ha de excluirse la responsabilidad de dichos agentes o de la entidad que los tiene asegurados". Este argumento de la diligencia de un buen padre de familia del 1903 VI es el más sólido para que la doctrina de forma mayoritaria, considere que se da una responsabilidad de carácter subjetivo, permitiendo la exoneración de las distintas partes implicadas ${ }^{381}$.

Aunque la mayoría de la doctrina considere la responsabilidad del titular del centro docente de carácter subjetivo, existe otro sector que defiende esa responsabilidad como objetiva.

Su argumento se basa en contemplar la actividad educativa de los centros privados como una explotación empresarial de la que se obtienen unos beneficios económicos de los que se pueden derivar unos perjuicios que tienen que asumir al tratarse de una responsabilidad por riesgo. El problema que surge al aplicar este argumento es que se dan centros docentes privados con fines lucrativos y otros no, lo que ha dado lugar a distinguir entre aquellos centros que pueden considerarse una empresa esencialmente privada que trata de obtener lucro, pudiendo repercutir las pérdidas en los precios de su enseñanza, así como en la contratación de seguros, de aquellos centros como los concertados que no tienen finalidad lucrativa, con precios fijos, en que no pueden contratar seguros ni socializar los costes.

\footnotetext{
${ }^{381}$ Atienza Navarro, M ${ }^{\mathrm{a}}$ Luisa, La responsabilidad, op.cit, pag 62 y ss.

Ver igualmente Moreno Martínez, Resp. Centros docentes, op.cit, pag 126 y ss
} 
Para solucionar el problema de la responsabilidad objetiva en los centro que no tienen fin lucrativo como los concertados, la solución es autorizar la subida de los precios y en caso de no autorizarse, habrá que proponer a los padres y tutores que contraten un seguro para hacer frente a los gastos que puedan originar esos posibles hechos dañosos de los menores. Un autor que ha defendido el criterio del riesgo empresarial ha sido Zelaya Echegaray, para todos los centros docentes, fundamentándolo en una socialización del riesgo. Este autor al considerar la responsabilidad objetiva o estricta para la aplicación del artículo $1903 \mathrm{~V}$, prescinde de los otros criterios posibles de culpa in procurando en la organización, in vigilando o in eligendo, ni la culpa in vigilando del profesor que se transmite o extiende de forma vicaria al titular del centro, lo que hace es emplear el más objetivo, que es el criterio del riesgo.

Zelaya Echegaray defiende en contra de la doctrina mayoritaria que la reforma de la Ley I/1991 ha supuesto un cambio fundamental al haber introducido un sistema de los más modernos en el derecho de daños, consistente en desplazar el centro de imputación de la responsabilidad desde el profesor hacia el titular del centro escolar, que debe de responder objetivamente socializando el riesgo como garantía del desarrollo de la actividad educativa, la cual comporta unos riesgos inevitables, inherentes a la misma. Considera la reforma muy positiva por estar en la misma tendencia que se da en el derecho extranjero. Otro autor en la misma línea es Tauler Romero que mantiene la necesidad de que el titular del centro docente debe resarcir los daños causados por los alumnos basándose en el criterio objetivo del riesgo empresarial.

Estos dos autores a pesar de sus argumentos coherentes para la exigencia de una responsabilidad objetiva al titular del centro docente por el artículo $1903 \mathrm{~V}$, al encontrarse vigente el párrafo VI del mencionado artículo, se admite prueba en contrario, por ello no se puede considerar esa responsabilidad totalmente objetiva, siempre podrá en determinados casos exonerado el titular, dándose una responsabilidad cuasi objetiva. Para que esa responsabilidad fuera totalmente objetiva, sería necesario que el legislador suprimiera el párrafo VI del artículo $1903^{382}$.

\footnotetext{
${ }^{382}$ Atienza Navarro, Ma Luisa, La Resp..... op.cit, pag 85 y ss.
} 


\subsubsection{RESPONSABILIDAD DEL TITULAR DEL CENTRO DOCENTE POR LA} LORPM.

Para exigir responsabilidad civil de acuerdo con la LORPM es necesario que el menor tenga una edad comprendida entre catorce y dieciocho años, los hechos sean tipificados penalmente y el perjudicado no se haya reservado las acciones civiles.

Si los hechos cometidos por un menor de edad generadores de responsabilidad civil son típicos penalmente, pero el perjudicado se reserva las acciones civiles, su régimen jurídico será el previsto en los artículos 1903 y ss CC.

Cuando los hechos cometidos por menores sean tipificados penalmente y estos menores tengan una edad inferior a catorce años, quedarán sometidos al CC.

En el caso de que los hechos cometidos por un menor de edad no se encuentren tipificados penalmente su régimen jurídico será el previsto en los artículos 1903 y ss $\mathrm{CC}^{383}$.

De acuerdo con el artículo 19 del Código Penal los menores de dieciocho años no serán responsables conforme a las reglas del Código Penal, sino conforme a la LORPM por su Disposición Final séptima.

El legislador al redactar la LORPM reguló una responsabilidad que ya se encontraba regulada en el artículo 1903 CC y no tuvo en cuenta lo que dispone el último de sus párrafos. El artículo 61.3 LORPM hace que los padres, tutores, acogedores y guardadores respondan por los hechos dañosos de los menores de catorce a dieciocho años de forma objetiva, si el hecho es tipificado penalmente en el Código Penal como delito o falta. Pero por otra parte responden de forma subjetiva, por el artículo 1903 CC, si el menor es de edad inferior a catorce años o el hecho dañoso no está tipificado penalmente, lo que constituye una contradicción y una duplicidad del derecho de daños por responsabilidad extracontractual que se podía haber corregido en la Ley I/1991.

\footnotetext{
${ }^{383}$ De la Rosa Cortina, Jose Miguel, op cit, pags 28 y 29.
} 
En la LORPM no se hace referencia a la posibilidad de condenar como responsable civil al centro docente en que el menor cometió el hecho dañoso tipificado como delito o falta. Ello ha dado lugar a que tanto la doctrina como la jurisprudencia se encuentren divididas sobre ello.

Existen varios procedimientos para exigir responsabilidad al centro docente, aunque no se contemple de forma expresa en el artículo 61.3 LORPM.

Uno de ellos consiste en aplicar de manera supletoria el Código Penal en su artículo $120.3^{384}$ para los centros privados o del artículo 121 si fuera de titularidad pública ${ }^{385}$, con lo que se haría responder de forma subsidiaria a los titulares del centro docente.

Otro procedimiento consiste en considerar al centro docente como guardador de hecho que contempla el artículo 61.3 de la LORPM, pues cuando los padres que tienen la guarda sobre sus hijos, los llevan al colegio, a partir de ese momento el colegio es el que se convierte en el guardador sobre ellos.

Finalmente, se puede aplicar de forma supletoria el artículo 1903 V CC en el proceso penal de menores, empleando el artículo 4.3 que contempla la posibilidad de aplicación en materias regidas por otras leyes.

\subsection{FISCALÍA GENERAL DEL ESTADO}

La Instrucción 10/2005 de la Fiscalía General del Estado sobre el tratamiento del acoso escolar considera que se puede accionar contra el centro docente en el proceso

\footnotetext{
${ }^{384}$ Art $^{\circ}$ 120.3 CP: "Las personas naturales o jurídicas en los casos de delitos o faltas cometidos en los establecimientos de que sean titulares, cuando por parte de quienes los dirijan o administren, o de sus dependientes o empleados, se hayan infringido los reglamentos de policía o las disposiciones de la autoridad que estén relacionados con el hecho punible cometido, de modo que éste no se hubiera producido sin dicha infracción”.

${ }^{385} \mathrm{Art}^{\circ} 121 \mathrm{CP}$ : "El Estado, la Comunidad Autónoma, la provincia, la isla, el municipio y demás entes públicos, según los casos, responden subsidiariamente de los daños causados por los penalmente responsables de los delitos dolosos o culposos, cuando estos sean autoridad, agentes y contratados de la misma o funcionarios públicos en el ejercicio de sus cargos o funciones siempre que la lesión sea consecuencia directa del funcionamiento de los servicios públicos que les estuvieren confiados...”

"Si se exigiera en el procedimiento penal la responsabilidad civil de la autoridad, agentes y contratados de la misma o funcionarios públicos, la pretensión deberá dirigirse simultáneamente contra la administración o ente público presuntamente responsable civil subsidiario"
} 
penal de menores, dejando libertad para elegir el tipo de fundamentación, ya sea por el Código Penal como dispone la Disposición Final Primera de la LORPM; el artículo 1903 V CC, mediante la cláusula de supletoriedad del $\operatorname{art}^{\circ} 4.3$ CC; o interpretando el artículo 61.3 LORPM en el sentido de considerar guardador al centro docente, al tener la guarda del menor durante el tiempo de las actividades escolares, extraescolares y complementarias.

\subsection{JURISPRUDENCIA}

Los centros docentes y profesores son responsables comprendidos en el artículo 61.3 LORPM, dentro de los guardadores de hecho por tener la guarda sobre los menores durante el tiempo que éstos se encuentran en los centros. Para ello el concepto de guardador de hecho ha de interpretarse en sentido amplio para poder incluir a centros y profesores. De los debates parlamentarios se deduce que el legislador ha querido incluir dentro de los guardadores de hecho a los centros docentes y profesores por ser la figura jurídica más próxima, que tiene una mayor afinidad para poder equipararse. El artículo 61.4 contempla la aplicación del artículo 145 de la Ley 30/1992 para la exigencia de responsabilidad civil a los titulares de centros educativos públicos, pues al ser transferidas las funciones educativas a las Comunidades Autónomas, serán éstas a través de su Consejería de Educación las titulares de sus centros de enseñanza ${ }^{386}$.

Para exigir responsabilidad al centro docente y a los profesores, hay que tener en consideración que al profesor sólo se le podrá exigir cuando hubiere actuado con dolo o negligencia grave, en caso contrario será el titular del centro docente el que responda. Ello es consecuencia de la Ley 1/1991 por la que se transfiere la responsabilidad del profesor al titular del centro cuando no se diera esa culpa por dolo o negligencia grave.

A los padres se les puede exigir responsabilidad por los hechos dañosos de sus hijos cuando éstos se encuentran bajo la guarda del colegio de acuerdo con el artículo 61.3 de

\footnotetext{
386 - López Sánchez, Cristina, La Responsabilidad Civil del Menor, op.cit, pags 422 y ss.

- Ver igualmente, Atienza Navarro, Ma Luisa, La Resp., op cit, pags 153 y ss.

- Peña López, Fernando, La Culpabilidad en la Responsabilidad Civil Extracontractual. Editorial COMARES, Granada 2002, pag 167 y ss.
} 
la LORPM y ello se hace por culpa “in educando", tratándose en general de peleas entre menores que reflejan una defectuosa educación por parte de sus padres a los que incumbe inculcarles tolerancia ante los demás, reprimir sus instintos violentos y asumir valores que hagan soportable la vida en sociedad. Tiene que darse un nexo de causalidad entre la conducta observada por el menor al producir el hecho dañoso y la defectuosa educación recibida por sus padres. Una Sentencia apropiada al caso es la de la AP de Pontevedra de 22 de febrero de $2011^{387}$, donde en su Fundamento de Derecho Primero dice que "el que el menor se encontrara cuando cometió la agresión contra otro menor en el centro escolar no excluye sin más a los padres de la responsabilidad que establece el artículo 61 de la LORPM". Sobre el orden de prelación dice: "una interpretación apriorística del precepto transcrito concluiría que el sistema de responsabilidad civil que establece es solidario, pero con un orden de prelación que cabrá calificar de excluyente”. No obstante, frente a tal interpretación formal del precepto, cabe otra de naturaleza material, pues tratándose de una responsabilidad solidaria, con un orden de asunción de responsabilidades, lo relevante no sería tanto la prelación establecida cuanto las efectivas facultades que los diversos responsables tuvieran atribuidas y ejercidas sobre el menor en el momento de acaecer los hechos que determinen su responsabilidad". Esto quiere decir que no se tiene que seguir el orden del artículo 61.3 sino que hay que analizar caso por caso para ver el haz de facultades que cada uno tiene sobre el menor, pues aunque en el momento de los hechos el colegio tiene la guarda son los padres los que tienen la responsabilidad por la patria potestad que tienen sobre su hijo, que no tiene el colegio.

La LORPM al ser una Ley que contempla una responsabilidad objetiva en la que sólo se permite una moderación en las personas responsables cuando no se haya dado dolo o negligencia grave, tiene como fines asegurar la indemnización a la víctima y además implicar a los padres y otros responsables en la socialización de los menores, pues los padres en este caso tienen que asumir la responsabilidad sobre los menores, sin hacer dejación de la misma, pues la tienen y muy grande sobre ellos.

En su Fundamento de Derecho Segundo dice: “Así pues el que los hechos sucedieran estando el menor expedientado en el colegio, no implica que el colegio

\footnotetext{
${ }^{387}$ S.A.P de Pontevedra de 22 de febrero de 2011 (JUR 2011/158 640).
} 
agotara el ejercicio de todas las funciones de vigilancia y control sobre aquél. Los padres encomiendan su custodia temporal al Colegio durante el tiempo en que el menor permanece en sus dependencias pero son aquellos los que ostentan la patria potestad y en esas funciones actúan sobre la formación y educación del menor dentro del seno de la familia, con potencialidad para incidir en su comportamiento en el exterior. En definitiva no se justifica la absolución y exclusión de responsabilidad de los padres del menor expedientado". Por ello no excluye a los padres, sino que les hace responsables junto con el menor, sin responsabilizar al titular del centro docente a pesar de que ningún profesor vigilase a los alumnos.

La no vigilancia a los alumnos es irrelevante, por no poder prevenirlo un profesor, pues es difícil entre muchos alumnos evitar que uno le propine un rodillazo a otro en el rostro, además de tratarse de menores cercanos a la mayoría de edad, con un grado de discernimiento considerable. De lo que se trata en el presente caso es de que el origen de la responsabilidad se establece por una deficiente educación del menor, en el ámbito familiar, al no haberle reprimido sus instintos violentos, cuya misión es propia de los progenitores, cosa que si lo hubieran hecho no se habría producido el hecho dañoso; de lo que se deduce que existe un nexo causal entre la deficiente educación recibida de sus padres y la agresión sobre el otro menor.

$\mathrm{Al}$ encontrarse la jurisprudencia y la doctrina divididas sobre la inclusión de los centros docentes en el artículo 61.3 LORPM, la jurisprudencia unas veces los incluye y otras no. Entre las que los incluye puede citarse la Sentencia de la Audiencia Provincial de Asturias de 26 de junio de $2008^{388}$, en la que se trata de unos menores en régimen de acogida bajo la custodia de la Diputación Foral de Vizcaya, que se hallaban de excursión en Llanes, uno de cuyos menores cometió un delito de lesiones el día 25 de junio de 2005 en la mencionada excursión.

En su Fundamento de Derecho Tercero se hace responsable solidario junto con el menor frente a la víctima a la Diputación Foral de Vizcaya como Administración demandada, sin que se permita moderación alguna. La Diputación Foral tiene como obligación en este caso "in custodiando" e "in vigilando" sobre el menor, a la que le

\footnotetext{
${ }^{388}$ Sentencia de la Audiencia Provincial de Asturias de 26 de junio de 2008 (JUR-2008/354.816)
} 
corresponde acreditar que ha observado las precauciones adecuadas para impedir el hecho dañoso, lo que no ha conseguido probar de ningún modo en su deber de vigilancia sobre el menor. Por otra parte el día de autos cuando se produjeron los hechos el menor no estaba bajo la vigilancia de los monitores como era su obligación, pues habían dejado a los menores libres por una zona de disco bares en Llanes, sin que ellos conocieran dicha localidad, lo que constituye una manifiesta transgresión de los deberes "in vigilando", al dejar solos a unos menores de edad en esa zona de bares, propensa a posibles riñas y altercados, lo que supone falta de diligencia, excluyéndose por ello toda moderación.

Otra sentencia favorable a la inclusión de los centros docentes en el artículo 61.3 LORPM es la Sentencia de la Audiencia Provincial de Málaga de 9 de noviembre de $2009^{389}$, en ella se contempla el caso de un menor que produjo lesiones a otro en el tiempo de recreo, teniendo que intervenir un profesor para evitar daños mayores.

En su Fundamento de Derecho Segundo el titular del Centro Docente, en este caso la Junta de Andalucía, recurre la sentencia basándose en que el orden de prelación del artículo 61.3 empieza por los padres, mientras que ella se puede encontrar comprendida en los acogedores que ocupan el tercer lugar o entre los guardadores legales o de hecho que ocupan el último lugar, por lo que habiendo padres que tengan la patria potestad serán ellos los responsables junto con el menor. El Juez no lo considera así, pues entiende que deben responder quienes tienen el control y vigilancia sobre el menor en el momento de producirse los hechos y como consecuencia de ello desestima ese motivo.

En su Fundamento de Derecho Cuarto, la Junta de Andalucía y la representación y defensa del menor solicitan la reducción o moderación de la cuantía de la indemnización del artículo 61.3 LORPM.

El Juez considera que no debe moderarse o reducirse la responsabilidad de los recurrentes pues en el Centro docente no se dan unas normas rígidas de disciplina, ni tampoco garantiza la integridad física de sus alumnos. Se deduce del informe del Equipo Técnico que el menor en cuestión no acataba la autoridad de sus padres, ni de los

\footnotetext{
${ }^{389}$ Sentencia de la Audiencia Provincial de Málaga de 9 de noviembre de 2009 (JUR-2010/211336)
} 
profesores, no cumplía las normas escolares, tenía enfrentamientos con los profesores y sus propios compañeros, lo que dio lugar a que fuera expulsado del centro en varias ocasiones. De todo ello se deduce que se trataba de un menor bastante conflictivo del que se podían esperar reacciones violentas imprevistas, que precisaban redoblar la vigilancia sobre él, por eso dice la Sentencia: "Esta situación, que entrañaba un mayor peligro de descontrol en el menor, no fue debidamente detectado y valorado por el Centro (ni por sus padres) de modo que en el momento de producirse los hechos no consta que se hubieran adoptado las suficientes medidas tendentes a paliar esa peligrosidad y/o a someter a una mayor vigilancia al menor para evitar actos agresivos del mismo que, como hemos visto, eran perfectamente previsibles". En mi opinión se da una relación causa a efecto entre la pasividad del personal docente y sus padres y el hecho dañoso cometido por el menor, que de haber observado un mayor control, educación y vigilancia sobre el mismo, los hechos pudieron haberse evitado. Por esos motivos el Juez desestima el recurso y no permite la reducción o moderación.

Una sentencia contraria a la inclusión de los centros docentes en el artículo 61.3 LORPM es la Sentencia de la Audiencia Provincial de Cáceres de 6 de julio de $2011^{390}$ que trataba de las agresiones sufridas por un menor de doce años, por un grupo de seis menores, de los que cinco eran de edad inferior a catorce años y por ello excluidos de esta Jurisdicción, los cuales dieron al menor Alesis, collejas, empujones, puñetazos y patadas, en uno de los pasillos del centro, teniendo que intervenir un profesor del mismo centro para dispersarlos.

En su Fundamento de Derecho Primero la parte recurrente insta la revocación parcial de la resolución impugnada basándose en infracción del artículo 1903.5 Código Civil, por entender que el responsable es el Centro docente donde ocurrieron los hechos y no los padres del menor.

El Juez no lo entiende así y condena al menor junto con sus padres, considerando que no se debe aplicar el artículo 1903.V del Código Civil, por ello dice en su Fundamento de Derecho Tercero que: "Respecto a la aplicación al caso de autos del artículo 1903 V Código Civil, conviene reseñar que la parte recurrente olvida que nos

\footnotetext{
${ }^{390}$ Sentencia de la Audiencia Provincial de Cáceres de 6 de julio de 2011 (JUR-2011/287100)
} 
encontramos ante un ámbito especial, la responsabilidad penal del menor, con una normativa específica de aplicación que regula todas las cuestiones relativas a la responsabilidad civil, por lo que es esa normativa y no la citada, norma de aplicación general, la que debe aplicarse al caso enjuiciado. Sentado lo anterior, procede desestimar el recurso interpuesto por cuanto el artículo 61.3 LORPM, precepto que establece un orden de prelación en cuanto a quién debe responder en caso de responsabilidad civil del menor de dieciocho años, es nítido al establecer que responderán los progenitores del menor, tal como acaece en el asunto que nos ocupa".

Se puede observar en esta sentencia que el Juez da prioridad a la norma específica que es la LORPM, frente a la de aplicación general del artículo 1903 V del Código Civil. Y por otra parte al aplicar el artículo 61.3 LORPM se fija en el orden de prelación existente en dicha norma y no en el criterio de quién tiene las facultades de guarda y vigilancia sobre los menores en el momento de producirse el hecho dañoso, como la hacían en las anteriores sentencias.

\subsubsection{DILIGENCIA EXIGIBLE A LOS TITULARES DE CENTROS DOCENTES} PRIVADOS.

El titular del centro docente privado queda exonerado si prueba que empleó toda la diligencia de un buen padre de familia para prevenir el daño, como establece el artículo 1903 VI del CC. Por otra parte, la responsabilidad del profesorado a partir de la Ley 1/1991 se ha traspasado a los titulares del centro docente, de tal forma que sólo se les puede exigir responsabilidad si obran con dolo o negligencia grave, para lo que será necesario emplear la vía de regreso.

La diligencia exigible al titular del centro docente ha de referirse a la elección y control del profesorado, infraestructuras y medios necesarios para desarrollar la actividad educativa, así como las medidas organizativas adoptadas en relación con todos esos medios humanos y materiales de que dispone. Lo relativo a vigilancia y control de los alumnos queda reservado o se asigna a los profesores, por hallarse directamente relacionados, pues muy raramente un titular del centro docente va a tener encomendadas funciones de vigilancia y control sobre los alumnos. 
El grado de diligencia evoluciona con los tiempos, el delimitar que es lo que se considera previsible o no depende de los límites que sean utilizados. En épocas pasadas se atendía a ejercer un control rígido sobre los menores, exigiéndoles mayor disciplina con frecuente aplicación de castigos; mientras que en los tiempos actuales se da una mayor libertad e iniciativa al alumno para de esta forma tenga un desarrollo correcto de la personalidad tal y como dispone la legislación nacional e internacional sobre la materia. Por ello no se deben limitar actividades de los centros docentes para evitar riesgos y no tener que indemnizar a los perjudicados, pues daría lugar a coartar las actividades y el desarrollo de los menores.

En los centros de enseñanza privados, a los que se asimilan los concertados, la exigencia de responsabilidad es subjetiva, aunque cada vez más objetivada, por ello los centros son responsables de los daños causados por sus alumnos menores de edad por culpa o negligencia de dichos centros, pudiendo exonerarse si demuestran que observaron la diligencia de un buen padre de familia. Se tiende en general a exigir mayor diligencia al centro docente, hasta llegar a la culpa in organizando con el fin de que la víctima no quede sin indemnización en virtud del principio "pro damnato".

Para valorar la diligencia del titular del centro docente, es necesario analizar las circunstancias en que se ha producido el hecho dañoso, ya sean subjetivas (edad, conflictividad del menor, etc) u objetivas (tipo de actividad, instrumentos utilizados, u otras), por ello analizaremos por separado para una mayor claridad de la exposición, las más comunes, así como su comparación con la jurisprudencia de los países de nuestro entorno.

\subsection{EDAD, CARÁCTER Y PERSONALIDAD DEL ALUMNO.}

La edad del alumno es de la máxima importancia a la hora de determinar la diligencia exigible al centro. Si se trata de menores de muy corta edad la vigilancia ha de ser muy intensa y continuada al ser unos menores que tienen muy poca capacidad de discernimiento, sin poder valorar el alcance de sus actos. Cuando se trate de menores próximos a la mayoría de edad la vigilancia y control sobre ellos ha de ser mucho menor, pues tienen un grado de discernimiento muy parecido al de una persona adulta, además 
de que las tendencias pedagógicas actuales exigen un importante grado de autonomía para el desarrollo de su personalidad. Puede decirse que a menor edad mayor control y vigilancia sobre el menor, así como una disminución de esa vigilancia a medida que la edad aumenta.

Si se trata de alumnos mayores de edad que están incapacitados o que no pueden gobernarse por sí mismos se consideran incluidos en los centros docentes, aunque se trate de centros especiales para discapacitados, siendo necesario para establecer la exigencia de responsabilidad sobre esos mayores incapacitados estar a lo que disponga la sentencia de incapacitación.

Para el caso de un menor legalmente emancipado o que lleve vida independiente se asimila a los mayores de edad de acuerdo con el artículo 323 CC, por ello responderán ellos personalmente de los daños que causen, quedando exonerado el centro docente. Puede darse el caso de que el alumno sea mayor de edad y se encuentre repitiendo curso, en cuyo caso al ser mayor de edad responderá él mismo, pues ya no le amparan las instituciones tutelares de menores.

Una sentencia ilustrativa sobre la vigilancia sobre los menores de corta edad es la STS de 31 de octubre de 1998 (RJ- 1998/8359), en ella se contempla el caso de un colegio que realiza una visita a un parque zoológico, donde un niño de cuatro años fue atacado por un león produciéndole heridas graves que le dejaron secuelas, al que dejaron solo los profesores del centro. Ello indica que los profesores incurrieron en responsabilidad por no aumentar o intensificar la vigilancia sobre los menores en un lugar con fieras expuestas, tratándose de niños de muy corta edad; además de tratarse de una excursión, pues en visitas a museos, excursiones y demás es obligatorio redoblar el cuidado sobre los menores.

Con respecto al carácter y personalidad del alumno, los padres deben informar al colegio cuando se trate de un menor con personalidad inestable para que los profesores incrementen la vigilancia sobre él a fin de evitar hechos dañosos. De igual forma se debe redoblar esa vigilancia cuando el menor sea reincidente en su mal comportamiento o con problemas de capacidad como es el caso de la STS de 15 de diciembre de 1994 (RJ1994/9421) en la que trata de un menor de diez años que se ausenta del colegio en 
compañía de otros dos menores y se fueron a unas obras cercanas en las que se subieron a un montacargas quedando atrapado al accionarse el mismo a consecuencia de lo cual falleció. El menor se había ausentado del colegio que era de internos, pero él estaba de mediopensionista por lo que se ausentaba para comer en su casa. El colegio fue condenado por no vigilar correctamente al menor, ya que se ausentaba antes de tiempo y en reiteradas ocasiones, lo que pone de manifiesto que no fue vigilado por el personal docente, el cual debería de ver que los mediopensionistas cumplían el horario. Además dicho menor tenía carencias y deficiencias mentales, una razón más para redoblar la vigilancia sobre él.

En el Derecho francés se aprecian sentencias como la del Tribunal de Dijon de 26 de junio de 1912, en la que se declaró la responsabilidad del profesor, al entender que el lanzamiento de piedras de un alumno a la víctima habría sido realizado precedentemente en varias ocasiones, por lo que el Tribunal declaró que el accidente no puede calificarse de imprevisible, lo que concuerda con la de los maestros. Otra Sentencia es la del Tribunal de Versalles de 17 de septiembre de 1996, en la que un niño de una escuela maternal se aprecia que los docentes no prestaban ninguna atención a que los menores jugaban con arena desde hacía tiempo, lo que dio lugar a responsabilidad del Estado por causar el accidente de un niño de tres años.

\subsection{ACTIVIDADES DEPORTIVAS}

Las actividades deportivas son potencialmente generadoras de accidentes de diversos tipos, ello implica que el profesor de deportes tiene que vigilar atentamente a los alumnos para evitarlos. Existen juegos que por su naturaleza no son peligrosos, en ellos el profesor ha de vigilarlos con una vigilancia normal; mientras que si se efectúan juegos más violentos como puede ser el rugby, salto de un trampolín u otros parecidos el profesor tiene que redoblar la vigilancia sobre los alumnos para evitar accidentes, así como adoptar todas las precauciones necesarias para evitarlos, tales como colchonetas, lonas, implicar a más personal para vigilarlos de tal forma que se disminuyan los peligros, 
pues hay actividades deportivas que no son peligrosas si se adoptan ese tipo de medidas preventivas, siéndolo en caso contrario ${ }^{391}$.

Una sentencia aplicable a este caso es la de 22 de diciembre de $1999^{392}$ del TS, trata de un menor de quince años que al saltar sobre un trampolín elástico tras una carrera de ocho metros, bota sobre dicho trampolín en posición vertical y cae sobre la colchoneta, como consecuencia de producirse un desequilibrio en el aire cayó golpeándose la barbilla sobre la mencionada colchoneta, lo que le causó graves lesiones y secuelas de gran invalidez.

En su Fundamento de Derecho Sexto se culpa a la profesora de no haber obrado con la diligencia debida que le era exigible, de no haber adoptado las medidas de seguridad y precaución por el riesgo previsible dada la naturaleza de la actividad que se encontraba realizando al actuar con evidente descuido y exceso de confianza, por no tener en cuenta el peligro que entrañaba la prueba que había mandado efectuar a los alumnos, circunstancia que por su preparación y titulación no le eran desconocidos. Cabe reseñar que los alumnos eran de quince años, lo que no es una edad demasiado corta para tenerse en cuenta, pues me parece que es apropiada para ese tipo de ejercicios, propios de adolescentes y necesarios para un adecuado desarrollo físico. El tipo de aparato entraña no una excesiva pero si cierta peligrosidad por lo que debió de redoblar la vigilancia y el cuidado sobre los alumnos. Las dificultades del ejercicio eran grandes y se demuestra por el temor de los alumnos a realizarlo, así como por las frecuentes caídas que se produjeron, lo que debería de haber inducido a la profesora a suspender el ejercicio, cosa que no hizo. Al tratarse del primer día del curso no debería de haber practicado ese ejercicio, pues creo que era necesario entrenar primero para que los alumnos se hubieran habituado al ejercicio durante un tiempo prolongado, además de haber hecho demostraciones prácticas sin limitarse a una simple explicación verbal. De igual forma habría sido necesario disponer de más personal en la zona de caída de tal forma que hubiera sido prácticamente imposible un accidente de esa naturaleza.

\footnotetext{
${ }^{391}$ Atienza Navarro, Ma Luisa, op.cit, pag 191 y ss.

392 Sentencia del Tribunal Supremo de 22 de diciembre de 1999 (RJ-1999/9487)
} 
Respecto al director no se puede descargar la responsabilidad sobre él por culpa in vigilando, pues debe recaer en la profesora que no ha actuado con la debida diligencia. En su Fundamento de Derecho Séptimo se condena al titular del Centro docente a indemnizar a la víctima con ciento veinte millones de pesetas. Por su Fundamento de Derecho Octavo se aplica para la exigencia de responsabilidad el artículo $1903 \mathrm{~V}$ del Código Civil por culpa "in vigilando" e "in eligendo" y el artículo 41 de la LRJAE al tratarse de un centro público, siendo la responsabilidad de carácter directo.

Otra sentencia sobre actividades deportivas es la de la Audiencia Provincial de Guipúzcoa de 8 de enero de $1998^{393}$, en ella trata de un menor que recibe un golpe en la cara mientras jugaba al hockey durante una clase de Educación Física.

En ella la Audiencia Provincial de Guipúzcoa condenó al colegio y a su compañía de seguros y absolvió a la profesora y a su entidad aseguradora. La Audiencia condena al colegio por no haber exigido que dicho juego se lleve a cabo con las protecciones que sean necesarias para evitar heridas en la cabeza o en la cara como consecuencia de un golpe fallido como así sucedió. Se condena también a la compañía de seguros por los artículos 73 a 76 de la Ley 50/80 de 8 de octubre sobre Contrato de Seguro.

La condena se basa en el artículo 1903 V del Código Civil y no se aplica el último párrafo del mencionado artículo, por no haber obrado el colegio con la diligencia de un buen padre de familia al haber permitido realizar el juego de hockey sin las protecciones adecuadas, lo que constituye una prueba manifiesta de negligencia.

En los tribunales franceses, se tiene en cuenta la necesidad de que le profesor de educación física tome precauciones especiales según el tipo de prueba o ejercicio, según sus dificultades, edad de los alumnos, etc, en ellas se han de adoptar medidas organizativas y una vigilancia constante.

El Tribunal de Pau en la sentencia de 22 de abril de 1986 se inclina por no ser necesaria una vigilancia individualizada. Los hechos ocurrieron en un gimnasio en el que un menor de quince años lanzó un balón sobre otro que saltaba sobre una barra transversal en la que practicaba "salto de altura", al incidir el balón sobre la barra, ésta le golpeó en la cara. El Tribunal no apreció responsabilidad del profesor al entender que

\footnotetext{
${ }^{393}$ Se ha obtenido del Tratado de Responsabilidad Civil de los docentes, de Muñoz Naranjo, Alfredo, op.cit, pag 143.
} 
no se producía un defecto de vigilancia. Se entendió que la responsabilidad incumbía al alumno causante del daño, por cuanto poseía suficiente discernimiento para responder de sus actos.

Otra sentencia ilustrativa sobre deportes es la del Tribunal de Paris de 4 de mayo de 1963, donde trata de los daños ocasionados por un alumno al realizar ejercicios sobre una barra libre, se apreció culpabilidad del profesor al no llevarse a cabo tales ejercicios sobre superficies que pudieran amortiguar el golpe para casos de caída de los alumnos. Por ello dice la sentencia: "El profesor de educación física que ordena a sus alumnos realizar movimientos peligrosos debe asegurarse que todas las medidas son tomadas para evitar los accidentes y especialmente prevenir la caída de un alumno después de un mal movimiento sobre la barra fija utilizando "colchonetas" o "arena", añadiendo la recomendación de que "el maestro debe elegir los ejercicios en función del material que posea".

Los tribunales alemanes exigen reforzar la vigilancia exigible al profesor sobre las actividades físicas tanto en gimnasios como en la práctica de cualquier deporte. La autoridad judicial valorará la diligencia del profesor de acuerdo con la peligrosidad del ejercicio, edad del alumno, estado y tipo de aparatos, así como el campo donde se practica. Las actividades deportivas han originado un gran número de pronunciamientos condenatorios para el profesor, por no haber observado el alto grado de diligencia en estos casos.

En varias sentencias los tribunales para imputar la responsabilidad del profesor han tenido en cuenta que antes de realizar la práctica del deporte deben inspeccionar las instalaciones de juego para detectar la posible existencia de objetos peligrosos, por ello deben realizar un reconocimiento del terreno que les rodea por si existen obstáculos que puedan producir accidentes.

A veces se han planteado dudas sobre si el profesor debe permitir que una alumna salte con gafas, con el consiguiente peligro de que los cristales se rompan y le causen algún tipo de lesión o si se debe exigir que se las quite lo que puede dar lugar a que la alumna sufra una caída por la defectuosa visión. En igual sentido si en una excursión en la que un alumno resulta herido por contusión en una pierna, se duda si el profesor tiene 
que acompañarle al centro médico más cercano o por el contrario, debe de dejarlo momentáneamente y conducir al grupo a su destino y pedir después la ayuda médica correspondiente.

\subsection{LA AUSENCIA DEL PROFESOR}

La ausencia injustificada del profesor cuando tenga encomendada su vigilancia y control sobre los alumnos constituye un aspecto que se tiene siempre en cuenta a la hora de exigir responsabilidades. La ausencia desde luego no tiene que estar justificada, pues si se trata de casos de fuerza mayor, el profesor quedaría exonerado de responsabilidad.

En la jurisprudencia francesa se consideran las ausencias aunque sean momentáneas como una falta de vigilancia manifiesta, en las que podría exonerarse de responsabilidad por causas legítimas, aunque los tribunales son restrictivos a la hora de apreciar su legitimidad. El Tribunal de Casación no ha concedido relevancia a la afirmación alegada por el profesor de que se trataba de un caso fortuito, el cual se hubiera producido de igual forma si hubiera estado presente. En reiteradas ocasiones el Tribunal no lo ha tenido en cuenta por considerar que de encontrarse presente el profesor, el hecho pudiera haberse evitado.

Por lo que se refiere a la jurisprudencia italiana la ausencia del docente se considera injustificada o no según como se adopten las medidas sustitutivas. La sentencia del tribunal de Milán de 9 de febrero de 1959 trata de un caso en el que un alumno le produjo la casi total pérdida de visión en un ojo a otro, el hecho sucedió durante la ausencia del profesor que encargó la vigilancia a otro alumno de edad de siete años. El Tribunal declara responsable al profesor por entender que encomendar la vigilancia a un alumno de la misma clase supone abandonar la clase sin medida sustitutiva adecuada. El propio Tribunal afirma que para no haberse apreciado negligencia, hubiera sido suficiente encomendar la vigilancia al profesor de la clase anexa como se habría hecho en otras ocasiones.

El profesor tiene que estar obligatoriamente como mínimo diez minutos antes del comienzo de la clase y otros diez minutos después de finalizada, de tal forma que si no 
se cumple con esta norma los tribunales lo califican de ausencia arbitraria y se imputarán los daños que se produzcan al profesor. Ello se basa en el artículo 350 del Reglamento General de los Servicios de Enseñanza Elemental, del RD n ${ }^{\circ}$ 1297, de 26 de abril de 1928 en el que se desarrollan las normas de enseñanza y dispone que "las obligaciones del profesor no se agotan con las de orden didáctico y educativo, sino que comprenden igualmente las referidas a una vigilancia constante de los alumnos durante el tiempo que se hallen confiados al mismo. El profesor no sólo deber de estar antes del comienzo de la clase en el Centro, sino que debe de permanecer en él hasta que hayan salido al término de las clases".

En la sentencia de 26 de septiembre de 1978, se exoneró de responsabilidad al profesor, en un caso en que un alumno resultó herido de gravedad en un ojo a consecuencia del impacto de un objeto que fue manipulado por otro de sus compañeros, el profesor quedó exonerado de la responsabilidad que se le imputaba al comprobarse que su ausencia fue comunicada al sustituto de dirección de la escuela así como al otro profesor que se encontraba presente en el patio del recreo, donde se produjeron los hechos.

La Sentencia del Tribunal de Casación de 28 de julio de 1972, en la que trata el caso de una profesora de enseñanza elemental que se ausenta momentáneamente del aula dejándola sin vigilancia para traer a un alumno que había huido de la clase, con tan mala fortuna que durante su corta ausencia otro alumno resultó herido en un ojo por un compañero. En instancias sucesivas se excluyó la culpa in vigilando de la maestra. El Alto Tribunal estimó correcta la valoración de los tribunales inferiores, según los cuales la violación del RD de 26 de abril de 1928, no tuvo una incidencia causal concreta en el hecho y debía considerarse irrelevante, ya que el referido hecho, por su carácter inesperado, no resultó ni previsible ni evitable. Lo relevante de esta sentencia es que al ausentarse para traer al alumno que se había fugado del aula y vulnerar el RD de 1928, la profesora no ha incurrido en responsabilidad, pues se trata de un hecho o caso fortuito, imprevisible e inevitable, que hubiera sucedido aunque la profesora se encontrara presente en el aula, por lo que no existe nexo causal entre la ausencia de la profesora y el hecho dañoso cometido por el alumno. 
Si un docente no ha incurrido en culpa, tampoco deberá responder el titular del centro por culpa in vigilando o in eligendo, aunque puede darse el caso en que el profesor no resulte culpable por haber avisado con la antelación suficiente y sea el titular del centro docente el que haya obrado con negligencia al no haber designado al profesor sustituto, en cuyo caso sería una culpa in organizando. Puede decirse en general que en la ausencia del profesor para que le sea imputable a él la responsabilidad del hecho dañoso originado en su ausencia, es necesario que se dé un nexo causal entre la ausencia del profesor y el daño causado ${ }^{394}$.

La Sentencia de la Audiencia Provincial de Barcelona (Sección 10ª de 25 de febrero de $1999^{395}$, ya vista anteriormente, trata de tres profesores a cargo de cincuenta y siete menores que fueron de excursión desde Barcelona a la playa de Ribes Roges, en Vilanova y Geltrú, permitiendo a los niños de unos nueve años bañarse en la playa, sin haberse asegurado que sabían nadar, con el mar en mal estado para bañarse, donde falleció un alumno ahogado y otro tuvo que ser evacuado a un hospital. Los alumnos pedían auxilio desde el agua, teniendo que ser rescatados por terceras personas, ajenas a la excursión que se hallaban en la playa realizando sus quehaceres respectivos, los cuales procedieron en la arena de la playa a su reanimación, auxiliados por la Policía Local de la población, sin que los profesores se apercibieran de lo sucedido, haciendo acto de presencia sólo cuando ya se estaban desarrollando los primeros auxilios a los dos niños. El cuerpo del niño fallecido fue avistado cuando ya era zarandeado por las olas, falleciendo a las doce horas a causa de la asfixia sufrida por la inmersión en agua salada. La niña consiguió salvarse tras ser reanimada y atendida hospitalariamente.

De lo expuesto en la sentencia, se deduce una grave irresponsabilidad por parte de los profesores, al dejar a los niños de corta edad solos en la playa en las mencionadas circunstancias, lo que constituye un caso manifiesto de negligencia grave, por lo que fueron condenados por delito de homicidio imprudente, siendo indemnizados los padres del menor fallecido por la compañía de seguros lo que dio lugar a que renunciaran a las acciones civiles y los padres de la niña renunciaron igualmente a cualquier

\footnotetext{
${ }^{394}$ Atienza Navarro, op cit, pags 211 y ss.

395 Obtenido de Muñoz Naranjo Alfredo, op cit, pag 154 y ss.
} 
indemnización. Se da claramente un nexo causal o relación de causa a efecto entre la ausencia de los profesores y el ahogamiento del niño, así como la reanimación de la niña, de manera que si los profesores no se hubieran ausentado, ni permitido entrar a los niños en el agua, o aunque hubieran entrado en el agua, sí se hubieran encontrado presentes, habrían podido atender a los menores cuando pedían auxilio, y por consiguiente haberlos rescatado de las olas y que no se hubieran producido esos hechos. El haber sido atendidos por personal ajeno a la excursión, que se encontraba limpiando la arena y demás cometidos propios de su empleo, indica que los profesores no se encontraban presentes, al acudir tiempo después cuando ya les estaban reanimando, lo que pone de manifiesto que la ausencia es totalmente injustificada, tanto por el tipo de actividad, al tratarse de una excursión, que ya exige incrementar el cuidado sobre los menores, como el lugar donde se realiza, en este caso una playa y con el mar en mal estado, lo que da lugar a la exigencia de responsabilidad tanto penal como civil.

\subsection{LA IRRELEVANCIA DE LAS PROHIBICIONES}

El establecer prohibiciones por parte de los profesores sobre los alumnos de no realizar determinados actos no les exime de responsabilidad, pues ello no es suficiente, se necesita una vigilancia de forma efectiva, con personal suficiente, que impida acercarse a determinados lugares o de no realizar actos peligrosos y ello ha de efectuarse de tal forma que no lleguen a materializarse esos hechos dañosos. Ello es debido a que los niños, sobre todo los de corta edad, no son conscientes de los peligros y basta que se les prohíba algo para que no hagan caso de la prohibición.

La S.A.P de Valencia de 20 de noviembre de $1995^{396}$ es un ejemplo de la irrelevancia de las prohibiciones y trata de unos menores que salen del colegio en el tiempo destinado al recreo, a un parque cercano, en el que uno de ellos le lanza al otro un trozo de barro endurecido, produciéndole lesiones en el ojo izquierdo. El colegio había establecido la prohibición de salir del recinto del mismo sin la autorización de los padres, para lo cual se había enviado a los padres un modelo de instancia para si

\footnotetext{
${ }^{396}$ Sentencia de la Audiencia Provincial de Valencia de 20 de noviembre de 1995 (AC-1995/2056)
} 
deseaban que sus hijos pudieran salir, los porteros habían sido advertidos de que sólo podían salir los que tuvieran dicha autorización. Constando que los menores involucrados en el hecho dañoso no tenían la autorización para salir. Por ello se condena al titular del centro en el Fundamento de Derecho Quinto de la sentencia que dice: "aunque se admita todo lo anterior, lo cierto es que se ha reconocido que los alumnos implicados en el hecho no habían sido autorizados por sus padres para salir del centro durante el tiempo de recreo y que, precisamente a esa hora y fuera del centro se produjo el hecho dañoso. Como esto es así, ello mismo pone de relieve que aquellas prohibiciones e instrucciones o bien fueron dispensadas o revocadas por los responsables de la dirección del centro, o bien fueron incumplidas por quienes tenían la obligación de llevarlas a cabo o de vigilar que se atendieran, lo que en definitiva lleva a la conclusión de que la entidad titular del centro docente no ha probado que empleó la diligencia exigible legalmente para prevenir el daño y, por consiguiente debe responder de éste con arreglo a lo dispuesto en el citado artículo 1903".

En la jurisprudencia francesa se consideran irrelevantes las prohibiciones e instrucciones como se contempla en la sentencia del Tribunal de Montpellier de 24 de septiembre de 1985, en la que el profesor en una prueba de lanzamiento de peso recomendó que los alumnos se mantuvieran detrás del área de lanzamiento, el tribunal apreció culpa en el profesor por entender que no era suficiente la mera recomendación, sino que era necesario que se hubieran verificado las instrucciones, y haber esperado a que cada alumno hubiera ocupado su lugar detrás del área de lanzamiento antes de cada prueba.

La jurisprudencia alemana en una línea mayoritaria exige una vigilancia activa y declara al profesor responsable de los daños de sus alumnos aunque hubieran establecido prohibiciones a estos efectos para evitar daños de los alumnos, no es suficiente hacer advertencias de no hacer a los alumnos, sino que debe alejar a los alumnos del peligro mismo. En la sentencia de la Audiencia Territorial de Breslau de 23 de agosto de 1910 advierte que si el profesor prohíbe algún acto tiene que contar con que la prohibición va a ser transgredida, y de ahí que a tal efecto se adopten las precauciones necesarias. 
La sentencia de la Audiencia Provincial de Trier de 17 de febrero de 1925, entiende que se vulnera el deber de vigilancia cuando a pesar de las advertencias a los alumnos de la peligrosidad de un juego, no se evita el mismo, por lo que se considera que es tolerado. Otra sentencia de Breslau de 20 de junio de 1927 considera que en un juego de deslizarse sobre el hielo, no es suficiente una mera prohibición, sino que se hace necesario que el profesor lo hubiera evitado o como mínimo haberlo vigilado de forma directa para evitar accidentes en su práctica. La sentencia de la Audiencia Provincial de Ausbach de 27 de enero de 1956, sobre una excursión organizada a unas montañas rocosas, el profesor incurrió en responsabilidad por los daños sufridos por un alumno al escalar en un monte, a pesar de la prohibición de hacerlo y caerse al practicarla.

\subsection{EMPLEO DE INSTRUMENTOS U OBJETOS PELIGROSOS.}

En determinadas actividades escolares con alumnos de corta edad se deben de incrementar la vigilancia y control sobre ellos en clases de dibujo, trabajos manuales y otras de carácter análogo por el riesgo que implica. Se debe de prohibir en la medida de lo posible el uso de objetos punzantes, cortantes o que puedan lanzarse fácilmente, lo que resulta potencialmente peligroso, sobre todo al producirse luchas o riñas entre los menores, al ser susceptibles de emplearse de forma ofensiva. Desde luego creo que debe de prohibirse el uso o los juegos con dardos, alfileres u objetos similares por entrañar grave riesgo. Los principales responsables son los profesores encargados de la vigilancia de los menores, aunque también pueden resultar responsables los padres si se demuestra que los trajeron de su casa, resultando introducidos en el colegio de forma oculta para evitar la vigilancia de los profesores. Una sentencia ilustrativa de estos casos es la del Tribunal Supremo de 3 de diciembre de $1991^{397}$ en ella se trata de una menor que llevó al colegio una ballesta que disparaba alfileres, con la que agredió a otro alumno en el ojo derecho perdiendo casi totalmente la visión en dicho ojo. Se condenó al colegio y a la compañía aseguradora a indemnizar a los padres del alumno lesionado. En su

\footnotetext{
${ }^{397}$ STS de 3 de diciembre de 1991 (RJ-1991/8910).
} 
Fundamento de Derecho Tercero se argumenta que la responsabilidad es del titular del centro docente por tener el deber de vigilancia y control sobre los menores al producirse los hechos que tuvieron lugar en el patio del colegio, al encontrarse finalizadas las clases, esperando para trasladarse a sus domicilios, espacio de tiempo y lugar que se considera es el colegio sobre el que recae la responsabilidad de vigilancia y control sobre los menores. Se intenta responsabilizar a los padres pero es el colegio el que resulta responsable, sin que la sentencia aclare cómo se introdujo la ballesta en el centro, pues pienso que si se la compraron sus padres y toleraron su uso, ellos deberían ser responsables.

Otra sentencia aplicable es la del Tribunal Supremo de 10 de diciembre de $1996^{398}$, en la que se condena al colegio por no haber vigilado correctamente a los alumnos, en un caso en que una niña de cuatro años, en un aula, al reñir con un compañero, le agredió con un broche ovalado al que se adosaba un imperdible en forma de alfiler, con el que lastimó el ojo a su compañero mediante el lanzamiento del mismo. Ello le produjo lesiones que precisarían intervención quirúrgica. En su Fundamento de Derecho Tercero, el Juez estima que no se debe de condenar a la madre de la niña por el artículo 1903.2 CC, sino al colegio y por tanto a los dos profesores que vigilaban la clase, los cuales no se apercibieron de los hechos, cosa que si hicieron algunos de los alumnos presentes. El broche aunque sea un objeto inocuo en personas adultas no lo es en niños de muy corta edad, motivo por el que los profesores debieron extremar la vigilancia sobre los menores, cosa que se omitió al permitir a la alumna llevar ese broche punzante, que puede dar lugar en una riña imprevisible entre niños menores a producir daños como así ocurrió, razón por la que se estima que los profesores actuaron de forma negligente y se condena a indemnizar al colegio al alumno dañado por el artículo 1903 del CC. Creo que de igual forma se debería de haber obligado a indemnizar a la madre de la niña por permitir que su hija llevara ese objeto peligroso al colegio.

La jurisprudencia francesa en la Sentencia del Tribunal de París de 16 de julio de 1921, responsabilizó al profesor, que se encontraba a cargo de unas niñas y permitió la práctica de un juego simulado de compra-venta de mercancías, para lo que se empleó

\footnotetext{
${ }^{398}$ Sentencia del Tribunal Supremo de 10 de diciembre de 1996 (RJ-1996/8975)
} 
escombros de vajilla y trozos de botellas de vidrio, con los que una alumna arrojó repentinamente sobre otra uno de dichos objetos, causándole la pérdida de la visión de un ojo. El Tribunal aprecia en el profesor una falta de diligencia al permitir emplear esos objetos en el juego, lo que motiva que no pueda procederse a su exoneración de responsabilidad al ser un resultado que, aunque remoto, podría prever.

La jurisprudencia alemana entiende que los padres no pueden verse responsabilizados por los posibles daños que puedan originar sus hijos cuando se encuentren en el colegio. Pero en determinadas circunstancias se ha llegado a responsabilizar a los padres por haber creado las circunstancias para que se produjera el accidente. Como el caso de un padre que entregó una navaja a su hijo (con capacidad disminuida) para que la llevara consigo a una excursión escolar, habiendo quedado demostrado que su capacidad disminuida o su clara torpeza fue la circunstancia determinante del accidente.

\subsection{ACTIVIDADES PELIGROSAS}

Existen actividades tales como excursiones, baños, juegos, salidas al campo, a la playa y demás que por su propia naturaleza entrañan peligros reales o potenciales, en los que se hace necesario extremar las precauciones de toda clase. El no hacerlo puede dar lugar a incurrir en responsabilidad por parte de los docentes. Los centros tienen que asignar para realizar las mencionadas actividades, el personal suficiente de profesores, instructores, monitores o vigilantes para que se desarrollen correctamente. El personal directamente encargado de realizarlos tiene que armonizar la seguridad de la actividad de que se trate, con un grado de libertad de los alumnos, de tal forma que puedan disfrutar de esas actividades formativas tan necesarias para los menores de edad.

Si se trata por ejemplo de baños en un rio habrá que controlar que los alumnos sepan nadar, según la edad que tengan que las aguas no sean demasiado profundas, que el rio no tenga obstáculos peligrosos, para ello será necesario hacer un previo reconocimiento de la zona donde se han de bañar. En cuanto a los juegos se ha de vigilar que se desarrollen de forma normal, pues si se varía la forma de realizarlos pueden ser potencialmente peligrosos y sobre todo que no se empleen objetos o elementos 
peligrosos en su desarrollo. En cuanto a las salidas al campo o al monte se ha de procurar que no vayan por precipicios y lo menos dispersos posible, sin que nadie se quede sólo o rezagado. Aunque la seguridad completa no existe, se trata de precauciones elementales que evitan la producción de accidentes.

La Sentencia del Tribunal Supremo de 10 de noviembre de $1990^{399}$ se aplica a este caso y consiste en que un alumno en el patio de recreo, después de haber concluido las clases, se encontraba esperando para entrar al comedor, al jugar con un palo afilado en los extremos (con puntas) conocido con el nombre de "lima" se lesionó el ojo izquierdo, todo ello en presencia de los profesores. En su Fundamento de Derecho Quinto dice " la actuación de los profesores presentes en el patio donde se encontraban los alumnos, pone de manifiesto que aquellos no observaron la diligencia precisa y exigible en el cumplimiento de su deber de vigilancia de los alumnos a ellos confiados al no advertir la práctica por el menor lesionado de un juego peligroso, que como dice la sentencia recurrida "debería haber sido prohibido incluso por el profesorado presente en la hora del recreo" y tal deber de vigilancia sobre los alumnos, entre los que se encontraban algunos de corta edad (seis años) como el menor, no cesaba por el hecho de haber concluido las horas de clase. Hubo por tanto una conducta culposa en los profesores del colegio por culpa in vigilando o in eligendo.

En la jurisprudencia francesa, en la mayoría de sus pronunciamientos, se entiende que un profesor comete una falta cuando no interviene para impedir que un juego se transforme en peligroso, por ello la imputabilidad no se da por la autorización del juego, sino por la inadecuada vigilancia especial, que sería la causa inmediata, para que el juego se convierta en violento o peligros y por ello generador de daños.

La Sentencia del Tribunal de Nimes de 7 de marzo de 1910, trata de los alumnos de una escuela municipal que no disponía de patio, realizaban el recreo en la plaza del pueblo, en sus juego de esconderse, uno de los alumnos chocó e hirió a una persona de avanzada edad que en aquel momento cruzaba la plaza. El Tribunal dijo que: "Los maestros no podían invocar la excusa de la imposibilidad física e inmediata en que se encontraran para impedir el hecho, si éste ha sido precedido de una falta por su parte,

\footnotetext{
${ }^{399}$ Sentencia del Tribunal Supremo de 10 de noviembre de 1990 (RJ- 1990/8538)
} 
sin la cual el acontecimiento no habría ocurrido, dado sobre todo la poca extensión de la plaza". Los maestros encargados de la vigilancia habían cometido una imprudencia por el simple hecho de tolerar el juego.

Otras sentencias son ilustrativas de peligrosidad como la de Montpellier de 24 de febrero de 1913, en ella un menor cae sobre unas zarzas por el empujón de un compañero, el Tribunal aprecia que "aunque los empujones son frecuentes, y difícilmente pueden ser impedidos, el maestro comete una falta grave al no prohibir a los alumnos que jueguen en un lugar peligroso". La sentencia del Tribunal de Rennes, de 14 de noviembre de 1936, no aplicó el artículo 1384 por haberse herido a sí mismo el alumno, el profesor cometió la falta de haber dejado jugar a los alumnos en el cauce seco de un rio, donde se hallaban múltiples escombros y chatarra. Finalmente la sentencia del Tribunal de Bordeaux de 14 de abril de 1951, sobre un caso de práctica de rugby dice: "Este ejercicio es violento, incluso peligroso. No debe ser practicado durante un simple recreo fuera de un terreno adecuado".

La jurisprudencia alemana insiste en lo relativo a baños colectivos o ejercicios de natación y condena al profesor por no haber explorado antes la zona de baño, como dice en la Sentencia del Tribunal de Konigsberg de 11 de junio de 1929. De igual forma en la Sentencia de Breslau de 9 de febrero de 1927, en que se responsabiliza al profesor por no haberse asegurado de que todos los alumnos habían abandonado la zona de baño o piscina, sin que pueda tolerarse que quede en dicha zona alguno sin la adecuada vigilancia $^{400}$.

\footnotetext{
${ }^{400}$ Las sentencias sobre la jurisprudencia francesa, alemana e italiana, relativas a la diligencia de los titulares de centros docentes, se han obtenido de Moreno Martínez, Juan Antonio, Resp. De Centros Docentes, op cit, pags 157 a 196.
} 


\section{LOS CENTROS DOCENTES PÚBLICOS.}

\subsection{GENERALIDADES}

Los centros docentes públicos no universitarios, dependen de la Consejería de Educación de cada Comunidad Autónoma, al haberles sido traspasadas las competencias en educación en virtud del artículo 149, apartado 30, de la Constitución Española, según el cual el Estado se reserva la "Regulación de las condiciones de obtención, expedición y homologación de títulos académicos y profesionales y normas básicas para el desarrollo del artículo 27 de la Constitución a fin de garantizar el cumplimiento de las obligaciones de los poderes públicos en esta materia". Por ello cuando se produce un hecho dañoso en un centro es la Consejería de Educación de la Comunidad Autónoma la que tiene que indemnizar, pues es la titular del centro docente. Conviene no identificar al director de un centro docente con el titular, pues, el director es un miembro más del profesorado al que le han sido encomendadas tales funciones, como al jefe de estudios u otros cargos.

La mayor parte de los centros de educación son públicos al considerar la educación como un derecho, que el Estado se encarga de garantizar como un servicio público más, habiendo pasado del ámbito privado, en que sólo una parte podía costeárselo a extenderse a toda la población de forma obligatoria y gratuita. Por ello el personal encargado de impartir la enseñanza son funcionarios públicos y se encuentran sujetos a las leyes de educación y de la Administración pública.

Cuando un alumno causa un daño en un centro docente público es responsabilidad de la Administración Pública y se regula por la Ley 30/1992 de 26 de noviembre, de Régimen Jurídico de las Administraciones Públicas y del Procedimiento Común (LRJAP y PAC), modificada por la Ley 4/1999, de 13 de enero; en sus artículos 139 y siguientes. Este artículo señala los principios de responsabilidad de la Administración Pública, siendo básico su apartado primero que dice: "Los particulares tendrán derecho a ser indemnizados por las Administraciones Públicas correspondientes, de toda lesión que sufran en cualquiera de sus bienes y derechos, salvo en los casos de 
fuerza mayor, siempre que la lesión sea consecuencia del funcionamiento normal o anormal de los servicios públicos.

Si el profesor al ser funcionario público, hubiera observado una conducta dolosa o gravemente negligente, contribuyendo a la causación del daño, la Administración una vez haya indemnizado al perjudicado o perjudicados, deberá dirigirse contra el funcionario por vía de regreso, de acuerdo con el artículo 145.2 LRJA y PAC.

\subsection{EL RECONOCIMIENTO DE LA RESPONSABILIDAD DE LA} ADMINISTRACION EN EL DEREHO COMPARADO.

Tradicionalmente la administración no era responsable ante los particulares, ello dio lugar a las reivindicaciones populares generadoras de las revoluciones burguesas, dirigidas a acabar con las apropiaciones autoritarias y abusivas de los monarcas, acompañados siempre de la más completa inmunidad. La garantía patrimonial del ciudadano se compone del régimen expropiatorio, la responsabilidad patrimonial de las administraciones públicas y el principio de legalidad, todo ello unido constituye el fundamento del actual Estado de Derecho ${ }^{401}$.

El sistema anglosajón consideró el principio de inviolabilidad de la Corona (the King can do not wrong - el rey no puede cometer error) el cual se basa en la ficción de que el Rey no puede realizar actividad ilícita alguna, lo que se traducía en una regla de inmunidad judicial. Se trata de un dogma procedente de la Edad Media, que con el constante intervencionismo del Estado en la sociedad y en la economía ha quedado totalmente obsoleto en el siglo XX, en que ya no se puede tener en consideración. Este sistema fue corregido con la construcción de una nueva ficción, consistente en la posibilidad de pedir justicia ante un funcionario, respaldado económicamente por el Estado y cuya misión exclusiva era responder por la Corona, al que se denomina "el acusado nombrado" ${ }^{402}$.

\footnotetext{
${ }^{401}$ Régimen Jurídico de las Administraciones Públicas y del Procedimiento Administrativo Común, Francisco LLiset Borrell, Federico Romero Hernández, Publicaciones Abella, Madrid 1994, pag 377

${ }^{402}$ Ibidem, pag 377 y 378.
} 
La ficción anterior no fue suficiente, por lo que se aprobó la "Crown Proceeding Act de 1947- Sometimiento de la Corona" a la misma responsabilidad que si fuera una persona privada, tanto por razón de los daños cometidos por los funcionarios, como por el incumplimiento de las obligaciones que toda persona tiene para con sus servidores y agentes por ser su empresario, o de los anejos a la propiedad, ocupación o posesión de las cosas ${ }^{403}$.

Será en Francia el primer país que en su ordenamiento contemple la responsabilidad de la administración del Estado por los daños cometidos a los particulares. La Revolución de 1789 mantuvo vigente el privilegio de inmunidad patrimonial de que la Administración pública gozó durante la monarquía absoluta. Se mantenía entonces que la noción de soberanía no debía de reconocer la responsabilidad civil del Estado, de acuerdo con la frase de Laferriere: "Le propre de la souveraineté est de s'imposer á tous sans compensation" (lo propio de la soberanía es imponerse a todos sin compensación). Esta situación se mantuvo hasta mediados del siglo XIX, en que el Consejo de Estado sentó por primera vez en el arrét Rothschild, de 6 de diciembre de 1855, la responsabilidad de la Administración del Estado.

El tribunal de Conflictos en el arrét Blanco de 1 de febrero de 1973 reconoció la responsabilidad civil del Estado, mediante la doctrina de la culpa, junto con la noción de funcionamiento de un servicio público, produjo la figura de la llamada faute de service que engendra la responsabilidad del ente público, con una faute personelle del funcionario autor material del hecho dañoso, que puede dar lugar a la responsabilidad personal del mismo. De todas formas a pesar de distinguir entre faute de service y faute personelle en el derecho francés, los entes públicos están obligados al resarcimiento de los daños causados por el ejercicio de su actividad jurídica o material independientemente de la falta o no del funcionario ${ }^{404}$.

En el derecho italiano hay que considerar lo que dispone el artículo 113 de la Constitución de 27 de diciembre de 1947 el cual dice: "Contra los actos de la administración pública se admitirá siempre la tutela jurisdiccional de los derechos y de

\footnotetext{
403 Ibidem, pag 378. Ver igualmente Régimen de la Responsabilidad de la Administración Pública y Procedimiento Administrativo Común, Ramón Parada, Marcial Pons, Madrid 1993, pag 418.

${ }^{404}$ La Responsabilidad Civil de la Administración Pública, Jesús Leguina Villa, Editorial Tecnos, Madrid, pags 150 y ss.
} 
los intereses legítimos ante los organismos de la jurisdicción ordinaria o administrativa $405 \%$.

Este artículo quiere decir que cuando a un particular la Administración le ocasiona un hecho dañoso o lesivo de sus derechos, no podrá sustraerse al conocimiento del juez ordinario y cuando surja el deber de indemnizar por parte del ente público, el derecho que asiste al particular podrá invocarse ante ese juez ordinario. Cuando se ha producido un daño a un administrado por parte de la administración, no tiene relevancia que funcionario lo ha cometido, lo que verdaderamente interesa es que se dé un nexo causal entre la actividad administrativa y el particular lesionado para que surja el deber de indemnizarle.

La administración a veces puede producir daños anónimos en los que es imposible identificar al funcionario, pero no por ello va a dejar de ser imputable. El conocer el funcionario o funcionarios que han cometido faltas o errores en relación con los administrados tiene importancia para que la propia administración pueda exigir responsabilidad por vía de regreso a sus propios funcionarios, sobre todo en casos de dolo o negligencia grave. Existe un arret del consejo de Estado francés de 17 de febrero de 1905 en el que en unos entrenamientos militares en los que un tiro de fusil ha partido de una tropa militar, el Estado tiene que responder aunque no se sepa que soldado concreto haya disparado, por todo ello lo que interesa es indemnizar al perjudicado en virtud del principio pro damnato, independientemente de qué o quiénes de los funcionarios produjeron el hecho dañoso.

El artículo 28 de la Constitución italiana contempla la responsabilidad de los funcionarios y agentes del Estado y dice: "Los funcionarios y empleados del Estado y de las entidades públicas son directamente responsables, según las leyes penales, civiles y administrativas, de los actos que ejecuten violando los derechos de los ciudadanos. En tales casos la responsabilidad civil se extiende al Estado y a las entidades públicas ${ }^{406 "}$. Este artículo contempla una responsabilidad directa frente a los administrados, pues, aunque el funcionario sea responsable, la Administración se encargará de indemnizar. La

\footnotetext{
${ }^{405}$ Constitución Españolas y Extranjeras, Jorge de Esteban, Ed. Taurus. Op cit. Pag 544.

406 Ibidem, pag 529
} 
víctima tiene una acción de resarcimiento frente al ente público, una vez que el ordenamiento positivo imputa un hecho dañoso a dicho ente público. Puede decirse, que se puede atribuir la responsabilidad por un mismo hecho dañoso, a dos sujetos distintos, es decir, la persona jurídica pública y el funcionario, por lo que siempre indemniza la Administración al particular lesionado.

En el Derecho alemán se empezó a considerar la responsabilidad patrimonial de la Administración con la Constitución de Weimar, en su artículo $131^{407}$ donde se contempla el deber profesional de los funcionarios por su actuación ilícita, que lleva implícita la responsabilidad indirecta de la Administración. Posteriormente se contempla con la posibilidad de indemnizar incluso cuando se trate de actuaciones lícitas que comporten la privación de un bien al administrado. Por la irrelevancia que tiene para el perjudicado el que se trate o no de un acto lícito, por el funcionamiento de los órganos administrativos, se ha llegado a un sistema que acoge ambos supuestos, además de resarcir todas las intervenciones antijurídicas sin culpa, así como de las situaciones de riesgo creadas por la Administración ${ }^{408}$.

La Constitución de Bonn de 1949 en su artículo 34 se expresa en parecidos términos al 131 de la de Weimar. Contempla una responsabilidad directa de la función pública, además del recurso contencioso-administrativo para los casos de dolo o negligencia grave.

En el Derecho alemán según Leguina Villa, se contempla todavía algún caso en que se da irresponsabilidad de los entes públicos tales como: los daños causados a ciudadanos o residentes extranjeros; los provocados por los servicios diplomáticos en virtud de finalidades políticas o en defensa de los intereses internacionales del Estado; o finalmente, los daños causados por agentes auxiliares de la Administración que no sean titulares de algún órgano público ${ }^{409}$.

Otro sistema en que se contempla alguna irresponsabilidad de los entes públicos es en el Derecho suizo, el cual es muy complejo por no existir un régimen uniforme de responsabilidad para toda la Administración, pues comprende una pluralidad de

\footnotetext{
407 Textos Constitucionales Españoles y Extranjeros, op.cit, pag 18.

${ }^{408}$ Régimen Jurídico.... Lliset Borrell, pag 378.

${ }^{409}$ Leguina Villa, op.cit, pag 297.
} 
regímenes distintos para la Confederación y para cada uno de los 26 cantones y semicantones lo que provoca desigualdades. Para que deba responder la Administración, es preciso que la lesión a un tercero tenga su causa en la conducta ilegal y culpable de algún agente público, el cual tiene que vulnerar positivamente alguna norma escrita o no escrita, o actúe sin cobertura legal suficiente. La vulneración que practica el agente se ha de referir a aquellas normas dictadas para proteger el bien jurídico que ha resultado lesionado. La culpabilidad de la acción u omisión causante del daño varía de unos cantones a otros: en unos se refiere al dolo o negligencia grave; en otros alcanza también a la culpa leve y para medir este grado de culpa se tiene en cuenta el tipo de función pública desempeñada, el peligro que entraña el realizarla, dificultades, importancia de dicha función y la experiencia del funcionario. Si no se dan estas circunstancias el perjudicado queda sin indemnización ${ }^{410}$.

\subsection{EL RECONOCIMIENTO DE LA RESPONSABILIDAD DE LA} ADMINISTRACIÓN EN EL DERECHO ESPAÑOL

Las fases que han seguido los ordenamientos para garantizar el patrimonio de los particulares frente a los daños extracontractuales por el poder público son generalmente cuatro: primera, caracterizada por una total y absoluta irresponsabilidad administrativa; segunda, consistente en la imputación exclusiva de daños a los agentes públicos culpables; la tercera, en la que se da un principio general de responsabilidad de la Administración, limitado a los daños causados por acciones ilegales y culpables de sus autoridades y funcionarios; finalmente la cuarta y última etapa en la que se reconoce el principio general de resarcimiento tanto de los daños anónimos, como los provocados por actuaciones administrativas lícitas o no culpables ${ }^{411}$.

Hasta la publicación del Código Civil de 1889 puede decirse que la Administración pública en España era totalmente irresponsable frente a los particulares por los daños originados a éstos. El Código en su artículo 1903, párrafo 5º, en su

\footnotetext{
410 Ibidem, pags 300 y 301

411 Ibidem pag 296
} 
redacción original dice: "El Estado es responsable en este concepto cuando obra por mediación de un agente especial, pero no cuando el daño hubiere sido causado por el funcionario a quien propiamente corresponda la gestión practicada, en cuyo caso será aplicable lo dispuesto en el artículo anterior". De este precepto se deduce que el Estado queda totalmente excluido de responsabilidad civil por su actividad institucional realizada a través de funcionarios que son en definitiva a los que les será exigida la pertinente responsabilidad. Al hablar de "agente especial" se trata de un agente que no es un órgano de la Administración, es por tanto un tercero respecto de ella y dará lugar a que quede exonerada, siendo imputado dicho "agente especial". Cuando deba de responder la Administración será a través de sus funcionarios, si estos causan el daño, en cuyo caso, responderá por hecho propio, pues el funcionario es un órgano de dicha Administración a través del cual actúa; pero para evitar ser imputada le remite al artículo 1902 de responsabilidad por hechos propios para imputar al propio funcionario, mediante la expresión "en cuyo caso será aplicable lo dispuesto en el artículo anterior", con lo que en uno u otro caso la Administración se exonera de responsabilidad.

En la Ley de 5 de abril de 1904 en su artículo primero, reconoce la obligación a los funcionarios de resarcir a los particulares, cuando con actos u omisiones infrinjan algún precepto. De ello se infiere que en este caso la Administración queda exonerada de responsabilidad al igual que en el caso anterior sobre el Código Civil en sus artículos 1902 y 1903, quedando al particular unas garantías patrimoniales muy escasas.

Se intentó en la Constitución republicana de 9 de diciembre de 1931 la introducción del principio general de responsabilidad civil del Estado y demás entes públicos, en su artículo 41, apartado tercero que dice: "Si el funcionario público, en el ejercicio de su cargo, infringe sus deberes con perjuicio de tercero, el Estado o la Corporación a quien sirva serán subsidiariamente responsables de los daños y perjuicios consiguientes, conforme determine la Ley”. En este precepto se reconoció por primera vez la responsabilidad patrimonial de los sujetos públicos por una norma con rango constitucional.

Después se promulgó la Ley Municipal de 31 de octubre de 1935, en cuyo artículo 209 se reconocía la responsabilidad de las entidades municipales, el cual decía: "las 
entidades municipales responderán civilmente de los perjuicios y daños que al derecho de los particulares causare la actuación de sus órganos de gobierno o la de sus funcionarios en la esfera de sus atribuciones respectivas, directa y subsidiariamente según los casos". Esta normativa de la época republicana fue bastante avanzada para la época, pero tuvo el inconveniente de que estuvo vigente durante poco tiempo, sin poder consolidarse por el estallido de la guerra civil y el consiguiente cambio de régimen. De todas formas esta Ley Municipal de 1935, aunque tuvo escasa vigencia, sirvió para la promulgación de la Ley de Régimen Local de 16 de diciembre de 1950 , en la que en su artículo 405 se reproduce el sistema empleado por la Ley de $1935^{412}$.

Será en el periodo 1954-1958, con la Ley de Expropiación Forzosa de 1954 y la Ley de Régimen Jurídico de la Administración del Estado de 1957, cuando se dio el gran paso para llegar al principio de garantía patrimonial de los ciudadanos, de tal forma que nos conecta con el sistema constitucional actual ${ }^{413}$.

Con la Ley de Expropiación Forzosa de 16 de diciembre de 1954 (LEF) se acabó con la situación de privilegio y de impunidad de la Administración que se causaba a los ciudadanos por las actividades de los entes públicos. En su artículo 121 se contempla el derecho de los particulares a ser indemnizados por las lesiones sufridas en sus bienes y derechos, originados por el funcionamiento normal o anormal de los servicios públicos, el cual dice lo siguiente : "Dará también lugar a indemnización con arreglo al mismo procedimiento toda lesión que los particulares sufran en los bienes y derechos a que esta Ley se refiere, siempre que aquella sea consecuencia del funcionamiento normal o anormal de los servicios públicos, o de la adopción de medidas de carácter discrecional no fiscalizables en vía contenciosa, sin perjuicio de las responsabilidades que la Administración pueda exigir de sus funcionarios con tal motivo". Esta Ley a pesar de su perfección técnica y de lo avanzado para su época, adolece de ser incompleta, al no abarcar los daños físicos a las personas, así como los daños morales o inmateriales. Esta anomalía fue corregida por el artículo $1331^{\circ}$ del Reglamento de Expropiación Forzosa

\footnotetext{
412 - Lliset Borrell op cit pag 379

- Leguina Villa, op.cit, pag 162 y nota n ${ }^{\circ} 119$ sobre Conido Falla.

- Ver igualmente, Atienza Navarro, Ma Luisa, op.cit, pag 243 y ss

413 Lliset Borrell, op.cit, pag 379
} 
en el que la indemnización alcanza a los daños sufridos en todos los bienes o derechos que sean evaluables económicamente ${ }^{414}$. De igual forma el artículo 122 de la Ley exige la evaluación económica, al decir: "En todo caso, el daño habrá de ser efectivo, evaluado económicamente e individualizado con relación a una persona o grupo de personas".

Posteriormente la Ley de Régimen Jurídico de la Administración del Estado de 26 de julio de 1957, reconoció como la Ley de Expropiación Forzosa el principio de responsabilidad estatal directa y objetiva, en su artículo 40, que fue redactado en parecidos términos al 121 (LEF), el cual dice: "Los particulares tendrán derecho a ser indemnizados por el Estado de toda lesión que sufran en cualquiera de sus bienes y derechos, salvo en los casos de fuerza mayor, siempre que aquella lesión sea consecuencia del funcionamiento normal o anormal de los servicios públicos o de la adopción de medidas no fiscalizables en vía contenciosa". En su artículo 43 se contempla la acción directa de resarcimiento de los particulares frente a los funcionarios, cuando éstos sean autores materiales del daño, en caso de comportamiento con culpa grave y dice: "Los particulares podrán también exigir a las autoridades y funcionarios civiles, cualquiera que sea su clase y categoría, el resarcimiento de los daños y perjuicios que a sus bienes y derechos hayan irrogado por culpa o negligencia grave en el ejercicio de sus cargos".

La Constitución de 1978, en su artículo 106.2, elevó a rango constitucional el principio de responsabilidad directa y objetiva de la Administración, al reconocer el derecho de los ciudadanos a ser indemnizados por los daños que sufran en sus bienes y derechos a consecuencia del funcionamiento de los servicios públicos, excepto en los casos de fuerza mayor. Por la Ley de ------ de Régimen Local de 2 de abril, Ley 7/1985, BOE $n^{\circ} 80$ de 3 de abril, en su artículo 54 se reconoce el derecho de los particulares a

\footnotetext{
414 Reglamento de Expropiación Forzosa de 26 de abril de 1957, artículo 133.1º que dice: “Dará lugar a indemnización toda lesión que los particulares sufran en sus bienes o derechos siempre que sean susceptibles de ser evaluados económicamente, en los supuestos a que se refieren los artículos 120 y 121 de la Ley, con arreglo al procedimiento seguido en los artículos siguientes”.

Este artículo fue derogado por el Real Decreto 429/1993 de 26 de marzo, por el que se aprueba el Reglamento de los procedimientos de las Administraciones Públicas en materia de responsabilidad patrimonial.
}

Eduardo García de Entenía y Santiago Muñoz Machado, Código de las Leyes Administrativas, Ed. Thomson-CivitasAranzadi- Navarra 2005, pag 877. 
ser indemnizados por responsabilidad objetiva y directa de las entidades locales como consecuencia del funcionamiento de los servicios públicos o de la actuación de sus autoridades, funcionarios o agentes, en los términos establecidos en la legislación general sobre responsabilidad administrativa.

\subsection{LA RESPONSABILIDAD OBJETIVA $Y$ DIRECTA DE LA ADMINISTRACIÓN PÚBLICA}

La responsabilidad objetiva y directa de la Administración se contempla en el artículo 121 del Código Penal como subsidiaria, tipificada como delito doloso o culposo, en los daños causados por los funcionarios públicos, y como consecuencia de ello los daños causados por hechos de los profesores, que también son funcionarios. EL mencionado artículo habla de delitos dolosos o culposos, pero "la jurisprudencia lo ha interpretado de forma extensiva y se ha encaminado hasta una especie de responsabilidad objetiva del Estado que va más allá de los tradicionales parámetros marcados por la culpa in vigilando o culpa in eligendo para deslizarse por los campos marcados por la creación del riesgo o peligro, hasta llegar al principio de que, quien se aprovecha de las ventajas de una actividad o servicio debe soportar los cargos que de él se derivan, siempre que se dé una situación de dependencia entre el funcionario y el perjudicado" ${ }^{415}$. Quiere ello decir que la doctrina jurisprudencial reconoce la responsabilidad subsidiaria del Estado por las faltas, al darse una interpretación extensiva del precepto, pues si se aplicara este literalmente sólo se podría exigir responsabilidad al particular por delitos dolosos o culposos y tratándose de faltas sería necesario recurrir a la vía contencioso-administrativa ${ }^{416}$.

La STS (Sala de lo Penal) de 11 de marzo de 1997 (RJ-1997/1128) ha incluido la falta entre los supuestos en que existe responsabilidad civil subsidiaria del Estado y otros entes públicos, por ello dice Conde Pumpido : "Si bien es cierto que el artículo 121, referido a la responsabilidad civil subsidiaria del Estado y demás entes públicos, sólo

\footnotetext{
${ }^{415}$ Conde-Pumpido Ferreiro, Cándido, Código Penal Comentado, Editorial Bosch, Barcelona 2004, pag 388.

416 Atienza Navarro, op.cit, pags 276 y 277
} 
habla literalmente de delitos y no de faltas, no es menos cierto que ello no implica necesariamente su exclusión a esos efectos, pues el vocablo delito ha de entenderse como sinónimo de infracción penal, y así lo considera el Código vigente en varios de sus preceptos...... existiendo también el argumento de que si se incluyen de modo expreso los delitos culposos, con más razón deben incluirse las faltas dolosas. Por ello el vocablo delito que emplea el artículo 121 hay que entenderlo en pura lógica, como infracción penal, comprensiva, tanto de los delitos stricto sensu, como de las faltas" ${ }^{\prime 417}$.

Para la exigencia de responsabilidad por los daños causados en los centros docentes públicos hay que basarse en lo que dispone la Ley 30/1992 de 26 de noviembre sobre Régimen Jurídico de las Administraciones Públicas y Procedimiento Administrativo Común (LRJAP). En concreto el artículo 139.1 que dice: "Los particulares tendrán derecho a ser indemnizados por las Administraciones Públicas correspondientes, de toda lesión que sufran en cualquiera de sus bienes y derechos, salvo en los casos de fuerza mayor, siempre que la lesión sea consecuencia del funcionamiento normal o anormal de los servicios públicos".

Los titulares activos del derecho a ser indemnizado por las Administraciones Públicas son los "particulares", se refiere a algo propio o privativo de una persona o cosa o que le pertenece con singularidad. Aunque habitualmente el concepto "particulares" se ha opuesto a lo público, se debe de incluir dentro del mismo a las distintas Administraciones públicas que se vieren lesionadas como consecuencia del actuar de los Entes Públicos ${ }^{418}$.

El derecho a ser indemnizado por responsabilidad civil consiste en la transferencia o desplazamiento de la detracción patrimonial producida por el hecho dañoso hacia otro sujeto declarado obligado por la norma jurídica a reintegrar a la víctima en su primitiva situación económica. Se puede definir como la imputación a un sujeto de un hecho dañoso sufrido por otro sujeto, mediante la aplicación de un determinado criterio normativo en virtud del cual el sujeto declarado responsable está obligado al resarcimiento patrimonial del daño. Para simplificar lo que es la responsabilidad civil se

\footnotetext{
${ }^{417}$ Conde Pumpido, op.cit, pag 389

${ }^{418}$ Lliset Borrell, Régimen Jurídico, op.cit, pag 390.
} 
puede decir, que consiste solamente en la transferencia o desplazamiento de la incidencia del hecho dañoso de un patrimonio a otro ${ }^{419}$.

Se ha de dar en toda responsabilidad civil una relación de causa a efecto entre la acción u omisión y el hecho dañoso. En el presente artículo 139.1, esta relación o nexo causal se da en la expresión "ser consecuencia". La jurisprudencia utiliza con mayor aceptación dos sistemas para resolver sus problemas: el criterio de la equivalencia de las condiciones y el de la causalidad adecuada. El criterio de la equivalencia de las condiciones consiste en considerar como causa del daño todos los hechos o acontecimientos sin los que el daño no se habría producido. El de la causalidad adecuada trata de seleccionar entre los distintos hechos, el que aparece como la causa generadora del daño ${ }^{420}$.

La atribución a la Administración del hecho causante de la lesión se contempla en la frase "siempre que la lesión sea consecuencia del funcionamiento normal o anormal de los servicios públicos". En cuanto a los actores físicos de la voluntad administrativa, el elemento relacional con capacidad atributiva no sólo se refiere a sus órganos o a los funcionarios públicos, sino que abarca a toda clase de empleados, incluyendo los de régimen laboral y a los gestores ocasionales u oficiosos que se encargan de prestar el servicio público. Puede decirse que la simple relación con un servicio de la Administración y su integración en ella, dan lugar a la atribución del daño de una forma efectiva, por la simple prestación del servicio ya funcione de manera normal o anormal $^{421}$.

En cuanto a los funcionarios públicos y por tanto a los profesores para exigirles responsabilidad hay que estar a lo que dispone el artículo 145.2 (LRJAP y PAC) que dice: "La Administración correspondiente, cuando hubiere indemnizado a los lesionados, exigirá de oficio a sus autoridades y demás personal a su servicio la responsabilidad en que hubieran incurrido por dolo, o culpa o negligencia graves, previa instrucción del procedimiento que reglamentariamente se establezca. Para la exigencia de dicha

\footnotetext{
${ }^{419}$ Leguina Villa, Jesús, op.cit, pags 128 y 129

${ }^{420}$ Ramón Parada, Régimen Jurídico de las Administraciones Públicas y Procedimiento Administrativo Común, Ed. Marcial Pons, Madrid 1993, pag 432

${ }^{421}$ Francisco Lliset Borrell, Régimen Jurídico, op.cit, pags 396 y 397
} 
responsabilidad se ponderarán entre otros, los siguientes criterios: el resultado dañoso producido, la existencia o no de intencionalidad, la responsabilidad profesional del personal al servicio de las Administraciones públicas y su relación con la producción del resultado dañoso".

Este artículo trata de la acción de regreso que corresponde exigir a la Administración contra sus autoridades y empleados cuando ha indemnizado a los particulares por la lesión sufrida en sus bienes o derechos, por una acción u omisión de aquellos interviniendo dolo, culpa o negligencia grave. El particular tiene que ser indemnizado antes por la Administración para poder repercutir contra el funcionario responsable, esto quiere decir que dicha Administración no puede financiar la indemnización que paga a terceros perjudicados con la indemnización que pudiera exigir previamente al funcionario responsable ${ }^{422}$.

La responsabilidad que se exige a los funcionarios es a título doloso o de culpa o negligencia grave, quedando fuera de este régimen los supuestos dañosos ocasionados por culpa leve o levísima, los cuales son asumidos por la Administración y que el legislador considera propios y debidos al propio actuar administrativo o burocrático ${ }^{423}$. La Administración goza de un considerable grado de discrecionalidad por lo que se establece al final del precepto al hablar del resultado dañoso producido, existencia o no de intencionalidad, la responsabilidad profesional del personal y su relación con la producción del hecho dañoso; al ser tenidas en cuenta estas circunstancias se altera la naturaleza de la acción de regreso. Con esta solución existe el riesgo de dar un trato desigual y discriminatorio entre los funcionarios que atraviesan la misma situación.

Para exigir responsabilidad a los docentes ha de hacerse de acuerdo con lo que dispone el artículo 1904, apartado segundo, en el que se exige dolo o culpa grave. Además al decir "en el ejercicio de sus funciones que fuesen causa del daño", se hace referencia a la necesidad de que haya relación de causa a efecto entre la conducta del docente y el hecho dañoso producido. Este tema ha sido tratado en el capítulo anterior por lo que no insistiré más sobre ello.

\footnotetext{
${ }^{422}$ Ramón Parada, Régimen Jurídico, op.cit, pags 450 y 451

${ }^{423}$ Pascual Sala Sánchez, Comentarios de la Reforma del Procedimiento Administrativo, Ed. Tirant lo Blanch, Valencia, 1999, pags 608 y 609
} 


\subsection{JURISDICCIÓN COMPETENTE SOBRE LA RESPONSABILIDAD CIVIL EN LOS CENTROS PÚBLICOS DE EDUCACIÓN}

Desde que se publicó la LRJAP se estableció que la Jurisdicción Contencioso Administrativa era la competente para conocer de cualquier litigio sobre indemnización contra la Administración, fueran de Derecho privado o de Derecho público.

En la Ley 29/1998, de 13 de julio, Reguladora de la Jurisdicción Contenciosoadministrativa (LRJCA) en su artículo 2.e dice: "La responsabilidad patrimonial de la Administración pública, cualquiera que sea la naturaleza de la actividad o el tipo de relación de que derive, no pudiendo ser demandada aquélla por este motivo ante los órdenes jurisdiccional civil o social". A pesar de no permitir la demanda a la Administración ante los órdenes jurisdiccional o social, no se excluiría, que sea demandada junto al particular posiblemente corresponsable ante el orden jurisdiccional civil o social, pues al no preverse que el particular pueda ser demandado ante el orden jurisdiccional contencioso-administrativo, lo contrario dividiría la continencia de la causa, pues esta unidad resulta indispensable en todo juicio ${ }^{424}$.

Con la promulgación de la LRJCA, al ir acompañada de la correspondiente reforma de la Ley Orgánica del Poder Judicial (LOPJ), ha solucionado esta cuestión en el ámbito educativo, estableciendo la competencia de los Tribunales contenciosoadministrativos para conocer de las demandas resarcitorias entabladas contra los sujetos privados que hubieran concurrido en la producción del daño, junto a la Administración y lo contempla en el último inciso del artículo 9.4 que dice: “También será competente este orden jurisdiccional si las demandas de responsabilidad patrimonial se dirigen, además contra las personas o entidades públicas o privadas indirectamente responsables de aquellas" ${ }^{425}$.

De esta forma mediante el artículo 9.4 LOPJ, si el perjudicado cree que algún sujeto privado, tales como los padres, han contribuido a la causación del daño por el

\footnotetext{
424 Jose María Ayala Muñoz, Comentarios a la Ley de la Jurisdicción Contencioso Administrativa de 1998, Ed. Aranzadi, Pamplona 1998, pag 131

425 Atienza Navarro, Ma Luisa, op.cit, pags 300 y 301
} 
alumno, puede dirigirse contra ellos por la vía contencioso-administrativa, si además de demandar a la Administración, desea reclamarles también a estos sujetos privados. Así se ha resuelto el problema que suscitaba la concurrencia de algún particular junto a la Administración, reconociéndose de forma clara para resolver estos asuntos que se han de conocer ante la jurisdicción contencioso-administrativa, de esta manera se impide a los particulares reclamar con la intención de conseguir que el caso se resuelva por la jurisdicción civil.

El artículo 9.4 LOPJ ha facilitado mucho las cosas para que las pretensiones de indemnización de perjudicados frente a la Administración, cuando ésta concurra con sujetos privados se resuelvan ante la jurisdicción contencioso-administrativa. El mencionado artículo en su apartado segundo dice: "Si a la producción del daño hubieran concurrido sujetos privados, el demandante deducirá también frente a ellos su pretensión ante este orden jurisdiccional", es decir, ante la jurisdicción contencioso administrativa, pero se da la circunstancia de que las compañías de seguros no han contribuido a la producción del daño. Las compañías de seguros prestan una cobertura importante en el sector educativo, pues los centros tanto públicos como privados disponen obligatoriamente de seguros de responsabilidad civil para hacer frente a sus posibles obligaciones resarcitorias. Por ello si esas compañías aseguradoras no han contribuido a la producción del daño, parece que no les es aplicable el artículo 9.4 LOPJ, con lo que habrá que aplicarles la jurisdicción civil ${ }^{426}$.

\subsection{FUNCIONAMIENTO NORMAL DEL CENTRO PÚBLICO DE EDUCACIÓN}

La Administración responde de los daños ocasionados por el funcionamiento normal de los servicios públicos, es decir, de los daños incidentales o eventuales causados por acciones lícitas de la Administración, basándose en el criterio del riesgo

426 Ibidem, pag 305 
creado por la misma en cuanto actividad organizada potencialmente dañosa para terceros ( cuins commoda eins incommoda) ${ }^{427}$.

Los Tribunales en general se han mostrado contrarios a la hora de condenar a la Administración Pública por los daños derivados del funcionamiento normal del servicio público educativo, habiendo exigido algún tipo de culpa del personal del centro o del funcionamiento del servicio ${ }^{428}$.

Esta idea de exigir alguna culpa por parte de los Tribunales, en la década de los años noventa se produjo un cambio en el sentido de no ser necesaria la culpa para exigir responsabilidad a la Administración por el funcionamiento normal del servicio educativo, pasando a una responsabilidad objetiva en la que no se tiene en cuenta el criterio de la culpa, llegándose a exigir indemnizar a la Administración por casos fortuitos $^{429}$. Una sentencia ilustrativa de ello es la STS de 26 de febrero de $1998^{430}$, en su Fundamento de Derecho Primero dice: "que se da una ausencia del factor de previsión del artículo 1105 CC por caso fortuito que queda suficientemente cobijado, además en la posibilidad de que la responsabilidad patrimonial sea exigible sobre la base también del funcionamiento normal de los servicios públicos". Por ello desestima el recurso de los Servicios Jurídicos de la Generalitat de Cataluña y obliga a ésta a indemnizar a los padres de la menor por caso fortuito y funcionamiento normal del servicio educativo.

Los daños causados en los supuestos de funcionamiento normal son aquellos daños incidentales que se producen aunque se haya observado la diligencia exigible y se hayan cumplido las prescripciones técnicas del servicio de que se trate. Ello quiere decir que el criterio de imputación no puede basarse en la culpa, sino en el del riesgo que para terceros supone la actividad potencialmente dañosa desarrollada por la Administración. Este criterio del funcionamiento "normal" permite imputar a la Administración los daños propios de su actividad de prestación y comprende los casos fortuitos. Quedan excluidos aquellos daños que sean fruto de riesgos inherentes al ámbito de actividad de que se trate y de los que, en su caso, el perjudicado hubiese sido convenientemente

\footnotetext{
${ }^{427}$ Leguina Villa, Jesús, op.cit, pag 345

${ }^{428}$ Atienza Navarro, Ma Luisa, op.cit, pag 261

429 Ibidem, pag 262

${ }^{430}$ STS de 26 de febrero de 1998, Sala de lo Contencioso-Administrativo, Sección 6 a (RJ-1998/1795)
} 
informado. Una sentencia aplicable a este caso es la STS $\left(3^{a}\right)$ de 10 de febrero de $1998^{431}$, en ella se trata de un niño que nació ciego, a pesar de que la actuación de los médicos fue totalmente correcta, por ello en su Fundamento de Derecho Octavo, dice que no se puede aplicar el artículo 139 de la Ley 30/1992, ni el artículo 106.2 de la Constitución, al no darse relación de causalidad entre la actuación médica y la enfermedad del menor. Por ello el recurso de los padres queda desestimado y no se produce indemnización ${ }^{432}$. Para imputar responsabilidad a la Administración Pública es necesario que se cumplan una serie de requisitos: que el hecho sea imputable a la Administración; se trate de una lesión o perjuicio antijurídico efectivo, evaluable económicamente e individualizado con relación a una persona o grupo de personas, y finalmente que haya una relación de causalidad entre la actividad administrativa y el daño producido. Si falta alguno de ellos, como en la sentencia anterior el de causalidad, no hay lugar a indemnización.

Cada vez son más los autores que en los últimos años proponen limitar esa responsabilidad tan amplia como es la responsabilidad por funcionamiento "normal" de la Administración, por los efectos negativos que puede provocar ${ }^{433}$. Con la creciente intervención del Estado en la vida moderna, con un sistema de responsabilidad tan amplio, puede comportar un aumento excesivo de los gastos públicos y una correlativa subida de la presión fiscal, que podrían alcanzar límites intolerables ${ }^{434}$. Al tratarse de un sistema de responsabilidad civil con un enorme potencial indemnizatorio que podría hacer quebrar el sistema de prestación de determinados servicios públicos (como la sanidad), o elevar las primas de las pólizas de seguros de responsabilidad civil hasta límites excesivos o inasumibles, se están buscando mecanismos que delimiten una frontera de los daños indemnizables ${ }^{435}$.

Para evitar estos problemas que origina el sistema tan amplio y cuantioso del artículo 139.1 LRJAP han inducido al legislador a limitar sus contornos. Para ello se ha promulgado la Ley 4/1999, de 13 de enero, con la que se modifica el artículo 141.1

\footnotetext{
431 STS (3 $\left.3^{\mathrm{a}}\right)$ de 10 de febrero de 1998 (RJ-1998/1452)

${ }^{432}$ Fernando Reglero Campos, Lecciones, op.cit, pag 494

433 Atienza Navarro, $M^{\mathrm{a}}$ Luisa, op.cit, pag 265 y ss

${ }^{434}$ Leguina Villa, Jesús, op.cit, pag 118, nota 39

435 Reglero Campos, Fernando, op.cit, pag 494
} 
LRJAP, añadiendo un párrafo que dice : "No serán indemnizables los daños que se deriven de hechos o circunstancias que no se hubiesen podido prever o evitar según el estado de los conocimientos de la ciencia o de la técnica existentes en el momento de la producción de aquellos, todo ello sin perjuicio de las prestaciones asistenciales o económicas que las leyes puedan establecer para estos casos". Este párrafo ha suscitado grandes polémicas al relacionarle con el artículo 106.2 de la Constitución, además de que el artículo 139.1 habla de indemnizar "siempre que la lesión sea consecuencia del funcionamiento normal o anormal de los servicios públicos". El artículo 106.2 de la Constitución, exonera de responsabilidad a la Administración por los casos de fuerza mayor, pero no por caso fortuito. El caso de fuerza mayor es por causas no sólo imprevisibles, sino además inevitables e irresistibles (ris cui resisti non potest) y se dan en el ámbito o círculo externo de la obligación; mientras que el caso fortuito es el acontecimiento que no puede preverse, pero que previsto pudiera haber sido evitado y tiene lugar dentro de la empresa o círculo afectado por la obligación.

A partir de la publicación de la Ley 4/1999, la Administración no indemniza por caso fortuito, ello se puede ver en las sentencias que tratan de niños de corta edad en las que se ocasiona un daño a otro, de forma rápida e imprevista, sin que se pueda imputar fallo al personal docente o a la organización del centro, se consideran caso fortuito y quedan sin indemnización.

\subsection{FUNCIONAMIENTO ANORMAL DEL CENTRO DOCENTE PÚBLICO DE EDUCACIÓN}

El funcionamiento anormal de los servicios públicos prestados por la Administración comprende no sólo las conductas ilegales llevadas a cabo por el personal a su servicio, sino también los supuestos en los que estos daños se hayan causado como consecuencia del funcionamiento de estos servicios públicos por debajo de los niveles 
exigibles, porque no se hayan adoptado las medidas de cuidado requeridas o se hayan incumplido los deberes de vigilancia y fiscalización ${ }^{436}$.

La Administración responde por el funcionamiento anormal del servicio público educativo por el comportamiento negligente de los profesores, o de cualquier otro miembro del personal del centro, que contribuya a la causación del daño por el alumno, así como por el defectuoso funcionamiento del servicio, ya sea por la mala organización o por otras deficiencias. En general puede decirse que los jueces a la hora de hacer indemnizar a la Administración, se fijan principalmente en la existencia de alguna anormalidad en su funcionamiento ${ }^{437}$.

La STS de 10 de marzo de $1994^{438}$, es un ejemplo de funcionamiento anormal del servicio público educativo, trata de un accidente sufrido por un menor en un Centro de Formación Profesional. En su Fundamento de Derecho Segundo se dice que la lesión física que sufrió el alumno, le produjo la amputación de los dedos segundo y tercero de la mano derecha a la altura de la primera falange, lo que fue directa consecuencia del funcionamiento del servicio público prestado por un Centro dependiente de la Administración educativa. La clase se habría de impartir al mencionado alumno a través de un Profesor del Centro Educativo que tendría que velar con la diligencia debida, de que aquel y sus compañeros, utilizaran las máquinas con las precauciones necesarias ya que dichos alumnos acudían por primera vez a tales enseñanzas y habiéndose de tener en cuenta su nula experiencia y tratarse de menores de edad. Dicha cautela del profesor deberá de extremarse porque la máquina donde se produjo el accidente, la alimentación eléctrica a los tornos paralelos en el taller, se realizaba a través de una línea común, con derivaciones desde una caja de registro existente frente a cada máquina, sin poderse desconectar cada desviación individualmente, de forma que sólo se puede desconectar a la vez todo el grupo de tornos paralelos, desde un único interruptor instalado para dicha línea en el cuadro general de protección, mando y control existente en el taller, además tal instalación no se ajustaba a lo dispuesto en el Reglamento Electrotécnico de Baja

\footnotetext{
${ }^{436}$ - Reglero Campos, Fernando, op.cit, pag 493

- Lequina Villa, Jesús, op.cit pags 344 y 345

437 Atienza Navarro, $M^{\mathrm{a}}$ Luisa, op.cit, pags 254 y ss

${ }^{438}$ STS Sala de lo Contencioso- Administrativo, Sección 3ª , de 10 de marzo de 1994 (RJ-1994/2427)
} 
Tensión y sus instrucciones técnicas complementarias. Por otra parte los tornos paralelos existentes no disponían de doble mando para su manejo, para que el enseñante pudiera controlar el mismo y, por último la caja de engranajes se podía abrir con el torno en marcha, sin impedir o bloquear el funcionamiento de cada una de las máquinas. De todo ello se infiere que la maquinaria no ofrecía tanto para los enseñantes como para los alumnos, la seguridad técnica, que por tratarse de menores inexpertos demandaba.

De lo expuesto se deduce que se cumplen los requisitos para indemnizar a los padres del alumno del artículo 139 LRJAP y PAC, pues no se trata de un caso de fuerza mayor, es consecuencia de un funcionamiento anormal del servicio público educativo, es un hecho antijurídico, se da un nexo causal entre el servicio prestado y el hecho dañoso producido; el daño es efectivo, evaluable económicamente e individualizado con relación a una persona o grupo de personas. Por todo ello, se condena a la Administración a indemnizar a los padres del alumno lesionado.

\subsection{EXENCIÓN DE RESPONSABILIDAD DEL TITULAR DEL CENTRO DOCENTE}

Respecto a los centros públicos para exigir responsabilidad a los titulares del centro docente no se emplea como en los de titularidad privada el último inciso del artículo 1903 CC que trata de la diligencia de un buen padre de familia para prevenir el daño. En los centros públicos se responde objetivamente por los daños causados por el funcionamiento normal o anormal de los servicios públicos, del artículo 139 LRJAP, con independencia de toda culpa individual o institucional. Se debe de tener en cuenta que los Tribunales civiles son tendentes a aplicar los preceptos civiles, en los casos acontecidos en centros públicos. El TS ha excluido de responsabilidad en supuestos en los que los daños derivan de acciones imprevisibles ejecutadas por menores, sobre otros menores utilizando objetos de uso normal, con la vigilancia adecuada y sin que en el agresor se dieran circunstancias que exigieran medidas especiales de vigilancia ${ }^{439}$. En

\footnotetext{
439 - De la Rosa Cortina, Jose Miguel, op.cit, pag 233 y ss

- Atienza Navarro, M ${ }^{\mathrm{a}}$ Luisa, op.cit, pags 184 y 185
} 
consecuencia, tiene que tratarse de casos en que no se dé relación de causalidad entre la Administración y el daño producido por el menor, como sucede con los casos fortuitos, que ya no tienen que ser indemnizados en virtud de la Ley 4/1999 de 13 de enero.

Una sentencia aplicable al caso es la del T.S. de 21 de noviembre de $1990^{440}$, en ella trata de un alumno que agredió a otro en el comedor de una guardería con un tenedor produciéndole la pérdida de un ojo. La profesora estaba presente y los vigiló de forma correcta por ello no resulta imputada. Los hechos ocurrieron de forma súbita e inopinada, el hecho era imprevisible dentro de un orden cotidiano y normal. El niño no tenía antecedentes que exigieran una vigilancia especial. Por ello se exonera a la profesora y a la guardería de indemnizar al tratarse de un caso fortuito.

Otra sentencia parecida es la del T.S. de 10 de marzo de $1997^{441}$, trata de una niña de seis años que hallándose en el colegio fue lesionada en presencia de un profesor del Centro, por otro menor, por haberle introducido en el ojo izquierdo un lápiz o bolígrafo. No hubo negligencia de la profesora que dispuso de una alumna mayor para reforzar la vigilancia sobre los menores en la clase de dibujo, ni del Centro. Los hechos se produjeron encontrándose presente la profesora de dibujo, por una discusión entre ellos sin que la profesora se apercibiera de lo sucedido, hasta haber sido informada con posterioridad. De todo ello se deduce que los hechos tuvieron que producirse de manera rápida e inopinada, difícilmente previsibles dentro de un orden cotidiano o normal, por lo que resultaba imposible imputar a la profesora, ni al Colegio de una conducta negligente. No se condena al Centro por no darse relación o nexo de causalidad entre el daño producido y la conducta de la profesora, ni de la organización del Centro. Se trata de unos hechos imprevisibles, por su rapidez con que se produjeron, tratándose en mi opinión de un caso fortuito.

\footnotetext{
440 STS de 21 de noviembre de 1990 (RJ-1990/9014)

441 STS de 10 de marzo de 1997 (RJ-1997/2483)
} 


\section{CAPÍTULO III: RESPONSABILIDAD POR LA \\ VIOLENCIA DE LOS MENOES EN LOS CENTRO \\ DE ENSEÑANZA NO UNIVERSITARIOS}

\section{GENERALIDADES}

La violencia en los centros de enseñanza es un problema que está de relieve constantemente en los medios de comunicación, no sólo en España sino en los demás países. Desgraciadamente además de mermar la eficacia del sistema educativo, se desarrolla con una gran crueldad entre los menores, habiéndose llegado a provocar hechos luctuosos.

Se trata de un conflicto o trastorno que no es nuevo, al haber existido siempre, pero ha sido en las tres últimas décadas cuando se ha desarrollado de forma extraordinaria; lo que ha dado lugar a redactar protocolos de actuación para su prevención por parte de los encargados del sistema educativo, así como a su estudio por parte de pedagogos, psicólogos, sociólogos y demás personal con afinidades sobre esta cuestión.

En el problema se encuentran involucradas varias personas e instituciones tales como los padres, los alumnos menores de edad, los profesores, las autoridades educativas, los jueces y la excesiva violencia que transmiten los medios de comunicación y las modernas tecnologías.

Los padres de unos años a esta parte son demasiado permisivos con sus hijos, dejándoles hacer lo que más les gusta, sin poner ningún límite a su conducta, lo que va en detrimento de su educación, y da lugar a que no obedezcan a los profesores. Entienden que la educación es cosa del colegio que es donde le deben enseñar, lo que no es del todo exacto, pues la educación básica sobre comportamiento debe enseñarse fundamentalmente en el ámbito de la familia. 
Con respecto a los profesores se encuentran desbordados por recibir insultos e incluso agresiones por parte de los menores, llegando a sufrir trastornos de ansiedad y depresiones. Piensan que la educación debe aprenderse en primer lugar en la familia y que su función es instruir más que educar ${ }^{442}$. Personalmente creo que la educación se debe de realizar la mayor parte en la familia y otra parte en el centro escolar, quedando la instrucción como algo propio o específico del colegio para adquirir los conocimientos que se imparten en el mismo. Los profesores se sienten a veces desprotegidos ante el director del centro o las autoridades educativas al no hacerles caso sobre los problemas que tienen al impartir sus enseñanzas.

En cuanto a los directores y autoridades educativas tratan de que no salgan a la luz estos hechos, pues a nadie le gusta que su colegio aparezca en los medios de comunicación, por lo que supone de desprestigio del mismo. Por otra parte a veces los medios materiales y humanos son insuficientes para hacer frente a esta problemática violenta que perturba la eficacia del sistema educativo. De la lectura de las sentencias se deduce que no se toman medidas drásticas sobre los alumnos mediante expulsiones y demás, que es propio de directores y autoridades tratando de minimizarlos lo que va en detrimento de la autoridad de los profesores.

Por lo que se refiere a los padres de los menores tratan de protegerlos demasiado y echan la culpa de todo a los profesores, llegando en algunos casos a proferir amenazas verbales e incluso a realizar agresiones físicas sobre ellos.

A los jueces se les reprocha el que las penas a los menores son demasiado benignas, por lo que se considera necesario un endurecimiento de las mismas sobre todo cuando en el acoso escolar se producen agresiones físicas e incluso llegar al suicidio del menor acosado.

Puede decirse que los medios de comunicación transmiten una excesiva violencia, que los menores al no hallarse completamente formados debido a su edad la asimilan

\footnotetext{
${ }^{442}$ Educar viene del latin "e+ducere=guiar” y quiere decir: enseñar, perfeccionar las facultades intelectuales y morales de una persona. Enseñar las normas de urbanidad y cortesía.

Instruir viene del latín “instructio” y quiere decir: Conjunto de conocimientos.
}

Educación, enseñanza. Reglas o advertencias. Órdenes.

Diccionario Etimológico Anaya de la Lengua, Ediciones Anaya, Madrid 1981 
mal, pues piensan que es correcto realizar esas malas conductas y si a ello unimos los nuevos medios tecnológicos de móviles, ordenadores y demás, a través de los cuales se puede acosar a alguien, el resultado es, que la violencia se hace cada vez más intensa y persistente.

\subsection{VIOLENCIA DE LOS ALUMNOS SOBRE LOS PROFESORES}

En la educación se ha pasado en las últimas décadas de un modelo de profesor que era quizás demasiado autoritario a otro que tiene muy poca autoridad por diversos motivos que veremos a continuación.

Los padres han dejado la educación de sus hijos exclusivamente en manos de los profesores, sin preocuparse ellos de colaborar, pues una parte importante de la educación tiene que darse en la familia. La labor de los profesores abarca tareas educativas, pero creo que es más de instruir a los alumnos, de impartir conocimientos sobre diversas materias y que los alumnos los asimilen progresivamente. De poco sirve que un profesor explique una determinada materia, si el alumno menor no tiene hábitos de disciplina, orden, obediencia, atención y respeto a los profesores y compañeros. Estos valores se deben de inculcar dentro de la propia familia, para que el alumno llegue al colegio predispuesto a obedecer a los profesores y a respetar a los demás alumnos.

Por otra parte se da una indiferenciación de roles con un igualitarismo entre alumno y profesor, cosa verdaderamente inadmisible pues es algo que va en contra de los principios de la sociología, ya que un profesor no es en modo alguno un colega del alumno. El profesor tiene que encargarse de impartir las enseñanzas que marque el programa de estudios, para ello debe de hallarse en disposición de dar la clase en su hora asignada. El alumno como es lógico tiene que prestar la atención debida, para asimilar las enseñanzas que le son impartidas.

Se da una gran dificultad para poder sancionar al alumno. Las sanciones son muy ligeras dando lugar a que los alumnos vean que "aquí no pasa nada" y así hacen lo que 
quieren. Puede decirse que nos podemos hallar ante una escuela sin normas en la que está prohibido prohibir ${ }^{443}$.

La violencia contra los profesores se incrementa en el paso de primaria a secundaria, de tal forma que el hostigamiento verbal y las coacciones se duplican; la intimidación y las amenazas físicas se triplican. La tasa de agresiones se multiplica por cinco.

El 75\% de los actos violentos contra profesores son realizados por alumnos. Como media un $80 \%$ de los profesores de E.S.O. refieren agresiones verbales, insultos y vejaciones. La mayor problemática se da en $3^{\circ}$ y $4^{\circ}$ de la ESO, por la mayor edad de los alumnos, al ser adolescentes se vuelven más conflictivos y rebeldes, lo que da lugar a que uno de cada cuatro profesores sea amenazado físicamente y uno de cada cinco profesores reciba agresiones físicas y robos. Los tipos de actos violentos contra los profesores consisten en hostigamiento verbal en un $60 \%$, intimidación $15 \%$, agresiones y robos $11 \%$, amenazas físicas $9 \%$, coacciones y chantajes un $6 \%$. Todo ello hace que los profesores en torno a un 40\% sufra trastornos depresivos y además deseen abandonar la profesión $^{444}$.

Un caso aplicado al tema tratado se contempla en la Sentencia de la S.A.P de Lugo de 9 de abril de $2002^{445}$, trata de un caso en el que dos menores Roberto y Gerardo se pusieron de acuerdo para rajar las ruedas de los vehículos de sus profesoras, para ello Roberto vigiló y los dos procedieron a llevar a cabo el hecho mencionado. Los actos realizados encajan en la coautoría, debiendo el menor Roberto y sus padres indemnizar a las demandantes en los daños causados, sin perjuicio de las facultades de repetición de la mitad frente al otro menor y representantes legales.

El fallo estima íntegramente la demanda planteada por Doña Susana y Doña María Luisa, profesoras del Centro frente al menor Roberto y sus representantes legales,

\footnotetext{
${ }^{443}$ Estudio Cisneros VIII, Violencia Contra Profesores, en la enseñanza pública de la Comunidad de Madrid, Instituto de Innovación Educativa y Desarrollo Directivo. Director, Prof. Iñaki Piñuel. Ficha Técnica, conjunto de 47000 profesores de centros públicos de la Comunidad de Madrid, realizado en los meses de marzo y abril de 2006, sobre una muestra de 2100 profesores pertenecientes a 237 centros públicos, pags 17 y ss

${ }^{444}$ Ibidem, pags 67 y ss

${ }^{445}$ S.A.P. de Lugo de 9 de abril de 2002 (Sección $1^{\text {a) }}$ ), no 74 (JUR-2002/153957)
} 
condenando solidariamente a los mismos a indemnizar a Doña Susana en la cantidad de 22.581 pts y a Doña María Luisa en 8.120 pts. Una vez que Roberto y sus padres hayan indemnizado a las profesoras tienen derecho de repetición sobre el menor Gerardo y sus padres por la mitad de lo indemnizado en virtud de las reglas de la solidaridad, en las que cuando uno paga el total y tiene derecho de regreso o repetición contra los demás.

Otra sentencia, ésta en una institución tutelar de menores es la S.A.P de Lleida de 11 de marzo de $2002^{446}$, en ella trata de un menor que agredió a una profesora en una clase de cocina en la que los alumnos tienen a su disposición instrumentos o utensilios peligrosos como el cuchillo con el que agredió a la profesora. La Generalitat de Catalunya, a través de la Dirección General de Atención al Menor, tiene la tutela sobre el menor, el cual es bastante conflictivo, por sus impulsos agresivos. La Generalitat pretende trasladar la responsabilidad sobre la profesora, pero ella no es la titular de la tutela, guarda, custodia y formación del menor, pues, se halla sometida a las instrucciones, supervisión, dirección y vigilancia de quien tiene asumida la tutela que es la Generalitat a través de su Dirección General de Atención al Menor y por tanto la responsable es la Generalitat de forma solidaria con el menor.

Un caso ilustrativo de esta violencia es el asesinato de un profesor en el Colegio Joan Fuster de Barcelona, en el que un menor de trece años asesinó a un profesor con una ballesta. El menor padecía una enfermedad que le obligaba a medicarse, además de haber estado en tratamiento psicológico, un diagnóstico que no constaba en su expediente académico y que el propio agresor ha confesado tras el suceso. Por ello la Generalitat exigirá para 2016 un informe del pediatra para ingresar en los centros ${ }^{447}$.

\subsection{VIOLENCIA DE LOS PROFESORES CONTRA LOS ALUMNOS}

Este tipo de violencia es muy poco frecuente, pues se trata de casos poco habituales en los que el profesor pierda su compostura ante la conducta de un alumno. Es poco probable que un profesor pueda maltratar de obra a un alumno en estos

\footnotetext{
${ }^{446}$ S.A.P de Lleida (Sección 2a) n 2, de 11 de marzo de 2002 (JUR-2002/118814)

447 Diario El Mundo, miércoles 22 de abril de 2015, pags 32 y 33
} 
tiempos, algo frecuente por otra parte hace varias décadas. Se dan sentencias en las que se exige responsabilidad a profesores por abusos sexuales sobre alumnos. Un caso de maltrato de obra se da en la S.A.P de Salamanca de 12 de febrero de $1998^{448}$, en ella el Juzgado de Instrucción n ${ }^{\circ} 4$ de Salamanca condena al profesor en virtud del art.617.2 del Código Penal, por malos tratos de obra sin causar lesión. En su Fundamento de Derecho Segundo, se dice que el acto de golpeo o maltrato, no justificado en forma bastante para llegar a eliminar la antijuridicidad propia del acto, en tanto el bien jurídico protegido para el tipo no es otro que la dignidad personal en el sentido contemplado por el artículo 15 de la C.E. En su Fundamento de Derecho Tercero, la Audiencia, rebaja la condena impuesta por el Juzgado $\mathrm{n}^{\circ} 4$, por considerarla excesiva, a diez días de multa con mantenimiento de la cuota de cinco mil pesetas en ella establecida.

Otra sentencia ésta del Tribunal Supremo de 21 de febrero $2000^{449}$, sobre un caso de abusos sexuales de un profesor, en una clase de música, a un menor de 15 años de edad, en ella se dice que el profesor, en la clase que le daba al menor de instrumento llamado requinto, en dos clases semanales de veinte minutos cada una, cometió abusos sexuales con el menor, prevaliéndose de su autoridad como profesor.

En su Fundamento de Derecho Séptimo, la Sala calificó los hechos como abuso sexual sin consentimiento, cuando en realidad se trata de un abuso sexual con prevalimiento como proponía el Ministerio Público en su calificación alternativa, sancionable en el artículo 182.1 ${ }^{\circ}$ del Código Penal de 1995, pero en el último inciso se establece una pena de uno a seis años de prisión para los supuestos de abuso de superioridad. El prevalimiento es manifiesto al tratarse de un profesor maduro que se aprovecha de su condición docente ante la temprana edad del menor de 15 años de edad para abusar sexualmente del mismo, coartando con su autoridad la libertad del menor.

Un caso más sobre abuso de profesor sobre menor, es el que se ha dado en una clase de Cuarto de Primaria del Colegio Virgen de la Vega de la localidad cacereña de Moraleja, el hecho fue cometido por el profesor sobre un menor al atarle de pies y brazos con cinta de embalar, el alumno tiene nueve años, es hiperactivo y con déficit de

\footnotetext{
448 S.A.P de Salamanca n ${ }^{\circ}$ 27, de 12 de febrero de 1998, Sección Penal (ARP-1998/462)

449 STS de 21 de febrero de 2000 (Sala de lo Penal), nº 223, Recurso nº 4932 (RJ-2000/875)
} 
atención. El profesor según el artículo sigue dando clase y la Junta de Extremadura ha incoado un expediente disciplinario al profesor. El Juzgado de Primera Instancia e Instrucción n ${ }^{\circ} 2$, de Coria, Cáceres, investiga al docente por un posible delito contra la integridad moral ${ }^{450}$.

\subsection{VIOLENCIA DE LOS PADRES DE LOS ALUMNOS SOBRE LOS PROFESORES}

Los padres ejercen una sobreprotección sobre sus hijos dándoles la razón en todo, en contra de los profesores, de esta forma si el alumno suspende por su propia culpa, por no realizar sus deberes de estudio, por no tener constancia en sus tareas educativa, inmediatamente descarga su culpa, su frustración, sobre el profesor, afirmando que "le tiene manía" u otras frases por el estilo.

Después, el padre se presenta en el colegio para protestar ante el profesor por la supuesta injusticia que se ha cometido con su hijo, todo ello con malos modos, amenazas y coacciones verbales que a veces se transforman en físicas, todo ello muy desagradable para el profesor. En algunas ocasiones en presencia del propio alumno, lo que da lugar a un desprestigio del profesor y a que el alumno siga sin rendir en el estudio, así como insultando y amenazando al mismo.

Otras veces el propio alumno le amenaza al profesor con frases como: "va a venir mi padre y te vas a enterar, te va a pegar dos hostias", o por ejemplo: "Ten cuidado, sé dónde vives"; o también: "Cuando salgas a la calle mira hacia atrás". Ante este tipo de amenazas los profesores se sienten frustrados; no se encuentran en disposición de dar la clase por no haber silencio, orden ni disciplina; ello da lugar a que tengan depresiones e incluso opten por un cambio de destino para impartir sus clases en otro colegio ${ }^{451}$.

\footnotetext{
${ }^{450}$ El Mundo, martes 28 de abril de 2015, pag 34, artículo firmado en Mérida por D. Vigario, P. Simón y O.R. Sanmartín.

451 Diario El Mundo, Domingo 24 de noviembre de 2013, Conflictividad en las Aulas; artículo de Alicia Calvo, Valladolid, pags 4 y 5
} 
Los actos violentos contra profesores en Infantil y Primaria tienen su origen en el $45 \%$ de los casos en los propios padres de los alumnos. Puede decirse que uno de cada tres actos violentos, es decir el 36\%, contra profesores proceden de padres de alumnos ${ }^{452}$.

\section{VIOLENCIA O MALTRATO ENTRE IGUALES, BULLYING}

\subsection{INTRODUCCIÓN}

En nuestra sociedad existe cada vez más violencia en todos los ámbitos de la vida diaria tales como el laboral, doméstico, educativo, medios de comunicación, ocio y otros. Siempre han existido estas conductas en el que el más fuerte hostiga el débil, pero ha sido en los últimos tiempos en que han salido a la luz con resultados trágicos, que han tenido gran repercusión en los medios de comunicación, con lo que se ha concedido gran importancia a este fenómeno. Por ello se ha tomado conciencia de la gravedad del problema de que existen comportamientos violentos en los centros de enseñanza no superiores llevando a su estudio a psicólogos, sociólogos, pedagogos y profesionales del derecho ${ }^{453}$.

El primer estudioso del tema del acoso escolar, fue el psicólogo Dam Olweus el cual comienza a preocuparse en su país, Noruega, en 1973, pero es a partir de 1982 cuando se vuelca en su estudio ante el suicidio de tres jóvenes estudiantes durante ese año. En Europa ya se estaba trabajando en ese tema en países nórdicos, también en Inglaterra donde hay tribunales escolares para tratar el acoso, así como una línea directa para casos de maltrato escolar. En España no es hasta la década de los años noventa en que se realizan estudios oficiales, siendo pioneros en la Universidad de Sevilla con el programa SAVE (Sevilla Anti-Violencia Escolar) y ANDAVE (Andalucía Anti-Violencia

\footnotetext{
${ }^{452}$ Estudios Cisneros VIII, op.cit, pags 57 a 59

${ }^{453}$ Fernández Moreno, Elisabet, Doctrina, La Responsabilidad Civil de los Centros Docentes en casos de Acoso Escolar, pag 7
} 
Escolar), en ellos se han recogido datos de unos siete mil alumnos de 25 centros educativos de Sevilla y de toda Andalucía, de entre 12 y 16 años ${ }^{454}$.

Las causas del aumento de la violencia escolar tienen su origen en los problemas que se han originado en el mundo moderno con el consumo de drogas, la violencia en los medios de comunicación, las familias desestructuradas y las nuevas tecnologías como ordenadores, móviles y demás.

El creciente consumo de drogas y alcohol entre los escolares, sobre todo en los fines de semana constituye un componente más que facilita el desarrollo de la violencia. El Ministerio de Sanidad ha realizado informes sobre el consumo de drogas entre alumnos de edades comprendidas entre 14 y 18 años, en los que se da una clara conexión con el fenómeno de la violencia escolar e incidiendo de forma notoria con el fracaso escolar. Como consecuencia de ello el Ministerio del Interior se ha visto obligado a adoptar medidas excepcionales de carácter policial para evitar que en las entradas y salidas de los centros, en el recreo o en los espacios libres de dichos centros se lleve a cabo tráfico de drogas ${ }^{455}$.

La convivencia en la familia es determinante para aprender las normas básicas de convivencia de un menor, de tal forma que si los padres no le exigen unas reglas básicas de comportamiento, puede desarrollarse en él un comportamiento violento. Los padres deben imponer a los hijos una conducta adecuada de tal forma que no sea demasiado severa ni demasiado permisiva, pues en caso contrario se puede favorecer la conducta violenta de los hijos.

En la organización del centro, la disposición de las aulas donde se imparten las clases, la masificación, la carencia de normas de comportamiento adecuadas, la aplicación incoherente de las normas disciplinarias, pueden favorecer tanto la violencia como el vandalismo. Por otra parte se ha demostrado que para la existencia de un buen clima escolar es conveniente el que se dé una adecuada proporción de alumnos que facilite el adecuado control sobre ellos, un control disciplinario coherente y un adecuado

\footnotetext{
454 Memoria del Defensor del Pueblo, del año 2000, pags 29 y ss

455 Moreno Martínez, Juan Antonio y otros, Responsabilidad Civil y su Problemática Actual, Problemática de la Violencia Escolar, Ed. Dikinson, Madrid 2007, pag 754
} 
sistema de vigilancia con turnos entre profesores en los recreos, a la salida y entrada a las clases, pasillos, etc, que es donde se producen los actos violentos ${ }^{456}$.

Los medios de comunicación, especialmente la televisión, desempeñan un papel de importancia decisiva en el desarrollo de la violencia en los menores. El ser humano no nace violento, lo hacemos. Fracasamos a veces en el proceso de educación, de socialización, en el que nace y se desarrolla la personalidad individual en relación con el medio social que le es transmitido. Aunque haya quien lo discuta, está clara la influencia que tiene en los menores la violencia de las series de televisión, dibujos animados, videojuegos, internet, violencia gratuita, donde gana el bueno, el que más mata, revistas donde se mezcla sexo y violencia, ello influye muy negativamente en los niños, pues banaliza la violencia. La televisión puede ser un instrumento al servicio de la educación y el conocimiento del mundo, sirve además para la socialización y educación, aunque por otra parte desinforma y deshumaniza, afecta positiva y negativamente sobre todo a personas no formadas.

Donde no llegan los educadores y los padres llega la televisión, por ello es necesario enseñar a ver la televisión con capacidad crítica, que la realidad no es como la refleja la televisión y se debe tener en cuenta que la ración de violencia que recibe el niño no lo hará violento, pero seguro que trivializará la agresividad y acabará por banalizar la violencia. El niño se encuentra en pleno desarrollo emocional y la exposición reiterada a imágenes violentas puede suponer una insensibilidad al sufrimiento y a los problemas del ser humano ${ }^{457}$.

Otro aspecto importante a tener en consideración es el de los videojuegos que utilizan niños, adolescentes y jóvenes, en ellos no se da control alguno por parte de los padres, los cuales desconocen su manejo y contenido, no pudiendo por tanto supervisarlos, ni controlar las copias piratas que manejan sus hijos.

Estos videojuegos despiertan un gran deseo entre los 7 y los 9 años, siendo los 12 años la edad en la que los menores utilizan con más frecuencia los de acción, dejando de interesar en torno a los 16 años. Sus jugadores son en un $60 \%$ adolescentes y jóvenes, su

\footnotetext{
456 Ibidem, pag 755

${ }^{457}$ Urra, Javier, El Pequeño Dictador Crece, Padres e hijos en conflicto, Esfera de los libros, Madrid 2015, pag 366 y ss
} 
carácter lúdico y violento lo ha convertido en una forma de entretenimiento muy demandada por muchos chicos. Son más usuarios los chicos que las chicas. Por cada chica muy aficionada hay diez chicos. Uno de cada cuatro chicos juega casi todos los días más de dos horas diarias. Los más utilizados tratan de deporte, aventura, disparo, lucha, simuladores, de plataforma y rol. Estos juegos manipulan los sentimientos, las sensaciones, incluyen mucha agresividad, violencia interactiva y buscan el detalle morboso ${ }^{458}$.

\subsection{DEFINICIÓN Y CARACTERÍSTICAS}

El acoso escolar, se conoce también como maltrato escolar, hostigamiento escolar, matonaje escolar, matoneo escolar. En inglés se conoce como bullying, que quiere decir, matón, valentón, intimidar, tiranizar, forzar a uno con amenazas, abusón, amenazador $^{459}$.

Según el noruego Olweus es una conducta de persecución física y/o psicológica que realiza el alumno o alumna contra otro al que elige como víctima de repetidos ataques. Esta acción, negativa e intencionada, sitúa a las víctimas en posiciones de las que difícilmente pueden salir por sus propios medios. La continuidad de estas relaciones provoca en las víctimas efectos claramente negativos: descenso de su autoestima, estados de ansiedad e incluso cuadros depresivos, lo que dificulta su integración en el medio escolar y el desarrollo normal de los aprendizajes ${ }^{460}$.

Debe deslindarse el acoso escolar de los incidentes violentos, aislados u ocasionales entre alumnos o estudiantes.

Se caracteriza en primer lugar por la intención de herir, amenazar o incomodar por parte de un alumno o grupo de alumnos a otro de sus compañeros. Es lo que Olweus viene a sintetizar como un comportamiento dañino negativo e intencional, todas las tipologías de acoso, ya sean físicas, verbales o psicológicas son actos agresivos en sentido lato o extenso.

\footnotetext{
${ }^{458}$ Ibidem, pag 377

${ }^{459}$ Diccionario Collins Dictionary, Third Edition, Harper Collins Publishers, Great Britain 1993

${ }^{460}$ Informe del Defensor del Pueblo de 2000, pag 17
} 
En segundo lugar, consiste en una reiteración o continuidad en el tiempo, que supone un quebranto o dolor no sólo en el momento del ataque, sino de forma sostenida. Esta continuidad puede realizarse mediante una sola modalidad de acoso o mediante una combinación de varias, tales como agresiones físicas, amenazas, vejaciones, insultos o en el aislamiento deliberado de la víctima, pudiendo emplear todos estos métodos o varios de ellos.

En tercer lugar se da un desequilibrio de poderes o desequilibrio de fuerzas entre el acosador o acosadores y acosado. Se forma así una relación de dominación del fuerte sobre el débil, y el acosado se tiene que someter al fuerte.

En cuarto lugar, el acoso en su modalidad de agresión emocional o psicológica es aún menos visible para los profesores, pero es extremadamente doloroso. Condenar a un menor al ostracismo escolar puede ser en determinados casos más dañino incluso que las agresiones leves continuadas. El acoso en su modalidad de exclusión social puede manifestarse en forma activa en no dejar participar y en forma pasiva al ignorar o en una combinación de ambas.

En quinto lugar el acoso puede practicarse individualmente o en grupo, siendo esta última modalidad la más peligrosa, pues si los acosadores son varios se diluye entre ellos el sentimiento de culpa y el efecto sobre la víctima es devastador a consecuencia de su sentimiento de soledad.

Como sexta nota característica se debe tener en cuenta que los alumnos acosan más que las alumnas y emplean distintas tipologías de agresiones, tanto contra alumnos o alumnas indistintamente. Las alumnas son más selectivas, acosan con mayor frecuencia a las de su mismo género, son más indirectas y delicadas: lo realizan difundiendo rumores, manipulando a otros para conseguir el rechazo o la exclusión de la víctima por parte del grupo.

Finalmente como última nota se puede decir que el que es acosador en el colegio, sigue de adulto observando esas malas prácticas. Según Olweus, en su seguimiento que hizo sobre 900 individuos, desde niños hasta que cumplieron la edad de 24 años, comprobó que el 60\% de los que habían sido acosadores escolares contaban al menos 
con una condena judicial, mientras que los que no habían sido acosadores, tenían una condena judicial tan sólo un $20 \%{ }^{461}$.

\subsection{MECANISMOS LEGALES DE PROTECCIÓN}

Para la protección de los derechos de los niños hay que tener en cuenta las disposiciones de la Convención sobre los Derechos del Niño adoptada por la Asamblea General de las Naciones Unidas de 20 de noviembre de 1989, que mediante recomendaciones, resoluciones, declaraciones y convenciones, supone la culminación en lo que a protección de menores se refiere.

De la Convención nos interesan en relación con el acoso en los centros, los artículos 2, 19, 32, 33, 34, 37 y 39, por ser los que de forma más directa se relacionan con esa problemática.

El artículo 2 dice en su apartado segundo que: "el niño se vea protegido contra toda forma de discriminación o castigo por causa de su condición”. En el artículo 19 se contempla la protección contra toda clase de abusos, perjuicios y malos tratos, que se comprenden en el acoso escolar, por ello dice en su apartado primero: "Los Estados Partes adoptarán todas las medidas legislativas, administrativas, sociales y educativas apropiadas para proteger al niño contra toda forma de perjuicio o abuso físico o mental, descuido o trato negligente, malos tratos o explotación, incluido el abuso sexual, mientras el niño se encuentre bajo la custodia de los padres, de un representante legal o de cualquier otra persona que lo tenga a su cargo".

Por el artículo 33 se trata de proteger a los niños "contra el uso ilícito de los estupefacientes y sustancias sicotrópicas enumeradas en los tratados internacionales pertinentes, y para impedir que se utilice a niños en la producción y el tráfico ilícitos de esas sustancias". Como ya se vio anteriormente el Ministerio de Sanidad detectó el consumo de drogas en menores de edad a partir de los catorce años, ello dio lugar a que el Ministerio del Interior tuviera que dar instrucciones a la policía para que interviniera

\footnotetext{
${ }^{461}$ Moreno Martínez, Juan Antonio, La Respon. op.cit pags 777 y ss Instrucción 10/2005, Fiscalía General del Estado, pags 4 y 5
} 
en las inmediaciones, así como en el interior de los colegios en los patios de recreo y demás para impedir la distribución y el consumo de drogas por parte de esos menores. Hay que tener presente que para aumentar el consumo de drogas por parte de los que se dedican a este tipo de comercio ilícito, nada hay más apropiado que tratar de iniciar a estos menores, dada su corta edad e inexperiencia en dicho consumo para asegurar mayores ingresos de cara al futuro.

Del artículo 34, se infiere el propósito de proteger a los menores de los abusos sexuales, pues una modalidad de los acosos en los colegios, consiste en que los menores tratan a veces de abusar sexualmente de los alumnos tratando de llegar a tener relaciones sexuales contra su voluntad.

En el artículo 37 en el apartado a, se trata de proteger al menor para que "ningún niño sea sometido a torturas ni a otros tratos o penas crueles, inhumanas o degradantes", pues el acoso escolar consiste en una especie de tortura metódica y sistemática, en lo que se trata de humillar a la víctima, de degradarla en definitiva con la complicidad, el silencio, la pasividad y la indiferencia de sus propios compañeros.

El artículo 39 trata de que los Estados Partes adopten las medidas apropiadas para recuperar a los menores que hayan sido objeto de abusos, torturas u otra forma de tratos o penas crueles y tratos inhumanos o degradantes. Hay que tener muy en cuenta que el alumno que haya sufrido acoso escolar, ha sufrido esos tratos que son sobre todo antihumanos, degradantes y humillantes que pueden y de hecho tienen, consecuencias para el resto de su vida, lo que le originará trastornos en su personalidad, depresiones, pérdida de confianza en sí mismo, dificultades en el rendimiento en los estudios, complicaciones para relacionarse con otras personas, aislamiento social y otras de carácter análogo. Para evitar o aminorar estas consecuencias, estos alumnos precisan de ayuda externa, por lo que deben de ser apoyados por psicólogos, profesores y familiares, de forma efectiva como dispone y se deduce de la intención de este artículo.

En el mismo sentido en la legislación europea hay normas sobre los Derechos del Niño, tales como la Convención Europea de los Derechos Humanos y de las Libertades Fundamentarles de Roma de 4 de noviembre de 1950, en su artículo 8. 
Otra norma es la Resolución A4-0393/96 del Parlamento Europeo, de 12 de diciembre de 1966 sobre medidas de protección de menores en la Unión Europea.

La Recomendación 874 (1979) de la Asamblea Parlamentaria del Consejo de Europa, de 4 de octubre de 1979, trata en su Preámbulo sobre la carta europea de los Derechos del Niño.

En la Resolución A3-0172/92 del Parlamento Europeo de 8 de julio de 1992, sobre una Carta Europea de Derechos del Niño, en sus párrafos 8.11, 8.12, 8.17 y 8.19.

La Constitución Española de 1978, en su artículo 15 dice: "todos tienen derecho a la vida y a la integridad física, sin que, en ningún caso, puedan ser sometidos a tortura ni a penas o tratos inhumanos o degradantes". Este artículo contempla el derecho a la vida y a la integridad física, que como veremos más adelante al estudiar la jurisprudencia, el acoso escolar ha hecho que los alumnos en situaciones de acoso lleguen a perder la vida suicidándose y a comprobarse en reconocimientos médicos la producción de lesiones físicas producidas por los acosadores. De igual forma la tortura o los tratos inhumanos y degradantes de los acosadores constituyen, en sí mismos, un claro atentado contra la persona.

Puede decirse en general que en todas las leyes de educación se hace referencia tanto en sus preámbulos como en el articulado a que se tienen que respetar el derecho a las libertades individuales, así como a la integridad física y moral. Podemos verlo en la Ley Orgánica 8/1985 de 3 de julio reguladora del Derecho a la Educación, BOE nº 159, en su preámbulo se hace referencia al "soporte de las libertades individuales en las sociedades democráticas"; de igual forma se alude al artículo 27 de la Constitución afirmando la salvaguardia de las libertades individuales y de los derechos del titular y de la comunidad escolar. En su artículo segundo apartado b se dice: "La formación en el respeto de los derechos y libertades fundamentales y en el ejercicio de la tolerancia y de la libertad dentro de los principios democráticos de convivencia". De la misma forma en su artículo sexto apartado b, se reconoce a los alumnos como derecho básico: "Derecho a que se respete su integridad y dignidad personales".

La Ley Orgánica 1/1996, de 15 de enero, BOE n 15, de Protección Jurídica del Menor, en su Exposición de Motivos, se refiere a la prohibición de difusión de datos o 
imágenes referidas a menores de edad en los medios de comunicación cuando sea contrario a su interés, para tratar de proteger al menor ante la manipulación de otros menores de los grupos en que se mueve. Ello tiene aplicación directa en el objeto de nuestro estudio, pues se dan casos frecuentes en los que se graban imágenes de tratos vejatorios o degradantes mediante el uso de móviles, difundiéndose posteriormente a través de ordenadores. En el artículo cuarto, apartado primero, se contempla el derecho al honor, a la intimidad personal y familiar y a la propia imagen; en su apartado segundo de dicho artículo, protege al menor si se da una intromisión ilegítima en su intimidad honra o reputación, con la intervención del Ministerio Fiscal.

En la Ley Orgánica 10/2002 de 23 de diciembre, BOE nº 30, sobre Calidad de la Educación en su Exposición de Motivos habla de que "se debilitaban los conceptos del deber de disciplina y del respeto al profesor", así como de la "convivencia ordenada y respeto hacia los demás". En su artículo dos, apartado segundo, letra d, se reconoce al alumno el derecho a "la protección contra toda agresión física o moral". En su apartado tercero, letra d se dice que el estudio es un deber básico del alumno que se concreta en: "Participar y colaborar en la mejora de la convivencia escolar y en la consecución de un adecuado clima de estudio en el centro, respetando el derecho de sus compañeros a la educación". Por su apartado cuatro, se dice que son deberes básicos de los alumnos: "Respetar la dignidad, integridad e intimidad de todos los miembros de la comunidad educativa; respetar las normas de organización, convivencia y disciplina del centro educativo; así como conservar y hacer un buen uso de las instalaciones del centro y materiales didácticos.

El Real Decreto 732/1995, de 5 de mayo, BOE $n^{\circ} 131$, sobre derechos y deberes de los alumnos y las normas de convivencia en los centros, trata de los aspectos organizativos de los centros, el establecimiento de la disciplina en los mismos, así como de los deberes y derechos de los alumnos. Lo que más interesa del mencionado Real Decreto, en relación con el acoso escolar es su artículo 17 que dice: "Todos los alumnos tienen derecho a que se respete su integridad física y moral y su dignidad personal, no pudiendo ser objeto, en ningún caso, de tratos vejatorios o degradantes". De igual forma se debe de tener en cuenta lo dispuesto en su artículo 43, apartado 2, sobre la imposición 
de correcciones que dice: "No podrán imponerse correcciones contrarias a la integridad física y a la dignidad personal del alumno".

En consecuencia, se puede considerar de lo expuesto que tanto la legislación internacional como la española, tratan de proteger a los menores contra los tratos inhumanos y degradantes como es el acoso escolar, asignándoles en las leyes la máxima protección.

\subsection{EL ACOSO ESCOLAR EN LOS PAISES DE NUESTRO ENTORNO}

Los primeros trabajos sobre acoso escolar se realizaron en Noruega por el profesor Dan Olweus, de la Universidad de Bergen en 1970. Se utilizó una muestra sobre 900 sujetos utilizando un Cuestionario abusón / víctima de Olweus, el cual fue introducido y estandarizado para ser utilizado en otros países, así sirvió como instrumento de medida para comprobar la incidencia del maltrato entre iguales en Suecia, Finlandia, Inglaterra, Estados Unidos, Canadá, Holanda, Irlanda, España y Australia.

En Inglaterra se iniciaron varios estudios sobre la violencia escolar a finales de 1980. El más importante se llevó a cabo en el área de Sheffield, utilizando el cuestionario de Olweus (1985) adaptado a la lengua inglesa y a las edades de los sujetos que formaban parte de la muestra.

De los resultados obtenidos se comprobó que el 10\% de los alumnos manifestaron haber sido agredidos de vez en cuando y el $4 \%$ una vez por semana. Los agresores afirmaron haber agredido el $6 \%$ de los estudiantes en algunas ocasiones y el $1 \%$ una vez a la semana.

Se comprueba que disminuyen las agresiones a medida que aumenta la edad. En secundaria de igual forma desciende el número de agresores. La mayor parte de las agresiones las realizan alumnos del mismo curso y grupo, aunque algunas veces las cometen los de cursos superiores. Las modalidades de acoso más frecuentes se cometen por alumnos y alumnas de 12 a 16 años en la proporción siguiente: Insultos, motes, 62\%; agresión física, 26\%; amenazas, 25\%; rumores, 24\%; insultos racistas, $9 \%$; aislamiento social, $7 \%$. 
Los alumnos emplean más las agresiones físicas directas y las amenazas. Las alumnas emplean formas indirectas de maltrato como rumores y exclusión.

Los lugares en que se producen los abusos son: el recreo, 45\%; las clases, 39\%; los pasillos, $30 \%$; otros lugares $10 \%$.

Francia carece de investigaciones sobre abusos entre los alumnos.

Italia, empezó el estudio sobre acoso escolar en 1996, llevándose a cabo por Genta, Menesini, Fonzi, Castalile y Smith en escuelas del centro y sur de Italia. Los resultados entre alumnos y alumnas entre 11 y 14 años dan los siguientes porcentajes: Víctimas, alguna vez o más veces, chicos $25 \%$, chicas $27,8 \%$; víctimas una vez a la semana, chicos $10,2 \%$, chicas $8,7 \%$; agresores, alguna vez o más, chicos $23,4 \%$, chicas $16,4 \%$; agresores, una vez a la semana, chicos $10,6 \%$, chicas $5,3 \%$.

Se dan las mismas tendencias que en otros países. El maltrato disminuye con la edad, la mayor parte de agresores son chicos, agresores y víctimas estaban normalmente en la misma clase y se aprecia que los niveles de acoso en Italia son superiores a los de otros países.

Las modalidades de maltrato dan los siguientes porcentajes: insultos verbales, chicos $44,9 \%$, chicas $45,3 \%$; daño físico, chicos $27,7 \%$, chicas $13,4 \%$; sembrar rumores sobre uno, chicos $23,3 \%$, chicas $26,3 \%$; amenazas chicos $17,7 \%$, chicas $8,4 \%$; ignorar (nadie me habla), chicos $6,8 \%$, chicas $6,2 \%$.

Respecto a los lugares donde se realiza el acoso: pasillos, chicos $23,5 \%$, chicas $16,5 \%$; recreo, chicos $13,5 \%$, chicas $11,2 \%$; clases, chicos $49,9 \%$, chicas $53,9 \%$, otros lugares, chicos $24,6 \%$, chicas $15,7 \%$. Se observa que la mayor parte de acosos se realizan en las clases, siendo el tanto por ciento ligeramente más elevado el de los chicos.

En Alemania a finales de los años ochenta se creó una Comisión Gubernamental Independiente para la Prevención y Control de la Violencia, de sus conclusiones se derivaron una serie de propuestas encaminadas a prevenir la violencia escolar invocando a la responsabilidad de los alumnos, el profesorado y prestando apoyo externo a las escuelas. No existe un estudio general de la violencia para toda Alemania, debido a que se trata de un Estado de tipo federal, en el que las competencias de educación se hallan 
residenciadas en los estados federados o länder, similares a nuestras comunidades autónomas, por ello, los datos se refieren a entidades locales o regionales.

Los datos de agresores referidos a Nuremberg en 1994 son los siguientes: los insultos representa la acción más violenta, con un $83 \%$ en los chicos y un $74 \%$ en las chicas; el acoso sexual a compañeros, es de un $6 \%$ en los chicos y de un $2 \%$ en las chicas; las amenazas con armas son de un $4 \%$ en los chicos y de $1 \%$ en las chicas.

Las agresiones hacia el profesorado son pocas, pero las padecen con mayor frecuencia las profesoras en la modalidad de violencia psíquica y verbal que los profesores.

Los estudios fueron realizados por Funk 1997; Losel y Bliesener en 1999, así como Von Spaun en 1996. De ellos se obtienen conclusiones como que los chicos eran más violentos que las chicas (Fuchs y otros 1996 y Von Spaun 1996). La franja de edad más violenta se distribuye entre los 13 y 15 años que corresponde a los cursos $7^{\circ}$ a $9^{\circ}$. En Hesse las mayores cotas de violencia se registraron en $8^{\circ}$ y $9^{\circ}$, y en Sajonia, en $8^{\circ}$ curso (Funk 1996).

Las peleas se dan más en primaria (49\%), que en los institutos $(23 \%)$ y en las escuelas profesionales (31,5\%). Los actos vandálicos se cometen más en institutos $(59,5 \%)$ y en centros de primaria (50\%), comparado con las escuelas secundarias profesionales (45\%) (Funk 1997, pag 61).

En Nuremberg el 15\% de alumnos admiten llevar consigo a la escuela armas como medio de defensa, los chicos (19,5\%) y las chicas (9,7\%). Los alumnos que llevan armas cometen agresiones con mayor frecuencia que los que no las llevan y son también con mayor frecuencia víctimas de violencia verbal y no verbal. Personalmente creo que se debería de prohibir a los alumnos la entrada con armas o medios de defensa.

Por lo que se refiere a las víctimas, el 5,8\% de las chicas declaraban haber sido pegadas o haber sido objeto de acoso sexual frente al 3,7\% de los chicos. El 59\% de los escolares de Baviera declaraban haber sido insultados en el curso de 1994. El 41\% se consideraba blanco de comentarios indecentes por parte de sus compañeros. 
En cuanto a los lugares de riesgo, los profesores afirmaban que el mayor número de abusos se producen en los lugares destinados a juegos (60,1\%), seguido por alrededores de la escuela o pasillos y en las clases $(9,2 \%)$

Los estudios sobre Portugal se comenzaron en 1996 por Pereira y otros, con una adaptación del cuestionario de Olweus (1991) y del trabajo y del estudio inglés correspondiente a Smith y Sharp (1994).

Del estudio realizado se deduce que las víctimas (tres o más veces en el trimestre), fueron $24 \%$ de chicos y $18,7 \%$ de chicas. Los agresores fueron (tres o más veces en el trimestre), 20,5\% chicos y $9,6 \%$ chicas.

Los chicos participan en los actos de acoso en mayor grado que las chicas pero también como víctimas. Los actos de acoso disminuyen a medida que aumenta la edad y pasan a cursos superiores.

Las modalidades de acoso son: verbal directa (insultar, amenazar) en chicos $(65,5 \%)$, en chicas $(66,5 \%)$; física directa (golpear, dar puñetazos, quitar pertenencias,) en chicos (63,1\%), en chicas (46,7\%); indirecta (rumores, nadie me habla) en chicos $(29,8 \%)$, en chicas $(54,5 \%)$.

En cuanto a los lugares donde se producen los hechos violentos es mayor en el recreo, chicos $(80,7 \%)$, chicas $(75,4 \%)$; pasillos, chicos $(28 \%)$, chicas $(35,2 \%)$; en clase, chicos $(19,3 \%)$.

Las chicas utilizan más la agresión indirecta que los chicos. Los chicos emplean más la agresión física. La violencia verbal directa es la más usual tanto para los chicos como para chicas en el ciclo secundario o preparatorio ${ }^{462}$.

\subsection{EL ACOSO ESCOLAR EN ESPAÑA}

En España, los estudios sobre la violencia escolar se han realizado en el ámbito de las comunidades autónomas, al encontrarse las competencias educativas transferidas a las mismas, de modo parecido a como se hace en Alemania con los estados federados o Länder.

\footnotetext{
${ }^{462}$ Informe del Defensor del Pueblo, 2000, pags 29 a 40
} 
El primer trabajo realizado en España, sobre violencia y abuso entre iguales se debe a un grupo de investigadores que estudiaron el problema en Madrid en 1989 formado por Viera, Fernández y Quevedo; después Fernández y Quevedo realizaron más trabajos en 1991; finalmente Ortega en 1998. Los trabajos se realizaron en un cuestionario de elección múltiple, sobre una muestra de 1200 alumnos, de edades comprendidas entre 8 y 12 años en diez escuelas de Madrid; cinco de ellas públicas y otras cinco privadas. De ellos los resultados fueron los siguientes: Sobre la incidencia de las agresiones, el 17,3\% afirmaba intimidar a sus compañeros y el 4,7\% lo había hecho muchas veces en el último trimestre. Las víctimas afirmaron haber sido intimidadas el $17,2 \%$ en el último trimestre y un 3,1\% muchas veces en el último trimestre. Sobre los tipos de maltrato, la mayor parte fueron las agresiones verbales $(19,3 \%)$, robos $(13,9 \%)$ y las intimidaciones físicas $(12,7 \%)$. Respecto a la comunicación a padres y profesores las chicas fueron más comunicativas, mientras que los chicos el 37,8\% preferían devolver las agresiones. La intimidación decrecía con el aumento de la edad. Por lo que se refiere a la incidencia según se trate de un centro público o privado, se comprobó una mayor agresividad en los centros privados, sin diferencias relevantes.

En Murcia en 1992 se hizo otro estudio por Cerezo y Esteban en el que se identificaba a víctimas y agresores de edades comprendidas entre 10 y 16 años, en cuatro centros de la Región. Los resultados se interpretaron por Ortega, resultando los siguientes: los agresores fueron un $11,4 \%$ y $5,4 \%$ víctimas; la mayor incidencia se daba entre los 13 y 15 años de edad; en cuanto al género, los chicos estaban más implicados que las chicas tanto en agresores como víctimas, actuando los chicos más como agresores y las chicas como víctimas.

La Comunidad Autónoma de Andalucía, ha realizado tres estudios sobre el maltrato entre alumnos, el primero se desarrolló entre los años 1990 y 1992 en colaboración con el británico Peter Smith, realizado en cinco centros de Sevilla, utilizando el cuestionario de Olweus, traducido y adaptado al español por un equipo dirigido por Rosario Ortega, en el que colaboraron Mora Merchán y Fernández.

El segundo trabajo fue el Proyecto Sevilla Anti-Violencia Escolar (SAVE) realizado entre 1995 y 1998, sobre 4914 alumnos de 25 centros educativos. Finalmente el 
tercero se hizo de 1997 a 1998 para estudiantes de la ESO, en ocho centros, uno en cada provincia de Andalucía, a un total de 2828 alumnos, denominándose a éste Proyecto Andalucía Anti-Violencia Escolar (ANDAVE). Sus conclusiones sobre los tipos de abusos son las siguientes: el tipo de maltrato o abuso más frecuente es el verbal (entre un 51 y 70\%), maltrato físico (entre 27 y 30\%) y con amenazas (30\%); las agresiones en su mayor parte la producen los varones (33\%), grupo mixto (entre 8 y 15\%), chicas 4\%; con respecto al lugar en que ocurren estos actos, el 33\% elige la calle, el 41\% el patio del recreo y entre el 24 y $29 \%$ la clase ${ }^{463}$.

En el ámbito estatal, en el año 2006, el Ministerio de Educación y Ciencia, con la idea de fomentar y mejorar la convivencia en los centros educativos, colaborando con las Comunidades Autónomas, ha aprobado el "Plan para la Promoción y mejora de la convivencia escolar", con la incorporación de una serie de medidas, a implantar en un plazo no superior al de un año. Entre ellas se puede citar, la creación de un premio nacional para el fomento de la convivencia escolar, en el BOE $\mathrm{n}^{\mathrm{o}} 141$ de 14 de junio de $2006^{464}$.

Existen estudios sobre esta materia como el Informe Cisneros VII ${ }^{465}$, para alumnos de Primaria, ESO y Bachiller, de sus resultados se desprende que el 24\% de los alumnos sufre acoso escolar. La tasa de acoso escolar por sexos se da un 26,8\% en los niños y un 21,1\% en las niñas. La tasa de acoso escolar disminuye con la edad de tal forma que en $2^{\circ}$ de primaria es de un $43 \%$, mientras que en $2^{\circ}$ de bachiller es del $6 \%$ lo que pone de manifiesto que disminuye 7 veces. En cuanto a los autores del acoso el $26,1 \%$ son niños de la propia clase, mientras que el 20,8\% son de otras clases. Es de destacar que el 4\% de los alumnos manifiesta ser maltratado por el profesor. Los niños que dicen que el profesor les maltrata son un 5,2\% frente al $2,2 \%$ de las niñas. Por el sexo es de destacar que los niños son el doble de agresores $(26 \%)$ que las niñas $(13 \%)$.

\footnotetext{
${ }^{463}$ Ibidem, pags de 41 a 46

464 Moreno Martínez, Juan Antonio. La Resp. Civil y su problema actual, op.cit, pags 750 y 751

465 Informe Cisneros VII, Instituto de Innovación Educativa y Desarrollo Directivo, Araceli Oñate Cantero e Iñaki Piñuel Zabala, Madrid, 2005
} 


\subsection{LOS PELT EN RELACIÓN CON EL ACOSO ESCOLAR}

Cuando se produce un caso de acoso en que como consecuencia del mismo se deriven responsabilidades civiles, se encuentran generalmente involucradas dos o más personas ya sean físicas o jurídicas y para indemnizar a la víctima hay que recurrir al instituto jurídico de la solidaridad o de la parciariedad, según los casos. Puede darse el caso de que el menor causante del daño sea responsable junto con sus padres o bien con los responsables del centro donde estudia el menor.

Para resolver estos casos hay que tener en cuenta lo que dispone el artículo 9:101 PELT, que trata la solidaridad y parciariedad, en relación entre la víctima y la pluralidad de causantes del daño. La solidaridad se da cuando la producción del daño no se puede considerar en partes divisibles, de esta forma la víctima puede accionar indistintamente contra uno solo o contra todos los participantes en la producción del daño, es lo que se denomina la relación externa entre la víctima y los causantes del daño; después habrá una relación interna entre los que causaron el daño, para indemnizar a la víctima, pues el que haya indemnizado dispone de una acción de regreso contra los demás para recuperar lo pagado por todos ellos. La parciariedad se da cuando la responsabilidad de los causantes del daño se puede dividir en partes proporcionales al daño que causó cada uno, es lo que en nuestro Derecho se denomina responsabilidad mancomunada.

Puede decirse que para la víctima es más fácil y operativo el sistema de la solidaridad, pues cobra de uno sólo el total de la indemnización, después por las reglas internas de la solidaridad, tendrán que entenderse entre ellos. Por el contrario si es un sistema parciario o mancomunado la víctima puede tener grandes dificultades para cobrar alguna parte del daño cuando uno de sus responsables sea insolvente ${ }^{466}$.

\footnotetext{
${ }^{466}$ Art $^{\circ} 9.101$ Solidaridad y parciariedad: relación entre la víctima y la pluralidad de causantes del daño.

1) La responsabilidad es solidaria si todo el daño sufrido por la víctima o una parte diferenciada del mismo es imputable a dos o más personas. La responsabilidad será solidaria si:
}

a) una persona participa a sabiendas en la actuación ilícita de otros que causa daño a la víctima, o la instiga o estimula.

b) el comportamiento o actividad independiente de una persona causa daño a la víctima y el mismo daño es también imputable a otra persona.

c) una persona es responsable por el daño causado por un auxiliar en circunstancias tales que también el auxiliar es responsable. 
El apartado 1, letra a del artículo 9:101, trata de la persona que aunque no cause daño a la víctima de forma directa, participa instigando o estimulando, esto es facilitando la comisión del hecho dañoso, como por ejemplo los niños en los colegios que marginan a otros alumnos hablando mal de ellos, predisponiendo a otros alumnos para "hacer el vacío" a alguien, suelen emplearlo más las chicas, aunque también lo hacen los chicos.

En su apartado 1, letra b, trata del caso de que dos o más personas se ponen de acuerdo para dañar a la víctima y unos de forma directa, mientras que otros de forma indirecta colaboran para la producción del daño, como por ejemplo unos vigilan por si llega el profesor mientras que otros se dedican a agredir y maltratar a la víctima.

La responsabilidad por los auxiliares se contempla en el apartado 1, letra c, si un auxiliar ha permitido un hecho dañoso, él mismo es responsable y la responsabilidad alcanza a la persona que le tiene a cargo, como puede suceder en casos de acoso en los que el profesor no ha actuado con la diligencia debida, él será responsable, pero además deberá de responder el titular del centro docente, por tenerle a su cargo.

El apartado 2 trata del enriquecimiento injusto, quiere ello decir que puede exigir a uno o varios de los responsables el total de la indemnización, pero sólo puede recibir el total a que ascienda, lo que no puede hacer es pedir varios totales, pues ello supondría recibir más de lo estipulado en la sentencia condenatoria y daría lugar a incurrir en responsabilidad frente a los obligados a responder.

En el apartado 3, se contempla el caso de solidaridad y parciariedad, teniendo presente que si se trata de un solo daño, se habrá de aplicar el régimen de la solidaridad, debiéndose dividir el total de la indemnización entre los sujetos solidarios. Si uno de los sujetos al régimen de solidaridad manifiesta que el daño no es el mismo, pudiéndose distinguir distintas aportaciones a la producción, susceptibles de ser individualizadas de forma proporcional, deberá de soportar él la carga de la prueba. De esta forma si la

2) Cuando varias personas se hallan sujetas a responsabilidad solidaria, la víctima puede reclamar toda la indemnización de una o varias de ellas, con tal que no obtenga mayor indemnización que la correspondiente al importe total del daño sufrido.

3) Se considera que un daño es el mismo daño a los efectos del apartado (1)(b) anterior si no existe una base razonable para imputar sólo una parte del mismo a cada una de las personas responsables ante la víctima. A tal efecto, la persona que afirma que el daño no es el mismo soporta la carga de la prueba. Si tal base razonable existe, la responsabilidad es parciaria, es decir, cada persona responde ante la víctima sólo por la parte del daño que le es imputable. 
responsabilidad fuera parciaria, cada persona responderá por la parte del daño del que sea responsable. Se emplea el sistema de solidaridad cuando el daño es indivisible, tanto en los ordenamientos del derecho continental como en los del Common Law. Cuando se trata de un daño indivisible se exige que respondan de todo el daño ante la víctima, hayan actuado de acuerdo o no, y en su relación interna pueden reclamar que la totalidad del daño se distribuya de acuerdo con la responsabilidad de cada uno. Estados Unidos es el país que más se aparta del régimen de la solidaridad, de tal forma que en los últimos veinte años, la gran mayoría de sus Estados federados se han apartado del régimen de solidaridad, adoptando en su lugar no una responsabilidad parciaria pura o proporcional, sino unos complejos sistemas de hasta cinco variantes.

El artículo 9:102 trata de las relaciones internas entre los responsables solidarios $^{467}$.

La responsabilidad solidaria se encuentra muy arraigada en los ordenamientos europeos, por lo que el abandonarla supondría un importante desplazamiento del equilibrio jurídico o lo que es lo mismo daría lugar a importantes distorsiones en la relación interna de los responsables de indemnizar. No es solamente la problemática que se origina cuando un responsable de indemnizar es insolvente, incluso aunque todos sean solventes la víctima tendría muchas dificultades para reclamar la indemnización. El

${ }^{467} \mathrm{Art}^{\mathrm{o}}$ 9:102 (1). La persona sujeta a responsabilidad solidaria tiene derecho de regreso frente a cualquier otra persona que sea responsable ante la víctima por el mismo daño. Este derecho se establece sin perjuicio de lo que disponga sobre la distribución de la pérdida cualquier contrato celebrado entre ellos o cualquier disposición legal o de un derecho de reembolso en virtud de la subrogación (cesio legis) o con base en el enriquecimiento injusto.

(2) De acuerdo con lo dispuesto en el apartado (3) de este artículo, la cuota de ese derecho de regreso será la que se considere justa a la luz de las respectivas responsabilidades por el daño, en consideración a sus culpas respectivas y a cualquier otro aspecto relevante para establecer o reducir la responsabilidad. El importe del regreso puede ascender al importe total de la indemnización. Si no puede determinarse la responsabilidad que corresponde a cada una de las personas responsables, se considerarán responsables por igual.

(3) Si una persona es responsable por el daño causado por un auxiliar de acuerdo con lo dispuesto en el artículo 9:101, se considerará responsable por toda la cuota imputable al auxiliar a los efectos de distribuir la responsabilidad entre él y cualquier otro causante del daño distinto de dicho auxiliar.

(4) La obligación de responder en vía de regreso por la parte respectiva es parciaria, es decir, la persona obligada responde sólo por la cuota de responsabilidad que, según este artículo, le corresponda por el daño; pero si no puede ejecutarse la sentencia que establece la condena de la persona responsable del daño en vía de regreso, su parte debe de ser redistribuida entre las demás en proporción a sus respectivas cuotas. 
problema principal es determinar cuando el daño es divisible o indivisible para poder recurrir a la parciariedad o a la solidaridad, por ello es muy difícil su regulación, lo que da lugar a que lo analicen los tribunales de acuerdo con la casuística.

Aunque el sistema básico sea el régimen de la solidaridad, el $\operatorname{art}^{\circ}$ 9:102 contempla la posibilidad de que los causantes pueden ponerse de acuerdo entre sí para distribuir la responsabilidad final de los mismos de acuerdo con su responsabilidad relativa. Esta regla es aplicada por la mayor parte de los ordenamientos y los que no la han aplicado, han tenido que rectificar y volver a aplicarla.

El apartado (2) del $\operatorname{art}^{\mathrm{o}}$ 9:102, concede al tribunal un poder bastante amplio para distribuir la responsabilidad parciaria en proporciones, sobre esa responsabilidad relativa, pues es el método correcto, al dejar al Juez que estudie caso por caso lo que es más conveniente. Esta manera de proceder es la que se emplea en Inglaterra, Alemania y Holanda.

Por el apartado (3) se trata de la responsabilidad del empleador o principal que responde por el auxiliar, aunque después podrá repetir contra dicho auxiliar, si es culpa de éste, pues puede tratarse de que el daño causado por el auxiliar tenga la culpa el principal, o los dos, según los casos.

El apartado (4) establece la regla básica de que entre los causantes la responsabilidad es proporcional de modo que si por ejemplo se trata de una deuda en la que intervienen tres causantes y uno de ellos es insolvente, los dos restantes deberán asumir la deuda del insolvente, de tal forma que cada uno de ellos deberá pagar la mitad de la deuda del insolvente.

En cuanto a la indemnización hay que tener en cuenta lo que dispone el artículo 10 PETL en sus distintos apartados.

El artículo 10:101 relativo a la naturaleza y objeto de la indemnización dice: "La indemnización es un pago en dinero para compensar a la víctima, es decir, para restablecerla, en la medida que el dinero pueda hacerlo, en la posición que hubiera tenido si el ilícito por el que reclama no se hubiera producido. La indemnización también contribuye a la finalidad de prevenir el daño". 
La indemnización consiste en un pago en dinero, mediante una suma que iguale en términos dinerarios la pérdida que ha sufrido el dañado por esos perjuicios ocasionados. En cuanto a la reparación en forma específica del artículo 10:104, creo que no tiene aplicación en los casos de acoso escolar, pues en estos casos se trata de daños que son algo intrínseco de la persona humana, que no se pueden reparar en forma específica; propio de las cosas materiales, en que se pueda entregar una cosa en sustitución de otra. L a indemnización sirve para prevenir el daño, pues si alguien trata de causar un daño a otro, si ve que tiene que pagarle una suma de dinero por ello se verá obligado a no causarlo, ya que el tener que desprenderse de dinero es lo que más duele a las personas. Suele consistir en una suma alzada que el Juez fija en la sentencia, al ser lo más cómodo para la víctima cobrándolo al principio de una sola vez; la renta periódica de que habla el artículo 10:102 es más complicada para cobrar y de las sentencias que he visto sobre casos de acoso, no se contempla ninguna sobre rentas periódicas.

El daño patrimonial se contempla en el artículo 10:201, que dice: "El daño patrimonial resarcible es la disminución del patrimonio de la víctima causada por el evento dañoso. Por regla general, tal daño se determina de un modo tan concreto como sea posible, pero puede determinarse en abstracto, como por ejemplo al valor de mercado, cuando resulte pertinente". Daño patrimonial se refiere a cuando la víctima ha sufrido una pérdida que disminuye su propio patrimonio, como en los casos en que ésta se ve obligada a realizar gastos en atención médica, como se aprecia en algunas sentencias. Estos gastos suelen estar cubiertos por compañías de seguros y se fijan por una suma alzada en función de los días de ingreso en el hospital y demás. Los gastos patrimoniales se refieren de igual forma a los ingresos dejados de obtener, como pueden ser uno de los padres que ha tenido que abandonar su trabajo para atender al hijo durante el periodo de tiempo de baja del menor.

En el artículo 10:202, apartado (1), trata del daño corporal, en el que dice: "En el caso de daño corporal, lo que incluye a la salud física y a la psíquica si comporta una enfermedad reconocida, el daño patrimonial incluye la pérdida de ingresos, el perjuicio de la capacidad de obtenerlos (incluso si no va acompañado de una pérdida de los mismos) y los gastos razonables, tales como el coste de la atención médica”. La pérdida 
de ingresos comprende los ingresos que la víctima habría podido obtener en el futuro si el daño no se hubiese producido. La expresión “incluso si no va acompañada de la pérdida de los mismos", se refiere a los ingresos que fuera a obtener en el futuro. En cuanto a un daño a la salud física o psíquica, no presenta problemas el determinar los daños físicos, pero no sucede así con los psíquicos, en éstos hay que reconocerlos como una enfermedad de acuerdo con los estándares de la ciencia médica, no contemplándose como tal el simple trastorno emocional En cuanto al daño corporal, como daño patrimonial comprende los gastos del tratamiento médico, las medidas de rehabilitación y similares para subsanar la lesión o enfermedad; estos gastos deben ser razonables y necesarios para el tratamiento médico, pudiendo incluirse hasta las destinados a adaptación de la vivienda de la familia.

El daño no patrimonial se contempla en el artículo 10:301 ${ }^{468}$ el cual es de gran importancia en los casos de acoso en que tienen un componente fundamental contra la dignidad humana, la libertad y otros derechos relativos a la personalidad. La indemnización de daños no patrimoniales en casos de daño corporal ha sido duramente criticada por entender que puede ser arbitraria en determinadas circunstancias o que es menos importante que los daños patrimoniales, dando ello lugar a grandes polémicas. En los ordenamientos jurídicos europeos se considera que son de gran utilidad al dar consuelo a la víctima por sus sufrimientos padecidos, como manifestación de la dignidad humana y para condenar los comportamientos improcedentes. Estos daños son difíciles de cuantificar y es importante considerar que Alemania haya eliminado la antigua

\footnotetext{
${ }^{468}$ Art $^{\circ}$ 10:301 Daño no patrimonial
}

(1) "En atención al alcance de su protección (artículo 2:102), la lesión de un interés puede justificar la compensación del daño no patrimonial. Este es el caso, en especial, si la víctima ha sufrido un daño corporal o un daño a la dignidad humana, a la libertad o a otros derechos de la personalidad. También puede resarcirse el daño no patrimonial de aquellas personas allegadas a la víctima de un accidente mortal o una lesión muy grave.

(2) En general, para cuantificar tales daños se tendrán en cuenta todas las circunstancias del caso, incluyendo la gravedad, duración y consecuencias del daño. El grado de culpa del causante del daño sólo se tendrá en cuenta si contribuye al daño de la víctima de modo significativo.

(3) En los casos de daño corporal, el daño no patrimonial corresponde al sufrimiento de la víctima y al perjuicio de su salud física o psíquica. En la cuantificación de las indemnizaciones (incluyendo las que correspondan a las personas allegadas a la víctima fallecida o que ha sufrido lesiones graves) se deberán conceder sumas indemnizatorias similares por aquellas pérdidas que sean objetivamente similares”. 
restricción de la indemnización de este tipo de daños en caso de responsabilidad objetiva.

La mayoría de ordenamientos permiten la indemnización de daños no patrimoniales a parientes de víctimas directas en caso de muerte, incluso Francia y Bélgica la reconocen cuando ésta no se produce. La determinación en la cuantía de estos gastos se da una mayor probabilidad de arbitrariedad que en un caso de daño corporal: la pérdida de una mano o un brazo puede evaluarse fácilmente, pero ¿quién puede avaluar la tristeza originada por la muerte de un padre o un cónyuge? En la mayoría de los ordenamientos en los que se reconoce este tipo de indemnización, resultaría muy complicado eliminarlo, como en Inglaterra donde no se admitió legalmente hasta 1981, que incluso los contrarios a su reconocimiento, entienden que ahora se encuentra plenamente incorporado a dicho ordenamiento.

Indemnizar por daño no patrimonial es posible y deseable en varias situaciones tales como intromisiones en la libertad, el honor, la reputación o la intimidad, siendo en ocasiones bastante cuantiosos, por la probabilidad de que la víctima sufra pérdidas económicas en el futuro como consecuencia de esas intromisiones, presentando el inconveniente de la dificultad que entraña el demostrar o justificar la relación causa a efecto entre tales intromisiones y la pérdida económica futura. Si en casos de calumnias, invasión de la intimidad y demás no se otorgara indemnización por daño no patrimonial las sanciones frente al infractor de dichos intereses se reducirían considerablemente, pues muchas personas a veces ponen denuncias por asuntos que no son muy importantes con la intención de obtener dicha indemnización. El hecho de que estos intereses sean difíciles de evaluar o cuantificar, no quiere decir que no sean importantes y beneficiosos para el orden público y el respeto en la sociedad. Lo que sí debe tenerse en consideración es que estas indemnizaciones por daños no patrimoniales, se deben vigilar y controlar de forma muy cuidadosa para que no sean desorbitadas o desproporcionadas y además deben ser equitativas de tal forma que situaciones parecidas sean tratadas de forma similar ${ }^{469}$.

\footnotetext{
${ }^{469}$ Martín Casals, Miguel, European....op.cit, pags 189 a 230
} 


\subsection{EL ACOSO ESCOLAR EN EL CÓDIGO PENAL}

El acoso escolar como tal no se contempla en el Código Penal tipificado como delito específico, por ello se hace necesario ver en qué artículos se puede integrar de acuerdo con su definición en que se trata de una persecución física o psicológica, intencionada y reiterada o repetida por algún tiempo, infligida por uno o varios alumnos a otro que se encuentra en una situación de inferioridad ${ }^{470}$. Al acosar los agresores a la víctima se producen con unos tipos de actos o que comprenden unos casos de violencia muy variados por lo que resulta muy difícil encuadrarlos en un tipo penal concreto.

Los Juzgados lo han incluido dentro del artículo 173.1 del Código Penal que dice: "El que infligiere a otra persona un trato degradante, menoscabando gravemente su integridad moral, será castigado con la pena de prisión de seis meses a dos años". Este artículo trata de proteger a la persona en su integridad moral, que el legislador ha querido que se haga de forma específica, así como contra el trato degradante que se contempla en el artículo 15 de la CE y que se identifica con la dignidad como fuente de todo derecho. Se trata de comportamientos que más allá de la integridad psicofísica de la persona niegan su condición de tal, al producirse un menoscabo de su integridad moral mediante ese trato degradante. Los tratos inhumanos o degradantes entrañan padecimientos físicos o psíquicos ilícitos e infligidos de modo vejatorio para quien los sufre, y con la intención de vejar y doblegar la voluntad del contrario, al que se produce una gran aflicción. Se trata en suma de unas torturas, pues el acoso es como una tortura, que se comete entre particulares, como es el caso de los acosos de los colegios, que se aprovecha la ausencia del profesor y la pasividad de los compañeros para realizarlo y con una continuidad en el tiempo, como otra de sus características. Ha de darse necesariamente una relación de causalidad entre la conducta y el resultado producido.

Además de la integridad moral los agresores pueden vulnerar en su actuación otros derechos como el derecho al honor mediante insultos, humillaciones o vejaciones y agresiones, en cuyo caso es de aplicación el artículo 177 del Código Penal, que dice: "Si en los delitos descritos en los artículos precedentes, además del atentado a la integridad moral, se produjere lesión o daño a la vida, integridad física, salud, libertad sexual o

\footnotetext{
${ }^{470}$ Fernández Moreno, Elisabet, doctrina, La Responsabilidad Civil, op.cit, pag 9
} 
bienes de la víctima o de un tercero, se castigarán los hechos separadamente con la pena que les corresponda por los delitos o faltas cometidos, excepto cuando aquél ya se halle especialmente castigado por la Ley". La lesión de la dignidad de la persona que contempla este artículo va a consistir en actos crueles, inhumanos, vejatorios, envilecedores. De igual forma puede producirse con atentados a su vida, honor, integridad física, libertad sexual, intimidad, libertad o a sus bienes privativos. Con la expresión "excepto cuando aquél ya se halle especialmente castigado por la Ley", se refiere a que no se puede imputar a una persona dos delitos por el mismo hecho, de acuerdo con el principio "non bis in ídem", pues el acoso escolar no se limita a un solo delito, sino, que suelen darse varios en un mismo caso. Esto es lo que sucedió en el llamado "Caso Jokin" "711, en el que la víctima sufrió en reiteradas ocasiones, durante un tiempo prolongado agresiones físicas, verbales, psicológicas, así como exclusión social, por un grupo de siete chicos y una chica, como consecuencia de ello el menor Jokin, se suicidó. La acusación particular y el Ministerio fiscal imputaron a los menores los siguientes tipos delictivos: inducción al suicidio del artículo 143.1 del C.P., artículo 173.1 del C.P. sobre la integridad moral; los padres de la víctima imputan además el delito contra la salud psíquica del artículo 147.1 C.P., en concurso con el artículo 173.1 C.P; falta de lesiones del artículo 617.1 C.P. y falta de maltrato de obra del artículo 617.2 C.P. $\mathrm{El}$ artículo 143.1 CP trata de la inducción al suicidio y dice: "El que induzca al suicidio de otro será castigado con la pena de prisión de cuatro a ocho años". En la Sentencia del Caso Jokin ${ }^{472}$, en su Fundamento de Derecho Tercero no se aprecia inducción al suicidio y dice: "La inducción al suicidio requiere una colaboración, una prestación coadyuvante que ofrezca una cierta significación y eficacia en la realización del proyecto que preside a un sujeto a acabar con su propia existencia, es decir, una conducta por parte del sujeto activo de colaboración prestada a la muerte querida por otra persona, en relación de causalidad con su producción y con pleno conocimiento y voluntad de cooperar a la misma, de tal modo que sea el propio suicida el que tenga en todo momento el dominio del hecho, o sea, el sujeto activo no haga otra cosa que cumplir la voluntad libre y

\footnotetext{
${ }^{471}$ Sentencia de la Audiencia Provincial de Guipúzcoa (Sección $1^{\text {a }}$ ), Sentencia $n^{\circ}$ 178/2005 de 15 de julio (JUR 2005/174855)

472 Juzgado de Menores de San Sebastián, Sentencia nº 86/2005 de 12 de mayo (ARP 2005/214)
} 
espontáneamente conformada y expresamente formulada por quien en todo momento decide finalización o desiste, requisitos que no se aprecian ni indiciariamente que concurran en el caso enjuiciado". Es evidente que no concurren en el presente supuesto los requisitos del tipo aludido por la acusación particular, puesto que se requiere un dolo directo en el inductor a la consecución del hecho criminal y, en modo alguno estos ocho menores en su comportamiento hacia Jokin, basado en insultos, agresiones y vejaciones, pensaron que su compañero iba a tomar esta trágica decisión.

En el artículo 147.1 se contempla delito contra la salud psíquica ${ }^{473}$ que constituye el tipo básico de lesiones, en el que se trata de proteger el bien jurídico de la salud física y psíquica de la persona, es decir, la ausencia de enfermedad o de alteración corporal. Su resultado consiste por tanto en un menoscabo de la integridad corporal o de la salud física o mental. En la Sentencia de la A.P. en el caso Jokin, en su parte IV, en sus apartados III y IV se dice que en el sentir jurisprudencial, únicamente el menoscabo de la salud psíquica que provenga de una lesión corporal encuentra acomodo en el tipo de lesiones descrito en el apartado 147.1. Sólo se subsumen en el artículo 147 las siguientes modalidades: daño o pérdida de la substancia corporal; perturbación de las funciones del cuerpo; modificación de la forma de alguna parte del cuerpo; malestares físicos de cierta entidad; terror o asco cuando, junto a la conmoción del equilibrio espiritual se da también una excitación de los nervios sensitivos del sistema central que transmiten las impresiones sensibles.

La sentencia describe el conjunto de agresiones que sufrió Jokin en el marco de hostigamiento a que era sometido, dándole puñetazos en la cara, empujones, cachetes en la cabeza, patadas en las piernas y en la espalda, golpes en los hombros y abdomen, balonazos, tortas. Estas huellas fueron percibidas por su madre y constatadas en el informe de la autopsia. La unión de la violencia física con la psíquica ejercida por los menores menoscabó la salud mental de Jorge en los términos que se han relatado. De

\footnotetext{
473 Artículo147.1 CP: "El que, por cualquier medio o procedimiento, causare a otro una lesión que menoscabe su integridad corporal o su salud física o mental, será castigado como reo del delito de lesiones con la pena de prisión de seis meses a tres años, siempre que la lesión requiera objetivamente para su sanidad, además de una primera asistencia facultativa, tratamiento médico o quirúrgico. La simple vigilancia o seguimiento facultativo del curso de la lesión no se considerará tratamiento médico”.
} 
todo ello se deduce que se encuentran presentes las notas jurídicas que definen el delito de lesiones tipificado en el artículo 147.1 C.P.

En cuanto a las faltas contra las personas se contemplan en el artículo 617 y siguientes del Código Penal. El artículo 617,1 CP dice: "El que, por cualquier medio o procedimiento, causare a otro una lesión no definida como delito en este Código, será castigado con la pena de arresto de tres a seis fines de semana o multa de uno a dos meses". Se trata en este artículo de faltas de lesiones que no puedan ser incluidas en el artículo 147 y siguientes del C.P.

El artículo 617, 20 dice: "El que golpeare o maltratare de obra a otro sin causarle lesión será castigado con la pena de arresto de uno a tres fines de semana o multa de diez a treinta días". En la sentencia del caso Jokin, se condena a Natalia, por haber dado una bofetada a Jokin, a dos fines de semana en centro educativo por maltrato de obra.

Dependiendo de la intensidad del trato degradante que inflige el acosador y del menoscabo producido en el acosado, nos podemos encontrar ante un delito contra la integridad moral o ante una falta del artículo 620.2 C.P. ${ }^{474} \mathrm{El}$ artículo 620.2 C.P. dice: "Los que causen a otro una amenaza, coacción, injuria o vejación injusta de carácter leve, serán castigados con la pena de multa de diez a veinte días". Se trata por tanto de una serie de faltas contra la libertad y el honor, consistentes en amenazas sin uso de armas o de otros instrumentos peligrosos; o de injurias leves, en que con independencia de que se cometan por escrito y con publicidad, son constitutivas de falta de injurias; la vejación injusta ha de constituir el carácter de leve, por lo que en este tipo de faltas de amenazas, coacciones e injurias, el Juez o Tribunal ha de analizar caso por caso y obrar según las circunstancias que concurran en el hecho constitutivo de la falta. Los que cometen estas infracciones semipúblicas, exigen denuncia de la persona agraviada o de su representante legal para perseguirlas, no precisando querella, siendo suficiente la denuncia.

\footnotetext{
${ }^{474}$ Fernández Moreno, Elisabet, op.cit, pag 9
} 


\subsubsection{LA LORPM EN EL ACOSO ESCOLAR}

Para la aplicación de la LORPM se ha de tener en cuenta la edad del menor, que ha de estar comprendida entre los catorce y dieciocho años. Si es un menor de catorce años, no se le puede exigir responsabilidad con arreglo a la LORPM, sino que se aplicará lo dispuesto en las normas sobre protección de menores previstas en el Código Civil y demás disposiciones vigentes; debiendo el Ministerio fiscal lo actuado a la entidad de protección de menores y dicha entidad deberá de adoptar las medidas de protección de acuerdo con la Ley Orgánica 1/1996, de 15 de enero sobre protección de menores (artículo 3, LORPM). Si fuera un mayor de edad, por hallarse repitiendo curso, le será aplicado el Código Penal, pues ya se trata de un adulto y uno de los motivos de que se aplique la LORPM es el separar a los menores de los adultos en el sistema penitenciario.

El artículo 61.3 LORPM establece la solidaridad del menor de entre catorce y dieciocho años, con sus padres, tutores, acogedores y guardadores legales o de hecho, por este orden y si no hubieren favorecido la conducta de ese menor con dolo o negligencia grave, su responsabilidad podrá ser moderada por el Juez según los casos. De este artículo se deduce que la responsabilidad será de carácter objetivo, asegurándose de que la víctima quedará garantizada; no quedando posibilidad de exonerarse por culpa o negligencia del artículo 1902 y siguientes del Código Civil; con ello sólo se permite la moderación de la indemnización de dicho artículo 61.3.

La expresión "por este orden", se presta a varias interpretaciones, en las que no se sabe si hay que entender que se exigirá prioritariamente responsabilidad a padres y tutores; o a los que lo tengan bajo su guarda en el momento de la producción del hecho dañoso; o finalmente que pueden ser varios de los enumerados a la vez responsables, lo que se denomina "orden acumulativo".

Esta tesis del "orden acumulativo" es por la que se decanta la Fiscalía General del Estado en el apartado noveno de la Instrucción 10/2005 en la que dice: "La omisión de la LORPM no debe interpretarse en el sentido de que se reserve la acción civil para su ejercicio en exclusiva contra las personas expresamente señaladas en el precepto. Con el fin de evitar el siempre odioso peregrinaje de jurisdicciones y conforme al principio de economía procesal - que exigiría que todos los eventuales responsables pudiesen ser 
demandados en un mismo proceso- de acuerdo con el principio de protección de la víctima, la interpretación que deberán defender los Sres. Fiscales es la de que los Centros docentes también pueden ser demandados con tal carácter en la pieza separada de la LORPM. A estos efectos puede fundamentarse la petición en la figura del guardador del artículo 61.3 de la LORPM, en la que puede incluirse también al centro docente, por ser quien en esos momentos está ejerciendo funciones de guarda".

Aunque la LORPM no regula el supuesto previsto en el artículo 1903.5 CC, cabe entender que puede demandarse como responsables civiles a los titulares de centros docentes de enseñanza por los daños y perjuicios derivados de delitos y faltas cometidos por los menores de edad "durante los periodos de tiempo en que los mismos se hallen bajo el control o vigilancia del profesorado del centro, desarrollando actividades escolares o extraescolares y complementarias", pues no debe a este respecto, olvidarse la cláusula general de supletoriedad contenida en el artículo 4.3 del Título Preliminar del Código Civil.

De igual forma, podrá fundamentarse la reclamación civil en la responsabilidad subsidiaria del centro de acuerdo con lo establecido en el artículo $120.3^{\circ}$ del Código Penal, teniendo en cuenta la supletoriedad del Código Penal en virtud de la Disposición Final Primera de la LORPM ${ }^{475}$.

\subsection{RESPONSABILIDAD CIVIL DE LOS CENTROS DOCENTES EN CASOS DE ACOSO ESCOLAR.}

Cuando se produce un caso de acoso escolar en el que se cometen hechos tipificados penalmente, hay que tener en cuenta la edad del menor, pues si es de edad comprendida entre catorce y dieciocho años será la LORPM, la que haya que aplicar como se vio anteriormente; si el menor es de edad inferior a catorce años es inimputable penalmente y deberá de aplicarse la legislación civil de menores.

\footnotetext{
${ }^{475}$ Fernández Moreno, Elisabet, op.cit, pag 11 Instrucción Fiscalía General del Estado 10/2005 apartado noveno.
} 
De la responsabilidad penal se puede derivar responsabilidad civil. La jurisdicción de menores se aplicará en casos de acoso cuando sean cometidos por menores de edad comprendida entre catorce y dieciocho años, cuya responsabilidad civil del centro podrá exigirse en el propio procedimiento de menores.

La jurisdicción civil, será competente cuando el centro sea de titularidad civil, aunque reciba fondos públicos, es decir, sea concertado, en los casos de acoso cometidos por menores de catorce años, o por menores de catorce a dieciocho años, cuando se haya reservado expresamente las acciones civiles.

Cuando el centro sea público, se aplicará la jurisdicción contenciosoadministrativa, para exigir responsabilidad civil a dichos centros de titularidad pública, por casos de acoso cometidos por menores de catorce años o por menores de catorce a dieciocho años, cuando exista declaración expresa de reserva de las acciones civiles.

Los centros docentes tienen una clara responsabilidad en que se garanticen espacios seguros para que los menores puedan cursar sus estudios en paz libres de agresiones y vejaciones, tanto en las aulas como en cualquier otra dependencia del centro, durante los periodos en que los alumnos se hallen bajo el control o vigilancia del profesorado del centro.

El acoso escolar ha existido desde siempre en los centros escolares, y es a sus titulares y personal a quienes incumbe evitarlo. No sirven las excusas de que es imposible evitarlo, de que no se puede saber cuándo se da el acoso, o el decir "es que son cosas de chicos". Es un problema muy complejo en el que se dan múltiples causas. Tiene consecuencias muy graves para el que lo sufre, tales como estrés postraumático infantil, fracaso en los estudios, trastornos en la personalidad, cuando sea adulto tiene mayores posibilidades de sufrir violencia de género o laboral y desde luego en casos extremos puede llegar al mismo suicidio ${ }^{476}$.

En los centros de titularidad privada, ya sean o no concertados se aplicarán los artículos 1903, en sus apartados 4, 5 y 6, así como el artículo 1904. El artículo 1903, 4 y 5 establece una responsabilidad directa y por culpa, en la que responden por los perjuicios causados por los alumnos, durante el tiempo que se encuentren bajo su vigilancia y

\footnotetext{
${ }^{476}$ Ferreiro Vega, José Manuel (2012), Bulling o Acoso Escolar, Editorial Formación Alcalá, Alcalá la Real, Jaén
} 
control. Es decir, se trata de una responsabilidad, en casos de acoso, de tipo subjetiva objetivada, en la que es difícil exonerarse. La inversión de la carga de la prueba, corresponde al centro docente, que tiene que probar que empleó la diligencia de un buen padre de familia para prevenir el daño. Para que el centro sea civilmente responsable tiene que producirse un daño, es decir, un caso de acoso escolar; el titular del centro tiene que haber obrado con negligencia y el daño se tiene que producir en el horario escolar cuando los alumnos se encuentran bajo el control o vigilancia del profesorado.

El artículo 1904 trata de la acción de regreso o también llamada de repetición, en la que le titular del centro podrá exigir de los profesores las cantidades satisfechas cuando estos hubieran actuado con dolo o negligencia grave y fuesen causa del daño. Esta acción es facultativa en la jurisdicción civil y desde luego tiene que darse dolo o negligencia grave en el profesor, pues en caso contrario el titular del centro no podrá accionar contra él.

Cuando el centro educativo es de titularidad pública se aplica para los casos de acoso escolar lo dispuesto en el artículo 106.2 C.E. y los artículos 139 a 146 de la LRJAP y PAC. En estos casos se tienen que dar unos requisitos para poder exigir la responsabilidad patrimonial a la Administración: efectiva realidad del daño, evaluable económicamente e individualizado; existencia del nexo causal entre el funcionamiento normal o anormal del servicio público y el daño producido; que la víctima no tenga el deber jurídico de soportarlo; y ausencia de fuerza mayor. En estos casos será el sujeto pasivo la Consejería de Educación, las aseguradoras de la Consejería del centro docente, las cuales responderán directa y solidariamente.

En cuanto a la acción de repetición o regreso, que en los centros privados vimos que era el artículo 1904, en los centros públicos es el artículo 145 de la Ley 30/92 o LRJAP y PAC, en el que se exigirá de oficio de sus autoridades y demás personal a sus servicio, la responsabilidad en que hubieran incurrido por dolo o culpa o negligencia graves. En este caso la acción de regreso, ya no es facultativa sino obligatoria ${ }^{477}$.

\footnotetext{
${ }^{477}$ Fernández Moreno, Elisabet, op.cit, pag 11 y ss
} 


\subsection{EL ACOSO ESCOLAR EN LA JURISPRUDENCIA}

Empezaremos por la S.A.P de San Sebastián de 15 de julio de 2005 (JUR 2005/174855) ya aludida anteriormente, por la importancia que tiene al haber supuesto un punto de inflexión en el tratamiento que hasta entonces se hacía en los centros docentes sobre el acoso escolar. Ha servido para concienciar sobre la gravedad del problema tanto a la Administración como a la sociedad en general. Se trata de la Sentencia del llamado caso Jokin, en la que ocho menores le maltrataron física y psíquicamente de tal forma que llegó a suicidarse. Los hechos probados son los siguientes: Jorge cursaba sus estudios de Educación Secundaria en el instituto Talaia de Hondarribia. El día 15 de septiembre de 2003, coincidiendo con el primer día de clase, se sintió indispuesto por problema intestinal que provocó una defecación involuntaria en la clase, lo que motivó que en las dos semanas siguientes recibiera burlas e insultos de sus compañeros. A mediados del curso académico 2003-2004, Jorge pasó de salir con su grupo de amigos a otro compuesto por Gustavo, Juan Ignacio, Bruno, José Angel, Gerardo, Casimiro, Millan y Natalia.

Durante la primera quincena de agosto, Jorge se fue de campamento a Zuaza, con Gustavo, Juan Ignacio y Bruno. Allí fueron sorprendidos por los monitores fumando hachís. A la vuelta, los monitores enviaron a los padres de los menores sendas cartas donde relataban los hechos. Estas cartas sólo llegaron a manos de los padres de Jorge, pues el resto interceptó la correspondencia, impidiendo que sus padres se enteraran de lo ocurrido. Los padres de Jorge tomaron la decisión de hablar con los padres de los otros tres amigos y contarles lo sucedido. Este hecho cambió radicalmente la posición de Jorge en su grupo de amigos, al pasar de ser uno más del mismo a convertirse en el chivato, todos sentían "que les había traicionado" y así se lo hicieron saber pues se inició su distanciamiento y actividades de reproche por lo sucedido.

A partir de ese momento le marginaron, le insultaron y le maltrataron física y psicológicamente. El día 13 de septiembre aprovechando un cambio de clase donde no había profesores, Gustavo le insultó, le pegó un puñetazo en la cara que le originó una herida sangrante en la boca como consecuencia del aparato de ortodoncia que portaba. Lo mismo le hicieron Bruno, Jose Angel, Millán, Gerardo y Casimiro, donde 
aprovechaban el término de las clases, dándole cachetes con la mano en la cabeza, empujones, llamándole "chivato cagón". Esto lo hacían dos o tres veces al día y para evita ser vistos por algún profesor, vigilaban Juan Ignacio y otras veces Jose Ángel.

El 14 de septiembre, Casimiro le dio un empujón empotrándolo contra el paragüero donde recibió patadas en las piernas y golpes en los hombros y abdomen de la mano de él y de Gustavo y Bruno. Este último le dio en su clase una patada por la espalda. Este mismo día en clase de gimnasia, Casimiro y Bruno le estuvieron dando balonazos a Jorge.

El 15 de septiembre, coincidiendo con la fecha en que Jokin tuvo su problema gastrointestinal del curso pasado (15-09-2003), en la primera hora de la clase le tiraron rollos de papel higiénico alrededor de su mesa, Casimiro cogió dos rollos del váter y se los puso encima de la mesa. Cuando apareció la profesora preguntó quién los había tirado y Gustavo indicó que Jorge, por lo que la profesora ordenó al mismo y a los que estaban a su lado que los recogieran. Natalia le dio a Jorge una torta en la cara.

Los días 16 y 17 de septiembre Jorge decide no acudir a clase.

El día 17 de septiembre la Jefa de Estudios Da Rosario nota la ausencia de Jorge. Decide llamar a su madre y ésta le dice que no le pasa nada que entra y sale a las horas habituales. Su madre $\mathrm{D}^{\mathrm{a}}$ Ángeles le preguntó y dijo los nombres de los que le pegaban e insultaban por lo que no quería ir al colegio.

El día 20 de septiembre la Jefa de Estudios y la orientadora educativa habla con los menores quienes reconocen su participación, al igual que Natalia. La Jefa de Estudios es requerida por la señora Ángeles para que vea los hematomas que Jorge presentaba en el cuerpo. El martes 20 de septiembre $D^{a}$ Rosario recibe una llamada de Ángeles para comunicarle que su hijo no estaba en casa, ignorando su paradero. Por la tarde se efectúa la reunión con los padres de Jorge y el resto de los menores, donde hay enfrentamientos verbales por ambas partes.

A las 18:50 horas del día 21 de septiembre aparece el cuerpo de Jorge al pie de las murallas de la localidad de Hondarribia desde donde se habrá precipitado, señalándose como dato del óbito alrededor de las 7:00 horas de ese día. 
Del informe de la autopsia se deduce que tenía varias lesiones en la región pectoral izquierda, cara externa y brazo del hombro izquierdo, cara anterior y externa del hombro derecho, región abdominal derecha así como en la pierna izquierda, todas ellas áreas equimóticas de tonalidad amarillenta, producidas entre 8 y 10 días antes de la muerte. Jorge sufrió como consecuencia de estas agresiones una depresión aguda que hubiera precisado una terapia dirigida por un psiquiatra.

A los menores se les impone por los hechos cometidos en los que se da una situación inequívoca de acoso, con relación probada de causa a efecto, a D. Gustavo, D. José Ángel, D. Casimiro y D. Bruno como autores de una falta de lesiones a la medida de tres fines de semana de permanencia en centro educativo. Los menores D. Gustavo, D. José Ángel, D. Casimiro, D. Bruno, D. Juan Ignacio, D. Gerardo y D. Millán autores de un delito contra la integridad moral y de un delito contra la salud psíquica de D. Jorge y les impone por ambas infracciones, a cada uno de ellos, la medida de dos años de internamiento en centro educativo en la modalidad de régimen abierto (límite máximo que se puede imponer al ser menores de dieciséis años de acuerdo con el artículo 7.2 y $9.3^{\circ}$ de la LORPM). A la menor Natalia se le impone la medida de dos fines de semana, por maltrato de obra sin causar lesión. Se absuelve a los menores del delito de inducción al suicidio por no haber colaborado a él, pues nunca pensaron que Jorge se suicidaría.

Esta sentencia es emblemática del acoso escolar por la gran difusión que tuvo en los medios de educación, al dar lugar a la toma de conciencia del grave problema del acoso escolar. Resulta sorprendente que los profesores no se dieran cuenta a tiempo de esa situación de acoso a la que se sometía a Jorge, sólo la Jefa de Estudios trató de solucionar el problema, pero lo hizo tarde y creo que no debería de haber esperado a reuniones ni avenencias entre los padres, hubiera sido preferible que desde que se conoció el problema no hubiera ido al colegio. Creo que hubo fallos de los profesores y de la organización del colegio por lo que deberían de haber sido imputados, pues deberían de haber expulsado del colegio a los acosadores desde el momento en que conocían las agresiones, sin esperar a ningún tipo de reuniones. Si los acosadores decían "Jorge está muy jodido", de igual forma deberían de haberlo observado los profesores. 
Otra sentencia de acoso es la del Juzgado de Menores $n^{\circ} 1$ de Bilbao de 23 de noviembre ${ }^{478}$, en ella trata de un menor de 15 años de edad en el Colegio La Milagrosa de Baracaldo, ha venido llevando un comportamiento de acoso, amenazas e injurias, contra otra menor llamada Sandra, a la que le decía "eres una gorda, una basura, me das asco, no sirves para nada, hija de puta, puta, a la salida te vamos a esperar, te voy a rajar", situación que se ha mantenido a pesar de haber abandonado el menor el citado centro educativo.

El día 20 de abril de 2005, sobre las 20:30 horas se dirigió a Sandra cuando esta salía de la academia San Vicente, en la calle Goya de Baracaldo, diciéndole "puta gorda, vas solita, ten cuidado cuando entres en el portal”. A raíz de esta situación Sandra contó con escolta policial desde el 28 de abril hasta el seis de mayo de 2005.

Los profesores y compañeros han visto éstos hechos muchas veces. Se sabe por testigos que el acoso era diario y que el agresor venía a esperarla a ella a la puerta del colegio para acosarla cuando ya el agresor no estaba estudiando en el colegio. El Jefe de Estudios ha señalado que no ha presenciado ningún hecho de los que relata la menor, pero que ella si le comentó el año pasado lo que sucedía, cuando el acosador ya no estaba en el colegio, manifestando a la semana siguiente que se había interpuesto una denuncia por tales hechos; también manifestó que en el periodo de tiempo al que se refiere la menor, la vio triste aunque no sabía la causa y que ella faltó al colegio un tiempo por cuestiones médicas.

El fallo de la sentencia condena al menor agresor como responsable de un delito contra la integridad moral del artículo $173.1 \mathrm{CP}$, en concurso con un delito de lesión mental del artículo 147.1 del mismo cuerpo legal, imponiéndole la medida de dieciocho meses de libertad vigilada, con la obligación de someterse a programa destinado a controlar sus impulsos y la prohibición de acercarse a Sandra, a su domicilio o a los lugares que ésta frecuente a una distancia inferior a 100 metros.

En este caso se observa que el acoso duró más de un año, tiempo suficiente para que los profesores que lo sabían, debieran de haber actuado con mayor diligencia y haber impedido los hechos, mediante denuncia, aviso a sus padres, u otras medidas análogas.

\footnotetext{
${ }^{478}$ Sentencia del Juzgado de Menores no 1 de Bilbao de 23 de noviembre de 2005, nº 216 (JUR-2006/103618)
} 
La Sentencia de la Audiencia Provincial de Valencia de 13 de octubre de $2006^{479}$,trata de una niña Natalia que estudia en el Colegio Hispano Americano S.A. de Valencia, desde la edad de tres años, comenzó a tener problemas con un muchacho de la clase de 14 años, un año mayor que ella, que la insultaba y humillaba, llegando a agredirle con puñetazos y a clavarle un bolígrafo en la espalda, todo ello ante la impávida reacción de los profesores, lo que provocó a la menor, además de hematomas, problemas emocionales y gastrointestinales en forma de colitis y cefaleas. Pese a que los padres solicitaron el cambio de aula de la menor el colegio no accedió a ello. Al no garantizarles la seguridad y ante la incapacidad de la Dirección del Colegio para dar una solución al problema, optaron por cambiarla de colegio.

La Audiencia confirma la sentencia del Juzgado de Primera Instancia, en que se condena al colegio al pago de 11221,21 €.

En esta sentencia se comprueba una falta del profesorado y de la Jefatura de Estudios por no tratar de solucionar el problema, al impedir el cambio de aula a la menor. El acoso se conocía desde el mes de octubre lo que contrasta con la dirección que alega que no le dio tiempo a corregir el problema en cuatro o cinco días, lo que es falso pues se trata de un trimestre. No avisaron a la familia sobre el problema de la situación de acoso. El colegio no adoptó ninguna medida correctora eficaz. El menor acosador era muy conflictivo y se conocía esta conflictividad por los alumnos, profesores y director. No demostró el Colegio haber obrado con la diligencia de un buen padre de familia para prevenir el daño del artículo 1903, pues no se puede permitir que unos menores sometan a una niña a una situación de acoso. La víctima es victimizada en este caso, pues no se hace nada por resolver el problema, teniendo que irse a otro colegio; cuando lo que debería de haber hecho el colegio es expulsar al alumno acosador. Por otra parte el colegio es privado y precisa de autorización para su fundación, lo que podría dar lugar, si se repiten los hechos de esta naturaleza y no los corrigen debidamente a revocar la autorización para impartir clases o a cesar al director y profesores

\footnotetext{
${ }^{479}$ Sentencia de la Audiencia Provincial de Valencia (Sección 7ª), número 579, de 13 de octubre de 2006 (JUR2007/76569)
} 
involucrados, lo que no se puede permitir es que se produzcan casos de acoso escolar y se trate de ocultarlos, sin hacer nada para su solución.

En la Sentencia de la Audiencia Provincial de Madrid de 18 de diciembre de $2008^{480}$, en ella se contempla el caso de un menor Joaquín que es acosado en reiteradas ocasiones por sus compañeros, siendo en una de ellas grabados los hechos con una cámara de grabación con la intención de difundirlos lo que agravó más los sufrimientos de dicho menor. Los hechos ocurrieron en el Colegio Suizo de Madrid el día 26-06-06, en un espacio entre clases, apercibiéndose de los hechos una profesora de matemáticas, que al ir a impartir su clase notó que los alumnos se encontraban visiblemente alterados, al preguntar qué pasaba la dijeron que se estaban tirando gomas y que lo habían grabado con una cámara. La profesora comunicó a la tutora y al Director del centro lo sucedido sin que tampoco estos tomaran la decisión de requerir la cámara para comprobar su contenido o a hablar con los alumnos implicados.

La grabación evidencia que los menores agresores provocan con golpes de estuche y collejas a Joaquín que ante su superioridad numérica se limita a defenderse como puede. El testimonio del padre de otro alumno del colegio D. Luis Alberto, afirma que la situación de maltrato a Joaquín era vox populi, y que se había tratado incluso en reuniones escolares. Otra alumna del mismo colegio llamada Nieves, había denunciado al colegio por acoso, ante el Defensor del Menor.

El colegio trata de exonerarse de responsabilidad afirmando que se trata de un hecho aislado, en el que los alumnos estaban solos, que se trataba de algo ocasional, que fue de forma imprevista y que obró con la diligencia debida, pero se comprueba que ello no es así.

El informe del Defensor del Menor expone que la situación vivida por Joaquín se ajusta a los parámetros que se define como acoso escolar. El colegio disponía de algunos datos y observaciones que suficientemente analizados podrían haber permitido prever y corregir algunos comportamientos de acoso. La tutora del menor, trata de minimizar los hechos, entiende que el menor no tiene carácter débil y por ello no necesitaba una

\footnotetext{
${ }^{480}$ Sentencia de la Audiencia Provincial de Madrid de 18 de diciembre de 2008, (Sección 10ª),número 737 (AC2009/124)
} 
especial protección, ello pese a reconocer que anteriormente en 2005, Joaquín había sufrido otro incidente parecido en el que había mediado solventando el conflicto, problema que no ha sido resuelto, y tal vez un mínimo de seguimiento de la interrelación entre Joaquín y el resto de los alumnos por el Centro, hubiera evitado el problema.

De ello se deduce la falta de diligencia del Centro demandado, es palpable y manifiesta e incurre en la responsabilidad del artículo 1903 del Código Civil. Por ello en su Fundamento de Derecho Cuarto, el Tribunal dice: "Atendiendo a lo acontecido y probado, e incardinándolo en la preocupación que socialmente existe sobre el maltrato entre alumnos en los colegios, que afecta a un número nada despreciable de escolares, que se constituyen en víctimas, agresores y espectadores de violencia entre sus iguales, que como de todos es conocido tiene a veces consecuencias fatales por los menores. Y siguiendo las directrices de la Conferencia de Utrech, de febrero de 1997, que ratificó como necesario y urgente, que en los centros educativos europeos se implementen y lleven a cabo medidas de prevención de la violencia escolar. Este Tribunal, considera que el centro docente demandado no ha empleado la diligencia exigible, en la prevención y evitación del daño causado a Joaquín, en sus dependencias, implantando las medidas necesarias para prevenir y evitar la violencia escolar que sufrió Joaquín".

Por todo ello se condena al Centro demandado Colegio Suizo de Madrid a indemnizar a D. José Ramón y a $\mathrm{D}^{\mathrm{a}}$ Frida, en representación de su hijo D. Joaquín a abonar a los demandantes la cantidad de 30000 euros, más los intereses legales desde el dictado de esta resolución. Esta sentencia es similar a la anterior y en ella se refleja, que los casos de acoso no sólo se dan en centros públicos a los que acuden los niños de las clases bajas de la sociedad, sino que también en colegios privados, que son caros y a los que asisten escolares que provienen de las clases medias y altas de la sociedad.

Del estudio de estas sentencias se deduce que en todo caso de acoso, existen siempre un acosador o acosadores con problemas emocionales no resueltos, que ven malos ejemplos en su casa, en su familia viven una situación de abandono pasivo muy grande, este abandono afectivo pasivo les crea mucho dolor y ese dolor lo manifiestan ellos en agresiones, en maldad, en llamar la atención de la forma que pueden para hacerse visibles ante las personas que no quieren verles. Después está el acosado que es 
un chico no muy fuerte físicamente, generalmente tímido, que por cualquier circunstancia, por la cosa más nimia, por obtener mejores calificaciones, ir mejor vestido, o cosas similares se atrae el odio de los acosadores, que le maltratan y le hacen la vida imposible, se encuentra solo ante los demás, le hacen objeto de humillaciones, vejaciones, agresiones, excluyéndole del entorno, lo que le origina grandes sufrimientos. Finalmente el resto de alumnos que son pasivos llegan también a ponerse en contra suya, sin tratar de ayudarle para no complicarse la vida, ni tampoco decírselo a los profesores o tutores para no ser considerados chivatos.

Los profesores tienen una gran responsabilidad en este asunto, y deben de saber girar el grupo, quiere esto decir que deben de tratar de poner al grupo pasivo, en contra de los agresores, para que éstos se vean contrariados por la mayoría de la clase, de esta forma dejarán de agredir al acosado. El profesor tiene, en general, problemas cuando denuncia casos de acoso, pues el Jefe de Estudios o el Director, así como titulares de centros docentes y demás, no quieren problemas por lo que no le ayudan a resolver estos casos y se encuentran solos, sin saber qué hacer, pues muchas veces unos y otros tratan de minimizar el problema, lo que da lugar a que se agrave y llegue un momento en que ya no tenga solución.

Existe por otra parte el problema de que el profesor está presente en la clase menos de una hora en cada clase, después se va a otra, lo que da lugar a que no tenga un contacto prolongado con cada clase y no pueda conocer esos problemas. Los que sí deben de implicarse más son los tutores, con un mayor contacto con el aula que tengan asignada, para tratar de conocer estas situaciones.

Se necesitan tener en los colegios unos protocolos de actuación que sean claros, concretos y rápidos para poder hacer frente de forma efectiva ante estas situaciones. Pues, este problema afecta en torno a medio millón de niños, que sufren acoso escolar intenso; un 3\% de los niños son acosados de manera cotidiana; y cerca de un 30\% sufren algún tipo de acoso.

Los pedagogos, educadores y psicólogos tienen una regla para detectar el acoso escolar, esta regla se llama de las tres "c" y se refiere a cambios, quiere decir cambios que sufre el acosado, como pueden ser que va mal en el colegio, que lleva la mochila 
rota, los objetos de material escolar rotos o muy deteriorados, botones arrancados y otras cosas por el estilo; luego la palabra campanas, esta hace referencia al absentismo escolar, el menor no acude a clase varias veces, en periodos prolongado, lo cual es otro síntoma de que algo va mal y hay que tratar de averiguar lo que pasa; la otra palabra es cuerpo, y en ella se comprende la situación en que el menor mira al suelo, no mira de frente o a lo alto, se encuentra encogido de cuerpo, trata de pasar desapercibido, se encuentra triste, cabizbajo y melancólico. Cuando se dan estas tres "c", los padres y profesores deben de tratar de averiguar a qué se debe, pues son síntomas inequívocos de que nos encontramos ante un caso de acoso escolar. 


\section{PARTE: CONCLUSIONES}

I Las barreras de edad de los menores se han mantenido con algunas variaciones desde la época del Derecho Romano hasta nuestros días. La infancia que comprende en general hasta los siete años, a los de esta edad en Derecho Romano se les denominaba infanti, eran inimputables por entenderse que carecían de razón, se les asimilaba al loco o furiosi y sus hechos dañosos se consideraban casos fortuitos. En la actualidad sucede lo mismo, en ningún código se considera imputables a los menores de siete años. La Jurisprudencia de nuestros Tribunales, en sus resoluciones sobre los menores de esta edad que hayan cometido actos dañosos, se consideran caso fortuito. La excepción se da en el artículo novecientos veintiuno del Código Civil argentino por el que se consideran inimputables a los menores de diez años.

A partir de los doce años los menores tienen en general capacidad intelectiva y volitiva suficiente para poder comprender la importancia y el alcance que se deriva de su propia actuación, por lo tanto, equiparable a la de una persona adulta. Esta edad se corresponde con los pubertati proximi y pubertati del Derecho romano, en que eran parcialmente responsables. En nuestro Código Civil a partir de los doce años tienen que ser oídos y podrían consentir su adopción. La LORPM considera imputables penalmente a los mayores de catorce años y menores de dieciocho, por lo que son responsables de la responsabilidad civil que se derive de los ilícitos penales. A esta edad al menor se le permite adquirir la nacionalidad española por opción o residencia, con asistencia del representante legal; reconocer la filiación extramatrimonial; ejercitar los actos relativos a los derechos de la personalidad, si tienen suficiente madurez de juicio para ello; hacer testamento, excepto el ológrafo; intervenir de testigo; contraer matrimonio, con dispensa y otorgar capitulaciones matrimoniales, pero con ciertas limitaciones.

Con respecto a la mayoría de edad, en el Derecho Romano se establecía a los veinticinco años. En los códigos de nuestro entorno se daba a los veintiuno. Desde hace varias décadas se estableció a los dieciocho años. Nuestra Constitución en su artículo doce la establece también a los dieciocho años, al igual que la Ley Orgánica de Protección Jurídica del Menor. En la legislación de los organismos internacionales, como 
la Convención sobre los Derechos del Niño de la ONU se establece de igual forma a los dieciocho años. La excepción se da en el Código Civil japonés que la reconoce a los veinte años cumplidos, en su artículo cuarto.

II Para exigir responsabilidad a un menor es necesario considerar las distintas franjas de edad que pueda tener. Si se encuentra comprendida entre catorce y dieciocho años habrá que aplicarle lo que dispone la LORPM, lo que no representa problema alguno. Cuando se trate de menores de catorce años es de aplicación las normas sobre protección de menores del Código Civil y demás disposiciones vigentes. Al establecer esta barrera de catorce años, el legislador ha querido diferenciar entre niño y adolescente, teniendo en cuenta que los menores de esa edad son absolutamente irresponsables criminalmente. El hecho de que esos menores no sean responsables criminalmente no quiere decir que no lo puedan ser civilmente.

Puede decirse que a partir de los diez años se puede imputar responsabilidad civil a un menor, como el Código Civil de Argentina que declara al menor civilmente inimputable; por debajo de los siete años la mayor parte de los códigos, como el portugués o el alemán declaran a dichos menores totalmente irresponsables o inimputables.

En los países de tradición latina a los menores de muy corta edad, cuando cometen un hecho dañoso se asimila al caso fortuito y el perjudicado queda sin indemnización. Por el contrario en los de tradición germánica, dichos menores si disponen de patrimonio, se les puede hacer responder. Francia a pesar de ser de tradición latina a partir de la Ley de 3 de enero de 1968, ha cambiado de orientación modificando su artículo $489.2^{\circ}$, mediante el denominado concepto "objetivo o abstracto" en el que se prescinde del discernimiento y voluntad del menor para exigir responsabilidad a los menores que no tengan capacidad intelectiva y volitiva.

En nuestro Código Civil se pueden aplicar determinados artículos como argumento para exigir responsabilidad a menores de muy corta edad, que pueden ser tres principalmente: el primero es el de la equidad contemplado en el artículo 3.2 CC "la equidad habrá de ponderarse según los casos", quiere decir que si el menor dispone de patrimonio se le puede aplicar el artículo 1902; el segundo es el del $\operatorname{art}^{\circ} 32$ CC que dice 
"la personalidad civil se extingue por la muerte", de donde se deduce que si se es persona, se encuentra sujeto a derechos y obligaciones, de donde se deduce que tendrá la obligación de indemnizar; el tercero y último sería el de la relación de especialidad que guardan los artículos 1903 y siguientes en relación con el 1902, de tal forma que si no es posible aplicar el 1903 por no haber padres o tutores o ser estos insolventes se recurre al artículo 1902.

III La expresión "por este orden” del artículo 51.3 de la LORPM ha dado lugar a varias interpretaciones de lo que ha querido el legislador al redactar el precepto. Para unos autores entienden que se trata de un orden excluyente, en atención al orden establecido en el precepto, primero los padres, después los tutores y así sucesivamente, pero este sistema es absurdo, pues se puede dar el caso de que unos padres privados de patria potestad fueran obligados a responder por los daños que causare un hijo, cuya guarda y custodia se hubiera encomendado a un tutor. Otros autores consideran que la responsabilidad ha de recaer sobre las personas que se enumeran en el artículo, y que en el momento que se causen los daños por el menor tuvieran sobre el mismo los contenidos de la patria potestad, es decir, su guarda y custodia. Finalmente, es posible el orden acumulativo, pues ante un hecho dañoso cometido por un menor, pueden resultar responsables varias de las personas físicas o jurídicas enumeradas en dicho artículo, ya sean por culpa in vigilando unos, o por culpa in educando otros.

IV Uno de los problemas más difíciles de resolver es el de la causalidad o relación causa a efecto entre el hecho dañoso cometido por un menor y la persona que tiene que responder por él. Este requisito es imprescindible para la exigencia de responsabilidad, pues si no se da, ésta no se puede exigir. Existen diversas teorías de la causalidad tales como la de la equivalencia de las condiciones, la causalidad próxima, la causalidad adecuada, la causa eficiente, pero todas ellas han sido desechadas por no ser válidas para resolver el problema. Para resolverlo se empleó el criterio de la imputación objetiva que ha sido introducido en la dogmática civil, tomado de la justicia penal, como viene ocurriendo en Alemania y en el Derecho angloamericano.

En la aplicación del requisito de la causalidad, hay ocasiones en que la responsabilidad no puede atribuirse en exclusiva a la acción del sujeto, por haber 
contribuido, coadyuvado o favorecido a su causación, elementos extraños tales como son el caso fortuito o la fuerza mayor, el hecho de un tercero o la acción de la propia víctima. Al darse alguno de estos elementos determinaría la exoneración total o parcial, al concurrir un acontecer ajeno entre la conducta del agente y el resultado dañoso.

$\mathrm{V} \quad$ Las relaciones abuelos-nietos han sufrido en los últimos decenios una profunda transformación debido a la disminución del número de matrimonios, retraso en las edades de las bodas, aumento de uniones libres; más de la mitad de las parejas se encuentran separadas, divorciadas o anuladas; disminución del número de hijos, inestabilidad de las parejas, las familias recompuestas; todo ello ha dado lugar a una transformación del concepto tradicional del abuelo y del nieto. Un nieto puede pasar a vivir en un ambiente extraño e incluso hostil al abuelo de siempre. Según estudios realizados sobre esta cuestión, se estima que uno de cada cinco niños, no vive con su padre, pues vive normalmente con su madre y ve a su padre cuando lo permite el régimen de visitas.

La interrupción forzada de las relaciones abuelos-nietos se produce: por ruptura del matrimonio o pareja de los padres; fallecimiento de uno de los progenitores o por diferencias personales entre los abuelos y los progenitores de los menores.

Los abuelos es necesario que se relacionen con los nietos de forma regular, sobre todo en caso de fallecimiento de uno de los progenitores, pues en este caso es el abuelo el referente principal que le queda al menor en la memoria del padre fallecido, y no sólo el abuelo, sino con sus tíos y primos, con los que tendrá lazos de afectividad.

Para regular estas relaciones se ha publicado la Ley 42/2003, la cual ha modificado varios artículos del Código Civil, con el fin de asegurar el correcto funcionamiento de las mismas. Hay que tener presente que los abuelos en determinadas circunstancias pueden ser tutores de los nietos, por lo que puede considerarse que estas relaciones revisten la máxima importancia. La casuística jurisprudencial revela que cuando los abuelos cuidan de sus nietos y se produce algún hecho dañoso, si no tienen asignada la patria potestad e incluso aunque la tengan, no suelen ser los jueces demasiado severos con los abuelos, pues se trata de incentivar estas relaciones que son beneficiosos socialmente por la ayuda que prestan a las familias, en estos tiempos en que los dos padres trabajan y no disponen 
de suficiente tiempo para atender a sus hijos.

VI En el Derecho portugués se ha creado recientemente un nuevo régimen de acogimiento que se llama apadrinamiento, el cual consiste en una relación tendencialmente de carácter de estabilidad y permanencia entre un niño o un joven menor de edad y una persona singular o uno familia que ejerza los poderes y deberes propios de los padres. El establecimiento de estos lazos afectivos no se consiguen en otro tipo de acogimiento como el residencial, de esta forma se contribuye al bienestar y desarrollo del menor, pues para ello no hay nada mejor para conseguirlo que realizarlo en el ámbito familiar.

Para su constitución es necesario como es lógico la intervención del Juez, así como su formalización mediante inscripción en el Registro Civil.

Al ser una institución nueva, se desconoce su resultado práctico desde su introducción en el ordenamiento nacional, no pudiéndose especular sobre las soluciones que aportará en el futuro.

VII Cada vez son más numerosas las familias recompuestas o reconstituidas, en las que uno o los dos nuevos esposos o convivientes tienen hijos menores de su anterior unión, y respecto de los cuales, el cónyuge o conviviente no progenitor realiza funciones tuitivas que no siempre se reconocen y regulan por el Derecho. Se trata del padrastro y la madrastra, en que sin vínculo de paternidad, desempeñan de hecho funciones de padre o madre, en el trato diario con los hijastros. Cuando se dan estos casos de nuevas uniones ya sean por un nuevo matrimonio civil o canónico o pareja de hecho, a la que se llama pareja reconstituida, en la que se dan relaciones entre hijastro y padrastro, es necesario regular si existen o no derechos y obligaciones entre ambos, y si existen en qué grado y contenido. Pensemos por ejemplo cuando el progenitor no está presente, el padrastro o madrastra tendrá que llevarle al colegio al menor o al hospital si se pone enfermo, o bien tendrá que tener su guarda o vigilancia y educarle, pues esos aspectos se deben regular, al haber aumentado en los últimos tiempos de forma extraordinaria ese tipo de uniones.

En los distintos ordenamientos europeos todos tienen reguladas las relaciones 
entre padrastro y menor, aunque las soluciones empleadas son variables de unos países a otros. En Francia, se calcula que uno de cada diez menores de edad, convive con un padrastro o con una madrastra. El Código Civil francés permite una intervención del padrastro en el ejercicio de la patria potestad sobre el menor, e incluso participar en ese ejercicio con uno de los progenitores o con los dos.

En Inglaterra se permite al padrastro compartir la patria potestad con los progenitores, sin tener en cuenta el estatuto jurídico ni la orientación sexual de los progenitores.

Los ordenamientos español, belga e italiano, contemplan al cónyuge del progenitor como un tercero sin poder alguno sobre el menor. Esta situación tendrá que ser actualizada en el futuro, cuando aumente el número de este tipo de uniones y el problema se agrave, para lo que habrá que modificar algunos artículos de sus respectivos códigos civiles.

VIII Como consecuencia de la inmigración originada por las condiciones tan precarias en que viven los pueblos de África y Asia, principalmente, ya sea por su atraso económico o social o de las guerras que se han producido, como la llamada "Primavera Árabe", han dado lugar a la aparición de un tipo de menor que viene solo, sin ningún familiar que le acompañe, por lo que ha sido denominado MENA (menor extranjero no acompañado).

Las comunidades más expuestas a este problema son Andalucía y Canarias por su proximidad al continente africano que es a través del que llegan a España. Para paliar este problema se requieren importantes medios materiales y humanos que no siempre es posible el que dispongan de ellos las mencionadas comunidades autónomas. Además es necesaria la solución de este problema para dar cumplimiento a la legislación internacional que ha sido suscrita por España y en virtud de ella estamos obligados a la protección de estos menores.

Estos menores una vez que entran en España y son reunidos en el centro de acogida se ausentan del mismo y se dirigen a otras provincias en la creencia de que van a mejorar su situación, esto hace necesario que se cree un único registro a nivel nacional 
para poder hacer un seguimiento de ellos y poder solucionar el problema.

IX Los Principios de Derecho europeo de la responsabilidad civil del European Group on Tort Law (PETL) es un grupo creado para debatir cuestiones fundamentales del Derecho de la responsabilidad civil. Anteriormente se llamaba Grupo de Tilburg y se viene reuniendo desde 1992 periódicamente para tratar como grupo de académicos expertos los problemas relativos al Derecho de Daños.

Es un grupo principalmente europeo en el que sus miembros proceden en su mayor parte de países de la Unión Europea y tratan de estudiar el Derecho en Europa que se compone del Derecho inglés o Common Law, así como del Derecho germánico y Derecho latino en la parte continental. Se dan diferencias importantes entre el Common Law del Derecho inglés y el Civil Law de la parte continental. El Common Law se basa más en el precedente, en la casuística, tratando de encontrar la solución de acuerdo con el caso precedente; mientras que el Civil Law se basa en las leyes que elabora el legislador, mediante la aprobación de leyes y códigos, sin que se de relevancia al caso precedente; esto es lo que se hace en el Derecho de orientación germánica o de orientación latina. El resultado que se obtiene en uno u otro sistema es muy similar.

El objetivo de estos Principios es servir de base para mejorar y armonizar el Derecho de la responsabilidad civil en Europa, tratando de superar esa diferencia entre Common Law y el derecho continental o Civil Law, así como las diferencias que se dan entre el Derecho germánico y Derecho latino que siempre ha existido en la parte continental. Son parecidos a los Principios Lando y adoptan su estructura y sistema de numeración.

Si hay una Europa Unida su Derecho habrá de ser necesariamente armonizado con el fin de que haya un Derecho civil común, que facilite los intercambios y las relaciones económica y comerciales, así como de otros tipos, entre los distintos países y no se den problemas en estas relaciones, para ello lo mejor será que se cumplan las reglas que contienen dichos Principios.

X En conclusión, se trata de cumplir los presupuestos de los artículos 1902, 1903 y 1904 en relación con la responsabilidad de los menores, lo cual involucra en su 
problemática a padres, tutores, acogedores, guardadores legales o de hecho, así como a los profesores y titulares de centros docentes no universitarios; todos ellos según las circunstancias de cada caso, tienen la responsabilidad objetiva o cuasiobjetiva y la obligación de indemnizar a la víctima por los hechos dañosos cometidos por los menores. La víctima, en virtud del principio pro damnato, no puede quedar sin indemnización, salvo en casos muy concretos como puede ser el caso fortuito.

Por otra parte se considera la imperiosa necesidad de proteger siempre al menor, por ser la parte más débil en estos casos, de acuerdo con lo que se establece en las leyes internacionales, así como en las españolas que se encuentran armonizados con ellos e incorporados a nuestro Ordenamiento jurídico.

Hay que tener presente que los menores a pesar de los avances del mundo moderno se encuentran sujetos, en muchos casos, a grandes sufrimientos originados por familias desestructuradas, recompuestas y demás así como otras por causas de inmigración y guerras, en que vienen no acompañados. De igual forma los casos de acoso escolar que constituyen un problema alarmante, un tanto por ciento considerable se encuentra sujeto a sufrimientos continuos, en los que el hecho de tener que asistir a clase es para ellos una verdadera tortura. Por todo ello se hace necesaria una especial protección de los menores en estos casos en que son extremadamente vulnerables. 


\section{BIBLIOGRAFÍA}

ACEVEDO BERMEJO, ANTONIO (2006), Las Relaciones Abuelos- Nietos, Ed. Tecnos, Madrid ARIAS RAMOS J. y ARIAS BONET J.A. (1988), Derecho Romano, Ed. Revista de Derecho Privado, Madrid

ATIENZA NAVARRO, MARIA LUISA (2000), La responsabilidad civil por los hechos dañosos de los alumnos menores de edad, Editorial Comares, Granada

AYALA MUÑOZ, JOSE MARÍA (1998), Comentarios a la Ley de la Jurisdicción ContenciosoAdministrativa, Ed. Aranzadi, Pamplona

BARBERÁN FRANCISCO y DOMINGO RAFAEL (2006), Código Civil Japonés, Thomson, Aranzadi, Navarra

BARRIO DÍAZ, RODRIGO (2010), El daño causado por un miembro indeterminado de un grupo, Ed. La Ley, $1^{\text {a }}$ Edición, Madrid

BELTRÁN DE HEREDIA DE ONIS, PABLO, Libro Homenaje al Profesor José Beltrán de Heredia y Castaño (1984), Ediciones Universidad de Salamanca, Salamanca

BENEYTO BERENGUER, REMIGIO (2009), La Protección del Menor, Ed. Tirant lo Blanch, Valencia

BLANCO GONZÁLEZ y otros (1997), Filosofía del Derecho, Ed. UNED, Unidad Didáctica, Madrid BONILLA CORREA, JESÚS ÁNGEL y CLEMENTE MARIO E. (2009), La responsabilidad civil ante el ilícito penal, Monografías Tirant lo Blanch, Valencia

CABELLO MOLLAL, VICENTE y CLOQUEL LOZANO, ALEXIS (2010), Los Menores Extranjeros no Acompañados en los Sistemas de Protección de las CC.AA, Ed. Tirant lo Blanch, Monografías, Valencia (Artículo de José María Felip y Sardá)

CASTÁN TOBEÑAS, JOSÉ (1993), Derecho Civil Español, común y foral, 15 Edición, Reus S.A. Madrid

COING HELMUT (1989), Derecho Privado Europeo. Clásicos Contemporáneos, Munchen traducción del alemán por Francisco Fernández Jordán, Universidad de Oviedo

DALLOZ, DESIREE (1951), Code Civil, Librerie Dalloz, Rue Soufflot, 11, Paris

DE ESTEBAN, JORGE (1977), Constituciones Españolas y Extranjeras, Ed. Taurus, Madrid

DE LA ROSA CORTINA, JOSÉ MIGUEL (2012), Responsabilidad civil por daños causados por menores, Ed. Tirant lo Blanch, monografías no 812, Valencia 
DELGADO CRIADO, BUENAVENTURA (1994), La Educación en la España Contemporánea, Ediciones S.M, Fundación Santamaría, Dr. Esquerdo, 125, Madrid

Diccionario Anaya de la Lengua (1981), Ed. Anaya, Madrid

Diccionario Collins Dictionary (1993) Third Edition, Harper Collins Publishers, Great Britain

DIEZ PICAZO, LUIS (1995), Sistema de Derecho Civil, Vol II, Ed. Tecnos, $7^{\text {a }}$ Edición, Madrid

FELDMAN ROBERS (2009), Desarrollo Psicológico, Universidad de Massachussetts, traducción de María Elena Ortiz Salinas, Ed. Pearson Educación, Cuarta Edición, México

FERNÁNDEZ MORENO, ELISABET (2014), Doctrina, La Responsabilidad Civil de los Centros Docentes en los casos de acoso escolar

FERREIRO VEGA, JOSE MANUEL (2012) Bullying o Acoso Escolar, Ed. Formación Alcalá, Alcalá la Real, Jaén.

FERREIRO VEGA, JOSÉ MANUEL (2012), Bulling o Acoso Escolar, Ed. Formación Alcalá, Alcalá la Real, Jaén

GABANELLAS DE TORRES, GUILLERMO (1988), diccionario jurídico, Ed. Eliasta SRL, Buenos Aires

GARCÍA GARRIDO, MANUEL JESÚS (1989), Derecho Privado Romano, Ed. Dykinson, Madrid

GARCÍA GARRIDO, MANUEL JESÚS (1989), Responsa Casos Prácticos, Ed. Centro de Estudios Ramón Areces, Madrid

GÓMEZ RIVERO, MARIA DEL CARMEN (2007), Comentarios a la Ley Penal del Menor, Iustel, Portal Derecho, $1^{\mathrm{a}}$ Edición, Madrid

GONZÁLEZ DORIA, FERNANDO (1986), Constituciones Españolas, Ed. Cometa S.A., Madrid IGLESIAS, JUAN (2004), Derecho Romano, Ariel Derecho, $15^{a}$ edición, Barcelona

LACRUZ VERDEJO, JOSE LUIS (2005), Derecho de obligaciones, $3^{\text {a }}$ edición, Dykinson, Madrid LAMARCA MARQUÉS, ALBERTO (2008) Código Civil Alemán, traducido, Ed. Marcial Pons, Madrid LARA PEINADO, FEDERICO (1982), Hammurabi Rey de Babilonia, Ed. Nacional, Madrid LASARTE CARLOS (2013), Derecho de Obligaciones, 17 Edición, Ed. Marcial Pons, Madrid LASARTE, CARLOS (2007), La Responsabilidad Civil en el Ámbito de los Centros Docentes, Ed. Dykinson, Madrid

LASARTE, CARLOS (2011), Relaciones Paterno-Filiales, Congreso IDADFE, Vol II (Estatuto del Cónyuge del Progenitor en la Legislación Europea, artículo de D. Iñigo Mateo Vila) 
LEGUINA VILLA, JESÚS (1983), La Responsabilidad Civil de la Administración Pública, Ed. Tecnos, Madrid

Leyes Victorianas (1928) Volúmenes 46 y 47, Inglaterra, Derecho Espasa Calpe, Barcelona, Tomo 28, $1^{\text {a }}$ parte

LLISET BORRELL, FRANCISCO y ROMERO HERNÁNDEZ, FEDERICO (1994), Regimen Jurídico de las Administraciones Públicas y del Procedimiento Administrativo Común, Ed. Publicaciones Abella, Madrid

LÓPEZ SÁNCHEZ, CRISTINA (2001), La responsabilidad civil del menor, Ed. Dykinson, Madrid

MARTÍN CASALS, MIGUEL (2008), European Group on Tort Law, Ed. Thompson, Aranzadi, Navarra

MARTÍN CASALS, MIGUEL (2011), Asociación de Profesores de Derecho Civil (APAC), Cuestiones Actuales en Materia de Responsabilidad Civil, XV Jornadas de la APDC, A Coruña 8 y 9 de abril, Editum Ediciones de la Universidad de Murcia, Murcia

MAZEAUD, HENRY (1960), Vol II, traducción de Luis Alcalá Zamora y Castillo, Ed. Jurídicas Europa-América, Buenos Aires

Memoria del Defensor del Pueblo del año 2000

MORENO MARTÍNEZ, JUAN ANTONIO (1996), Responsabilidad del Centro Docente y Profesorado por los daños causados por los alumnos, Mc. Craw Hill, Madrid

MORENO MARTÍNEZ, JUAN ANTONIO y otros (2007), La Responsabilidad Civil y su Problemática Actual, Problemática de la Violencia Escolar, Ed. Dikynson, Madrid

MORENO, JUAN MANUEL POBLADOS, ALFREDO Y DEL RÍO, DIONISIO (1986), Biblioteca de Innovación Educativa, Ed. Paraninfo, Madrid

MUÑOZ NARANJO, ALFREDO (1999), Responsabilidad Civil de los Docentes, Ed. Praxis, Barcelona

NUÑEZ IGLESIAS, ÁLVARO (2005), Código Civil Francés, Traducido, Marcial Pons, Madrid

PAÑOS PÉREZ, ALBA (2010), La responsabilidad civil de los padres por los daños causados por menores e incapacitados, Atelier, Barcelona

PARADA VAZQUEZ, RAMÓN (1993), Regimen de la Responsabilidad de la Administración Pública y Procedimiento Administrativo Común, Marcial Pons, Madrid

Patrología latina (1891), Tomo CLXXX, Causa XXII, Question V, Canon XV, Apud Garnier Fratres, Editores ET, JP, Mique Successores, Avenue Du Maine, 208, pag 1156, Paris 
PEÑA LÓPEZ, FERNANDO (2002), La Culpabilidad Civil en la Responsabilidad Extracontractual, Ed. Camares, Granada

PERLINGIERI, GIOVANNI (2010), Códice Civile Italiano, Ed. Scientifiche Italiane

PIÑUEL ZABALA, IÑAKI (2005), Informe Cisneros VII, Instituto de Innovación Educativa y Desarrollo Directivo, Madrid

PIÑUEL ZABALA, IÑAKI (2006), Estudios Cisneros VIII, Violencia contra profesores, Instituto de Innovación Educativa y Desarrollo Directivo, Madrid

RASCÓN GARCÍA, CÉSAR (1992), Manual de Derecho Romano, Ed. Tecnos, Madrid

REGLERO CAMPOS, FERNANDO (2002), Lecciones de Responsabilidad Civil, Ed. Aranzadi, Navarra

RODRIGUEZ DEVESA, JOSE MARÍA (1990), Derecho Penal Español, Dykinson, pag 433

SALA SÁNCHEZ, PASCUAL (1999), Comentarios a la reforma del procedimiento administrativo, Ed. Tirant lo Blanch, Valencia

SANZ CABALLERO, SUSANA (2009), La Protección del Menor, CEU Universidad Cardenal Herrera, Ed. Tirant lo Blanch, Valencia

SOLÉ FELIU, JOSEP (2012), La Responsabilidad Extracontractual del Principal por los hechos de sus auxiliares, Ed. Reus S.A., Madrid

Textos Constitucionales Españoles y Extranjeros (1930), Ed. Atheneum, Zaragoza

URRA, JAVIER (2015), El Pequeño Dictador Crece, Padres e hijos en conflicto, Esfera de los libros, Madrid

WESENBERG GERHARD y WESENER GUNTER (1998), Historia del Derecho Privado Moderno en Alemania y en Europa, Ed. Lex Nova, Valladolid

WIEACKER, FRANZ (1957), Historia del Derecho Privado en la Edad Moderna, Ed. Aguilar, Madrid YZQUIERDO TOLSADA, MARIANO (2001), Sistema de Responsabilidad Civil Contractual y Extracontractual, Dykinson, Madrid 


\section{JURISPRUDENCIA}

\section{JURISPRUDENCIA ESPAÑOLA}

\subsection{Tribunal Supremo}

RJ-1946/253

RJ-1948/1212

RJ-1950/394

RJ- 1959/1483

RJ-1963/5220

RJ-1969/2411

RJ-1983/867

RJ-1983/4688

RJ-1983/6116

RJ-1988/1961

RJ-1990/9014

RJ-1993/4056

RJ-1994/6776

RJ-1996/3915

RJ-1996/7011

RJ-1996/8979

RJ-1997/1650

RJ-1997/4142

RJ-1999/1130

RJ-1999/2249

RJ-1999/2786

RJ-1999/4963

RJ-1999/4576
STS de 22 de febrero de 1946

STS de 22 de octubre de 1948

STS de 21 de marzo de 1950

STS de 10 de febrero de 1959

STS de 10 de diciembre de 1963

STS de 30 de abril de 1969

STS de 8 de febrero de 1983

STS de 30 de septiembre de 1983

STS de 16 de noviembre de 1983

STS de 11 de marzo de 1988

STS de 21 de noviembre de 1990

STS de 31 de mayo de 1993

STS de 25 de julio de 1994

STS de 24 de mayo de 1996

STS de 3 de octubre de 1996

STS de 15 de diciembre de 1996

STS de 5 de marzo de 1997

STS de 27 de mayo de 1997

STS de 23 de febrero de 1999

STS de 8 de marzo de 1999

STS de 21 de abril de 1999

STS de 6 de mayo de 1999

STS de 12 de mayo de 1999 


\begin{tabular}{|c|c|}
\hline RJ-1999/4582 & STS de 22 de mayo de 1999 \\
\hline RJ-1999/6154 & STS de 31 de mayo de 1999 \\
\hline RJ-2000/1161 & STS de 17 de febrero de 2000 \\
\hline RJ-2000/875 & STS de 21 de febrero de 2000 \\
\hline RJ-2000/1304 & STS de 2 de marzo de 2000 \\
\hline JUR-2000/3933 & STS de 17 de mayo de 2000 \\
\hline RJ-2002/4603 & STS de 15 de marzo de 2002 - Sala Tercera \\
\hline RJ-2002/9701 & STS de 20 de octubre de 2002 Sala Tercera \\
\hline RJ-2002/3094 & STS de 29 de diciembre de 2001 \\
\hline RJ-2003/962 & STS 23 de enero de 2003 - Sala Tercera \\
\hline RJ-2003/5186 & STS de 9 de abril de 2003 Sala Tercera \\
\hline RJ-2003/9314 & STS de 19 de diciembre de 2003 - Sala Tercera \\
\hline RJ-2004/4321 & STS de 28 de junio de 2004 \\
\hline RJ-2005/3059 & STS de 17 de febrero de 2005 \\
\hline RJ-2006/7705 & STS de 10 de octubre de 2006 - Sala Tercera \\
\hline RJ-2007/4713 & STS de 1 de marzo de 2007 Sala Tercera \\
\hline RJ-2007/1828 & STS de 6 de marzo de 2007 \\
\hline RJ-2007/4895 & STS de 17 de julio de 2007 \\
\hline RJ-2007/6813 & STS de 10 de octubre de 2007 \\
\hline RJ-2008/44 & STS de 18 de enero de 2008 Sala Tercera \\
\hline
\end{tabular}

1.2 Sentencias de las Audiencias Provinciales

ARP 1998/462 S.A.P de Salamanca de 12 de febrero de 1998

AC 1999, $7346 \quad$ S.A.P de León de 21 de julio de 1999

JUR-2001, 309599 S.A.P de Asturias de 18 de julio de 2001

JUR-2002, 118814 S.A.P de Lleida de 11 de marzo de 2002 
JUR-2002/153957

JUR-2002, 284904

JUR-2002, 28544

AC 2003, 801

JUR-2003, 214024

JUR-2003, 19730

JUR-2003, 34960

ARP 2004, 226

JUR-2004, 105382

ARP 2004, 251

AC-2005, 333

JUR-2005, 90985

JUR-2005, 99769

JUR-2005, 123453

ARP 2005/214

JUR-2005, 238714

JUR-2005, 218946

JUR-2005/174855

JUR-2005, 58338

JUR-2005, 36761

JUR-2006, 166775

JUR-2006/103618

JUR-2007, 8026

JUR-2007/76569

JUR-2008, 129485

JUR-2009, 199267

AC 2009, 776
S.A.P de Lugo de 9 de abril de 2002

S.A.P de Burgos de 22 de octubre de 2002

S.A.P de Toledo de 28 de noviembre de 2001

S.A.P de Zaragoza de 31 de marzo de 2003

S.A.P de Álava de 31 de julio de 2003

S.A.P de Valladolid de 22 de noviembre de 2002

S.A.P de Valladolid de 23 de diciembre de 2002

S.A.P de Álava de 10 de febrero de 2004

S.A.P de Córdoba de 20 de febrero de 2004

S.A.P de Zaragoza de 25 de abril de 2004

S.A.P de Badajoz de 25 de enero de 2005

S.A.P de Asturias de 24 de febrero de 2005

S.A.P de Cáceres de 5 de abril de 2005

S.A.P de Tarragona de 12 de abril de 2005

S. Juzgado de Menores de San Sebastián de 12 de mayo de 2005

S.A.P de Sevilla de 3 de junio de 2005

S.A.P de Burgos de 14 de julio de 2005

S.A.P de Guipúzcoa de 15 de julio de 2005

S.A.P de Huelva de 18 de octubre de 2004

S.A.P de Asturias de 16 de diciembre de 2004

S.A.P de Asturias de 27 de abril de 2006

S. Juzgado de Menores de Bilbao de 23 de noviembre de 2005

S.A.P de Alicante de 26 de junio de 2006

S.A.P de Valencia de 13 de octubre de 2006

S.A.P de Alicante de 26 de septiembre de 2007

S.A.P de Córdoba de 23 de enero de 2009

S.A.P de Baleares de 25 de marzo de 2009 
JUR-2009, 220677

JUR-2009, 439536

JUR-2009, 476974

AC 2009/124

JUR-2010, 78554

JUR-2011, 129237
S.A.P de Zaragoza de 3 de abril de 2009

S.A.P de S.C. de Tenerife de 3 de julio de 2009

S.A.P de Burgos de 20 de octubre de 2009

S.A.P de Madrid de 18 de diciembre de 2008

S.A.P de S.C. de Tenerife de 2 de noviembre de 2009

S.A.P de Jaén de 15 de noviembre de 2010

\section{JURISPRUDENCIA FRANCESA}

. Sentencia Blick de la Asamblea Plenaria de la Corte de Casación de 29 de marzo de 1991

. Sentencia Bertrand de la Corte de Casación de 19 de febrero de 1997

. Sentencia Samda de la Corte de Casación de 19 de febrero de 1997

. Resolución de la Corte de Casación de 24 de febrero de 2006

\section{JURISPRUDENCIA BELGA}

. Sentencia del Tribunal Constitucional de Bélgica de 8 de octubre de 2003 